\title{
Water Resources of the
}

Delaware River Basin

By GARALD G. PARKER, A. G. HELY, W. B. KEIGHTON, F. H. OLMSTED and OTHERS

GEOLOGICAL SURVEY PROFESSIONAL PAPER 381 A study of the hydrology and geology of the basin and the effects of physical and cultural environments on the water supply

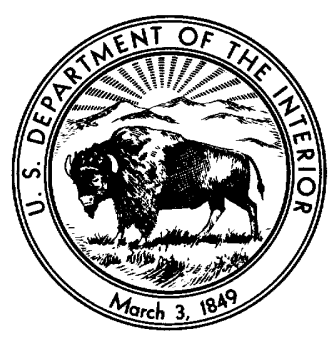

UNITED STATES GOVERNMENT PRINTING OFFICE, WASHINGTON : 1964 


\title{
UNITED STATES DEPARTMENT OF THE INTERIOR
}

\section{STEWART L. UDALL, Secretary}

\section{GEOLOGIGAL SURVEY}

\author{
Thomas B. Nolan, Director
}

The U.S. Geological Survey Library has cataloged this publication as follows :

\section{Parker, Garald Gordon, 1905-}

Water resources of the Delaware River basin, by Garald G. Parker and others. Washington, U.S. Govt. Print. Off., 1964.

vii, 200 p. illus., maps $(7$ col. $)$ diagrs. $(2$ col. $)$ tables. $29 \mathrm{~cm}$. (U.S. Geological Survey. Professional paper 381)

Part of illustrative matter fold. in pocket.

Bibliography : p. 189-193.

1. Water-supply-Delaware River basin. 2. Water, UndergroundDelaware River basin. I. Title. (Series) 


\section{CONTENTS}

Abstract.

Introduction

Acknowledgments

The Delaware River region and its water problems The role of water resources in the modern communityThe Delaware River basin and its environment.....

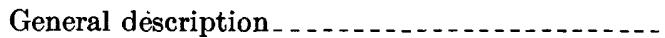

The climate.................................

Water problems of the Delaware River basin.....

Natural variations in supply . . ..............

Growth of population and industry ..........

Increasing agricultural and recreational uses...-

Increasing per capita use. . . . .

Pollution of streams and aquifers . ...........

Salt-water encroachment.................

Hydrologic effects of urbanization.........

Interbasin diversions.

Economic and legal aspects of water development. . . . . . . . . .

Summary of water law by States.

Deficiencies of data

The water supply

The hydrologic cycle and water budgets . . . . . .

The gross supply-precipitation

Causes and forms of precipitation......

Variations in precipitation . . . . . . . . . . .

Variations in place.

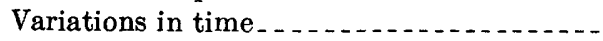

Long-term records . . . . . . . . .

Coefficient of variation of annual precipitation

Monthly precipitation

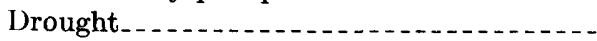

Hydrometeorology of floods in Delaware

River basin, by W. W. Swayne and C. S.

Gilman (U.S. Weather Bureau) .......

Disposition of precipitation

Natural water loss-evapotranspiration

Evaporation from free water surfaces.........

Transpiration . . . . . .

Runoff and the water crop.......................

Factors affecting the quantity and distribution

of the water crop

Surface storage

Ground-water storage

Infiltration capacity

Factors affecting the quality of the water crop.-

Impurities derived from the atmosphere. -

Impurities derived from rocks and soils

Municipal, industrial, and agricultural

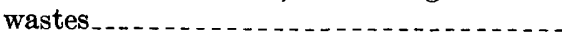

Mine drainage

Sediment . . . . . . . . . .

Salt water in the Delaware estuary.

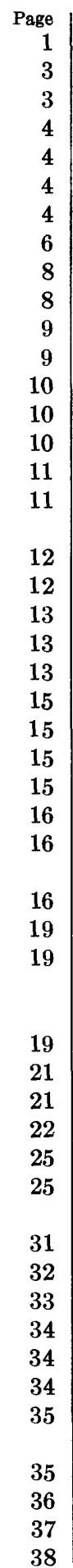

Ground water-its availability and character..........

General ground-water hydrology of the basin....... Source of ground water.

Occurrence and movement................

Discharge

Types of aquifers

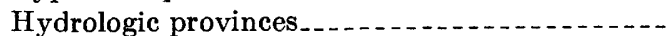

The Coastal Plain . .

General features.

Occurrence of ground water................

Nonmarine sediments of Cretaceous age-

the major group of aquifers. .........

Merchantville and Woodbury clays-a major aquiclude.........................

Minor aquifers and aquicludes above the Merchantville and Woodbury clays .... -

Englishtown sand..........

Marshalltown formation ...........

Wenonah and Mount Laurel sands....

Navesink marl.......................

Red Bank sand..........................

Hornerstown marl . . . . . . . . . . . .

Vincentown sand . . . . .

Manasquan and Shark River marls _. -

Piney Point formation

Kirkwood formation-an important group of aquifers and aquicludes _..........-

Cohansey sand-an aquifer of great potential . . . . . . . . . . . . . . . . . .

Beacon Hill Gravel-a remnant cap...-.--

Quaternary deposits-an important group of aquifers and a portal for ground-water recharge and discharge..............

Bridgeton and Pensauken formations.-

Unclassified deposits of Pleistocene age.

Cape May and Talbot formations.-.--

Basin-rim sand ...................

Glacial outwash and alluvium .......

Marsh and swamp deposits..........

Beach and dune sand...............

Chemical character of ground-water supplies in Quaternary deposits.--.

Recharge and discharge......................

Patterns of movement........

Ground-water storage

Use of storage . . .

Storage fluctuations and aquifer recharge - -

Natural conditions................

Conditions under development . . ....

The Appalachian Highlands

General features

64

64

64

65

65

65

65

66

66

66

68

69

69

69

69

70

70

70 
Ground water-its availability and character-Continued The Appalachian Highlands-Continued

Occurrence of ground water Crystalline rocks

Gneiss and related crystalline rocks of Precambrian age................. Glenarm series . ................... Quartzose rocks of Cambrian age ..... Basalt and diabase of Triassic age... Hydrologic properties of the crystalline rocks_........................ Chemical character of ground water.-.

Carbonate rocks ........................... Franklin limestone............... Cockeysville marble Carbonate rocks of Cambrian and Ordovician age..................

Carbonate rocks of Silurian and Devonian age

Hydrologic properties of the carbonate

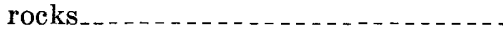

Chemical character of ground water from carbonate rocks.........

Clastic rocks ...........................

Rocks of the Valley and Ridge province

Rocks of the Appalachian Plateaus province................................. Rocks of the Triassic Lowland.......

Unconsolidated sediments of glacial origin. Unstratified glacial sediments....... Stratified glacial sediments........... Chemical character of ground water.-.

Recharge and discharge

Ground-water storage.

Chemical character of ground-water supplies

The Coastal Plain . ...................

The Appalachian Highlands. . . . . . . . . . .

Salt-water encroachment.....................

Surface water-its variations and character ...........

Summary of average annual runoff ..............

Areal variations in average annual runoff .........

Variability of discharge and runoff

Annual runoff .......

Monthly runoff

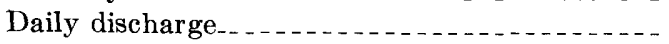

Floods and flood-frequency analysis . . . . . . . .

Causes and occurrence of floods...........

Regional flood-frequency analysis, by R. H. Tice.

Flood-frequency relationships ...........

Mean annual flood......................

Construction of a frequency curve......

Historical floods.

Rare floods.

Some aspects of flood damage and flood control

Droughts and low-flow frequency analyses........

Low-flow frequency, by C. H. Hardison and

R. O. R. Martin ...

Storage required to maintain flows

Base flow of streams

Base-flow recession curves . . . .

Runoff from natural storage.............

Uses of base-flow data.

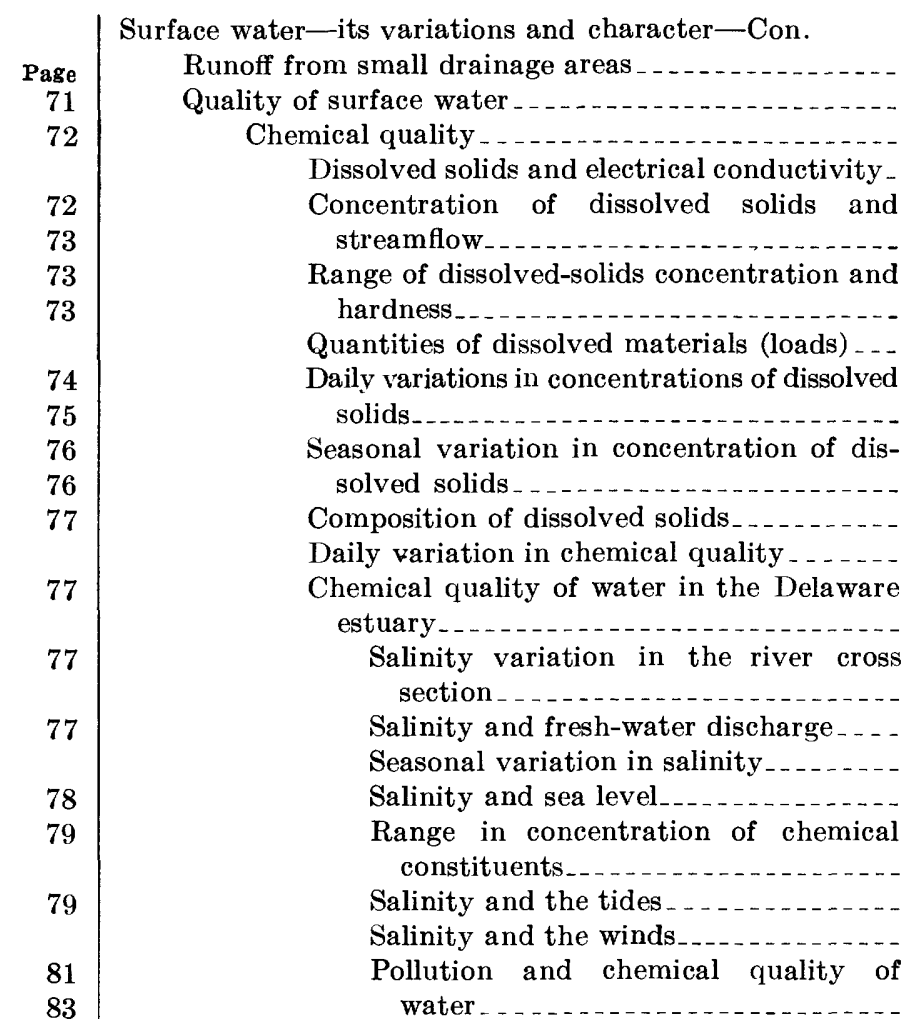

Physical quality ........................

Temperature and its variation..........

Fluvial sediment....................... Suspended sediment................ Transport of streambed material .....

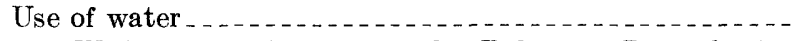

Withdrawal of water in the Delaware River basin,

by John C. Kammerer..............................

Terminology, units, and sources of information -

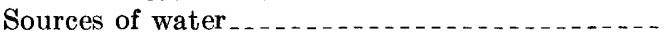

Types of supplies $\ldots$

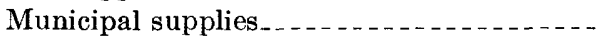

Industrial supplies. ...................

Irrigation and rural supplies..............

Consumptive use, reuse, and average use . . . .

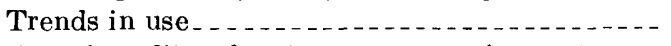

Relation of quality of water to use requirements...-

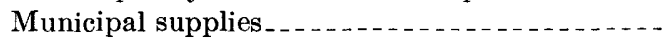

Industrial supplies .

Agricultural supplies . ........................

Use of water from the Delaware estuary ......

Development of the water resources of the Delaware

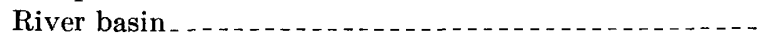

Increasing and protecting the water crop ........

Surface reservoirs........................

Ground-water development and management.-.

Design, development, and operation of wells and well fields..........................

Augmentation of ground-water supplies.-.Induced recharge Artificial recharge..................

Conservation measures . . . . . . .

Reuse and recycling of industrial water Use of low-quality water where high quality is not required.

Elimination of wasteful practices......... 
Development of the water resources of the Delaware

River basin-Continued

Increasing and protecting the water crop-Con.

Conservation measures-Continued

Evaporation suppressants

Land-use practices . . . . . . .

Phreatophytes and swampland......

Protection of water quality

Pollution control

Sediment control .......................

Salt-water encroachment controls . . . . . . . .

Increasing the total fresh-water supply . . . . . . . . .

Weather modification . . . .

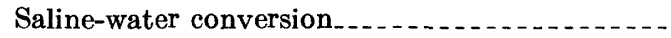

Development of the water resources of the Delaware River basin-Continued

Interbasin diversions . . . . . .

Comparison of available supply and demand......

River Master of the Delaware River, by Robert E. Fish

Historical background of the Delaware River case

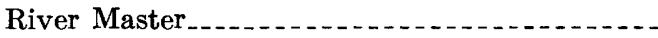

Records for 1956-57.

Decree of U.S. Supreme Court

Selected Bibliography

Index
Page

179

180

181

181

183

184

187

189

195

\section{ILLUSTRATIONS}

[Plates are in separate volume]

Plate 1. Topographic and physiographic map of Delaware River basin.

2-4. Maps of Delaware River basin and New Jersey:

2. Showing average annual temperature in degrees Fahrenheit.

3. Showing average annual and seasonal precipitation, 1921-50.

4. Showing average annual water loss, 1921-50.

5. Geologic map of Delaware River basin and adjacent New Jersey.

6. Fence diagram of Coastal Plain in Delaware River basin and adjacent New Jersey.

7. Map showing surficial geology and extent of glaciation in Delaware River basin and New Jersey.

8. Correlation chart of Paleozoic formations in Delaware River basin and New Jersey.

9. Generalized geologic sections of southern part of Appalachian Highlands.

10-12. Maps of Delaware River basin and New Jersey:

10. Showing locations where surface-water records were obtained to Sept. 30, 1955.

11. Showing approximate average discharge of principal streams by width of line.

12. Showing average annual and seasonal runoff, 1921-50.

Figure 1. Physiographic block diagram of the region.

2. Average monthly temperature at Dover, Del., Allentown, Pa., and Roxbury, N.Y

3. Average monthly potential evapotranspiration and precipitation at Delhi, N.Y. and Philadelphia, Pa......

4. Geologic materials of contrasting hydrologic properties: outcrop of Marcellus shale of Devonian age in Strouds-

burg, Pa., and kame-terrace deposit at Hawley, Pa.

5. Population curves for the Delaware River service area, 1870 1955

6. Urban and rural population of Delaware River basin States, 1790 1950

7. Long-term records of annual precipitation in and near Delaware River basin

8. Actual and normal distributions of annual precipitation

9. Maximum, mean, and minimum monthly precipitation at typical stations

10. Examples of situations where topographic and ground-water divides do not coincide

11. Map of Delaware River basin and New Jersey showing average annual and seasonal evaporation from free water surfaces, 1921-50

12. Configuration of bedrock beneath Coastal Plain

13. Idealized cross section illustrating funnel effect in recharge to Coastal-Plain aquifers . . . . . . . . .

14. Map of nonmarine sediments of Cretaceous age showing their extent, subsurface configuration, and thickness

15. Map of nonmarine sediments of Cretaceous age showing productive area and theoretical interface between fresh water and salt water.

16. Map showing theoretical flow pattern and location of the interface between fresh water and salt water in nonmarine sediments of Cretaceous age under natural conditions

17. Map of Englishtown sand showing its extent, subsurface configuration, and productive area..................

18. Map of Wenonah and Mount Laurel sands showing their extent, subsurface configuration, and productive area

19. Map of Vincentown sand showing its extent, subsurface configuration, and productive area.

20. Map of Piney Point formation showing its subsurface extent, configuration, and productive area..........

21. Martinsburg shale along Delaware River near Delaware Water Gap.

22. Mauch Chunk formation near White Haven, Pa

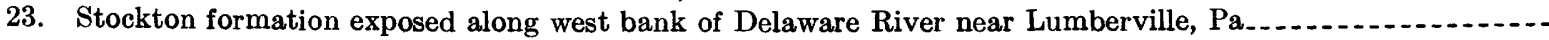

Page 
Figure 24. Bouldery glacial till 2 miles south of Hawley, $\mathrm{Pa}$

25. Geologic cross sections of major stream valleys in northern part of Delaware River basin..................

26. Fluctuations of water levels in representative wells in unconsolidated sediments of glacial origin in northern part of Delaware River basin.

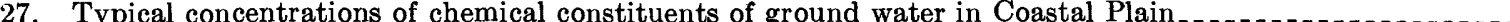

28. Typical chemical compositions of ground water in Coastal Plain

29. Typical concentrations of chemical constituents of ground water in Appalachian Highlands. . . . . . .

30. Typical chemical compositions of ground water in Appalachian Highlands

31. Map showing chloride concentration of water in nonmarine sediments of Cretaceous age, 1957

32. Map showing chloride concentration of water in Kirkwood formation, 1957

33. Map showing chloride concentration of water in Cohansey sand and Quaternary deposits, 1957

34. Annual runoff and 5-year moving averages for three gaging stations.

35. Actual and normal distributions of annual runoff

36. Maximum, mean, and minimum monthly runoff as percentage of average annual runoff for six typical gaging stations, 1921-50.

37. Seasonal changes in the coefficient of variation of monthly runoff, $1921-50$

38. Regionalized daily-flow duration curves for three gaging stations, 1914-53

39. Effect of regulation on the duration of daily flow at two gaging stations

40. Effect of diversion on the duration of daily flow of Schuylkill River

41. Comparison of duration curves of daily and monthly flow of East Branch Delaware River at Fishs Eddy, N.Y., 1921-50

42. Relation curve for obtaining 90-percent daily-flow duration from 90-percent monthly-flow duration . . . . .

43. Composite flood-frequency curves for Delaware River basin and southern New Jersey

44. Relation of mean annual flood to drainage area in Delaware River basin and southern New Jersey ........

45. Map of Delaware River basin and New Jersey showing flood regions used in regional flood-frequency analysis

46. Flood-reduction factor for streams in area 6, figure 45

47. Regionalized low-flow frequency curves for Perkiomen Creek at Graterford, Pa., 1913-52 .

48. Effect of storage on minimum 7-day flow of Perkiomen Creek at Graterford, Pa., 1913-52

49. Comparison of the effects of storage on minimum 7-day flows at selected gaging stations

50. Summer and winter curves of base-flow recession and runoff from natural storage for Little Beaver Kill at Livingston Manor, N.Y.

51. Comparison of base-flow recession and natural-storage characteristics for two adjacent streams in different geologic environments

52. Variation of conductance and concentration of dissolved solids with discharge at two stations . . . . .

53. Usual range of dissolved-solids concentration and hardness at six stations.

54. Monthly loads of dissolved solids at selected stations

55. Variation of dissolved-solids load with discharge, Delaware River at Trenton, N.J., 1949-51

56. Duration curves of concentration of dissolved solids at selected locations

57. Range in position of duration curves of dissolved-solids concentration for two stations

58. Average monthly conductance, Delaware River at Trenton, N.J., and Schuylkill River at Berne, Pa . . . . .

59. Seasonal variations in concentration of dissolved solids at six stations

60. Typical chemical character of water at six stations.

61. Cumulative quantities of chemical constituents in Schuylkill River water

62. Comparison of composition of dissolved solids for selected periods of high and low flow at six stations . . . -

63. Composition of dissolved solids in the ocean and in Delaware estuary

64. Effect on maximum daily chloride concentration in Delaware River at Chester, Pa., of a period of low flow and a large increase in flow.

65. Fresh-water discharge and salinity in Delaware River, July and August 1957

66. Fresh-water discharge and salinity in Delaware River, October and November 1957

67. Average monthly discharge of Delaware River at Trenton, N.J., and average monthly sea level at Atlantic City, N.J., 1923-55.

68. Effect of tides on specific conductance at Reedy Island Jetty, October 1956

69. Hurricane winds relative to position of entrance of Delaware Bay

70. Monthly variation in Delaware River water temperature and air temperature at Trenton, N. J., 1944-52_...

71. Withdrawal of water in Delaware River basin by type of source and type of supply

72. Map showing ground-water pumpage in Coastal Plain of Delaware River basin

73. Effect of regulation on monthly flow of Delaware River at Montague, N.J., December 1955 to November 1957.

74. Effect of regulation on daily-flow duration of Delaware River at Montague, N.J., December 1955 to November 1957

75. Contents, releases, and diversions at Pepacton and Neversink Reservoirs, December 1955 to November 1957 .- 


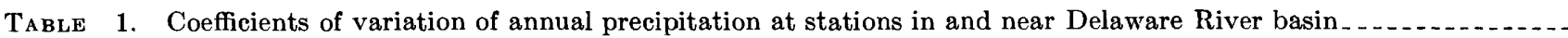
2. Estimated average annual evaporation losses from free water surfaces in Delaware River basin, Delaware, New Jersey, and southeastern New York for water years 1921-50

3. Stratigraphy of Delaware River basin.

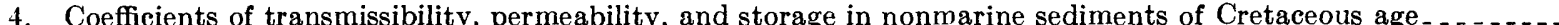

5. Coefficients of transmissibility, permeability, and storage in Cohansey sand

6. Water budget for Coastal Plain in Delaware River basin

7. Ground-water budget for Coastal Plain in Delaware River basin.

8-17. Summary of chemical analyses.

8. Twelve samples of ground water from gneiss and related crystalline rocks of Precambrian age

9. Twenty-two samples of ground water from the Wissahickon formation.

10. Sixty samples of ground water from carbonate rocks in Pennsylvania

11. Nine samples of ground water from the Martinsburg shale

12. Eighteen samples of ground water from the Catskill formation

13. Fifty-four samples of ground water from the Stockton formation

14. Nine samples of ground water from the Lockatong formation

15. Eighteen samples of ground water from the Brunswick formation

16. Twenty-five samples of ground water from glacial outwash and alluvium in central part of Delaware River basin

17. Twenty samples of ground water from glacial outwash and alluvium in northern part of Delaware River basin

18. Water budgets for Pomperaug River basin, Conn., and Appalachian Highlands part of Delaware River basin -

19. Representative chemical analyses of ground water in Coastal Plain of Delaware River region

20. Representative chemical analyses of water in unconsolidated sediments in Appalachian Highlands.......

21. Representative chemical analyses of water in consolidated rocks in Appalachian Highlands .

22. Bar graph showing periods of surface-water records to September 30, 1955

23. Summary of average annual discharge, precipitation, and runoff for areas above selected gaging stations, 1921-50.

24. Coefficients of variation of annual runoff for selected gaging stations

25. Regionalized duration of daily flow at selected gaging stations on unregulated streams, 1914-53 .

26. Regionalized duration of daily flow at selected gaging stations on regulated streams, 1914-53 .

27. Duration of daily flow at selected gaging stations, 1921-50.

28. Duration of monthly flow and equivalent 90-percent duration of daily flow at selected gaging stations, 1921-50..

29. Minimum 7-day and 30-day discharges that recur at 2-year and 20-year intervals, 1913-52

30. Minimum 7-day flows that could be maintained for selected recurrence intervals with indicated amounts of storage, 1913-52.

31. Summer base-flow recession and natural storage characteristics for selected gaging stations

32. Equations for the estimation of the dissolved-solids concentration from the measured specific conductance

33. Monthly and annual loads of dissolved solids for selected drainage areas...

34. Average annual loads of dissolved solids carried by streams from specified areas . . . . . . . . .

35. Specific electric conductance and concentrations which were equaled or exceeded in percent of days shown $\ldots . .$.

36. Effect of high streamflow on salinity in Delaware estuary, 1955

37. Range in concentrations of mineral constituents in water of Delaware estuary

38. Temperatures which were equaled or exceeded in percent of days shown

39. Temperatures which were equaled or exceeded in percent of days shown, by months, for Schuylkill River at Philadelphia, Pa., 1946-52.

40. Annual sediment load at six selected stations and annual runoff at one station for comparison

41. Withdrawal of water in Delaware River basin by State parts of the basin, 1955

42. Withdrawal of water in the Coastal Plain of Delaware River basin by type of supply and geologic source for each county, 1956-57.

43. Source and type of withdrawal by large municipal water systems serving areas within Delaware River basin, 1955

44. Withdrawal of water by Philadelphia Water Department, 1946-57

45. Withdrawal, discharge, and evaporation of water by steam-electric generating plants, Delaware River basin, by counties, 1954

46. Withdrawal, discharge, and recirculation of water by manufacturing industries in Delaware River basin, by selected counties, 1954

47. Withdrawals by nine large municipal water systems for selected years, 1895-1955.

48. Suggested water-quality tolerance for boiler-feed water

Page

18

26

44

52

63

67

67

76

76

78

80

83

85

85

87

90

90

91

96

96

97

105

110

115

120

121

121

121

131

135

137

140

142

143

150

153

154

158

158

160

163

164

165

165

166

166

168

169 



\title{
WATER RESOURGES OF THE DELAWARE RIVER BASIN
}

\author{
By Garald G. Parker, A. G. Hely, W. B. Keighton, F. H. Olmsted, and Others
}

\section{ABSTRACT}

The Delaware River basin, including areas tributary to Delaware Bay, contains 12,765 square miles. This area occupies major parts of Delaware, New Jersey, Pennsylvania, and New York, plus an 8-square mile area in Maryland. In 1950 about 6 million people lived within the basin and about 14 million lived in the New York metropolitan area, which now obtains part of its water supply from the Delaware River basin. The population of these areas doubled between 1900 and 1950 and is still increasing rapidly (1958).

Requirements for water are increasing even more rapidly than the population, chiefly because of the rapid expansion of industry and irrigation. Many serious local water problems which had developed by 1955 may be expected to increase, because the estimated water requirements in $\mathbf{1 9 7 5}$ are approximately double those of 1955 .

The basin and adjoining areas occupy parts of two major physiographic divisions separated by the Fall Line, which extends northeastward across the region through Wilmington, Del., and New York, N.Y.

The Coastal Plain lies southeast of the Fall Line and is underlain by a seaward-thickening wedge of deposits that attains a thickness of more than 6,000 feet beneath the mouth of Delaware Bay. These deposits consist of a sequence of alternating sandy or gravelly aquifers and clayey or silty aquicludes and contain enormous quantities of water. Most of the aquifers yield moderate to large amounts of water to wells and help to maintain streamflow at relatively high levels during fair-weather periods. The aquicludes are of value chiefly-and importantly-in helping to prevent salt-water encroachment from upper contaminated zones to underlying fresh-water aquifers.

Northwest of the Fall Line is the Appalachian Highlands division. This division occupies the upper three-fourths of the basin and is characterized by rolling uplands, ridges, valleys, and plateaus; it is underlain predominantly by consoljdated rocks of complex composition and structure. The consolidated-rock aquifers include three major types: (1) crystalline rocks, such as granite, gneiss, and basalt; (2) carbonate rocks, such as limestone and dolomite; and (3) clastic rocks, such as shale, sandstone, and conglomerate.

Consolidated-rock aquifers ordinarily store and transmit much less water than the unconsolidated granular aquifers of the Coastal Plain, and in most places only small or moderate individual ground-water supplies can be developed from consolidated rocks.

Aquifers of large yield occur, however, in the glacial outwash which underlies many. valleys throughout both the northern glaciated part of the region and the southern part, beyond the limits of the continental ice sheets of the Pleistocene epoch. Because of the smaller natural storage capacity of rocks in the Appalachian Highlands, the streams generally have higher floodflows and lower fair-weather flows than those of the Coastal Plain.
The average annual water budget of the basin, based on the standard period $1921-50$, is:

Precipitation $(P)=44$ inches (30 million acre-ft, or 9.8 trillion gal).

Water loss $(L)=23$ inches $(16$ million acre-ft, or 5.1 trillion gal).

Runoff $(R)=21$ inches (14 million acre-ft, or 4.7 trillion gal).

The runoff of $4.7 \mathrm{tgy}$ (trillion gallons per year) represents approximately the ultimate, though practically unattainable, "water crop"; it is the only part of the hydrologic cycle that is manageable, to any considerable extent, for human needs. This figure of 4.7 tgy represents much more than the quantity that is harvestable, however, because part of $R$ is flood runoff that cannot be economically stored. Also, part of $R$ must be reserved for the dilution of wastes, to flush salt water frcm the estuary, and for other nonwithdrawal purposes.

Increased use of the natural storage capacity of aquifers and of surface storage reservoirs will capture a much larger part of the potential supply and make it available for use. For instance, if storage capacity equivalent to 50 million gallons per square mile of drainage area were made available above each of the four following locations, the approximate increase in allowable draft rate would be:

Station $\quad$ Mod

$\begin{array}{ll}\text { East Branch Delaware River at Fishs Eddy, N.Y --- } & 350 \\ \text { West Branch Delaware River at Hale Eddy, N.Y --- } & \mathbf{2 5 0}\end{array}$

Neversink River at Oakland Valley, N.Y ........ 100

Lehigh River at Bethlehem, Pa.............. 560

Total

Thus, even moderate development of surface storage in strategic locations would augment low flows and provide abundant water to meet much larger demands than those predicted for 1975 , at which time the maximum consumptive use may reach about $610 \mathrm{mgd}$ (million gallons per day).

Large expansions of ground-water developments can be made both in the Appalachian Highlands and in the Coastal Plain. It should be understood however, that if any such developments are made they will be done chiefly, although not entirely, at the expense of streamflow.

In the Appalachian Highlands part of the basin, an area of about 9,700 square miles, the estimated annual ground-water recharge (potential ground-water crop) is about $0.75 \mathrm{mgd}$ per sq mi. This is about 7.3 bgd (billion gallons per day), or 2.65 tgy. Current pumpage is only about $130 \mathrm{mgd}$, or about 2 percent of the annual ground-water recharge. Greatly increased pumpage could be obtained, especially from the glacial outwash deposits where wells yielding as much as $1,000 \mathrm{gpm}$ (gallons per minute) have been constructed.

In the Coastal Plain, ground-water sources are annually recharged by about $1.1 \mathrm{mgd}$ per sq $\mathrm{mi}$. At this rate the 2,750 
square miles within the Delaware River basin receive an annual recharge of about $3.0 \mathrm{bgd}$ or $1.1 \mathrm{tgy}$. By comparison, this is equivalent to about 40 percent of the average flow of the Delaware River at Trenton, N.J., which is $7.6 \mathrm{bgd}$. Water pumped from the Coastal Plain aquifers within the basin is estimated to be about $210 \mathrm{mgd}$; thus, only about 7 percent of the annual ground-water recharge in the Coastal Plain is being pumped. The principal controls governing additional development are a variety of hydrologic, economic, engineering, legal, and political factors.

An adequate water supply must be satisfactory in quality as well as in quantity. The quality determines the usefulness of a water supply and, because of pollution loads, may also determine the minimum flow that can be tolerated in principal streams. The chemical quality is closely related to such factors as magnitude of streamflow, geology of the drainage area, salt-water encroachment, and disposal of municipal and industrial wastes.

Information on the quality of ground water in the Delaware River basin is scarce. From the data available we conclude that, in general, the ground-water supplies of the basin are satisfactory for most uses and that they will remain so provided that the aquifers do not become contaminated with saline water or with wastes.

Most of the surface water in the basin is of good quality, but serious local problems have developed, particularly in the Schuylkill River basin and along the Delaware estuary. A large part of the water withdrawn for use in the Delaware River basin is obtained from the Delaware estuary. The quality of the water at Trenton, N.J. (the upper limit of tidewater) is good. However, large quantities of wastes are discharged to the estuary at, and especially below, Trenton; also, the fresh river water mixes with sea water, principally below Chester, $\mathrm{Pa}$., and at times significant salinity extends upstream as far as Philadelphia.

Salt-water encroachment and pollution, or contamination, by industrial and municipal wastes are the two principal causes of deterioration of water quality. Salt-water encroachment results chiefly from a slowly rising sea level that causes saline water (defined herein as water in which the concentration of dissolved solids is greater than 1,000 parts per million) to move upstream, or inland, beyond normal limits. Pollution increases with growth of population and expansion of industry. Augmentation of low flows increases the dilution of wastes and helps to prevent the upstream movement of saline water.

Drainage from mines in the area above Reading, Pa., on the Schuylkill River, is acid and has an unusually high concentration of dissolved solids. The mine drainage makes the Schuylkill River acid to a point near Reading, Pa., where alkaline water enters the river and neutralizes the acid. Organic matter in acid water tends to remain unchanged for long periods. Consequently, if a reservoir were built where the stream is acid, sewage wastes might accumulate and create serious health hazards and esthetic nusiances.

Sediment in streams of the Delaware River basin creates difficult problems even though sediment concentrations are commonly lower than in streams of the arid or semiarid western United States. These problems are concerned with water treatment, maintenance of harbors and shipping channels, sedimentation of reservoirs, recreation, fish and wildlife, and other aspects of water-resources development.

The available sediment data are not sufficient to provide a suitable basis for estimating the useful life of reservoirs. However, many small reservoirs built 50 or more years ago have been completely filled with sediment.
The most serious sediment problem in the basin was created by uncontrolled dumping of mine waste which contaminated the Schuylkill River throughout its length and the Delaware River near its confluence with the Schuylkill. An extensive restoration project and State control of such waste disposal have virtually corrected this situation. Land-conservation measures practices in the Brandywine Creek valley appear to have reduced significantly the amount of sediment carried by the stream.

Demands for water are increasing rapidly, both within the basin and in the metropolitan areas of New York City and northeastern New Jersey; further, these demands are expected to continue to increase. The use of water tends to increase more rapidly than the population, largely because of the rapid growth of industry in which uses are much greater than the combined uses of water for domestic, commercial, and public purposes. In 1955, total per capita use of water in the Delaware River basin was between 1,000 and 1,100 gpd (gallons per day), based on an average withdrawal of $6.1 \mathrm{bgd}$ and an estimated population of between 5.7 and 6 million. Per capita use of municipal supplies was between 60 and 220 gpd.

The greater part of the per capita use of more than 1,000 gpd in the Delaware River basin was by large water-using industries, such as steel, petroleum, and chemicals. About 87 percent of the water used in the basin was self-supplied by industry. Of this industrial withdrawal, which amounted in 1955 to about $5,280 \mathrm{mgd}$, about $5,100 \mathrm{mgd}$ was from streams and $180 \mathrm{mgd}$ was from wells.

Irrigation of farm crops by the sprinkler system is used widely in this region. As about 90 to 95 percent of the water so applied is used consumptively, it is a particularly important use. Furthermore, acreage under irrigation is increasing rapidly, especially in the Coastal Plain. The U.S. Census Bureau reported 32,500 acres in 5 New Jersey counties and 4,300 acres in 2 Delaware counties under irrigation in 1954. These had increased, respectively, 110 percent and 1,000 percent since 1949.

Water withdrawals (use) in 1955 in the Delaware River basin was about 6.1 bgd or 2.23 tgy. About 95 percent of this comes from surface water and the remainder from ground water, and about 98 percent of it is used for municipal and industrial purposes. Additionally, about $1.6 \mathrm{bgd}$, totaling about $0.6 \mathrm{tgy}$, is used for generation of hydroelectric power.

Almost all water withdrawn for use within the basin is returned to the streams after use; therefore, the withdrawal use figures include a substantial amount of reuse. About 70 percent of all water use in the basin occurs in the 11 counties bordering the Delaware estuary between Trenton, N.J., and Wilmington Del.

Because water may be used over again and again, a comparison of withdrawal use and total potential supply $(R)$ would be meaningless or highly misleading. On the other hand, comparison with consumptive use of water may be of value. In 1955 , consumptive use of Delaware River basin water, including 38 mgd to New Jersey (through the Delaware and Raritan Canal) and $350 \mathrm{mgd}$ to New York City (equivalent to consumptive use in the Delaware basin as it is no longer available for reuse there) amounted to $600 \mathrm{mgd}$. This use is about $2.19 \mathrm{bgy}$ (billion gallons per year), or a little less than 5 percent of $R(4.7 \mathrm{tgy})$. These consumptive-use figures refer to annual averages. Considerably larger water uses, however, are made during dry seasons or droughts. For example, maximum water use per day by municipalities may be three times greater than the average daily use. Maximum use per day for the Delaware River basin in 1955 is estimated to be about $670 \mathrm{mgd}$, which is only about 11.6 percent 
larger than the average use per day. It might seem, therefore, that water use could be greatly expanded without increased storage.

Another, and better, means of comparison exists. This is a comparison of the maximum daily rate of consumptive use to low flows of the Delaware River. In making such a comparison, diversions to other basins are included in the consumptive use if they deplete low flows (as the New Jersey diversion via Delaware and Raritan Canal) but are excluded if they do not deplete low flows (as the New York City diversions). New York City's water management operations related to diversions actually increase the usable supply in the basin during times of low flow. This is accomplished by releasing water stored during times of high flow-water that would otherwise have wasted to the sea.

In 1955 the maximum daily rate of consumptive use within the basin was about $280 \mathrm{mgd}$ and diversions to New Jersey were $38 \mathrm{mgd}$, for a total of about $320 \mathrm{mgd}$. The minimum 7-day flow that can be expected once in 20 years from the entire Delaware River basin drainage is about $1,700 \mathrm{mgd}$. This is more than five times the maximum rate of consumptive use in 1955 Thus, we conclude that there is ample water to meet current rates of consumptive use and to allow for some expansion. We still do not know, however, how much water will be required for waste dilution, navigation, and similar needs and for flushing salt water from the estuary. The existence of serious local problems now indicates that future increases in water demand must be met by increasing available supplies.

The amount of water available for use can be increased principally by utilization of storage, both of surface and groundwater sources. Because of the great geologic and topographic differences of the two major divisions of the kasin, development of water supplies will be accomplished in the Coastal Plain largely by utilization of aquifers and in the Appalachian Highlands largely by utilization of surface reservoirs. However, aquifers in the Appalachian Highlands and surface reservoirs in the Coastal Plain may provide many small supplies that contribute significantly to the total.

The quantity of water obtainable from aquifers hydraulically connected with streams and lakes may be augmented by induced recharge from those bodies. For example, by pumping from wells adjacent to the estuary below Trenton, N.J., where the river water is fresh, induced recharge of about $100 \mathrm{mgd}$ may be obtained by well-planned development. Artificial recharge with excess streamflow may be used both to prevent contamination and to augment ground-water supplies. Augmenting groundwater supplies with surface water does not increase the total supply, but it does increase its availability; the water stored would otherwise have wasted to the sea.

Water supplies of the Coastal Plain are, in general, more than adequate to meet the foreseeable future needs for irrigation. Additionally, parts of the area east of the basin are a potential source for diversion of water to the Camden, N.J., area and to coastal resorts, such as Atlantic City, N.J. It may be practical to obtain $500 \mathrm{mgd}$ or more chiefly from aquifers of the Pine Barrens, an area of about 2,000 square miles in south-central New Jersey.

Conversion of brackish water from the Delaware and Hudson estuaries may eventually become locally competitive with fresh-water supplies, thus helping to relieve the struggle for additional water. There seems to be scant hope of increasing the Delaware Basin supply by weather-modification practices.

Conservation measures, such as more and better treatment of wastes, reuse of water that is now discharged to the ocean or other unusable water body, and recycling of water in industrial plants, could become highly important in meeting the water requirements for the future.

Development of the water resources of the basin is limited more by economic and human factors, such as costs and water rights, than by the magnitude of the potential supply of water of good quality.

\section{INTRODUCTION}

Unusually large and increasing demands are made of the water resources of the Delaware River basin because of its proximity to great urban and industrial centers. The basin covers major parts of four States; consequently, large-scale development of water resources in any one State may seriously affect the rights of the others. Such development has begun and additional development probably will be required in the next few years to provide enough water to meet the increasing demands.

Development of water supplies to meet the needs of all parts of the basin, and other areas that are partly dependent on it, requires an appraisal of the water resources of the entire basin. Present and future demands also must be considered. Although many reports have been written on various phases of the water resources of parts of the basin, no previous attempts have been made to describe the water resources of the basin as an entity and to show the effects of the natural environment and of man's activities on the available water supply. This report is primarily a summary and analysis of hyrologic data and wateruse data for the basin, but it includes some discussions on part or all of eastern New Jersey. Additionally, the report discusses the gross supply and water available for use by man, the variations in both quantity and quality of the supply and the factors affecting these variations, and the interrelations between the factors.

\section{ACKNOWLEDGMENTS}

Garald G. Parker, geologist, directed the Delaware River basin project and is senior author of the report. Special assistance was given by Tinco E. A. van Hylckama, who prepared basic information on climate, weather, and evapotranspiration, by J. Stuart Meyers, who developed data on evaporation from open bodies of water, marshes, and swamps, and by several other specialists whose names are given in the text.

Several U.S. Geological Survey field offices also contributed data and made special studies. Surfacewater data for Delaware and Maryland were furnished by John W. Odell, for New Jersey by Donald F. Dougherty, for Pennsylvania by John J. Molloy, and for New York by Arthur W. Harrington. Data on quality of water were furnished for Delaware, New Jersey, and Pennsylvania by Norman H. Beamer, James H. Culbertson, and John W. Wark, and for 
New York by Felix H. Pauszek. Ground-water data were furnished and special hydrogeologic studies were made for Delaware by William C. Rasmussen; for New Jersey by Henry C. Barksdale, Allen Sinnott, Paul R. Seaber, Solomon M. Lang, and Leo Jablonski; for Pennsylvania by David W. Greenman, Donald R. Rima, Norman H. Blanchard, Jr., and William N. Lockwood; and for New York by George C. Taylor, Jr., Nathaniel M. Perlmutter, Edward H. Salvas, Julian Soren, and John Isbister.

Additional geologic information, much of it unpublished, was furnished by Carlyle Gray, State Geologist of Pennsylvania; Meredith E. Johnson, State Geologist of New Jersey until 1958, and his successor, Kemble Widmer; Johan J. Groot, State Geologist of Delaware; Horace G. Richards of the Philadelphia Academy of Natural Sciences and the University of Pennsylvania; Edward H. Watson and Lincoln Dryden of Bryn Mawr College; Bradford Willard of Lehigh University; Herbert P. Woodward of Rutgers University; and Paul MacClintock of Princeton University. Horace G. Richards assisted in the study of the geology of the Coastal Plain, especially with interpretations of the stratigraphic relations in that region.

\section{THE DELAWARE RIVER REGION AND ITS WATER PROBLEMS}

\section{THE ROLE OF WATER RESOURCES IN THE MODERN} COMMUNITY

The available water supply has long been recognized as a principal limiting factor in the development of the drylands (arid and semiarid regions) of the western United States. The humid eastern States, by contrast, have been almost free of this limitation; but even so, the relative abundance of water in some areas and scarcity in others is important in establishing the pattern of regional development. Today, many densely populated areas are faced with serious water problems, and some eastern cities import water fron distant sources to augment local supplies.

The very life of a community depends on the availability of adequate supplies of water suitable for the many domestic, commercial, public, and industrial uses. Many industries require vast quantities of water. In the Philadelphia metropolitan area, for example, the use of water by industry is many times greater than the total domestic, commercial, and public use. Future growth of population and industry depends on the availability of additional supplies or better utilization of existing supplies.

Recreational areas with streams and lakes suitable for fish and wildlife, swimming, boating, camping, and other outdoor activities become more important as the population increases, but usually are more difficult to maintain because of pollution of streams and decreases in low flows.

The supply of water available without extensive development differs from place to place. The demand for water also varies greatly, and maximum demand generally occurs at times of minimum streamflow and low ground-water levels. Consequently, as population increases and industrial growth proceeds, serious water problems arise unless planning and development of the water supply keep pace with, or ahead of, the everincreasing demand.

Low-lying lands along many large rivers and in mountain valleys make attractive sites for urban, industrial, and agricultural development for many reasons, including readily available water supply, water or rail transportation, relatively flat terrain, and superior soils; however, such advantages generally are accompanied by flood hazards, and flood protection must be provided if serious damage and loss of life are to be avoided or minimized.

\section{THE DELAWARE RIVER BASIN AND ITS ENVIRONMENT}

Large-scale diversion of water from the Delaware River basin has already begun, and by 1951 some water was already being imported into the Delaware basin from the Susquehanna. Consequently, the problems of the basin cannot be completely separated from those of the adjacent regions. A discussion of some of the pertinent features of the basin and the region of which it is a part will help to clarify some of the specific water problems of the area.

\section{GENERAL DESCRIPTION}

The Delaware River and its tributaries are of unusual importance not because of the volume of flow or the size of the drainage areas, but because they serve the Nation's most densely populated and intensively industrialized area, which includes the New York City and Philadelphia metropolitan areas and several smaller ones (pl. 1). The river and the streams tributary to Delaware Bay drain an area of 12,765 square miles. This area is divided among five States as follows:

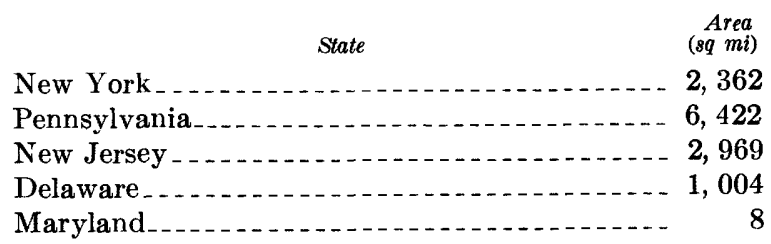

The Delaware River basin is bounded on the north and west by the drainage basin of the Susquehanna River in New York, Pennsylvania, and Maryland; on the east by the lower part of the Hudson River basin in New York and New Jersey and by the Passaic and Raritan River basins and many smaller basins in New 


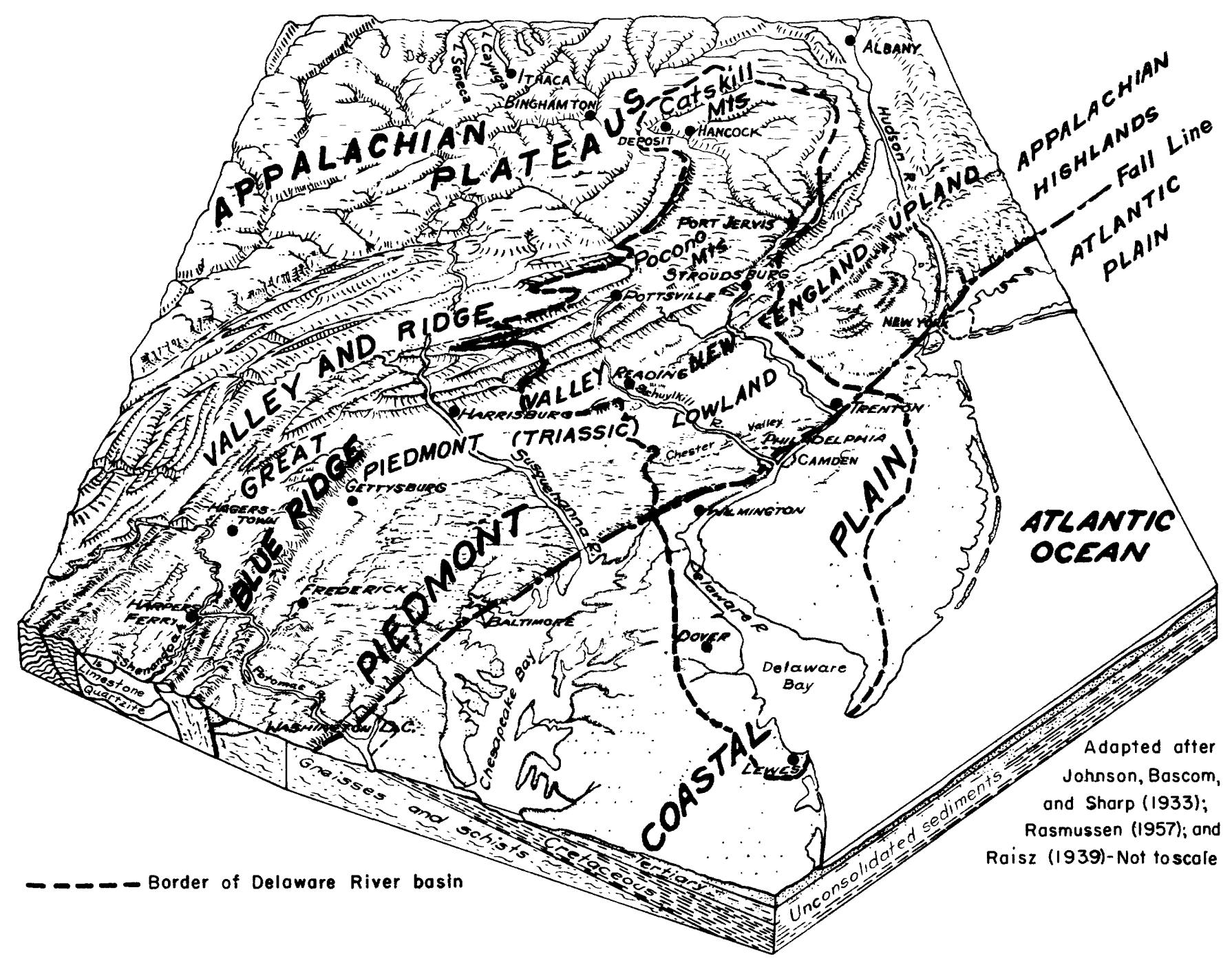

FrguRe 1.-Physiographic block diagram of the region.

Jersey; and on the south by small basins in Delaware and Maryland.

The Fall Line, which passes through Baltimore, Md., Wilmington, Del., Trenton, N.J., and New York, N.Y. (fig. 1), divides this region into two parts with markedly different topographic, geologic, and hydrologic characteristics. The Appalachian Highlands lie northwest of the Fall Line. Much of this region is forested and is characterized by ridges and valleys, plateaus and mountains. Bedrock in most places is hard and dense and is relatively close to the surface. In general, the rock formations are geologically old and, having undergone a long and involved history, are structurally complex. Some of the rocks contain numerous cracks and solution channels caused by earth movements and weathering; other rocks are almost impervious to water.

During the Pleistocene epoch, or Great Ice Age, continental glaciers occupied the northern part of the region several times (pl. 7). The most important effects of the ice sheets were the scouring of soil from the upland and the deposition of glacial debris in many areas. Most of these deposits are more permeable than the underlying materials and are of considerable importance in the development of local water supplies that may, in favorable places, be of considerable magnitude.

The Coastal Plain, an area of low relief lying southeast of the Fall Line, consists of deposits of unconsolidated clay, silt, sand, and gravel overlying the bedrock. The bedrock surface dips southeast at a rate of about 76 feet per mile, and ranges from a few feet below the land surface near the Fall Line to more than 6,000 feet below the mouth of Delaware Bay. Huge quantities of water are stored in the unconsolidated sediments of the Coastal Plain, and they assume great importance in the general circulation and future use of water in the area. 
In the Appalachian Highlands most streams have moderate to steep slopes. In the Coastal Plain, stream slopes are very flat, and at many places tidewater extends inland for long distances. The Delaware River crosses the Fall Line at Trenton, N.J., and flows along it from there to Wilmington, Del. The river is tidal below Trenton. Fresh water of the river mixes with saline water in the lower reaches, the upper limit of saline water generally being near Marcus Hook, Pa., at the Pennsylvania-Delaware State line. Water is usually considered saline (salty) when the dissolvedsolids content (salts) is $1,000 \mathrm{ppm}$ (parts per million) or more. The salt content increases gradually between Marcus Hook and the head of Delaware Bay.

The great concentrations of population and industry are along the Fall Line and in the lower parts of the Lehigh and Schuylkill River valleys. The total population of the Delaware River service area (fig. 5) in 1955 was more than 21 million. More than 4 million of these people were in the Philadelphia metropolitan area and more than 14 million were in the New York metropolitan area east of the basin. Both these areas contain major seaports and industrial, financial, and commercial centers. Ocean-going vessels navigate the Delaware River up to Trenton, N.J.

North and west of the major urban areas, the basin is occupied by a rural population with many small towns and cities. The northern part of the area, including the Catskill and Pocono Mountains, is famous as a resort area conveniently located to serve the huge population in the urban centers. The west-central part (headwater areas of Lehigh and Schuylkill Rivers) is also mountainous but is noted chiefly as a coalmining region which includes some of the largest anthracite deposits in the nation. Agriculture and dairying predominate in the lower parts of the Appalachian Highlands and in some of the mountain valleys.

In the Coastal Plain, southeast of the urban centers, agricultural and dairying industries are concentrated in the Delaware River basin and east of it. However, a large area in this region, the Pine Barrens, is covered by a forest of scrub trees having little economic value. Much of the Atlantic coast in New Jersey is a thickly populated resort area.

The New York metropolitan area now depends on the Delaware River basin for a large part of its water supply. Other areas in New Jersey and Delaware, east and south of the basin, obtain some water from the basin and are expected to obtain more in the future. Th eregion east of the Delaware River basin, including the New York metropolitan area and parts of Delaware (totaling about 17,000 square miles), is included in the Delaware River service area, but not all this service area, is dependent on the Delaware River basin for supplemental supplies. For example, the Pine Barrens is a possible source of water for diversion both to the Camden-Gloucester, N.J., area and to nearby seashore communities.

Another major source for possible future diversion to parts of the Delaware River service area is the Susquehanna River basin. Although this basin contains many cities and towns, the concentrations of population and industry do not approach those in the Delaware River service area. Water is already being diverted from the Susquehanna River basin to supply the city of Chester, Pa.

\section{THE CLMMATE}

Most of the region has a continental climate, because the prevailing direction of air movement is from west to east at this latitude. Consequently, winters are rather cold and summers generally are warm or hot; however, a strip along the coast and around Delaware Bay is influenced considerably by the moderating effect of the sea and therefore might be said to have a modified continental climate.

The effects of elevation, combined with those of latitude, make the central and northern parts of the Delaware River basin considerably colder than the southern part and the Coastal Plain.

Temperature characteristics of the region are summarized in plate 2-a map showing areal variations in the average annual air temperature-and in figure 2-a graph showing average monthly temperatures for three typical weather stations. The map shows a range in average annual temperature from $44^{\circ} \mathrm{F}$ in the mountains of the northern part to $56^{\circ} \mathrm{F}$ in the southern lowlands. The pattern of equal temperature lines is controlled largely by ground elevation and latitude. The graph of monthly temperatures indicates that the pattern of seasonal variation is remarkably similar throughout the area.

The precipitation is generally abundant and rather evenly distributed throughout the year, but marked variations do occur; these are discussed in a later section. Though the region has no distinct wet or dry season, there is a pronounced difference in the winter and summer precipitation. Winter is characterized by more cloudy and rainy days than summer, which is characterized by thundershowers that often are sharply localized; thus, the winter precipitation is usually more widespread and less intense than the summer precipitation.

Floods may occur at any season; some of the most damaging have been associated with hurricanes, which have been relatively rare in this region. Droughts also may occur at any season, including winter. Winter droughts, however, often escape public notice and are 


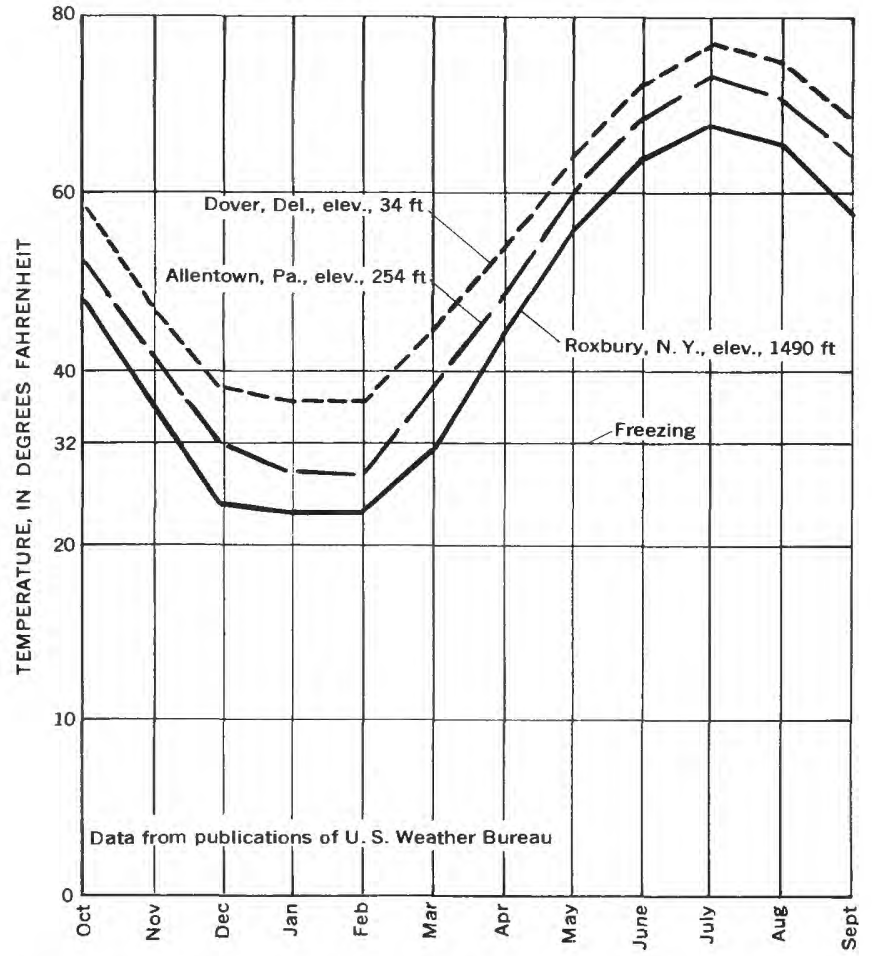

Figure 2.-A Aerage monthly temperature at Dover, Del., Allentown, Pa., and Roxbury, N.Y.

frequently not of immediate concern because their effects do not become apparent until the following growing season.

The inadequacy of climatic descriptions or classification based on yearly average data alone was forcefully demonstrated by Thornthwaite (1948, p. 55-94). He pointed out that climates differ greatly, depending largely on the distribution of the annual precipitation over the year. For example, three separate regions might have the same average annual precipitation and temperature, but one might be characterized by even distribution with resulting luxuriant plant growth, the second by cold wet winters and hot dry summers, and the third by cold dry winters and hot humid summers.

If enough water is available to supply the needs of plants and to maintair soil moisture, the combined evaporation from the soil and transpiration through the plants (evapotranspiration) proceeds at a maximum rate, which is called potential evapotranspiration. Thornthwaite developed an empirical formula for computing potential evapotranspiration from temperature and length of daylight. Average monthly potential evapotranspiration is compared with average monthly precipitation at Delhi, N.Y., and Philadelphia, Pa., in figure 3.

At Delhi the average potential evapotranspiration slightly exceeds the average precipitation for only a short period, whereas at Philadelphia the difference is much greater because of the higher temperature.

The actual evapotranspiration is somewhat less than the potential when the soil surface is not wet or when the root zone has less moisture than the plants could withdraw if it were available. Moisture withdrawn from the soil makes up at least a part of the difference between potential evapotranspiration and precipitation. In a humid climate the graph of actual evapotranspiration is very similar to that of potential evapotranspira-

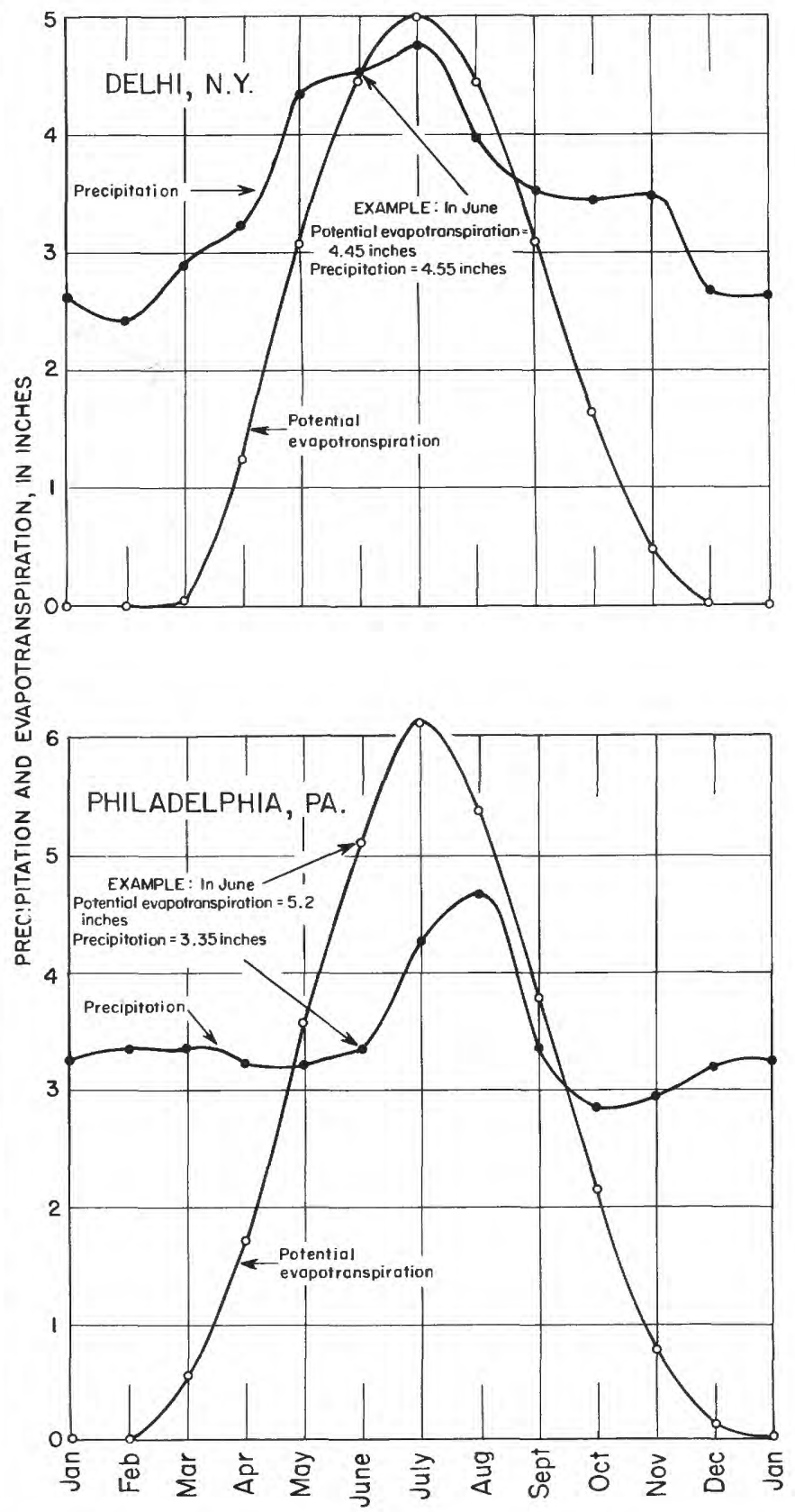

FIGURE 3.-Average monthly potential evapotranspiration and precipitation a Delhi, N.Y., and Philadelphia, Pa. 
tion. The increased evapotranspiration in summer is the principal cause of lower streamflow during that season.

\section{WATER PROBLEMS OF THE DELA WARE RIVER BASIN}

\section{NATURAL VARIATIONS IN SUPPLY}

Although the region is one of almost uniform precipitation and runoff, variations are great enough to cause distress at times even in areas where demands on the water supply are not great. At Philadelphia, $\mathrm{Pa}$., for example, the monthly precipitation has ranged from less than 0.1 inch to more than 15 inches. Conse-
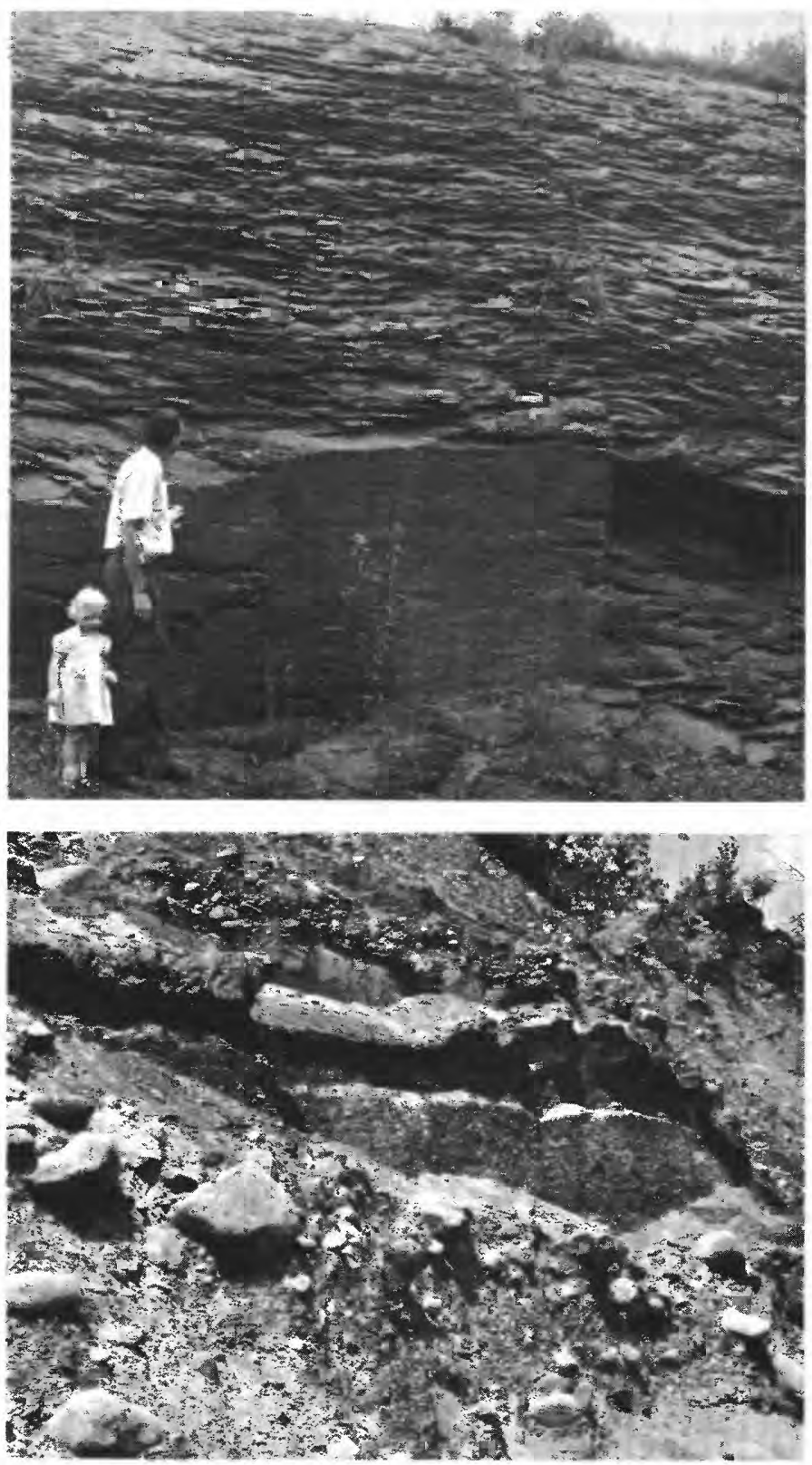

FIGURE 4.-Geologic materials of contrasting hydrologic properties: above, outcrop of Marcellus shale of Devonian age in Stroudsburg, Pa.; below, kame-terrace deposit at Hawley, Pa. quently, crops are damaged from drought or from flood. Similarly, the monthly runoff of Lehigh River at Bethlehem, Pa., has ranged from less than 0.3 inch to more than 10 inches. The low flows of many unregulated streams are insufficient to meet requirements for water supply and dilution of wastes.

Although most current and past water problems in the basin are concerned with shortages of good water, excessively high storm runoff causes considerable damage. The flood problem was considered to be minor until the floods of August 1955 caused unprecedented loss of life and damage and created an urgent

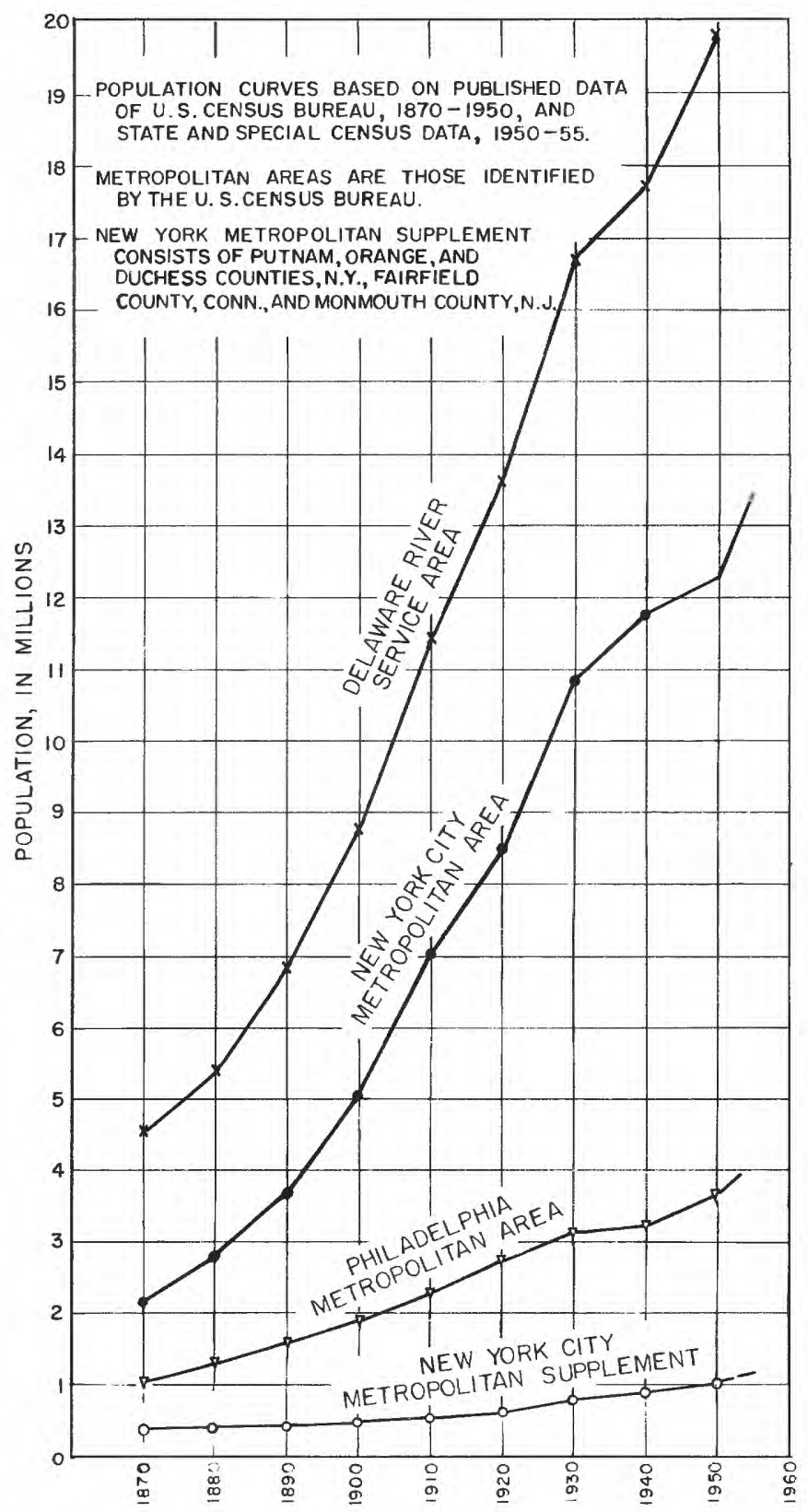

FigURE 5.-Population curves for the Delaware River service area, 1870-1955. 
demand for protection from such floods. There is also an increasing interest in reducing the damages from more frequent, but less spectacular, floods.

Yields of wells in the region range from less than a few gallons per minute to several thousand gallons per minute, depending on the geology. The variations in geology, as they affect the occurrence, movement, and chemical character of water, are so complex in most of the region, particularly in the Appalachian Highlands, that evaluation of the quantity and quality of the recoverable ground water can be made only after detailed, local geologic investigation. Figure 4 illustrates geologic materials of contrasting hydrologic properties.

The chemical quality of natural waters also differs, depending on the kinds of rock with which the water comes into contact and the length of time that contact is maintained. Thus, ground-water supplies generally contain more dissolved solids than fresh surface water, and the concentrations of dissolved solids in surface water are highest during times of low flow. Treatment of some supplies to remove or alter the dissolved solids is desirable or necessary for many purposes.

All these variations are considered in greater detail in later sections.

\section{GROWTH OF POPULATION AND INDUSTRY}

The population of the Delaware River service area more than doubled between 1900 and 1950. The increases since 1870 for the service area and for three metropolitan areas are shown in figure 5 .

Coupled with the population growth is a tremendous expansion in industry. For this report the principal interest in industry is in the water requirements. Figures on use of water by industry are available only for recent years, and such use is summarized in a later section on water use (p. 160-169).

Even if the increases in population and industry were uniformly distributed over a large area, problems would arise from the steadily increasing demand. The increases, however, are not evenly distributed but are largely concentrated in a few metropolitan areas. The resulting concentration of demand greatly magnifies the water problems. The change from predominantly rural to predominantly urban population between 1790 and and 1950 is shown by figure 6 .

The continued growth of population and industry will require extensive and integrated development of water resources of the entire Delaware River basin to make a much larger part of the water supply available for use.

INCREASING AGRICULTURAL AND RECREATIONAL USES

Irrigation of farm crops, which requires water when water supplies are scarcest, is profitable under certain circumstances, and since 1950 has increased rapidly.
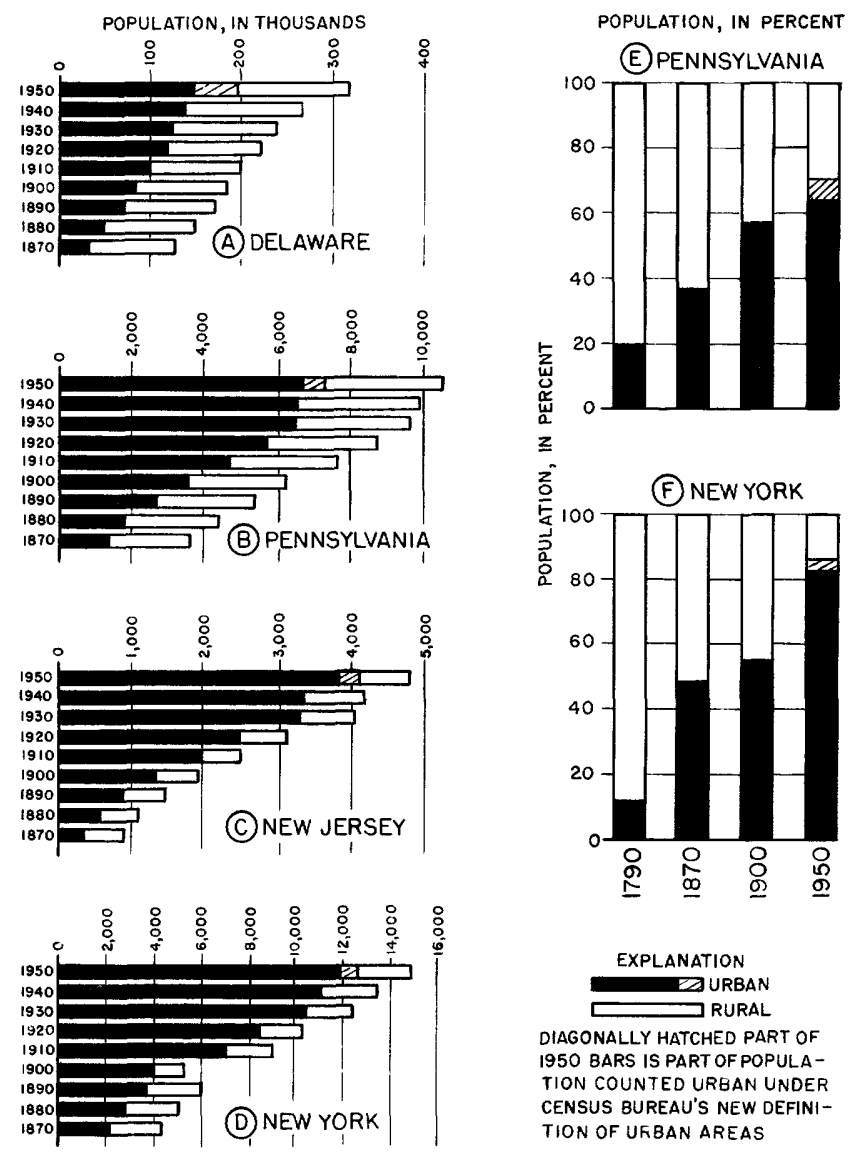

FiguRe 6.-Urban and rural population of Delaware River basin States, 1790-1950.

The practice of irrigation is likely to increase regardless of population trends. Use of water for irrigation is of particular importance, because in this region it is estimated that about 90 to 95 percent of the water applied (usually by sprinkler systems) becomes a part of the crop or is lost by evapotranspiration. Such water is thus used consumptively and is not available for any additional use. Only a small percentage of the water withdrawn for most other purposes is used consumptively. The remainder, if returned to a stream or aquifer at a favorable location, is available for reuse.

The people of the region are fortunate in having recreational areas conveniently located near the large population centers. The Catskill and Pocono Mountains in New York and Pennsylvania and parts of the Pine Barrens and the Appalachian Highlands in New Jersey are well suited for recreational purposes, because they are upstream from the areas of intensive water use. Use of such recreational areas is increasing rapidly and doubtless will continue to increase in the future. Outdoors recreation, especially camping, boating, and hiking, is rapidly becoming a principal leisure pastime of of the people of this region. 


\section{INCREASING PER CAPITA USE}

Demands for water are increasing more rapidly than the population, principally because of rapidly increasing use by industry and for irrigation. Higher living standards for larger numbers of people tend to increase per capita use for domestic purposes. Furthermore, the stimulus to industry which such living standards provide causes an even greater increase in water use. On the other hand, increasing costs of water and metering of formerly unmetered supplies tend to reduce waste of water and consequently to reduce per capita use.

Statistics on per capita use of water vary greatly and may be misleading unless a full description of water included and water excluded is made. For example, most municipalities and water companies furnish all the water for domestic and public requirements but supply only a part of the water for iudustrial requirements. Use of water in an arid region with extensive irrigation might be several thousand gallons per capita per day, and that in a predominantly residential and business area in a humid region might be less than 100 gped (gallons per capita per day).

According to figures collected by the U.S. Geological Survey on water withdrawn for use in the Delaware River basin in 1955 (excluding water for hydroelectric power development), 6,100 mgd is used by about 5.8 million people. This water is withdrawn at a rate of more than 1,000 gpcd, a rate above the average for eastern United States and caused by the large withdrawals of water for industrial use. It is less than the national average (about 1,600 gpcd), which is strongly influenced by use of very large quantities of water for irrigation in the arid West.

POLLUTION OF STREAMS AND AQUIFERS

Disposal of wastes from municipalities and industry in densely populated areas is a particularly vexing problem. It has received considerable attention in this region in the past and doubtless will receive even more in the future. Wastes are commonly discharged to streams, either before or after treatment. Many streams at times have become too polluted for some uses and some have been, or are, obnoxious.

Organic wastes discharged to flowing streams are decomposed by aerobic bacteria where sufficient dissolved oxygen is present. The streams thus tend to purify themselves, though the self-purification capacity of a stream is limited and excessive amounts of organic matter cause serious pollution problems. Treatment of some wastes before discharge and State control of other waste discharge have done much to alleviate the problem.

Many of the industrial. wastes reaching streams are inorganic and remain practically unaltered throughout the stream courses. Water in the Schuylkill River above Reading, Pa., is acid during periods of low flow because of the drainage from mines in the area. The normal purification processes do not occur in the acid environment, and no fish live in it. Alkaline waters entering the river near Reading neutralize the acid and restore normal conditions.

Although disposal of large amounts of waste is usually accomplished by dumping in streams, considerable quantities in some places reach aquifers, generally the shallow ones. Poorly located and poorly constructed wells in shallow aquifers are easily polluted from local sources, such as barnyards and privies. About 50 years ago such pollution was so common that many people considered all shallow aquifers to be polluted, and to this day this erroneous idea is widely held. Pollution of deep aquifers is less common but sometimes does occur, particularly in limestones where large solution channels exist.

During periods of high runoff streams in the region generally become muddy or turbid, and for many uses the suspended sediment must be removed from the water. Although the problem is less acute in this region than in many others, it is one of considerable magnitude.

In addition to making the water temporarily unsuitable for use, suspended sediment settles out and builds deposits in reservoirs, lakes, bays, and navigation channels. During periods of high runoff, movement of coarse sediment along streambeds adds to the finegrained deposit. Many small reservoirs in the region have been filled with sediment, and repeated dredging is required to keep ship channels and harbors open.

Some erosion-derived sediment is present in most streams, at least during high stages, regardless of man's activities. However, cultivation of soils or removal of protective vegetation accelerates erosion.

An especially serious sediment problem arose in the Schuylkill River as a result of uncontrolled dumping and erosion of coal-mine wastes. The river became notorious throughout the nation as an extreme example of deterioration. This situation has been corrected to a great extent by an intensive restoration project and the controlling of waste disposal.

\section{SALT-WATER ENCROACHMENT}

A problem confronting all areas near salt-water bodies is the contamination of fresh-water supplies by salt water. The large metropolitan areas of the region are near salt water, and the problem has become a major one.

Encroachment by salt water may occur either in streams or aquifers, commonly in both. Prolonged periods of low flow in the Delaware River result in the 
encroachment of salt water into the reach of the estuary between Wilmington, Del., and Philadelphia, Pa. During such periods, salt water may also encroach into aquifers along the river, most noticeably as a result of large-scale pumping, which induces a flow from the river into the adjacent aquifers. However, simply because it is heavier and denser than fresh water, salt water seeps out of stream channels to contaminate areas normally containing fresh water whether pumping occurs or not, if the hydraulic head in the aquifers is not sufficiently high to prevent the seeping.

The rising sea level is another factor in the salt-water problem. Marmer (1949, p. 203) has shown that the sea level along the entire Atlantic coast rose in relation to the land surface at the rate of 0.02 foot $(6 \mathrm{~mm})$ per year between 1930 and 1947. Although this rate seems negligible, the total rise of sea level would amount to 2 feet per 100 years if the rate were maintained. An increase in salinity of the Delaware estuary, probably due to this recent rise in sea level, caused Chester, Pa., to abandon its local supply in 1951 and to obtain a safe supply inland from the Susquehanna River basin. If the sea level continues to rise, streams and aquifers all along the coast will be vitally affected and water supplies now seemingly safe (as those of Philadelphia and Camden) will be ruined by salt-water encroachment.

According to Barghoorn (1953), the long-term rate of submergence by the sea at Boston, Mass., was about 6 inches per century in the 4,500 years prior to 1620 , and at Saugus, Mass., the submergence was $2 \frac{1}{2}-3$ feet in the period 1650-1952.

Under natural conditions, fresh ground water extends below sea level in many areas close to the shore. Heavy pumping of wells near the salt water causes it to move toward and sometimes into the wells. Contamination of this kind has occurred along much of the coast of New Jersey and southern Delaware and along the shore of Delaware Bay.

\section{HYDROLOGIC EFFECTS OF URBANIZATION}

The growth of urban areas is one of the greatest forces affecting water supplies. It brings many changes which have local and even regional effects on the occurrence and use of water. The net effect is difficult to evaluate and undoubtedly varies a great deal both in place and in time. Some of the results of the change from native or rural conditions to urban are listed:

1. Water use increases sharply, except in areas formerly irrigated.

2. Scattered small ground-water supplies are replaced largely by a single public surface-water supply, or ground-water withdrawals may be multiplied by numerous privately or municipally owned wells.
3. Large areas are covered by roofs and pavements which intercept precipitation and thus tend to increase runoff, especially in the form of sudden, concentrated discharge; this change in runoff characteristics tends to reduce ground-water recharge.

4. Storm-drainage systems provide rapid runoff and decrease recharge, except as noted in item 6.

5. The increased use of water tends to cause lower flows in drought periods, and the more rapid runoff tends to cause higher flood flows in streams.

6. Sewers often develop leaks. If sewers are below the water-table, ground water is drained away and the water table falls. If sewers are above the water table, leaking sewerage adds to recharge and pollutes affected aquifers.

7. Large numbers of septic tanks in some suburban areas tend to pollute shallow aquifers, and where these areas are served by public water supplies, the "imported" water discharged through the septic tanks recharges the local aquifers and raises water levels.

8. Municipal and industrial waste disposal tends to increase pollution of streams and aquifers.

9. Urban developments often encroach on stream flood plains, which are natural waterways and an integral part of the river's discharge system. The encroachment on the flood plain impedes flood flows and increases flood hazards to life and property.

INTERBASIN DIVERSIONS

Diversion of water from the Delaware River basin to areas east of the basin has become a factor of considerable importance, and diversions to the Delaware River basin are being made and probably will increase.

In 1955 a diversion of $365 \mathrm{mgd}$ was made to the New York metropolitan area from the headwaters of the Delaware River in the Catskill Mountains. The U.S. Supreme Court has granted permission for an increase to $800 \mathrm{mgd}$ after completion of the Cannonsville Reservoir. These diversions are compensated, at least in part, by release of water from storage to augment low flows of the river. Although the total water supply at points below the diversion has been reduced, a larger part of the remaining supply has been made available for users downstream. The reduction in total supply would be detrimental to users downstream only if a very large proportion of the total water resources of the entire basin were developed and used.

The U.S. Supreme Court has granted New Jersey permission to divert $100 \mathrm{mgd}$ from the basin without compensating releases from storage. The present diversion (1958) amounts to about $40 \mathrm{mgd}$ through the Delaware and Raritan Canal. 
On the estuary, where salt-water encroachment and pollution are serious problems, the city of Chester, Pa., abandoned its Delaware River supply in 1951 and began diverting water from Octoraro Creek in the Susquehanna River basin. The diversion system is designed to yield $30 \mathrm{mgd}$; this amount can be increased to $75 \mathrm{mgd}$ when needed. Present (1958) diversion is about $13 \mathrm{mgd}$.

Diversions from a basin are equivalent to consumptive use, because none of the water returns to the streams or aquifers of the basin from which the diversion occurs.

ECONOMIC AND LEGAL ASPECTS OF WATER DEVELOPMENT

Development of new supplies of satisfactory quality becomes more difficult and costly as demands increase because (1) the most suitable reservoir sites may be already developed, (2) distant sources require costly aqueducts to transport the water to the place of use, (3) competition for supplies increases, (4) sites suitable for reservoirs and well fields commonly may be occupied by urban and industrial developments and are very expensive to acquire for water developments, (5) pollution and water-purification problems tend to increase.

Costs of water in this region are very low in relation to costs of most other raw materials used in industry. If necessary, the economy of the region could absorb a comparatively large increase in water costs. Nevertheless, costs of water are important and often are a determining factor in the location of an industry and in the ability of some industries to compete with similar industries in other localities.

In arid regions the existence of organized human activities depends on the appropriation and use of most or all of the water supply. The water law of many arid regions, consequently, is based largely on the principle of prior appropriation. In regions with abundant supplies and low demands there is no need for such laws, thus in such regions the doctrine of riparian rights has become the principal basis of water law. This doctrine permits use of streams by landowners whose property adjoins a stream or lake, provided there is no undue interference with the stream or lake. Increasing use of the water supplies in humid regions has forced many departures from a strictly riparian principle. Water law varies considerably between States, and many of the principles upon which laws are based are scientifically unsound. For example, ground water is often regarded as a part of the land so far as legal rights are concerned. This view disregards the fact that ground water is not static like the land, but crosses property lines and political boundaries as it moves from points of recharge to points of discharge. A well field on a single property might lower the water table for many miles in all directions and at the same time reduce streamflow. For example, the pumping of some wells in Camden; N.J., affects ground-water levels in Philadelphia, $\mathrm{Pa}$., and vice versa, that is, the effects of withdrawal extend beneath the Delaware River and across State boundaries.

\section{SUMMARY OF WATER LAW BY STATES}

Use of water by one State, which affects the rights of another State, is governed by Federal law, and several U.S. Supreme Court decisions have been made for the Delaware River basin. Some of these decisions are discussed in the preceding section on interbasin diversions. Others are discussed later under "River Master of the Delaware River." Navigable waters. and interstate commerce is also under control of the Federal Government. Short descriptions of water laws as they have been enacted and interpreted in the several States of the basin follow.

Delaware.-The riparian doctrine applies to natural water courses in Delaware, and some versions of the English common law hold with respect to absolute ownership of percolating ground water. The right to unlimited consumptive use of ground water seems much more secure than that to use of surface water, especially the water from smaller streams. But the water law in Delaware, as a whole, is not defined clearly, either in the statutes or in the court decisions.

New Jersey.-Basically, the riparian doctrine holds in New Jersey, but it is modified by court decisions to a doctrine of reasonable use for ground water and beneficial use for surface water. There is no State control over either consumptive or nonconsumptive private use of surface water. Riparian law does not apply to public water supplies sold for use off the property on which the supply is developed. This use is controlled by the State on the principle that all waters of the State belong to the public and shall be allocated in the public interest. Such State control of surface water was enacted in 1907 and of ground water in 1910. Encroachment of buildings on flood plains, even if the flood plain is on private property, may be controlled below high-level flood line by application of riparian law. In this sense, buildings or developments that impede flood flows or increase flood hazards may be declared against the public interest, and court action may be brought to force their removal.

New York.-Water rights are generally considered as property rights in New York. They are not absolute; they are usufructuary and subject to many controls and limitations by the State. Domestic use has a constituted priority over all other uses. Except for statutory control over public water supplies, navigable waters, canal waters, Long Island ground water (in part), and pollution of water, the laws are a part of the common law. 
Pennsylvania.-The riparian doctrine generally prevails in Pennsylvania, and several Commonwealth agencies have control over different aspects of water law. The Water and Power Resources Board allocates water to "public water-supply agencies" and "surface water" only; thus, less than 10 percent of surface water in Pennsylvania is under this control. The board must also determine whether to grant or reject applications for charters by water companies. Well drillers must be licensed by the Commonwealth and are required to supply the Pennsylvania Topographic and Geologic Survey with certain information regarding each well.

\section{DEFICIENCIES OF DATA}

Solutions for the long-term water problems of the region depend in large measure on detailed knowledge of the occurrence of water and its circulation through the hydrologic cycle (described at the beginning of the next section). Information concerning this circulation in the Delaware River basin is incomplete and will require considerable time, effort, and money to obtain.

Precipitation has been measured at a few places for more than 100 years, but a reasonably adequate network of gaging stations has been in operation for only a few years, and some areas, particularly in the mountains, still are not adequately covered.

The longest streamflow records cover about 50 years, but satisfactory areal coverage was achieved only very recently. Records are too short to provide an adequate basis for determining frequencies of occurrence of large floods or severe droughts. Information about the runoff from large parts of the Coastal Plain and from areas of less than about 10 square miles is very inadequate.

The occurrence and movement of ground water have been investigated intensively in only a few small areas. Data on well yields are generally very sparse. Reported well yields may often represent pumping rates that are less than the actual water-yielding capacity of the aquifers or they may represent short-period pumping rates that are greater than the long-term capacity.

Much detailed geologic and hydrologic information is needed to aid in evaluation of ground-water supplies and their relation to surface water.

The chemical quality of water supplies has been investigated intensively in only a few areas and for a period of less than 15 years (beginning about 1943). Most of the investigations have been limited to surface waters.

In the Delaware River basin the areal changes in ground-water quality and the changes in quality with increased pumping rates are very poorly understood. The variations in chemical quality of surface water are due to the geologic environment, changes in rate of flow, sea-water encroachment, and pollution from agricultural, municipal, and industrial sources. The quantitative effects of these variations are not yet understood.

Data on sediment loads of streams are very scanty. It is impossible to make accurate forecasts of the reduction in storage capacity caused by deposits in reservoirs. Satisfactory methods of measuring the total sediment load, especially of the heavy materials transported along the bottom of the streams, do not yet exist.

Evaporation from water surfaces has been measured by evaporation pans at a few widely scattered localities for a number of years, but interpretation of the results is complicated by energy storage in deep water and methods of computing evaporation loss are still in the developmental stage. Evapotranspiration can be measured accurately only on a laboratory scale. In practice it is usually approximated by subtracting runoff from precipitation. This method gives no clue to the time variations in evapotranspiration.

Detailed analyses of the elements of the hydrologic cycle require a knowledge of changes in soil moisture. Measurements of soil moisture have been made for only a few areas. Techniques are being developed to remedy this situation.

Most hydrologic data apply only to specific points. For example, a precipitation record shows the amount of water falling at a specific location, a streamflow record shows the flow past a gaging station, and a chemicalquality record shows the water quality at the station. Until the present, very little has been done to construct a regional picture with the various hydrologic data or to relate them to such relevant factors as topography, geology, and land use.

The water problems, classified here for convenience of discussion, are closely interrelated. Developments designed primarily for one purpose commonly have either beneficial or adverse effects on many other problems as well. This discussion presents a general view of the problems for the basin. Most of these are considered in greater detail in later sections.

\section{THE WATER SUPPLY}

\section{THE HYDROLOGIC CYCLE AND WATER BUDGETS}

Water is not a static resource but a changing one. The quantity and quality of water at a particular place may vary greatly from time to time. The changes may be rapid or very slow; they may occur on the land surface, underground, or in the atmosphere, and they may involve all forms of water-solid, liquid, and vapor. Optimum development and- use of water depend in large part on adequate understanding of the complex pattern of circulation (from oçean to 
atmosphere to land and, by various processes, back to ocean or atmosphere) known as the hydrologic cycle.

The hydrologic cycle is described in qualitative terms in most hydrology textbooks and in many waterresources reports. However, quantitative information is needed for the evaluation of the water resources of a region, and such information is available for only a few of the many phases of this complex cycle. For large areas, measurements of the quantities involved are limited to precipitation, streamflow, and evaporation from water surfaces. Therefore, except for a few small experimental areas, the quantitative relations of the components of the cycle can be expressed only in a rather simplified form, usually called a water budget.

For a particular area and interval of time, the inflow of water is equal to the outflow (solid, liquid, and vapor) plus or minus the change in storage. Water in storage includes that in surface-water bodies, in ground-water bodies, and as soil moisture in the soil and subsoil above the zone of saturation. It is seldom possible to evaluate the storage change for large areas, such as the Delaware River basin, but if the time interval selected is sufficiently long (usually several years), the net change in storage is negligible in comparison with the total inflow or outflow. The relation then reduces to: inflow equals outflow.

The boundaries of many budget areas are chosen to coincide with topographic divides. For such areas the inflow under natural conditions is usually the precipitation on the area. The most accurate estimate of precipitation on large areas would be obtained from an isohyetal map for the budget period. When the network of precipitation stations is adequate, satisfactory estimates may often be made without constructing an isohyetal map. If the boundaries of the budget area do not coincide with topographic divides, inflow includes both streamflow and ground-water inflow. In some areas, however, there is some groundwater inflow even where the area boundaries coincide with the topographic divides. Streamflow and groundwater inflow must be estimated from streamflow records and the hydrogeology of possible inflow sites.

Outflow may occur by evaporation from water surfaces or moist ground surfaces, by transpiration from plants, by streamflow, or by ground-water flow. The streamflow and ground-water outflow are measured or estimated from streamflow and ground-water records and the geology of possible outflow sites. Measurements of the vapor discharge are limited to evaporation from water surfaces, which generally is only a small part of the total vapor discharge. Consequently, the evaporation and transpiration measurements are usually combined in a single term, "evapotranspiration." When the total inflow is the precipitation and the total liquid outflow is the runoff (the natural, or unregulated, streamflow), the difference between precipitation and runoff is a good estimate of evapotranspiration. However, because the calculated difference includes all the errors in records of precipitation and runoff, and all unknown amounts of ground-water outflow, a more general term, "water loss," is commonly used. The relation of water loss to evapotranspiration depends on the accuracy of the precipitation and runoff data and on the net amount of ground-water flow into, or out of, the area. Those who plan development of additional supplies of water regard most of the evapotranspiration as a loss because it cannot be recaptured for use. However, agronomists, foresters, and conservationists interested chiefly in increasing soil moisture and reducing direct runoff regard the runoff, rather than the evapotranspiration, as a loss.

In its simplest form the long-term water budget is expressed as:

$$
P=L+R,
$$

in which

$$
P=\text { precipitation on the area, }
$$$$
L=\text { water loss, } P-R \text {, }
$$$$
R=\text { runoff from the area. }
$$

Activities of man have marked influences on the hydrologic cycie and water budgets. Interbasin diversion introduces additional inflow or outflow. Deforestation may decrease evapotranspiration and increase runoff. In some drylands regions, runoff has been nearly eliminated by diversion and consumptive use of streamflow and by the increased use of ground water. This decrease in runoff is accompanied by a corresponding increase in total evapotranspiration. In an area where the water table has been lowering for many years, a water budget would have to include the change in ground-water storage.

Average annual values of $P, L$, and $R$ for the Delaware River basin were compiled and mapped for the 30-year period, 1921-50, and may be used instead of total values in the simplified budget. Thus, for the Delaware River basin:

$$
P=L+R, \text { or }
$$

44 inches $=23$ inches +21 inches.

By converting these figures from inches (measured as depth of water over the entire area) to other units of annual volume, we obtain:

$P=44$ inches (30 million acre-feet, or 9.8 trillion gal)

$L=23$ inches (16 million acre-feet, or 5.1 trillion gal)

$R=21$ inches (14 million acre-feet, or 4.7 trillion gal). 
How much of this water can be used? There is no simple answer to this question. Part of $R$ is derived from floods of infrequent occurrence and cannot be stored economically. A minimum flow must be maintained in many streams for nonwithdrawal uses, such as dilution of wastes, and a part of $R$ must be reserved for these purposes. A part of $L$ may be recoverable by development of ground-water supplies (or by drainage), which lowers the water table and consequently decreases the evapotranspiration loss from ground water, or by changing to land-use practices that result in less evapotranspiration. The total effect of ground-water developments probably would be small in the Appalachian Highlands but might be of considerable importance in the Coastal Plain, if large quantities of water were withdrawn.

Withdrawal of water for use does not remove the water from the hydrologic cycle. Some of it may be returned to streams or ground-water storage and the remainder is evaporated or transpired. In some drylands regions, the precipitation is approximately equal to evapotranspiration, because all streamflow, except that from rare floods, has been eliminated.

Better concepts of the water available for use can be formulated after studying the separate parts of the budget and their variations.

\section{THE GROSS SUPPLY-PRECIPITATION}

The source of all the water that enters the Delaware River region, except for ocean water in bays and estuaries, is the precipitation.

\section{CAUSES AND FORMS OF PRECHPITATION}

Precipitation occurs when moisture in the atmosphere condenses around condensation nuclei to form drops or snow crystals that become large enough to fall to earth. This process may be modified by ascending and descending air currents that cause freezing (or "supercooling") and result in raindrops or snowflakes, of different sizes or in hailstones.

Whatever the nature of the precipitation in the region, the primary causes are the movement of moist air masses into or over the region, the ascent and cooling of the moist air and the formation of clouds, and the subsequent condensation. Three processes can cause precipitation, according to Blair (1942).

Cyclonic precipitation, the first of these processes, is the result of the meeting of masses of air of different temperature and moisture content. If cold air moves into the basin and forces moist warm air upward, precipitation occurs. Such cold masses move into the region frequently in wintertime from the northwest or west. They meet the warm air which has moved up from the Atlantic Ocean or the Gulf of Mexico and cause rainfall or snow over large areas. In summer, the movement of the cold air southward is less pronounced, but rainfall may result from warm moist air that is moving in from the south or southwest and that is being forced upward over a stationary mass of cooler air. In this situation too, rainfall can occur over extensive areas.

Most of the summer rains, however, are caused by a second process, different in origin and much more local in character: The surface air, differentially heated during periods of hot sunny weather, rises and cools, and results in thunderstorms and sometimes hailstorms. These storms are often of very high intensity and local flooding may follow.

Orographic precipitation, brought about by the third process in Blair's classification, follows when moistureladen air is forced upward because of mountain barriers. In the mountainous northern part of the basin this type of precipitation is of considerable significance, but in the southern part of the basin it is of only slight significance because of the relatively flat terrain. However, even in the Coastal Plain the areas of higher elevation generally receive more precipitation than the lower adjacent areas; and over the whole region rainfall increases on the windward side of the higher hills and mountains and decreases on the leeward side.

No discussion of the precipitation in the Delaware River region can be complete without mentioning the effect of hurricanes. Hurricanes Connie and Diane, which occurred within a 5-day period in August 1955, demonstrated dramatically the flooding that can result from the deluge that tropical storms can unload. Historically most tropical storms bypass this region, but when such storms do reach the area, they usually are accompained by very heavy rains.

\section{VARIATIONS IN PRECLPITATION \\ VARIATIONS IN PLACE}

The areal variations in average annual precipitation for the period 1921-50 are shown by the isohyetal map (pl. 3). The isohyets (lines of equal average precipitation) are based on records from 266 stations and on the correlation of precipitation with such topographic parameters as elevation, distance from a mountain barrier, and orientation to prevailing-wind direction. The method used is described by Nordenson (Hely, Nordenson, and others, 1960). By this method the isohyets in mountainous regions can be defined with much greater accuracy than was formerly possible. Prior to compilation of plate 3 , it was not possible to make satisfactory estimates of precipitation on drainage areas in the Catskill Mountains region. 
On plate 3 thin black lines indicate percentage of the total annual precipitation falling in the 5 -month period, May through September-the summer or growing season. Although the average precipitation varies little from month to month, the U.S. Weather Bureau discovered a slight but significant increase in percentage of summer precipitation from the coast toward the interior. Above the Fall Line the growing-season precipitation is 47-50 percent of the annual precipitation, but below the Fall Line it drops off rather steadily and reaches a low of 43 percent in southeastern New Jersey.

Although the differences may appear slight, the average difference of about 3 inches of summer rain between the low and the high percentages is significant.

\section{VARIATIONS IN TIME}

LONG-TERM RECORDS

Average values have a limited usefulness and may even be misleading unless additional information about the range and distribution of the individual values is available. Graphs of annual precipitation and the 5-year moving averages for long-term records at Philadelphia, Pa., and for the average of a group of three stations, Albany and New York, N.Y., and Philadelphia, Pa., are shown on figure 7. The records in this group, obtained from the "Climatic Summaries" of the U.S. Weather Bureau, have been checked for consistency by double-mass plotting, a correlation technique explained in the discussion of runoff records (p. 103). On the basis of the double-mass analysis, Albany records prior to 1874 were adjusted by a factor of 0.857 ; records for New York City and Philadelphia were considered satisfactory. (Records for Baltimore, Md., go back to 1817 but comparison with records for nearby localities indicates the probability of serious errors in parts of the Baltimore record prior to 1871.)

The Philadelphia records show that the annual totals of precipitation range from less than 30 to more than 60 inches and have an overall average of 42.4 inches. Periods of wet and dry weather stand out very clearly. For example, in the period from 1860 to 1875 the precipitation was well above average, but during the period from 1880 to 1895 rainfall was below average for 13 years and above average for only 3 . Sudden changes also occur frequently, as shown by the years 1920 and 1921 , with 46 and 36 inches, respectively, and 1953 and 1954 with 48 and 37 inches.

The graph of the averages of the three stations shows less pronounced extremes because the wet periods at one station may be accompanied by dry periods at another.

Figure 8 shows by means of vertical bars the number of years when the annual precipitation at Philadelphia and the group average were within indicated limits. If the occurrence of weather events were entirely a matter of chance and if a very large number of years of record were available, these bars should follow rather closely the normal (Gaussian) distribution indicated by the smooth probability curve. It is well known that precipitation data, especially for periods shorter than a year, are not distributed normally. In this region, however, the distribution of annual precipitation is not very different from the normal. Consequently, the following statistical parameters are approximate measures of dispersion or variation of annual precipitation in northeastern United States.

In drylands regions the differences between the actual and normal distributions are greater, and these parameters are not valid as measures of dispersion, although they may be of some use as a means of comparing variability of annual precipitation in different regions.

COEFFICIENT OF VARIATION OF ANNUAL PRECTrITATION

The coefficient of variation is derived from a more basic statistical parameter, the standard deviation. The standard deviation is the most commonly accepted and useful measure of dispersion about a mean (average) and is defined by the formula

$$
S=\sqrt{\Sigma x^{2} / n}
$$

but is usually computed by the more convenient but equivalent formula

in which

$$
S=\sqrt{\Sigma X^{2} / n-M^{2}},
$$

$S=$ standard deviation

$\Sigma=$ summation

$X=$ an individual value of the variable

$n=$ number of individual values summed

$x=$ an individual deviation, $X-M$

$M=$ mean value, $\Sigma X / n$.

If the distribution of the variable is normal, as just described, about 68 percent of the values will fall between the limits $M-S$ and $M+S$ and about 95 percent will fall between $M-2 S$ and $M+2 S$. At this point the question may be raised concerning the validity of using parameters based on the normal distribution, when the distribution of annual precipitation may not be normal. Many controversial statements have been made on the basis of statistical analyses. Nearly all these analyses have been made to determine the significance or nonsignificance of certain events, such as rainfall resulting from cloud seeding, usually without adequate data for the analyses. The present analysis is not concerned with such significance but merely attempts to summarize briefly a large mass of statistical data and to point to general probabilities of the precipitation pattern. 


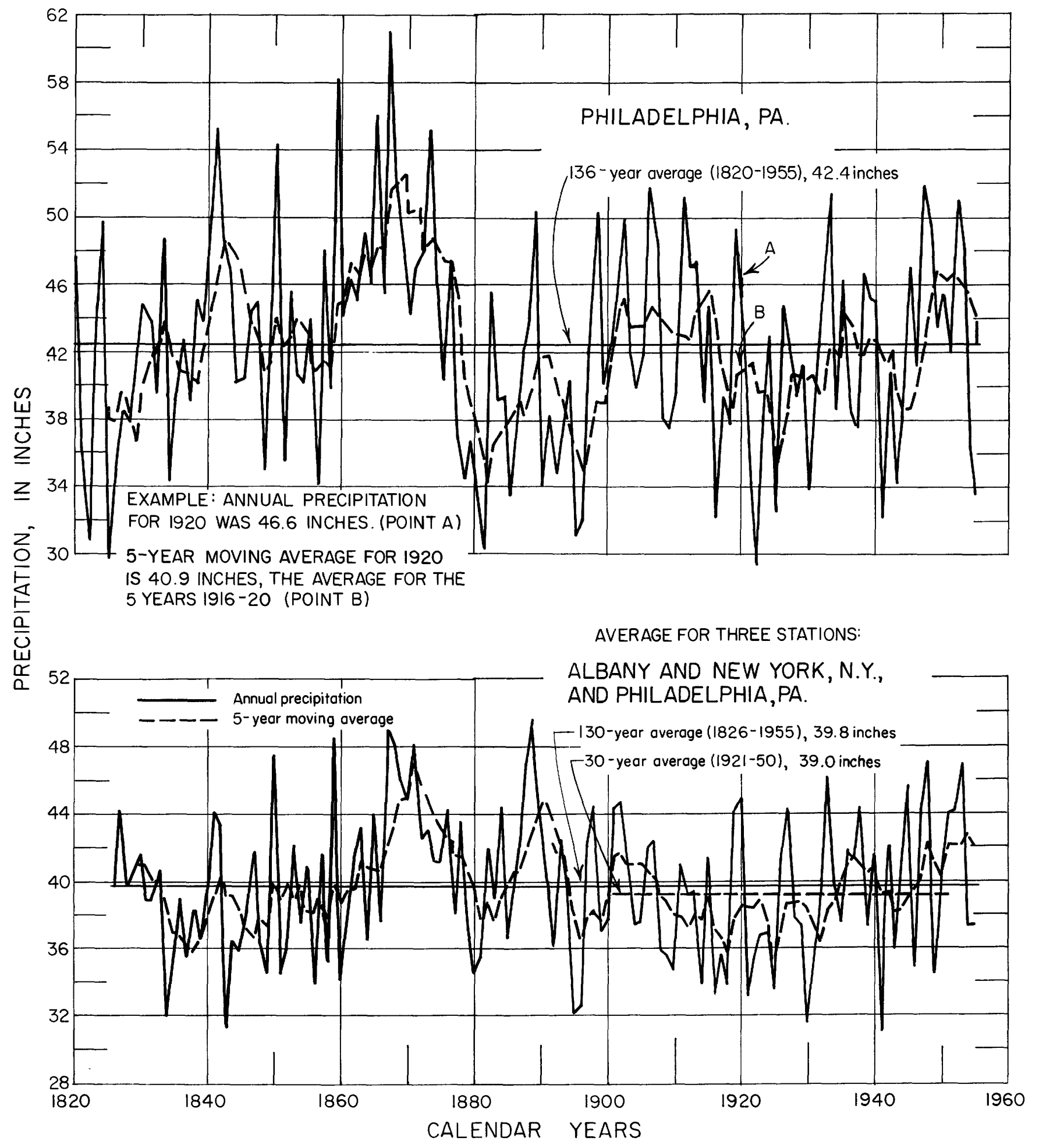

Figure 7.-Long-term records of annual precipitation in and near Delaware River basin. 


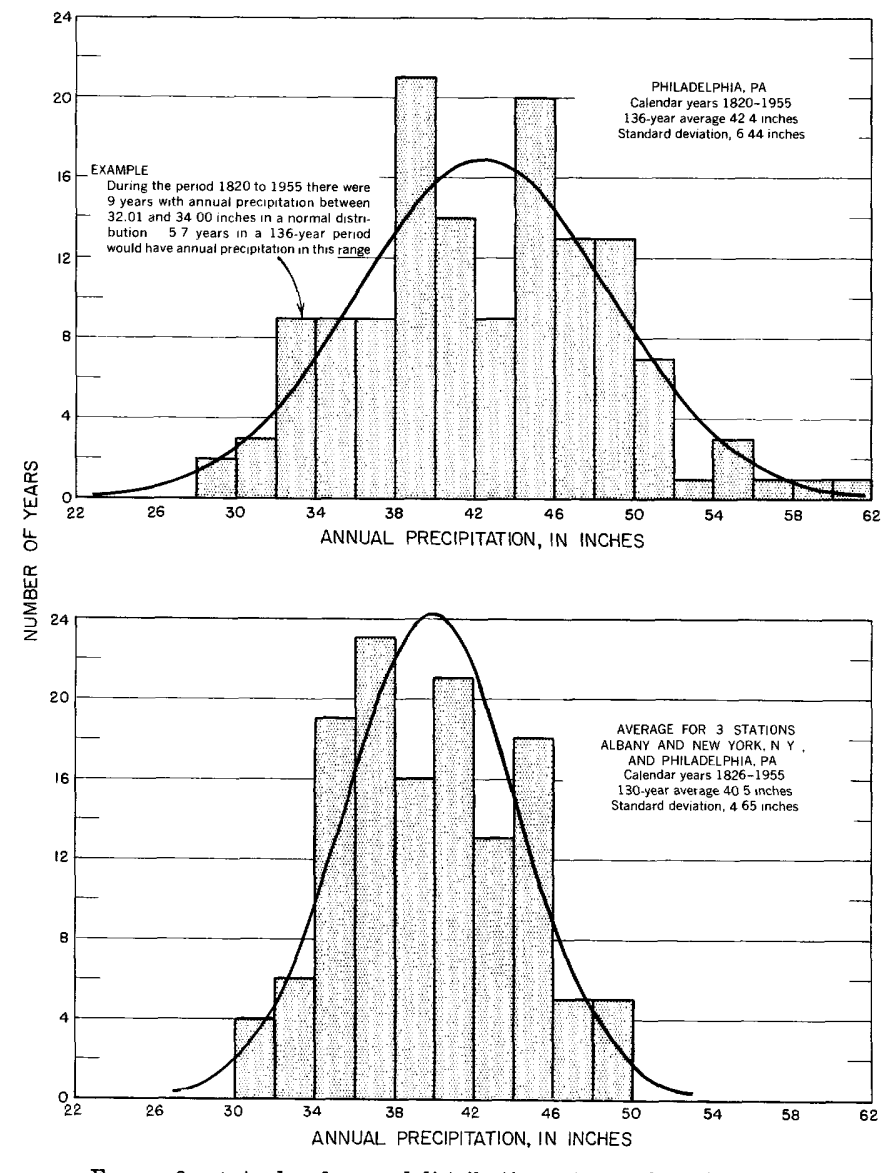

Figure 8.-Actual and normal distributions of annual precipitation.

The standard deviation tends to vary as the mean varies, consequently, it is not satisfactory for comparing groups of data with greatly differing means. Relative variation is measured by the coefficient of variation $(C)$ which is the standard deviation expressed in percentage of the mean: $C=100 S / M$. This coefficient is useful in studying variations in rainfall and runoff independently of the areal variations of the means. $C$ is dimensionless and therefore independent of units used. If $M$ and $C$ are known, $S$ can be computed in the same units as $M$. For example, a station with mean annual precipitation $(M)$ of 60 inches and standard deviation $(S)$ of 6 inches has a coefficient of variation $(C)$ of 10. A station with $M=15$ inches and $S=3$ inches has $C=20$. The second station has half as much absolute variation as the first, but twice as much relative variation.

A study of coefficients of variation of annual precipitation at 19 stations in or near the area covered by this report was made and the results are summarized in table 1. The coefficient $(C)$ was computed for different periods depending upon length of record available. Records for a 29-year period within the 30-year standard period (1921-50) were considered equivalent to the 30 -year record for this purpose. The values for the longer periods provide an estimate of the long-term value of $C$.

No areal pattern in the values of $C$ is evident. The average coefficient for the 30-year period is 14.7 and the range is 11.6 to 19.5. Estimates of $C$ for past periods of 50 years or less might be made on the basis of values shown for stations nearest the point where a value is desired. If the coefficient is 16 , about 68 percent of the annual amounts can be expected to range from 84 to 116 percent of mean, and about 95 percent of the annual amounts can be expected to range from 68 to 132 percent of mean. If the coefficient is 20 , the limits become 80 to 120 percent and 60 to 140 percent, respectively. However, because the actual distribution of annual precipitation differs somewhat from the normal, the error involved in a range of $M-2 S$ to $M+2 S$ is much greater than that for $M-S$ to $M+S$.

All the foregoing discussion refers to the coefficient of variation for a single station. Average precipitation over a large area is less variable than precipitation at a point. The average of the coefficients for the three individual long-term records shown in figure 9 is 14.8 , but the coefficient for the group average of the same

TABLE 1.-Coefficients of variation of annual precipitation at stations in and near Delaware River basin

\begin{tabular}{|c|c|c|c|c|c|}
\hline station & Period & Years & $\begin{array}{c}\text { Mean } \\
\text { (inches) }\end{array}$ & $\begin{array}{c}\text { Standard } \\
\text { deviation } \\
\text { (inches) }\end{array}$ & $\begin{array}{c}\text { Coeffi- } \\
\text { cient of } \\
\text { variation }\end{array}$ \\
\hline \multirow[t]{3}{*}{ Albany, N.Y } & $\begin{array}{l}1921-50 \\
1001-50\end{array}$ & 30 & $\begin{array}{l}33.78 \\
33.23\end{array}$ & $\begin{array}{l}4.31 \\
4.30\end{array}$ & \\
\hline & $1876-1950$ & $\begin{array}{l}50 \\
75\end{array}$ & $\begin{array}{l}-47 \\
34.47\end{array}$ & $\begin{array}{l}\text { 4. } \\
\text { 4. } 91\end{array}$ & \\
\hline & & 100 & 34. 33 & 5.02 & \\
\hline \multirow[t]{3}{*}{ Cooperstown, N.Y.. } & & $\begin{array}{l}130 \\
30\end{array}$ & $\begin{array}{l}54.74 \\
42.10\end{array}$ & $\begin{array}{l}4.89 \\
4.94\end{array}$ & 14 \\
\hline & $\begin{array}{l}1901-50 \\
1876-1950\end{array}$ & $\begin{array}{l}50 \\
75\end{array}$ & $\begin{array}{l}42.96 \\
41.70\end{array}$ & $\begin{array}{l}7.25 \\
7.26\end{array}$ & $\begin{array}{l}16 \\
17\end{array}$ \\
\hline & & 100 & 41.10 & 6.85 & 16 \\
\hline \multirow[t]{3}{*}{ New York, N.Y } & & $\begin{array}{l}30 \\
50\end{array}$ & $\begin{array}{ll}42.02 \\
4103\end{array}$ & $\begin{array}{l}6.50 \\
5.88\end{array}$ & \\
\hline & & 75 & 42.80 & $\begin{array}{l}0.07 \\
6.07\end{array}$ & \\
\hline & & $\begin{array}{l}100 \\
130\end{array}$ & $\begin{array}{l}42.89 \\
42.20\end{array}$ & $\begin{array}{l}6.27 \\
6.42\end{array}$ & \\
\hline \multirow[t]{4}{*}{ Philadelphia, $\mathrm{Pa}$} & & 30 & 41.34 & 5.63 & \\
\hline & & $\begin{array}{l}50 \\
75\end{array}$ & $\begin{array}{l}42.17 \\
41.07\end{array}$ & $\begin{array}{l}5.60 \\
5.75\end{array}$ & \\
\hline & & 100 & 42.42 & 6.36 & \\
\hline & & 136 & $\begin{array}{l}42.43 \\
42.58\end{array}$ & 6.38 & \\
\hline \multirow{2}{*}{ Baltimore, } & & $\begin{array}{l}50 \\
50\end{array}$ & $\begin{array}{l}42.58 \\
42.40\end{array}$ & $\begin{array}{l}6.01 \\
6.54\end{array}$ & \\
\hline & $\begin{array}{l}1921-4 \\
1820-4\end{array}$ & $\begin{array}{l}75 \\
29\end{array}$ & $\begin{array}{l}42.89 \\
37.66\end{array}$ & $\begin{array}{l}6.63 \\
4.69\end{array}$ & \\
\hline Oneonta, N.Y & & 55 & 38. 22 & $\begin{array}{l}5.52 \\
6.57\end{array}$ & \\
\hline \multirow{3}{*}{$\begin{array}{l}\text { Roxbury, N.Y } \\
\text { Hawley, }{ }_{\text {Pa }} \\
\text { Reading, Pa. }\end{array}$} & 1950 & 61 & 43.82 & 6.77 & \\
\hline & & $\begin{array}{l}30 \\
29\end{array}$ & 42.53 & $\begin{array}{l}4.92 \\
6.63\end{array}$ & \\
\hline & & 30 & 40.02 & 5. 67 & \\
\hline Belvidere, N.J. . . & $1921-50$ & 30 & 47.38 & 7.04 & \\
\hline \multirow{2}{*}{ Indian Mills, N.J } & & 57 & 47.22 & 6.94 & \\
\hline & & 50 & 46.75 & 6.16 & \\
\hline \multirow{2}{*}{$\begin{array}{l}\text { New Milford, N.J } \\
\text { Plainfield, N.J }\end{array}$} & $\begin{array}{l}1921-50 \\
1921-50\end{array}$ & $\begin{array}{l}30 \\
30\end{array}$ & $\begin{array}{l}43.42 \\
47.68\end{array}$ & $\begin{array}{l}5.59 \\
6.34\end{array}$ & \\
\hline & $1890-1917$ & 60 & 48.43 & 5.85 & 12. \\
\hline Pleasantville, N.J. & & 30 & 43.39 & 7. 50 & \\
\hline & & 52 & $\begin{array}{l}42.91 \\
444\end{array}$ & $\begin{array}{l}7.63 \\
6.56\end{array}$ & \\
\hline & & 51 & 44.44 & 7. 18 & \\
\hline Bridgeville, De & & 30 & 43.24 & 8.41 & \\
\hline $\begin{array}{l}\text { Dover, I } \\
\text { Wilming }\end{array}$ & & 29 & $\begin{array}{l}44.81 \\
44.03\end{array}$ & $\begin{array}{l}7.99 \\
646\end{array}$ & \\
\hline Wilmington, Del & $\begin{array}{l}1921-49 \\
1894-1949\end{array}$ & 56 & $\begin{array}{l}44.03 \\
44.19\end{array}$ & $\begin{array}{l}\begin{array}{l}0.40 \\
6.86\end{array} \\
\end{array}$ & \\
\hline
\end{tabular}


three is 10.8. This may be considered an indication of the order of magnitude of the difference between the coefficient for an area of several thousand square miles and the coefficient for a locality within that area.

\section{MONTHLY PRECIPITATION}

The previous discussion has shown that there is considerable variation in annual precipitation from year to year. The differences for a given month can be even larger. A striking example is the difference in monthly totals of August 1955 and August 1957. At Scranton, Pa., for example, 12.11 inches fell in August 1955, the larger part of which was due to hurricanes Connie and Diane. In August 1957 a total rainfall of only 1.38 inches was recorded, as compared with a 20-year average of 4.08 inches. At Allentown, Pa., 12.10 inches fell in August 1955 as compared with 1.39 inches in August 1957 and with a long-term mean of 4.49 inches. Similarly, the record for Newton, N.J., was, respectively, $15.19,1.30$, and 4.66 inches.

Diagrams of maximum, mean, and minimum monthly precipitation (fig. 9) illustrate the magnitude of the variations that occurred during the standard period September 1920 to October 1950, which is used for most compilations of runoff data in this report. These diagrams also show the relatively uniform distribution of mean monthly precipitation throughout the year. Summer precipitation is, on the average, slightly greater than winter precipitation. Extreme values, either high or low, are most likely to occur in the summer or fall-the seasons of thunderstorms and hurricanes. Greater monthly precipitation occurred during August 1955 at three of these stations:

\begin{tabular}{|c|c|c|c|}
\hline \multirow[b]{2}{*}{ Station } & \multirow[b]{2}{*}{ Period } & \multicolumn{2}{|c|}{$\begin{array}{l}\text { Precipitation, } \\
\text { August } 1955\end{array}$} \\
\hline & & Inches & $\begin{array}{l}\text { Percent of } \\
\text { average } \\
\text { annual }\end{array}$ \\
\hline $\begin{array}{l}\text { Roxbury, N.Y. } \\
\text { Plainfield, N.J- } \\
\text { Reading, Pa.- }\end{array}$ & $\begin{array}{l}1915-1955 \\
1888-1955 \\
1870-1955\end{array}$ & $\begin{array}{l}11.59 \\
15.64 \\
14.85\end{array}$ & $\begin{array}{l}27.2 \\
32.8 \\
37.3\end{array}$ \\
\hline
\end{tabular}

\section{DROUGHT}

Although there is no adequate definition of drought, the effects are well known: soils dry out and plants wither, small springs and streams cease flowing or are reduced to a mere trickle, and major streams decline to unusually low flows. Where severe drought continues long enough or covers a large enough area, whole populations are affected as people leave their droughtstricken homelands to seek a living in other areas-the vast migration in the 1930 's from the "dust bowl" in the Great Plains is a recent, well-known example.
Communities, industries, and the native vegetation all tend to adapt themselves to the generally prevailing or normal conditions of their environment. Thus, any extended period with precipitation sufficiently below normal to affect the life and culture of an area may be considered a drought, even though a similar amount of precipitation might be considered abundant moisture in a more arid region.

In the Delaware River region, water shortages resulting from drought usually occur in summer or early fall, because streamflow and ground-water levels are normally lowest and the demand for water is highest then. However, drought effects that become apparent during the growing season may develop from lack of precipitation many months earlier; these are the socalled "delayed" or "hidden" droughts. Although spring and summer rains may be adequate for the needs of growing crops, they may provide little or no contribution either to streamflow or to ground water. For example, in 1930 New York State had 65 municipalities that were seriously affected by the low streamflow, but crop yields were above normal (Hoyt, 1936, p. 35-36); farmers would not recognize such a period as being a time of drought, but water-supply operators would.

Municipal and industrial water shortages, especially, have often occurred because water-supply facilities did not keep pace with the needs of growing communities; such was the situation in New York City in 1948-49. Such water shortages should be carefully distinguished from those resulting from droughts.

The low flows of streams in the Delaware River basin and southern New Jersey and the frequency of the low flows are discussed on page 128. Because of large aquifer storage, ground-water supplies from deep wells in major aquifers may be unaffected even by lengthy droughts, but shallow wells or wells in less extensive aquifers having very limited storage may be affected adversely by several weeks or months of subnormal precipitation.

\section{HYDROMETEOROLOGY OF FLOODS IN DELAWARE RIVER BASIN}

By W. W. Swa yne and C. S. Gilman (U.S. Weather Bureau)

Basinwide rain of greater intensity and of more critical distribution of time and space than any during the meteorological history of the Delaware River basin (including the record-breaking August 1955 occurrence) may reasonably be expected to occur at some time in the future. This occurrence must be considered in planning and design. A brief summary of some characteristics of basinwide flood situations, considered in relation to the factors that control rainfall intensity, will provide some insight into the reasons for this viewpoint. 


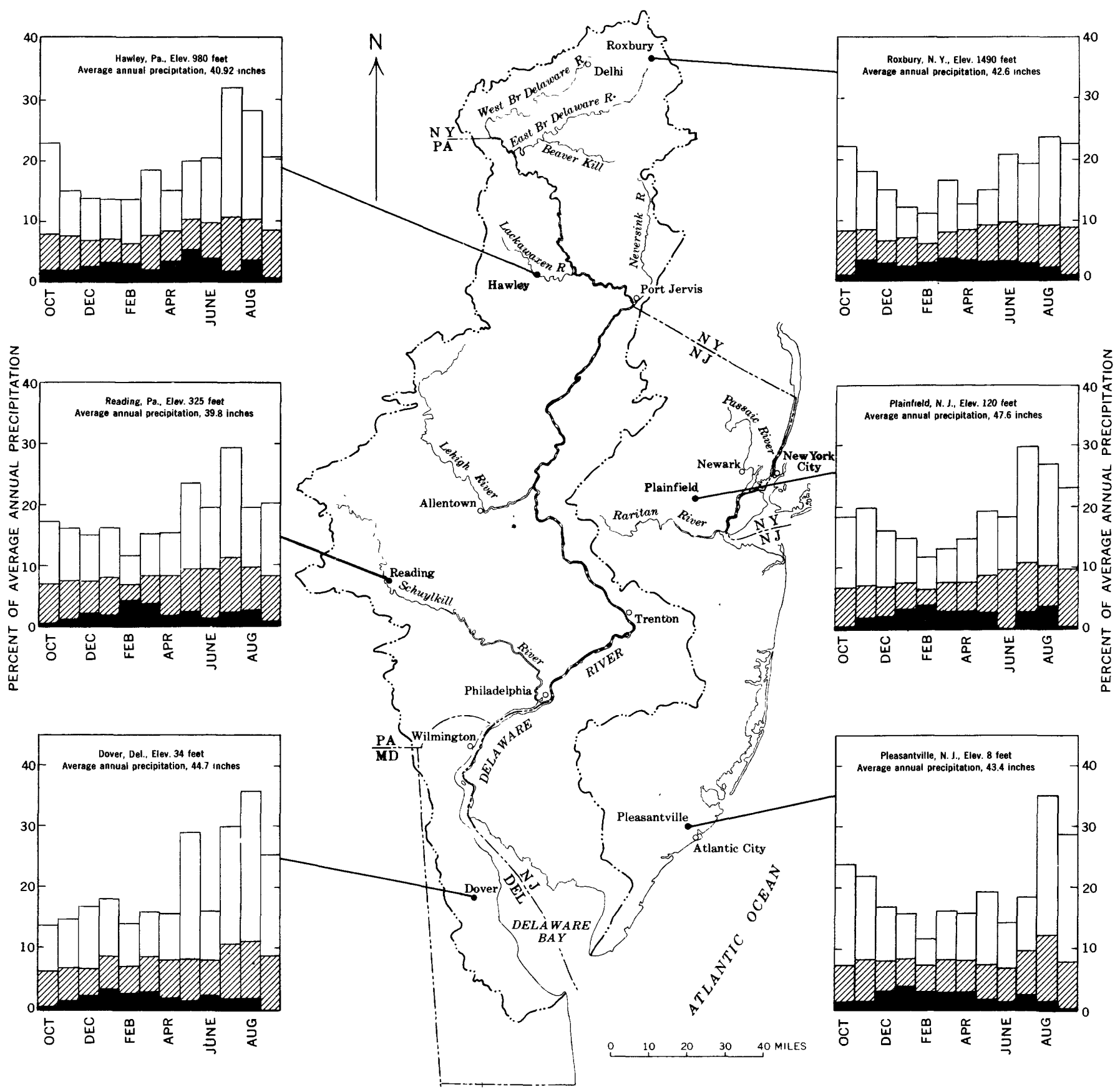

FIGURE 9.-Maximum, mean, and minimum monthly precipitation at typical stations.

The water that falls as rain over the Delaware River basin is transported into the region by currents of moist air blowing perhaps 40 miles per hour from the southeast and south and at elevations as high as about 5,000 feet. The winds pick up their load of moisture by evaporation from the south Atlantic Ocean or the Caribbean Sea. To fall as precipitation, this moisture must undergo intensive lifting with consequent expansion and cooling of the air. The lifting is most often associated with situations in which potential energy is being converted to the kinetic energy of the winds. Such a conversion may result when warm air rises and cold air nearby sinks or when the air aloft is very cold relative to that at the surface. The first situation is illustrated by the storms, popularly called "northeasters," that form off the Atlantic coast, and the second by hurricanes and other tropical storms.

The hurricanes that deliver heavy rainfall to the basin usually form over the Atlantic Ocean between the Antilles and the Cape Verde Islands. They first 
move westward, then turn northward, and strike the Delaware River basin from the south. One hurricane may follow another within a few days. For example, the rainfall from hurricane Connie occurred on August 14-15, 1955, and was followed by rainfall from hurricane Diane on August 18. It is possible that the time interval could be even shorter. The rainfall from the second storm could also occur farther downstream than that from the first, and thus make a more critical hydrologic sequence.

The rainfall connected with a hurricane is not necessarily associated with any one part of the storm. The rainfall of a young storm in a more tropical location is commonly located close to the path. If the storm moves into more temperate latitudes and weakens, the rainfall may spread out well ahead of the storm and to the right of the storm's path. However, even here there may be two general areas of rainfall, one well ahead of the storm and one near the center. These areas of rainfall may change from time to time during the life of the storm. Thus, even within a single storm, it would be possible to have a heavyrainfall sequence in which one burst would occur upstream on the rivers and then again farther downstream within the same day. This situation is illustrated to some extent by hurricane Diane which delivered rain over New York and northeastern Pennsylvania on August 17, and early on August 18 but over eastcentral Pennsylvania, farther south, later on August 18.

The intensity of rainfall associated with winter and spring floods is completely overshadowed by the tropical storms in summer. The most noteworthy spring occurrence was a storm in March 1936 which delivered rainfall for 36 hours (amounting to less than one-third of that associated with hurricane Connie, August 12-16, 1955) on a snowpack in the basin. Another noteworthy occurrence was that of March 1904, when ice jams produced the highest water levels of record at several points on the Delaware River, a situation in which a pronounced warm spell after many weeks of unusually cold weather, rather than any excess of precipitation, caused the flooding.

Hydrologic factors, particularly infiltration rate and water-equivalent of snow on the ground, are of considerable significance in affecting flood intensity. Though the volume of rain ranks among the top five for the basin as a whole, the floods on the Delaware River associated with hurricane Connie were inconsequential, largely because a long drought preceded the rain. The rains associated with Diane about 4 days later were only slightly more intense, but they resulted in the recordshattering floods of August 19-20.
Plainly, the occurrence of high rates of rainfall in a basin are not solely dependent on either the position of the storm tracks with respect to the basin nor on the original location of the storm circulation.

\section{DISPOSITION OF PRECIPITATION}

The precipitation that reaches the ground within a particular region leaves as streamflow, ground-water outflow, evaporation, transpiration, or diversion to another region. A large part of the total streamflow may occur within brief periods after storms or snowmelt, or the streamflow may be well sustained even through long dry periods. The mode of outflow, the streamflow characteristics, and the availability of water in the soil and aquifers all depend on weather and on climatic, physical, and cultural characteristics of the region.

Prevailing temperatures may determine the type of precipitation (rain or snow), cause snow to melt, influence evapotranspiration, decrease absorptive capacity (infiltration capacity) of the soil by freezing, increase infiltration capacity by alternate freezing and thawing, and influence water use. The intensity and duration of rainfall may be such that the infiltration capacity of the soil, the drainage capacity of the subsoil, or the storage capacity of shallow aquifers is exceeded and the excess must run off as overland flow. Steep slopes cause rapid runoff. Unfilled permeable aquifers provide storage space to absorb precipitation, and aquifer discharge sustains fair-weather flow of streams. Land use influences infiltration capacity and evapotranspiration. Urban and industrial development affect infiltration capacity of parts of the region and influence water use and diversion. There can be no simple relation between precipitation and the various modes of outflow, except possibly on a basis of long-term averages.

\section{NATURAI WATER IOSS-EVAPOTRANSPIRATION}

Evapotranspiration, the discharge of vapor to the atmosphere, continues as long as moist surfaces are exposed to the atmosphere or moisture is available to living plant roots. The rate depends chiefly on the following factors (not arranged in any order of importance): (1) exposed area of moist surfaces and water surfaces, (2) vegetational cover, (3) relative availability of moisture to plant roots, (4) humidity, (5) temperature, (6) winds, and (7) duration and intensity of sunshine.

The section on climate (p. 6-8) includes a discussion of air temperature and its variations and indicates the amount of seasonal variation in potential evapotranspiration. Quantitative measurements of evapotranspiration from large areas, such as the Delaware River basin, are not possible. Consequently, the best estimates are usually obtained by computing average annual water loss ( $L$ in the simplified water budget, p. 13-15) and by 
making allowances, if necessary, for effects of groundwater inflow and outflow.

Although ground-water divides may occur very close to, or coincide with, topographic divides, particularly in hilly and mountainous areas such as most of the Appalachian Highlands, in some places the two divides may be a considerable distance apart. In the flat terrain of the Coastal Plain an intense local rain might cause a temporary shift of several miles in the ground-water divide. Figure 10 presents some examples of situations where the topographic and ground-water divides do not coincide and where ground-water outflow might bypass a stream-gaging station.

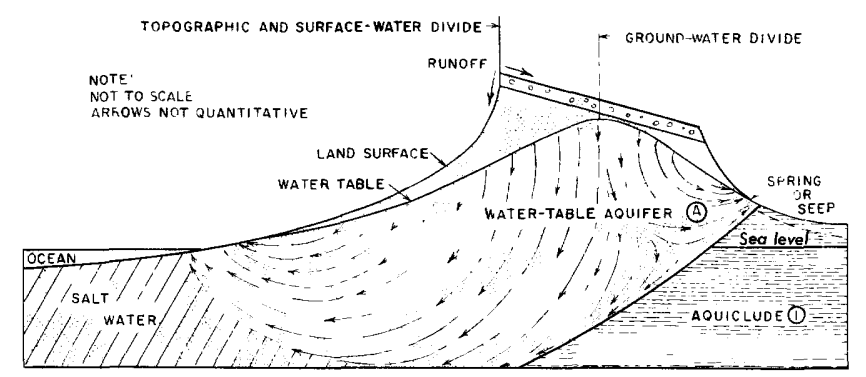

A

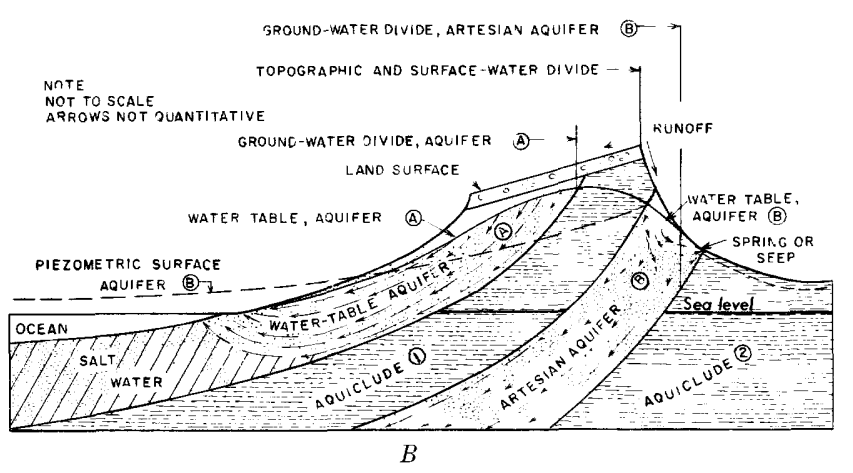

FIGURE 10.-Examples of situations where topographic and ground-water divides do not coincide.

Average annual water loss for the standard period, 1921-50, was computed for the Delaware River basin and all New Jersey; the results are presented on plate 4 and in table 23. The isograms on this map are based on computed losses from the area above each gaging station and between gaging stations on the same stream and are adjusted where advisable to be compatible with the data from the precipitation map (pl. 3) and the runoff map (pl. 12). Comparison of the water-loss map with the precipitation and runoff maps shows that the pattern of isograms on the precipitation and runoff maps are similar, but the pattern of equal-loss lines is strikingly different.
The water losses range from 18 inches over the higher part of the Catskill Mountains to 30 inches west of the Delaware Bay. One area of low losses (20 inches or less) lies mostly in Passaic County, N.J., but extends into Orange County, N.Y. From this low-loss area northwestward there is a steep increase to 25 inches in a long narrow strip extending through the Pequest River basin in Sussex County, N.J., and then into New York beyond Middletown. Another area of high loss (27 inches) centers around Allentown and Bethlehem, $\mathrm{Pa}$, in the Great Valley.

Some of the water-loss differences can be explained easily. The steep hills and mountains of the Appalachian Plateaus, with their shallow soils, absorb and hold little water; a large part of the precipitation runs off rapidly, and there is therefore comparatively little opportunity for evapotranspiration. The high losses around Allentown and Bethlehem and also those in the strip in Sussex County, N.J., probably are caused by the limestone aquifers and deep residual limestone soils that absorb water readily, cause increases in evapotranspiration, and permit significant amounts of groundwater outflow.

Generally thin soils overlie gneissic bedrock in the area of low water loss in Passaic County and cause rapid runoff (Rogers and others, 1951). The higher losses along the coastal areas and around Delaware Bay, on the other hand, are the result of higher temperatures, greater water-holding capacity of the soil, flatter terrain, and probably of ground-water outflow.

In general, the water losses indicated for areas within the Appalachian Highlands are approximately equal to the evapotranspiration from those areas, except for a few limestone valleys where considerable ground-water outflow may be included in the loss and some areas in northeastern New Jersey where large withdrawals of ground water influence the computed loss.

In the Coastal Plain ground-water outflow from most areas is probably appreciable. Losses are believed to exceed evapotranspiration by about 2 inches on the average, but in some areas the difference is much greater.

The average annual water loss in the Delaware River basin is about 15.6 million acre-feet, or 5.1 trillion gallons.

\section{EVAPORATION FROM FREE WATER SURFACES}

Evaporation from standard class-A pans has been measured by the U.S. Weather. Bureau for many years. The measurements multiplied by a coefficient (usually about 0.70 ) were commonly accepted as good estimates of the evaporation from all water surfaces. Recent and current investigations, however, have added much to the understanding of evaporation, and it is now known 
that the simple procedure just described is not adequate except for shallow-water bodies or for averages of a year or several years.

Temperature of the water surface is one of the factors controlling evaporation rates. When the water surface is cooler than the air, some of the incoming heat energy is absorbed through evaporation and some warms the water and is temporarily stored there. When the water surface is warmer than the air, the water cools and releases some of the stored energy to supplement incoming energy in causing evaporation.

The heat-storage capacity of water in evaporation pans is negligible because of their small size. The storage effect of most shallow-water bodies is considerably greater, but the daily (or monthly) temperature of such bodies tends to be about equal to the corresponding air temperature. Deep-water bodies change temperature much more slowly and to not reach the extremes that air temperature does. Consequently, heat storage in deep-water bodies is important in calculating monthly and seasonal evaporation rates. During the annual cycle of temperature change the heat energy released by the water tends to balance the heat absorbed; thus the annual evaporation from deep water is about the same as from shallow water.

Investigations at Lake Hefner, Oklahoma City, Okla. (Kohler, 1954, p. 136-137) resulted in the development of a formula which makes it possible to compute evaporation from meteorological factors observed at first-order weather stations. Data from cooperative weather stations may be used in conjunction with those from first-order. stations to supplement the network. This method was used by the U.S. Weather Bureau to compute evaporation at 72 stations in the Delaware River basin and in New Jersey, including 12 first-order stations and also including those where pan evaporation was observed. The agreement between computed and observed evaporation was satisfactory at all stations.

The results of these computations are shown on the map of mean annual evaporation (fig. 11). The indicated evaporation for most areas is probably within 10 percent of actual evaporation, although some generalization or smoothing of the isograms was necessary.

The map shows a general decrease in evaporation ranging from 37 inches in the south to 28 inches over the Appalachian Plateaus. No correlation is apparent between the pattern of isograms and the detailed topography of the area, but the general decrease toward the north is undoubtedly due to lower temperatures resulting from the combination of higher elevation and more northern latitude.

The lines of equal evaporation from lakes differ considerably from the lines of equal water loss, not only because they were drawn from data based on different principles, but also because the loss from land areas is affected by a greater number of influences than the evaporation from open water.

Nonetheless, in general, there is only a slight range in the difference between annual water loss and evaporation from free water surfaces. This difference is about 9 inches in the hills and mountains north of Blue Mountain and Kittatinny Mountains, is just south of the 30 -inch line on figure 11 , and averages 8 inches along the 34-inch evaporation line.

Figure 11 also shows the percentage of the annual evaporation from shallow-water bodies that takes place during the growing season (May through September). It ranges rather uniformly from 65 percent in the southern part to 73 percent in the northern part. The smaller percentage of winter evaporation in the northern part of the area is a result of the prevalence of lower temperatures and ice cover.

The heat storage in deep-water bodies causes the actual evaporation from such bodies to be less than that indicated by the map for the growing season and larger than that indicated for the nongrowing season.

As a part of the Geological Survey's Delaware River basin hydrologic investigation, J. Stuart Meyers made a detailed study to determine the mean annual volume of evaporation in the basin and in New Jersey east of the basin. Meyers used the latest topographic maps to determine the surface areas of fresh-water bodies and of permanently wet swamps. The accuracy was limited, however, for several reasons:

1. Some areas were mapped only on 15-minute quadrangles at $1: 62,500$ scale, and the maps are not up to present standards of accuracy. Such maps may not show swamp areas adequately. For example, on the map available to Meyers, Manantico Creek basin in New Jersey is shown with 0.15 square mile of swamp, but on the map issued since Meyers' study was made the area shown as swamp is 1.7 square miles. Doubtless there are numerous other situations where similar errors may have occurred.

2. Areas of lakes, ponds, and reservoirs were taken directly from maps; no adjustment was made to obtain average pool areas.

3. Areas in cranberry bogs are included in total swamp areas.

4. Lengths and widths of permanent streams could not always be determined accurately, especially on the 1:62,500 quadrangle maps. For larger streams, average widths were carefully measured on the maps; for many small streams it was com- 


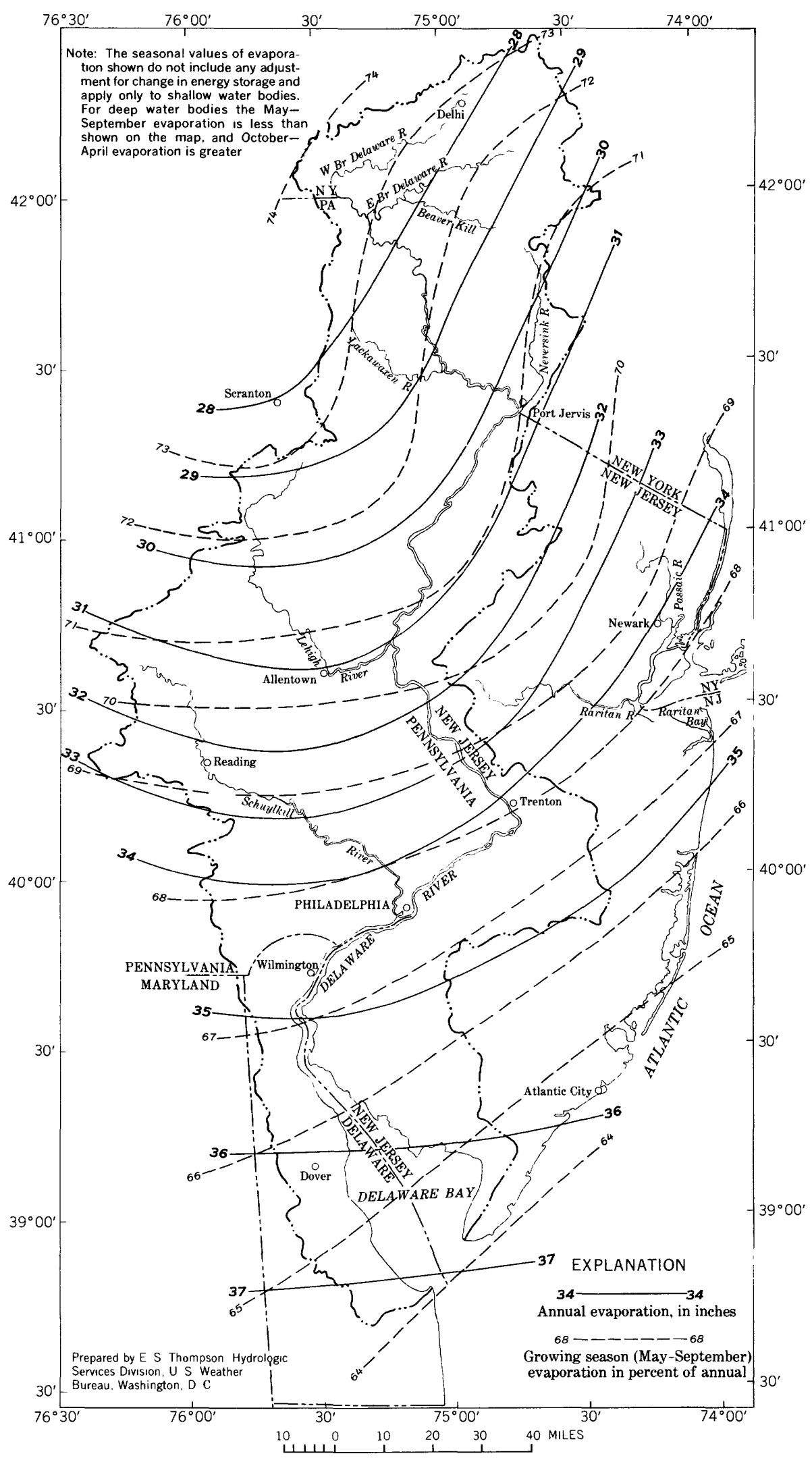

Figure 11.-Map of Delaware River basin and New Jersey showing average annual and seasonal evaporation from free water surfaces, 1921-50. 
monly necessary to estimate width on basis of tributary drainage area, flow regimen, and general knowledge of the geographic setting of the streams under consideration.

Evaporation rates used are shown in figure 11.

Meyers' study indicates that lakes, reservoirs, and ponds cover only 53,000 acres of the approximately $8,170,000$ acres in the Delaware River basin. This area amounts to about 0.6 percent of the area of the basin from which an average of 135,000 acre-feet of water evaporates annually. Swamps cover about 94,000 acres in the basin, which is approximately 1.2 percent of the area; the average annual evaporation from these swamps is 251,000 acre-feet. Perennial streams have a total surface area in the basin of about 41,000 acres, or 0.5 percent. From the surface of these streams the computed annual average evaporation is 107,000 acre-feet. The total area of fresh-water surface in the basin is about 188,000 acres, or 2.3 percent and the average annual evaporation is 493,000 acrefeet, or about 3.2 percent of the water loss. The total fresh-water area in New Jersey east of the basin is about 217,000 acres, or 7 percent of the total land area, and the average annual evaporation is 618,000 acre-feet.

The parts of these losses that occur during the growing season can be estimated from figure 11 if consideration is given to the extent of deep-water bodies and to heat storage.

The quantity of water lost by evaporation from exposed-water surfaces in the Delaware River basin is less than 2 percent of the total precipitation in the basin and less than 4 percent of the total runoff. Losses by evaporation from water surfaces alone are relatively insignificant in comparison to the total of the water resources of the basin. Nevertheless, the loss from individual reservoirs may be a serious problem to the users.

Results of this study are summarized in greater detail in table 2, pages $26-30$.

\section{TRANSPIRATION}

Transpiration is the method by which moisture from living cells of plants and animals is returned to the atmosphere. However, transpiration by animals (vapor discharge by perspiration and respiration) is such a small fraction of the total that it is usually neglected in water budgets, and only plant transpiration is usually considered.

In a sense each plant is a water pump. Actuated by the sun's energy, plants withdraw water from the ground through their roots and discharge the excess water chiefly through their leaves. Consequently, transpiration occurs during the daylight hours. Transpiration also fluctuates seasonally; it is lowest in the winter when plants are dormant or dead and highest during the growing season when plant activity is at its greatest.
Direct measurement of transpiration over large areas is not possible; indeed, measurement of transpiration even on small controlled plots is difficult. Moreover, evaporation from land and water surfaces and transpiration from the associated plant assemblages are not easily separated; therefore, in the study of vapor discharge from land areas it is usually evapotranspiration rather than transpiration that is measured.

In some field studies the evapotranspiration loss from shallow aquifers can be estimated from an analysis of continuous water-level records of wells tapping these aquifers, and in some places, especially in the drylands, the effects of evapotranspiration on streamflow can be determined by analysis of meteorological and hydrologic data. In the Delaware River basin it has not been possible to make such estimates.

\section{RUNOFF AND THE WATER CROP}

"Runoff," the third term in the simplified water budget mentioned on page 14 , is discussed in considerable detail on pages 103-121. From such a simple budget it is commonly inferred that average annual runoff represents the potentially usable yearly water supply, or the theoretical annual water crop. Certainly, $R$ is the only potentially manageable part of the water cycle, and it is from this that all man's water needs must be met.

The term "water crop" is commonly used for either total stream discharge or water yield, which includes net ground-water outflow. Such a concept, however, is oversimplified for it does not take into account the fact that part of the discharge $(R)$ may not be recoverable for use and that part of the natural evapotranspiration may be recoverable. Nevertheless, the water crop is most useful as an aid in estimating the safe water development of a basin.

The term "water crop" is here defined as the water from streams and aquifers that annually may be used by man, provided that long-term withdrawals do not exceed long-term replenishment. Floodwaters that are not stored for future use are wasted and therefore are not a recoverable part of the water crop. In addition to natural limitations, man places his own limitations on the water that can be used. Usually a large part of the water withdrawn returns to streams or aquifers after use and may be withdrawn again. Water diverted to another basin does not return to the basin of its origin and is therefore equivalent to water used consumptively, at least so far as the basin of origin is concerned.

The quantity of water available for withdrawal depends on many variable and partly interrelated factors among which are: (1) weather and climate; (2) physical, characteristics of the drainage basins involved; and 
TABLE 2.-Estimated average annual evaporation losses from free water surfaces in Delaware River basin, Delaware, New Jersey, Pennsylvania, and southeastern New York for water years 1921-50

Table compiled by J. Stuart Meyers

[Areas of salt marshes, bays, and portions of streams that are subject to tidal influence have not been included; thus, Delaware estuary is excluded. Figures are obtained by measurement and computation to nearest acre and acre-foot. They should be rounded to not more than 2 signiflcant flgures for small areas and 3 significant areas for large areas]

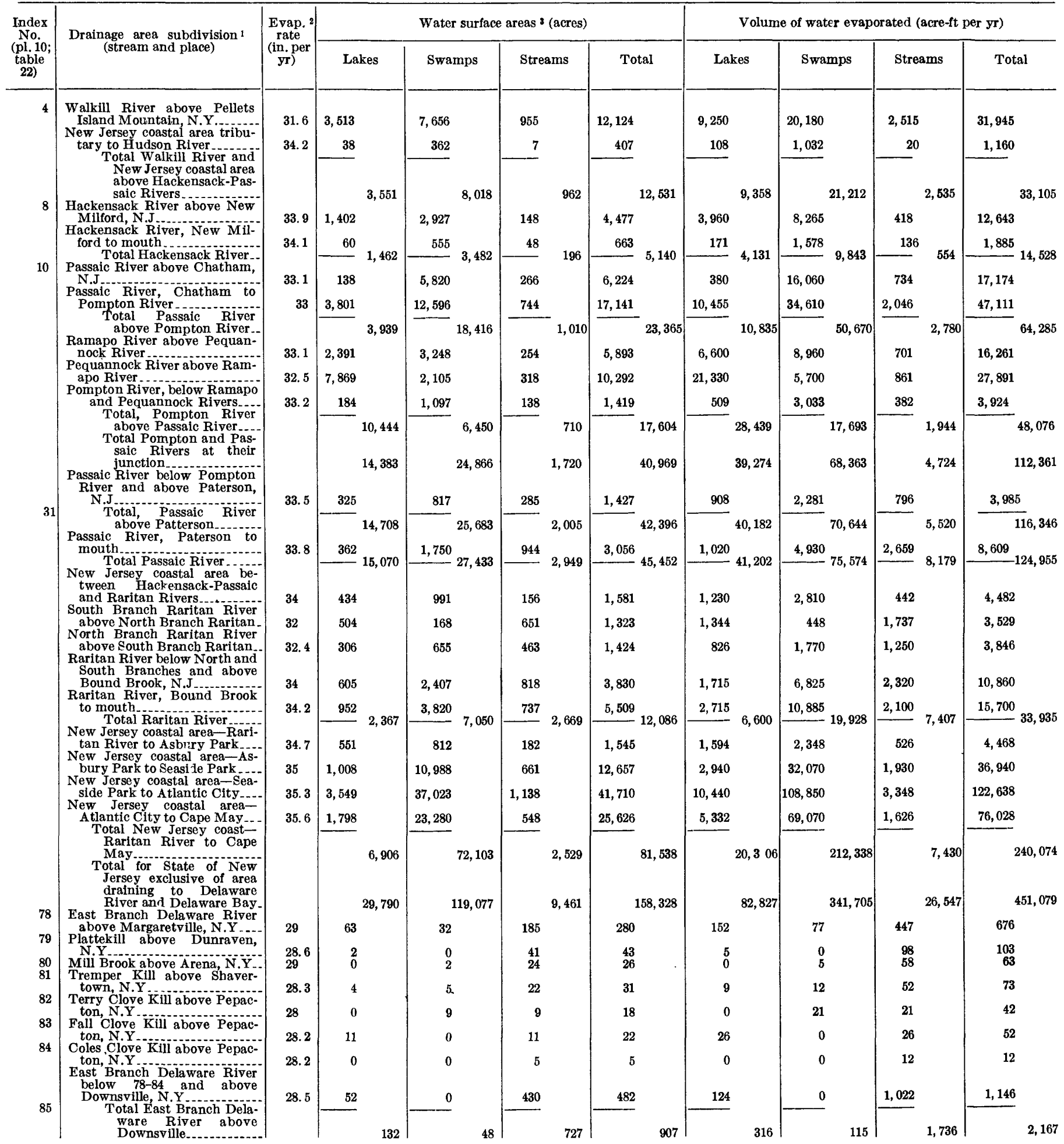

See footnotes at end of table. 
TABLE 2.-Estimated average annual evaporation losses from free water surfaces in Delaware River basin, Delaware, New Jersey, Pennsylvania, and southeastern New York for water years 1921-50-Continued



See footnotes at end of table. 
TABLE 2.-Estimated average annual evaporation losses from free water surfaces in Delaware River basin, Delaware, New Jersey, Pennsylvania, and southeastern New York for water years 1921-50-Continued

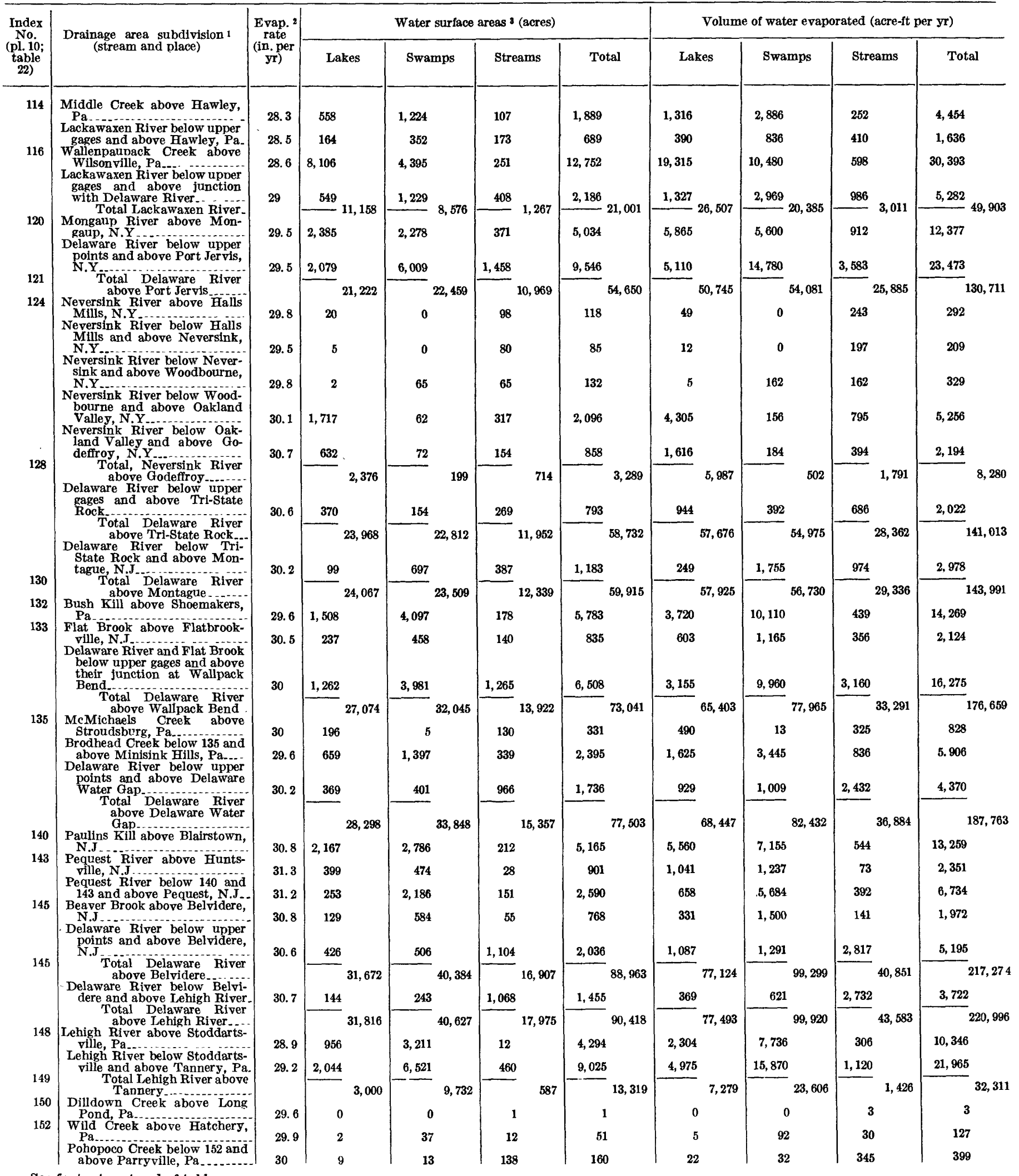

See footnotes at end of table. 
TABLE 2.-Estimated average annual evaporation losses from free water surfaces in Delaware River basin, Delaware, New Jersey, Pennsylvania, and southeastern New York for water years 1921-50-Continued

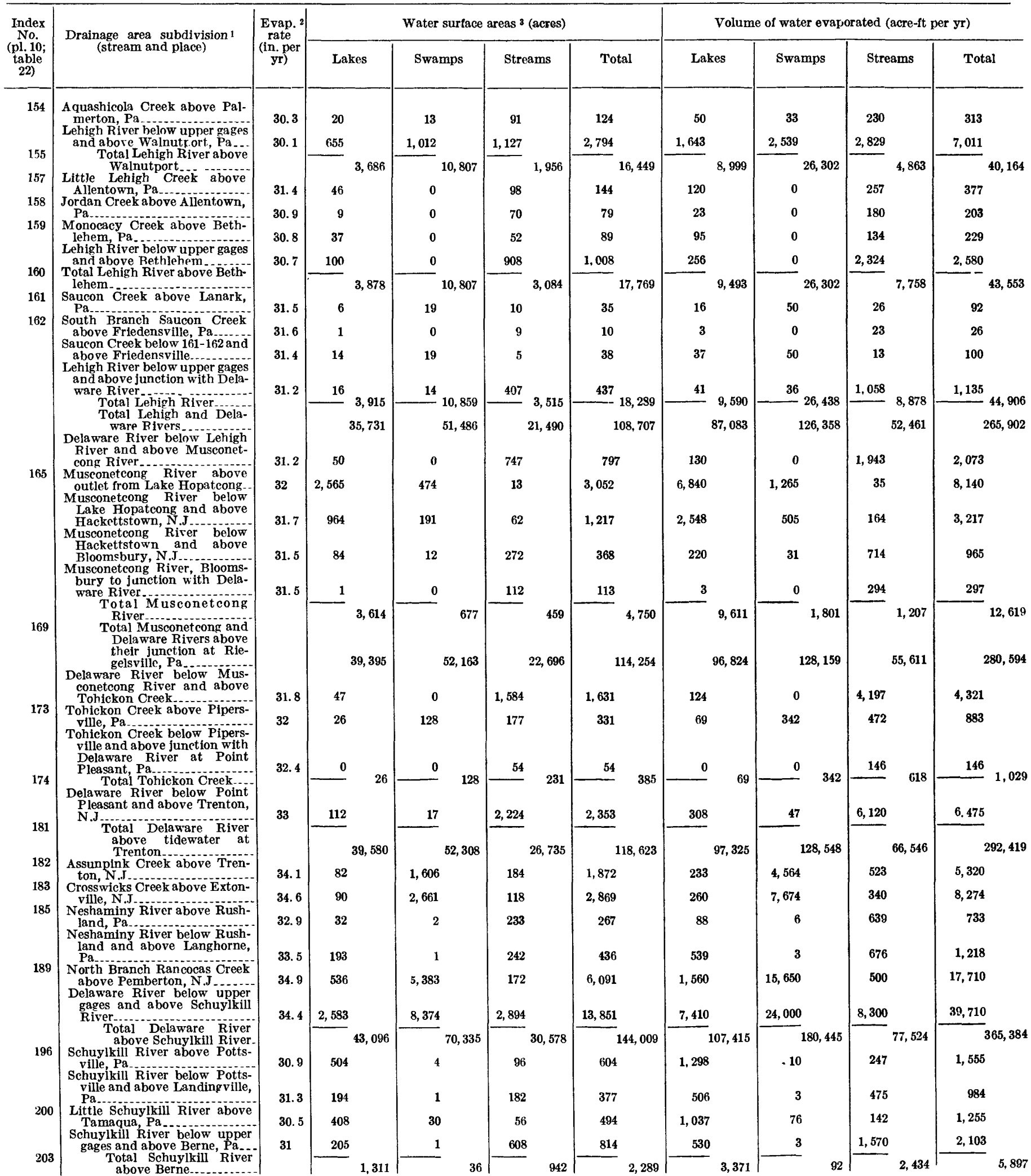

See footnotes at end of table. 
TABLe 2.-Estimated average annual evaporation losses from free water surfaces in Delaware River basin, Delaware, New Jersey, Pennsylvania, and southeastern New York for water years 1921-50-Continued

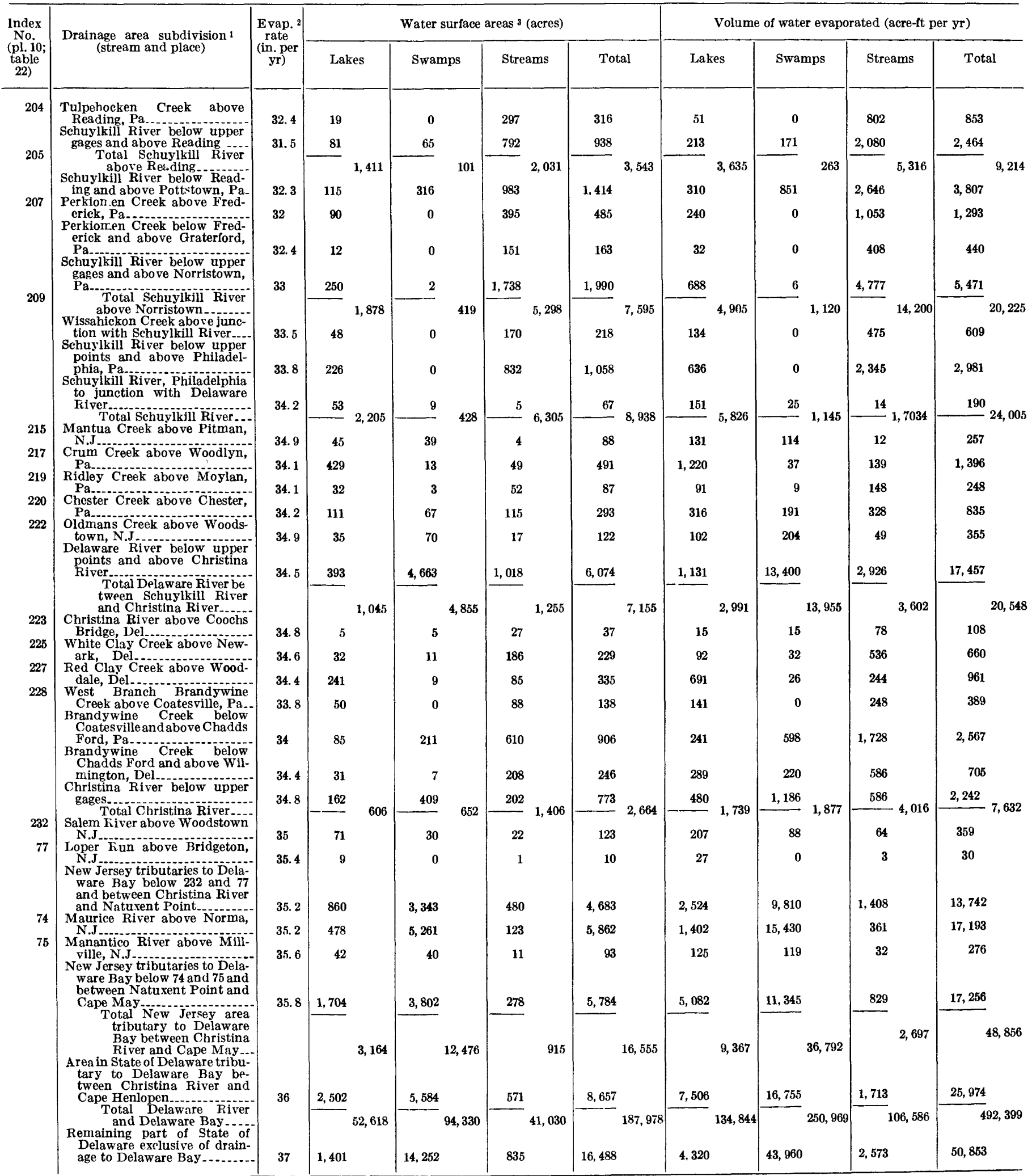

1 Areas are subdivided at river gaging stations and of her convenient points. The ndex number ( $\mathrm{pl}, 10$ and table 22) of the gaging station is given in addition to the place name when the data as listed apply to the entire drainage area above the gage. U.S. Geological Survey topographic quadrangle maps available in March 1957. 
(3) economic, legal, and political aspects of water development. Important among the factors under (3) are the requirements for nonwithdrawal uses, such as hydroelectric power development, dilution of wastes, prevention of salt-water encroachment, navigation, maintenance of fish and wildlife, and recreational uses. The latter requirements are usually met by low or normal streamflow. Withdrawals may be made downstream from places of nonwithdrawal use, but usually some water is discharged to the ocean (or leaves the particular region) to meet some requirement for maintenance of flow; such water is not a withdrawable part of the water crop.

The magnitude of the water crop varies from year to year and from place to place. The variations due to weather can be averaged over a period of years to obtain the perennial water crop. As man's needs increase, however, the development of ground-water supplies and surface-storage facilities results in an increase in the average quantity available for consumptive use.

For example, the water crop might be considered to be the water available from natural (unregulated) streamflow. The low flows of streams would then impose limitations on the withdrawal of water and might even be insufficient to meet requirements of nonwithdrawal uses. Provision of facilities for storing water during periods of high streamflow make it possible to augment low flows at points downstream and to withdraw a larger part of the total streamflow. If sufficient storage is available for regulation complete enough for uniform streamflow, and if no water is required for nonwithdrawal use, the water crop is equal to the runoff. Complete regulation, however, is seldom possible or practical in humid regions; also advantage, may be taken of the natural storage capacity in aquifers by withdrawing ground water. Extensive groundwater development may result in lowered water tables, decreased evapotranspiration from ground water, decreased ground-water outflow, and increased space in which flood waters may be stored. Thus, a part of the natural water loss might be salvaged and become a part of the water crop.

With the economic conditions that are likely to prevail in the foreseeable future, the attainable perennial water crop in the Delaware River basin probably is considerably less than the runoff, which averages about 4.7 tgy. Even though the harvestable water crop could be increased by water recovered from the natural water loss, there probably always will be a great deal of storm runoff that cannot be stored because of physical or economic reasons. Additionally, demands for nonwithdrawal uses must be satisfied; for example, unless a salt-water barrier of some kind is constructed to pre- vent ocean water from moving ever farther up the Delaware River, increasingly larger amounts of fresh water will be required to flush the salt water seaward as time goes on. This procedure will diminish the recoverable water crop to the extent that fresh water is "wasted" to the sea in the flushing action.

The runoff (which is the principal budget item involved in the water crop) is conveniently divided into two major parts: (1) direct runoff, which reaches stream channels by overland flow quickly after rain or snowmelt or by lateral percolation through surface and subsurface layers of litter and shallow soil; and (2) base runoff (or base flow), which reaches stream channels after considerable delay usually as ground-water discharge or as release from natural surface storage (in swamps, lakes, and stream channels). The direct runoff is the principal contributor to storm and flood flows, and the base runoff maintains the fair-weather flow of streams.

\section{FACTORS AFFECTING THE QUANTITY AND DISTRIBUTION} OF THE WATER CROP

The three principal groups of factors that influence the water crop were mentioned on pages 14 and 21 and are used as the basis of the following discussion:

1. Weather and climate: Climate is one of the most important factors influencing the magnitude of the water crop and its variability in place; weather is the principal factor causing variability of the water crop in time. The most important elements of weather, precipitation and temperature, are discussed elsewhere in this report.

Snow, one of the forms of precipitation, deserves some special comment. The principal hydrologic effect of snow is temporary storage of water during cold weather and the release of the stored water with the advent of warm weather. Storage in snow is of great importance in parts of the western United States where the snow accumulation on the high mountains provides delayed runoff for use in the spring and summer. Snow is much less important to the Delaware River region, because the differences in elevation and climate are less extreme and because snowmelt runoff usually occurs in winter and early spring when runoff from rainfall is sufficient to meet most demands. The effect on the regimen of streams in the northern part of the Delaware River basin is significant, however. Snow may also have several minor effects. For example, insulation of the ground from sudden changes in air temperature may prevent the ground from freezing and allow infiltration to continue; or the cover of snow on frozen ground may prevent the ground from thaw- 
ing and may increase direct runoff from snowmelt or rain. The snow cover may absorb considerable quantities of rain. If rain saturates the snow and continues to fall, large quantities of snowmelt, in addition to the rainfall, may be released in a flash flood.

2. Physical characteristics of the drainage basin: The storage capacity of a basin is determined by its physical characteristics, including the works of man. Temporary storage of water within a drainage basin generally has a stabilizing influence on streamflow and thus on the water crop. Storage is the most important of all the factors subject to human control and development; it is discussed in following sections on surface storage and groundwater storage.

The ability of the soil to absorb precipitation and transmit it to the aquifers is a closely related factor of great importance, which is discussed in the section on infiltration capacity. The principal effects of land use or vegetational cover on the water crop are reflected in the infiltration capacity.

Topography also has important effects, some of which are related to storage. Areas of considerable relief commonly contain suitable sites for construction of artificial surface-storage facilities, but practically none are suitable for providing storage for all storm runoff from major floods. These areas are also deficient in natural storage capacity, both on the surface and underground. Areas of low relief in the basin have few suitable sites for any but very small surface reservoirs, but these areas commonly have large groundwater storage capacities. Steep land slopes favor direct runoff, and flat slopes allow more time for infiltration.

The topography has a controlling influence on land use and thus affects the water crop indirectly. For example, steep slopes may be suitable only for forest, and level lands near a stream may be suitable for agricultural, urban, or industrial development.

3. Economic, legal, and political aspects of water development: Detailed analysis of specific projects is beyond the scope of this study, but the limitations imposed by these projects are important in any evaluation of the water crop. For example, economic limitations probably would prevent the storage of all the water that it is physically possible to store. Legal and political considerations might impose additional restrictions. All the human factors are subject to change, and the overall limitations imposed will probably decrease as the need for water increases, but at any particular place the limitations may increase appreciably. As water becomes more difficult to obtain, users will pay higher prices, and laws may be altered to meet new conditions.

The requirements for nonwithdrawal use also are dependent upon human factors, subject to change both in time and place. In drylands regions higher priority uses often take nearly all the available supply. In the Delaware River basin, however, an increase in nonwithdrawal uses is more likely to occur than a decrease because of the increasing needs for: (1) dilution of wastes; (2) control of salt-water encroachment; and (3) maintenance of navigation facilities.

SURFACE STORAGE

The natural surface-storage capacity of a basin includes the capacity of its lakes, ponds, swamps, and stream channels. During periods of storm runoff the inflow to these water bodies usually exceeds the outflow, consequently the water levels rise. The outflow rate is partly determined by the stage, or elevation of the water surface. When the inflow rate drops below the outflow rate, the stage begins to fall and the release of stored water sustains flow at downstream points. Thus, surface-water storage and ground-water storage together provide the fair-weather flow of streams, and increase the harvestable water crop by making more of the streamflow available for withdrawal.

Natural storage may be supplemented by artificial reservoirs with either controlled or uncontrolled outlets. When outlets are uncontrolled, the effects of the storage are similar to those of natural storage except that outflow rates are partly determined by design of the outlet structure. Such storage reduces flood peaks, unless the reservoir is full at the time of peak runoff, but has no effect on low flows occurring long after storm runoff has ceased.

Controlled storage may be classified as flood-control storage or as conservation storage. Flood-control storage is utilized to reduce flood peaks and thus to diminish damage at downstream points; but, because storage space must be emptied soon after each flood, flood-control storage has no effect on most low flows. Conservation storage is utilized to store excess runoff for later use during periods of low runoff. Storage for hydroelectric power is intermediate between these two types. Its purpose is to supply power when needed, regardless of streamflow conditions. In practice its effects are usually closer to those of conservation storage than to those of flood-control storage.

In the Delaware River basin the best storage sites are upstream from the Fall Line. In the Coastal Plain, surface-water storage sites are scarce, even for small 
reservoirs. However, in places where ground water is locally scanty and where the area is underlain by thick aquicludes, small serviceable surface reservoirs have been constructed, especially in some of the westwardflowing tributaries of the Delaware River in New Jersey. Some sites for such small reservoirs still remain and may eventually be utilized if economically feasible.

The useful life that may be expected of these small reservoirs is unknown because the sediment-transport data for the small streams involved does not exist. Neither, for that matter, can we be certain of the expected life of large reservoirs, such as Pepacton or the one proposed at Tocks Island. The useful life of these large reservoirs probably will be about several hundred years; that of small reservoirs will be much less, probably less than a hundred years.

Surface-water storage and ground-water storage are closely related in some places. For example, the water level in swamps rises and falls with the connecting water table; leakage from reservoirs and ponds may become ground water; raising the level of water in a reservoir in permeable materials may cause a rise of the water table for considerable distances and increase the storage of water in the aquifers.

There is a widespread movement in the Delaware River basin to construct farm ponds. In the more rugged parts of the region these ponds are filled mostly by storm runoff in small wet-weather drainage courses. They are usually built on relatively impermeable materials, and the pond water is therefore insulated from, and commonly above, the water table. Such ponds have little or no effect on ground-water storage. Evaporation takes a heavy toll from such ponds during dry weather, but because the area of these ponds is not great, the total effect on the basin's water crop is small.

In the lower lands of the basin, especially where the soils and aquifers are thicker and more permeable, the ponds commonly connect with the water table, and the effects of ponds on ground water are greater. For example, Barksdale and Remson (1956, p. 524) report:

In August 1953 the floodgates were opened in a small dam near Seely, N.J. The level of the pond, which is about 2,000 feet long, was lowered more than 4 feet. As a result, in the course of the next several weeks the water level in a well 500 feet from the pond fell 1.5 feet. The specific yield of the aquifer is about 30 percent, so that obviously several million gallons of ground water was being drained from the aquifer in the area within a few hundred yards on either side of the pond. Thus, it can be appreciated that the impounding of this small surfacewater body resulted in the storage of a substantial amount of ground water. In many and perhaps most areas this would be considered advantageous; in others, particularly areas of heavy precipitation, it might be better to allow the drainage of this soil so that the storage space would be available to reduce overland flow and erosion. Where the aquifer materials have large specific yields, the judicious placement of small dams can result in substantial increases in local ground-water storage. On the other hand, in areas where the specific yield is low, relatively little water could be stored in the ground around such a pond.

\section{GROUND-WATER STORAGE}

Aquifers serve dually as natural reservoirs and conduits, and they have a pronounced effect on the time distribution and magnitude of the water crop. As in a surface reservoir, the quantity of water stored underground fluctuates in response to changing rates of inflow and outflow, although with considerable lag. The amount in storage increases during and after periods of precipitation, or water added to the soil in excess of field capacity percolates downward to the zone of saturation; in contrast, storage decreases during and after periods of drought. Recharge from equivalent amounts of precipitation is much less during the growing season than during the winter, because during the growing season more of the water is lost by evapotranspiration from the soil and vegetation and less water infiltrates to the water table. At the same time the discharge from the ground-water reservoir continues; hence, the amount of water in storage decreases. Limits within which the quantity of water stored underground fluctuates naturally are determined chiefly by the volume of pore space in the reservoir that can accept and transmit water and by the elevations of the discharge outlets.

The chief effect of ground-water storage on the water crop is to maintain streamflow during dry periods and to distribute the flow more evenly in time. In the Delaware River basin this regulatory effect is of great importance; it is estimated that about half the average annual runoff is derived from ground-water discharge, but marked variations in this proportion occur within the basin.

When a ground-water supply is developed, the ground-water storage has even more effect on the water crop than it has under natural conditions. When water is pumped from aquifers, more storage space is provided to accept recharge from precipitation, which otherwise might have run off directly. Pumping lowers the water table and reduces: (1) natural evapotranspiration; (2) underground outflow; and (3) groundwater discharge to streams or other surface-water bodies. The draft on storage is offset by additional recharge that is induced where the normal water-table slope toward a surface-water body is reversed.

Ground water can be withdrawn from storage at rates temporarily exceeding the rate of natural recharge (temporary overdraft), and the aquifers can be replenished either naturally or artificially. When with- 
drawals exceed recharge mining of ground water occurs. In such instances mining the aquifer depletes the supply. In several parts of the United States, including parts of New Jersey, aquifers have been recharged artificially with excess local streamflow or with imported supplies (Barksdale and DeBuchananne, 1946, p. 726-737).

By use of these processes during the development of ground-water supplies, recharge and discharge of the aquifers are increased, and the fluctuations in groundwater storage may be greater than those under natural conditions. Except for the decrease in natural loss by evapotranspiration and ground-water outflow, the potential water crop in the basin is not thereby increased; however, more of it is made available for use locally.

The part of the annual water crop that is available locally from ground water varies greatly, depending chiefly on the storage and transmissibility characteristics of the aquifers. Thus, less ground water is available in an area underlain by impermeable rocks or clay than in an area underlain by thick permeable sand. In the Delaware River basin ground water is most abundant in the Coastal Plain; in the Appalachian Highlands, where ground water is not so abundant, it occurs in greatest quantities in the deeper valleys that are underlain by coarse glacial deposits or limestone.

Ground-water supplies tend to differ from surfacewater supplies in physical, chemical, and biological character, and ground-water supplies therefore may be more desirable than surface supplies for some purposes. For example, at Louisville, Ky., a plentiful supply of water is available from the Ohio River, but many industries prefer ground water for cooling in summer because of its lower temperature, greater clarity, and more uniform chemical characteristics. Accordingly, withdrawals from the aquifer in summer greatly exceed the natural recharge, and in winter cold river water is used to recharge the aquifer. Thus, aquifer storage is utilized to provide cold water when surface supplies are too warm.

\section{INFILTRATION CAPACITY}

The characteristics of the rocks and soils above the zone of saturation determine the rate at which water can be absorbed and transmitted to the underlying aquifers. Consequently, the rocks and soil largely determine the proportions of direct runoff and groundwater recharge. Permeable well-drained soils absorb water readily and continue to do so as long as storage space is available in the aquifer. Most soils absorb water more readily when nearly dry than when wet. A permeable soil over an impermeable subsoil quickly becomes saturated and infiltration decreases to the rate at which the subsoil transmits water downward.

The infiltration capacity of a soil may be changed by:
(1) freezing, which makes the surface less permeable; (2) alternate freezing and thawing, which loosens the soil; and (3) changes in vegetational cover and methods of cultivation, which affect soil structure, organic matter, and plant and animal life in the soil. Furthermore, urbanization results in elimination of infiltration from large areas.

A virgin soil tends to be much more permeable than the same soil under cultivation or grazing. The effects of cultivation on infiltration capacity are illustrated by experience at Seabrook, N.J., where almost one billion gallons of cannery waste is disposed of annually by irrigation from large sprinkler nozzles in a wooded area of approximately 260 acres. In describing the experience at Seabrook, Thornthwaite (1951) states:

Any land that had been tilled would become saturated and soupy to plow depth after 2 inches of water had been applied. At the same time, adjacent pine-oak woodland which had not been plowed took 56 inches at the rate of 6.3 inches per hour without becoming saturated. This area received more than 150 inches in 10 days with still no sign of being satisfied.

The infiltration rates observed at Seabrook could be maintained only where soils and subsoils are deep, permeable, and well drained.

Land use and management may affect the infiltration capacity to extents that vary in time and in place, depending upon local conditions. The effects of various types of land use and various methods of cultivation have been studied extensively by small-plot experiments, but evaluation of the effects in a large complex area, such as the Delaware River basin, is difficult.

FACTORS AFFECTING THE QUAUTTY OF THE WATER CROP

A satisfactory water supply must be adequate in quality and quantity. Water passing through the atmosphere and over or through the soil and rocks acquires suspended and dissolved impurities. Some of these impurities may be of no consequence for a particular use, but may seriously impair the water for other uses. For example, water containing a small concentration of dissolved iron may be suitable for drinking but not satisfactory for the manufacture of plastics or rayon. Dissolved oxygen enhances the palatability of drinking water, is essential to the existence of some forms of aquatic life, and plays a part in the self-purification of natural waters. Dissolved oxygen also makes water corrosive to metal pipes, and for such uses as boiler-feed water its concentration should be below a certain level. Natural water is never chemically pure although much is biologically pure. We shall, therefore, consider the sources of the impurities and their effect on the uses of the water.

\section{IMPURITIES DERIVED FROM THE ATMOSPHERE}

Rainwater and snowmelt are the purest of natural waters. In some areas, rain falling on the rooftops is 
collected in cisterns and serves for domestic use without further treatment. Even this relatively pure water contains oxygen, nitrogen, and carbon dioxide dissolved from the atmosphere, but oxygen and carbon dioxide are found in greater proportions in the dissolved gases than in the air. The rain washes from the atmosphere other gases and such substances as ammonia, nitric acid, and sulfuric acid, as well as fine particles of dust and soot. The nature and proportion of the impurities in the rainwater are variable: mineral acids, for example, are common near cities or industrial centers, and ordinary salt is common near the seacoast. Mineral impurities, however, are present in rainwater in extremely small quantities.

\section{IMPURITIES DERIVED FROM ROCKS AND SOILS}

Rain that falls on the earth's crust begins immediately to dissolve rock and soil. Clarke $(1924$, p. 116) estimated that, in the region draining to the North Atlantic, 130 tons of minerals per square mile of land is dissolved annually and carried off to the ocean. The nature and concentration of the dissolved matter in the water depend upon many conditions. Long contact between water and rock material favors solution, consequently, ground water is usually more mineralized than water which runs quickly over the surface to the streams. When the ground is frozen, or saturated by previous rainfall, little rain penetrates the ground and runoff to the streams is increased. In the early spring, rain accompanied by snowmelt results in heavy discharge to streams. In either situation, the stream waters are less mineralized than in periods of low flow when streamflow is largely derived from ground water.

Water may react chemically directly with rock minerals, as it does with feldspars, or serve as a solvent of oxygen or carbon dioxide, which also react with earth materials. The direct action of water is referred to as "hydrolysis," the action of oxygen as "oxidation," and the action of carbon dioxide as "carbonation." Whether the action be hydrolysis, oxidation, or carbonation, the water leaches out and carries away in solution ions of sodium, potassium, calcium, magnesium, iron, manganese, chloride, sulfate, nitrate, bicarbonate, and colloidal or soluble silica, iron, and aluminum. Through hydrolysis the feldspars give up their potassium, sodium, and calcium to the water. These ions are then replaced by hydrogen ions from the water. By this process the feldspars are converted to less soluble clay minerals, and as a result the solvent water becomes more alkaline and more mineralized. Silica minerals, which are very abundant in the Delaware River basin, are attacked more by acid ground water than by neutral or alkaline water.

Dry air contains about 0.03 percent carbon dioxide by volume, but rainwater may contain as much as
3 percent dissolved carbon dioxide (Rankama and Sahama, 1950, p. 312). Aerobic bacteria in the soil oxidize organic material to carbon dioxide which further enriches the soil water in carbon dioxide. Dissolved carbon dioxide forms carbonic acid which is very effective in dissolving such carbonate rocks as limestone or dolomite.

The concentration and proportions of dissolved materials depend chiefly upon the mineral constituents of the aquifer from which the water came. Compared to water from other sedimentary rocks, water flowing over or through limestone or dolomite will be rich in calcium and magnesium. On the other hand, water flowing from an acidic, igneous, rock terrane, such as an area underlain by granite, gneiss, or schist is low in dissolved solids but relatively high in silica, sodium, and potassium.

\section{MUNICIPAL, INDUSTRIAL, AND AGRICULTURAL WASTES}

Natural water contains some impurities, and use of the water for domestic, industrial, or agricultural purposes usually adds more. Whether these additional impurities impair the usefulness of the water depends upon their nature, their concentration in the water, and what use is to be made of the water.

The quality of water may be impaired by some uses even when no impurities are added. For example, far more water is used for cooling than for all other industrial purposes. The discharge of waste cooling water to a stream raises the stream temperature, especially where the stream water is reused several times, and it may become too warm for further use as a coolant. Fish and other aquatic life are affected by a rise in temperature because (1) warm water contains less dissolved oxygen than cooler water, and (2) fish are more active at the higher temperature and therefore consume more oxygen. Thus, an increase in water temperature may asphyxiate the fish by depleting the oxygen.

Some organic wastes, such as those in sewage, are oxidized by the dissolved oxygen in stream waters with the aid of certain kinds of bacteria. This natural purification process, too, proceeds faster at higher temperatures. Faster reaction may be an advantage if there is sufficient dissolved oxygen to consume all the organic waste material. However, the waste putrefies if the dissolved oxygen is not sufficient to oxidize it, for in the absence of oxygen the waste is destroyed by reactions producing gases of objectionable odor, such as hydrogen sulfide. Thus, information on the concentration of dissolved oxygen is useful in evaluating water quality; so also is the biochemical oxygen demand, which is a measure of the oxygen required for the destruction of organic matter by aerobic biochemi- 
cal action. If the dissolved oxygen is sufficient to satisfy the biochemical oxygen demand, the oxidizable wastes probably will be removed by natural purification in the stream.

Dissolved minerals, such as common salt (sodium chloride), do not disappear in this fashion. They may, however, be flushed away or be sufficiently diluted that they are not deleterious. The sewage of the city of Philadelphia adds about 100 tons of sodium chloride daily to that already in the Delaware River. With a fresh water flow of $12,000 \mathrm{cfs}$ (cubic feet per second), for example, the 100 tons per day of sodium chloride constitutes only 3 to $4 \mathrm{ppm}$ in the river water. This concentration is not objectionable and is insignificant compared to the amount of salt introduced from the ocean.

Industrial wastes are of many kinds. Wastes from breweries, dairies, and slaughter houses, for example, contain organic material which, like sewage waste, is subject to oxidation. Some contain toxic substances, such as the phenols from coke plants, the arsenic from weed-killers or insecticides, and the cyanides from electroplating processes. Others include mineral acids from chemical manufacturing or salt brines from petroleum wells. Some wastes do not dissolve in the water. Oils and greases float or become emulsified; solid particles, such as paper fibers, sewage solids, or sediment may make the water turbid by remaining suspended; or may foul stream beds or reservoir bottoms by settling out there.

Radioactive substances from nuclear reactors and radioisotopes used in medical therapy or in industrial processes are potential contaminants of aquifers and streams. Although their disposal is restricted by various regulations, it is always possible that-througb accident, ignorance, carelessness, or sabotage-radioactive materials may reach ground- and surface-water bodies. The rate at which these materials give off radioactive radiation can neither be retarded nor accelerated. If ingested, some may become concentrated in lethal quantities in particular tissues of the body. Radioactive materials are also harmful to some industrial processes, such as the manufacture or processing of photographic film.

Drainage from farmlands is sometimes rich in ammonia, nitrates, and phosphates, which stimulate the growth of algae. Algae are beneficial in that they produce oxygen and consume carbon dioxide and some are a food supply for fish and other aquatic life; but where algal growth is excessive the algae or their products can poison farm animals and impart undesirable taste and odor to domestic water. Algae are undesirable in cooling water and in water used for laundry, photography, and the manufacture of paper and rayon.
When the streamflow is large compared to the volume of waste discharge, dilution may be sufficient to reduce the concentration of impurities to an unobjectionable level. The disposal of wastes by dilution, however, is not as simple as it may seem. Suppose an industry wishes to discard 500 gpd of a waste containing $20 \mathrm{ppm}$ of cyanide by dumping it into a small stream having an average flow of $1 \mathrm{mgd}$ (millions gallons per day), or $1.55 \mathrm{cfs}$. If the waste is uniformly mixed with the total daily flow of the stream, the resulting cyanide concentration in the stream will be only $0.01 \mathrm{ppm}$. But in dry seasons the stream discharge will be less than $1 \mathrm{mgd}$, and the resulting concentration of cyanide will be greater. If the batch of waste is all dumped within a half-hour period, the concentration of cyanide in the stream may be $0.5 \mathrm{ppm}$, which would be fatal to most fish. Again, the waste may not mix thoroughly with the stream water, and some of the water may contain more than $0.5 \mathrm{ppm}$ of the waste. The waste may concentrate on one side of the stream or, if denser than the stream water, on the bottom. Mixing is also affected by wind, river alinement, roughness of the channel, and tidal action.

Most polluted water can be made suitable for use by treatment, but the process may be too costly. For example, several treatment methods are known for the conversion of sea water to fresh water, but as yet none of these methods produce fresh water at a cost low enough to compete in the Delaware River basin with naturally fresh water for irrigation, domestic, or industrial use.

Most wastes are introduced into the streams in areas of heavy population and industrial concentration, as the Allentown-Bethlehem area on the Lehigh River, the Easton, Trenton, and the Philadelphia metropolitan areas on the Delaware River, and on the Schuylkill River at and below Reading. Other important sources of pollution are in the headwater areas of the Schuylkill and Lehigh Rivers.

\section{MINE DRAINAGE}

The anthracite coal mines of the Schuylkill and Lehigh River basins have a pronounced effect on the quality of the water in these streams and on some of their tributaries. Associated with the coal are shales containing pyrite, a sulfide of iron. When the coal is mined, the shales are exposed to attack by air and running water. As water saturated with air flows across these shales or through the pyrite-bearing refuse in or near the mines, iron and sulfur are dissolved in the water. The ferrous iron oxidizes to ferric iron and the sulfur to sulfate ion and free sulfuric acid.

The resulting dilute sulfuric acid readily dissolves additional rock materials so that in addition to the hydrogen, ferrous, and sulfate ions, these mine waters 
often contain high concentrations of calcium, magnesium, aluminum, and manganese as well. Owing to hydrolysis of salts of iron, manganese, and aluminum, the $\mathrm{pH}$ of acid mine drainage usually is low, about 3 or 4. The composition of water from any particular mine is rather uniform, but the composition of water from different mines varies because of differences in length of contact of water with air and acid-forming minerals and because of the different mineral composition of the rock. In the streams, however, the mine drainage is diluted by overland runoff. Although there is little seasonal change in the concentration or composition of drainage from a given mine, the stream water generally has lowest concentrations of acid wastes from December to June and greatest concentration in September and October, because the volume of streamflow available for dilution is greatest in the former period and least in the latter.

The Schuylkill River rises in the coal regions, then cuts through shale and sandstone, limestone, diabase, and finally through the crystalline rocks of the Piedmont upland. The coal-mining region is upstream from Berne, $\mathrm{Pa}$. The following data, based on the 4year period October 1947 to September 1951, show that: (1) the water dissolves, per square mile of drainage area, 3.5 times as much material in the coal-mining region as in the rest of the drainage basin; and (2) that nearly as much material is dissolved above Berne (19 percent of total drainage area) as in the remainder of the Schuylkill River basin.

\begin{tabular}{c|r|r|r}
\hline Location & $\begin{array}{r}\text { Drainage } \\
\text { area } \\
\text { (sq mi) }\end{array}$ & $\begin{array}{r}\text { Dissolved } \\
\text { solids (tons } \\
\text { per year) }\end{array}$ & $\begin{array}{r}\text { Dissolved } \\
\text { solids (tons } \\
\text { per sq mi per } \\
\text { year) }\end{array}$ \\
\hline $\begin{array}{r}\text { At Berne, Pa } \\
\text { Berne to Philadelphia, Pa. }\end{array}$ & $\begin{array}{r}355 \\
\text { Total }\end{array}$ & $\begin{array}{r}229,000 \\
283,000\end{array}$ & $\begin{array}{r}640 \\
184\end{array}$ \\
\hline
\end{tabular}

For many industrial uses, water of the Schuylkill River must be treated because of the dissolved impurities resulting from mine drainage. Iron and manganese cause stains or discoloration on white porcelain, paint, enamel, and laundry; they create additional problems in the manufacture or processing of paper, rayon, plastics, textiles, and leather. Calcium and magnesium form scale in steam boilers which reduces their efficiency and increases maintenance costs. Mineral acids corrode metal and concrete and are injurious to fish and other forms of aquatic life.

Acid mine drainage may have a pronounced effect on natural purification processes in a stream, as has been shown by Chubb and Merkel (1946) for the Schuylkill River. Domestic sewage contains the organisms that promote its decay. When the sewage is diluted with stream water containing dissolved oxygen, these organisms aid the oxidation of organic matter. If, however, the stream water is acid (as it is in the upper Schuylkill River), the sewage remains practically unchanged in the stream. The dissolved-oxygen concentration increases in this reach of the stream, for little is consumed by the sewage. At or near Reading, tributaries draining a limestone region add their waters to the stream; these waters are alkaline enough to neutralize the water of the main stream. The inactive organisms then function again, the sewage is oxidized; and the dissolved-oxygen concentration decreases. If the dissolved oxygen is insufficient to oxidize the sewage when the acid stream is neutralized, nuisance conditions can be created, for in the absence of oxygen the sewage which accumulated in the acid reach of the stream is putrefied.

Sediment in streams is due to erosion and to municipal and industrial wastes. If a drainage basin is covered with protective vegetation, comparatively little erosion occurs; but if the ground is bare and exposed to raindrop impact and rapid runoff, soil erosion and stream loads are greater. Although industrial or municipal wastes may contribute sediment to the streams, most of these are treated before discharge; simple treatments are used to remove the settleable solids. Sediment may be sand, clay, silt, vegetation, or material of mining or other industrial origin. Perhaps the greatest sediment problems in the basin have been those associated with coal mining. At one time coal-cleaning operations and the erosion of culm piles were the source of sediment discharged principally into the Schuylkill River. Now coal washeries have settling ponds to remove the culm before the wash water is discharged to the streams, old deposits have been dredged from the Schuylkill River, and desilting basins have been provided to remove sediment that reaches the river.

Sediment interferes with natural purification in streams by reducing the penetration of sunlight and by its adverse effect on aquatic growth. Sediment in suspension clogs the gills of many fish and mollusks. Worms, protozoa, algae, insects, and crustacea may be injured or destroyed. During settling, inorganic sediment carries organic matter with it. The decay of the organic matter requires oxygen, and the sediment hinders access of oxygen to the organic matter.

The load that a stream can carry in suspension or move along its bed as bedload is largely a function of stream velocity. The faster a stream flows, other factors being equal, the more sediment the stream can transport. Stream velocity is not constant, either in place or time, and sediment load constantly changes. When velocity drops below the point at which a stream 
can carry fine gravel in suspension, it still may carry sand, silt, and clay particles. Given a lesser velocity, the sand may be dropped and only silt and clay still remain in suspension. Where streams enter reservoirs and velocity becomes negligible, only the very finest sediment remains in suspension, and even this, given enough time in quiet water, settles out.

Organic sediments may be deposited in a streambed or carried downstream in suspension, depending largely upon the stream velocity. In either situation, such sediments are slowly decomposed by bacterial action with the aid of dissolved oxygen. In a turbulent stream the oxygen consumed is replaced through aeration, unless the organic matter is oxidized too rapidly.

Where an organic pollutant is released to a stream upgradient from a reservoir, two possibilities must be considered: (1) All the organic pollutant will be deposited in the streambed or be oxidized before it reaches the reservoir; or (2) some or all of the oxidizable matter will reach the reservoir.

In the first possibility, all the oxidation occurs in the turbulent stream above the reservoir, and the oxygen in the reservoir water is not depleted. In the second possibility, all or some of the organic material is trapped in the reservoir and undergoes decomposition there, resulting in depletion of the oxygen in the reservoir water. In the reservoir, as well as in the stream, the oxygen consumed is replaced to some extent through aeration. However, owing to depth and lack of turbulence, aeration occurs at a slower rate in the reservoir than in the stream. When no more dissolved oxygen is left, anaerobic decomposition may begin and produce odors. In a situation of this kind, a regulated release of water to the reservoir for the purpose of maintaining a specified minimum flow through it could be highly undesirable. At sufficiently low discharge rates, the organic solids would be oxidized before they reach the reservoir, but at the higher discharge rates provided by the regulated releases, they might be carried into the reservoir, there to undergo either oxidation or anaerobic decomposition.

Sediment is deposited in navigation channels in many places, and dredging becomes necessary. Sediment must be removed from water to be used in the manufacture of such products as ice, bottled beverages, food, paper, and rayon. Some suspended solids are abrasive and erode turbine blades in hydroelectric plants. Often the most expensive part of the purification of domestic water is the removal of sediment.

\section{SALT WATER IN THE DELAWARE ESTOARY}

Below Trenton the Delaware River is tidal. Salt water from the ocean mixes with the fresh water of the river as far upstream as Philadelphia. In addition, large quantities of sanitary and industrial wastes are discharged into this reach of the river. The salinity ranges from that of the river water at Trenton (40$120 \mathrm{ppm}$ of dissolved solids) to that of ocean water $(35,000 \mathrm{ppm})$. The salinity at intermediate points varies under the effects of changes in sea level, in freshwater discharge, wind, and other factors, that is, the usable supply of water at some places in this urban and industrial area varies greatly because of variations in water quality. The varying chemical quality of water in the tidal reach of the Delaware River is discussed on pages $149-156$.

\section{GROUND WATER-ITS AVAILABILITY AND CHARACTER \\ GENERAL GROUND-WATER HYDROLOGY OF THE BASIN}

GOURCE OF GROUND WATER

All ground water in the Delaware River basin is derived from precipitation. When the capacity of the soil to retain water against gravity (the field capacity of the soil) is exceeded, the excess water percolates to the zone of saturation to become ground water. Throughout most of their courses the streams of the Delaware River basin act as drains rather than as sources of ground water. Seepage from streams contributes a significant amount of recharge to ground water only where pumping of wells reverses the natural direction of ground-water movement toward the streams. Under these circumstances, substantial quantities of recharge may be induced from the streams.

\section{OCCURRENCE AND MOVEMENT}

Ground water is water occurring in saturated openings in earth materials; it provides water to wells, springs, and the fair-weather flow of streams. A bed or zone of such materials capable of yielding collectible quantities of water to wells or springs is called an aquifer. Aquifers have two principal functions: (1) storage of water; and (2) transmittal of water.

Storage is perhaps the primary function of aquifers in which the water exists under unconfined, or watertable, conditions. The water table is the top of the zone of saturation, below the capillary fringe, where pressures are atmospheric. Water-table conditions are most common in shallow permeable materials such as the coarse-grained deposits in large areas in the Coastal Plain and the thick mantle of weathered rock in many parts of the Piedmont physiographic province. Such aquifers are naturally recharged directly from precipitation on their intake areas.

On the other hand, aquifers that contain water under confined, or artesian, conditions serve principally as conduits to transmit water from intake (recharge) areas to discharge areas, although they may store immense quantities of water. Artesian aquifers are enclosed by 
beds or zones of relatively impermeable materials (aquicludes) which, though they may be saturated, yield little water and act as barriers to water movement. The heights to which water will rise in cased wells penetrating an artesian aquifer define its piezometric surface. The best examples of aquicludes and artesian aquifers in the basin are, respectively, the extensive alternate layers of clay and sand in the Coastal Plain province.

Aquifers in the basin range widely in their capacity to store, transmit, and yield water. Their most significant hydrologic parameters are their coefficients of storage, permeability, and transmissibility. Porosity, which is the ratio of pore space to total volume, is not so important, because not all (and in some materials, such as clay, very little) the water stored in the openings of a material will drain by gravity; hence, some of this storage capacity is not usable.

Coefficient of storage.-The coefficient of storage is the volume of water released from or taken into storage by an aquifer per unit surface area per unit change in the component of head (water pressure) perpendicular to that surface. In artesian aquifers, where the discharge is due to elastic adjustment to changes in head rather than to drainage of pores, the coefficient of storage is very small, commonly $0.00001-0.001$; whereas in watertable aquifers, where the material is actually drained, the coefficient of storage commonly ranges from 0.05 to 0.30 .

Storage fluctuations.- The storage fluctuations in an aquifer are caused by changing rates of recharge to, and discharge from, the aquifer. The changes in storage are reflected by fluctuations in the water table, or piezometric surface; the ratio of the volume of water released from or taken into storage to the total volume represented by the zone of fluctuation of the water table, or piezometric surface, is the coefficient of storage of the aquifer. For example, in a water-table aquifer having an average coefficient of storage of 0.1 , a 10-foot decline in water table over a specified area represents a decline in storage equal to a 1-foot depth of water over the area.

In an artesian aquifer having a coefficient of storage of 0.0001 , a 10 -foot lowering of the piezometric surface represents a decline in storage of only 0.001 foot of water. In a water-table aquifer where part of the material actually is drained as the water table declines, the coefficient of storage is practically equal to the specific yield; but in an artesian aquifer none of the material is drained, and the water released from storage is derived principally from a slight expansion of the water itself and a slight decrease in the volume of the aquifer and of adjacent silt and clay beds. An artesian aquifer, however, becomes a water-table aquifer when the water level is lowered beyond its upper confining layer; the storage coefficient within the area of unwatering then becomes practically equal to the specific yield.

Coefficient of permeability.-The coefficient of permeability of a material, as used by the U.S. Geological Survey, is the rate of flow of water in gallons per day through a cross section of 1 square foot under a hydraulic gradient of 1 foot per foot, at a temperature of $60^{\circ} \mathrm{F}$. The field coefficient of permeability is the same, except that it is measured at the prevailing water temperature rather than at $60^{\circ} \mathrm{F}$. Some of the deposits of coarse sand and gravel have permeability coefficients exceeding 3,000 gpd per sq ft, whereas most beds of clay have permeability coefficients measured as a very small fraction of a gallon per day per square foot.

Coefficient of transmissibility.-The coefficient of transmissibility may be obtained by multiplying the coefficient of permeability of an aquifer by its thickness. It is expressed in gallons per day per foot, and it indicates the capacity of the aquifer, as a unit, to transmit water at the prevailing temperature under any given hydraulic gradient. Transmissibility coefficients greater than 100,000 gpd per $\mathrm{ft}$ have been measured for sand aquifers in the Coastal Plain, but coefficients less than $1 \mathrm{gpd}$ per foot have been estimated for adjacent clay aquicludes.

Paths of movements.-Ground water, like surface water, moves in the direction of decreasing hydraulic head. In water-table aquifers, the water moves in fairly direct paths from higher to lower areas in the outcrop; but in artesian aquifers, the water may follow long and sometimes rather circuitous paths. In the Delaware River basin, distances traveled from intake points to discharge points in water-table aquifers range from only a few feet to thousands of feet. In artesian aquifers, such as those of the Coastal Plain, distances traveled by some of the water from the recharge area at the outcrop to discharge points range from a few miles to tens of miles. Some artesian recharge is obtained from leakage through confining beds, and the water from such sources may move vertically only a few tens to several hundreds of feet. Times of transit also range widely-from a few hours or days to tens and even hundreds of thousands of years.

\section{DISCHARGE}

Natural discharge of ground water takes place where the water table (or the overlying capillary fringe) is at or near the land surface. Some of this water returns to the atmosphere by evapotranspiration and thus may be considered as part of the natural water loss. The remainder enters streams or other bodies of surface water.

In addition to natural discharge, considerable quantities of water are discharged artificially by pumped 
wells, mines, and quarries. New patterns of groundwater movement toward the pumped areas become established and discharge at natural outlets may diminish or cease.

Most natural ground-water discharge in the Delaware River basin occurs at relatively low parts of the outcrop of aquifers-along streams, in wet or swampy areas, and into bays, estuaries, or the ocean. The total discharge, including evapotranspiration, is estimated to average about $10 \mathrm{bgd}$ and it is estimated that about half the average annual streamflow in the basin is supplied from ground-water discharge.

\section{TYPES OF AQUTFERS}

Two major types of aquifers exist in the basin and adjacent areas: one consisting of unconsolidated sediments, or "soft" rocks, and the other consisting of consolidated, or "hard" rocks.

Unconsolidated sediments consist of loose granular materials, deposited by water, wind, or glacial ice; in such materials almost all the water-bearing openings are pores between the grains. For some sand samples from the Coastal Plain in New Jersey, the porosities as determined in the laboratory range from about 25 to 45 percent (Barksdale and others, 1958), and some Recent clays have even higher porosities.

Not all the water stored in the pores will drain by gravity. The term "specific yield" is used to indicate the ratio of the volume of water that can drain by gravity from a saturated material to the total volume of the material. This ratio, like porosity, usually is expressed as a percentage. Where free drainage occurs, as under water-table (unconfined) conditions, the specific yield is practically equal to the coefficient of storage.

In many parts of the basin, the specific yield of sand and gravel exceeds 25 percent. In clay and silt, however, most of the water is retained in the tiny pores by molecular forces (capillary attraction), and the specific yield may approach zero.

Consolidated rocks are dense, coherent materials which, in their fresh, unweathered state, have little or no intergranular porosity. Instead, the water-bearing openings consist largely of fractures, some of which are enlarged by solution. Where weathered, such rocks may resemble unconsolidated sediments in having intergranular pores, and the distinction between the two types is not sharp.

The consolidated rocks in the Delaware River basin comprise three principal categories, each having distinct water-bearing properties: clastic, carbonate, and crystalline rocks.

Clastic rocks include shale, sandstone, conglomerate, and related rocks, all of which were deposited originally as unconsolidated sediments. These materials have been hardened by cementation or compaction so that little remains of their original intergranular porosity; most of their water occurs in fractures. Some sandstone and conglomerate, however, contain significant amounts of water in their intergranular pores where the cementing material has been dissolved or was never deposited.

Carbonate rocks, also of sedimentary origin, include limestone (calcium carbonate), dolomite (calcium and magnesium carbonate), dolomitic limestone, and rocks gradational between the pure carbonate rocks and the clastic sedimentary rocks in which the carbonate content is substantial. Carbonate rocks differ from the rocks in other categories, chiefly by having solution chanmels or cavities in addition to the other types of openings. Although the aggregate volume of the solution openings usually is but a small percentage of the total volume of rock, their relatively large size and extent permits rapid movement of water, and the permeability of some carbonate rocks in the basin area compares favorably with that of the coarse-grained unconsolidated sediments.

Crystalline rocks, which are composed of interlocking mineral grains (crystals) have virtually no intergranular porosity, except where altered by weathering. Fractures in these rocks commonly contain small but significant quantities of water; however, in the Delaware River basin few such openings extend deeper than about 300 feet, and most of the water is contained at much shallower depths. Considerable quantities of water occur in thick zones of weathered crystalline rocks such as are found in the Piedmont Upland (pl. 1).

The consolidated-rock aquifers, as a group, are markedly inferior to the aquifers composed of coarsegrained unconsolidated sediments in their capacity to store, transmit, and yield water. Probably few consolidated rocks have a specific yield as great as 2 percent, in contrast to the specific yields of 20 percent or more common in sand and gravel. Coefficients of transmissibility of $50,000-150,000$ gpd per $\mathrm{ft}$ have been measured in several unconsolidated granular aquifers (tables 4 and 5), but, with the exception of some of the carbonate-rock aquifers and possibly some of the coarse-grained sandstone and conglomerate aquifers, probably few consolidated-rock aquifers have coefficients of transmissibility higher than $5,000 \mathrm{gpd}$ per $\mathrm{ft}$.

\section{HYDROLOGIC PROVINCES}

The Delaware River basin lies in two greatly different hydrologic provinces which correspond to two of the major physiographic divisions in Northeastern United States, as classified by Fenneman (1938): (1) the Atlantic Plain occupying approximately the southern fourth 
of the basin; and (2) the Appalachian Highlands constituting the northern three-fourths of the basin (pl. 1). The two provinces are separated by the Fall Line, which extends northeastward across the southern part of the basin and lies along the northwest side of the Delaware River between Wilmington, Del., and Trenton, N.J.

The Atlantic Plain, or Coastal Plain as its emerged part is designated, is underlain by a wedge of unconsolidated sediments having its northwest edge along the Fall Line. This great wedge thickens seaward, reaching a maximum thickness within the basin of about 6,000 feet beneath the mouth of Delaware Bay (fig. 12). It consists of an alternating sequence of sheetlike and lenslike layers of sand, clay, and gravel. Enormous quantities of water are stored in this great mass of deposits, and the aquifers transmit water much more readily than most of the consolidated-rock aquifers of the Appalachian Highlands.

In contrast, the Appalachian Highlands are underlain predominatly by consolidated rocks. In general, the consolidated-rock aquifers store and transmit much less water than the unconsolidated granular aquifers of the Coastal Plain. Unconsolidated deposits of glacial origin discontinuously mantle the northern part of the Appalachian Highlands and occur also as valley fills of glacial outwash throughout both northern and southern parts. Although the aggregate amount of water stored in the outwash is small compared with that in the consolidated rocks, the supplies from these deposits are readily available to wells and, under favorable conditions, may be augmented considerably by recharge induced from hydraulically connected streams and lakes; such wells may yield a thousand gallons per minute or more.

The Appalachian Highlands includes four physiographic provinces each of which has distinctive landforms resulting from the nature and structure of the underlying rocks and geologic history of the province. From the Fall Line northward these physiographic provinces, as classified by Fenneman (1938), are: (1) the Piedmont, (2) New England, (3) Valley and Ridge, and (4) Appalachian Plateaus (pl. 1). The characteristics of each province and its subdivisions are described briefly in the discussion of the Appalachian Highlands.

\section{THE COASTAL PLAIN}

\section{GENERAL FEATURES}

The Coastal Plain physiographic province is the emerged part of the Atlantic Plain (pl. 1), a gently sloping surface that extends $125-175$ miles southeastward from the Fall Line beyond the present coastline to the edge of the Continental Shelf. A net rise of sea level in the last 10,000 years since the shrinkage and disappearance of the latest continental glaciers of the Ice Age (Wisconsin stage) has inundated the outer part of the Atlantic Plain and drowned the lower reaches of the streams; bays, estuaries, and tidal marshes have been formed near their mouths. Delaware Bay and the estuary of the Delaware River, which extend inland 133 miles from the mouth of the bay to the Fall Line at Trenton, N.J., have been formed by this sea-level rise, which amounted to more than 150 feet according to Flint $(1957$, p. 262) and probably to more than 300 feet according to Upson (1949).

The Coastal Plain occupies the southern half of New Jersey, most of Delaware, and a narrow strip in southeastern Pennsylvania along the northwest side of the Delaware River. Excluding tidal marshes and bays, the Coastal Plain includes an area of about 2,750 square miles within the basin, about 2,150 square miles in coastal New Jersey outside the basin, and 480 square miles in coastal Delaware outside the basin. The Coastal Plain decreases in width toward the northeast from about 70 miles in Delaware to less than 20 miles at Raritan Bay in New Jersey.

Throughout most of New Jersey the Coastal Plain consists of an inner part which slopes gently northwest toward the Delaware and Raritan Rivers and an outer part which slopes even more gently southeast toward the ocean and, in the south end of the State, south and southwest toward Delaware Bay. In Delaware the plain slopes east toward the Delaware River and Bay.

The land surface is nearly flat over wide areas but is moderately hilly in places, particularly toward the northeast, in the vicinity of Raritan Bay. In that area a few hilltops rise to nearly 400 feet above sea level, but altitudes are generally not greater than 200 feet, and more than half the plain is below an altitude of 100 feet.

The inner, northwestern part of the Coastal Plain in New Jersey is crossed by a sequence of approximately parallel belts, which are the beveled edges or outcrops of the geologic formations that dip gently toward the ocean (pls. 5 and 6 ). Where outcrops are not mantled by younger deposits of sand and gravel, each belt has a distinctive landform resulting from the different resistances to erosion of the underlying materials. Unusually resistant beds, such as sandstone or conglomerate (naturally cemented sand or gravel), form steep-sided hills and ridges; beds of clay tend to form broad interstream surfaces with steep streambanks; and beds of loose sand form gentle valley sides or, where wind action is strong and the sand is not held in place by vegetation, dunes and blowouts may be formed. In plan view, some of the outcrop belts are deeply frayed or indented where they are crossed by the small streams flowing toward the Delaware or 
Raritan Rivers (pl. 5). Below the bend at Trenton, N.J., the Delaware River follows the innermost beltthe largely concealed beveled edge of the basal unit consisting of nonmarine sediments of Cretaceous age. The relative weakness of these materials, and the resistance to erosion of the hard crystalline rocks immediately to the northwest across the Fall Line, have largely determined the course of this part of the river.

The outer margin of the Coastal Plain in New Jersey has very low relief and slopes gently toward the ocean on the east and southeast and toward the bay on the south. The topography in Delaware is similar, except that the prevailing slope and drainage is toward the east. For the most part, these areas are immediately underlain by permeable sand and gravel and are traversed by perennial streams of low gradient. In their shoreward reaches most of the streams are tidal and are bordered by marshes. The coast in central and southern New Jersey and in Delaware south of Cape Henlopen is characterized by a line of offshore sand bars, formed by longshore currents and wave action, behind which lie shallow bays and marshes. Atlantic City, N.J., is built on one of these bars.

The wedge-shaped mass of deposits underlying the Coastal Plain consists of an alternating sequence of relatively permeable beds of sand and gravel and relatively impermeable layers of clay and silt. The beds of coarse-material and the layers of clay and silt constitute, respectively, aquifers and aquicludes of variable thickness and extent. These aquifers and aquicludes correspond in a general way to the geologic formations that have been established on the basis of physical character and age. However, the boundaries of the aquifers and aquicludes are not everywhere the same as those of the formations for the following reasons: (1) The formations change in character from place to place - a formation may be predominantly coarse grained and therefore classed as an aquifer at one place, but predominantly fine grained and classed as an aquiclude at another; (2) some of the formations are divided into several aquifers and aquicludes; (3) permeable parts of two adjacent formations may form a single hydrologic unit (aquifer).

The geologic formations that comprise the unconsolidated sediments of the Coastal Plain are listed in table 3 . The sequence lies on a platform of consolidated rocks of the same type as those exposed northwest of the Fall Line. This platform, which had been eroded to a surface of very low to moderate relief by the beginning of the Cretaceous period, about 125 million years ago (table 3 ), now slopes southeastward toward the ocean from slightly above sea level at the Fall Line to about 6,000 feet below sea level at the mouth of Delaware Bay. Figure 12 and plate 6 show the configuration of this surface in a very general way; not enough deep-well information and seismic geophysical data are available to determine the buried topography in detail, and the depths determined by the seismic method are somewhat inaccurate; the probable error in seismic depth determinations is less than 10 percent (Ewing and others, 1939, p. 294).

Figures 14 to 20 show the configurations of the tops of several of the formations in the overlying wedge of deposits that constitute aquifers or groups of aquifers. Plate 6 shows the relations of the formations in three dimensions; the vertical scale is exaggerated 42 to 66 times.

The contours of the top of each formation are based on well-log data rather widely scattered throughout most of the Coastal Plain, they necessarily are generalized and do not indicate details in the configurations of the surfaces represented. Accordingly, the maps and fence diagram are regarded as preliminary, and doubtless the interpretations will be refined from time to time as more subsurface data become available.

All the formations dip southeast in New Jersey and northern Delaware, but they dip east or slightly north of east in southern Delaware. The dips decrease from 60 to 100 feet per mile (about $12^{\circ}-1^{\circ}$ ) near the base of the sequence to about 10 feet per mile near the top. This decrease is due to the fact that many of the formations thicken seaward (pl. 6); but they become finer grained and more difficult to differentiate in that direction.

Most of the sandy beds become thinner or finer grained southeast from their outcrops. Many beds of sand probably do not extend as far as the edge of the Continental Shelf, about 100 miles east of the present shoreline, and some sandy beds, such as those in the Englishtown, Red Bank, and Vincentown sands, either grade into finer materials or pinch out beneath parts of the Coastal Plain (pl. 6, figs. 17 and 19). Nevertheless, some of the sandy aquifers probably extend at least as much as 10 miles beyond the present shoreline. Some of these aquifers were deposited in the ocean and therefore were originally saturated with salt water. Now, however, they contain fresh water, which indicates that infiltrating precipitation has filled the inland recharge areas of the aquifers and flushed the original salt water out as it moved through them to discharge outlets far beyond the shore. This implied connection between sea and land through the aquifers has an important bearing on problems of salt-water encroachment along the coast.

Very large quantities of fresh water occur in the unconsolidated sediments underlying the Coastal Plain. 


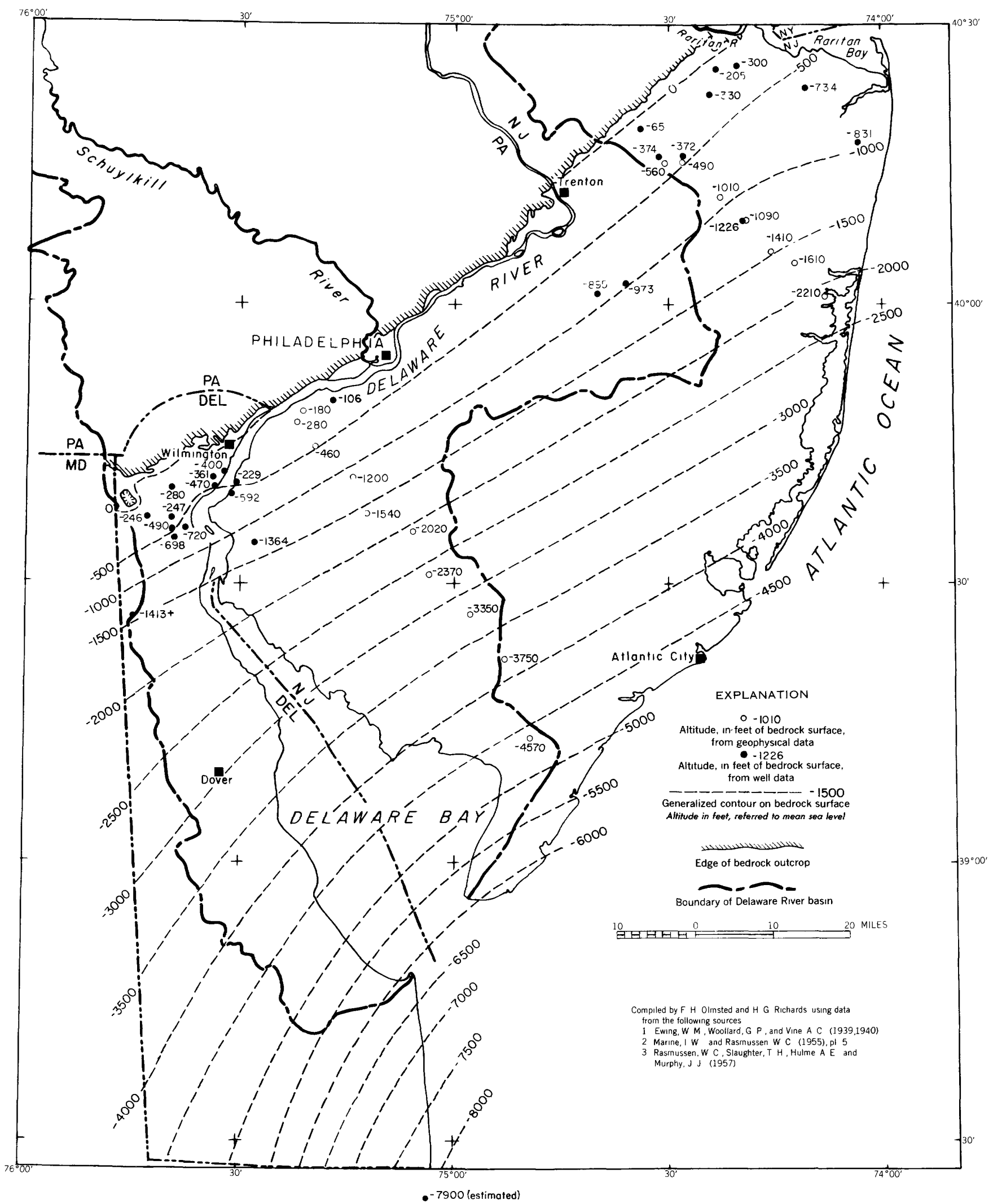

FIGURE 12.-Configuration of bedrock beneath Coastal Plain. 
TABLE 3.-Stratigraphy of Delaware River basin

[Formations of Paleozoic age listed in this table occur in the Valley and Ridge and the New England provinces in eastern Pennsylvania; equivalent formations in other provinces are listed in plate 8 . Formations or units separated by dashed lines are considered to be single hydrologic units]

\begin{tabular}{|c|c|c|c|c|c|c|c|}
\hline \multicolumn{5}{|c|}{ Stratigraphic assignment or age } & \multirow{2}{*}{ Formation or unit } & \multirow{2}{*}{$\begin{array}{l}\text { Maximum } \\
\text { (feet) }\end{array}$} & \multirow{2}{*}{ Physical properties } \\
\hline Era & $\begin{array}{l}\text { or } \\
\text { period }\end{array}$ & $\begin{array}{l}\text { (millions } \\
\text { of years) }\end{array}$ & $\begin{array}{l}\text { Series or } \\
\text { epoch }\end{array}$ & $\begin{array}{l}\text { Group, stage, or } \\
\text { age equivalent }\end{array}$ & & & \\
\hline \multirow{25}{*}{ 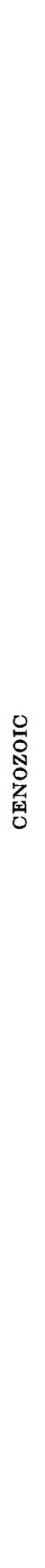 } & \multirow{12}{*}{ 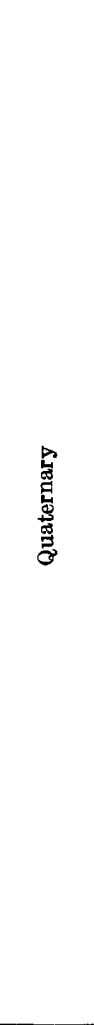 } & \multirow{12}{*}{$0-1$} & \multirow{3}{*}{ 崖 } & & Beach and dune sand & 80 & $\begin{array}{l}\text { Well-sorted loose white and gray sand along beaches and off- } \\
\text { shore bars. }\end{array}$ \\
\hline & & & & & Marsh and swamp deposits ${ }^{3}$ & 30 & $\begin{array}{l}\text { Dark clay, silt, and organic matter in marshes and swamps } \\
\text { bordering streams, lakes, estuaries, and bays. }\end{array}$ \\
\hline & & & & & Alluvium ${ }^{3}$ & $50 \pm$ & $\begin{array}{l}\text { Unconsolidated stream deposits ranging from clay to coarse } \\
\text { gravel. Not differentiated from glacial outwash where present. }\end{array}$ \\
\hline & & & \multirow{9}{*}{$\frac{\mathbb{8}}{8}$} & \multirow{4}{*}{ Wisconsin stage } & Glacial outwash 4 & $400 \pm$ & $\begin{array}{l}\text { Valley-fill deposits ranging from coarse gravel to silt and clay, } \\
\text { Includes lake deposits and a few small masses of glacial till and } \\
\text { morainal deposits. Not differentiated from stratified glacial } \\
\text { drift of uplands on plate } 7 \text {. }\end{array}$ \\
\hline & & & & & $\begin{array}{l}\text { Stratified glacial drift of up- } \\
\text { lands. }{ }^{4}\end{array}$ & $500 \pm$ & $\begin{array}{l}\text { Deposits distinguished from glacial outwash chiefly by higher } \\
\text { topographic position; occur as dissected outwash fills, river } \\
\text { terraces, kame terraces, kames, eskers, and deltas. }\end{array}$ \\
\hline & & & & & Glacial till 4 & $350 \pm$ & $\begin{array}{l}\text { Heterogeneous unsorted deposits ranging from clay to boulders. } \\
\text { Forms a discontinuous, generally thin irregular blanket over } \\
\text { glaciated northern part of basin. }\end{array}$ \\
\hline & & & & & $\underset{\text { moraines. } 4}{\text { Terminal and recessional }}$ & $250+$ & $\begin{array}{l}\text { Elongate sinuous ridges composed of heterogeneous unsorted } \\
\text { materials deposited at margins of } W \text { isconsin ice sheet. }\end{array}$ \\
\hline & & & & & Basin-rim sand & 30 & $\begin{array}{l}\text { Sandy, silty, and gravelly deposits forming small, generally } \\
\text { elliptical basins throughout Coastal Plain. }\end{array}$ \\
\hline & & & & $\begin{array}{l}\text { nlinoian and Kan- } \\
\text { san stages. }\end{array}$ & Early glacial drift & $150 \pm$ & $\begin{array}{l}\text { Stratified and nonstratified glacial deposits, including Jerseyan } \\
\text { drift; contains more clay and silt than Wisconsin deposits. } \\
\text { Not differentiated from wisconsin deposits except south of } \\
\text { limit of Wisconsin glaciation (pl. 7). }\end{array}$ \\
\hline & & & & \multirow{3}{*}{ Columbia group } & $\begin{array}{l}\text { Talbot and Cape May for- } \\
\text { mations. }\end{array}$ & $100+$ & $\begin{array}{l}\text { Form a roughly wedge-shaped mass thinning inland and have } \\
\text { tonguelike extensions up major valleys. Consist of relatively } \\
\text { unweathered stream-deposited sand and gravel; toward coast } \\
\text { in upper part, silt and clay is deposited in estuarine and marine } \\
\text { environments. }\end{array}$ \\
\hline & & & & & Unclassified deposits ${ }^{\circ}$ & 70 & $\begin{array}{l}\text { In Delaware, deposits topographically higher, but older than } \\
\text { Talbot formation and at least partly equivalent to Wicomico } \\
\text { formation. In New Jersey, deposits (not shown on pl. 7) } \\
\text { topographically and stratigraphically between Bridgeton or } \\
\text { Pensauken formation and Cape May formation. }\end{array}$ \\
\hline & & & & & $\begin{array}{l}\text { Pensauken and Bridgeton } \\
\text { formations. }\end{array}$ & & $\begin{array}{l}\text { Complex sequence of streamlaid deposits consisting of lenticular } \\
\text { beds of yellow, brown, or red gravel, sand, and silt. Remnant } \\
\text { caps on Cohansey sand and older formations. }\end{array}$ \\
\hline & \multirow{13}{*}{ 密 } & \multirow{6}{*}{$10-25$} & \multirow{2}{*}{ 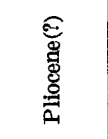 } & Hiatus & Hiatus & Hiatus & \multirow[b]{2}{*}{$\begin{array}{l}\text { Semiconsolidated weathered gravelly deposits capping a few of } \\
\text { the highest hills in the Coastal Plain (Beacon Hill gravel) and } \\
\text { Piedmont (Bryn Mawr gravel). }\end{array}$} \\
\hline & & & & & $\begin{array}{l}\text { Bryn Mawr and Beacon } \\
\text { Hill gravels. }\end{array}$ & 20 & \\
\hline & & & \multirow{2}{*}{ 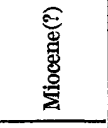 } & Hiatus & Hiatus & Hiatus & \multirow[b]{2}{*}{$\begin{array}{l}\text { Quartzose, somewhat micaceous sand, lenses of silt and clay as } \\
\text { much as } 40 \text { ft thick, and some gravel. Probably deltaic and } \\
\text { estuarine, possibly grading toward coast into marine deposits. }\end{array}$} \\
\hline & & & & & Cohansey sand & 265 & \\
\hline & & & & Hiatus & Hiatus & Hiatus & \multirow[b]{2}{*}{$\begin{array}{l}\text { Quartzose micaceous sand and extensive beds of diatomaceous } \\
\text { silt or clay. Shiloh marl member, a fossiliferous clayey or silty } \\
\text { sand, at top of formation in southern New Jersey. Probably } \\
\text { estuarine and marine. }\end{array}$} \\
\hline & & & $\underset{8}{\stackrel{d}{8}}$ & Middle Miocene & Kirkwood formation & $700+$ & \\
\hline & & $25-40$ & $\begin{array}{c}\text { Oligo- } \\
\text { cene }\end{array}$ & Hiatus & Hiatus & Hiatus & \\
\hline & & \multirow{6}{*}{$40-60$} & \multirow{4}{*}{ 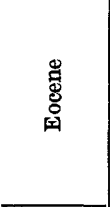 } & Upper Eocene & Piney Point formation & 290 & $\begin{array}{l}\text { Glauconitic sand and greenish-gray clay. Occurs only in sub- } \\
\text { surface within Delaware River basin. Fossiliferous; marine. }\end{array}$ \\
\hline & & & & Hiatus & Hiatus & Hiatus & \\
\hline & & & & Middle Eocene & Shark River marl & \multirow{2}{*}{200} & Mixture of glauconite and light silty clay. Marine. \\
\hline & & & & Lower Eocene & Manasquan marl & & $\begin{array}{l}\text { Glauconite in lower part; very fine grained sand and greenish- } \\
\text { white clay in upper part. Marine. }\end{array}$ \\
\hline & & & \multirow{2}{*}{ 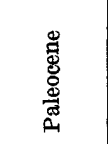 } & \multirow[t]{2}{*}{ Rancocas group } & Vincentown sand & 460 & $\begin{array}{l}\text { Limy sand, fossiliferous and somewhat consolidated, and quartz } \\
\text { sand containing some glauconite. Beds of sand grade south- } \\
\text { eastward into beds richer in clay and glauconite. Marine. }\end{array}$ \\
\hline & & & & & Hornerstown marl & 55 & $\begin{array}{l}\text { Glauconite (greensand) and some sand and clay. Locally fossil- } \\
\text { iferous; marine. }\end{array}$ \\
\hline
\end{tabular}

See footnotes at end of table. 
TABLE 3.-Stratigraphy of Delaware River basin-Continued

\begin{tabular}{|c|c|c|c|c|c|c|c|}
\hline \multicolumn{5}{|c|}{ Stratigraphic assignment or age } & \multirow{2}{*}{ Formation or unit } & \multirow{2}{*}{$\begin{array}{l}\text { Maximum } \\
\text { thickness }\end{array}$} & \multirow{2}{*}{ Physical properties } \\
\hline Era & $\begin{array}{l}\text { System } \\
\text { or } \\
\text { period }\end{array}$ & $\begin{array}{c}\text { A bsolute age } 1 \\
\text { (millions } \\
\text { of years) }\end{array}$ & $\begin{array}{l}\text { Series or } \\
\text { epoch }\end{array}$ & $\begin{array}{l}\text { Group, stage, or } \\
\text { age equivalent }\end{array}$ & & & \\
\hline \multirow{19}{*}{ 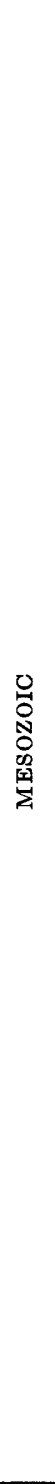 } & \multirow{13}{*}{ 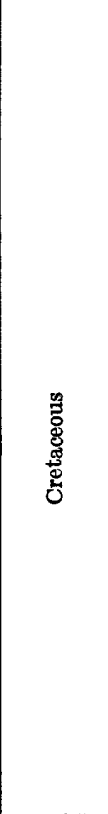 } & \multirow{13}{*}{$60-125$} & \multirow{11}{*}{ 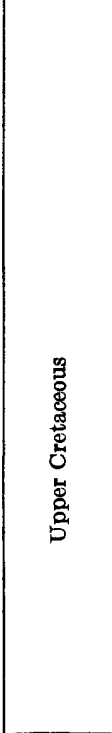 } & \multirow{3}{*}{ Monmouth group } & Red Bank sand & 185 & $\begin{array}{l}\text { Sand, some clay and glauconite in lower part. Missing in central } \\
\text { and southern New Jersey. Tinton sand member, at top of } \\
\text { formation in Monmouth County, N.J., consists of glauconitic } \\
\text { clayes sand. Marine. }\end{array}$ \\
\hline & & & & & Navesink marl & 55 & $\begin{array}{l}\text { Glauconitic, marly sand and clay and a basal bed of shells. In } \\
\text { Delware, not distinguished from Mount Larel sand. Marine. }\end{array}$ \\
\hline & & & & & Mount Laurel sand & \multirow{2}{*}{110} & $\begin{array}{l}\text { Glauconitic quartz sand; minor amount of clay, except in northern } \\
\text { Delaware where not readily distinguishable from Navesink } \\
\text { marl. Marine. }\end{array}$ \\
\hline & & & & \multirow{5}{*}{ Matawan group } & Wenonah sand & & $\begin{array}{l}\text { Micaceous, slightly glauconitic quartz sand; local beds of silt and } \\
\text { clay. Marine. }\end{array}$ \\
\hline & & & & & Marshalltown formation & 125 & $\begin{array}{l}\text { Sandy clay and lenses of glauconitic sand. Not recognized in } \\
\text { Delaware. Fossiliferous; marine. }\end{array}$ \\
\hline & & & & & Englisbtown sand & 160 & $\begin{array}{l}\text { Quartz sand, and clay and silt which increase in abundance down- } \\
\text { dip and toward top of formation. Missing in Delaware and } \\
\text { southernmost New Jersey. Lagoonal and marine. }\end{array}$ \\
\hline & & & & & Woodbury clay & \multirow{2}{*}{$250+$} & $\begin{array}{l}\text { Somewhat micaceous tough clay, not glauconitic; upper part } \\
\text { slightly sandy and distinctly laminated. Not recognized in } \\
\text { Delaware. Marine. }\end{array}$ \\
\hline & & & & & Merchantville clay & & \multirow[t]{2}{*}{$\begin{array}{l}\text { Glauconitic micaceous clay, generally greasy and massive; some } \\
\text { silt and fine-grained sand, particularly in upper part. Marine. }\end{array}$} \\
\hline & & & & Hiatus & Hiatus & Hiatus & \\
\hline & & & & & Magothy formation & & A. seaward-thickening wedge of nonmarine deposits representing \\
\hline & & & & & Raritan formation ? & $5000+$ & in upper part, local near-shore marine environments. Deposits \\
\hline & & & Lower & Potomon moum & Patapsco formation & ד, ד, & Many-colored tough clay is characteristic, as is locally cross- \\
\hline & & & ous & & Patuxent formation & & sulfide) occur locally, and a few thin beds containing shells are \\
\hline & Jurassic & $125-150$ & & Hiatus & Hiatus & Hiatus & Des. \\
\hline & \multirow{5}{*}{ 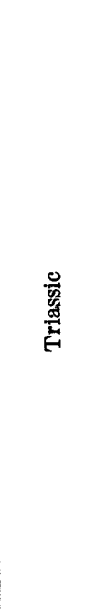 } & \multirow{5}{*}{$150-180$} & \multirow{5}{*}{ 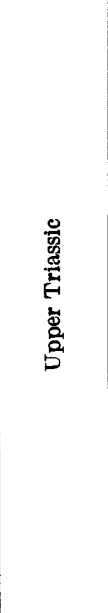 } & & Diabase & $2,000 \pm$ & $\begin{array}{l}\text { cipally of plagioclase and augite. Occurs as sills and dikes } \\
\text { intruding Triassic and older rocks. Forms prominent ridges } \\
\text { and hills. }\end{array}$ \\
\hline & & & & \multirow{4}{*}{ Newark group } & Basalt & 900 & $\begin{array}{l}\text { Dark fine-grained crystalline rock consisting principally of } \\
\text { plagioclase and augite. Occurs as flows interbedded with } \\
\text { upper part of Newark Group, and locally as small dikes. Forms } \\
\text { prominent creseent-shaped ridges, the Watchung Mountains, } \\
\text { in northern New Jersey. }\end{array}$ \\
\hline & & & & & Brunswick formation 8 & $7,000 \pm$ & $\begin{array}{l}\text { Soft red shale, some brownish-red siltstone and fine-grained } \\
\text { sandstone, and green, yellow, gray, and purple shale and } \\
\text { argillite. Along borders of area, includes discontinuous lenses } \\
\text { of sandstone and conglomerate. Near diabase, altered to } \\
\text { hornfels. Soft unaltered shale forms elongate lowlands between } \\
\text { low ridges of more resistant rocks. }\end{array}$ \\
\hline & & & & & Lockatong formation 8 & $3,800 \pm$ & $\begin{array}{l}\text { Chiefly thick-bedded dark argillite; some zones of thin-bedded } \\
\text { dark shale, impure limestone, and limy argillite; in upper part, } \\
\text { tongues of dark-red argillite and some red shale similar to that } \\
\text { in Brunswick formation. Argillite forms prominent ridges } \\
\text { where interbedded with softer shale, and plateaus where weaker } \\
\text { zones are absent. }\end{array}$ \\
\hline & & & & & Stockton formation 8 & $5,000 \pm$ & $\begin{array}{l}\text { Gray or yellow arkose; smaller amounts of conglomerate, fine- } \\
\text { grained red or brown sandstone, and soft red shale. Fine- } \\
\text { grained beds more abundant in upper part of formation than in } \\
\text { lower part. Arkose and conglomerate form ridges; soft red } \\
\text { sandstone and shale form intervening valleys. }\end{array}$ \\
\hline \multirow{5}{*}{ 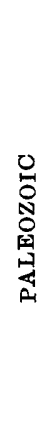 } & Permian & $180-205$ & & Hiatus & Hiatus & Hiatus & \multirow[b]{2}{*}{$\begin{array}{l}\text { Gray or brown shale and fine-grained sandstone; some anthracite } \\
\text { coal, fire clay, black carbonaceous slate or shale, and scattered } \\
\text { lenses of coarse-grained sandstone and conglomerate. In } \\
\text { synclinal valleys surrounded by canoe-shaped ridges. }\end{array}$} \\
\hline & \multirow{4}{*}{ 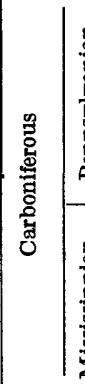 } & \multirow{4}{*}{$205-255$} & & & Allegheny formation & $1,500 \pm$ & \\
\hline & & & & & Pottsville formation & 1,500 & $\begin{array}{l}\text { Hard quartzose conglomerate and coarse-grained sandstone; a few } \\
\text { thin beds of coal and carbonaceous slate or shale. Becomes } \\
\text { thinner and finer grained toward the northeast. Forms ridges } \\
\text { enclosing synclinal coal basins underlain by Allegheny forma- } \\
\text { tion. }\end{array}$ \\
\hline & & & & & Mauch Chunk formation & $3,000 \pm$ & $\begin{array}{l}\text { Alternating lenses of red shale and green sandstone; some lenses } \\
\text { of conglomerate in upper part. Becomes thlnner and finer } \\
\text { grained toward the north. Forms valleys. }\end{array}$ \\
\hline & & & & & Pocono formation & $1,600 \pm$ & $\begin{array}{l}\text { Hard quartzose sandstone and conglomerate; some thin beds of } \\
\text { sandstone, shale, and coal. Becomes thinner and finer grained } \\
\text { toward the north. Forms prominent ridges. }\end{array}$ \\
\hline
\end{tabular}

See footnotes at end of table. 
TABLE 3.-Stratigraphy of Delaware River basin-Continued

\begin{tabular}{|c|c|c|c|c|c|c|c|}
\hline \multicolumn{5}{|c|}{ Stratigraphic assignment or age } & \multirow{2}{*}{ Formation or unit } & \multirow{2}{*}{$\underset{\text { (feet) }}{\text { Maximum }}$} & \multirow{2}{*}{ Physical properties } \\
\hline Era & $\begin{array}{l}\text { system } \\
\text { or } \\
\text { period }\end{array}$ & $\begin{array}{l}\text { A osolute age } 1 \\
\text { (millions } \\
\text { of years) }\end{array}$ & $\begin{array}{l}\text { Series or } \\
\text { epoch }\end{array}$ & $\begin{array}{l}\text { Group, stage, or } \\
\text { age equivalent }\end{array}$ & & & \\
\hline \multirow{23}{*}{ 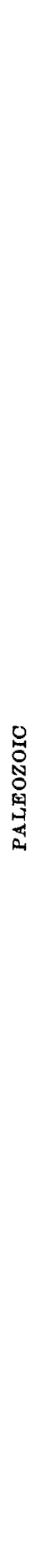 } & \multirow{12}{*}{ 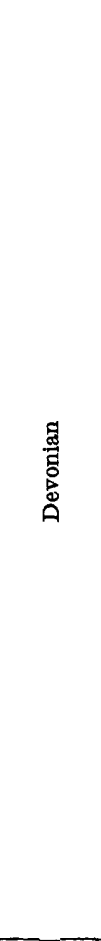 } & \multirow{12}{*}{$255-31.5$} & \multirow{2}{*}{ 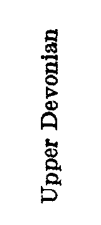 } & & Catskill formation & $6,000 \pm$ & $\begin{array}{l}\text { Somewhat lenticular beds of red, gray, or green sandstone, shale, } \\
\text { and some conglomerate. Represents a vast nonmarine, prob- } \\
\text { ably deltaic deposit; toward the west, lower part contains } \\
\text { marine tongues equivalent to Portage and Hamilton groups. } \\
\text { Underlies most of Appalachian Plateaus; forms low ridges and. } \\
\text { valleys elsewhere. }\end{array}$ \\
\hline & & & & $\begin{array}{l}\text { Portage group, as } \\
\text { used in Penn- } \\
\text { sylvania. }\end{array}$ & & 1,500 & $\begin{array}{l}\text { Hard gray or greenish-gray sandstone interbedded with sandy } \\
\text { shale and dark shale. Forms broad ridges having moderate } \\
\text { relief. }\end{array}$ \\
\hline & & & \multirow{3}{*}{ 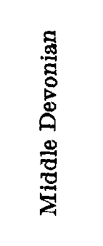 } & \multirow{2}{*}{ Hamilton group } & $\begin{array}{l}\text { Mahantango formation of } \\
\text { Willard (1935). }\end{array}$ & 1,600 & $\begin{array}{l}\text { Hard dark shale, thin-bedded sandstone and sandy shale, thin } \\
\text { beds of limy shale, and, in upper part, a prominent bed of } \\
\text { fossiliferous impure limestone known locally as the Centerfield } \\
\text { reef. Forms valleys and low ridges. }\end{array}$ \\
\hline & & & & & Marcellus shale & 900 & $\begin{array}{l}\text { Dark shale, sandy shale, claystone, and siltstone; some slaty shale } \\
\text { in lower part. Forms valleys and is covered by glacial outwash } \\
\text { northeast of Stroudsburg, } \mathrm{Pa} \text {. }\end{array}$ \\
\hline & & & & & Onondaga limestone & 250 & $\begin{array}{l}\text { Dark-gray cherty limestone, shaly limestone, and limy shale. } \\
\text { Thins toward the southwest. Forms narrow low-lying belt. }\end{array}$ \\
\hline & & & 率: & & Esopus shale & 375 & $\begin{array}{l}\text { Slaty dark sandy shale and limy shale; dark gritty sandstone. } \\
\text { Coarsest and thickest in northwestern New Jersey. Forms } \\
\text { rtdges with extensive areas of bare rock. }\end{array}$ \\
\hline & & & \multirow{6}{*}{ 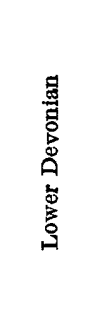 } & & Oriskany sandstone & 175 & $\begin{array}{l}\text { Granular quartz sandstone and fine-grained conglomerate; some } \\
\text { sandy fossiliferous limestone, chert, and shale. Sandy lime- } \\
\text { stone predominates in New Jersey. Forms narrow ridges. }\end{array}$ \\
\hline & & & & \multirow{5}{*}{ Helderberg group } & Port Ewen limestone & 190 & $\begin{array}{l}\text { In New Jersey and New York, poorly exposed shale; in Pennsyl- } \\
\text { vania, not known to be present. }\end{array}$ \\
\hline & & & & & Becraft limestone & 20 & Hard gray cherty limestone, fossiliferous. \\
\hline & & & & & New Scotland limestone & 160 & Limy shale and hard cherty limestone. \\
\hline & & & & & $\begin{array}{l}\text { Stormville sandstone of } \\
\text { Weller (1900) }\end{array}$ & 10 & Limy sandstone. \\
\hline & & & & & Coeymans limestone & 75 & Pure to sandy limestone, highly fossiliferous. \\
\hline & \multirow{8}{*}{ 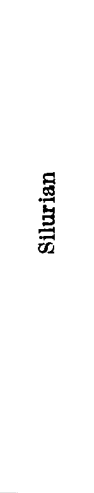 } & \multirow{8}{*}{$315-350$} & \multirow{8}{*}{ 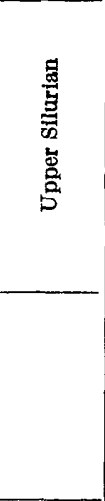 } & & Manlius limestone & 35 & Dark-blue to nearly black fossiliferous limestone. \\
\hline & & & & & Rondout limestone & 40 & $\begin{array}{l}\text { Thinly laminated limestone; near top includes bed of silty dolo- } \\
\text { mitic limestone. }\end{array}$ \\
\hline & & & & & Decker limestone & 90 & $\begin{array}{l}\text { In Pennsylvania, thick-bedded limy sandstone and some lime- } \\
\text { stone. }\end{array}$ \\
\hline & & & & & Bossardsville limestone & 100 & $\begin{array}{l}\text { Banded fine-grained bluish-gray limestone and basal slaty lime- } \\
\text { stone, in places having columnar structure. }\end{array}$ \\
\hline & & & & & Wills Creek shale $\theta$ & $200 \pm$ & $\begin{array}{l}\text { Unfossilfferous buff, green, and variegated beds of limy shale; } \\
\text { hard bluish-gray fossiliferous crystalline limestone near base. }\end{array}$ \\
\hline & & & & & Bloomsburg red beds & 2,000 & $\begin{array}{l}\text { Red or green shale and sandstone; some conglomerate near base. } \\
\text { Nonmarine, at least in part. Forms northwest slope of Blue } \\
\text { Mountain ridge. }\end{array}$ \\
\hline & & & & & $\begin{array}{l}\text { Shawangunk }{ }^{10} \text { conglomer- } \\
\text { ate. }\end{array}$ & $1,900+$ & $\begin{array}{l}\text { Hard quartzitic sandstone and conglomerate and a few thin beds } \\
\text { of shale. Forms southernmost ridge in Valley and Ridge } \\
\text { province. }\end{array}$ \\
\hline & & & & Hiatus & Hiatus & Hiatus & \\
\hline & & & 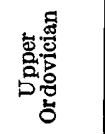 & & Martinsburg shale 11 & $4,000 \pm$ & $\begin{array}{l}\text { Upper } 500 \mathrm{ft} \text {, medium- to fine-grained arkosic sandstone or gray- } \\
\text { wacke, and a few lenses of shale and conglomerate. Lower } \\
3,500 \mathrm{ft} \text {, banded bluish-gray shale and slate; some fine-grained } \\
\text { limy sandstone and some red beds. Forms the higher, more } \\
\text { dissected and hilly part of the Great Valley. }\end{array}$ \\
\hline & 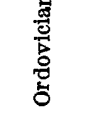 & $350-430$ & 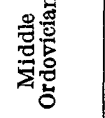 & & Jacksonburg limestone & 700 & $\begin{array}{l}\text { Dark shaly or slaty impure limestone and thin beds of limy shale } \\
\text { which increase in abundance toward top of formation. Ex- E } \\
\text { tensively quarried as "cement rock." Forms slopes at valley } \\
\text { margins. }\end{array}$ \\
\hline & & & 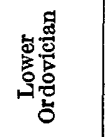 & & Beekmantown limestone & 2,000 & $\begin{array}{l}\text { Gray to blue dolomite and dolomitic limestone; some siliceous } \\
\text { and shaly beds. Forms valleys. Equivalent to the Cone- } \\
\text { stoga limestone in Chester Valley of Pennsylvania. Overlies } \\
\text { the Conococheague limestone in central southern Pennsyl- } \\
\text { vania, western Maryland and northwestern Virginia, which } \\
\text { in turn overlies the Elbrook limestone. }\end{array}$ \\
\hline
\end{tabular}

See footnotes at end of table. 
TABLE 3.-Stratigraphy of Delaware River basin-Continued

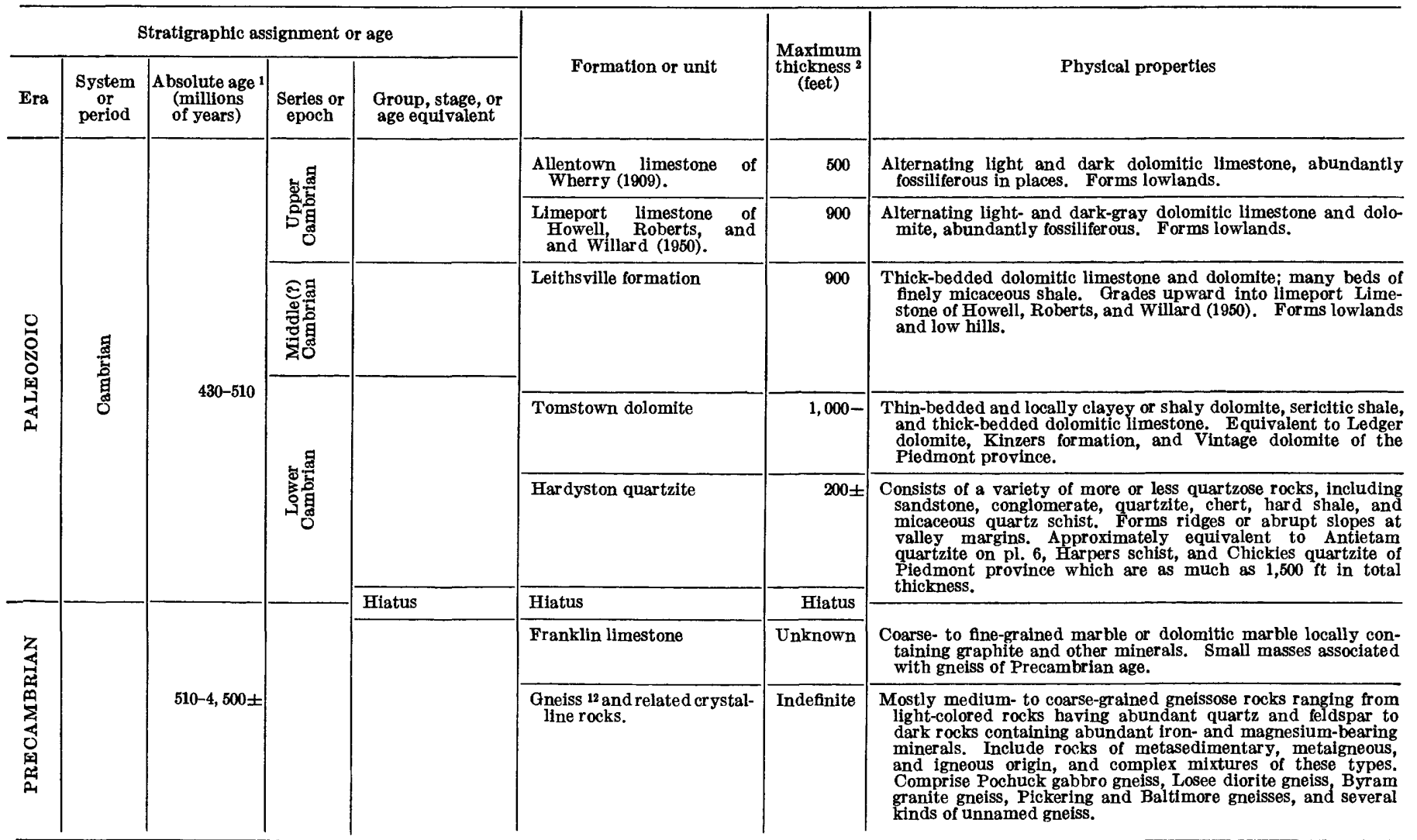

1 Figures adopted by U.S. Geological Survey, Geologic Names Committee, 1958, except for age of Precambrian, which is based on an estimate by Harrison Brown (1957).

2 Maximum thickness in Delaware River basin or New Jersey.

3 Beach and dune sand, marsh and swamp deposits, and alluvium are contemporaneous, at least in part.

4 Glacial outwash, stratified glacial drift of uplands, terminal and recessional moraines, and glacial till are contemporaneous, at least in part.

In vicinity of Trenton, N.J., Cape May formation has not been differentiated with certainty from glacial outwash.

may be equivalent in part to Pensauken and Bridgeton ormations.

Nearly all the available water-that is, the water that can be withdrawn by wells-is in sheetlike layers of sand and lenslike beds of sand and gravel. These layers of sand and gravel - the aquifers-are interbedded with aquicludes composed of silt and clay which restrict the movement of water and confine the water in some of the aquifers under artesian pressure. Most of the aquicludes increase in thickness and relative abundance toward the coast; this evidence suggests that the sediments near the present coast were deposited in deeper water than those farther inland.

Fresh water occurs, or occurred under native conditions, in all the near-surface material in the Coastal Plain; however, salt water is contained in the lower, seaward part of the wedge largely in accordance with the Ghyben-Herzberg principle, which is discussed in the section on salt-water encroachment (p. 98).

The inland extent of the salty ground water is different in each aquifer. In general, the salt water extends
7 Raritan formation of New Jersey may include equivalents of Patapsco and Patux

ent formations of Delaware.
B Brunswick, Lockatong, and Stockton formations considered as lithofacies, rather than distimet stratigraphic units by McLaughlin (in Greenman, 1955).

Locally called Poxono Island shale (of White, 1882)

Equivalent to the Tuscarora sandstone and at least part of the Clinton formation west of the Delaware River basin (Cray and others, 1960).

aroup by some geologists rea (pl. 8)

e-element age determinations indicate that the Baltimore gneiss and its equivalents were crystallized or recrystallized about 1-1.1 billion years ago (Tilton and others, 1958)

farthest inland in the lowest aquifers. The aquifers in the nonmarine sediments of Cretaceous age may contain salt water as far inland as 50 miles (fig. 15). At Atlantic City, N.J., the "800-foot" sand aquifer in the Kirkwood formation still contains fresh water, despite pumping which has lowered the fresh-water head in the aquifer by more than 100 feet (Barksdale, and others, 1958, p. 153), but the aquifers below the Kirkwood formation in this area are reported to contain only salty water. Salty water occurs in shallow aquifers of both the Cohansey sand and the Quaternary deposits at places along the coast (fig. 33), but this occurrence probably has resulted largely from pumping and to a lesser extent from dredging and draining activities; it is not a natural condition.

The outcrops of the aquifers or the areas where the aquifers are covered only by Quaternary deposits in the Coastal Plain are shown on plate 5 and figure 19. The Quaternary deposits (pl. 7), which blanket large 
areas of the older aquifers and cover practically all Delaware and much of southern New Jersey, contain unconfined to semiconfined water and function somewhat as a sponge to receive infiltration from precipitation and transmit it to the underlying aquifers.

Figure 13 is an idealized cross section showing geologic and hydrologic conditions in a coastal-plain setting similar to that of New Jersey or Delaware. A capping layer of permeable sand and gravel of Quaternary age lies unconformably on the seaward-dipping pre-Quaternary deposits that constitute a system of aquifers and aquicludes. The capping layer itself is largely an unconfined aquifer; its water table is a subdued replica of the land surface, and water flows from high to low areas. The recharge that does not escape locally to surface-water bodies or to the atmosphere through evapotranspiration is available to underlying aquifers (designated $\mathrm{A}, \mathrm{B}$, and $\mathrm{C}$ in the diagram) through the so-called funnel effect, by which precipitation collected over a fairly extensive area of land surface is made available as recharge to smaller underlying permeable zones-the subsurface intake areas of the older aquifers.

Figure 13 illustrates also how parts of an aquifer can be both artesian and nonartesian, although the situation depicted is necessarily greatly oversimplified.

Down the dip, toward the coast, water in the aquifers below the Cohansey sand is confined by the intervening aquicludes. Under natural conditions interchange of water through the aquicludes is extremely slow and probably minor in amount. Significant quantities of water, however, may move through an aquiclude where

NW.

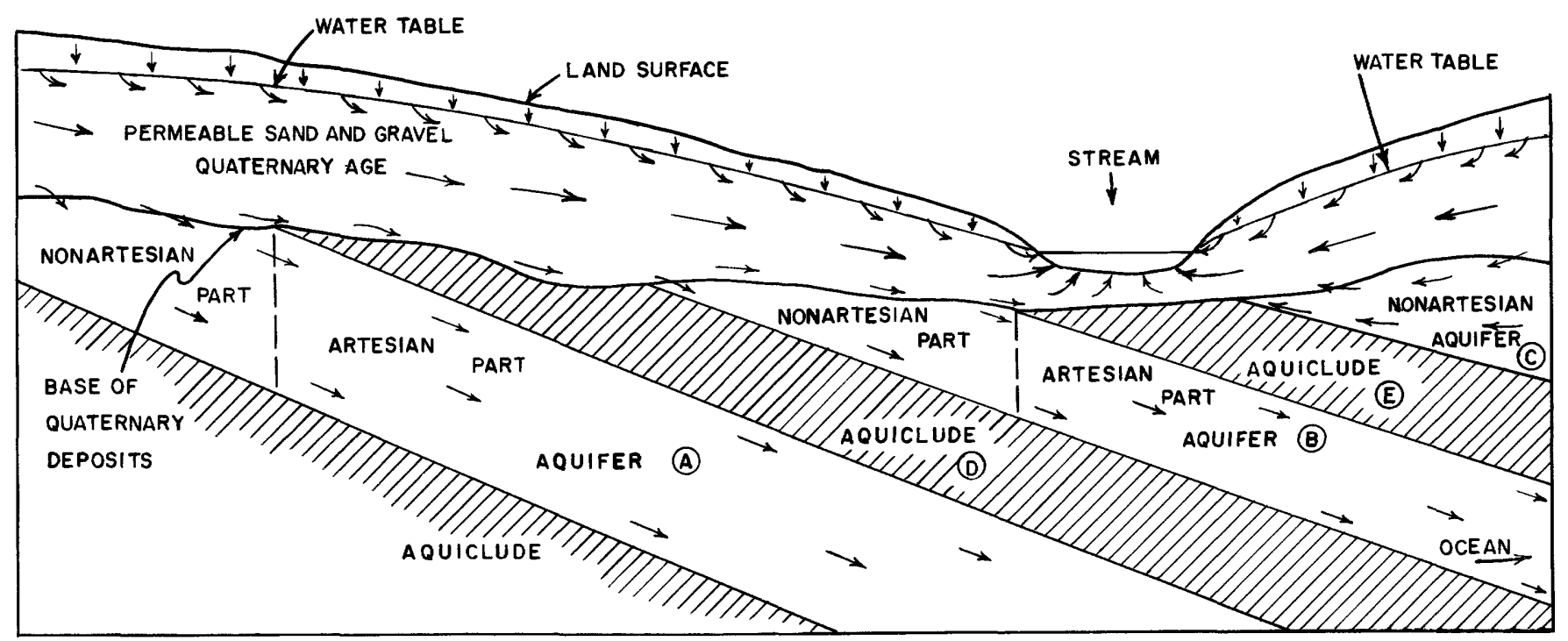

NOTE: Vertical scale greatly exaggerated, hence dip of oquifers and aquicludes is more neorly horizontal. Poths of ground-woter movement, indicoted by orrows, likewise ore not to scale; vertical components of movement ore greatly exogjerated, (components of movement perpendicular to diagram ore not indicated)

FIGURE 13.-Idealized cross section illustrating funnel effect in recharge to Coastal Plain aquifers. a large difference in hydraulic head between the adjacent aquifers is created by pumping from one aquifer. As an example, assume the following conditions: Thickness of aquiclude, 100 feet; average coefficient of permeability of aquiclude, $0.01 \mathrm{gpd}$ per sq $\mathrm{ft}$; and difference in head between adjacent aquifers, 50 feet. Under these conditions, the quantities of water moving through a square-mile area of the aquiclude would be about $140,000 \mathrm{gpd}$-an amount sufficient to supply a town of 1,000 people at an average rate of consumption of 140 gallons per capita per day.

The physical and hydrologic properties and the chemical character of the ground-water supplies of the aquifers and aquicludes of the Coastal Plain are described below from oldest to youngest; a more abbreviated description is provided in table 3. Later sections summarize ground-water recharge and discharge, the movement of ground water through the Coastal Plain deposits, and the importance of storage.

\section{NONMARINE SEDIMENTS OF CRETACEOUS AGE-THE MAJOR GROUP OF AQUIFERS}

The nonmarine sediments of Cretaceous age include in ascending order the Patuxent, Patapsco, Raritan, and Magothy formations (table 3). These formations are not treated separately herein, because together they constitute a major hydrologic unit in which the individual aquifers and aquicludes are less extensive than most of the overlying aquifers and aquicludes. These formations, therefore, can be identified only in restricted areas. 
These nonmarine sediments - the lowermost part of the unconsolidated sediments in the Coastal Plainform a wedge that thickens seaward and that lies on a surface of low relief cut on consolidated rocks similar to those which crop out northwest of the Fall Line (pl. 6 and fig. 12). The wedge thickens southeastward or southward from zero along the Fall Line to more than 3,500 feet beneath the mouth of Delaware Bay and more than 5,000 feet beneath the southeast corner of Delaware (fig. 14). The beveled northwest edge of the nonmarine sediments, most of which is largely covered with Quaternary deposits (compare pls. 5 and 7), forms a lowland that extends from northern Delaware 100 miles to the lower Raritan River and Raritan Bay in northeastern New Jersey. Much of the Delaware estuary lies along this belt, as does the Raritan River and its southwestern tributaries. Largely because of their location near the Fall Line where the large centers of population and industry are concentrated, the aquifers in the nonmarine sediments are better developed and provide more water supplies than any other aquifers in the basin.

The sediments were deposited in several nonmarine environments-stream, marsh, lagoonal, and estuarine - and, in the upper part, there are thin tongues of marine deposits. The individual beds or layers, which are much less extensive than the beds in the overlying formations of marine origin, consist of sand, clay, silt, and a little gravel. Varicolored tough clay and light crossbedded fine- to coarse-grained sand are typical. Lignite and pyrite are common in some places. A few thin limy beds containing shells occur in the seaward part of the sequence.

The hydrologic properties of the nonmarine sediments vary greatly. Some of the layers of coarsegrained sand are highly permeable, but many of the intervening layers of clay are nearly impermeable. Laboratory coefficients of permeability for samples from the Raritan formation in Middlesex County, N.J., ranged from 25 to $3,500 \mathrm{gpd}$ per sq $\mathrm{ft}$ and had a weighted average of about 1,300 gpd per sq $\mathrm{ft}$; the average coefficient for sands in the Magothy formation was about $400 \mathrm{gpd}$ per sq ft (Barksdale and others, 1943).

Aquifer tests in New Jersey indicated permeability coefficients that ranged from 240 to 2,500 gpd per $\mathrm{sq} \mathrm{ft}$ and averaged about 1,200 gpd per sq $\mathrm{ft}$, although the results of two tests in northern Delaware indicated lower permeabilities there (table 4).

Midpoint values of coefficients of transmissibility from 14 aquifer tests in New Jersey, Delaware, and Pennsylvania (table 4) ranged from 4,000 to 150,000 gpd per $\mathrm{ft}$ and averaged 60,000 gpd per $\mathrm{ft}$. None of these values is based on a penetration of the entire thickness of the nonmarine sediments; the thickness of aquifers tapped ranges from 10 to 100 feet, and even the 100-foot thickness represents only partial penetration of the unit.

In contrast to the moderate to high permeability and transmissibility of the aquifers in the nonmarine sediments, the clay aquicludes generally have permeability coefficients of less than $0.1 \mathrm{gpd}$ per sq ft. One aquiclude in the vicinity of Camden, N.J., has an estimated coefficient of transmissibility of about 0.4 gpd per ft (Barksdale and others, 1958, p. 41).

Midpoint values of coefficient of storage determined from the pumping tests given in table 4 ranged from 0.000062 to 0.0016 -indicative of confined to semiconfined conditions-and averaged 0.0005 .

In New Jersey most large wells in the Raritan formation yield from 250 to $1,000 \mathrm{gpm}$, and yields exceeding $1,000 \mathrm{gpm}$ are not uncommon. In Delaware, yields are generally considerably less. Rasmussen, Groot, Martin, and others (1957, table 15) reported an average specific capacity (discharge of a pumping well divided by the drawdown of water level) of only $2 \mathrm{gpm}$ per foot of drawdown for 66 wells tapping the nonmarine sediments in northern Delaware. This value indicates an average coefficient of transmissibility of only 4,000-5,000 gpd per $\mathrm{ft}$, which is roughly comparable with the values of 2,500-12,000 gpd per ft derived from aquifer tests at two sites in the area (table 4).

Properly designed and constructed drilled wells, tapping the full thickness of the nonmarine sediments, should yield between 100 and $1,000 \mathrm{gpm}$ within the productive area shown on figure 15 .

Although individual beds of sand and clay in the nonmarine sediments are lenticular, distinct water-yielding zones have been recognized in the most intensively studied areas. These zones appear to be separated by layers of clay that are more extensive than those separating the individual sandy layers within each zone, and definite differences in artesian pressure and also in the chemical character of the contained water exist between the zones. In northern Delaware, Rasmussen, Groot, Martin, and others (1957) defined three zones which were called the lower, middle, and upper aquifers; in the Philadelphia-Camden area, two principal zones appear to be present. Graham (1950, p. 214-216; fig. 3) described the ground-water occurrence in the Philadelphia-Camden area and illustrated in a geologic section the nature of these two zones.

The uncontaminated waters from the nonmarine sediments of Cretaceous age are relatively low in dissolved solids (30-200 ppm), soft, and generally of high quality (table 19). Near the intake areas where the recharge 


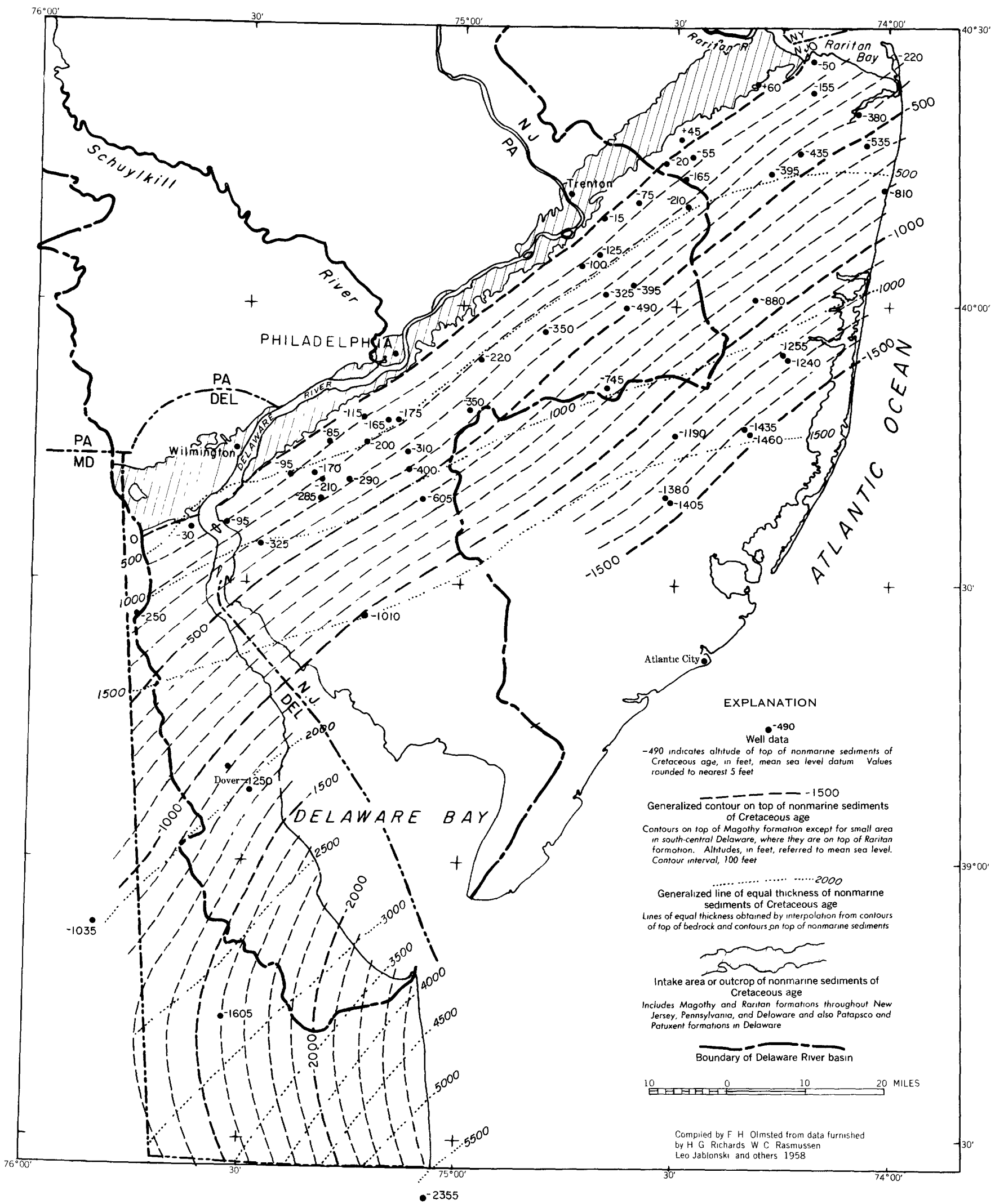

Figure 14.-Map of nonmarine sediments of Cretaceous age showing their extent, subsurface configuration, and thickness. 


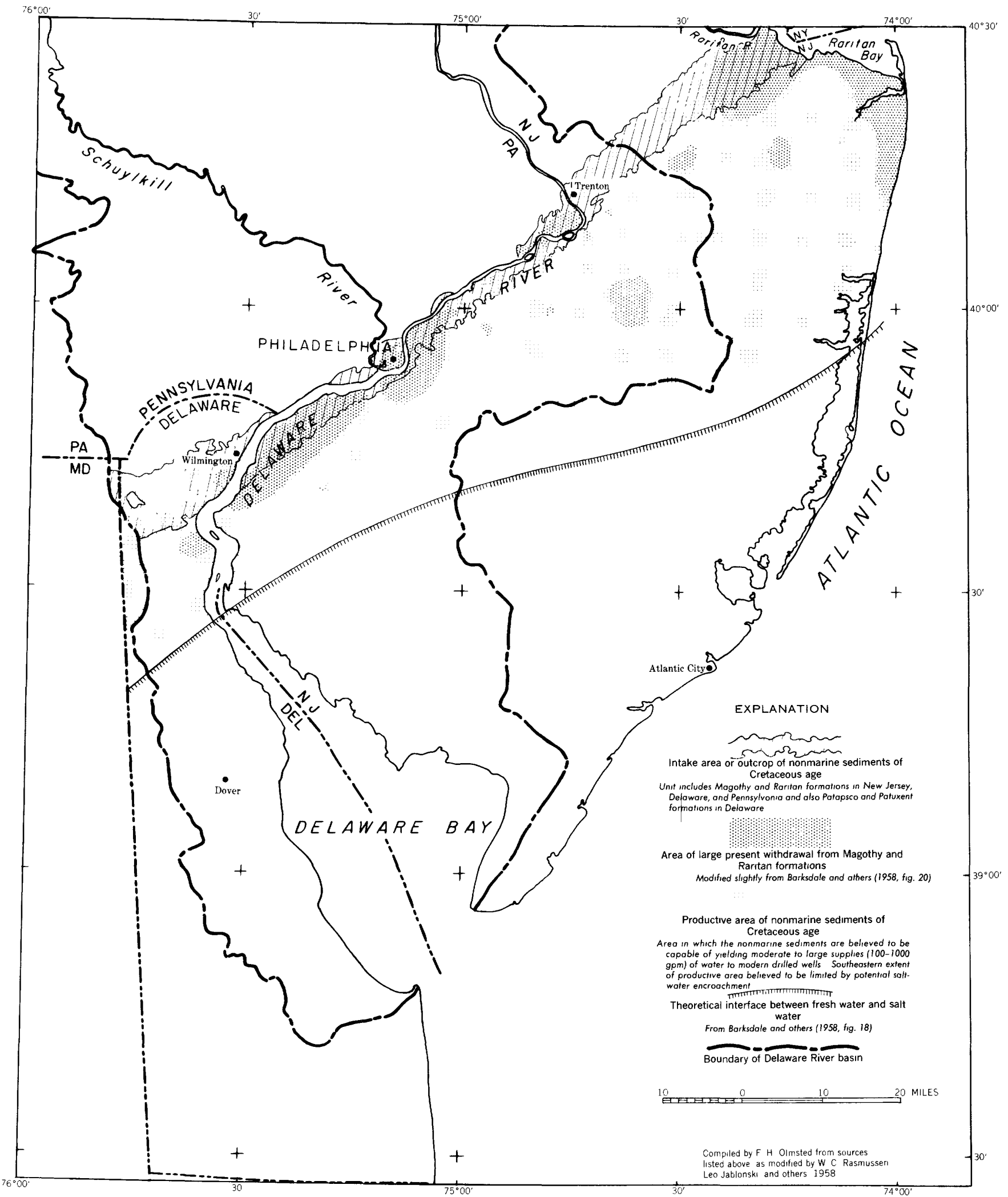

FIGURE 15. - Map of the nonmarine sediments of Cretaceous age showing productive area and theoretical interface between fresh water and salt water. 
TABLE 4.-Coefficients of transmissibility, permeability, and storage in nonmarine sediments of Cretaceous age

[Rounded to two significant figures]

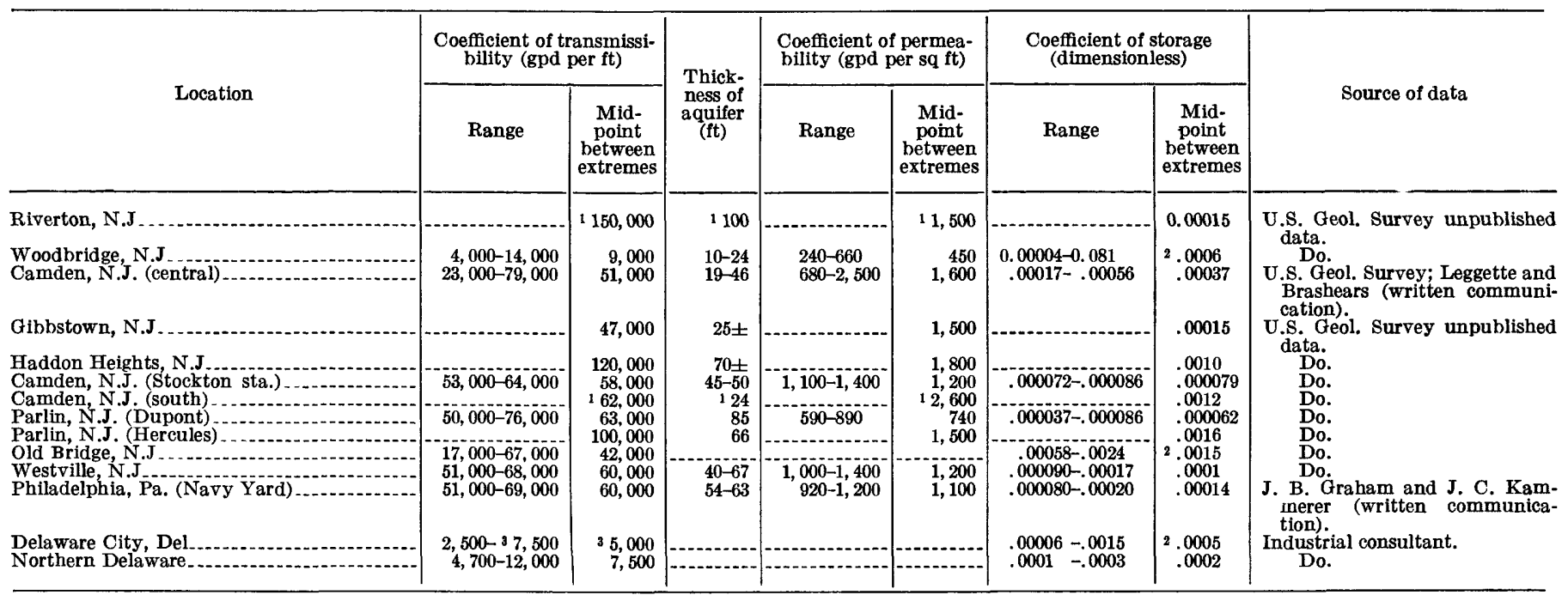

1 Aquifer probably was not fully penetrated.

${ }^{2}$ Assumed average.

consists chiefly of rainwater, the water is soft, slightly mineralized, slightly acid, and somewhat corrosive. As the water flows downgradient in the formation, it becomes more mineralized, slightly alkaline, and noncorrosive; it generally contains more iron, sometimes locally in objectionable quantities. The fluoride concentration is usually $0-0.1 \mathrm{ppm}$, but in the vicinity of Woodstown and Glassboro, N:J., it exceeds $1 \mathrm{ppm}$.

In several places the native waters are contaminated. The location of the hypothetical interface between fresh and salt water is shown on figures 15 and 16 . Where withdrawals of water near the interface are large, there may be salt water encroachment, as has already occurred in the vicinity of Salem and Woodstown, N.J. Near Camden and Philadelphia, the Delaware River flows over the outcrop of the Raritan and Magothy formations. Here, where large quantities of water are withdrawn, the aquifers are recharged with river water, and the quality of the well water approaches that of river water. Above Camden, the river water is no more mineralized than the native ground water, and river recharge has no adverse effects on, or may even improve, the quality of the well water. Downstream from Camden, however, the river water is more mineralized and (or) polluted, and wells near the river have been, and more of them may be, adversely affected by induced recharge of such water.

The highest concentrations of dissolved solids in the lower aquifers of the Raritan formation are within the city of Philadelphia. They come principally from three sources: (1) the disposal of wastes on dumps on the intake area of the aquifers; (2) seepage from leaky sewers; and (3) wastes discarded into sanitary or dry wells.

\section{MERCHANTVILLE AND WOODBURY CLAYS-A MAJOR AQUICLODE}

The Merchantville clay and the overlying Woodbury clay together form a widespread major aquiclude confining the water in the nonmarine sediments. The combined unit crops out or is covered by thin Quaternary deposits in a belt $11_{2}^{\prime}-4$ miles wide lying immediately southeast of the intake area of the nonmarine sediments. Southeast of its outcrop, the unit underlies all the Coastal Plain. The Woodbury clay has not been recognized in northern Delaware, but the Merchantville clay there probably is equivalent to the combined Merchantville and Woodbury clays and possibly also to the Marshalltown formation of New Jersey (Rasmussen, Groot, Martin, and others, 1957, p. 116). Near the outcrop, the Merchantville and Woodbury clays together range in thickness from about 100 to 140 feet, but they thicken downdip and attain a maximum known thickness of more than 250 feet in the seaward part of Ocean County, N.J.

The Merchantville clay is a black or greenish-black glauconitic micaceous clay. Glauconite is a yellowishto blackish-green amorphous mineral, which is composed of hydrous iron, aluminum, magnesium, and potassium silicate. It has pronounced cation-exchange properties and is commercially open-pit mined in parts of New Jersey for use as a water-softening agent. The Merchantville clay is generally greasy and massive, although the upper part is somewhat sandy and in places, particularly in Delaware, is distinctly laminated. 


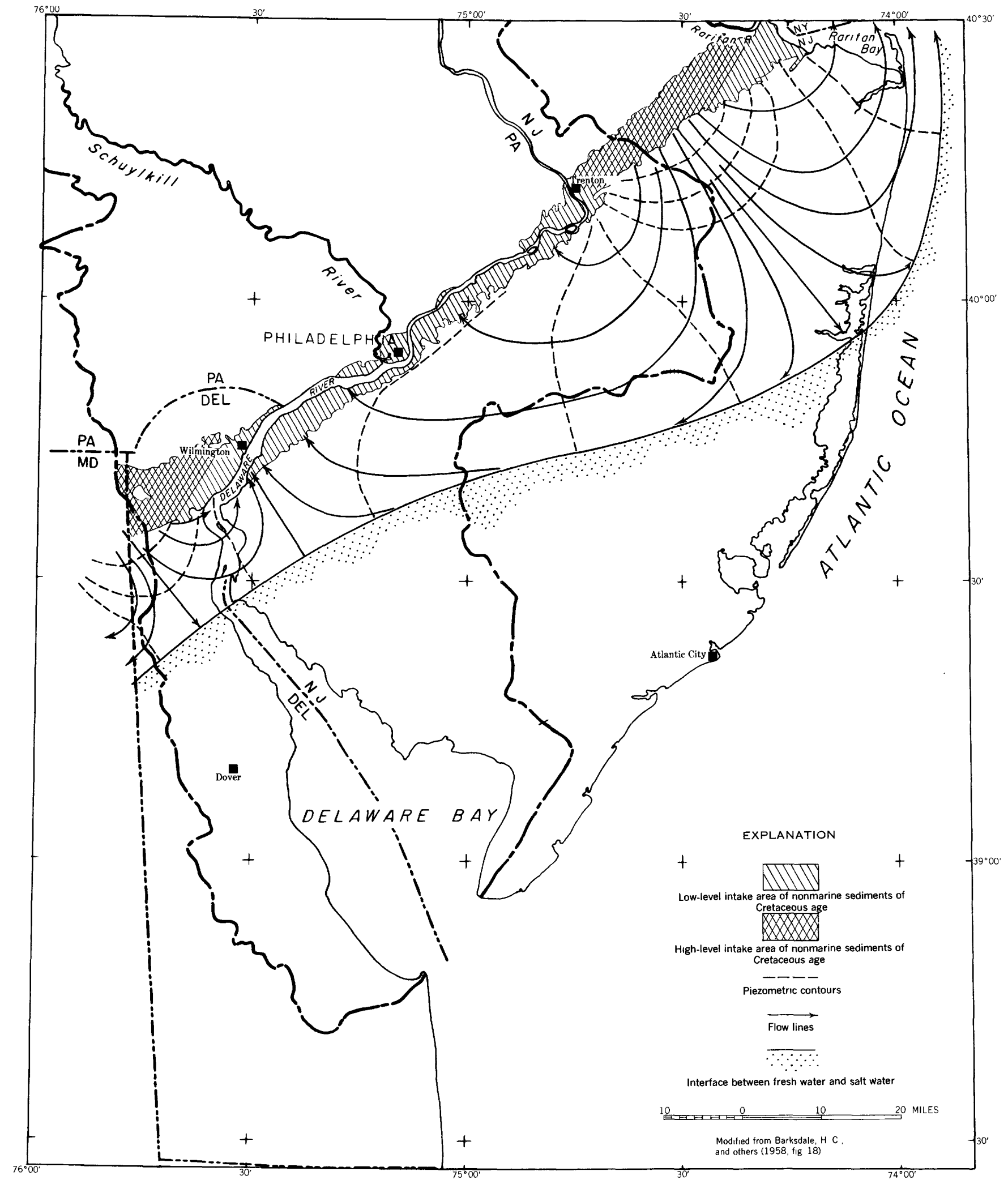

FIGURE 16.-Map showing theoretical flow pattern and location of the interface between fresh water and salt water in nonmarine sediments of Cretaceous age under natural conditions. 
The Woodbury clay, on the other hand, is not glauconitic; it consists of a black or bluish-black, somewhat micaceous tough clay. The Woodbury weathers light brown and breaks into distinctive blocks having curved or shell-shaped fracture.

The Merchantville and Woodbury clays, which form the most extensive and impermeable aquiclude in the Coastal Plain, are important chiefly in protecting the underlying aquifers in the nonmarine sediments from contamination or encroachment of salt water from above and in restricting the loss of water from those aquifers by upward leakage. Even though their permeability is very low, the Merchantville and Woodbury clays are capable of transmitting significant quantities of water where sizable differences in head exist between the overlying and underlying aquifers.

A few wells tap the sandy phases of the Merchantville clay, but the Woodbury clay is everywhere too impermeable to be a source of supply.

\section{MINOR AQUIFERS AND AQUICLUDES ABOVE THE MERCHANTVILLE AND WOODBORY CLAYS}

Between the aquiclude formed by the Merchantville and Woodbury clays and the Kirkwood formation is a sequence of aquifers and aquicludes ranging in thickness from an average of about 400 feet in its northwestern part to perhaps 1,000 feet beneath the coast at Atlantic City, N.J. None of the aquifers in this sequence is now an important source of water supply within the Delaware River basin, although two of them-the Englishtown sand and the Red Bank sandare important outside the basin in the northeastern part of the Coastal Plain, and the Wenonah and Mount Laurel sands yield moderate supplies at several places both inside and outside the basin. All the aquifers are capable of being used to a considerably greater extent than at present, should the need arise and economic conditions be favorable.

\section{ENGLISHTOWN SAND}

Overlying the aquiclude formed by the Merchantville and Woodbury clays in the central and northern parts of the Coastal Plain is the Englishtown sand, a minor aquifer in the basin but a fairly important source of water supply northeast of the Coastal Plain part of the basin in Monmouth and Ocean Counties, N.J.

The Englishtown sand consists typically of fine to pebbly quartz sand and a few inextensive layers of silt and clay. The sand contains small amounts of mica and glauconite and, in places, some lignite. Locally, it is cemented by iron oxide. In outcrop the sand is white, yellow, or brown, but in subsurface it is light gray. Clay and silt, which are not generally abundant, occur mostly in the upper part of the formation.
The Englishtown sand becomes finer toward the south and east and generally thins southward and westward, although variations in thickness appear to be somewhat random throughout much of its extent (fig. 17). Its maximum thickness is about 160 feet, in coastal Ocean County, N. J., but within the Delaware River basin its thickness at most places is 20-75 feet. The Englishtown sand probably is absent in Delaware and in southernmost and westernmost New Jersey.

The sandy beds probably are moderately to highly permeable, whereas the few layers of silt and clay are relatively impermeable. No data on the hydraulic coefficients are available, nor have detailed data on productivity of wells been assembled. Because of the fairly wide range in thickness of the aquifer, its potential productivity probably varies greatly from place to place. Within the basin the maximum reported yield per well is $200 \mathrm{gpm}$, but more might be obtained in some places, particularly in the northeastern part of the Coastal Plain, outside the basin. Within the productive area shown on figure 17, yields ranging from about 50 to $500 \mathrm{gpm}$ might be obtained from large drilled wells of modern design.

The Englishtown sand yields water that is soft to moderately hard (table 19). Normally the water is slightly alkaline and contains less than $200 \mathrm{ppm}$ of dissolved minerals. It is suitable for most uses without treatment, although softening or the removal of iron is required in some places. The Englishtown sand is less subject to salt-water encroachment than are the other Coastal Plain aquifers.

\section{MARSHALLTOWN FORMATION}

The Marshalltown formation is an imperfect aquiclude and, in a few places, a minor aquifer. It overlies the Englishtown sand in most of the Coastal Plain in New Jersey but overlies the Woodbury clay in much of Salem County, N.J. The Marshalltown has not been recognized in Delaware, but possibly equivalent beds there have been assigned to the Merchantville clay (Rasmussen, Groot, Martin, and others, 1957, p. 117).

The Marshalltown formation consists of greenishblack to black sandy clay and lenticular beds of glauconitic sand. Downdip to the southeast where the beds of sand become more abundant, the Marshalltown resembles the Englishtown sand and the Wenonah sand. Throughout most of its extent the Marshalltown formation ranges in thickness from about 20 to 60 feet; the maximum known thickness is 125 feet, outside the basin in Ocean County, N.J.

Because the Marshalltown formation is thin and contains some slightly to moderately permeable beds, it constitutes a leaky aquiclude. Downdip, the Mar- 


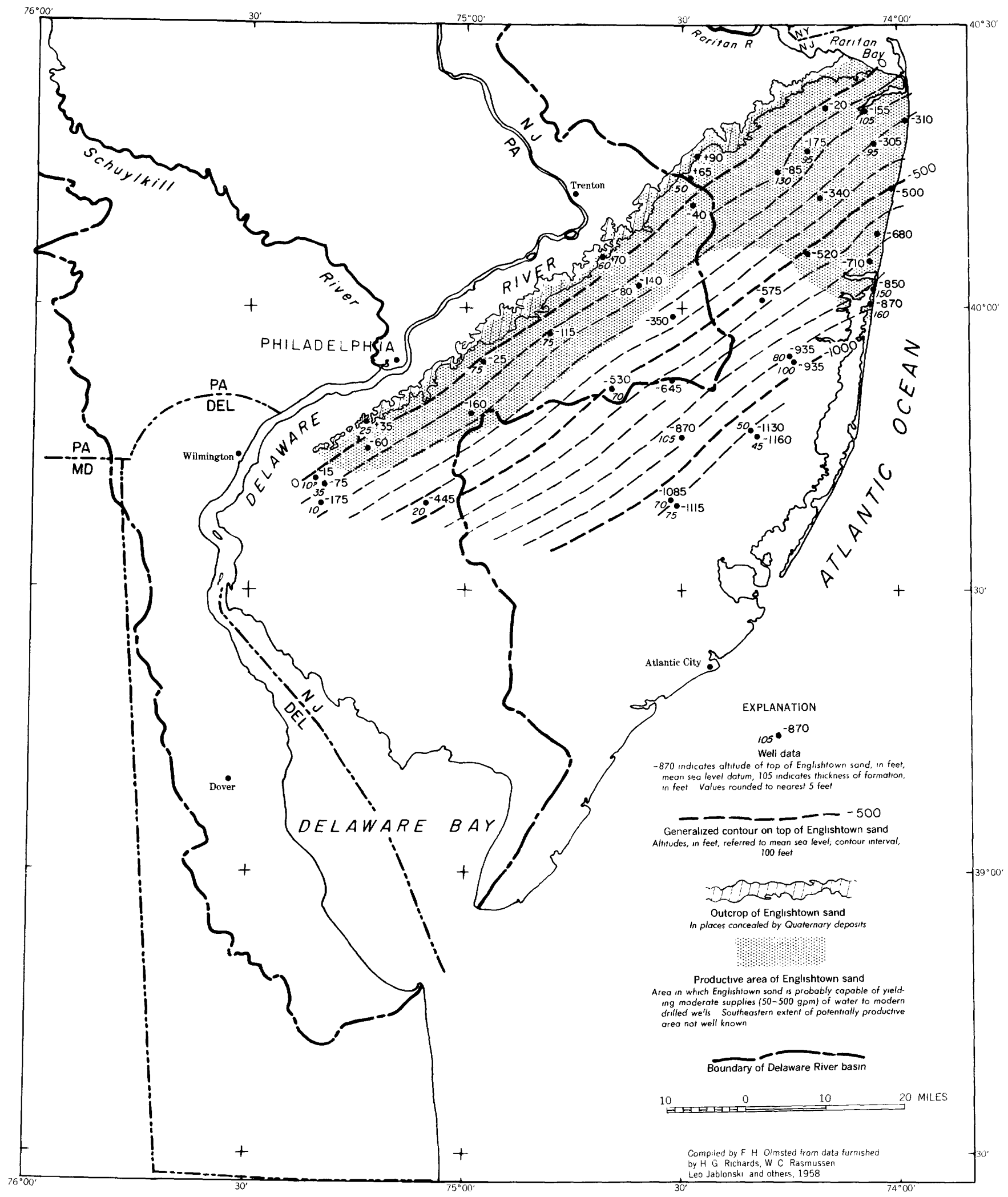

FigURE 17.-Map of Englishtown sand showing its extent, subsurface configuration, and productive area. 
shalltown becomes more sandy and functions even less effectively as an aquiclude; water moves between the underlying Englishtown sand and the overlying Wenonah sand where the required hydraulic gradients exist (Barksdale and others, 1958, p. 141). Domestic supplies of water may be obtained from the Marshalltown formation at many places, and the sandy parts yield as much as $40 \mathrm{gpm}$ to drilled wells.

\section{WENONAH AND MOUNT LAUREL SANDS}

Throughout most of the Coastal Plain in New Jersey, the Wenonah sand and the overlying Mount Laurel sand together form a minor aquifer. In northern Delaware the Mount Laurel sand has been grouped, instead, with the overlying Navesink marl, which it resembles there (Rasmussen, Groot, Martin, and others, 1957, p. 118).

The Wenonah sand is a slightly glauconitic, micaceous quartz sand containing thin layers of silt and clay locally. The sand is mostly fine to medium sized and gray or black where unweathered, although its outcrop is generally white, yellow, brown, or red. In northern Delaware it grades downward into the Merchantville clay.

The overlying Mount Laurel sand contains more glauconite than the Wenonah sand, is salt-and-pepper colored, and is mostly medium to coarse, though in northern Delaware it is finer and contains considerable amounts of silt and clay. In places the Mount Laurel is cemented by iron oxide to form a brown sandstone.

The outcrop of the Wenonah and Mount Laurel sands forms an irregular belt 1/4-3 miles wide across the northwestern part of the Coastal Plain, about 8 miles southeast of the Delaware River (fig. 18). Like the other formations of the Coastal Plain wedge, the unit dips southeast, and its top is 2,150 feet-below sea level at Atlantic City, N.J. The top dips 33-42 feet per mile but steepens to as much as 62 feet per mile toward the coast near Atlantic City (fig. 18). In New Jersey the combined thickness of the Wenonah and Mount Laurel sands ranges from 35 to 110 feet; at most places the thickness is between 60 and 100 feet. Subsurface in Delaware the Wenonah sand generally has not been separated from the underlying Merchantville clay; hence, the thickness of the Wenonah sand there is not known at present.

For the most part, the beds of sand in the Wenonah and Mount Laurel sands are moderately permeable. Thompson (1930) reported laboratory coefficients of permeability of about 570 and $890 \mathrm{gpd}$ per sq $\mathrm{ft}$ for sand samples from the upper and lower parts of the aquifer, respectively. An average coefficient of permeability for the aquifer in New Jersey might be in the range of 500-700 gpd per sq $\mathrm{ft}$ (Barksdale and others,
1958 , p. 142); hence, the coefficient of transmissibility of an average section, 70 feet thick, would be about 35,000-50,000 gpd per ft. One pumping test at Bradley Beach, Monmouth County, N.J., gave a transmissibility coefficient of only about 7,000 gpd per $\mathrm{ft}$ (Lang, written communication, 1958). The storage coefficient for this test was 0.0001 , which is indicative of confined conditions.

Few data are available on the productivity of wells in Wenonah and Mount Laurel sands. From the known properties of the aquifer, it may be inferred that properly constructed wells of large diameter penetrating the entire aquifer should yield from about 50 to 500 gpm. The potentially productive area may extend farther southwest than the limit shown on figure 18, although the increasing depth and probably decreasing permeability of the aquifer in that direction favor instead the development of the overlying aquifers.

Water of good quality is obtained from the Wenonah and Mount Laurel sands (table 19). It is soft to moderately hard and is fairly uniform in chemical composition. It is suitable for most uses without treatment, although excessive amounts of iron occur in some parts of the aquifer, and water from such parts must be treated to remove the iron.

NAVESINK MARL

Within the Delaware River basin the Navesink marl and the overlying formations, the Red Bank sand and especially the Hornerstown marl, form a leaky aquiclude overlying the aquifer formed by the Wenonah and Mount Laurel sands. The Red Bank sand supplies only small amounts of water to wells within the basin and is absent in much of central and southern New Jersey; in that area the Navesink and Hornerstown marls form one aquiclude having generally similar characteristics. In Delaware the Navesink marl is similar to the underlying Mount Laurel sand, and together with that formation forms a poor aquifer south of the Chesapeake and Delaware Canal and an imperfect aquiclude north of the canal.

The Navesink marl consists of a green glauconitic limy clay and sand with a basal bed of shells. Clay is most abundant in the upper part of the formation. Its maximum thickness in New Jersey is about 55 feet, and it diminishes toward the south to 25 feet or less. In Delaware the maximum thickness may be greater, but there the difficulty in distinguishing the Navesink marl from the underlying Mount Laurel sand precludes a reliable estimate of thickness for either formation. In New Jersey the combined thickness of the Navesink and Hornerstown marls ranges from 35 to 70 feet.

Although the Navesink marl is generally regarded as an aquiclude, it has been developed to a small extent as 


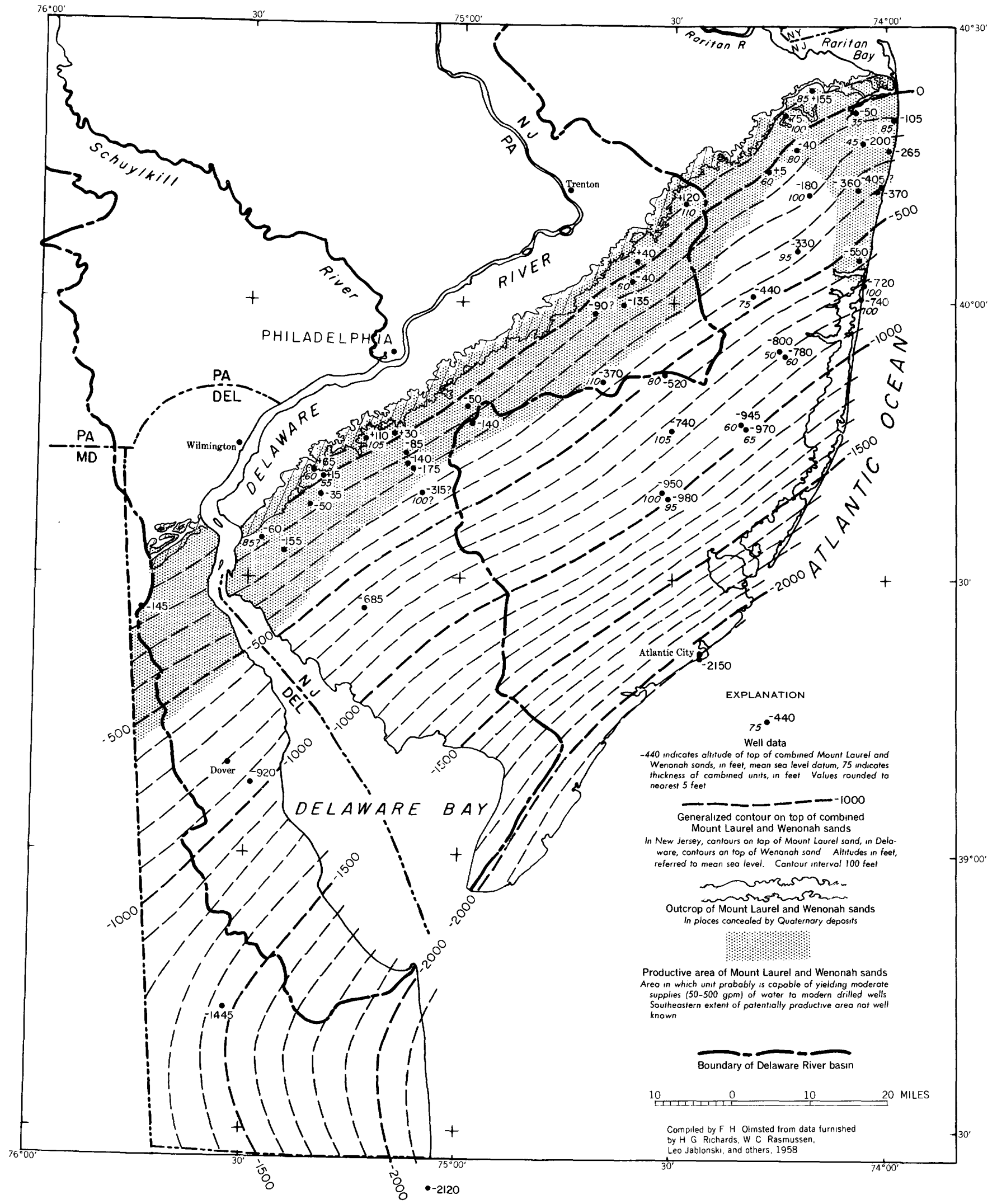

FIGURE 18.-Map of Wenonah and Mount Laurel sands showing their extent, subsurface configuration, and productive area. 
a source of domestic supplies (1-5 gpm per well) in parts of Monmouth County, N.J., where the adjacent aquifers yield water containing objectionable amounts of iron (Jablonski, oral communication, 1958).

RED BANK SAND

The Red Bank sand is fairly coarse although it contains clay and some glauconite in the lower part. In outcrop the sand is typically yellow or reddish brown, owing to oxidation of the iron-bearing minerals, but in subsurface the color is commonly dark gray. White micaceous sand and dark clay occur locally as do some beds cemented by iron oxide. In Monmouth County, N.J., an upper unit-the Tinton sand member-consists of somewhat cemented glauconitic clayey sand.

The Red Bank sand, including the Tinton sand member, attains a thickness of 185 feet in coastal Ocean County, N.J., outside the basin, but generally it is much thinner; it is missing altogether in central and southern New Jersey, but occurs again in Delaware, where it is less than 20 feet thick.

Few hydrologic data are available for the Red Bank sand, but it is probably similar in physical properties to the Englishtown sand (Barksdale and others, 1958 , p. 145). Within the basin it is not thick enough to be developed for more than domestic supplies, but outside it yields considerable quantities of water to wells in Monmouth and northwestern Ocean Counties, N.J.

HORNERSTOWN MARL

The Hornerstown marl, lowest formation of Tertiary age in the Coastal Plain (table 3), is scarcely distinguishable from the Navesink marl, which underlies it in much of the area. In the northeastern part of the Coastal Plain in New Jersey and in Delaware, the two formations are separated by the Red Bank sand; but in central and southern New Jersey, the Hornerstown and Navesink marls together form an aquiclude 35-70 feet thick. The maximum thickness of the Hornerstown is about 55 feet in Monmouth County, N.J., where it confines the water in the Red Bank sandan aquifer of some importance in that area.

The Hornerstown marl is not a true marl-an unconsolidated sediment containing a considerable amount of carbonate, as the term is defined geologically-but actually is a dark-green to greenish-black glauconite or greensand mixed with some glauconitic clay and nonglauconitic sand. Toward the southwest, sand and clay become more abundant, and in Delaware it is difficult to distinguish the Hornerstown marl from the overlying Vincentown sand. At some places, the sandy phases of the Hornerstown yield small supplies of water for domestic use.
VINCENTOWN SAND

The Vincentown sand gradationally overlies the Hornerstown marl and underlies nearly all the Coastal Plain southeast of the outcrop of the Hornerstown, except in southern Delaware (fig. 19). The outcrop of the Vincentown, itself, however, is missing in eastern Salem County, Gloucester County, and Camden County, N.J., where it is overlapped by the Kirkwood formation (pl. 5 and fig. 19).

In and near its outcrop, the Vincentown sand consists of a fossiliferous and somewhat consolidated limy sand and a sparsely glauconitic quartz sand. The limy sand is more abundant in the lower part of the formation and also is more abundant within the basin, whereas the quartz sand is more abundant in the upper part of the formation, especially northeast of the basin in Monmouth County, N.J.

Downdip, the sandy beds pinch out and are replaced by beds richer in clay and glauconite. This change, which occurs within 2 to 10 miles of the outcrop, greatly restricts the area in which the Vincentown is useful as an aquifer. The formation also thickens downdip toward the southeast from 10 to 130 feet in outcrop to more than 300 feet in parts of Salem County, N.J., and to about 460 feet at Atlantic City, N.J., (pl. 6 and fig. 19).

The top of the Vincentown sand dips from 15 to 35 feet per mile to a depth of 200 feet below sea level; its dip there steepens seaward and is more than 40 feet per mile near Atlantic City, N.J. (fig. 19).

No data are available on the coefficients of permeability, transmissibility, and storage of the Vincentown sand. The quartz sand, however, is at least moderately permeable, as may be inferred from the medium- to coarse-grain size and from well-yield information. The limy sand probably is less permeable because of cementation and somewhat smaller average size of grains.

Yields of wells in the Vincentown sand have a rather wide range owing in part to the variability in thickness and permeability of the formation from place to place. Well yields as much as $300 \mathrm{gpm}$ are reported for the thicker parts of the aquifer in Monmouth County, N.J., and in the vicinity of Salem, N.J., but elsewhere, yields of 50-100 gpm are more common (Barksdale and others, 1958 , p. 148). Figure 19 indicates the area in which sandy beds in the Vincentown are believed to be sufficiently thick and permeable to yield $30-300 \mathrm{gpm}$ of water to modern drilled wells of large diameter. The width of this productive area is less than that of the other Coastal Plain aquifers because of the abrupt southeastward pinch out of the sandy beds. 


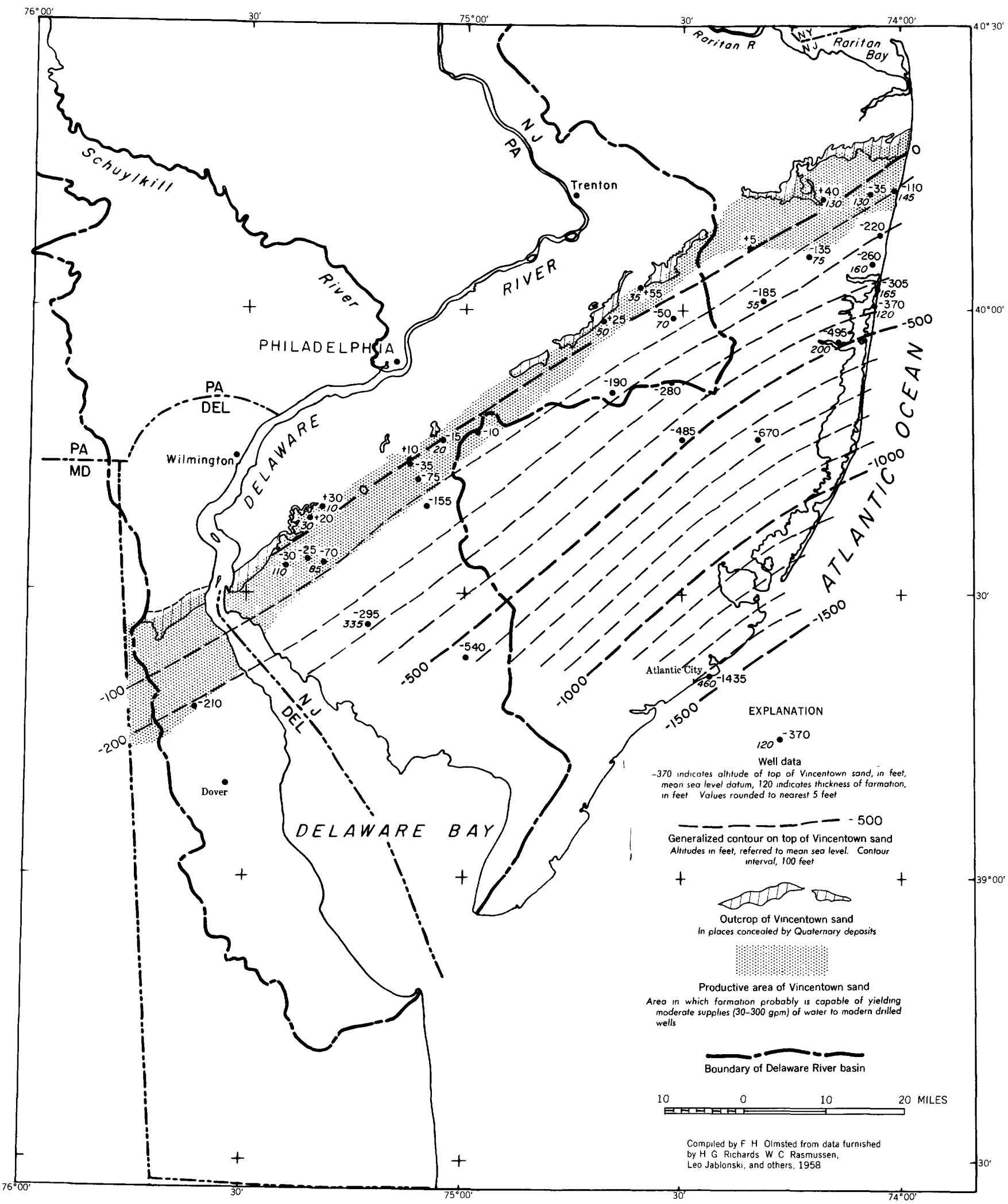

FIGURE 19.-Map of Vincentown sand showing its extent, subsurface configuration, and productive area. 
The Vincentown sand yields water that is moderately hard and moderately high in dissolved solids (table 19). The water is mildly alkaline according to the $\mathrm{pH}$ scale and in places contains objectionable concentrations of iron. Near the Delaware River there is a possibility of salt-water encroachment, but a considerable thickness of silt and clay in the river channel at the outcrop area probably retards the interchange of water between the Vincentown sand and the river (Barksdale and others, 1958, p. 149). Water from the Vincentown sand is used for farm and domestic supplies and as a supplementary municipal supply for Salem, N.J.

MANASQUAN AND SHARK RIVER MARLS

The Manasquan marl crops out in a discontinuous belt generally less than a mile wide from Clementon in eastern Camden County, N.J., to the vicinity of Long Branch in Monmouth County, N.J., (pl. 5). Overlap by the Kirkwood formation creates long gaps in this belt, and parts of the beveled edge of the Manasquan marl are covered by Quaternary deposits. The Manasquan marl is present beneath the surface in most of coastal New Jersey southeast of its outcrop but is missing in Delaware and probably in southwesternmost New Jersey. The Shark River marl overlies the Manasquan and is known only in Monmouth County, N.J. In outcrop the maximum thickness of the Shark River marl is about 11 feet and of the Manasquan marl about 30 feet. In subsurface the combined unit thickens southeastward to 200 feet at Atlantic City, N.J., (pl. 6).

The lower part of the Manasquan marl is composed chiefly of glauconite (greensand), whereas the upper part is composed of an ashy mixture of very fine sand and greenish-white clay. The Shark River marl consists of a mixture of greensand and light silty clay in which the uppermost 2-3 feet is cemented.

The Manasquan and Shark River marls form an aquiclude confining water in the Vincentown sand. Where the Vincentown is productive, the aquiclude is not more than 30 feet thick and contains beds having moderate permeability; the aquiclude therefore is probably not very effective.

\section{PINEY POINT FORMATION}

The Piney Point formation does not crop out within the basin and was not recognized as a distinct aquifer in the area until Marine and Rasmussen (1955) described the formation in Delaware. Equivalent sediments were recognized somewhat earlier in New Jersey, where they were called Jackson by Richards (oral communication, 1958).

The Piney Point has been recognized only beneath the southern part of the Coastal Plain in Kent and Sussex Counties, Del., and in the southern parts of
Cumberland, Cape May, and Atlantic Counties, N.J., (fig. 20). It rests on a surface eroded across the Manasquan marl, Vincentown sand, and Hornerstown marl; it is overlain unconformably by the Kirkwood formation. The Piney Point formation ranges in thickness from zero, along its northern edge where it wedges out between the overlying and underlying formations, to 290 feet at Atlantic City, N.J.

As determined from well samples, the Piney Point formation consists of beds of coarse to fine glauconitic salt-and-pepper-colored sand and greenish-gray clay. Clay and silt predominate at Atlantic City where the formation is thickest. The Piney Point is subject to recharge only from adjacent beds, especially where they are relatively permeable, and all water in the formation is confined. To date (1958) the Piney Point formation has been developed only slightly for water supplies; consequently few data on its water-yielding character are available. A test well at Dover Air Force Base, Del., screened for a total length of 40 feet in the coarsest parts of the aquifer, yielded $211 \mathrm{gpm}$ at a drawdown of 25.5 feet during a 12-hour pumping test (Rasmussen, Groot, and Depman, 1958, p. 5, 30 ). Because considerably more than 25 feet of drawdown is available throughout much of the known or inferred productive area of the Piney Point formation (fig. 20) and because the test well at the Dover Air Force Base was neither designed for large production nor pumped near its capacity, it may be possible to obtain yields substantially more than $200 \mathrm{gpm}$. Figure 20 indicates the known or inferred productive area of the aquifer in Delaware. The range in yields of modern large drilled wells is estimated to be $50-500 \mathrm{gpm}$ within that area.

In southern New Jersey, the Piney Point formation has not been tested as a source of water supplies, and its northern extent there is unknown. It may be potentially productive in parts of Cumberland County.

\section{KIRKWOOD FORMATION-AN IMPORTANT GROUP OF AQUIFERS AND AQUICIODES}

The Kirkwood formation, which contains several important aquifers, underlies most of the outer part of the Coastal Plain in New Jersey and crops out in a northeast-trending belt seaward from the outcrops of the older formations (pl. 5). The Kirkwood does not crop out in Delaware but underlies the Quaternary deposits in approximately the southern two-thirds of the State (compare pls. 5 and 7). It extends seaward beneath the Cohansey sand and, where salt-water encroachment has not resulted from pumping of wells, contains fresh water beyond the present shoreline (fig. 32). 


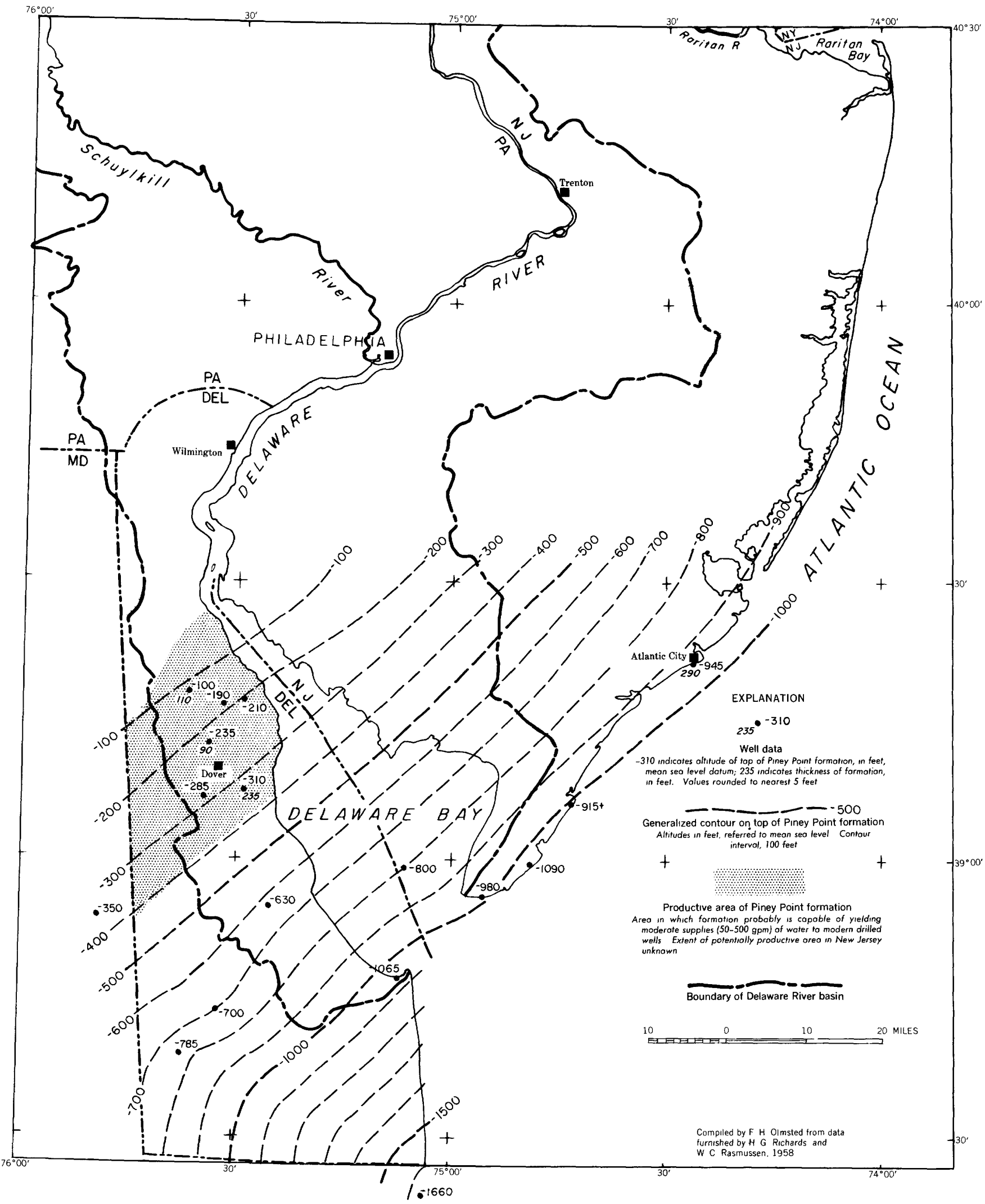

FIGURE 20.-Map of Piney Point formation showing its subsurface extent, configuration, and productive area. 
The Kirkwood formation lies on a buried surface of very low relief cut on formations ranging in downward order from the Piney Point formation to the Navesink marl (table 3). The lower part of the formation dips 20-30 feet per mile to the southeast, whereas the upper part dips 8-12 feet per mile. The thickness ranges from zero along its northwest edge to probably more than 700 feet beneath the mouth of Delaware Bay (pl. 6).

The outcrop of the Kirkwood formation consists chiefly of fine micaceous quartzose sand alternating with layers of silt and clay of variable thickness. Locally, beds of lignitic black clay are prominent. The Shiloh marl member, a highly fossiliferous clayey or silty sand, occurs at the top of the formation in southern New Jersey.

In subsurface the proportion of silt and clay increases down-dip toward the coast, but the beds of sand become coarser grained and more permeable (Barksdale and others, 1958, p. 150). Silt and clay are estimated to constitute at least four-fifths of the total thickness of the Kirkwood formation at Atlantic City.

Several conspicuous sandy zones in the Kirkwood have been designated as aquifers: the Cheswold aquifer in Delaware and its possible equivalent, the " 800 -foot" sand, at Atlantic City, N.J.; the Frederica aquifer in Delaware, separated from the underlying Cheswold aquifer by about 100 feet of silt and clay (pl. 6); and some aquifers above the " 800 -foot" sand in coastal New Jersey, including the "upper aquifer" of Gill (1958) in Cape May County, the highest of which may be equivalent to the Shiloh narl member or to the Frederica aquifer.

Probably not all the aquifers in the Kirkwood formation are known because of the absence of wells penetrating the formation throughout much of its extent, particularly in southern New Jersey between the coast and the area of outcrop.

Field and laboratory tests to date have indicated only moderate permeabilities for the aquifers in the Kirkwood formation. Laboratory-determined coefficients of permeability for several samples of the " 800 foot" sand at Atlantic City averaged about $860 \mathrm{gpd}$ per $\mathrm{ft}$ (Thompson, 1928). A pumping test made in 1952 in the saine area indicated nearly the same average coefficient, about $880 \mathrm{gpd}$ per sq $\mathrm{ft}$ for an 80 -foot thickness of aquifer. Elsewhere, pumping tests and estimates based on yields of individual wells have indicated smaller values, ranging from 100 to 500 gpd per sq $\mathrm{ft}$.

Coefficients of transmissibility derived in pumping tests range from 9,000 to $70,000 \mathrm{gpd}$ per $\mathrm{ft}$, and coefficients of storage determined so far are all about 0.0003 , except in one test at Ancora, N.J., which indicated a value of 0.0004 . The remarkably consistent values of storage coefficient may be due to the small statistical sample. Coefficients of this magnitude indicate confined conditions.

Large drilled wells of modern design probably will yield from 50 to $500 \mathrm{gpm}$ from inost aquifers in the Kirkwood formation, but yields of as much as 1,000 gpm may be obtained from wells in soine locations.

The Kirkwood formation yields soft to moderately hard water, generally of good quality, containing usually less than $250 \mathrm{ppm}$ of dissolved solids (table 19). The iron concentration is generally less than $0.3 \mathrm{ppm}$, but occasionally it is higher; commonly the silica concentration is $30-50 \mathrm{ppm}$. The water from soine parts of the Kirkwood is slightly acid. The water is usually used without treatment; sometimes it is softened or the $\mathrm{pH}$ adjusted before use. Salt water has encroached in the aquifers in a few places near the seacoast.

COHANSEY SAND-AN AQUIFER OF GREAT POTENTIAL

The Cohansey sand, perhaps the most promising future source of ground-water supplies in the Coastal Plain in New Jersey and Delaware, occurs at or near the land surface throughout most of the outer part of the Coustal Plain in New Jersey and southernmost Delaware (pl. 5). In New Jersey much of the Cohansey sand is blanketed by Quaternary deposits, chiefly the Bridgeton and Cape May formations; in Delaware the Quaternary deposits entirely conceal the Cohansey. The Quaternary deposits generally are less than a few tens of feet thick but attain a thickness of as much as 200 feet in buried valleys and in places along the coast (Gill, 1958). In New Jersey the outcrop of the Cohansey is a gently seaward sloping plain of low relief characterized by extensive marshes along nost of the streams.

The Cohansey sand lies on a buried surface of low relief eroded on the Kirkwood and older formations. At many places the Cohansey cannot readily be distinguished from the Kirkwood; the contact of the two formations shown on plate 6 is uncertain at nost places. The dip of beds in the Cohansey sand averages about 10 feet per mile to the southeast, and the formation extends seaward beyond the coast beneath Quaternary deposits (pl. 6). In New Jersey the maximuin known thickness of the formation is about 265 feet at Atlantic City.

The Cohansey consists largely of light-colored quartzose, somewhat micaceous sand, but it also contains lenses of silt and clay, as much as 40 feet thick, and some gravel. The sediments probably were deposited in estuaries and deltas except toward the southeast, where they may have been deposited in the ocean. The average grain size of the inaterials decreases southeastward; beds of silt and clay becoine thicker, more numerous, and inore extensive near the coast. 
The Cohansey sand is generally a highly permeable formation. The coefficient of permeability of the wellsorted medium to coarse sand probably is exceeded only by some of the sand and gravel in the glacialoutwash and channel-fill deposits of Pleistocene age. Coefficients of permeability for the Cohansey, determined from pumping tests made in Cumberland, Atlantic, and Cape May Counties, N.J., range from about 500 to more than 5,000 gpd per sq $\mathrm{ft}$ and average more than 1,000 gpd per sq ft (table 5).

The transmissibility ranges from moderate to high, depending, in part, on the thickness of the aquifer. Coefficients of transmissibility determined from the pumping tests cited in table 5 range from about 40,000 to more than 200,000 gpd per $\mathrm{ft}$. All these values are based on less than complete penetration of the Cohansey and, hence, are too low to be representative of the full thickness. Even so, they are comparable to transmissibility coefficients determined for the aquifers that at present are most productive - those in the nonmarine sediments of Cretaceous age (table 4).

The coefficients of storage listed in table 5 range from 0.00025 to 0.0025 - values representative of confined to semiconfined conditions rather than of unconfined conditions. Such storage coefficients are not representative of the specific yield which might average about 0.25 for the sandy beds. If pumping of the confined sands should proceed at any place to the point where the piezometric surface falls below the confining layers, then values of the coefficient of storage would approach or equal the specific yield.

Modern drilled wells in the Cohansey sand may reasonably be expected to yield from 100 to $1,000 \mathrm{gpm}$, and even higher yields may be obtained without excessive drawdown in places where the thickness of the aquifer exceeds 100 feet.

The water from the Cohansey sand is generally the best obtained from the Coastal Plain aquifers (table 19). It is only slightly mineralized and therefore is soft. Some samples, however, are moderately high in iron. The water is generally slightly acid and tends therefore to be corrosive to iron pipes and fixtures. Soluble materials in or near the land surface may be dissolved by infiltrating precipitation and (or) irrigation water; this condition affects the composition of the ground water locally. In this way the leaching of chemical and organic fertilizers yields nitrate concentrations that are above normal. Salt water has encroached into the Cohansey sand in a few places where extensive cones of depression have formed near saltwater bodies (fig. 33). Few industrial plants in the area are underlain by Cohansey sand; therefore, the present (1958) industrial use of water from the Cohansey is not great; the water is used chiefly on a large scale for municipal supplies and for irrigation.

The Cohansey sand is potentially the most productive aquifer in the New Jersey part of the Coastal Plain, but it must be protected from contamination and saltwater encroachment if it is to continue to produce a large quantity of high-quality water.

\section{BEACON HILI GRAVEL-A REMNANT CAP}

The Beacon Hill Gravel, and its probable equivalent-the Bryn Mawr Gravel-in the Piedmont province (Richards, 1956), occur at scattered places where they cap broad hills and ridges. The Beacon Hill occurs at only two places in the part of the Coastal Plain within the basin but caps about 25 hills outside the basin in Monmouth, Ocean, and Burlington Counties, N.J., (pl. 5). In the Piedmont province in southeastern Pennsylvania and northern Delaware, the Bryn Mawr gravel caps several broad interstream areas at altitudes of about 300 feet.

The Beacon Hill gravel consists of highly weathered deposits of sand, gravel, silt, and some clay which are, in places, cemented by iron oxide. Some of the pebbles are so weathered that they crumble to tripoli-a friable or dustlike silica. The Pliocene(?) age given in table 3 is uncertain because no fossils have been found in the formation.

TABLE 5.-Coefficients of transmissibility, permeability, and storage in Cohansey sand [From unpublished data of U.S. Geological Survey. Values rounded to two significant figures]

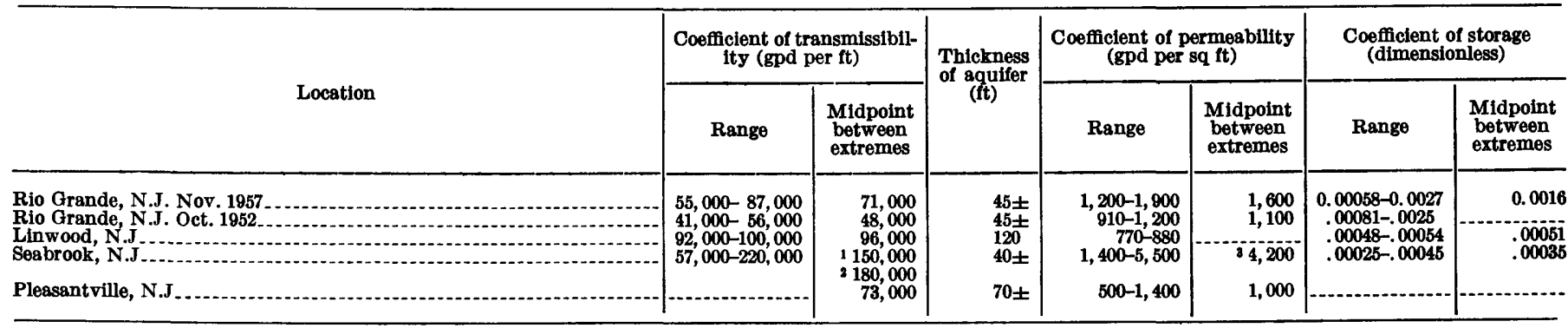

1 A verage of tests in west part of area.

3 A verage of tests in all the area. 
Because of its position on hilltops above the water table, wells in the outcrop pass through the Beacon Hill gravel into saturated materials below. Therefore, its hydrologic significance lies in its function as a moderately to highly permeable intake material for the underlying formations (fig. 13).

QUATERNARY DEPOSITS-AN IMPORTANT GROUP OF AQUIFERS AND A PORTAL FOR GROUND-WATER RECHARGE AND DISCHARGE

In the Coastal Plain the unconsolidated sediments of Quaternary age are divided into several geologic formations and units that overlie the older formations as valley fills, thin blanketlike masses, and scattered caps on ridges and hills. With the exception of relatively thin deposits of Recent age along streams, marshes, and beaches, these deposits were laid down during the Pleistocene epoch. All the deposits are less than a million years old and are much younger than the underlying Cretaceous and Tertiary formations (table 3). The Quaternary deposits are shown on a separate geologic map (pl. 7), because they mask the Cretaceous and Tertiary formations so extensively in some areas that their relations could not be shown on the same map. The extent of some of the Quaternary formations has not been defined accurately in much of the region, partly because of the lack of detailed geologic study and partly because of the difficulty of distinguishing these formations at many places from the underlying formations of Cretaceous and Tertiary age. Recent soil mapping in New Jersey (Holman and others, 1957) and field reconnaissance studies by the writers indicate that in some areas the Quaternary deposits are even more extensive than shown on plate 7 .

BRIDGETON AND PENSAUKEN FORMATIONS

The Bridgeton formation and the younger Pensauken formation are blanketlike deposits of quartzose gravel, sand, and silt in broad interstream areas in the Coastal Plain (pl. 7). The deposits of the Bridgeton are generally older, more highly weathered, and topographically higher than those of the Pensauken, although the two formations are difficult to differentiate at many places. MacClintock and Richards (1936, p. 295-299) believed that the two formations actually are a complex of deposits representing several episodes of deposition separated by periods of erosion and that they might therefore be considered either as one formation having many parts at different levels or as a series of many formations. Because of this reasoning and also because they are hydrologically similiar, the Bridgeton and Pensauken formations are herein considered to be one complex hydrologic unit and are not differentiated on plate 7.

The deposits, which lie at altitudes of as much as
150 feet in parts of central New Jersey, were laid down in broad valleys by the ancestral Delaware River and its tributaries. The maximum known thickness of the deposits is about 70 feet but at most places the thickness is less than 20 feet.

Although these deposits are extensive in many parts of the Coastal Plain (pl.-7), they are scarcely thick enough to provide large supplies of water to wells. Nonetheless, they are permeable and act as intake areas for ground-water recharge. Where they overlie permeable formations, such as the Cohansey sand and permeable beds in the nonmarine sediments of Cretaceous age, they constitute water-table aquifers in conjunction with those formations, as shown in the schematic diagram (fig. 13). Where they overlie aquicludes or less permeable beds, the Bridgeton and Pensauken probably are capable of yielding only small supplies sufficient for domestic or small-farm uses. In such situations the water they contain discharges naturally along a line of seeps or small springs near their base.

UNCLASSIFIED DEPOSITS OF PLEISTOCENE AGE

The unclassified deposits of Pleistocene age include a variety of materials that do not belong to the Bridgeton, Pensauken, Cape May, or Talbot formations. In Delaware these deposits were assigned to the Wicomico formation in the U.S. Geological Survey Geologic Atlas Folios (Miller, 1906; Bascom and Miller, 1920). In New Jersey the unclassified deposits were described in the U.S. Geological Survey Folios as a discontinuous mantle of surface material whose age, in many places, is not determinable. Owing to their thinness and uncertain extent, the unclassified deposits in New Jersey are not shown on plate 7.

The Wicomico formation in Delaware is a broad blanketlike deposit of loam, sand, gravel, and scattered boulders that lies topographically above the adjacent younger Talbot formation (Miller, 1906). The Wicomico, which is as much as 50 feet thick, is somewhat fine grained toward the top.

In New Jersey the unclassified deposits include a variety of materials ranging from silt and clay to coarse sand and gravel. The deposits generally are only a few feet thick, and at many places they closely resemble the weathered parts of the underlying formations of Cretaceous and Tertiary age.

The hydrologic properties of these unclassified deposits are not well known. Evidently they serve primarily as a moderately to highly permeable blanket through which recharge enters the underlying aquifers or through which ground water discharges. In Delaware, buried valleys or channels filled by these deposits provide large yields to favorably situated wells. 
CAPE MAY AND TALBOT FORMATIONS

The Cape May formation and its probable equivalent in Delaware, the Talbot formation, form a roughly wedge shaped mass thinning inland and having tonguelike extensions up the larger stream valleys. Both formations include broad, blanketlike deposits and channel-fill or valley-fill deposits which may be more than 100 feet thick in northern Delaware.

The relation of the Cape May formation to the glacial outwash to the north has not been worked out. The coarse gravelly deposits in the broad valley adjacent to the Delaware River near Trenton, N.J., have been described both as outwash and as Cape May formation in earlier reports (compare Greenman, 1955; and Bascom, Darton, Kümmel, and others, 1909). Richards (1956, p. 89) believes that no sharp line exists between the Cape May and the glacial outwash. Parts of the Cape May formation near the coast are of marine origin, and the upper part includes estuarine deposits of clay and silt.

Much of the material in the Cape May and Talbot formations consists of stream-deposited sand and gravel that are much less weathered than the materials of the Bridgeton and Pensauken formations. Where such deposits lie in buried valleys more than 100 feet deep, large yields may be obtained from drilled wells. Rasmussen, Groot, Martin, and others (1957, p. 124) reported yields of as much as $1,000 \mathrm{gpm}$ from drilled wells in these buried valleys in Delaware. At present, however, the location of the buried channels and valleys is known in a general way in northern Delaware and in southern Cape May County, N.J.

Toward the shore the estuarine deposits of clay and silt in the upper part of the Cape May formation confine the water in the underlying deposits of sand and gravel. The top of this silt-clay aquiclude is as much as 30 feet above sea level, but the underlying sand and gravel extend below sea level; the ground water of these deposits is therefore hydraulically continuous with sea water. Such conditions make salt-water encroachment possible where pumping has lowered water levels below sea level. In some places encroachment already has occurred.

Together with the glacial outwash, the Cape May and Talbot formations constitute one of the most promising sources of ground-water supplies in the southern part of the Delaware River basin. Yields of several thousand gallons per minute to individual wells are recorded in places, and such yields are permanent where recharge may be induced from adjacent streams and other fresh-water bodies.
BASIN-RIM SAND

Throughout the Coastal Plain are small, generally elliptical basins, the rims of which, as well as the interiors in places, are formed by deposits called Basin-rim sand (Rasmussen, 1953). The upper part consists of fine sand and silt, whereas the lower part is a deposit of reddish-brown, poorly sorted, coarse sand and gravel.

The basins collect runoff and allow it to infiltrate to the underlying aquifer unless the aquifer is already filled. In this latter condition, the basin centers are sites for large evapotranspiration losses. Thus the basins function as portals for both recharge or discharge of ground water, or for both, at different times of the year.

GLACIAL OUTWASH AND ALLUVIOM

The glacial outwash was deposited by melt-water streams flowing from the continental glaciers that occupied the northern part of the basin and adjacent areas. The most extensive and permeable outwash deposits in the Coastal Plain are those of the Wisconsin glacial stage that occupy the broad valley adjacent to the Delaware River near Trenton. Older outwash deposits are grouped herein with the Pensauken formation and the Bridgeton formation. Thin alluvium of Recent age is grouped with the underlying outwash of Wisconsin age because of the difficulty in differentiating the two deposits either geologically or hydrologically, and because they are hydraulically connected. The glacial outwash appears to be mixed with the similar deposits of the Cape May formation downstream from Trenton, N.J. (pl. 7).

The glacial-outwash deposits, which are largely almost unweathered sand and gravel, are highly permeable and yield as much as $1,050 \mathrm{gpm}$ to wells in southeastern Bucks County, Pa. (Greenman, 1955, p. 39). The outwash is similar in hydrologic properties to the coarsegrained part of the Cape May formation.

\section{MARSH AND SWAMP DEPOSITS}

The marsh and swamp deposits occur along the streams and tidal estuaries and consist of dark silt and clay mixed with organic matter. They are covered by water most of the time and generally are in such a loose, fluocculent state that appreciable recharge and discharge may pass through them. Along bays and estuaries the marsh deposits may serve as portals for salt-water encroachment into underlying shallow aquifers, in which the hydraulic head has been lowered below sea level by pumping or by drainage operations that materially reduce fresh-water head. In this connection it is pertinent to recall that the costly salt-water encroachment problems of southeastern Florida were 
caused by swamp-drainage operations to reclaim the Everglades (Parker and others, 1955, p. 580-592). Under natural conditions the fresh-water marshes and swamps of the Delaware River basin area are probably the sites of great quantities of ground-water discharge.

BEACH AND DUNE SAND

The beach and dune sands consist of loose well-sorted sand along the beaches and offshore bars. The total thickness of these deposits probably does not exceed 30 feet, except near Lewes, Del., where dunes areas much as 80 feet high. The beach and dune sands act as a permeable collector for recharge which in places may be transmitted to the underlying Cape May formation; they also locally provide supplies of fresh water for domestic use along the shore.

CHEMICAL CHARACTER OF, GROUND-WATER SUPPLIES IN QUATERNARY DEPOSITS

Some of the best ground water in the Coastal Plain is obtained from the aquifers of Quaternary age (mostly Pleistocene), which comprise the shallowest (or uppermost) aquifers. The water is, for the most part, soft or only moderately hard. It contains relatively low concentrations of calcium and magnesium and is only moderately mineralized, the dissolved solids being usually less than $200 \mathrm{ppm}$. The average hardness, as $\mathrm{CaCO}_{3}$, determined from 41 analyses of water from Quaternary deposits in Delaware, was $51 \mathrm{ppm}$ and ranged from 7 to $248 \mathrm{ppm}$ (Marine and Rasmussen, 1955 , p. 85). The water from Quaternary deposits commonly contains excessive concentrations of iron. Occasional samples with high concentrations of nitrate, sulfate, hardness, or dissolved solids (table 19) usually represent contamination from surface sources. The native water is generally satisfactory for most uses without further treatment unless the removal of iron is required. The principal discharge of ground water to the streams of Delaware and much of the discharge to streams in parts of coastal New Jersey is from Quaternary deposits; this is largely responsible for the good quality of water in many of the streams of the Coastal Plain.

\section{RECHARGE AND DISCHARGE}

Under natural conditions the aquifers of Cretaceous and Tertiary age in the Coastal Plain are recharged largely by infiltration of precipitation on their intake areas, which consist of either the outcrops themselves or the overlying blanket of Quaternary deposits (fig. 13). Seepage from the headwater reaches of streams may contribute a small amount of additional recharge.

Some buried aquifers receive recharge from adjacent aquifers across the intervening aquicludes, but such recharge does not constitute a net gain of water in the system.

The average rate of natural recharge to the Coastal Plain aquifers has not been determined directly. A 2-year water budget, however, was made by Rasmussen and Andreasen (1959) for the drainage basin of Beaverdam Creek, an area of 19.5 square miles in the Coastal Plain of Maryland about 50 miles southwest of the mouth of Delaware Bay. The physical and climatic conditions at Beaverdam Creek are fairly similar to those in much of the Coastal Plain in the Delaware River basin. Rasmussen and Andreasen found that the average rate of infiltration or recharge was a little more than a million gallons per day per square mile, which amounted to slightly more than half the average annual rate of precipitation.

A semi-independent check of the results of the Beaverdam Creek study is provided by an analysis of precipitation and runoff data for the Coastal Plain in the Delaware River basin (p. 67). Table 6 is a water budget summarizing the data derived from maps showing precipitation, water loss, and runoff (pls. $3,4,12)$. The values of precipitation, water loss, and runoff are averages for the 30-year period, 1921-50, and thus are virtually unaffected by change in storage.

Total ground-water discharge, or recharge, may be calculated as the sum of the base flow of streams leaving the area, the discharge of ground water by evapotranspiration, and the underground outflow (table 7).

The first item-base flow of streams-is estimated from base-flow recession curves and streamflow hydrographs described in the section Surface Water-its variation and character. From the meager data available for Coastal Plain streams, both within the Delaware River basin and in adjacent New Jersey, it is estimated that, on the average, roughly two-thirds of the runoff of these streams is base flow (chiefly groundwater discharge). By comparison, the base flow of Beaverdam Creek was estimated to be about 72 percent of the runoff (Rasmussen and Andreasen, 1959).

The second item-evapotranspiration of ground water-is estimated to be about 40 percent of the total evapotranspiration on the basis of the Beaverdam Creek study (Rasmussen and Andreasen, 1959). The estimated total evapotranspiration is less than the average loss in table 6 by the estimated amount of underground outflow.

The third item-underground outflow-is believed to be less than $0.20 \mathrm{mgd}$ per sq mi, and the most likely value is estimated to be about $0.10 \mathrm{mgd}$ per sq $\mathrm{mi}$.

Because of the sizable uncertainty in the estimated average values of base flow, evapotranspiration from ground water, and underground outflow, an attempt was made to determine their probable range. The 
Table 6.-Water budget for Coastal Plain in Delaware River basin

\begin{tabular}{l|r|r|r}
\hline Item & $\begin{array}{r}\text { Approxi- } \\
\text { mate range } \\
\text { within area } \\
\text { (mgd per } \\
\text { sq mi) }\end{array}$ & $\begin{array}{r}\text { Average } \\
\text { (mgd per } \\
\text { sq mi) }\end{array}$ & $\begin{array}{c}\text { Average } \\
\text { perent of } \\
\text { precipita- } \\
\text { tion }\end{array}$ \\
\hline Precipitation. & $\begin{array}{r}1.9-2.3 \\
1.1-1.4\end{array}$ & $\begin{array}{r}2.08 \\
1.25\end{array}$ & 100 \\
Water loss 1 & 60 & 40 \\
Runoff - & $.65-1.1$ & 40 & \\
\hline
\end{tabular}

1 Largely evapotranspiration, but includes some underground flow.

TABLE 7.-Ground-water budget for Coastal Plain in Delaware River basin

\begin{tabular}{|c|c|c|}
\hline Item & $\begin{array}{l}\text { Estimated } \\
\text { value (mgd } \\
\text { per sq } \mathrm{mi})\end{array}$ & Basis of estimate \\
\hline $\begin{array}{l}\text { Base flow } \\
\text { Evapotranspiration from ground water. }\end{array}$ & $\begin{array}{r}0.56 \\
.46\end{array}$ & \multirow{3}{*}{$\begin{array}{l}67 \text { percent of runoff. } \\
40 \text { percent of evapotranspira- } \\
\text { tion }(0.40 \times 1.15) \text {. } \\
\text { Median value in range of } 0 \\
\text { to } 0.20 \mathrm{mgd} \text { per sq mi. }\end{array}$} \\
\hline Underground outflow & .10 & \\
\hline $\begin{array}{l}\text { Total ground-water recharge or } \\
\text { discharge. }\end{array}$ & 1.12 & \\
\hline
\end{tabular}

coefficients used in table 7 are the most likely values in a range of about 60-75 percent of runoff for base flow and about 30-50 percent of the total evapotranspiration for evapotranspiration from ground water; the range in underground outflow is believed to be $0-0.20 \mathrm{mgd}$ per sq mi.

Table 7 shows that the average ground-water recharge or discharge in the Coastal Plain is estimated to be about $1.1 \mathrm{mgd}$ per sq mi-slightly more than the value obtained in the Beaverdam Creek study. This value also is in approximate agreement with unpublished U.S. Geological Survey data obtained from hydrologic studies at Brookhaven, Long Island, N.Y. The uncertainties in the estimated average values of base flow, evapotranspiration from ground water, and underground outflow being sizable, the lower and upper limits of average ground-water recharge or discharge in the Coastal Plain are probably about 0.9 and 1.3 mgd per sq mi, respectively.

Sizable areal variations in the recharge or discharge, base flow, evapotranspiration from ground water, and underground outflow (table 7) are suggested by the ranges in values of precipitation, water loss, and runoff shown in table 6 .

The area of the Coastal Plain in the Delaware River basin, excluding salt-water marshes, bays, and estuaries, is about 2,750 square miles. If the average recharge for this area is $1.1 \mathrm{mgd}$ per sq $\mathrm{mi}$, the average recharge to ground water in the Coastal Plain in the Delaware River basin is about 3,000 mgd. By comparison, this recharge is equivalent to about 40 percent of the flow of the Delaware River at Trenton, N.J., which is about $7,600 \mathrm{mgd}$, and which represents the runoff from that part of the basin above Trenton, about 6,780 square miles. As another comparison, discharge from pumped wells in the Coastal Plain of the basin was estimated to average about $210 \mathrm{mgd}$ for $1956-57$ (p. 163), which is 7 percent of the estimated total natural ground-water recharge of $3,000 \mathrm{mgd}$. But because part of the water pumped returns to the aquifers, the net discharge of ground water by pumping is even less than 7 percent of the natural discharge.

Pumping of ground water has induced recharge from streams and other bodies of surface water where the pumping has reversed the natural hydraulic gradients toward the surface-water bodies. Where the surfacewater bodies are fresh, the induced recharge augments the ground-water supply, but where the surface-water bodies are salty, this saline water replaces the pumped fresh water in the aquifers.

The largest amount of induced recharge occurs along the Delaware River estuary below Trenton, N.J., where in several well fields on both sides of the estuary large amounts of water are being withdrawn from the nonmarine sediments of Cretaceous age (fig. 15). The present (1958) amount of induced recharge is not known, but the potential amount under a planned system of development may be about 100 mgd (Barksdale and others, 1958, p. 131).

By far the greater part of total ground-water discharge occurs at natural outlets-stream channels, estuaries, bays, the ocean, springs and seeps, lakes and ponds, and in marshes and other lands where the water table is sufficiently near the land surface to allow discharge by evapotranspiration. Determination of the magnitude of the discharge through each of these outlets would require detailed and costly water-budget studies; such studies have only been attempted in a few places in this part of the country. However, the approximate magnitude of the total discharge to streams and the atmosphere was indicated in the preceding discussion and is believed to be sufficiently accurate that, except in unusual circumstances of local importance, such costly water-budget studies need not be made.

The amount of ground water that can be diverted from natural discharge outlets and used by man-in other words, the part of the water crop that is available from ground-water sources-probably is only a fraction of the estimated total of $3,000 \mathrm{mgd}$ of ground-water discharge from the Coastal Plain. The recoverable amount is not a fixed quantity but depends on a variety of hydrologic, economic, engineering, legal, and political considerations. Under any rational developmental plan, the potential ground-water supply in the Coastal Plain is several times the average discharge from pumped wells of about $210 \mathrm{mgd}$ for 1956-57. 


\section{PATTERNS OF MOVEMENT}

Where not affected by pumping, most ground water in the Coastal Plain moves from high parts to low parts of the outcrop areas of the aquifers; the quantity moving through the aquifers and aquicludes downdip from the intake areas is relatively small, even though the quantity in storage is very large.

In the intake areas the water either is unconfined or is semiconfined by inextensive layers of silt and clay. The configuration of the water table is somewhat like that of the land surface except that it is more subdued and regular. Hydraulic gradients are steep compared to those in confined parts of the aquifers; the gradients slope toward areas of discharge, which are near the exposed base of the aquifers or along stream channels and marshes.

In confined, or artesian, parts of the aquifers the much gentler gradients explain the smaller quantities of' water movement as compared with that in the intake areas.

Unfortunately, comprehensive regional water-level data are lacking for nearly all the aquifers in the Coastal Plain of New Jersey and Delaware. Almost all water-level data are for small areas in and near well fields, where the natural pattern of ground-water movement has been altered radically by pumping; it would be impossible now to reconstruct the original water tables and piezometric surfaces.

Some useful information is available, however, on the natural pattern of movement of water in the nonmarine sediments of Cretaceous age. Figure 16 shows the theoretical original flow pattern in the artesian part of the nonmarine sediments (Raritan and Magothy formations), prior to changes caused by pumping, as postulated by Barksdale and others (1958, fig. 18). The theoretical natural flow pattern is based on several simplified assumptions and does not, therefore, indicate the original conditions in detail.

For example, the interface between fresh water and salt water is not a sharply defined vertical surface (as might be inferred from fig. 16). Instead, it is an inclined zone of considerable thickness and is more nearly horizontal than vertical. The position of the interface shown on figure 16 is an average for the entire wedge of nonmarine sediments and might correspond to the actual position near the middle of the unit. The interface probably is farther seaward in the upper aquifers and farther inland in the lower aquifers. Supporting evidence for this relation is afforded by electric logs of several test holes in Burlington and Ocean Counties, N.J., several miles seaward from the interface shown on figure 16 , which indicate the presence of apparently fresh water in the top 100-200 feet of the nonmarine sediments. The validity of the theoretical original flow pattern is confirmed in part by the earliest water-level data for wells penetrating the nonmarine sediments (Barksdale and others, 1958, p. 112).

Most of the water that moved through the buried artesian part of the nonmarine sediments travelled curving paths from two relatively high intake areasone northeast of Trenton, N.J., the other in northern Delaware - to discharge areas along the Delaware River estuary below Trenton and along Raritan Bay. A greater quantity of water moved in much shorter and more direct paths from high to low parts of the outcrop area and discharged into the Delaware and Raritan Rivers and their tributary streams.

Less is known about original patterns of movement in the other aquifers having outcrop or intake areas along the inner, northwest part of the Coastal Plain. In general, however, the aquicludes separating these aquifers are neither as thick nor as impermeable as aquiclude composed of the Merchantville and Woodbury clays which overlies the nonmarine sediments of Cretaceous age. Substantial amounts of water probably move from one aquifer to another, and the intake and discharge areas are less well defined than those of the nonmarine sediments. Early water-level data for the Englishtown sand indicate that prior to 1910 its major intake area lay several miles southeast of the outcrop and coincided more nearly with the topographic divide between the inner and outer parts of the Coastal Plain (Seaber, P. R., written communication, 1959). This fact would suggest a considerable amount of recharge to the Englishtown by downward leakage through the overlying aquifers and aquicludes.

The predominant movement in the Cohansey sand and overlying Quaternary deposits in the outer part of the Coastal Plain was, and for the most part still is, along relatively short paths from intake points in the broad, flat interstream areas to discharge points along the adjacent streams and marshes. Longer and more devious paths are followed where there are layers of silt and clay, but such layers are not extensive or thick except near the coast or the shores of Delaware Bay.

Artificial discharge through pumped wells has changed the pattern of ground-water movement considerably in parts of the Coastal Plain. Water now is diverted from natural outlets, and moves toward the pumped areas, generally from all directions within the influence of the cone of depression that surrounds pumped wells.

The greatest changes have occurred in the most heavily pumped areas, principally along the Delaware River estuary from Trenton, N.J., to northern Delaware, in the vicinity of Raritan Bay, and along the coast of New Jersey. 
Large-scale pumping of ground water from wells in the nonmarine sediments in places along the Delaware estuary has diverted water from its former paths leading to discharge points in the channel and has induced movement from the estuary into the aquifers at those places. Also, hydraulic gradients from the intake areas have been increased, and the loss of natural discharge to the estuary in some cases has been exceeded by the gain in artificial discharge in the pumped areas. Some ground water has been withdrawn from storage, and recharge to the aquifers probably has increased.

Concentrated pumping in the intake area of nonmarine sediments along the Raritan and South Rivers, outside the Delaware River basin, has induced large quantities of recharge - some of it of very poor quality from those streams (Barksdale, and others, 1958). Figure 15 shows the heavily pumped areas in the nonmarine sediments of Cretaceous age in 1958.

Along parts of the coast in New Jersey, heavy pumping of water from artesian aquifers, particularly from the "800-foot" sand in the Kirkwood formation at Atlantic City, has greatly lowered the artesian pressure. There, over an area extending 20-30 miles along the shore, where natural water levels unaffected by pumping were about 25 feet above sea level, pumping has lowered the head to more than 75 feet below sea level. The total head loss of more than 100 feet (Barksdale, 1945, p. 565) has caused movement of large quantities of water toward the centers of withdrawal. Almost certainly, some of the recharge to the Kirkwood formation within the Delaware River basin moves toward the major center of pumping near Atlantic City. Although much of the water moves into the area from the seaward side, little salt-water encroachment has been detected (fig. 32). Large fresh-water storage in the aquifer seaward from Atlantic City is thus indicated.

The flow pattern in the Kirkwood formation has been changed also in Kent and Sussex Counties, Del., where withdrawals from the Cheswold and Frederica aquifers have caused declines in artesian head of more than 80 feet in places (Rasmussen, Groot, Martin, and others, 1957).

\section{GROUND-WATER STORAGE}

DSE OF STORAGE

The aquifers underlying the Coastal Plain constitute large ground-water reservoirs which, because of the scarcity of sites suitable for surface reservoirs, are potentially very important in the management of water supplies. The calculation of the enormous storage capacity of these reservoirs is of little consequence other than to indicate that it is many times greater than either the actual or potential annual recharge. To use more than a small fraction of this capacity the average rate of ground-water withdrawal would have to exceed the average rate of recharge for a long period - an overdraft or mining, procedure.

Ground-water overdraft is a common practice in the western drylands but is not likely to become a widespread practice in the Coastal Plain of the Delaware River region. A continued overdraft of groundwater supplies near the interface between fresh and salt water would lead to lowered ground-water levels and salt-water encroachment.

The aquifers of the Coastal Plain are much more likely to be used on a sustained-yield basis wherein the storage depleted during periods of excess discharge, both natural and artificial, is replenished either naturally or artificially during periods of excess recharge. The long-term yield of the reservoirs, then, is limited by the long-term average recharge, and the storage used is that required to level out the fluctuations in recharge and discharge. In the Coastal Plain of New Jersey and Delaware, water supplies are relatively abundant and are uniformly distributed in time; drought periods seldom are sufficiently long or severe to require unusually large drafts on ground-water storage. Peak consumptive use of ground-water supplies is for irrigation of crops in the summer, at a time when natural recharge is at a minimum. Such seasonal demands can be readily met with the available ground-water storage in the shallow aquifers.

Rasmussen (1955) estimated that the usable reservoir capacity of the Coastal Plain aquifers in Delaware was sufficient to store more than a year's recharge, considering the recharge as $1 \mathrm{mgd}$ per sq mi of aquifer intake area. No such estimate has been made for New Jersey; however, because of the similar hydrologic and geologic conditions there, Rasmussen's estimate indicates the order of magnitude of usable aquifer storage for all the Coastal Plain of this region. The aquifer capacity appears to be more than adequate to meet maximum fluctuations in ground-water storage that would occur on a sustained-yield method of operations.

\section{STORAGE FLOCTOATINS AND AQDIFER RECHARGE}

Fluctuations in ground-water storage are related directly to fluctuations in the rates of recharge and discharge. The magnitude of the storage fluctuation depends on the amount of the imbalance between the rates of recharge and discharge and on the length of time this imbalance occurs.

\section{NATURAL CONDITIONS}

Under natural conditions the fluctuations in storage in most Coastal-Plain aquifers are small compared to the total storage capacity of those aquifers. For example, base-flow recession data for Coastal-Plain 
streams indicate that in an average year the maximum fluctuation in ground-water storage supplying base flow to the streams amounts to a little less than 4 inches of water. Fluctuations in storage caused by changing rates of evapotranspiration might amount to an additional 3 inches of water; hence, in an average year the total natural storage fluctuation ordinarily would be about 7 inches of water. If the average coefficient of storage is $0.1-a$ conservative estimate for the water-table aquifers of the Coastal Plainthe 7 inches of water would cause an average water-table fluctuation of 70 inches (about 6 feet), which is a small fraction of the saturated thickness of most water-table aquifers of the Coastal Plain. Fluctuation of average ground-water level in Beaverdam Creek basin amounted to about 7 feet during the period from November 24, 1950, to March 28, 1952 (Rasmussen and Andreasen, 1959 , p. 48).

CONDITIONS UNDER DEVELOPMENT

Storage fluctuations may either increase or decrease when an aquifer is developed on a sustained-yield basis. Continuous, steady pumping, which is characteristic of many withdrawals for industrial use, might eventually result in a decrease in storage fluctuations, owing to the changed relations between recharge and discharge. By contrast, pumping for irrigation use, which is highly seasonal in pattern, tends to increase the fluctuations, sometimes by a large amount.

An increase in ground-water storage fluctuation may be accompanied by a corresponding increase in the amount of recharge to the aquifer, or aquifers. In most humid areas such as the Coastal Plain, pumping of ground water may increase recharge to aquifers in two ways: (1) by lowering the water table and thus providing additional space to receive precipitation that otherwise would have been rejected and become direct runoff in areas where the water table is near the land surface; and (2) by inducing infiltration from streams, lakes, and swamps, where the normal hydraulic gradient toward those discharge areas is reversed.

If the recharge, both from precipitation and from induced infiltration from surface-water bodies, is insufficient to replace the water withdrawn in heavily pumped areas, overdraft results unless the aquifers can be recharged artifically with surplus streamflow. Aquifers can be recharged artificially by several means such as input wells, check dams, infiltration canals, and spreading basins; these are discussed on p. 171-173. Except for heavily pumped industrial and municipal well fields in which large withdrawals are concentrated in small areas, it is unlikely that artificial recharge with imported supplies would be needed in the Coastal Plain.

\section{THE APPALACHIAN HIGHLANDS} GENERAL FEATURES

The extensive region north of the Fall Line is a part of the Appalachian Highlands-a major physiographic subdivision of the United States (Fenneman, 1938). The region comprises parts of four physiographic provinces, each having distinctive landforms which are related to the types and structure of the rocks and to the geologic history of the province. From the Fall Line northward these provinces are: (1) Piedmont, (2) New England, (3) Valley and Ridge, and (4) Appalachian Plateaus (pl. 1). Each province is further subdivided into sections or subprovinces.

The Piedmont province contains two very distinct subprovinces: (1) the Piedmont Upland, a considerably eroded low plateau formed primarily of weathered crystalline rocks such as schist, gneiss, and granite; and (2) the Piedmont or Triassic Lowland, a lower and less rugged area formed largely of relatively soft shale and sandstone but including also ridges, hills, and small plateaulike surfaces formed of harder rocks-principally diabase, basalt, and argillite. Another, much smaller, area is Chester Valley (pl. 1), a narrow lowland trending westward across the center of the Piedmont Upland. Chester Valley is underlain by limestone and dolomite (carbonate rocks on pl. 5), which are soluble and therefore less resistant to erosion than the surrounding rocks.

The New England province extends into the basin from the northeast as a long tongue terminating near Reading, Pa. Within the basin it consists entirely of the Reading prong of the New England Upland subprovince which is called "the Highlands" in New Jersey. The area is moderately rugged and is characterized by approximately parallel, somewhat irregular ridges and intervening valleys all trending northeast, especially in its northeastern part. The ridges, which rise about 300-800 feet above the valleys, are formed largely of gneiss and related hard crystalline rocks; the valleys are underlain by weaker rocks-principally carbonate rocks and shale. Most of the New England province has been glaeiated. In the northeastern part, in New Jersey, the ridges are blanketed by extensive deposits of glacial till, and the valleys contain thicker deposits, largely outwash, which completely mask the bedrock in most places.

The ridge known in Pennsylvania as Blue Mountain, in New Jersey as Kittatinny Mountains, and in New York as Shawangunk Mountains-for convenience hereinafter designated simply as Blue Mountaindivides the Valley and Ridge province into two parts: (1) the Great Valley to the south; and (2) a sequence of narrow valleys and ridges to the north.

The Great Valley, a relatively broad feature $8-20$ miles wide in the basin, actually consists of uwo belts 
of contrasting landforms. The southern, and narrower, belt is a lowland of gentle relief formed of relatively weak carbonate rocks. The northern belt, formed of more resistant shale, slate, and sandstone, is a more deeply eroded surface rising abruptly several hundred feet above the lowland to the south. As in the New England province, the northeastern part of the Great Valley has been glaciated, and parts of this area are covered by glacial deposits of variable thickness and character.

From Blue Mountain north, the Valley and Ridge province is characterized by alternating ridges and valleys which trend generally northeast, giving a regional "grain" to the topography. At many places these ridges and valleys curve, bend abruptly, reverse direction, or zigzag (pl. 1). The higher and steeper ridges, which have rather uniform summit altitudes of 1,500-2,000 feet, are formed of the hardest materialschiefly thick-bedded quartzose sandstone and conglomerate. Lower ridges are formed of more thinly layered sandstone and hard shale. The valleys are underlain by rocks less resistant to erosion such as soft shale, or by soluble rocks - chiefly the carbonates.

The most extensive occurrence of these valleys and ridges is west of the Lehigh River; to the east the belt narrows between the Lehigh River and the Delaware Water Gap near Stroudsburg, Pa. Northeast of Stroudsburg the belt narrows still more and consists principally of the Kittatinny-Shawangunk Mountains ridge and the valley of the Delaware River. The area northeast of Stroudsburg has been glaciated, and the valleys of the Delaware River and its major tributaries contain glacial outwash.

The Appalachian Plateaus province, which occupies approximately the northern third of the basin, is an upland of flat-lying to very gently folded beds of sandstone, shale, and conglomerate. The gentle to flat structure of the beds contrasts with the strongly folded and faulted structure of similar beds in the adjoining Valley and Ridge province and accounts for the difference in landform between the two provinces. The relation of rock structure to topography is shown by the gradational change from one province to the other near the Lehigh River; there the folds in the Valley and Ridge province flatten toward the northeast gradually, rather than abruptly.

The two sections or subprovinces of the Appalachian Plateaus province in the basin-the Southern New York section (which includes the Pocono Mountains) and the Catskill section-differ chiefly in relief; the boundary between them shown on plate 1 is vague and arbitrary. In both areas the layers of rock are nearly flat. The Catskill section attains an altitude of 4,200 feet at Slide Mountain on the east border of the basin; the greater altitude and relief is due to the superior resistance to erosion of the conglomerate and coarsegrained sandstone, which are more abundant there. Few summits exceed 2,000 feet in altitude in the Southern New York section of the plateaus, and altitudes of most of the area range from 1,000-1,500 feet. The Delaware River and its major tributaries have carved deep, narrow valleys across the plateaus in both subprovinces.

Probably all the plateau region has been glaciated, although the most recent glaciation-that of the Wisconsin stage (table 3 ) - did not extend into the southernmost part of the region (pl. 1). Glacial till mantles most of the area, and the drainage pattern has been modified greatly by the effects of the ice sheets. Marshes and lakes dot the flatter parts of the plateaus in Pennsylvania. The larger valleys contain thick deposits of glacial outwash 200 feet or more deep in some places.

\section{OCCURRENCE OF GROUND WATER}

In the Appalachian Highlands, ground water occurs in both of the principal types of aquifers-the consolidated rocks and the unconsolidated sediments-but, although the glacial outwash supplies the most productive wells, the consolidated rocks contain most of the water because of their much greater areal extent and volume.

The glaciated northern half of the area is blanketed discontinuously by unconsolidated sediments. Thin deposits of glacial till lie on the interstream areas; bedded deposits of glacial outwash lie along the major stream valleys, both in the glaciated area and in the unglaciated area to the south. The glacial outwash is the most permeable and productive aquifer in the Highlands, but its total volume is comparatively small. Nonetheless, the best sites for the development of large local supplies of ground water are where the larger bodies of glacial outwash are in hydraulic connection with perennial streams, as they generally are in the larger stream valleys. Though much more extensive than the outwash, the glacial till is less permeable and usually is too thin to yield large perennial supplies of ground water.

The consolidated rocks underlie all the unconsolidated sediments and are exposed at or near the land surface throughout most of the southern, unglaciated part of the Appalachian Highlands. The capacity of the consolidated-rock aquifers to store and transmit water ordinarily is much less than that of the unconsolidated sediments, but their great thickness and areal extent make the consolidated rocks the most commonly used aquifers in the Appalachian Highlands.

The consolidated rocks are herein divided into three major categories based on the nature and distribution 
of their water-bearing openings: (1) crystalline, (2) carbonate, and (3) clastic. The general characteristics of each of these categories are described, and the geologic formations that compose each type are listed in the following sections. The individual formations are described very briefly in table 3 , which also shows the relative ages and stratigraphic sequence of the formations. Because it is impossible to show in one table all the consolidated-rock formations in so large and diverse an area as the Appalachian Highlands part of the Delaware River basin, plate 8 lists the formations of Paleozoic age in each of the physiographic subdivisions of the Appalachian Highlands and indicates their approximate age relations.

The outcrops of the consolidated-rock formations are shown on plate 5 , and the stratigraphic and structural relations of the rocks in part are shown diagrammatically on plate 9 .

The unconsolidated sediments are described in a later section. Their extent is shown on plate 7 , and their thickness and distribution in and adjacent to the major stream valleys are shown in figure 25 .

\section{CRYSTALLINE ROCKS}

Crystalline rocks are composed of interlocking mineral grains, or crystals, which may range in size from microscopic to many inches in diameter. These rocks are formed chiefly in two ways: (1) by the cooling of molten material (magma) to form igneous rocks; or (2) by the recrystallization of preexisting rocks to form metamorphic rocks. Metamorphism results either through tremendous pressure and heat or by deep-seated emanations of hot liquids or gases that "cook" the preexisting rocks; sometimes both processes are involved.

The common igneous rocks in the Delaware River basin are granite, gabbro, diabase, basalt, and several types between granite and gabbro in composition. The granitic to gabbroic rocks of magmatic origin cooled slowly at considerable depth in the earth's crust and are relatively coarse grained. All the granitic to gabbroic rocks were formerly believed to be of igneous origin; now, however, many are known to be of metamorphic origin. Diabase, a dark rock generally having smaller crystals than gabbro, forms sills and dikes in sedimentary rocks into which it was injected by great subterranean pressures. Basalt, which is a still finergrained rock, originated as lava flows that poured out upon the land surface and in some places subsequently became buried under younger sedimentary rocks.

The metamorphic rocks of the Appalachian Highlands include gneiss, schist, phyllite, slate, quartzite, and probably some of the granitic- to gabbroic-rock types previously mentioned. These rocks commonly have a pronounced banding, layering, or alinement of crystals.

Some of the crystalline rocks grade imperceptibly into the other major types, so that any classification is arbitrary. For example, marble, a crystalline carbonate rock originating as a sedimentary rock (limestone), has water-bearing properties similar to those of the noncrystalline carbonate rocks; for this reason it is grouped herein with the carbonate rocks rather than with the crystalline rocks. Slate, a metamorphosed shale, grades into shale in parts of the basin and is grouped more conveniently with the clastic rocks than with the crystalline rocks. Some quartzite differs little from hard, strongly cemented quartzose sandstone and conglomerate and might be grouped with the clastic rocks.

As defined herein, the crystalline rocks include the following units shown on plate 5 and listed in table 3 :

\begin{tabular}{|c|c|c|}
\hline $\begin{array}{c}A g e \\
\text { Triassic }\end{array}$ & $\begin{array}{l}\qquad \text { Map unit } \\
\text { Diabase. } \\
\text { Basalt. }\end{array}$ & Formation \\
\hline Cambrian..... & Quartzose rocks_- & $\begin{array}{l}\text { Antietam quartzite. } \\
\text { Harpers schist. } \\
\text { Chickies and Hardyston } \\
\text { quartzites. }\end{array}$ \\
\hline $\begin{array}{l}\text { Early Paleo- } \\
\text { zoic(?). }\end{array}$ & $\begin{array}{l}\text { Glenarm series } \\
\text { and related } \\
\text { crystalline } \\
\text { rocks. }\end{array}$ & $\begin{array}{l}\text { Unnamed granitic to gab- } \\
\text { broic and ul'tramafic } \\
\text { rocks. } \\
\text { Peters Creek schist. } \\
\text { Wissahickon formation. } \\
\text { Setters formation.1 }\end{array}$ \\
\hline Precambrian _. & $\begin{array}{l}\text { Gneiss and related } \\
\text { crystalline } \\
\text { rocks. }\end{array}$ & $\begin{array}{l}\text { Various unnamed rocks. } \\
\text { Byram granite gneiss. } \\
\text { Losee diorite gneiss. } \\
\text { Pochuck gabbro gneiss. } \\
\text { Pickering gneiss. } \\
\text { Baltimore gneiss. }\end{array}$ \\
\hline
\end{tabular}

${ }_{1}$ May be, at least in part, equivalent to quartzose rocks of Cambrian age.

GNEISS AND RELATED CRYSTALLINE ROCKS OF PRECAMBRIAN AGE

The oldest rocks in the Delaware River basin are various types of gneiss and related crystalline rocks of Precambrian age (table 3). They occur in both the major areas of crystalline rocks-the Piedmont Upland and the New England Upland-but are more extensive in the New England Upland.

The gneiss and related rocks are of diverse origin; they include highly metamorphosed sedimentary and igneous rocks, unmetamorphosed to moderately metamorphosed igneous rocks, and complex mixtures of these types. Because of their similar water-bearing properties, their uncertain correlation, and their complex associations, all these rocks are herein grouped in one hydrologic unit (pl. 5).

In the Piedmont Upland the igneous and metaigntous ${ }^{4}$ types include diabase (or metadiabase), pegmatite, various rock types of granitic to gabbroic composition,

4 Meta-, when used as a prefix in a rock name, indicates that the rock has been altered by metamorphic processes. 
and several kinds of ultramafic rocks which are generally altered to serpentine; the metasedimentary types, where they can be mapped separately from the igneous and metaigneous types, have been called the Pickermg gneiss and the Baltimore gneiss (Bascom and Stose, 1938; Watson, 1957). Gabbro is the most abundant type in the southern part of the Piedmont Upland, south of Chester Valley, whereas granitic and granodioritic types and anorthosite predominate north of Chester Valley. Pegmatite dikes are locally abundant in both parts of the Upland.

In the New England Upland the named formations of Precambrian age include the Byram granite gneiss, the Losee diorite gneiss, and the Pochuck gabbro gneiss, but there are many kinds of unnamed rocks which include probable equivalents of the formations listed above (Sims, 1958; Hotz, 1953; Hague and others, 1956; and Smith, 1957). Most of the rocks are metamorphosed, some highly, and are of igneous and sedimentary origin. As in the Piedmont Upland, pegmatite is abundant at many places.

Most of the Precambrian rocks in the Piedmont and the New England provinces are medium to coarse grained, and the crystals are generally banded or layered. In composition the types range from light-colored rocks having abundant quartz and feldspar to dark rocks containing abundant iron- and magnesium-bearing minerals. Graphitic gneiss or schist occurs at several localities in the Piedmont Upland, and marble (Franklin limestone), grouped with the carbonate rocks in this report, is associated with some of the other rock types ut several places, particularly in the New England Upland in New Jersey.

\section{GLENARM SERIES}

A large part of the Piedmont Upland south of Chester Valley is underlain by a sequence of schistose and gneissose rocks of predominantly metasedimentary origin known as the Glenarm series (Bascom, Clark, Darton, and others, 1909, p. 4). In order of decreasing age the Glenarm series in the Delaware River basin consists of the Setters formation, the Cockeysville marble, the Wissahickon formation, and the Peters Creek schist. The age of these rocks formerly was believed to be Precambrian (Knopf and Jonas, 1929). However, age determinations made recently from radioactive elements (Postel and Jaffee, 1957) indicate that the Wissahickon formation may be as young as Ordovician. Increasing evidence indicates that the Glenarm series consists of more highly metamorphosed equivalents of known Cambrian and Ordovician rocks farther north (Watson, 1957), as shown in plate 8 .

The Setters formation consists largely of quartzite and mica-quartz schist and is similar to the Chickies quartzite of Cambrian age to the north.

The Wissahickon formation, which constitutes the bulk of the Glenarm series in the Delaware River basin, includes a variety of rocks ranging from gneiss in the southern part of the area to fine-grained schist and phyllite in the northern part. Micas (muscovite and biotite) are the most abundant minerals; other important constituents include feldspar, quartz, chlorite, and garnet.

The Peters Creek schist, which occurs in the northern part of the outcrop of the Glenarm series, is generally similar to the fine-grained mica schist and phyllite in the Wissahickon formation immediately south.

The Glenarm series, particularly the Wissahickon formation, contains considerable quantities of granitic to gabbroic rocks similar to those in the gneissose rocks of Precambrian age. Gabbro and amphibolite (metagabbro?) occur in the southwestern part of the Piedmont in the Delaware River basin, and granodiorite, granite, and ultramafic rocks are locally abundant in the southern part of the area.

\section{QUARTZOSE ROCKS OF CAMBRIAN AGE}

The quartzose rocks of Cambrian age include the Chickies quartzite, the Harpers schist, and the Antietam quartzite in the Piedmont Upland, and their approximate equivalent, the Hardyston quartzite in the New England Upland (table 3 and plate 8). Some of these rocks actually are intermediate in character between the crystalline rocks and the clastic rocks; they consist in part of quartzose sandstone and some conglomerate and shale that have been metamorphosed slightly to moderately. However, because of their almost total lack of intergranular porosity, they resemble in hydrologic properties the crystalline rocks more closely than the clastic rocks. Because of their brittleness, the quartzose rocks are highly fractured at many places, particularly in the vicinity of faults or contacts with older rocks, and in such places the highest yielding wells in the locality are commonly developed.

In parts of the Piedmont Upland the hard, weatherresistant quartzose rocks attain a thickness of more than 1,000 feet and form conspicuous ridges and hills. In the New England Upland, where these rocks generally are only a few tens of feet thick, they form inconspicuous low ridges or abrupt slopes at valley margins.

BASALT AND DIABASE OF TRIASSIC AGE

In the Delaware River Basin and adjacent New Jersey the youngest crystalline rocks are basalt and diabase-commonly called trap rock-of Triassic age. 
Both are dense dark rocks of igneous origin and consist mostly of about equal amounts of plagioclase and augite. The basalt is fine grained and occurs as lava flows interbedded with the shale and sandstone of the Newark group; the diabase is coarser grained and forms sills intruded between the beds of sedimentary rock of the Newark group or as dikes cutting across those beds. The basalt and the diabase are much more resistant to erosion than the surrounding sedimentary rocks and form prominent ridges and hills several hundred feet high in the Triassic Lowland. The basalt forms a series of concentric arcuate ridgesthe Watchung Mountains-in northern New Jersey, outside the Delaware River Basin; the diabase forms many scattered hills and ridges across the basin and is the bedrock of the well-known Palisades along the west bank of the Hudson River.

HYDROLOGIC PROPERTIES OF THE CRYSTALLINE ROCKS

In spite of their diverse origin, all the crystalline rocks have generally similar hydrologic properties: (1) they have little or no intergranular porosity except in the weathered zone near the land surface; (2) solution openings such as those in the carbonate rocks are scarce or absent; and (3) practically all water in the fresh rock occurs in fracture openings. Porosity of the crystalline rocks decreases with depth more rapidly than in any of the other rock types in the basin, and, except locally, little water is obtainable below a depth of about 300 feet.

As a general rule the following zones occur in downward succession in the crystalline rocks: (1) soil and decomposed rock, consisting of granular materiallargely a mixture of clay, silt, and some sand; (2) disintegrated rock, which downward contains more and more residual masses of fresher rock; (3) relatively fresh fractured rock; and (4) fresh rock in which the fractures are closed by the weight of the overlying rock.

Usually these zones are irregular and gradational, and local exceptions to the sequence are common. At some places where erosion has been very active or the rocks are unusually resistant to weathering, fresh rock extends to the land surface, and in much of the glaciated part of the New England Upland glacial deposits directly overlie fresh rock.

The thickness and character of the zones are determined by many factors, among which are the landform, the type of rock, and the geologic history of the area. Other factors being equal, the weathered zone also varies considerably with the original rock type. The hardest and chemically most stable rocks, such as quartzite, tend to form the thinnest weathered zones; the weak and chemically unstable rocks, such as much of the gneiss and schist of the Glenarm series, tend to form thick weathered zones. The thickness of highly weathered material in the outcrop of the Glenarm series of the Piedmont Upland commonly exceeds 25 feet and in places exceeds 50 feet.

The character of the weathered material is closely related to that of the parent rock; rocks high in quartz tend to form sand, but rocks such as gabbro or diabase, which have little or no quartz, form clay and silt. Most of the crystalline rocks in the basin weather to an unsorted assemblage of clay, silt, and sand having low to moderate permeability.

Weathering is most active in the zone above the lowest level of the water table. The principal weathering agents in this area consist of dissolved carbon dioxide and oxygen, and organic acids. Although some geologists believe that the lowest level of the water table is the lower limit of normal weathering processes (Penck, 1953, p. 61), much evidence exists to the contrary. In most crystalline-rock areas in the Delaware River basin, the zone of fluctuation of the modern water table is well above the base of the weathered zone. In discussing the weathering of granite in Hong Kong, Ruxton and Berry (1957, p. 1275) list three reasons for such a seemingly anomalous condition: (1) deep weathering may have taken place before an integrated circulation of water was established in the rock; (2) local deepening of the weathered profile may occur along prominent fractured zones; and (3) the level of the water table may be higher now than at the time the lower part of the weathered zone was established. In any case, considerable quantities of water now are stored in the weathered crystalline rocks in many parts of the Piedmont Upland and New England Upland, and water released from groundwater storage sustains the high base flow of the stream in those areas.

Fractures are caused by stresses of various origins. Deformation of the rocks during folding and faulting probably caused most fractures in the crystalline rocks of the basin, but shrinkage resulting from cooling of igneous rocks also caused many fractures, particularly in the basalt and diabase. Depths to which open fractures extend are related to the strength and brittleness of the rock type as well as to the degree of deformation the rocks have undergone. As a rule, open fractures extend to greater depths in the hard quartzitic rocks than in the softer, less brittle rocks, such as phyllite and micaceous schist. Records of drilled wells indicate that open fractures do not ordinarily extend beyond a depth of about 300 feet and that yields of wells are not increased appreciably by drilling below that depth. However, a few wells have obtained water from greater depths, probably from fractures along faults or in shattered pegmatite dikes and quartz 
veins. Many of these veins and dikes are highly fractured and thus yield more water than the surrounding less-fractured rocks.

The spacing and orientation of fractures in crystalline rock are dependent on the composition and texture of the rock and the direction of application of the deformational forces that have acted on the rock. For example, where mica and chlorite are abundant, as in much of the Wissahickon formation, the rock tends to split readily parallel to the layering of these minerals. Such fractures, however, do not ordinarily extend very far below the weathered zone; other sets of fractures, of deformational origin, extend to greater depths and have more water-bearing capacity. As a rule, fractures are farthest apart and most evenly spaced in coarsegrained massive rocks such as granite and gabbro where the fractures (joints) commonly form a set of three mutually perpendicular planes several feet, or even tens of feet, apart. A set of curved fractures (sheeting) approximately parallel to the land surface occurs in some of the sparsely jointed rocks.

The porosity of the fractured fresh crystalline rock is considerably less than that of the weathered zone, but the larger size of many of the fracture openings in the unweathered rocks often permits more rapid movement of water through them. The occurrence of water in fractured rock is much more irregular than in the highly weathered rock, owing to the unequal distribution of fractures. Adjacent wells commonly tap fracture systems that lack nearby hydraulic connection, so that pumping of one well may not affect the water level in the other, at least not immediately. In the granular material in the weathered zone the water table may be the usual subdued replica of the topography, but in a fracture system, especially one in which the fractures are far apart and not interconnected freely, a true water table commonly is absent, and water will stand at different levels in each fracture or set of fractures. At some localities, water-bearing fractures may be separated from the water-bearing weathered zone by a zone of dry unfractured rock; at other places, ledges of hard massive rock separate water-bearing zones in the weathered material (Ward, 1956). Much study remains to be done before the occurrence of water in the crystalline rocks in the Delaware River basin can be better understood.

As indicated by the rather scanty data available, the coefficient of storage of the crystalline rocks probably ranges from about 0.005 to about 0.02 -in the low range of values for unconfined conditions (Greenman, 1955, p. 6). The higher values probably are representative of the unconsolidated granular material in the weathered zone, whereas the lower values are representative of the fractured fresh rock.
The transmissibility and average permeability of these rocks also are moderately low to very low, as indicated by the reported specific capacities of wells. Rasmussen, Groot, Martin, and others (1957, p. 99) reported the following specific capacities of wells tapping several types of crystalline rocks in the Piedmont upland of northern Delaware:

\begin{tabular}{|c|c|c|c|c|}
\hline \multirow{2}{*}{ Type of rock } & \multicolumn{3}{|c|}{$\begin{array}{l}\text { Speciffc capacity in gpm per ft of } \\
\text { drawdown }\end{array}$} & \multirow{2}{*}{ Wells } \\
\hline & Mardmum & Minimum & Average & \\
\hline $\begin{array}{l}\text { Granodiorite (igneous): } \\
\text { Weathered material.... } \\
\text { Hard rock- } \\
\text { Gabbro (igneous) } \\
\text { Wissahickon formation. }\end{array}$ & $\begin{array}{l}3.2 \\
1.0 \\
15 \\
13\end{array}$ & $\begin{array}{c}0.005 \\
.07 \\
.003 \\
.01\end{array}$ & $\begin{array}{r}.3 \\
1.6 \\
.7\end{array}$ & $\begin{array}{r}2 \\
10 \\
33 \\
74\end{array}$ \\
\hline
\end{tabular}

From these hydraulic characteristics it is apparent that a typical well tapping the crystalline rocks will exhibit considerable drawdown at any pumping rate, but substantial lowering of the water table will not extend more than a few hundred feet from the well unless the rate of pumping is high.

Reported yields of 202 wells tapping crystalline rocks in the basin range from less than $1 \mathrm{gpm}$ to more than $300 \mathrm{gpm}$ and average about $50 \mathrm{gpm}$. Except for the basalt and diabase, which are perhaps the poorest water producers in the basin and seldom yield more than a few gallons per minute to wells, differences in productivity among the many types of crystalline rocks seem to be outweighed by local differences within each type. Detailed hydrologic studies should be made to determine the factors that affect the productivity of the crystalline rocks.

\section{CHEMICAL CHARACTER OF GROUND WATER}

The crystalline rocks of Precambrian and early Paleozoic age in the Delaware River basin yield excellent water low in dissolved solids and hardness. Table 8 summarizes the chemical analyses of 12 samples of water from gneiss and related crystalline socks of Precambrian age. With the exception of iron, which is locally present in excessive concentrations, the water generally contains no objectionable quantities of mineral impurities.

The Wissahickon formation in Pennsylvania and Delaware generally yields water of high quality, unless the water becomes contaminated; 15 of 22 samples contained less than $100 \mathrm{ppm}$ of dissolved solids. The water is soft or only moderately hard, and is low in chloride content. Half the samples analyzed for iron contained more than $1.0 \mathrm{ppm}$. The harder waters generally have the higher concentrations of sulfate. According to Hall (1934, p. 27), excessive hardness is sometimes due to pegmatite dikes which contain large percentages of 
TABLE 8.-Summary of chemical analyses of 12 samples of ground water from gneiss and related crystalline rocks of Precambrian. age

[Concentrations in parts per million]

\begin{tabular}{|c|c|c|c|c|}
\hline & Maximum & Median & Minimum & Analyses \\
\hline $\left.\mathrm{SiO}_{2}\right)$ & 35 & & 8.7 & \\
\hline $\begin{array}{l}\text { Iron (Fe), total } \\
\text { Calcium (Ca) }\end{array}$ & 20 & - & 2.9 & \\
\hline $\begin{array}{l}\text { Magnesium }(\mathrm{Mg}) \\
\text { Sodium }(\mathrm{Na})\end{array}$ & $\begin{array}{l}9.0 \\
16\end{array}$ & (n) & $\begin{array}{l}1.3 \\
4.3\end{array}$ & \\
\hline $\begin{array}{l}\text { Potassium }(\mathrm{K}) \\
\text { Sodium and potassium }(\mathrm{N} a+\mathrm{K})\end{array}$ & $\begin{array}{c}3.3 \\
19\end{array}$ & & 2.4 & 12 \\
\hline Bicarbonate $\left(\mathrm{HCO}_{3}\right)$ & 106 & 34 & 8 & 12 \\
\hline $\begin{array}{l}\text { ulfate }\left(\mathrm{SO}_{4}\right) \\
\text { Chloride }(\mathrm{Cl})\end{array}$ & 14 & $\begin{array}{r}18 \\
7.2\end{array}$ & 1.0 & 12 \\
\hline $\begin{array}{l}\text { Fuoride (F) } \\
\text { Nitrate }\left(\mathrm{NO}_{3}\right)\end{array}$ & $23^{.1}$ & & .00 & 12 \\
\hline Dissol & 170 & 90 & 51 & 10 \\
\hline $\begin{array}{l}\text { Hardness as } \mathrm{CaCO}_{3} \\
\text { Noncarbonate hard }\end{array}$ & $\begin{array}{r}108 \\
58\end{array}$ & ${ }_{20}^{45}$ & ${ }^{13} .0$ & $\begin{array}{l}12 \\
12\end{array}$ \\
\hline Specific conductan & & & & \\
\hline micromhos & $\begin{aligned} 284 \\
7.9\end{aligned}$ & $\begin{array}{l}156 \\
6.6\end{array}$ & ${ }_{5.3}^{64}$ & ${ }_{11}^{11}$ \\
\hline Temperature & 57 & 54 & & 10 \\
\hline
\end{tabular}

lime-soda feldspar. On the whole, however, the water contained in the Wissahickon formation is of good quality. Springs in the Wissahickon formation on occasion become polluted, as in the fall of 1957 when (Philadelphia Inquirer, 1957) 75 springs issuing from the Wissahickon formation in Fairmount Park, Philadelphia, Pa., were posted (closed for use) by the State Department of Health. Pollution of these springs in a highly residential neighborhood probably stems largely from leaky sewers. Twenty-two analyses of water from the Wissahickon formation are summarized in table 9; five analyses that are regarded as representative of the formation are given in table 21 .

TABLE 9.-Summary of chemical analyses of 22 samples of ground water from the Wissahickon formation

[Concentrations in parts per million]

\begin{tabular}{|c|c|c|c|c|}
\hline & Maximum & Median & Minimum & Analyses \\
\hline $\begin{array}{l}\text { Silica }\left(\mathrm{SiO}_{2}\right) \\
\text { Iron (Fe) total }\end{array}$ & 87 & 20 & 7.3 & \\
\hline $\begin{array}{l}\text { Iron (Fe), } \\
\text { Calcium (Ca) }\end{array}$ & 26.7 & $\begin{array}{l}1.0 \\
9.0\end{array}$ & & \\
\hline $\begin{array}{l}\text { Magnesium (Mg) } \\
\text { Sodium (Na) }\end{array}$ & 2.3 & $\begin{array}{l}4.1 \\
5.7\end{array}$ & $\begin{array}{l}1.7 \\
2.2\end{array}$ & \\
\hline Potassium (K) & 2.8 & 1.8 & .7 & \\
\hline $\begin{array}{l}\text { Bicarbonate }\left(\mathrm{HCO}_{3}\right) \\
\text { Sulfate }\left(\mathrm{SO}_{4}\right.\end{array}$ & $\begin{array}{l}70 \\
60\end{array}$ & 32 & 8 & $\begin{array}{l}22 \\
22\end{array}$ \\
\hline $\begin{array}{l}\text { Sulfate }\left(\mathrm{SO}_{4}\right) \\
\text { Chloride }(\mathrm{Cl})_{-}\end{array}$ & ${ }_{40}^{60}$ & $\begin{array}{c}13 \\
5.5\end{array}$ & $\begin{array}{l}1.6 \\
1.8\end{array}$ & \\
\hline $\begin{array}{l}\text { Fluoride }(\mathrm{F}) \\
\text { Nitrate }\end{array}$ & $34^{3}$ & .1 & .0 & \\
\hline $\begin{array}{l}\mathrm{N}_{3} \\
\mathrm{~N} \text { solids. }\end{array}$ & $\begin{array}{l}549 \\
246\end{array}$ & 77.0 & $40^{\circ}$ & \\
\hline Total hardness as $\mathrm{CaCO}_{3}$ & 102 & 45 & 17 & \\
\hline $\begin{array}{l}\text { Noncarbonate nara } \\
\text { Specific conductane }\end{array}$ & & & & \\
\hline pH $\quad$ micromhos at $25^{\circ} \mathrm{C}$ & $\begin{array}{l}384 \\
6.9\end{array}$ & $\begin{array}{c}176 \\
6.1\end{array}$ & $\begin{array}{r}76.3 \\
5.2\end{array}$ & 13 \\
\hline
\end{tabular}

Water samples from four wells in diabase, all near Quakertown, $\mathrm{Pa}$., had from 66 to $398 \mathrm{ppm}$ of dissolved solids, 32 to $272 \mathrm{ppm}$ of hardness as $\mathrm{CaCO}_{3}, 18$ to 31 ppm of silica, 6.3 to $169 \mathrm{ppm}$ of sulfate, 2.2 to $12 \mathrm{ppm}$ of chloride, and 0.18 to $1.4 \mathrm{ppm}$ of iron. Three of these samples are calcium and magnesium bicarbonate waters, one (sample 23 of table 21) contains considerable sulfate. The hardness of this sample would not be removed by heating.
The analyses of two samples of water from the Chickies quartzite are given in table 21. These samples are soft to moderately hard water. One contains $1.6 \mathrm{ppm}$ of iron, the other $25 \mathrm{ppm}$ of nitrate; both concentrations are excessive for some purposes although the water is suitable for other uses without treatment.

Hall (1934) gives four analyses of water from serpentine rock in the Delaware River basin. These waters had from 23 to $40 \mathrm{ppm}$ of silica, 2.1 to $62 \mathrm{ppm}$ of calcium, 17 to $76 \mathrm{ppm}$ of magnesium, 3.2 to $50 \mathrm{ppm}$ of sulfate, 2.4 to $30 \mathrm{ppm}$ of chloride, and 111 to $333 \mathrm{ppm}$ of dissolved solids. Total hardness ranged from 84 to $317 \mathrm{ppm}$. Most ground water contains more calcium than magnesium, but in three of the four samples analyzed the magnesium concentration was far greater than that of the calcium, the reason being that serpentine consists mostly of magnesium silicate minerals. One sample had $5.4 \mathrm{ppm}$ of iron.

\section{CARBONATE ROCKS}

The carbonate rocks, as herein defined, consist of the following types: (1) limestone (calcium carbonate); (2) dolomite (calcium magnesium carbonate); (3) rocks intermediate in composition between limestone and dolomite, sometimes called magnesian limestones; (4) rocks intermediate between limestone or dolomite and other types, in which the carbonate content is substantial; and (5) marble, a metamorphic crystalline carbonate rock which resembles the noncrystalline carbonate rocks in its water-bearing properties.

The carbonate rocks comprise several formations of Paleozoic age and one formation of Precambrian age (table 3 and plate 8). As shown on plate 5 and discussed in the following paragraph, these formations have been grouped as follows: (1) Franklin limestone (Precambrian age); (2) Cockeysville marble (part of the Glenarm series of early Paleozoic (?) age); (3) carbonate rocks of Cambrian and Ordovician age; and (4) carbonate rocks of Silurian and Devonian age.

\section{FRANKLIN LIMESTONE}

The Franklin limestone, one of the oldest rocks in the region (table 3), typically is a white or gray coarsegrained to locally fine-grained marble or dolomitic marble which in places contains considerable amounts of graphite and many other minerals. The Franklin limestone is most abundant just east of the Delaware River basin in the New Jersey Highlands of the New England province, but it occurs also at scattered localities throughout the New England province in the basin and in small areas in the Piedmont. The marble is associated with other types of metamorphic rocks of Precambrian age. 
COCKEYSVILLE MARBLE

The Cockeysville marble is a massive medium- to coarse-grained sugary marble which in places grades into impure schistose marble and limy mica schist. It underlies several small valleys in the southwestern part of the Piedmont Upland, where it characteristically is covered by a thick residual deposit of clay.

The Cockeysville marble overlies the Setters formation and is overlain by the Wissahickon formation. All three formations are part of the Glenarm series whose age is now believed to be early Paleozoic (?). The Cockeysville probably is a more highly metamorphosed equivalent of part of the carbonate rocks of Cambrian and Ordovician age to the north (Watson, 1957, p. 158).

CARBONATE ROCKS OF CAMBRIAN AND ORDOVICIAN AGE

The thickest and most extensive unit composed of carbonate rocks comprises several formations of Cambrian and Ordovician age which are grouped herein because of their general hydrologic similarity and because of the uncertainty of their correlation from one area to another. The formations are listed in table 3 and plate 8 and are described briefly in table 3 .

These carbonate rocks crop out chiefly in the southern (lowland) belt of the Great Valley, but they occur also in the Chester Valley in the Piedmont Upland, in small areas in the Triassic Lowland, and in several long narrow valleys in the New England Upland (pls. 1, 5).

Typically, these Cambrian and Ordovician carbonate rocks consist of a thick sequence of limestone, shale, and slate, and, in the southern part of the Piedmont, some mica schist and phyllite. The limestone and dolomite weather to a thick residual deposit of clay and silt and form lowlands having only a few outcrops; the zones containing noncarbonate rock types form low ridges and hills.

The total thickness of the carbonate rocks of Cambrian and Ordovician age varies widely throughout the basin owing to the intense folding and faulting of the beds. The total stratigraphic thickness of the unit probably exceeds 2,500 feet and may be very much more.

CARBONATE ROCKS OF SILURIAN AND DEVONIAN AGE

The carbonate rocks of Silurian and Devonian age comprise several relatively thin formations which are described briefly in table 3. In ascending order they are the Bossardsville, Decker, Rondout, Manlius, Coeymans, New Scotland, Becraft, Port Ewen, and Onondaga limestones. The formations below the Onondaga limestone crop out in a narrow belt across the Valley and Ridge province a few miles north of the Blue Mountain ridge. The Onondaga is separated from the other formations by the Esopus shale and the Oriskany sandstone and forms a similar narrow outcrop belt. The beds dip steeply to the north and are within reach of wells in only a small area in and near the outcrops.

For the most part, the sequence consists of light-gray to nearly black limestone and dolomitic limestone, and smaller amounts of limy sandstone and shale. Excluding the Onondaga limestone the totäl thickness of the beds probably does not exceed 800 feet within the basin, and in places is much less. The Onondaga limestone reaches a maximum thickness of about 250 feet within the basin.

\section{HYDROLOGIC PROPERTIES OF THE CARBONATE ROCKS}

The carbonate rocks differ from the other consolidated rocks in having a significant number of solutionally enlarged openings. Water percolating downward from the soil contains small amounts of dissolved carbon dioxide and organic acids which make a weak acid capable of dissolving carbonate rocks. Solution commonly develops along pre-existing fractures or root cavities and enlarges them to form a network of more or less interconnected channels. Some such channels become enlarged to considerable size to form caverns; in time a limestone may become honeycombed with caverns and the land surface pitted with sink holes. Part of the drainage is on the land surface and the rest takes place through these underground solution channels.

The distribution of solution openings in most carbonate rocks is extremely irregular and usually is difficult if not impossible to predict in advance of drilling. In some of these rocks, particularly those that are sandy or shaly and contain less calcium carbonate, solution openings may be almost absent. In such rocks all the water may occur in ordinary fracture openings similar to those in unweathered crystalline rocks. Where the fractures are tightly closed, as in some of the Jacksonburg limestone, little or no water may be yielded to wells. In the Delaware River basin the most abundant fracture and solution openings are between depths of about 50 and 300 feet, although some wells have penetrated large openings at depths of more than 1,000 feet. Openings also seem to be more abundant in the vicinity of surface streams.

Overlying the fresh carbonate rocks at most places is a weathered zone, commonly as much as 50 feet thick, composed of residual clay, silt, and some sand. Owing to its considerable clay content, this material generally has rather low permeability and specific yield, and it does not ordinarily yield much water to wells. However, at some localities, such as in the outcrop of the Cockeysville marble in the Piedmont, where the 
weathered zone averages more than 80 feet in thickness, the few available data suggest that the yields from the weathered material may exceed those from the underlying fresh rock where the fresh rock contains relatively few solution openings (Rasmussen, Slaughter, Hulme, 1957, p. 102).

Ground water in the carbonate rocks occurs under unconfined to almost completely confined conditions. Unconfined or semiconfined conditions prevail in the weathered zone and in the immediately underlying fractured rock. The deeper fractures and solution channels contain semiconfined to confined water and may, in some places, transmit water many miles from intake areas to discharge areas.

Solution channels usually are more abundant in valleys than in hills and are most common near streams; at many places surface drainage is largely controlled by the distribution of the subsurface openings. Stream valleys and other low areas therefore are favorable sites for wells.

In areas underlain by carbonate rocks streamflow is unusually steady and includes a high proportion of base flow-chiefly ground-water discharge (p. 21). Water budgets are particularly difficult to estimate for drainage basins in carbonate-rock terrane because much of the water that moves through the networks of solution channels may either enter or leave drainage basins unseen and unmeasured through underground channels.

Detailed data on hydraulic coefficients of carbonaterock aquifers of this region are lacking. From observed behavior of pumped wells tapping the artesian zone and the effects of the pumping on adjacent wells, however, it may be concluded that a decline of artesian pressure, as an effect of pumping, generally is transmitted rapidly to some distant points. but seldom is transmitted equally in all directions. In fact, nearby wells may tap different systems of rock openings and then the pumping of one well will not affect the water level in the adjacent well.

The transmissibility of many of the carbonate-rock aquifers appears to be high. This conclusion is indicated by reported yields of several hundred gallons per minute with pumping drawdowns of less than 20 feet indicate high transmissibility of these rocks. Small yields with large drawdowns are not uncommon, however, which suggests great variability in the aquifers. In the fresh rock, coefficients of storage probably are about 0.0001-0.001 (Barksdale and others, 1958); in the weathered zone near the land surface, where watertable conditions prevail, the storage coefficients may be about $0.01-0.10$.

Although successful wells in the carbonate rocks yield larger supplies than wells in any other type of consolidated-rock aquifers, unsuccessful wells, or wells having disappointingly low yields, are not uncommon. In some areas, particularly where noncarbonate rock types are abundant among the carbonate rocks, yields of wells average less than $25 \mathrm{gpm}$, and the drilling of two or more test wells may be required to obtain a successful supply well. At other localities, especially in the stream valleys, although test wells still may be needed, well yields exceeding $500 \mathrm{gpm}$, have been obtained, and yields of as much as $1,500 \mathrm{gpm}$ are reported.

In the Pennsylvania part of the Delaware River basin, reported yields of 127 wells in carbonate rocks range from 4 to about $1,500 \mathrm{gpm}$ and average nearly 200 gpm. Modern drilled wells 300-500 feet deep in the relatively pure carbonate rocks may be expected to yield about $50-500 \mathrm{gpm}$, but wells in formations that contain considerable amounts of noncarbonate minerals, such as the Jacksonburg limestone, are generally incapable of producing more than domestic or smallscale farm supplies.

CHEMICAL CHARACTER OF GROUND WATER FROM CARBONATE ROCKS

Rainwater containing dissolved carbon dioxide and organic acids is slightly acid; therefore it is an excellent solvent for limestone and other carbonate rocks. Consequently, ground water from the carbonate rocks in the Delaware River basin characteristically is moderately mineralized and hard. The chief mineral constituents are calcium and magnesium bicarbonates. Ground water from carbonate rocks in the Delaware River basin usually is slightly alkaline, low in iron, and of excellent quality except for its hardness. Table 10 summarizes analyses of 60 samples of water from carbonate rocks in Pennsylvania. These include many of the 41 analyses for southeastern Pennsylvania discussed by Hall $(1934$, p. 42 ) and lead to much the same conclusions. Hall found that only 2 of his 41 samples contained more than $1 \mathrm{ppm}$ of iron and more than half contained less than $0.1 \mathrm{ppm}$ of iron. Additional

TABLE 10.-Summary of chemical analyses of 60 samples of ground water from carbonate rocks in Pennsylvania [Concentrations in parts per million]

\begin{tabular}{|c|c|c|c|c|}
\hline & Maximum & Median & Minimum & Analyses \\
\hline 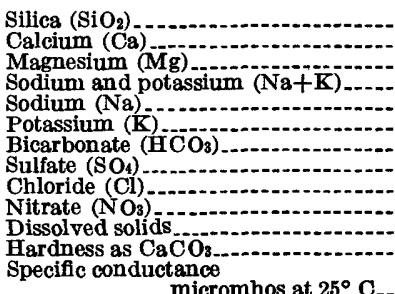 & $\begin{array}{c}33 \\
107 \\
52 \\
29 \\
38 \\
7.7 \\
388 \\
120 \\
58 \\
73 \\
609 \\
508\end{array}$ & $\begin{array}{c}13 \\
57 \\
18 \\
6.0 \\
51.7 \\
1.9 \\
186 \\
26 \\
7.5 \\
12 \\
245 \\
201\end{array}$ & $\begin{array}{r}4.7 \\
5.6 \\
2.4 \\
1.9 \\
1.3 \\
4.6 \\
41.3 \\
2.3 \\
1.0 \\
70^{.0} \\
24\end{array}$ & $\begin{array}{l}53 \\
34 \\
35 \\
30 \\
24 \\
24 \\
56 \\
60 \\
58 \\
60 \\
35 \\
56\end{array}$ \\
\hline 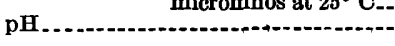 & 8.3 & 7.6 & ${ }_{6.0}^{138}$ & 28 \\
\hline
\end{tabular}


information is presented in table 21 giving analyses from five samples regarded as typical.

The ratio of calcium to magnesium in water from the Conestoga limestone is significantly greater than in water from the Conochocheague limestone, Cockeysville marble, and other carbonate rock formations. Water from the Cockeysville marble (four samples) appears to be less mineralized than water from other carbonate rocks.

\section{CLASTIC ROCKS}

Consolidated clastic rocks consist chiefly of fragments of rocks or minerals that have been derived from the disintegration of older rocks, transported to the site of deposition, and then cemented or otherwise consolidated. In the Delaware River basin these rocks represent both marine and nonmarine depositional environments, but, with a few local exceptions, all the rocks now contain fresh water at depths ordinarily penetrated by wells. The clastic rocks are the most extensive aquifers in the Appalachian Highlands; they underlie most of the Valley and Ridge province and the Triassic Lowland, and all the Appalachian Plateaus.

All the principal types of clastic rocks, ranging in texture from fine-grained shale in which the grains are microscopic in size to conglomerate containing boulders as much as several feet in diameter, are represented in the basin. On the basis of their age, as determined from fossil content and less direct lines of evidence, and their physical character, or lithology, the clastic rocks have been subdivided into numerous geologic formations, which are described briefly in table 3 and listed in part also in plate 8 . The general characteristics of these rocks in each of the three major areas where they occur are discussed in the following pages. More detailed descriptions of the individual formations are given by Hall (1934) and Lohman (1937).

ROCKS OF THE VALLEY AND RIDGE PROVINCE

Except for the southern part of the Great Valley and the two narrow belts several miles north of Blue Mountain, which are underlain by carbonate rocks, all the Valley and Ridge province is underlain by clastic rocks.

The oldest formation is the Martinsburg shale of Ordovician age. It underlies the northern part of the Great Valley and several scattered areas farther south and is an intensely crumpled sequence of beds of shale, slate, and sandstone.

Lying on the eroded surface of the Martinsburg shale is the Shawangunk conglomerate of Silurian age, which dips moderately to steeply northward and forms the Blue Mountain ridge. In Pennsylvania all beds equivalent to the Shawangunk conglomerate formerly were assigned to the Tuscarora sandstone and at least part of the overlying Clinton formation. More recently,
Gray and others (1960) assigned these beds to the Shawangunk formation in the Delaware River region, and this usage is adopted in this report.

From the Shawangunk conglomerate upward, the formations of Silurian to Pennsylvanian age are folded into a series of anticlines and synclines and are cut by numerous faults. A large volume of the originally deposited material has been removed by erosion since the end of the Paleozoic era (table 3), so that only the roots of the anticlines and synclines remain. The harder beds of sandstone and conglomerate form ridges rising to altitudes of as much as 2,000 feet above sea level; the softer beds of shale and some limestone form the intervening valleys.

The clastic rocks of the Valley and Ridge province include conglomerate, sandstone, siltstone, claystone, shale, and slate which occur in alternating beds or zones of variable thickness and extent. Most of the thicker beds or sequences of beds can be identified over large areas and, with the fossils they contain, form mappable units, or geologic formations. Some formations have a distinctive character and are composed predominantly of one rock type. Most of the thicker formations, however, are more or less heterogeneous and contain numerous alternating layers of different rock types, each having distinctive hydrologic properties. The formations are described briefly in table 3 .

Martinsburg shale.-The most extensive formation in the Valley and Ridge province is the Martinsburg shale, which underlies the northern part of the Great Valley in a belt about 6-13 miles wide extending east-northeast across the basin. It also occurs farther south in several long narrow belts bounded by the carbonate rocks of Cambrian and Ordovician age. The Martinsburg consists largely of gray shale which in many places is metamorphosed slightly to form slate, but it also includes sandstone, particularly in the upper part, and some conglomerate.

In an extensive area between the Delaware and Schuylkill Rivers, thick zones of slate of commercial quality are mined for roofing material, flagstones, and other uses. In the slate the bedding of the original shale has been obscured by metamorphism, and instead, a prominent cleavage, usually at a high angle to the bedding, has been formed (fig. 21).

The most widely accepted value for the maximum thickness of the Martinsburg shale in the basin is about 4,000 feet; however, Behre (1933), using a different interpretation of the geologic structure, estimated a maximum thickness of nearly 12,000 feet.

Although the shale and slate have little or no effective intergranular porosity, small but dependable supplies of water are yielded from fractures in these fine-grained rocks (fig. 21). The sandstone beds in the weathered 


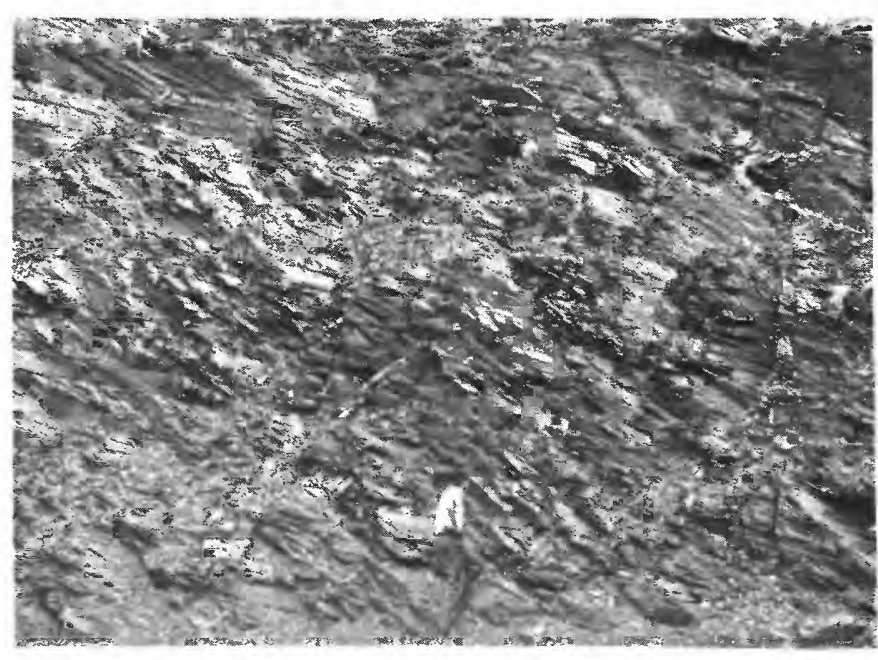

Figure 21.-Martinsburg shale along Delaware River near Delaware Water Gap.

zone contain some water in the intergranular pores where the cementing material has been leached out, and these beds generally are more permeable than the shale and slate. Most water yielded to wells in the Martinsburg shale is from depths of less than 200 feet, and it is seldom profitable to prospect beyond that depth. Most drilled wells yield less than $50 \mathrm{gpm}$, but a few yield $50-250 \mathrm{gpm}$.

The outcrop of the Martinsburg shale is a dissected upland in which the bottoms of the narrow steep-sided stream valleys lie as much as 500 feet below the broad interstream areas. The soils commonly are less than 1 foot thick and have a relatively low infiltration capacity; storage capacity in the underlying rock is small, hence a relatively large proportion of the precipitation runs off quickly as overland flow. In the glaciated area to the northeast, however, a mantle of glacial deposits acts as more permeable intake, and streamflow is less flashy there.

The water from the Martinsburg shale is soft to moderately hard. A summary of the analyses of water from nine wells and springs in Lehigh County, Pa., is presented in table 11 (Rima, written communication, 1957) and two representative analyses are given in table 21.

\begin{tabular}{l} 
TABLE 11.- Summary of chemical analyses of nine samples of \\
ground water from the Martinsburg \\
[Chale \\
[Concentrations in parts per million] \\
\hline \\
\hline Sodium and potassium (Na+K)
\end{tabular}

Conglomerate and sandstone aquifers.-The beds of conglomerate and coarse-grained sandstone are more resistant to erosion than the adjacent shale and thinbedded sandstone, therefore, they form prominent rocky ridges. The thickest and coarsest beds are those in the Shawangunk conglomerate, the Oriskany sandstone, the Pocono formation, and the Pottsville formation (table 3). Although these formation are not tapped by many wells, they very likely are the most permeable bedrock aquifers in the Valley and Ridge province.

Water occurs in the fairly abundant fractures in the brittle quartzitic sandstone and conglomerate and in the intergranular voids in the rocks of the weathered zone where the cementing material has been dissolved. Less permeable beds of sandstone or shale locally confine water, and flowing wells have been developed a.t several localities.

Data on hydraulic coefficients of the conglomerate and sandstone aquifers are not available, but the physical characteristics of these rocks and the behavior of wells tapping them indicate that modern drilled wells more than 100 feet deep might be expected to yield about $50-300 \mathrm{gpm}$. Lohman (1937) reported that in Schuylkill County, Pa., several public-supply wells ranging in depth from 350 to 1,000 feet in the Pottsville formation yielded $65 \mathrm{gpm}$ to more than $125 \mathrm{gpm}$. However, he reported also that several deep wells in that area, had been unsuccessful owing to the absence of permeable fractures in the rock penetrated.

Because they are firmly cemented and have a very high content of quartz, the fresh conglomerate and sandstone are difficult and costly to drill. Moreover, the yields of wells in these rocks may not increase with depth. There is always a risk involved in drilling for water in these rocks, and the chance of getting large supplies decreases as the depth increases.

Interbedded sandstone and shale aquifers. - Several formations in the Valley and Ridge province are not composed predominantly of one rock type. Instead they consist of alternating layers or coarse- to finegrained sandstone, shale, siltstone, claystone, and some conglomerate. In order of decreasing age these formations include: (1) the Bloomsburg red beds-a sequence of red and green shale, sandstone, and some conglomerate which is largely of nonmarine origin; (2) the Mahantango formation of Willard (1935) - mostly beds of gray flaggy sandstone and shale of marine origin; (3) the Portage group (as used in Pennsylvania)several formations consisting of thin-bedded to thickbedded sandstone and sandy shale of marine origin which form broad ridges having moderate relief; (4) the Catskill formation - a thick sequence of red, brown, gray, and green somewhat lenticular beds of sandstone, shale, and conglomerate of nonmarine origin which 
also underlies nearly all the Appalachian Plateaus province; (5) the Mauch Chunk formation consisting of red and green shale and sandstone with some conglomerate in the upper part; and (6) the Allegheny formation, a coal-bearing sequence containing irregular beds that range from shale and fire clay to coarsegrained sandstone and conglomerate.

It is risky to generalize about the hydrologic properties of such a heterogeneous class of rocks. However, the beds of sandstone generally, seem to be more permeable than the beds of shale. In weathered sandstone water occurs in intergranular pores as well as in fractures, but water in the shale is contained almost entirely in fractures, many of which are along the bedding planes. Artesian conditions, which are common, are caused by dipping beds of quite different permeability. Water-table conditions generally occur in the weathered rock near the land surface.

Reported yields of wells in the interbedded sandstone and conglomerate aquifers have a great range. Some beds of shale yield only a few gallons per minute to wells, whereas wells tapping some beds of coarsegrained sandstone yield more than $150 \mathrm{gpm}$, and several deep wells are reported to yield more than 300 gpm.

Because it underlies valleys that contain important centers of population, the Mauch Chunk formation (fig. 22) is a particularly important source of water supplies, even though much of the formation is composed of shale. It receives ample recharge from adjacent ridges, owing to its low topographic position. Reported yields of 100 wells in the Mauch Chunk range from less than 1 to $375 \mathrm{gpm}$ and average about $50 \mathrm{gpm}$. The average yield, which is affected by the values for many small domestic wells, is too low to be representative of yields that might be expected from deeply drilled wells used for municipal and industrial supply.

The Mauch Chunk formation is the most important source of ground-water supply in Schuykill and Carbon Counties, Pa. Lohman (1937) reported that many municipal and industrial wells there yielded more than $100 \mathrm{gpm}$, and that a well 452 feet deep in Schuylkill County yielded $350 \mathrm{gpm}$ with a drawdown of 217 feet-a specific capacity of $1.6 \mathrm{gpm}$ per foot of drawdown. If the drawdown caused by entrance losses in the well is assumed to be small and the aquifer to be artesian, the coefficient of transmissibility may be estimated at 3,000-4,000 gpd per foot.

Because of its location in the coal basins, the Allegheny formation is a special case. Coal-mining operations have extensively dewatered parts of the formation and have made the water in many places acidic and high in sulfate content; this water is unsuitable for

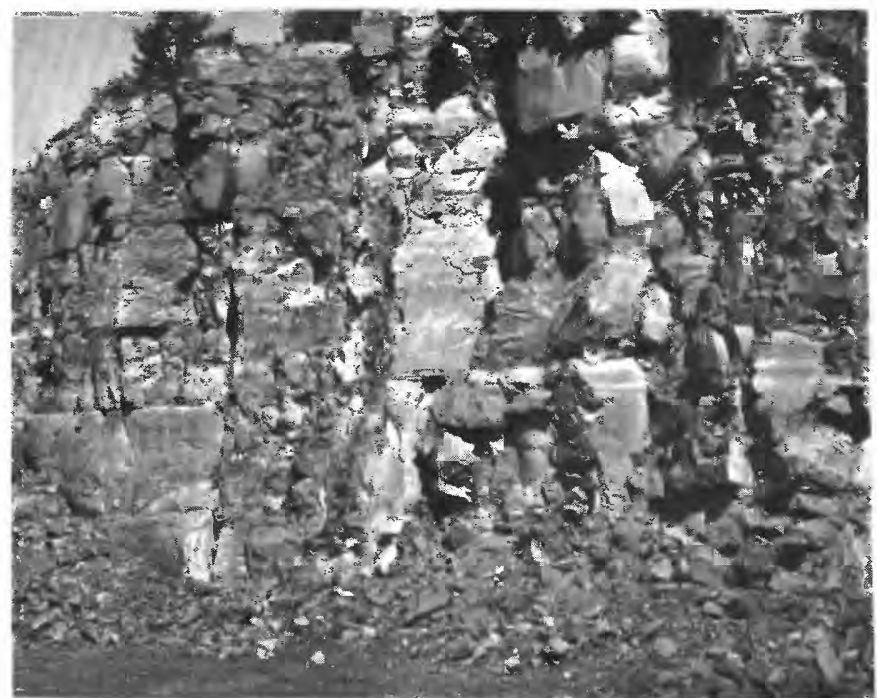

Figure 22.-Mauch Chunk formation near White Haven, Pa.

most uses, but usable supplies of ground water may be obtained in the Allegheny formation in areas remote from mines.

Shale aquifers.-Besides the Martinsburg shale discussed earlier, three formations in the Valley and Ridge province are composed predominantly of shale, siltstone, or claystone: (1) the Wills Creek, (2) the Esopus, and (3) the Marcellus shales.

The Wills Creek shale, locally called the Poxono Island shale of White (1881), occurs in a narrow band just north of Blue Mountain where it is largely covered by glacial deposits and is not tapped by many wells. Little is known about its water-bearing characteristics.

The Esopus shale and the Marcellus shale are separated by the Onondaga limestone. Both are largely dark sandy shale or siltstone (fig. 4) and both contain hard slaty beds. These rocks are relatively impermeable, and the small amount of water they contain occurs almost entirely in fractures. In many localities the fractures are so tightly closed, or so scarce, that little or no water is yielded to wells. However, some wells in the more highly fractured rock yield as much as $25 \mathrm{gpm}$.

rocks of the appalachian plateaus province

The Appalachian Plateaus province, which occupies a third of the total area of the Delaware River basin, is underlain almost entirely by a sequence of predominantly nonmarine sandstone, shale, and some conglomerate. This sequence, which in places is more than 6,000 feet thick, is called the Catskill formation. The Catskill formation has been divided into several smaller units which are listed in plate 8. Toward the west and southwest the nonmarine beds intertongue with marine formations of the Portage group (as used 
in Pennsylvania) and the upper part of the Hamilton group. The younger Pocono formation crops out on the west and southwest flanks of the plateaus and is believed by some geologists to cover a fairly large part of the plateaus. However, the question as to the presence or absence of the Pocono formation on the plateaus is of little or no hydrologic importance because of the similarity of the Pocono to the immediately underlying part of the Catskill formation.

In contrast to the folded beds in the Valley and Ridge province, the beds underlying most of the Appalachian Plateaus province are either nearly flat lying or very gently folded. They consist largely of red, brown, gray, and green sandstone, shale, and some conglomerate. Beds of homogeneous material range in thickness from a fraction of an inch to several tens of feet. The following log of a test boring typifies the character of the beds.

Well Sv114, New York City Board of Water Supply, test boring for shaft on line of East Delaware Tunnel, near Neversink River, about 4 miles southeast of Willowemoc, Sullivan County; altitude of land surface 1,612 feet; compiled from driller's log:

\begin{tabular}{|c|c|c|}
\hline & $\begin{array}{c}\text { Thickness } \\
\text { (feet) }\end{array}$ & $\begin{array}{l}\text { Depth } \\
\text { (feet) }\end{array}$ \\
\hline Till ....... & 13 & 13 \\
\hline Shale, red. & 5 & 18 \\
\hline Sandstone, red & 2 & 20 \\
\hline Sandstone, gray & 25 & 45 \\
\hline Conglomerate, gray, white quartz pebbles.-- & 5 & 50 \\
\hline Sandstone, gray & 15 & 65 \\
\hline Shale, gray & 1 & 66 \\
\hline Sandstone gray & 4 & 70 \\
\hline Shale, red and gray & 2 & 72 \\
\hline Sandstone, gray & 62 & 134 \\
\hline Shale, red and gray & 3 & 137 \\
\hline Sandstone, gray & 27 & 164 \\
\hline Shale, sandy, gray & 8 & 172 \\
\hline Sandstone, gray $\ldots$ & 9 & 181 \\
\hline Shale, gray & 2 & 183 \\
\hline Sandstone, gray & 13 & 196 \\
\hline Shale, red & 22 & 218 \\
\hline Sandstone, gray, trace of coal at $237 \mathrm{ft}_{\ldots} \ldots$ & 29 & 247 \\
\hline red, gray, some sandy shale $\ldots$ & 61 & 308 \\
\hline Sandstone, gray, and red, shale streaks $\ldots$ & 23 & 331 \\
\hline Shale, sandy, red & 12 & 343 \\
\hline Sandstone, gray & 20 & 363 \\
\hline $\begin{array}{l}\text { Conglomerate, gray, some sandstone and } \\
\text { shale }\end{array}$ & 61 & 424 \\
\hline Sandstone, gray, some shale, in thin strata & 162 & 586 \\
\hline Shale, sandy, red & 7 & 593 \\
\hline Sandstone, gray, some shale & 73 & 666 \\
\hline Shale, sandy, red $\ldots$ & 29 & 695 \\
\hline $\begin{array}{l}\text { Sandstone, gray, vein of calcite, } 0.4 \mathrm{ft} \text { thick, } \\
\text { at } 731 \mathrm{ft}\end{array}$ & 43 & 738 \\
\hline Shale, sandy, red and green & $\mathbf{5}$ & 743 \\
\hline
\end{tabular}

Most of the beds are cut by comparatively smooth, regular planes of fracture (joints) which commonly consist of three nearly perpendicular sets, one of which is parallel to the bedding. Joints at oblique angles to the bedding are not uncommon, however, These joints greatly facilitated "quarrying" of the rock by the glacial ice that scoured most of the area several times during the Pleistocene epoch. Tablelike surfaces, bounded by nearly vertical cliffs as much as several tens of feet in height, have resulted from such quarrying action at many places.

Most of the consolidated rocks in the plateaus are covered by glacial deposits of varying thickness. These consist largely of till but include scattered bodies of outwash, some of which are of considerable size (pl. 7). Where permeable, these deposits, especially the outwash, absorb much of the precipitation and transmit some of it to the underlying bedrock; however, a large part of the till is relatively impermeable and does not allow much recharge to the underlying hard-rock aquifers. The exposures of bedrock, which probably cover less than 10 percent of the area of the plateaus, are characterized by numerous outcrops of rock and generally thin stony soils; these conditions result in a rather low infiltration capacity and a high direct runoff.

The beds in the Catskill formation underlying, the plateaus are moderately good to poor aquifers. Large variations in yield of wells occur within short distances, both vertically and horizontally. For example, dry holes as much as 400 feet deep have been reported in areas where successful wells are common. Also, much deeper wells have been abandoned owing to great depths to water, to insufficient yields, or to poor chemical quality of water. In general, the beds of sandstone are more permeable than the beds of shale; however, some of the sandstone is so completely cemented and lacking in fractures that it yields little or no water.

Exceptional yields are obtainable in scattered large fracture systems, generally along faults or unusually large joints. Fluhr (1953) reported that flows of as much as $600 \mathrm{gpm}$ occurred in such zones at depths of as much as 1,700 feet below the land surface during the construction of the New York City water-supply tunnels. Elsewhere the tunnels were almost completely dry.

Records of 371 wells in the Appalachian Plateaus in the Delaware River basin show a range in depth from 5 to 960 feet; most wells are in the depth range of 100-300 feet. Reported water levels range from 11 feet above the land surface-flowing artesian wells are not uncommon-to 540 feet below. Yields of wells range from 0 to $600 \mathrm{gpm}$ and average more than 25 $\mathrm{gpm}$; specific capacities range from less than 0.2 to about $4 \mathrm{gpm}$ per $\mathrm{ft}$ of drawdown. Springs are numerous and are used as sources of supply at many places.

The Catskill formation yields water of excellent quality, which is used for domestic, industrial, and 
TABLE 12.-Summary of chemical analyses of 18 samples of ground water from the Catskill formation [Concentrations in parts per million]

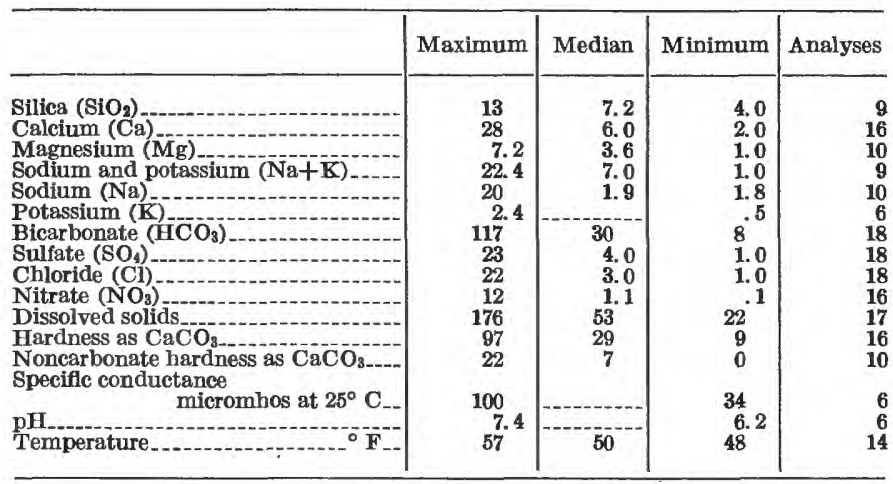

municipal supplies, generally without treatment. The water ranges from very soft to moderately hard and has low concentrations of dissolved mineral matter. It is commonly low in iron, although locally the concentrations of iron are high. A few deep wells in Wayne County, Pa., give water containing small quantities of hydrogen sulfide. Table 12, prepared from data supplied by D. R. Rima (written communications, 1957, 1958), summarizes chemical analyses of 18 samples of ground water from the Catskill formation; two representative analyses are given in table 21 .

ROCKS OF THE TRIASSIC LOWLAND

The Triassic Lowland, a broad belt about 9-32 miles wide which extends across the southern part of the Appalachian Highlands, is underlain chiefly by clastic rocks belonging to the Newark group of Triassic age (table 3). The clastic rocks are intruded by sills and dikes of diabase, and east of the basin in New Jersey they contain also several flows of basalt. The basalt and diabase are discussed in the section on crystalline rocks.

Most of the sedimentary rocks are of nonmarine origin and are believed to have been deposited under drylands conditions in a northeast-trending basin having a somewhat greater extent than the present Triassic Lowland (Johnson and McLaughlin, 1957, p. 36). The rocks are a thick sequence of shale, sandstone, argillite, and conglomerate. They lie on the eroded surface of much older rocks of Precambrian and Paleozoic age (pl. 9), from which the Triassic rocks were in large part derived.

The beds are tilted to the northwest in most of the region, although locally they dip in other directions where they are warped into broad folds, particularly in the vicinity of the masses of diabase. At most places the dips are less than 20 degrees, although adjacent to some of the large faults along the northwest border of the lowland, dips are as much as 50 degrees. The maximum thickness of the Newark group in the Delaware River basin is about 12,000 feet along the Delaware River (Johnson and McLaughlin, 1957, p. 32).

The Newark group has been divided into three formations, each having more of less distinctive types of rock (Kümmel, 1897). From oldest to youngest, they are: (1) the Stockton formation, which is characterized by prominent beds of arkose, a light sandstone high in feldspar content; (2) the Lockatong formation, which is chiefly argillite and hard shale; and (3) the Brunswick formation, which is a thick, monotonous sequence of red shale and sandstone. A fourth unit, commonly grouped with the Brunswick formation, consists of lenticular beds of conglomerate and coarsegrained sandstone. Unlike most of the formations of the Delaware River basin, these formations are not clearly defined time units but instead represent changing conditions of deposition both in place and in time; they are, in fact, regarded by McLaughlin as lithofacies rather than as formations (Greenman, 1955). In general, however, the Stockton formation is the oldest unit and the Brunswick is the youngest. The Lockatong formation represents a swamp and lake deposit near the center of the ancient Triassic basin, and it intertongues with the lower part of the Brunswick formation over a wide area, largely in Bucks County, Pa.

Plate 5 shows the general extent of the formations but does not show the complex local intertonguing of the beds that is described and mapped by McLaughlin (Johnson and McLaughlin, 1957; Greenman, 1955, pl. 1).

Stockton formation.-In the Delaware River basin the Stockton formation crops out principally in two belts: (1) a southern belt along the south margin of the Triassic Lowland; and (2) a northern belt in the central part of the lowland. Outside the basin in New Jersey the Stockton occurs in two smaller areas: (1) between the two principal belts just east of the basin; and (2) along the Hudson River at the eastern margin of the Triassic Lowland (pl. 5). The Stockton formation overlies the eroded edges of rocks of Precambrian to Ordovician age and is in turn overlain by the Lockatong formation, or by the Brunswick formation where the Lockatong is absent. In the Delaware River basin the thickness of the Stockton ranges from about 1,000 to 3,000 feet in the southern belt of exposures and reaches a maximum thickness of about 5,000 feet in the northern belt, along the Delaware River (Johnson and McLaughlin, 1957).

The most distinctive rock type in the Stockton formation is an arkose, a light-gray or light-yellow medium- to coarse-grained sandstone that contains much feldspar and some mica (fig. 23). Other types 
include conglomerate, fine- to medium-grained red or brown quartzose sandstone, siltstone, and soft red shale similar to that in the Brunswick formation. Arkose and conglomerate are more abundant in the lower part of the formation than in the upper part and also are more abundant in the southern belt of exposures than in the northern belt. Individual beds are not extensive, although some of the thicker zones or sequences of beds extend for many miles. The rock materials appear to have been derived in large part from the crystalline rocks to the south and apparently were deposited in a nonmarine environment (Johnson and McLaughlin, 1957, p. 40).

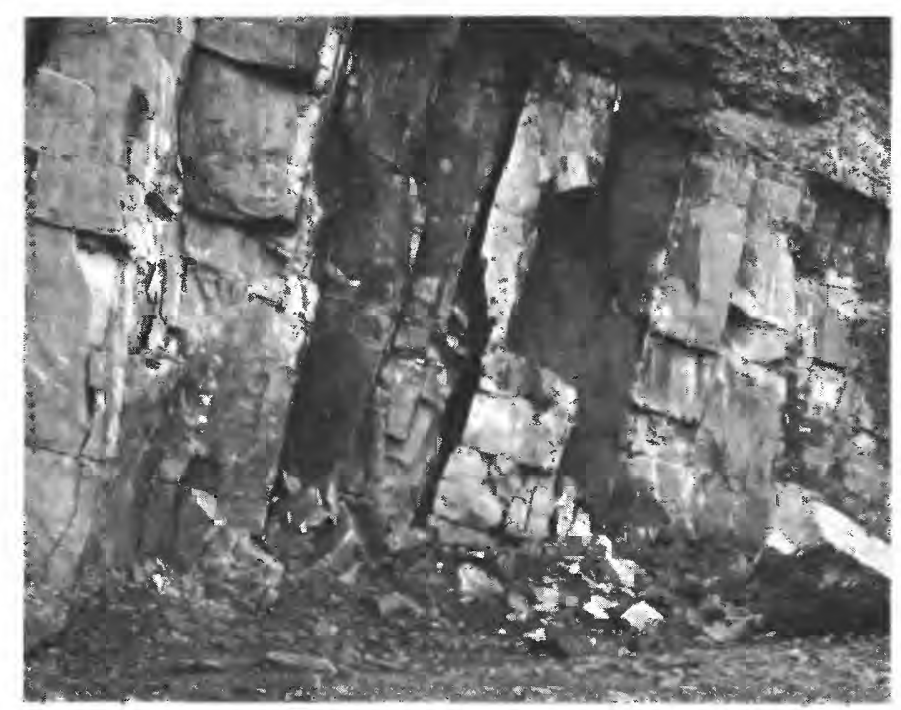

FiGURE 23.-Stockton formation exposed along west bank of Delaware River near Lumberville, $\mathbf{P a}$.

The beds of arkose and conglomerate form low ridges; the softer beds of red shale and fine-grained sandstone form the intervening valleys. The soils formed on these rocks are nearly as variable as the rocks themselves; in general the soils are thickest and most permeable on the coarse-grained arkose and conglomerate and thinnest on the red shale, where, in places, they are less than an inch to only a few inches thick.

The Stockton formation is one of the most productive of the consolidated-rock aquifers in the Delaware River basin and has perhaps the highest average permeability of any of the clastic rock formations. Most of the water in the Stockton occurs in the weathered and fractured rock within about 500 feet of the land surface (Greenman, 1955, p. 27). The most permeable beds are composed of fine- to medium, grained sandstone and are most abundant in the upper part of the formation; the coarse-grained arkose and conglomerate are generally less permeable than the finer grained but better sorted sandstone. The least permeable beds are composed of shale. The shale yields all or nearly all its water from fractures, in contrast to the sandstone, arkose, and conglomerate which in the weathered zone yield some of their water from intergranular openings.

The beds of shale and the less permeable zones in the arkose, sandstone, and conglomerate act as confining layers; hence most water in the Stockton formation is semiconfined or confined. Short-term pumping tests have given coefficients of storage of about 0.00001 or 0.00002 , indicative of artesian conditions; probably nowhere does the coefficient exceed about 0.001 (Greenman, 1955, p. 28). However, after long periods of dewatering, the storage coefficient in the materials nearest the land surface locally might approach the specific yield. According to A. I. Johnson (1958), laboratory-determined specific yields of a dozen samples of arkose, conglomerate, sandstone, and sandy siltstone from exposures of the Stockton formation ranged from nearly 0 to 19 percent and averaged about 8 percent. Porosities of these samples ranged from 7 to 30 percent and averaged about 15 percent.

Coefficients of permeability for movement of water parallel to the bedding determined in 10 of the 12 laboratory samples ranged from 0.001 to 0.3 gpd per sq $\mathrm{ft}$ and averaged only 0.04. Permeability coefficients for movement perpendicular to the bedding ranged from 0.001 to 0.2 and average about 0.03 gpd per sq $\mathrm{ft}$ - somewhat less than the average permeability for movement parallel to the bedding. The fact that both these average values are much less than the average permeability of sandstone, arkose, and conglomerate aquifers suggested by well-yield data indicates that most of the water moves toward pumped wells through the fractures in the rock rather than through the intergranular pores. The surprisingly high specific yields for the laboratory samples of weathered rocks suggest that much of the ground-water storage capacity in the aquifers of the Stockton formation is in the pore spaces between grains in the weathered zone near the land surface rather than in the fractures, even though the water moves much more readily through the fractures. As a result, wells may have relatively high initial yields, owing to the high permeability of the fractured zones, but the ultimate or long-term yields may be substantially less, because they are governed by the much lower permeability of the weathered granular materials that supply most of the water withdrawn from storage. During droughts the decreased difference in head between the upper, highly weathered zones and the lower zones also contributes to decreased yields. A more favorable aspect is that the low permeability of the granular materials causes them to retain water in storage for considerable periods.

Reported yields of 180 wells tapping the Stockton formation in the Delaware River basin range from 2 to 
$800 \mathrm{gpd}$ and average about $100 \mathrm{gpm}$. Specific-capacity tests for 23 wells in Bucks County, Pa., showed a range in values from 0.35 to $44 \mathrm{gpm}$ per foot of drawdown and an average of about $6.0 \mathrm{gpm}$ per foot (Greenman, 1955, p. 28).

From all these data it may be concluded that most deep drilled wells of modern design in the Stockton formation should obtain yields in the range of 30 to $300 \mathrm{gpm}$, but that the long-term yields under continuous pumping might be less than the initial yield, depending in part on the availability of recharge. Because of the low coefficients of storage and the relatively high coefficients of permeability of the artesian aquifers, drawdown effects of pumping would extend considerable distances, so that proper spacing of wells to minimize interference is particularly important.

Runoff from the outcrop of the Stockton formation tends to be less flashy than that from the other formations in the Triassic Lowland, owing to the greater permeability of many of the beds and the thicker soils.

Samples of water from the Stockton formation differ markedly in their chemical characteristics. The water commonly has moderate concentrations of dissolved solids, generally less than $400 \mathrm{ppm}$. In the more mineralized samples, sulfate constitutes a large proportion of the anions, probably because of leaching deposits of localized glauberite, $\left(\mathrm{Na}_{2} \mathrm{SO}_{4} \cdot \mathrm{CaSO}_{4}\right)$. Most of the samples tested range from moderately hard to hard. The very hard waters have a large proportion of noncarbonate hardness; rarely is the concentration of iron objectionable. Table 13, compiled from data furnished by Rima (written communications, 1957, 1958), summarizes a group of chemical analyses of ground water from the Stockton formation; analyses of six additional samples regarded as typical are given in table 21.

TABLE 13.-Summary of chemical analyses of 54 samples of ground water from the Stockton formation

[Concentrations in parts per million]

\begin{tabular}{|c|c|c|c|c|}
\hline & Maximum & Median & Minimum & Analyses \\
\hline 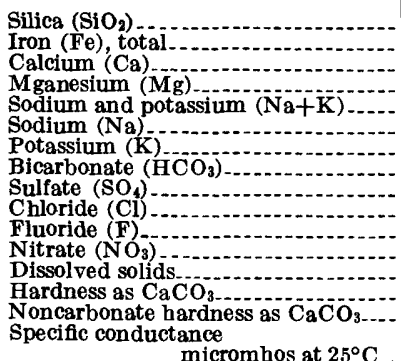 & $\begin{array}{c}33 \\
2.3 \\
233 \\
27 \\
46 \\
37 \\
3.5 \\
258 \\
603 \\
80 \\
1.1 \\
48 \\
1,040 \\
660 \\
562\end{array}$ & $\begin{array}{c}23 \\
3.2 \\
31 \\
11 \\
15 \\
12 \\
1.3 \\
115 \\
36 \\
9.5 \\
7.1 \\
202 \\
132 \\
32\end{array}$ & $\begin{array}{c}8.4 \\
.02 \\
2.5 \\
1.6 \\
.7 \\
8.1 \\
.5 \\
7.5 \\
9.4 \\
1.2 \\
.0 \\
.4 \\
45 \\
18 \\
0\end{array}$ & $\begin{array}{l}46 \\
40 \\
46 \\
46 \\
54 \\
10 \\
10 \\
54 \\
54 \\
54 \\
46 \\
54 \\
46 \\
54 \\
54\end{array}$ \\
\hline pHemperature & $\begin{array}{c}1,230 \\
8.5 \\
58\end{array}$ & $\begin{aligned} 306 \\
7.6 \\
55\end{aligned}$ & $\begin{array}{c}69 \\
5.2 \\
53\end{array}$ & $\begin{array}{l}5 \\
5\end{array}$ \\
\hline
\end{tabular}

- Lockatong formation.-The Lockatong formation overlies the Stockton formation and crops out in three principal belts lying north or northwest of the outcrops of the Stockton in the central and south-central parts of the Triassic Lowland (pl. 5). The Lockatong is absent in most of the lowland northeast of the Delaware River basin and is missing in the western part of the basin. It attains a maximum thickness of more than 3,800 feet in the outcrop along Tohickon Creek and the Delaware River (pl. 5).

The most abundant and distinctive rock type is a thick-bedded dark-gray to black argillite (hard claystone or siltstone). Other types include thin-bedded dark shale, impure limestone, and limy argillite. The upper part of the Lockatong, which grades into the Brunswick formation, includes tonguelike beds of darkred argillite and red shale of the type occurring in the Brunswick. A thin zone at the base of the Lockatong contains beds of arkose like those in the underlying Stockton formation.

The argillite is a dense hard rock and forms prominent ridges where it is interbedded with softer shale, or broad plateaus where the soft rocks are absent. At many places regularly spaced perpendicular fractures break the rock into distinctive rectangular blocks. Most of the Lockatong formation weathers to thin soil composed of yellowish-brown clay loam.

Yields reported for 205 wells in the basin and adjacent New Jersey range from 0.2 to $55 \mathrm{gpm}$ and average about $10 \mathrm{gpm}$; specific capacities reported for 65 wells range from 0.02 to $2.0 \mathrm{gpm}$ per foot of drawdown and average about $0.6 \mathrm{gpm}$ per foot (Barksdale and others, 1958).

Runoff from the outcrop areas of the Lockatong formation probably is extremely flashy because of the low infiltration capacity of the thin rather impermeable soils and the small ground-water storage capacity available to sustain base flow.

The Lockatong formation yields hard water; calcium and magnesium bicarbonates are the principal dissolved minerals. Aralyses of nine samples of water from this formation are summarized in table 14. Analyses of two typical samples are given in table 21 .

TABLE 14.-Summary of chemical analyses of nine samples of ground water from the Lockatong formation

[Concentrations in parts per million]

\begin{tabular}{|c|c|c|c|c|}
\hline & Maximum & Median & Minimum & Analyses \\
\hline 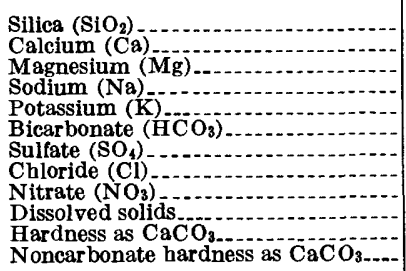 & $\begin{array}{c}28 \\
66 \\
31 \\
22 \\
2.7 \\
283 \\
61 \\
42 \\
16 \\
339 \\
282 \\
82\end{array}$ & $\begin{array}{c}14 \\
47 \\
23 \\
14 \\
1.7 \\
236 \\
37 \\
11 \\
2.1 \\
274 \\
212 \\
44\end{array}$ & \begin{tabular}{c|}
11 \\
28 \\
15 \\
7.0 \\
120 \\
120 \\
3.8 \\
5.5 \\
19 \\
199 \\
132 \\
0
\end{tabular} & $\begin{array}{l}9 \\
9 \\
9 \\
9 \\
9 \\
9 \\
9 \\
9 \\
9\end{array}$ \\
\hline
\end{tabular}


The Lockatong formation contains some of the least permeable rocks in the basin. The fresh argillite has very little intergranular porosity, and fracture openings in this rock are neither large nor abundant. Most of the water occurs under unconfined or semiconfined conditions in the weathered zone near the land surface.

Brunswick formation.- The Brunswick formation is the thickest and most extensive formation in the Triassic Lowland (pl. 5). In the Delaware River basin its outcrop is about equal in area to the combined outcrops of the Stockton and Lockatong formations; in New Jersey outside the basin it underlies most of the Triassic Lowland. Its maximum thickness within the basin probably is about 7,000 feet; outside the basin in New Jersey, where the Brunswick includes beds that are probably equivalent in age to the Lockatong formation and possibly to part of the Stockton formation as well, the total thickness may be greater.

The Brunswick formation consists typically of soft red shale interbedded with smaller amounts of brownishred siltstone and fine-grained sandstone, and green, yellow, gray, and purple shale and argillite. East of the basin, sandstone is more abundant, and beds of conglomerate occur in places. Along the northern border of the Triassic Lowland the fine-grained materials grade into conglomerate and coarse-grained sandstone that probably represent alluvial-fan deposits laid down by torrential streams near the end of Triassic time (Johnson and McLaughlin, 1957). In the vicinity of the Delaware River and to the west in Bucks County, $\mathrm{Pa}$., the lower part of the Brunswick is graditional with the upper part of the Lockatong formation and includes beds of dark argillite interbedded with the typical red shale. Near the intrusive masses of diabase, the soft red shale of the Brunswick formation is altered to hornfels, a hard, dark, finely crystalline rock that closely resembles some argillites.

Because of its great extent and its moderate permeability, the Brunswick formation is one of the most important sources of ground-water supplies in the Appalachian Highlands. A detailed study by Rima (1955) in the Lansdale, $\mathrm{Pa}$., area revealed that the weathered part of the formation, which extends to a maximum depth of about 250 feet, generally contains unconfined water, although the permeability of this zone is low. Below this upper zone and extending to a maximum depth of about 600 feet are one or more artesian or semiartesian zones, each of which generally is less than 20 feet thick. Compared to the water-table zone, these artesian or semiartesian zones either have lower hydraulic head in them or have higher permeability, or both.

The nature of the water-yielding openings in the shale of the Brunswick formation is not well known, but it is believed that very little water is yielded from intergranular pores; most of the drainable water is contained in fractures. Herpers and Barksdale (1951, p. 27) estimated that in the zone within 300 feet of the land surface (the water-table zone), in the Newark N.J., area, the specific yield is about 1 or 2 percent. A decline of the water table of a foot over an area of a square mile therefore would represent a release from storage of about 2-4 million gallons. In the artesian or semiartesian zones the water-bearing openings probably occur as fractures which are widely spaced and have been in part secondarily enlarged by solution (Rima, 1955, p. 11). Most of the solutionally enlarged fractures are vertical or perpendicular to the bedding and constitute only a small part of the total volume of rock.

The upper, water-table zone receives recharge directly from precipitation; the underlying artesian or semiartesian zones are in turn recharged by drainage from the water-table zone. Most wells in the Brunswick formation tap both the water-table and the artesian or semiartesian zones. The long-term yield of a well tapping these rocks is related to the rate at which the water-table zone can supply recharge to the generally more permeable artesian or semiartesian zones beneath; this yield commonly is only a fraction of the short-term yield.

Successful methods have not yet been derived to calculate meaningful hydraulic coefficients from pumping tests in the Brunswick formation, chiefly for two reasons: (1) Present methods of analysis cannot be used where wells tap both water-table and artesian or semiartesian aquifers and derive water in unknown proportions from the two types of sources; (2) present methods of analysis assume isotropic conditions (equal coefficients in all directions), but the size, distribution, and degree of interconnection of the fractures in the Brunswick is not uniform in all directions.

Herpers and Barksdale (1951, p. 31) reported that, in the Newark, N.J., area, water is able to move and hydraulic head is transmitted through the formation much more readily parallel to the strike of the beds (northeast or southwest) than in a transverse direction (northwest or southeast). This fact is of considerable importance in planning a rational spacing of wells to avoid or minimize interference caused by pumping, and also in designing facilities for artificial recharge.

For the reasons given above, reported yields of wells in the Brunswick formation should be interpreted with caution. Reported yields of 164 wells in the Delaware River basin range from 2 to about $400 \mathrm{gpm}$ and average about $90 \mathrm{gpm}$. East of the basin, where the Brunswick contains a higher proportion of coarse- 
grained beds, the average yield of wells is higher; for example, at Ridgewood in Bergen County, N.J., well yields up to $750 \mathrm{gpm}$ are reported. Most deepdrilled wells of modern design in the Brunswick formation should obtain yields in the range of 20 to $200 \mathrm{gpm}$, but the long-term yields might be substantially less than the initial yield-perhaps only one-third as much.

Runoff from the outcrop of the Brunswick formation. is flashy, owing to the low infiltration capacity of the thin, poorly permeable clayey soils and to the low ground-water storage in the zone of natural fluctuation of the water table.

The Brunswick formation yields water that is moderately mineralized and generally ranges from moderately hard to very hard. Much of the water requires softening or treatment to remove iron before it is used for some industrial processes or for laundries. Table 15, prepared from data furnished by Rima (written communications, 1957, 1958) summarizes analyses of 18 samples of ground water from the Brunswick formation. In addition, four typical analyses are given in table 21. Water from the Brunswick formation is a calcium, magnesium bicarbonate, sulfate water. All samples were slightly alkaline, probably because of the limy sandstone and conglomerate associated with this aquifer.

TABLE 15.-Summary of chemical analyses of 18 samples of ground water from the Brunswick formation

[Concentrations in parts per million]

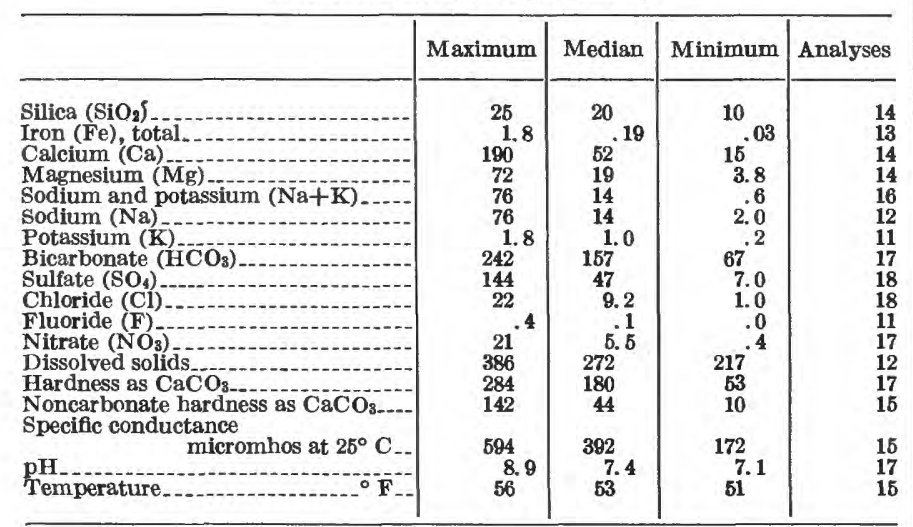

UNCONSOLIDATED SEDIMENTS OF GLACIAL ORIGIN

Continental glaciers covered all the northern part of the Delaware River basin at least three and possibly four times during the last million years. The last ice sheet-that of the Wisconsin stage (table 3)-retreated from the region about 10,000 years ago (Flint, 1957).

The Wisconsin ice sheet and its predecessors-those of the Illinoian and Kansan stages (pl. 7)-removed the soil and loose weathered material, quarried and scraped the underlying fresh rock, modified the pre- existing drainage pattern, deepened some of the stream valleys and filled others with deposits, and left a mantle of unsorted deposits as till or ground moraine over most of the area. Ridges composed of unsorted debris were deposited at the margins of the ice as terminal and recessional moraines, and lateral moraines accumulated along the margins of some of the ice tongues in the valleys. Glacial outwash and other stratified deposits were laid down in the valleys and along the margins of the ice masses by melt-water streams, and finegrained sediments were deposited in lakes and marshes. Southward-flowing melt-water streams deposited outwash in the major valleys far south of the ice margin.

On the basis of their hydrologic properties the glacial sediments of the basin are herein divided into two main categories, unstratified and stratified which are described briefly in the sections following.

UNSTRATIFIED GLACIAL SEDIMENTS

The unstratified sediments, which were deposited directly by the ice, consist of unsorted materials ranging in size from clay to boulders and having low permeability (fig. 24). The most extensive of these deposits is till, which blankets perhaps 90 percent of the glaciated area. Other unstratified sediments are the morainal deposits of various types, which differ from the till chiefly in their greater thickness, their distinctive landform expression as curved or sinuous ridges, and their somewhat greater content of permeable bodies of sand and gravel.

The oldest glacial deposits are of Kansan age, formerly, in this region, called "Jerseyan." These deposits consist largely of scattered boulders south of the Illinoian drift border (pl. 7). Scattered thin deposits of Illinoian age occur south of the Wisconsin drift border, but only a few of the thicker masses, such as the terminal moraines near Allentown, Pa., are shown as early glacial drift on the geologic map (pl. 7). North of the Wisconsin drift border the till and moraines are almost entirely of Wisconsin age; the earlier deposits of Kansan and Illinoian age were largely reworked by the Wisconsin ice and incorporated into the younger deposits.

The till consists of an unsorted mixture ranging in size from microscopic clay particles to boulders many feet in diameter (fig. 24). The character of these materials varies from place to place, depending largely on the nature of the parent rocks. Sand and gravel are abundant where the materials are derived largely from sandstone, but clay predominates where the parent rocks are mostly shale. Limestone is not an abundant constituent of till at most places in the Delaware River basin. 


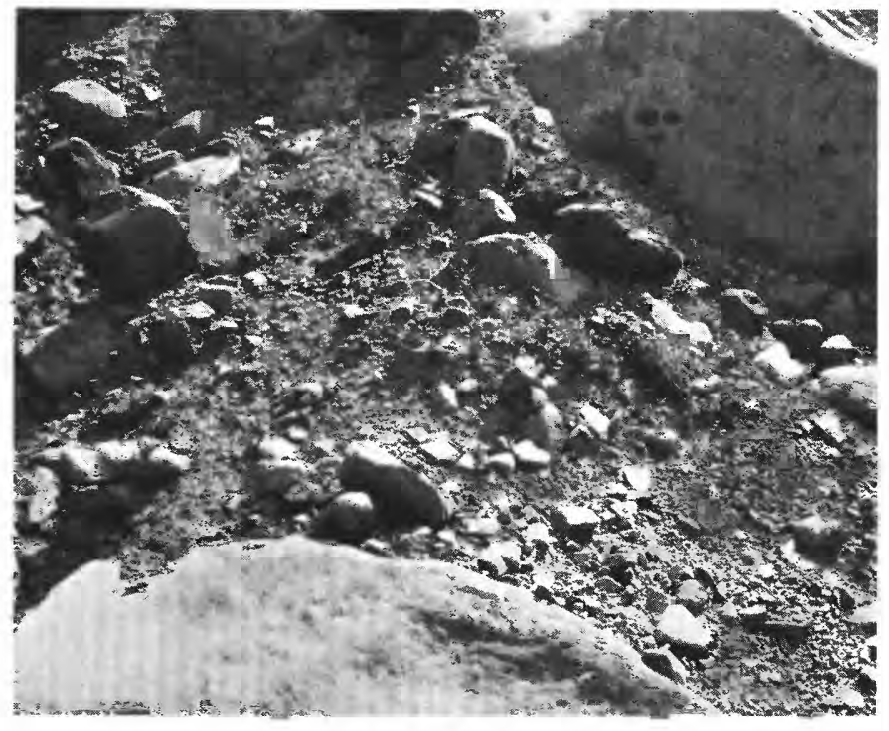

Figure 24.-Bouldery glacial till 2 miles south of Hawley, Pa.

In the broad upland areas the till generally is less than 30 feet thick, but in buried valleys the thickness is greater; Fluhr (1953) reported a thickness of as much as 350 feet in Delaware County, N.Y. In many of the present stream valleys fairly thick masses of till are interbedded with glacial outwash (fig. 25).

The overall permeability of till is very low, owing to the usual moderate to large content of clay and silt and to the fact that smaller particles commonly fill space between larger ones (fig. 24). Direct runoff from most till-covered areas is large because of the low infiltration capacity of the materials. At many places till forms an aquiclude confining water in permeable outwash deposits, with which it is interbedded, or in the underlying bedrock. Much till in the upland area contains bodies of perched water lying above zones rich in clay or dense, almost impermeable bedrock.

Most wells in till yield only a few gallons of water per minute. Rates of inflow into the wells commonly are even less, so that dug wells having large storage capacity are used. Such wells can be pumped for short periods at considerably greater rates than they could be pumped continuously. Most dug wells extend only a short distance below the water table, which depends on frequent precipitation for recharge. Seasonal watertable fluctuations in till may be large (fig. 26); many wells are reported to go dry after several weeks of drought; but others will yield water for months. The continuity of the supply from such wells depends chiefly upon favorable location for continuous flow from extensive higher parts of the till aquifer.

The moraines are believed to be similar to the till in hydrologic characteristics, except that they are thicker than most of the upland till and probably are more reliable as sources of perennial water supplies. The older morainal deposits south of the Wisconsin drift border (pl. 7), such as those in the vicinity of Allentown, Pa., are generally more highly weathered and, owing to their high content of clay and silt, are less permeable than the moraines of $W$ isconsin age.

\section{STRATIFIED GLACIAL SEDIMENTS}

In the Appalachian Highlands the stratified sediments were deposited in several environments: (1) in the open valley bottoms by melt-water streams as glacial outwash; (2) in depressions on the ice as kames; (3) in long, sinuous ridges beneath the ice as eskers; (4) along the valley sides at the margins of the ice tongues as kame terraces; and (5) in glacial lakes and marshes as deltaic, marsh, and lake-bottom deposits. Postglacial alluvium of Recent age occurs as thin stream and marsh deposits which are difficult to distinguish from the underlying deposits of Pleistocene age.

Although the deposits of Recent age are as heterogeneous as the till and morainal deposits, they differ in having definite bedding as a result of their being sorted by water. The most evenly bedded and most finegrained sediments are the lenses and layers of clay, silt, and fine sand that were deposited in lakes and marshes, dammed either by the ice or by moraines, and rock walls beyond the ice margin. Such deposits are most widespread in the area of glacial Lake Passaic in northern New Jersey, near the cities of Morristown and Madison (pl. 7); smaller masses of similar deposits occur at many other localities. Outwash is fairly well bedded, but the individual beds are exceedingly lenticular. The ice-contact deposits - those in kames, kame terraces, and eskers-commonly are chaotically or crudely bedded (fig. 4) and locally contain bodies of till derived from the adjacent ice.

The outwash, which is the most abundant and important of the stratified glacial sediments, forms elongate masses partly filling the preglacial stream valleys. Tongues of outwash extend along the major valleys far beyond the borders of the glaciated areas into the Coastal Plain province. The Cape May formation in the Coastal Plain may be in part equivalent to the outwash of Wisconsin age, and the Pensauken and Bridgeton formations may be in part equivalent to the older outwash.

Cross sections of the outwash in the Appalachian Highlands (fig. 25) are typically U-shaped in basal outline as a result of quarrying and scour of the bedrock by the ice that occupied the valleys before the outwash was deposited. At many places the locations of the present streams do not coincide with the centers of the old valleys cut in the bedrock surface, and ridges of bedrock extend to the land surface at numerous places in the present valleys. The outwash generally ranges 

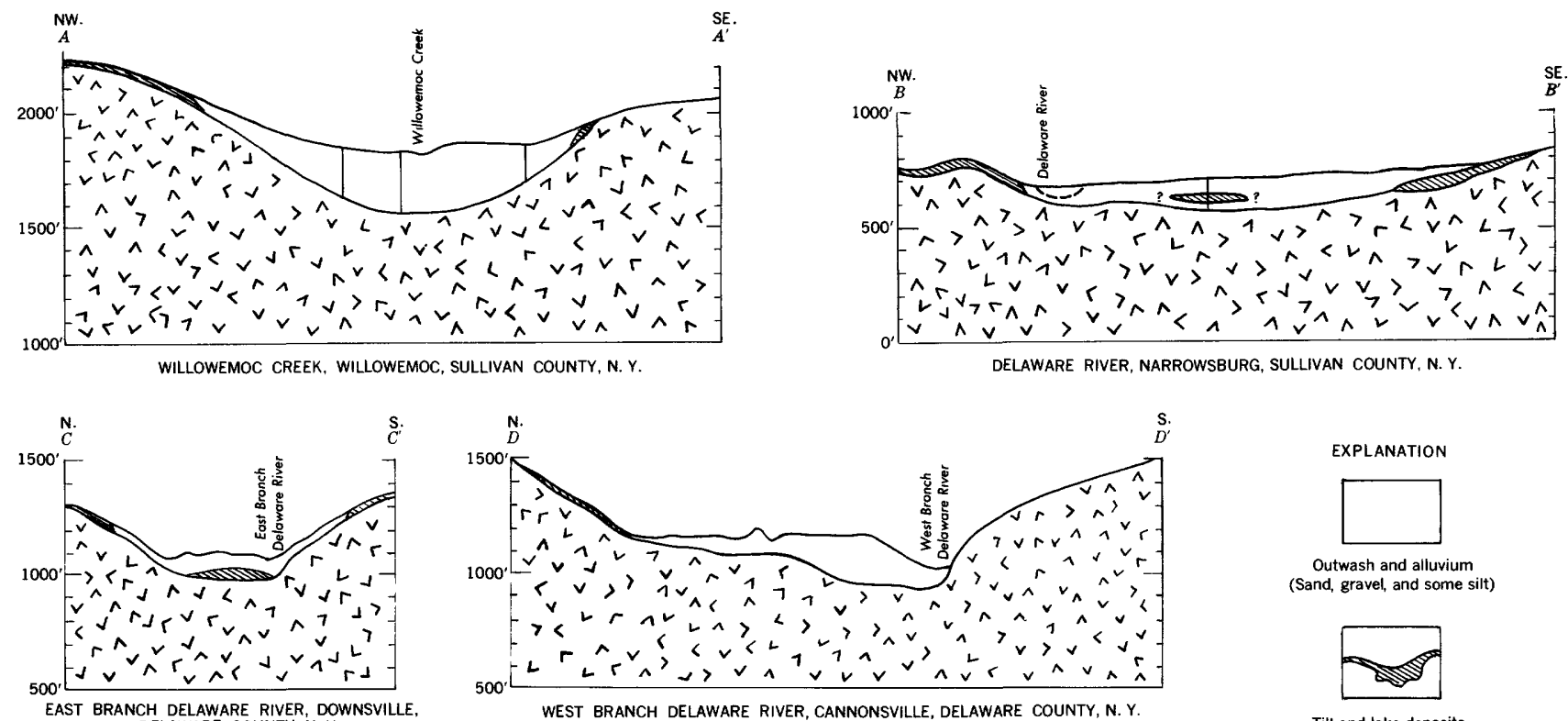

s.

EXPLANation

EAST BRANCH DELAWARE RIVER, DOWNSVILLE,
DELAWARE COUNTY, N. Y.

WEST BRANCH DELAWARE RIVER, CANNONSVILLE, DELAWARE COUNTY, N. Y.
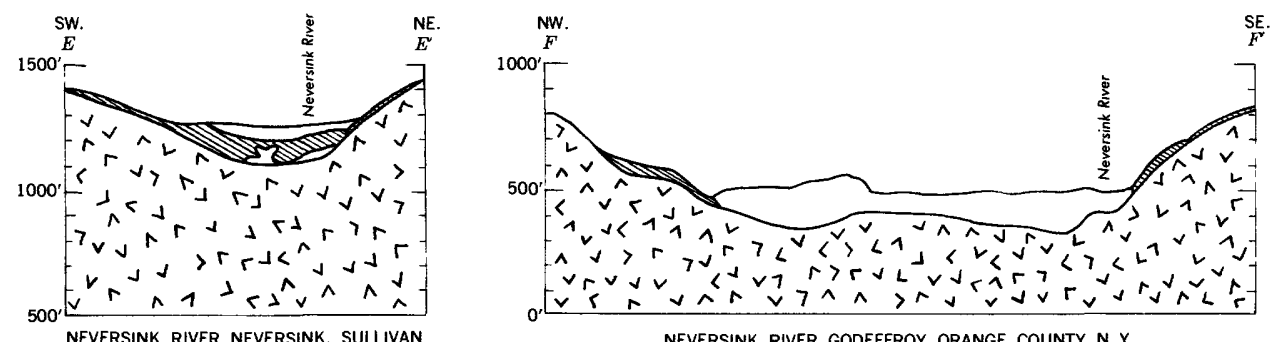

VER, NEVERSINK,
COUNTY, N.Y.
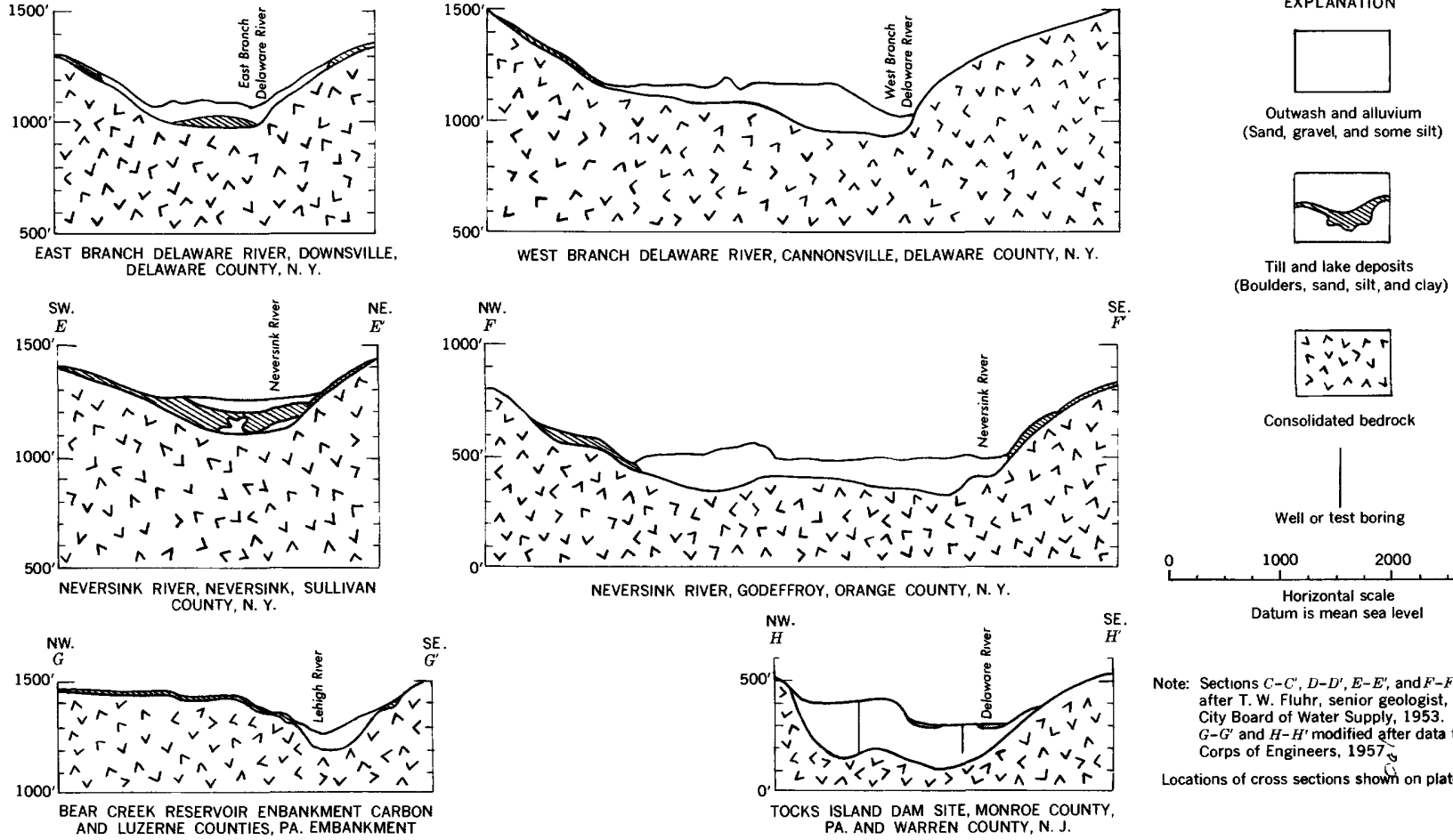

Till and lake deposits (Boulders, sand, sitt, and clay)

FiGURE 25.-Geologic cross sections of major stream valleys in northern part of Delaware River basin.

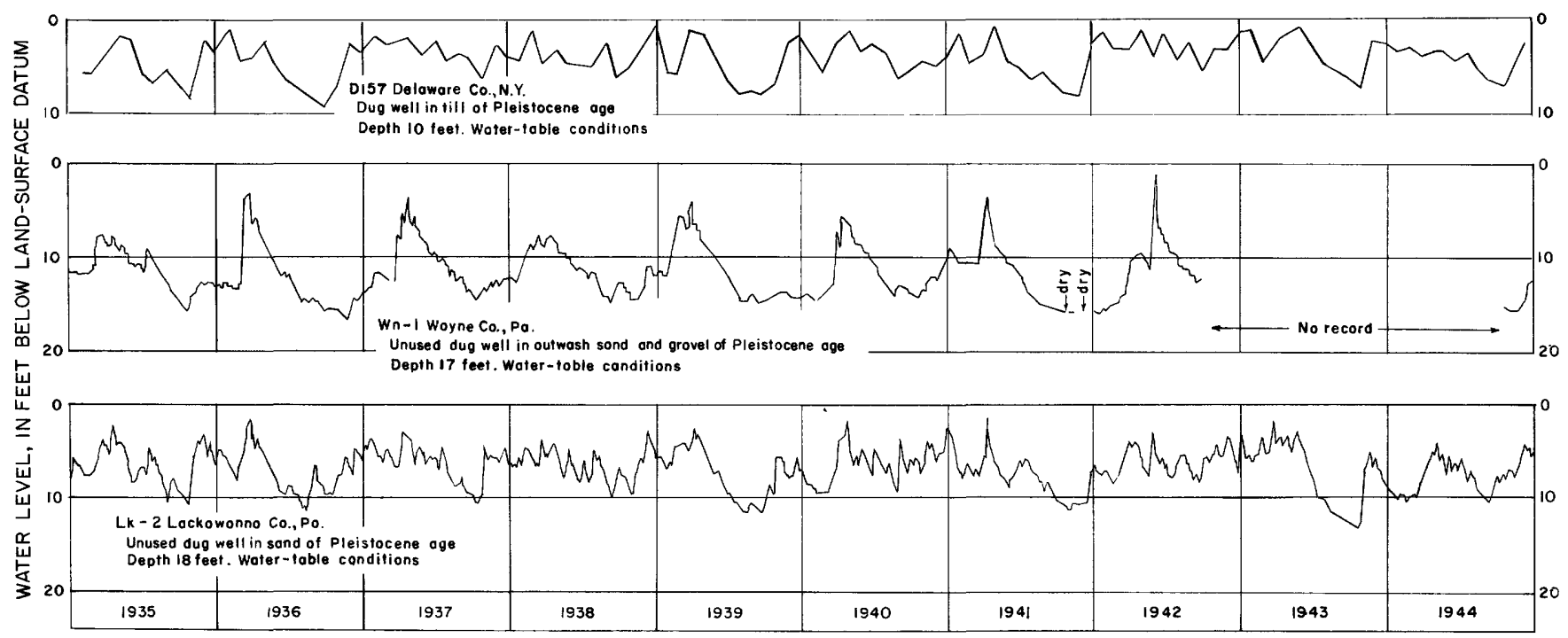

FIGURE 26.-Fluctuations of water levels in representative wells in unconsolidated sediments of glacial origin in northern part of Delaware River basin. 
in thickness from about 50 to 200 feet, although locally it is thicker. Stratified deposits as much as 500 feet thick generally form kame terraces along valley margins, and only the lower part is saturated.

Water generally occurs in the stratified glacial sediments under unconfined to semiconfined conditions. In some places, however, where till beds or lake clays are intercalated with the outwash sand and gravel, the lower beds may be confined and will yield water under artesian pressure.

Under natural conditions the stratified glacial deposits are recharged largely by infiltration of precipitation on their outcrop; the outwash in the valleys also receives recharge from adjacent and underlying bedrock and, in minor amounts, from till along the valley sides. Under conditions of development, where the normal hydraulic gradients toward streams and lakes are reversed by pumping, recharge may be induced from surface-water bodies; recharge may also include septic tank and cesspool effluents, and leakage from sewers or other underground pipes.

Some of the coarser and thicker deposits of outwash constitute the most productive aquifers in the entire Delaware River basin, although in some localities where silt and clay predominate, yields of wells are disappointingly low. Reported yields of 55 wells tapping outwash in the basin range from 2 to $900 \mathrm{gpm}$. The median yield of 28 large-diameter drilled wells used for industrial or public supply is $215 \mathrm{gpm}$. Sustained yields of as much as several thousand gallons per minute doubtless could be obtained largely from induced recharge to deposits of coarse-grained sand and gravel that are hydraulically connected with perennial streams or lakes. The advantages and disadvantages of pumping from wells versus pumping or diverting the water directly from the stream would, of course, have to be appraised locally. As often as not, the quality and temperature of the water would be as important as the quantity.

\section{CHEMICAL CHARACTER OF GROUND WATER}

The chemical quality of water from unconsolidated sediments of glacial origin is summarized in tables 16 and 17. Table 16, for the central part of the Delaware River basin, was prepared from analyses supplied by Rima (written communications, 1957, 1958), and table 17 from data furnished by Perlmutter and Salvas (written communications, 1957). Representative chemical analyses are given in table 20. Water from glacial deposits in the Delaware River basin ranges from soft to hard, but in general it is not highly mineralized. Iron is present locally; unpredictably distributed in the aquifers, its concentration in the water is objectionably high in some of the samples. Where pumping is heavy enough to induce recharge from adjacent streams, a considerable part of the pumped water is derived from the streams, and the water is usually of better quality than the native ground water. Shallow wells may be contaminated from surface sources. A few samples of well water had very high concentrations of nitrate and chloride, perhaps owing to contamination from barnyards or cesspools. Water from the glacial outwash in the northern part of the basin is less mineralized and softer than water from the glacial outwash of the central part. The quality of the stream water in the northern part of the basin also is better than that in the central part.

TABLE 16.-Summary of chemical analyses of 25 samples of ground water from glacial outwash and alluvium in central part of Delaware River basin.

[Concentrations in parts per million]

\begin{tabular}{|c|c|c|c|c|}
\hline & Maximum & Median & Minimum & Analyses \\
\hline 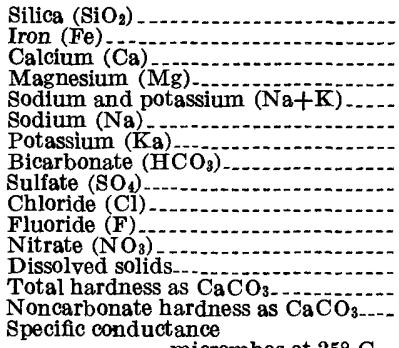 & $\begin{array}{c}20 \\
7.2 \\
57 \\
43 \\
88 \\
76 \\
12 \\
123 \\
189 \\
122 \\
107^{.4} \\
716 \\
319 \\
276\end{array}$ & $\begin{array}{l}9.6 \\
21.43 \\
9.7 \\
7.0 \\
8.3 \\
2.1 \\
29 \\
32 \\
10 \\
.1 \\
8.6 \\
145 \\
71 \\
42\end{array}$ & $\begin{array}{l}5.1 \\
.04 \\
4.1 \\
3.4 \\
1.2 \\
3.1 \\
.9 \\
7.9 \\
4.9 \\
3.0 \\
.0 \\
63 \\
18 \\
12\end{array}$ & $\begin{array}{l}19 \\
15 \\
19 \\
19 \\
25 \\
19 \\
19 \\
25 \\
25 \\
25 \\
19 \\
25 \\
19 \\
25 \\
25\end{array}$ \\
\hline $\begin{array}{l}\text { micromhos at } 25^{\circ} \mathrm{C}_{--} \\
\text {Temperature }\end{array}$ & $\begin{array}{c}1,090 \\
9.3 \\
60\end{array}$ & $\begin{array}{l}195 \\
6.3 \\
55\end{array}$ & $\begin{array}{l}82 \\
5.2 \\
47\end{array}$ & $\begin{array}{l}25 \\
25 \\
25\end{array}$ \\
\hline
\end{tabular}

TABLE 17.-Summary of chemical analyses of 20 samples of ground water from glacial outwash and alluvium in northern part of Delaware River Basin.

[Concentrations in parts per million]

\begin{tabular}{|c|c|c|c|c|}
\hline & Maximum & Median & Minimum & Analyses \\
\hline 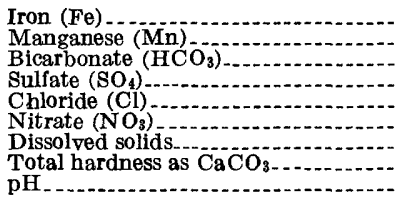 & $\begin{array}{c}4.5 \\
117.28 \\
27 \\
20 \\
2.0 \\
145 \\
124 \\
7.9\end{array}$ & $\begin{array}{l}0.19 \\
34.01 \\
9.3 \\
4.4 \\
-94 \\
50 \\
6.8\end{array}$ & $\begin{array}{l}0.03 \\
15^{.01} \\
4.4 \\
.4 \\
33^{.1} \\
22.8\end{array}$ & $\begin{array}{r}20 \\
12 \\
18 \\
11 \\
19 \\
4 \\
13 \\
20 \\
19\end{array}$ \\
\hline
\end{tabular}

RECHARGE AND DISCHARGE

The aquifers of the Appalachian Highlands are recharged largely by infiltration of precipitation on their outcrops or, in the glaciated northern part of the region, on the overlying blanket of glacial till and outwash. Seepage from the headwater reaches of some streams probably contributes a small amount of additional recharge, and some of the aquifers in the valleys are recharged in part from the adjacent ridges.

The infiltration capacity of the outcrops is a function of several variables, among which are the permeability of the soil and underlying weathered rock and the 
topography. The infiltration capacity ranges from very high in the sandy and gravelly glacial outwash to low in the thin, poorly permeable soils on shale and in the outcrops of dense massive rocks.

The average rate of natural recharge to the aquifers of the Appalachian Highlands differs more from place to place and is more difficult to estimate than the recharge to the aquifers of the Coastal Plain. However the average recharge in the Highlands may be estimated roughly by comparison with a nearby area of similar climatic, hydrologic, and geologic conditions, the Pomperaug River basin in Connecticut, where a detailed water budget was calculated by Meinzer and Stearns (1929).

The Pomperaug River basin, an area of 89 square miles in west-central Connecticut, is underlain largely by crystalline rocks except for the south-central part, which is underlain by diabase and sedimentary rocks of Triassic age; these consolidated rocks are covered by a discontinuous mantle of glacial deposits.

Water budgets for the Pomperaug River basin and the Appalachian Highlands part of the Delaware River basin are compared in table 18 . The data from the Pomperaug River basin have been modified slightly to allow for change in storage during the budget period, 1913-16.

TABLE 18.-Water budgets for Pomperaug River basin, Conn., and Appalachian Highlands part of Delaware River basin

\begin{tabular}{|c|c|c|c|c|c|}
\hline & \multicolumn{3}{|c|}{$\begin{array}{l}\text { Modified from Meinzer and } \\
\text { Stearns, 1929, Pomperaug } \\
\text { River basin }\end{array}$} & \multicolumn{2}{|c|}{$\begin{array}{l}\text { Appalachian } \\
\text { Highlands in } \\
\text { Delaware River } \\
\text { basin }\end{array}$} \\
\hline & $\underset{\mathrm{mi}}{\mathrm{Mgd}}$ & $\begin{array}{l}\text { Percent } \\
\text { of precip } \\
\text { itation }\end{array}$ & $\begin{array}{l}\text { Percent } \\
\text { of runoff }\end{array}$ & $\underset{\substack{\text { per sq } \\
\text { mi }}}{\mathrm{Mgd}}$ & $\begin{array}{l}\text { Percent } \\
\text { of precip- } \\
\text { itation }\end{array}$ \\
\hline $\begin{array}{l}\text { Precipitation } \\
\text { Water loss }\end{array}$ & $\begin{array}{r}2.12 \\
11.13\end{array}$ & $\begin{array}{l}100 \\
153\end{array}$ & & $\begin{array}{l}2.11 \\
1.04\end{array}$ & $\begin{array}{r}100 \\
49\end{array}$ \\
\hline $\begin{array}{l}\text { Runoffi } \\
\text { Direct runoff }\end{array}$ & $\begin{array}{r}.98 \\
1.55\end{array}$ & $\begin{array}{r}47 \\
126\end{array}$ & $\begin{array}{ll}100 \\
156\end{array}$ & 1.07 & 51 \\
\hline $\begin{array}{l}\text { Base fiow (chiefiy ground- } \\
\text { water discharge) } \\
\text { Ground-water recharge }\end{array}$ & 1.43 & 121 & 44 & & \\
\hline Ground-water recharge........... & .74 & 35 & & & \\
\hline
\end{tabular}

1 Figures adjusted to allow for change in storage during budget period.

The similarity of the values of precipitation, water loss, and runoff in the two areas is at once apparent. Streamflow data for the Delaware River basin are not sufficiently detailed to permit close estimates of direct runoff and base flow. However, the value of 44 percent for the base-flow part of total runoff determined in the Pomperaug River basin study is probably somewhat lower than the average value in the Appalachian Highlands of the Delaware River basin. All the Pomperaug basin is glaciated and generally has thin soils of low permeability, whereas only the northern part of the Highlands in the Delaware River basin is glaciated; in the southern part many of the soils and zones of weathered rock are fairly thick and permeable.
Likewise, the value of about $0.75 \mathrm{mgd}$ per sq $\mathrm{mi}$ for ground-water recharge in the Pomperaug River basin probably is somewhat lower than the average for the Highlands in the Delaware River basin; in any case, an estimated average rate of recharge of $0.75 \mathrm{mgd}$ per $\mathrm{sq} \mathrm{mi}$ for the Highlands appears to be conservative. A similarly conservative estimate for the recharge to the aquifers of the Coastal Plain, which generally have more permeable intake areas that those of the consolidatedrock aquifers, gave a value of $1.1 \mathrm{mgd}$ per sq mi (table 7).

The estimated recharge rate of $0.75 \mathrm{mgd}$ per sq mi is, of course, an average for the entire Appalachian Highlands; rather large variations from the average are to be expected. As shown on plates 3,4 , and 12, precipitation on the area ranges from 42 to 60 inches per year (2.0-2.9 mgd per sq $\mathrm{mi}$ ); water loss ranges from 18 to 28 inches per year $(0.9-1.3 \mathrm{mgd}$ per sq $\mathrm{mi})$; and runoff ranges from 15 to about 42 inches per year (0.7-2.0 mgd per sq mi).

The area of the Appalachian Highlands in the Delaware River basin is about 9,700 square miles; thus, at an average rate of $0.75 \mathrm{mgd}$ per sq $\mathrm{mi}$, the total ground-water recharge or discharge averages about $7 \mathrm{bgd}$, or about 2.56 tgy (trillon gallons a year). Most of this water moves only short distances through the weathered and fractured rocks within a few hundred feet of the land surface to discharge outlets in stream channels, springs, seeps, lakes, ponds, marshes, and low-lying areas where the saturated zone is sufficiently near the land surface to allow discharge by evapotranspiration. Discharge through pumped wells is less than 2 percent of the total; about $130 \mathrm{mgd}$ was being withdrawn in 1958 (tables 40 and 41). This discharge does not include pumpage from mines and quarries which may equal or exceed all withdrawals from wells.

Because of the low productivity and small storage capacity of most of the aquifers, and also because of many practical limitations, chiefly economic, only a small part of the ground-water discharge at natural outlets in the Appalachian Highlands can be diverted for man's use. However, pumpage substantially in excess of the 1955 rate of $130 \mathrm{mgd}$ doubtless could be maintained with increased ground-water development, especially in the glacial outwash deposits in the major valleys, where induced recharge from streams is significant. (See following discussion of ground-water storage.)

\section{GROUND-WATER STORAGE}

The aquifers in the Appalachian Highlands differ greatly in their capacity to store water. As groundwater sources, the deposits of glacial outwash in the major stream valleys compare favorably with the 
coarsest grained aquifers in the Coastal Plain, whereas most of the consolidated-rock aquifers, which make up the bulk of the water-bearing materials in the Highlands, have comparatively little storage capacity.

Some of the beds of gravel and sand in the outwash probably have specific yields exceeding 30 percent. In consolidated-rock aquifers, however, specific yields of more than 2 percent probably are uncommon, except in the upper part of the weathered zone. In most consolidated rocks the specific yield decreases markedly with depth, and most of the usable storage capacity is in the weathered and highly fractured material near the land surface. Although the storage capacity of the consolidated rocks is much less than that of the unconsolidated sediments, the runoff from ground-water storage in some of the shallow weathered and fractured rocks is comparable to that in many of the unconsolidated sediments.

Lack of adequate storage capacity is most likely to be important in limiting the ground-water development in moderately permeable aquifers having low specific yields, such as the aquifers in the Brunswick formation of Triassic age.

Some of the larger masses of glacial outwash receive and store tremendous volumes of water. One of the largest of such masses in this region extends up the Delaware River from below Milford, Pa., to Port Jervis, N.Y., thence along the Neversink River and Basher Kill to Summitville, N.Y., and beyond. From Milford to Summitville the length of this outwash body is 28 miles, its width averages a little less than a mile, and its average thickness is between 100 and 150 feet. A conservative estimate of the total volume of its saturated materials is 75 billion cubic feet. If the specific yield of this aquifer is only 15 percent, its storage capacity is about 11.3 billion cubic feet, or about 84.4 billion gallons.

To this storage, in an average year, nature adds another 10.2 billion gallons in estimated ground-water recharge. If all this annual recharge were developed, it would be enough to supply a city of 187,000 persons with water at a rate of 150 gpcd (gallons per capita per day).

Of course, all this water could not be developed without affecting the flow of the stream; neither could the water in storage be greatly developed without reducing flow in the river. But as an example of what might be done on a small scale in this area, consider a segment only 2 miles in length. The storage capacity of this segment is estimated to be about 6 billion gallons $(10,560$ feet $\times 5,000$ feet $\times 100$ feet $\times 0.15 \times 7.5$ gallons per cubic foot).

Suppose, by proper spacing and pumping of wells, that one-fourth of this stored water were withdrawn from the aquifer except for a strip 1,000 feet wide beneath the river which would remain saturated-in other words, that one-fifth of the total stored ground water could be withdrawn. Under these assumed conditions, the amount that would be produced from storage alone would be about 1.2 billion gallons, and the average rate of withdrawal from storage for a dewatering period of 90 days would be about $13 \mathrm{mgd}$. However, while this water was being withdrawn from storage, a large amount would seep both from the river, and, to a lesser extent, from the adjacent rocks of the valley walls and floor, as induced recharge. If large-scale pumping were continued long enough, recharge from the river and adjacent valley wallrocks would offset the pumping, and the flow in the river would be reduced proportionally.

Fairly large seasonal drafts thus could be made during the dry season, most or all of which would be replaced at flood or high-water stages of the river. Such aquifer management would be a great boon to this region for it utilizes natural reservoirs in which water is stored, some of which otherwise would have wasted to the ocean, and makes available for local use naturally stored water that otherwise lies there unused. Such aquifer management would require careful local geologic and hydrologic studies upon which to base development and control.

The character of fluctuations in ground-water storage in glacial deposits is shown in the hydrographs of three unused shallow dug wells (fig. 26). The fluctuations in all three wells are probably entirely the result of changing rates of natural recharge and discharge. The peak water levels in the spring reflect high rates of recharge from rain and melting snow; the low water levels in the summer and fall are a result of high evapotranspiration losses and, hence, lack of infiltration to the aquifer. The average yearly watertable fluctuations in the 3 wells are from 5 to 10 feet; because of the lack of specific-yield data for the materials penetrated by the wells, the changes in ground-water storage indicated by the fluctuations are not known.

\section{CHEMICAL CHARACTER OF GROUND-WATER SUPPLIES}

\section{THE Coastal plarn}

Representative analyses of ground water from seven aquifers in the Coastal Plain are given in table 19. To facilitate comparison of the chemical quality of the ground water from the seven aquifers, typical samples have been chosen and the concentrations of their dissolved constituents (in parts per million) shown in figure 27. These typical samples were chosen so as to have concentrations close to the median concentrations 
found for the aquifer. The proportions, by equivalents, of the dissolved ions are shown in figure 28 for the same samples. Water from the Kirkwood formation and from the Vincentown sand has the greatest concentrations of dissolved solids, and that from the Cohansey sand is the least mineralized-only $25 \mathrm{ppm}$ of dissolved solids in the typical sample. The water from the Coastal Plain aquifers is generally less mineralized and softer than water from the aquifers of the Appalachian Highlands. Compared to other Coastal Plain aquifers, the Kirkwood formation yields water with a relatively high silica content, probably derived from the diatomaceous material in the aquifer. The water is characterized by calcium-magnesium bicarbonate and contains a greater number of calcium and magnesium ions than sodium and potassium ions. For water from the nonmarine sediments of Cretaceous age, this situation is reversed and there are more sodium plus potassium ions than calcium plus magnesium ions in the typical water samples.
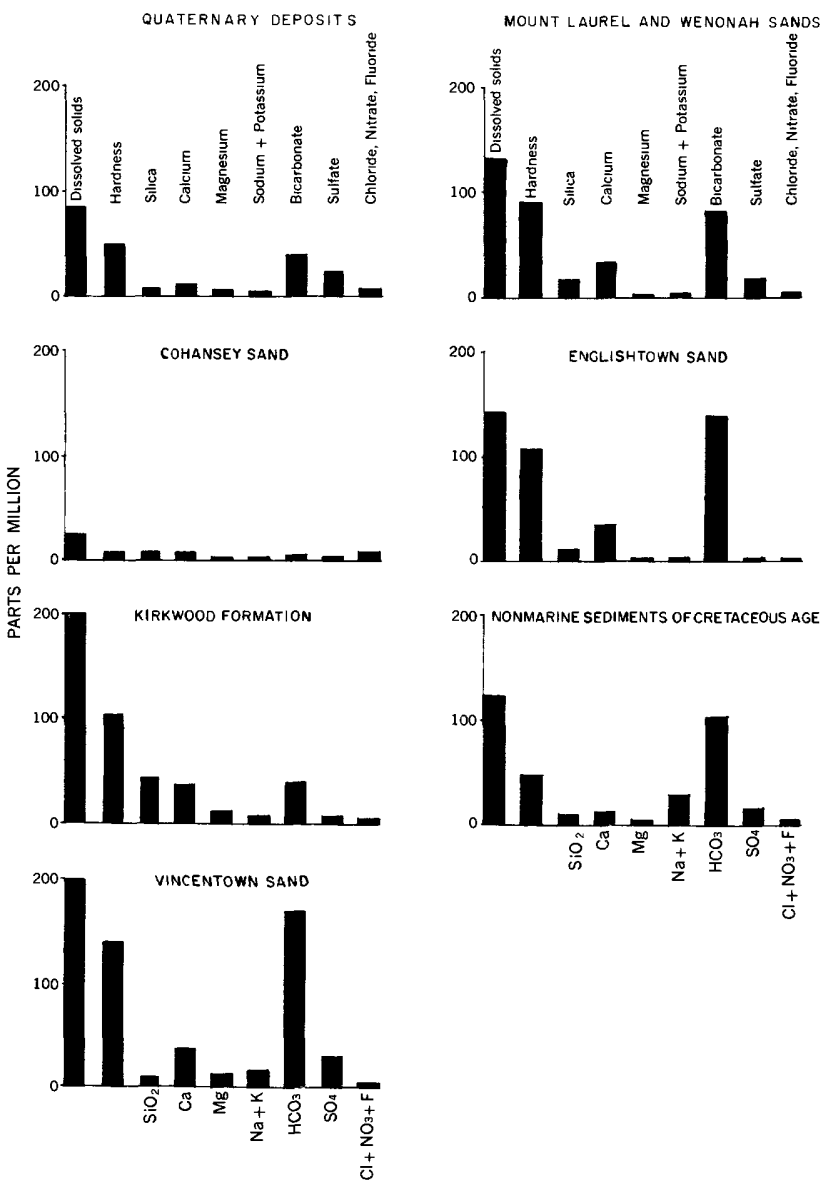

FIGURE 27.-Typical concentrations of chemical constituents of ground water in Coastal Plain.

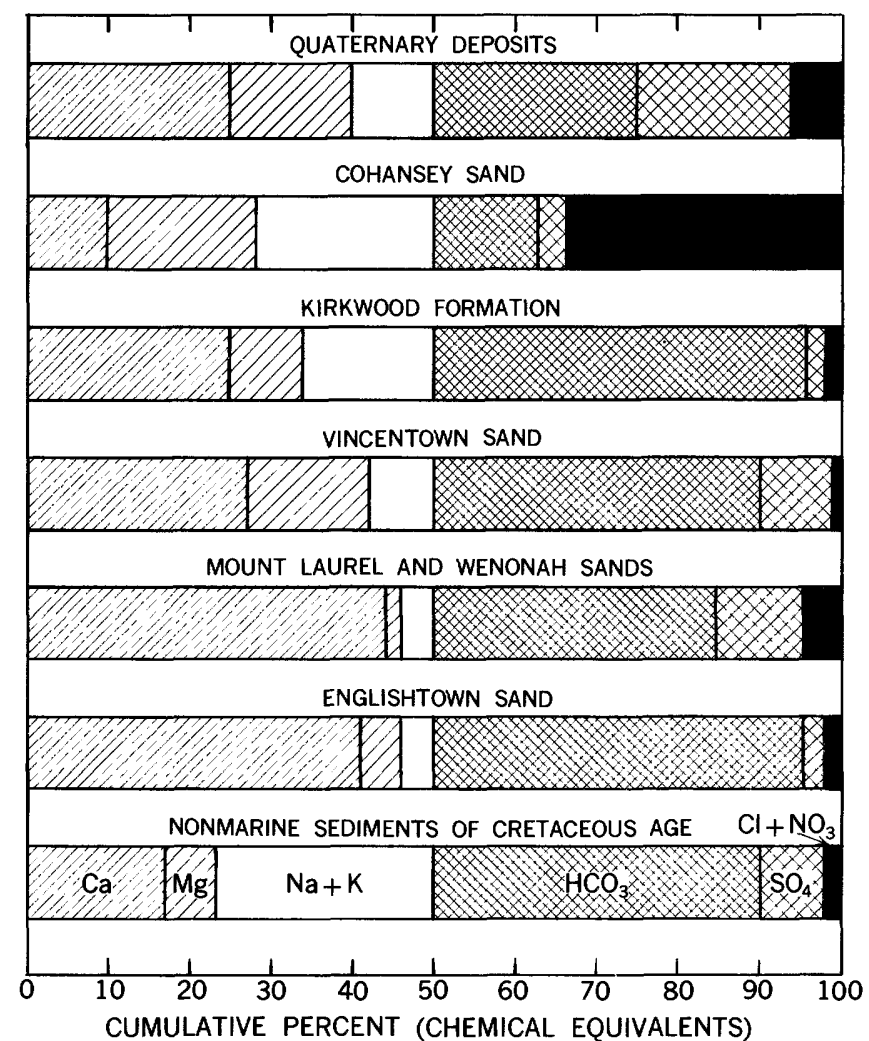

FIGURE 28.-Typical chemical compositions of ground water in Coastal Plain.

THE APPALACHIAN HIGHLANDS

The chemical analyses of representative samples of ground water from the Appalachian Highlands are given in table 20 and 21 . The concentrations of chemical constituents of typical samples (again chosen to approximate the median concentrations for the aquifers) are shown in figure 29 and the composition of the dissolved solids, for the same samples, in figure 30 .

Excellent water, low in dissolved solids and hardness, is obtained from the Catskill formation, from the gneiss, and from the Wissahickon formation. Water from the glacial outwash also is not highly mineralized. As is to be expected, the most highly mineralized and hardest water is that from the carbonate rocks. The carbonate rocks yield water with the highest proportion of chloride plus nitrate in the dissolved solids. Water flows through solution channels in carbonate rock and for this reason pollutants may be carried for considerable distances without being chemically altered. Perhaps this is the cause of the high content of chloride and nitrate.

Other aquifers that yield highly mineralized and hard waters are the Lockatong formation, the diabase, the Brunswick formation, and the Stockton formation. Only a few analyses are available for water from the Martinsburg shale and the Marcellus shale, but this 


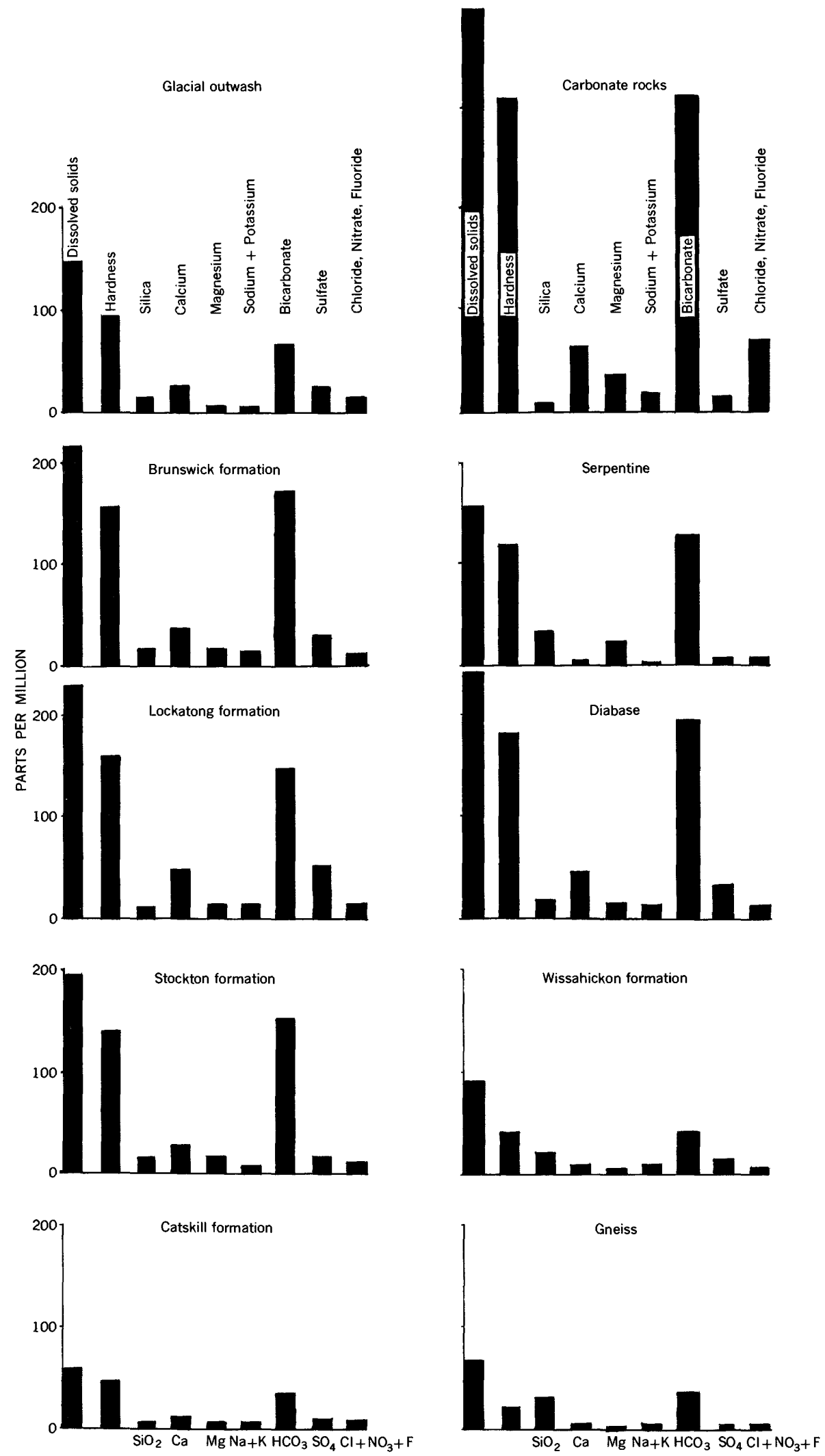

FIGURE 29.-Typical concentrations of chemical constituents of ground water in Appalachian Highlands. 


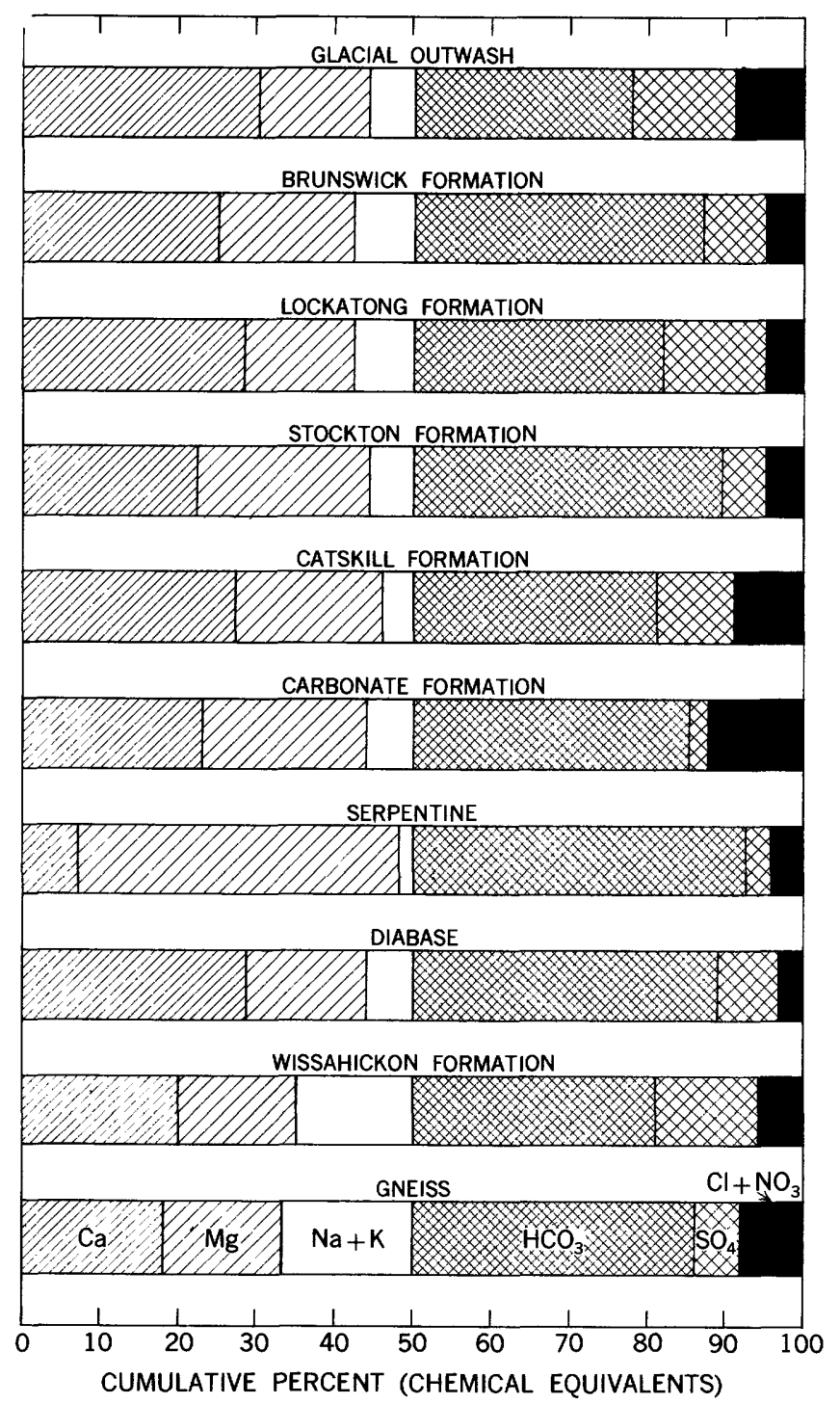

Figure 30.-Typical chemical compositions of ground water in Appalachian Highlands.

water appears to range from soft to moderately hard and to be not highly mineralized. Figure 30 shows that, although in most of the ground waters represented there are more calcium ions than magnesium ions, the ratio is reversed in typical water from serpentine and there are six times as many magnesium as calcium ions. Serpentine consists mostly of magnesium-silicate which dissolves readily in ground water. The high magnesium to calcium ratio adversely affects the fertility of the soil, and areas in Chester and Delaware Counties, Pa., underlain by serpentine, are locally known as The Barrens because of the poor plant growth there.

\section{SALT-WATER ENCROACHMENT}

One of the most important factors limiting the development of the coastal aquifers is salt-water encroachment or the threat of it. Salt-water encroachment has been defined in many ways. In this report it is defined broadly as the encroachment into a freshwater domain of any saline water in concentrations and volumes large enough to be deleterious.

Saline water may have many different sources. Fortunately, in the Delaware River region the sources are few and readily identifiable; they are: (1) ocean water; (2) residual saline water left on the land by high-level Pleistocene seas; and (3) connate water, some of it entrapped with sediments as they were being deposited in the Cretaceous sea. In the Delaware River basin area the first source, modern ocean water, is by far the most important and is discussed at length in following sections. Connate water is believed to be of secondary importance.

Residual saline water may be similar in chemical character to connate water, but it differs from connate water in that it is of late marine origin and that it gained entrance into the coastal aquifers and aquicludes during Pleistocene interglacial stages when the land was flooded by high-level seas. Most residual saline water is modified greatly from its original chemical condition. Usually it has been diluted and has undergone ion exchange in which either the calcium or magnesium in the water has been exchanged for sodium and to a lesser extent for potassium in the enclosing rocks, or vice versa, depending upon the local conditions.

Inland from the shore area, residual saline water occurs most commonly in the deepest and least permeable parts of aquicludes. Ice-Age salt water has been flushed out of the aquifers and the higher and more permeable parts of the aquicludes since the time of the last high-level Pleistocene sea, but not enough time has elapsed for flushing to take place by slow, normal circulation through the deepest and (or) least permeable sediments. Residual saline-water bodies in the Coastal Plain are less saline than the present ocean, and unlike the ocean, the supply of saline water of this type is limited.

Within the Delaware River basin and the adjacent Coastal Plain parts of New Jersey and Delaware, saltwater encroachment is a serious threat to shallow aquifers along the shores and the tidal reaches of streams that sometimes carry salty water. The entire eastern shore of Delaware and the area near the Chesapeake and Delaware Canal are potentially threatened. At times, salty water extends up the Delaware estuary to Philadelphia, hence New Jersey is surrounded by salty water from below Philadelphia to Cape May and northward along the Atlantic Ocean to and beyond Newark.

Average ocean water has a density 1.025 times greater than pure water and a dissolved-solids content 
TABLE 19.-Representative chemical analyses of ground water in Coastal Plain of Delaware River region

[Concentrations in parts per million]

\begin{tabular}{|c|c|c|c|c|c|c|c|c|c|c|c|c|c|c|c|c|c|c|c|c|}
\hline \multirow{2}{*}{$\underset{\text { ysis }}{\text { Anal- }}$} & \multirow{2}{*}{ County, state } & \multirow{2}{*}{$\begin{array}{l}\text { Depth } \\
\text { (feet) }\end{array}$} & \multirow{2}{*}{$\begin{array}{l}\text { Date of } \\
\text { collec- } \\
\text { tion }\end{array}$} & \multirow{2}{*}{$\begin{array}{l}\text { Tem- } \\
\text { pera- } \\
\text { ture } \\
{ }^{\circ} \mathbf{F}\end{array}$} & \multirow{2}{*}{$\begin{array}{c}\text { Silica } \\
\left(\mathrm{SiO}_{2}\right)\end{array}$} & \multirow{2}{*}{$\begin{array}{l}\text { Iron } \\
(\mathrm{Fe})\end{array}$} & \multirow{2}{*}{\begin{tabular}{|c} 
Man- \\
ganese \\
(Mn)
\end{tabular}} & \multirow{2}{*}{$\begin{array}{l}\text { Cal- } \\
\text { cumm } \\
\text { (Ca) }\end{array}$} & \multirow{2}{*}{$\begin{array}{l}\text { Mag- } \\
\text { ne- } \\
\text { sium } \\
(\mathrm{Mg})\end{array}$} & \multirow{2}{*}{$\begin{array}{c}\text { Sodi- } \\
\text { um } \\
(\mathrm{Na})\end{array}$} & \multirow{2}{*}{$\begin{array}{l}\text { Potas- } \\
\text { sium } \\
(\mathbf{K})\end{array}$} & \multirow{2}{*}{$\begin{array}{c}\text { Bicar- } \\
\text { bonate } \\
\left(\mathrm{HCO}_{3}\right)\end{array}$} & \multirow{2}{*}{$\begin{array}{c}\text { Sul- } \\
\text { fate } \\
\left(\mathrm{SO}_{4}\right)\end{array}$} & \multirow{2}{*}{$\begin{array}{l}\text { Chlo- } \\
\text { ride } \\
\text { (Cl) }\end{array}$} & \multirow{2}{*}{$\begin{array}{l}\text { Fluo- } \\
\text { ride } \\
\text { (F) }\end{array}$} & \multirow{2}{*}{$\begin{array}{c}\mathrm{Ni-} \\
\text { trate } \\
\left(\mathrm{NO}_{3}\right)\end{array}$} & \multirow{2}{*}{$\begin{array}{l}\text { Dis- } \\
\text { solved } \\
\text { solids }\end{array}$} & \multicolumn{2}{|c|}{$\underset{\mathrm{CaCO}_{3}}{\text { Hardness as }}$} & \multirow{2}{*}{$\mathrm{pH}$} \\
\hline & & & & & & & & & & & & & & & & & & Total & $\begin{array}{l}\text { Noncar- } \\
\text { bonate }\end{array}$ & \\
\hline
\end{tabular}

Pleistocene deposits

\begin{tabular}{|c|c|c|c|c|c|c|c|c|c|c|c|c|c|c|c|c|c|c|c|c|}
\hline $\begin{array}{l}1 \\
2 \\
3 \\
4 \\
5 \\
5 \\
6\end{array}$ & $\begin{array}{l}\text { Sussex, Del } \\
\text { New Castle, Del. } \\
\text { Salem, N.J, } \\
\text { Burlington, N.J. } \\
\text { Cape May, N.J } \\
\text { Bucks, Pa. }\end{array}$ & $\begin{array}{r}131,102 \\
24-25 \\
242 \\
45 \\
50 \\
35\end{array}$ & $\begin{array}{r}9-23-44 \\
4-23-31 \\
1-11-51 \\
7-3-53 \\
10-17-56 \\
2-28-56\end{array}$ & 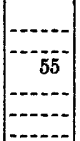 & $\begin{array}{l}25 \\
14 \\
9.7 \\
5.3 \\
12 \\
12\end{array}$ & $\begin{array}{c}14 \\
.03 \\
4.8 \\
.20 \\
.19 \\
.16\end{array}$ & $\begin{array}{r}.00 \\
.33 \\
.01 \\
.00\end{array}$ & $\begin{array}{l}17 \\
11 \\
14 \\
13 \\
14 \\
21\end{array}$ & $\begin{array}{l}5.3 \\
8.1 \\
2.3 \\
4.5 \\
1.8 \\
8.8\end{array}$ & \begin{tabular}{l|l}
37 & \\
18 & \\
90 & \\
3.8 & 12 \\
& 9.
\end{tabular} & $\begin{array}{r}3.3 \\
1.2 \\
4.0 \\
2^{1.8} \\
0\end{array}$ & $\begin{array}{r}23 \\
20 \\
131 \\
40 \\
31 \\
53\end{array}$ & $\begin{array}{l}9.8 \\
40 \\
25 \\
24 \\
12 \\
48\end{array}$ & $\begin{array}{c}86 \\
27 \\
74 \\
4.2 \\
16 \\
8\end{array}$ & $\begin{array}{r}0.5 \\
.0 \\
.1 \\
.1\end{array}$ & $\begin{array}{r}0.0 \\
15 \\
.8 \\
1.3 \\
8.7 \\
4.1\end{array}$ & $\begin{array}{r}204 \\
146 \\
244 \\
85 \\
106 \\
140\end{array}$ & $\begin{array}{l}64 \\
61 \\
44 \\
51 . \\
42 \\
89\end{array}$ & $\begin{array}{r}45 \\
41 \\
0 \\
18 \\
17 \\
45\end{array}$ & $\begin{array}{l}6.5 \\
7.2 \\
7.4 \\
7.4\end{array}$ \\
\hline
\end{tabular}

Cohansey sand

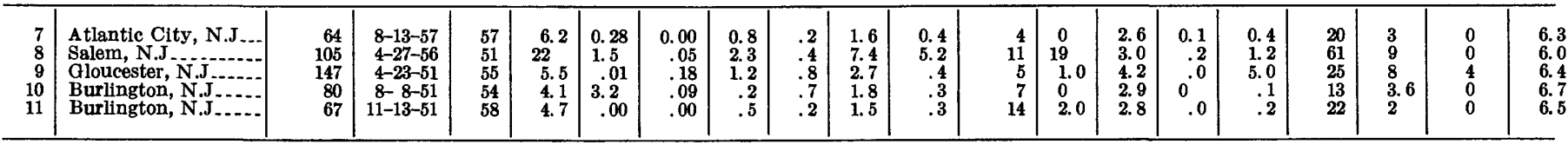

\section{Kirkwood formation}

\begin{tabular}{|c|c|c|c|c|c|c|c|c|c|c|c|c|c|c|c|c|c|c|c|}
\hline $\begin{array}{l}12 \\
13 \\
14\end{array}$ & $\begin{array}{l}\text { Sussex, Del } \\
\text { Kent, Del-... } \\
\text { Burlington, N.J.... }\end{array}$ & $\begin{array}{l}242 \\
253 \\
350\end{array}$ & $\begin{array}{r}12-28-51 \\
1-26-52 \\
8-14-51\end{array}$ & & $\begin{array}{l}55 \\
47 \\
26\end{array}$ & $\begin{array}{r}0.13 \\
.16 \\
10\end{array}$ & $\begin{array}{l}0.01 \\
.00\end{array}$ & & $\begin{array}{r}6.9 \\
6.4 \\
.9\end{array}$ & $\begin{array}{l}6.4 \\
2.9\end{array}$ & $\begin{array}{l}2.5 \\
2.2\end{array}$ & $\begin{array}{r}192 \\
174 \\
1\end{array}$ & $\begin{array}{r}2.0 \\
6.0 \\
10\end{array}$ & $\begin{array}{l}3.4 \\
2.8 \\
3.1\end{array}$ & $\begin{array}{r}0.1 \\
.2 \\
.0\end{array}$ & $\begin{array}{r}0.0 \\
.1 \\
.1\end{array}$ & $\begin{array}{r}219 \\
202 \\
49\end{array}$ & $\begin{array}{r}148 \\
104 \\
6\end{array}$ & $\begin{array}{l}4 \\
0 \\
5\end{array}$ \\
\hline
\end{tabular}

Vincentown sand

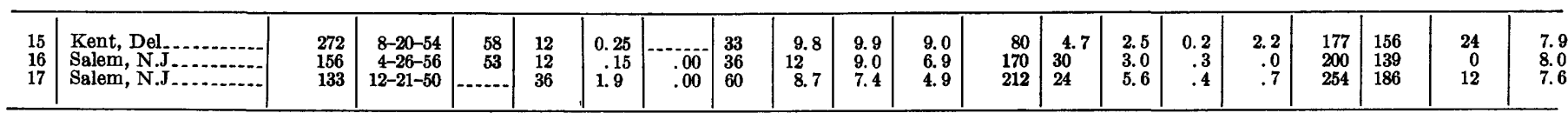

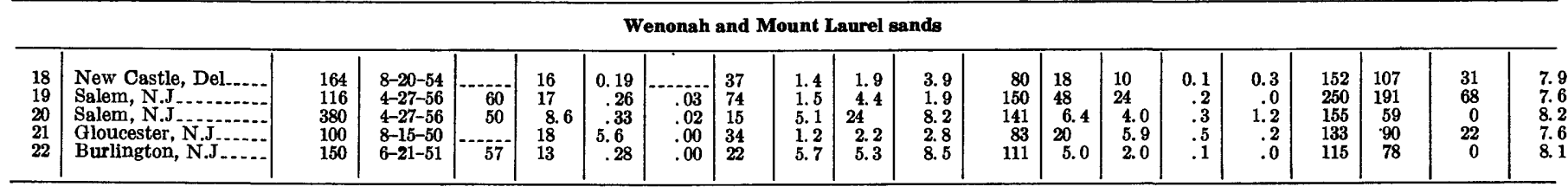

\begin{tabular}{|c|c|c|c|c|c|c|c|c|c|c|c|c|c|c|c|c|c|c|c|c|}
\hline \multicolumn{21}{|c|}{ Englishtown sand } \\
\hline & Monmox & & $3-13-$ & & & 0.62 & 0.02 & & & 2.3 & 2.5 & & & 4. 5 & 0.1 & 0.2 & & & & \\
\hline $\begin{array}{l}24 \\
25\end{array}$ & $\begin{array}{l}\text { Burlington, N.J- } \\
\text { Monmouth, N.J- }\end{array}$ & $\begin{array}{l}260 \\
480\end{array}$ & $\begin{array}{l}3-22-51 \\
3-1-57\end{array}$ & $\begin{array}{l}56 \\
58\end{array}$ & 27 & .45 & .10 & 43 & $\begin{array}{l}4.0 \\
3.2\end{array}$ & 2.2 & $\begin{array}{l}5.7 \\
3.9\end{array}$ & $\begin{array}{l}149 \\
136\end{array}$ & $\begin{array}{l}7.0 \\
4.6\end{array}$ & $\begin{array}{l}2.6 \\
2.7\end{array}$ & $\begin{array}{r}.4 \\
1\end{array}$ & .3 & $\begin{array}{l}166 \\
143\end{array}$ & $\begin{array}{l}124 \\
108\end{array}$ & & 8.2 \\
\hline 26 & Monmouth, N.J. & 657 & $8-8-51$ & 54 & 13 & $\begin{array}{l}. \infty \\
.60\end{array}$ & & & $\begin{array}{l}5.2 \\
5.1\end{array}$ & & & $\begin{array}{r}100 \\
98\end{array}$ & 14 & 4.0 & .1 & & 113 & 86 & & 7.8 \\
\hline
\end{tabular}

\begin{tabular}{|c|c|c|c|c|c|c|c|c|c|c|c|c|c|c|c|c|c|c|c|c|}
\hline \multicolumn{21}{|c|}{ Nonmarine sediments of Cretaceous age } \\
\hline $\begin{array}{l}29 \\
30 \\
31 \\
32 \\
33 \\
34\end{array}$ & $\begin{array}{l}\text { New Castle, Del. } \\
\text { Salem, N.J } \\
\text { Camden, N.J } \\
\text { Burlington, N.J. } \\
\text { Burlington, N.J } \\
\text { Mercer, N.J. } \\
\end{array}$ & $\begin{array}{r}322 \\
387 \\
57 \\
120-140 \\
205\end{array}$ & $\begin{array}{l}7-2-56 \\
4-26-56 \\
5-1-51 \\
7-3-53 \\
5-22-51 \\
9-26-49\end{array}$ & $\mid \begin{array}{r}-54 \\
61 \\
\hdashline 57 \\
\hdashline-2\end{array}$ & $\begin{array}{c}14 \\
8.3 \\
10 \\
9.4 \\
14 \\
9.3\end{array}$ & $\begin{array}{l}0.01 \\
.11 \\
.11 \\
.00 \\
9.3 \\
4.1\end{array}$ & $\begin{array}{l}.05 \\
.00 \\
.19 \\
.00\end{array}$ & $\begin{array}{l}4.7 \\
11 \\
14 \\
12 \\
16 \\
2.2\end{array}$ & $\begin{array}{r}2.7 \\
5.4 \\
2.9 \\
10 \\
5.2 \\
1.2\end{array}$ & $\begin{array}{cc}11 & 7 \\
21 & \\
10 \\
2.7 \\
2.3\end{array}$ & $\mid \begin{array}{r}2 \\
1.9 \\
6.3 \\
3.6 \\
4.3 \\
1.0\end{array}$ & $\begin{array}{r}21 \\
20 \\
103 \\
34 \\
64 \\
8\end{array}$ & \begin{tabular}{|c|}
16 \\
44 \\
15 \\
40 \\
16 \\
6.2
\end{tabular} & $\begin{array}{r}3.0 \\
7.5 \\
1.8 \\
12 \\
2.1 \\
2.4\end{array}$ & $\begin{array}{r}0.1 \\
.2 \\
.4 \\
.0 \\
.2 \\
.1\end{array}$ & $\begin{array}{r}0.1 \\
.8 \\
13.2 \\
13.3 \\
.3\end{array}$ & $\begin{array}{r}64 \\
107 \\
124 \\
145 \\
86 \\
27\end{array}$ & $\begin{array}{l}23 \\
50 \\
47 \\
71 \\
61 \\
10\end{array}$ & $\begin{array}{l}5.8 \\
34 \\
0 \\
43 \\
9 \\
4\end{array}$ & $\begin{array}{l}6.4 \\
7.2 \\
7.8 \\
6.9 \\
7.1 \\
5.6\end{array}$ \\
\hline
\end{tabular}

TABLE 20.-Representative chemical analyses of ground water in unconsolidated sediments in Appalachian Highlands [Concentrations in parts per million]

\begin{tabular}{|c|c|c|c|c|c|c|c|c|c|c|c|c|c|c|c|c|c|c|c|c|}
\hline \multirow{2}{*}{$\begin{array}{l}\text { Anal- } \\
\text { ysis }\end{array}$} & \multirow{2}{*}{ County, state } & \multirow{2}{*}{$\begin{array}{l}\text { Depth } \\
\text { (foet) }\end{array}$} & \multirow{2}{*}{$\begin{array}{l}\text { Date of } \\
\text { collec- } \\
\text { tion }\end{array}$} & \multirow{2}{*}{$\begin{array}{l}\text { Tem- } \\
\text { pera- } \\
\text { ture, } \\
{ }^{\circ} \mathrm{F}\end{array}$} & \multirow{2}{*}{$\begin{array}{l}\text { Silica } \\
\left(\mathrm{SiO}_{2}\right)\end{array}$} & \multirow{2}{*}{$\begin{array}{l}\text { Iron } \\
(\mathrm{Fe})\end{array}$} & \multirow{2}{*}{$\begin{array}{l}\text { Man- } \\
\text { ganese } \\
\text { (Mn) }\end{array}$} & \multirow{2}{*}{$\begin{array}{c}\text { Cal- } \\
\text { caum } \\
\text { (Ca) }\end{array}$} & \multirow{2}{*}{$\begin{array}{c}\text { Mag- } \\
\text { ne- } \\
\text { sium } \\
\text { (Mg) }\end{array}$} & \multirow{2}{*}{$\begin{array}{l}\text { Sodi- } \\
\text { um } \\
\text { (Na) }\end{array}$} & \multirow{2}{*}{$\begin{array}{l}\text { Potas- } \\
\text { sium } \\
(\mathbf{K})\end{array}$} & \multirow{2}{*}{$\begin{array}{c}\text { Bicar- } \\
\text { bonate } \\
\left(\mathrm{HCO}_{3}\right)\end{array}$} & \multirow{2}{*}{$\begin{array}{l}\text { Sul- } \\
\text { fate } \\
\text { (SOt) }\end{array}$} & \multirow{2}{*}{$\begin{array}{l}\text { Chlo- } \\
\text { ride } \\
\text { (Cl) }\end{array}$} & \multirow{2}{*}{$\begin{array}{l}\text { Fluo- } \\
\text { ride } \\
\text { (F) }\end{array}$} & \multirow{2}{*}{$\begin{array}{c}\mathrm{Ni-} \\
\text { trate } \\
\left(\mathrm{NO}_{3}\right)\end{array}$} & \multirow{2}{*}{$\begin{array}{c}\text { Dis- } \\
\text { solved } \\
\text { solids }\end{array}$} & \multicolumn{2}{|c|}{$\underset{\mathrm{CaCO}_{3}}{\text { Hardness as }}$} & \multirow{2}{*}{$\mathrm{pH}$} \\
\hline & & & & & & & & & & & & & & & & & & Total & $\begin{array}{l}\text { Noncar- } \\
\text { bonate }\end{array}$ & \\
\hline \multirow{3}{*}{$\begin{array}{l}1 \\
\mathbf{2} \\
3 \\
\mathbf{4} \\
5 \\
6\end{array}$} & $\underset{\mathbf{W}}{\mathbf{M}}$ & & $9-22-30$ & 48 & & & & 2 & & & & 16 & 2 & 1.0 & & 0.1 & 18 & 14 & & \multirow{3}{*}{$\begin{array}{l}7.8 \\
6.0 \\
6.8 \\
7.8\end{array}$} \\
\hline & $\mathrm{N}_{\mathrm{N}} \mathbf{Y}$ & $\begin{array}{r}28 \\
110\end{array}$ & $\begin{array}{l}-20-30 \\
8-7-47\end{array}$ & & -...-.- & 0.18 & 0.01 & & & & & $\begin{array}{r}25 \\
133 \\
22\end{array}$ & $\begin{array}{l}14 \\
10\end{array}$ & $\begin{array}{l}4.0 \\
2.4 \\
7.8\end{array}$ & ........ & 2.4 & $\begin{array}{c}50 \\
144\end{array}$ & $\begin{array}{l}40 \\
88\end{array}$ & (n) & \\
\hline & $\begin{array}{l}\text { Delaware, N.Y. } \\
\text { Delaware } \mathrm{Y}\end{array}$ & $\begin{array}{c}5 f \\
166 \\
70\end{array}$ & $7-10-46$ & $\cdots$ & (n) & .15 & .015 & 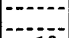 & $\cdots$ & & 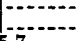 & $\begin{array}{l}50 \\
15\end{array}$ & 8.9 & .8 & $\cdots$ & 1.0 & 33 & $\begin{array}{l}58 \\
28\end{array}$ & ............. & \\
\hline
\end{tabular}


TABLE 21.-Representative chemical analyses of ground water in consolidated rocks in Appalachian Highlands

[Concentrations in parts per million]

\begin{tabular}{|c|c|c|c|c|c|c|c|c|c|c|c|c|c|c|c|c|c|c|c|c|}
\hline \multirow{2}{*}{$\underset{\text { ysis }}{\text { Anal- }}$} & \multirow{2}{*}{ County, state } & \multirow{2}{*}{$\begin{array}{l}\text { Depth } \\
\text { (feet) }\end{array}$} & \multirow{2}{*}{$\begin{array}{l}\text { Date of } \\
\text { collec- } \\
\text { tion }\end{array}$} & \multirow{2}{*}{$\begin{array}{c}\text { Tem- } \\
\text { pera- } \\
\text { ture, } \\
\circ \mathrm{F}\end{array}$} & \multirow{2}{*}{$\begin{array}{l}\text { Silica } \\
\left(\mathrm{SiO}_{2}\right)\end{array}$} & \multirow{2}{*}{$\begin{array}{l}\text { Iron } \\
(\mathrm{Fe})\end{array}$} & \multirow{2}{*}{$\begin{array}{c}\text { Man- } \\
\text { ganese } \\
\text { (Mn) }\end{array}$} & \multirow{2}{*}{$\begin{array}{l}\text { Cal- } \\
\text { clum } \\
(\mathrm{Ca})\end{array}$} & \multirow{2}{*}{$\begin{array}{c}\text { Mag- } \\
\text { ne- } \\
\text { sium } \\
(\mathrm{Mg})\end{array}$} & \multirow{2}{*}{$\begin{array}{l}\text { Sodi- } \\
\text { um } \\
(\mathrm{Na})\end{array}$} & \multirow{2}{*}{$\begin{array}{c}\text { Potas- } \\
\text { sium } \\
(\mathbf{K})\end{array}$} & \multirow{2}{*}{$\begin{array}{c}\text { Bicar- } \\
\text { bonate } \\
\left(\mathrm{HCO}_{3}\right)\end{array}$} & \multirow{2}{*}{$\begin{array}{c}\text { Sul- } \\
\text { fate } \\
\left(\mathrm{SO}_{4}\right)\end{array}$} & \multirow{2}{*}{$\begin{array}{l}\text { Chlo- } \\
\text { ride } \\
\text { (Cl) }\end{array}$} & \multirow{2}{*}{$\begin{array}{l}\text { Fluo- } \\
\text { ride } \\
\text { (F) }\end{array}$} & \multirow{2}{*}{$\begin{array}{c}\mathrm{Ni}- \\
\text { trate } \\
\left(\mathrm{NO}_{3}\right)\end{array}$} & \multirow{2}{*}{$\begin{array}{c}\text { Dis- } \\
\text { solved } \\
\text { solids }\end{array}$} & \multicolumn{2}{|c|}{$\underset{\mathrm{CaCO}}{\mathrm{Hardness}}$} & \multirow{2}{*}{$\mathrm{pH}$} \\
\hline & & & & & & & & & & & & & & & & & & Total & $\begin{array}{c}\text { Noncar- } \\
\text { bonate }\end{array}$ & \\
\hline
\end{tabular}

\section{Martinsburg shale}

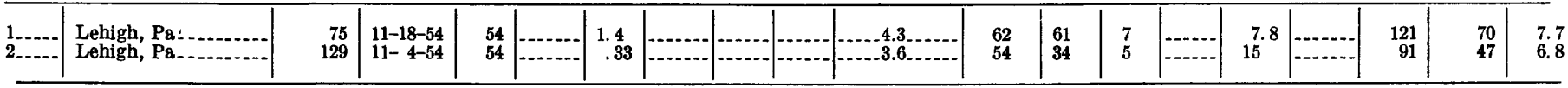

Catskill formation

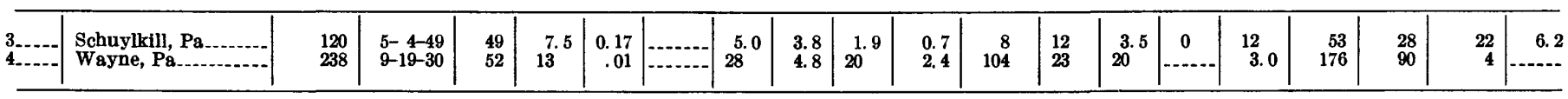

Lockatong formation

\begin{tabular}{|c|c|c|c|c|c|c|c|c|c|c|c|c|c|c|c|c|c|c|c|c|}
\hline $\begin{array}{l}5 \ldots \\
6 \ldots\end{array}$ & $\begin{array}{l}\text { Bucks, Pa } \\
\text { Bucks, Pa. }\end{array}$ & $\begin{array}{r}330 \\
-\end{array}$ & $\begin{array}{l}4-22-53 \\
4-16-53\end{array}$ & $\begin{array}{l}53 \\
53\end{array}$ & $\begin{array}{l}14 \\
13\end{array}$ & $\begin{array}{r}0.04 \\
.29\end{array}$ & $\mid$\begin{tabular}{l}
$\mid \cdots$ \\
\hdashline$-\cdots$
\end{tabular} & $\begin{array}{l}28 \\
50\end{array}$ & $\begin{array}{l}15 \\
15\end{array}$ & 15 & $\begin{array}{l}0.6 \\
1.2\end{array}$ & $\begin{array}{l}120 \\
174\end{array}$ & $\begin{array}{l}38 \\
54\end{array}$ & 16.0 & $\begin{array}{r}0.0 \\
.1\end{array}$ & $\begin{array}{r}2.1 \\
.1\end{array}$ & $\begin{array}{l}229 \\
274\end{array}$ & $\begin{array}{l}132 \\
186\end{array}$ & $\begin{array}{l}33 \\
\mathbf{4 4}\end{array}$ & $\begin{array}{l}7.4 \\
7.5\end{array}$ \\
\hline
\end{tabular}

Stockton formation

\begin{tabular}{|c|c|c|c|c|c|c|c|c|c|c|c|c|c|c|c|c|c|c|c|c|}
\hline $\begin{array}{l}7-\cdots- \\
8-\cdots-\end{array}$ & $\begin{array}{l}\text { Chester, } \mathrm{Pa} \\
\text { Montgomery, } \mathrm{Pa}_{-}\end{array}$ & 752 & $\begin{array}{l}6-7-56 \\
6-28-56\end{array}$ & & $\begin{array}{l}26 \\
30\end{array}$ & $\begin{array}{r}0.14 \\
.17\end{array}$ & $\begin{array}{r}0.01 \\
.00\end{array}$ & $\begin{array}{l}45 \\
59\end{array}$ & $\begin{array}{l}24 \\
17\end{array}$ & & $7 \ldots$ & $\begin{array}{l}127 \\
154\end{array}$ & $\begin{array}{r}123 \\
47\end{array}$ & 28.5 & $\begin{array}{r}0.1 \\
.1\end{array}$ & $\begin{aligned} & 2.7 \\
& 48\end{aligned}$ & $\begin{array}{l}346 \\
351\end{array}$ & $\begin{array}{l}211 \\
217\end{array}$ & $\begin{array}{r}107 \\
91\end{array}$ & $\begin{array}{l}8.1 \\
7.2\end{array}$ \\
\hline 9 & Bucks, Pa & 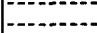 & $3-24-53$ & 54 & 18 & .66 &. .00 & 29 & 17 & 8.3 & .8 & 154 & 19 & 8.5 & .0 & 5.5 & 195 & 142 & 16 & 7.7 \\
\hline $10 \ldots$ & Bucks, $\mathbf{P a}$ & $-\ldots$ & $4-17-53$ & 54 & 15 & .04 & & 30 & 9.9 & 37 & 3. 5 & 48 & 72 & 54 & .0 & 16 & 304 & 116 & 76 & 6.0 \\
\hline $11 \ldots$ & Bucks, Pa & 227 & $4-9-53$ & 53 & 20 & .25 & $\ldots . .$. & 22 & 6.7 & 12 & 1 & 72 & 34 & 10 & .0 & 1.2 & 156 & 82 & 23 & 6.3 \\
\hline $12 \ldots$ & Mercer, N.J. & 372 & $9-27-49$ & $\ldots . .$. & 27 & .03 & $\ldots . .$. & 27 & 6.8 & 12 & 1.7 & 88 & 20 & 11 & .0 & 12 & 158 & 95 & 28 & 6.7 \\
\hline
\end{tabular}

Brunswick formation

\begin{tabular}{|c|c|c|c|c|c|c|c|c|c|c|c|c|c|c|c|c|c|c|c|c|}
\hline $\begin{array}{l}13 . \ldots- \\
14 \ldots \\
15 \ldots \\
16 \ldots\end{array}$ & $\begin{array}{l}\text { Montgomery, } \mathbf{P a} \\
\text { Bucks, } \mathbf{P a} \\
\text { Bucks, } \mathbf{P a} \\
\text { Bucks, } \mathbf{P a}\end{array}$ & $\begin{array}{l}100 \\
300 \\
303 \\
511\end{array}$ & $\begin{array}{l}4-21-49 \\
3-25-53 \\
4-7-53 \\
9-8-53\end{array}$ & $\begin{array}{l}54 \\
52 \\
53 \\
56\end{array}$ & $\begin{array}{l}20 \\
22 \\
19 \\
17\end{array}$ & $\begin{array}{l}0.17 \\
1.3 \\
1.1 \\
.04\end{array}$ & 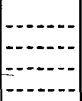 & $\begin{array}{l}\mathbf{5 2} \\
\mathbf{7 7} \\
\mathbf{3 7} \\
\mathbf{4 9}\end{array}$ & $\begin{array}{l}13 \\
18 \\
16 \\
14\end{array}$ & $\begin{array}{l}11 \\
13 \\
13 \\
26\end{array}$ & $\begin{array}{l}1.4 \\
1.0 \\
1.8 \\
.6\end{array}$ & $\begin{array}{l}198 \\
164 \\
172 \\
156\end{array}$ & $\begin{array}{r}23 \\
144 \\
31 \\
53\end{array}$ & $\begin{array}{l}7.0 \\
7.0 \\
10 \\
22\end{array}$ & $\begin{array}{r}0.0 \\
.3 \\
.1 \\
.1\end{array}$ & $\begin{array}{c}12 \\
2.8 \\
1.8 \\
21\end{array}$ & $\begin{array}{l}\mathbf{2 4 2} \\
381 \\
217 \\
\mathbf{3 1 1}\end{array}$ & $\begin{array}{l}183 \\
266 \\
158 \\
180\end{array}$ & $\begin{array}{r}21 \\
132 \\
117 \\
52\end{array}$ & $\begin{array}{l}7.5 \\
7.7 \\
7.4 \\
7.7\end{array}$ \\
\hline
\end{tabular}

Carbonate rocks

\begin{tabular}{|c|c|c|c|c|c|c|c|c|c|c|c|c|c|c|c|c|c|c|c|c|}
\hline 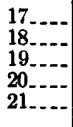 & $\begin{array}{l}\text { Lanicaster, Pa } \\
\text { Bucks, } \mathbf{P a} \\
\text { Lehigh, } \mathbf{P a} \\
\text { Lehigh, } \mathbf{P a} \\
\text { Lehigh, } \mathbf{P a}\end{array}$ & $\begin{array}{r}105 \\
175 \\
100 \\
34\end{array}$ & $\begin{array}{l}9-24-25 \\
4-14-53 \\
5-15-53 \\
5-12-53 \\
1-6-55\end{array}$ & $\begin{array}{l}54 \\
58 \\
52 \\
50\end{array}$ & $\begin{array}{r}7.9 \\
7.2 \\
9.8 \\
6.0 \\
-.-\end{array}$ & $\begin{array}{r}0.10 \\
.08 \\
.01 \\
.02 \\
.63\end{array}$ & 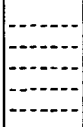 & 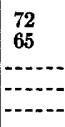 & 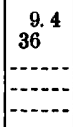 & \begin{tabular}{l}
11 \\
18 \\
\hdashline-6 \\
\hdashline-9
\end{tabular} & $\begin{array}{r}7.1 \\
2.2 \\
6.5 \\
-3.5 \\
-4.2 \\
\end{array}$ & $\begin{array}{l}217 \\
312 \\
134 \\
108 \\
258\end{array}$ & $\begin{array}{c}30 \\
15 \\
2.3 \\
8.4 \\
92\end{array}$ & $\begin{array}{l}22 \\
46 \\
4.0 \\
4.5 \\
7\end{array}$ & 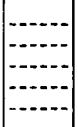 & $\begin{array}{l}1.0 \\
22 \\
10^{.3} \\
15\end{array}$ & \begin{tabular}{r|}
290 \\
397 \\
\\
\hdashline-0 \\
-2
\end{tabular} & $\begin{array}{l}219 \\
310 \\
104 \\
104 \\
320\end{array}$ & $\begin{array}{r}40 \\
55 \\
0 \\
16 \\
109\end{array}$ & $\begin{array}{l}7.0 \\
7.8 \\
7.7 \\
7.4\end{array}$ \\
\hline
\end{tabular}

\begin{tabular}{|c|c|c|c|c|c|c|c|c|c|c|c|c|c|c|c|c|c|c|c|c|}
\hline \multicolumn{21}{|c|}{ Diabase } \\
\hline $\begin{array}{ll}22 \\
23 \\
24\end{array}-\ldots$ & $\begin{array}{l}\text { Montgomery, Pa } \\
\text { Bucks, } \mathbf{P a} \\
\text { Bucks, Pa }\end{array}$ & $\begin{array}{r}350 \\
765 \\
70\end{array}$ & $\begin{array}{l}4-21-49 \\
4-8-53 \\
4-20-53\end{array}$ & 55 & $\begin{array}{l}31 \\
25 \\
18\end{array}$ & $\begin{array}{r}1.0 \\
.4 \\
1.4\end{array}$ & 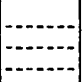 & $\begin{array}{l}22 \\
94 \\
48\end{array}$ & $\begin{array}{c}9.6 \\
9.1 \\
15\end{array}$ & $\begin{array}{r}6.1 \\
4.4 \\
11\end{array}$ & $\begin{array}{l}0.9 \\
1.0 \\
2.3\end{array}$ & $\begin{array}{r}78 \\
126 \\
196\end{array}$ & $\begin{array}{r}25 \\
169 \\
34\end{array}$ & $\begin{array}{r}12 \\
2.2 \\
8.5\end{array}$ & $\begin{array}{r}0.1 \\
.1 \\
.1\end{array}$ & $\begin{array}{l}0.2 \\
.3 \\
3.7\end{array}$ & $\begin{array}{l}144 \\
398 \\
247\end{array}$ & $\begin{array}{r}94 \\
272 \\
181\end{array}$ & $\begin{array}{r}31 \\
169 \\
21\end{array}$ & $\begin{array}{l}7.2 \\
7.5 \\
7.3\end{array}$ \\
\hline
\end{tabular}

\begin{tabular}{|c|c|c|c|c|c|c|c|c|c|c|c|c|c|c|c|c|c|c|c|c|}
\hline $\begin{array}{l}25 \ldots \\
26 \ldots \\
27 \ldots- \\
28 \\
29 \\
\ldots \ldots\end{array}$ & $\begin{array}{l}\text { Chester, Pa } \\
\text { Bucks, Pa } \\
\text { Bucks, Pa } \\
\text { Lehigh, Pa. } \\
\text { Lehigh, Pa. }\end{array}$ & $\begin{array}{r}84 \\
226 \\
198 \\
250 \\
90\end{array}$ & $\begin{array}{r}9-25-25 \\
9-7-53 \\
4-9-53 \\
12-2-54 \\
12-7-54\end{array}$ & $\begin{array}{r}53 \\
54 \\
53 \\
53\end{array}$ & \begin{tabular}{c}
31 \\
8.7 \\
15 \\
\hdashline- \\
\hdashline-
\end{tabular} & $\begin{array}{l}0.31 \\
.29 \\
1.1 \\
.61 \\
1.5\end{array}$ & 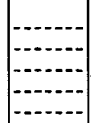 & \begin{tabular}{c}
4.7 \\
2.9 \\
18 \\
\hdashline- \\
\hdashline-1
\end{tabular} & \begin{tabular}{|c|}
2.3 \\
1.3 \\
7.0 \\
\hdashline.-- \\
.--
\end{tabular} & $\mid$\begin{tabular}{c}
4.3 \\
5.0 \\
16 \\
\hdashline-.2. \\
\hdashline.--2
\end{tabular} & $\begin{array}{l}0.9 \\
1.3 \\
3.3 \\
-\end{array}$ & $\begin{array}{r}30 \\
8 \\
106 \\
45 \\
29\end{array}$ & $\begin{array}{r}3.7 \\
.3 \\
9.5 \\
5.6 \\
29\end{array}$ & $\begin{array}{l}2.1 \\
7.0 \\
8.0 \\
1 \\
1\end{array}$ & $\begin{array}{r}0.0 \\
.1 \\
-2 \\
-0\end{array}$ & $\begin{array}{r}1.5 \\
7.9 \\
5.8 \\
3.1 \\
14\end{array}$ & $\begin{array}{r}67 \\
51 \\
138 \\
\hdashline---\end{array}$ & $\begin{array}{l}21 \\
13 \\
74 \\
41 \\
62\end{array}$ & $\begin{array}{r}0 \\
6 \\
0 \\
4 \\
38\end{array}$ & $\begin{array}{l}5.4 \\
6.8 \\
7.9 \\
6.6\end{array}$ \\
\hline
\end{tabular}

\section{Chickies quartzite}

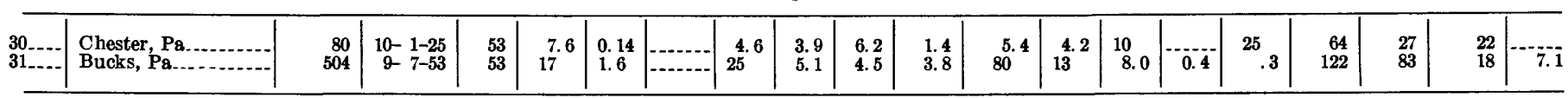

\begin{tabular}{|c|c|c|c|c|c|c|c|c|c|c|c|c|c|c|c|c|c|c|c|c|}
\hline \multicolumn{21}{|c|}{ Wissahickon formation } \\
\hline 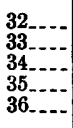 & $\begin{array}{l}\text { New Castle, Del } \\
\text { Chester, Pa } \\
\text { Delaware, Pa. } \\
\text { Bucks, Pa.... } \\
\text { Bucks, Pa... }\end{array}$ & $\begin{array}{r}110 \\
184 \\
48 \\
300 \\
90\end{array}$ & $\begin{array}{l}1-19-56 \\
9-21-25 \\
9-26-25 \\
4-28-53 \\
1-21-54\end{array}$ & $\begin{array}{c}51 \\
-54 \\
57 \\
58\end{array}$ & $\begin{array}{l}18 \\
23 \\
28 \\
24 \\
20\end{array}$ & $\begin{array}{l}0.04 \\
.11 \\
4.1 \\
3.4 \\
.15\end{array}$ & 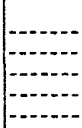 & $\begin{array}{l}11 \\
5.4 \\
11 \\
4.1 \\
14\end{array}$ & $\begin{array}{l}4.0 \\
4.6 \\
4.2 \\
1.7 \\
8.3\end{array}$ & $\begin{array}{l}3.7^{5} \\
5.8 \\
8.3 \\
7.4\end{array}$ & $\begin{array}{l}1.6 \\
1.4 \\
2.4 \\
2.8\end{array}$ & $\begin{array}{l}35 \\
22 \\
43 \\
26 \\
26\end{array}$ & $\begin{array}{r}11 \\
5.0 \\
4.3 \\
9.1 \\
18\end{array}$ & $\begin{array}{r}7 \\
4.0 \\
5.2 \\
5.4 \\
16\end{array}$ & $\begin{array}{r}0.0 \\
\hdashline .1 \\
\hdashline .1\end{array}$ & $\begin{array}{l}7.6 \\
16^{7} \\
34^{3}\end{array}$ & $\begin{array}{r}87 \\
74 \\
85 \\
72 \\
154\end{array}$ & $\begin{array}{l}44 \\
32 \\
45 \\
17 \\
69\end{array}$ & $\begin{array}{r}15 \\
9 \\
14 \\
0 \\
48\end{array}$ & \begin{tabular}{r}
6.3 \\
\hdashline 5.9 \\
6.9
\end{tabular} \\
\hline
\end{tabular}


of about $35,000 \mathrm{ppm}$. Because it is heavier and denser than fresh water, salt water typically lies in a blunt-nosed wedge in the bottom of tidal channels and fills the immediately underlying aquifers in narrow prisms beneath the channels. In the Delaware estuary, however, turbulence from tidal and river currents, the rough bottom, and the propeller wash from ships mix the fresh and salt water to a considerable degree.

In aquifers, turbulence occurs only close to some large-capacity pumped wells and perhaps in solution channels in limestone or lava tubes in basalt where high gradients exist. Turbulence is much less common in aquifers than in streams, and in shore areas salty ground water tends to remain unmixed with fresh water and to underlie it (Parker, 1955, p. 615-635). In permeable materials the relation of salt water to fresh water is governed largely by the Ghyben-Herzberg principle. This principle, in effect, states that because salt water is $41 / 40$ as heavy as fresh water, a column of fresh water 41 feet high is required in a U-tube to counterbalance a column of salt water 40 feet high. To apply the rule to a coastal aquifer, given 1 foot of fresh water above sea level, the top of the salt water will occur at approximately 40 feet below sea leve]; given 2 feet of fresh water, the salt water would be about 80 feet below sea level, and so on.

However, the relation of fresh to salt water in aquifers is dynamic and is not the simple static relation expressed by the Ghyben-Herzberg principle. All the factors involved in the dynamic situation have not yet been defined adequately, but they are being studied intensively by the U.S. Geological Survey, the University of California, and others. Some of these factors are: 1. Molecular diffusion in the interface zone which tends to dissipate the encroaching salt-water wedge.

2. Alternate tidal thrust and pull in and near the shore zone which mixes fresh and salt water in the aquifer and widens and thickens the zone between the fresh water and the salt water.

3. Fresh-water flow over the salty wedge, which exerts a slight downward pressure but acts principally as an eroding force (Parker and others, 1955, p. 612 ) that sweeps the tidally mixed and diffused salt water seaward. This action is believed to be especially effective during the falling stage of the tidal cycle, when the main body of the salt-water wedge not only moves seaward but also loses height throughout the area from which it withdraws.

The Ghyben-Herzberg principle cannot be applied without making due allowance for the preceding factors. However, the 1:40 ratio of the Ghyben-Herzberg principle is a safe factor to apply in the development or conservation of water supplies in coastal aquifers, because the depth to salt water will be somewhat greater than that predicted on a 1:40 ratio, and, likewise, the amount of inland encroachment of an intruding salt-water wedge will be somewhat less.

In general accord with the Ghyben-Herzberg principle, with modifications imposed by dynamic conditions, the interface between fresh water and salt water has become established in each aquifer at a position that depends largely on the hydraulic head in the aquifer. The position of the interface is different in each aquifer, and, particularly if the aquifer is thick, the salt water extends farther inland in the lower part of the aquifer than in the upper part.

Salt-water encroachment eventually occurs in an aquifer when the fresh-water head near the interface is lowered relative to that of the salt water. The hydraulic head may be lowered by pumping, by construction of canals or drainage facilities, by rise of sea level, or in other ways. This situation has occurred at several places in the coastal parts of New Jersey and Delaware, particularly in shallow aquifers that are in direct contact with salt-water bodies.

For example, at Lewes, Del., salt water encroached into the municipal well field from the Lewes-Rehoboth Canal when the pumping rate was increased during World War II, and the original well field had to be abandoned (Marine and Rasmussen, 1955, p. 138). New well supplies distant from the canal were quickly developed and were still being used in 1958. Meanwhile, ground water in the old well field freshened as recharge from precipitation flushed the salty water out of the aquifer. However, if the old wells were to be used heavily again, salt water would encroach upon them again.

The actual inland extent of salt water is not accurately known for most of the Coastal Plain aquifers of New Jersey and Delaware, particularly for the lower aquifers. In Figures 31-33 the location of the $250 \mathrm{ppm}$ isochlor is shown for the nonmarine sediments of Cretaceous age, the Kirkwood formation, and the Cohansey sand and Quaternary deposits, respectively. The interface of salt and fresh water probably is not far seaward from the $250 \mathrm{ppm}$ isochlor; this isochlor may be considered the limit of sea-water encroachment. Water with as much as $250 \mathrm{ppm}$ of chloride is unsatisfactory for many uses. High concentrations of chloride may be objectionable in make-up water for steam boilers, in water for such industrial uses as brewing or textile processes, the manufacture of sugar or carbonated beverages, or in water for irrigation. The U.S. Public Health Service standards (1946) recommend that drinking water should not contain more than 250 ppm of chloride.

In the nonmarine sediments of Cretaceous age (fig. 31) the $250 \mathrm{ppm}$ isochlor is a line crossing New Jersey 
diagonally from a few miles south of Toms River to a point a few miles south of Salem and into Delaware near Odessa. This position represents the hypothetical interface about midway in the unit as estimated by Barksdale and others (1958, fig. 18). Salt water may extend farther inland in the lower aquifers, and available evidence indicates that fresh water extends at least several miles farther seaward in the uppermost aquifers (p. 63).

The next major aquifer group above the nonmarine sediments of Cretaceous age in New Jersey is the Kirkwood formation. This formation contains the aquifer called the " 800 -foot sand," which is especially utilized along the shore at Atlantic City. The map (fig. 32) shows two areas along the ocean where the Kirkwood yields water containing more than 250 ppm of chloride. One is at the tip of Cape May peninsula, the other in the vicinity of Manasquan and Point Pleasant. Between these two areas the hydraulic head has been sufficient to hold sea water in the Kirkwood some distance seaward of the present shore. Thompson (1928, p. 70-74) calculated that this interface of salt and fresh water in the Kirkwood was at least 7 miles offshore at Atlantic City in 1928. Highchloride water also is probably present in the Kirkwood in a narrow zone adjacent to the Delaware River near Salem, N.J.

The next important aquifer, or aquifer group, above the Kirkwood formation is the Cohansey sand. This formation, in the Atlantic City area, contains the " 100 foot" and the "200-foot" sands (Barksdale and others, 1936, p. 52-91. For convenience, aquifers in the overlying Quaternary deposits are here grouped with the Cohansey sand except in New Jersey northwest of the outcrop of the Cohansey; the chloride concentration in the Quaternary deposits is not mapped in fig. 33. The Cohansey (fig. 33) contains water of $250 \mathrm{ppm}$ chloride or more in a narrow zone bordering the sea coast and Delaware Bay and including the offshore bars and islands.

Wells in the high-chloride regions yield water containing more than $250 \mathrm{ppm}$ chloride, owing to salt-water encroachment. Wells to the landward of the $250 \mathrm{ppm}$ isochlor yield water containing less than $250 \mathrm{ppm}$ chloride, but if larger quantities of water were pumped from wells near the salt-water interface, the interface would more farther inland.

Chloride contamination from sea water or other sources is indicated when the ground water has a greater than normal chloride concentration for the region. In Delaware, a concentration of $25 \mathrm{ppm}$ chloride is used as an index of chloride contamination, and in New Jersey $10 \mathrm{ppm}$ is used. Figures 31-33 shows zones in which chloride concentration is moderate and those in which it is high. (greater than $250 \mathrm{ppm}$ ).

In the nonmarine sediments of Cretaceous age this zone of moderate concentration (fig. 31) includes areas in Gloucester and Salem Counties, N.J., a narrow zone along both banks of the Delaware River as far north as Trenton, and smaller areas in Delaware underlying Wilmington, Delaware City, and Newark. All these areas are industrialized and the chloride contamination may result from pollution by industrial wastes, leaky sewers, or by encroachment of river water owing to large-scale pumping. Most of the Kirkwood formation (fig. 32) in Cape May County, N.J., except the southern tip, yields water containing $10-250 \mathrm{ppm}$ chloride; in Delaware an area bordering Delaware Bay, including Smyrna, Cheswold, and Dover, yields water with $25-250 \mathrm{ppm}$ chloride. The regions of moderate chloride concentration of water from the Cohansey sand and overlying Quaternary deposits are shown in figure 33 . They include most of Cape May County, N.J. (except the highchloride parts), a region in Delaware south of Cape Henlopen, and a narrow zone bordering the Delaware River, the ocean, or the high-chloride region. These aquifers are near the surface and subject to contamination from soluble materials on the land surface; in places they are also in hydraulic contact with the Delaware River.

From known instances of salt-water encroachment, we may see ways in which future encroachment could occur and thus devise ways to prevent it. Largescale pumping adjacent to salt-water bodies has threatened with encroachment or already caused the loss of once-used wells or well fields in Newark, Perth Amboy, South Amboy, Sayreville, Asbury Park, Atlantic City, Cape May, and Penns Grove-all in New Jersey-and Lewes and Rehoboth Beach in Delaware. In Newark, N.J., heavy pumping has induced salt-water encroachment from Newark Bay and the Passaic River. Dredging the ship channels in these salt-water bodies breached the imperfect seal of Recent and, in some places, Pleistocene silt and clay (Herpers and Barksdale, 1951, p. 50) thus exposing the permeable sand and gravel directly to salt water. No doubt this accelerated the movement of salt water into the aquifer as effectively as an increase in hydraulic head. Such a possibility should be seriously considered in connection with the dredging of canals or other channels subject to tidal action. Such dredging would undoubtedly facilitate the movement of water from the river into the aquifers, or vice versa, according to the relative hydraulic heads. No harmful results could accrue -in fact benefits would resultfrom such dredging if the quality of the water were to be maintained in a satisfactory condition. But if the 


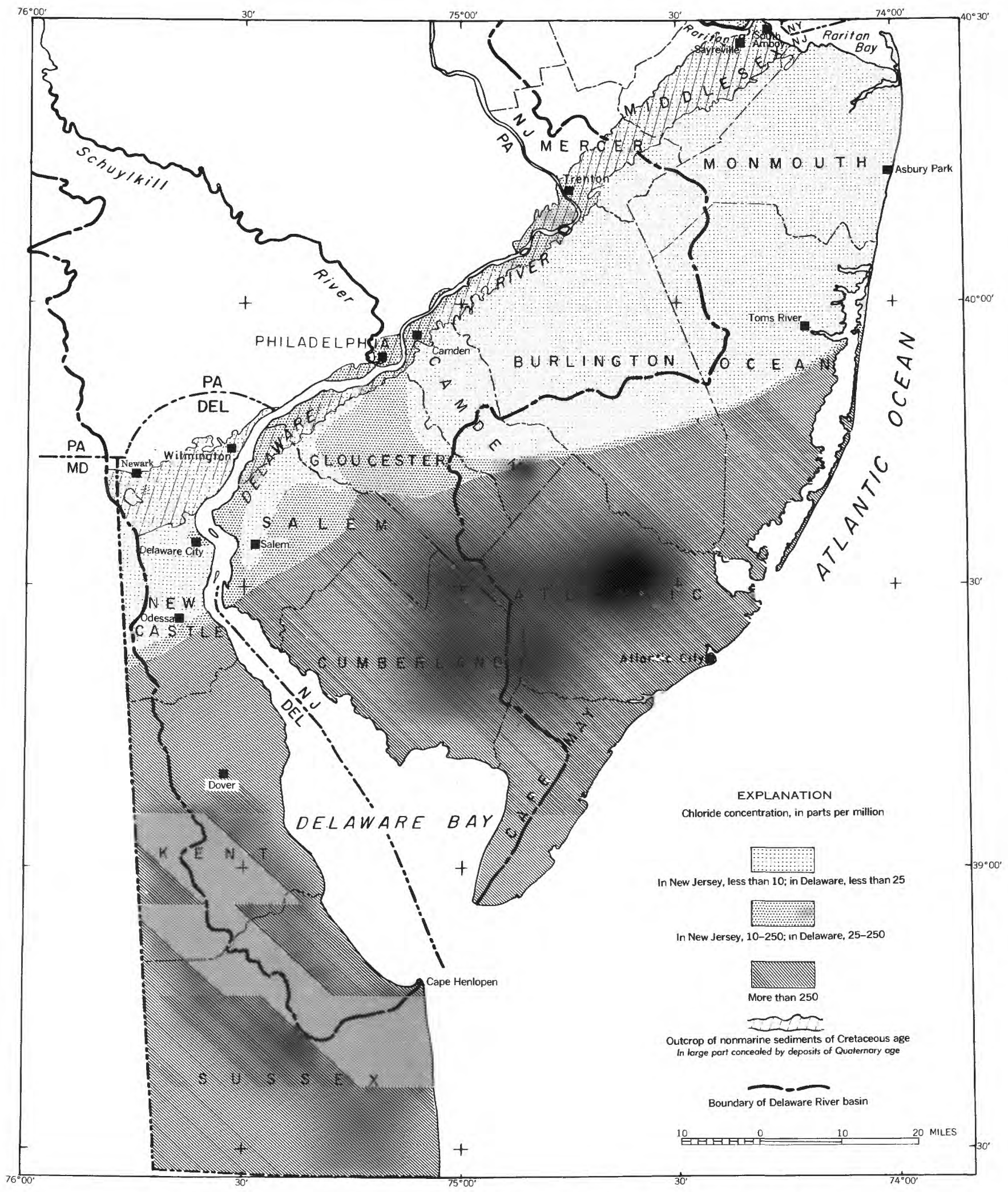

FIGURE 31.-Map showing chloride concentration of water in nonmarine sediments of Cretaceous age, 1957. 


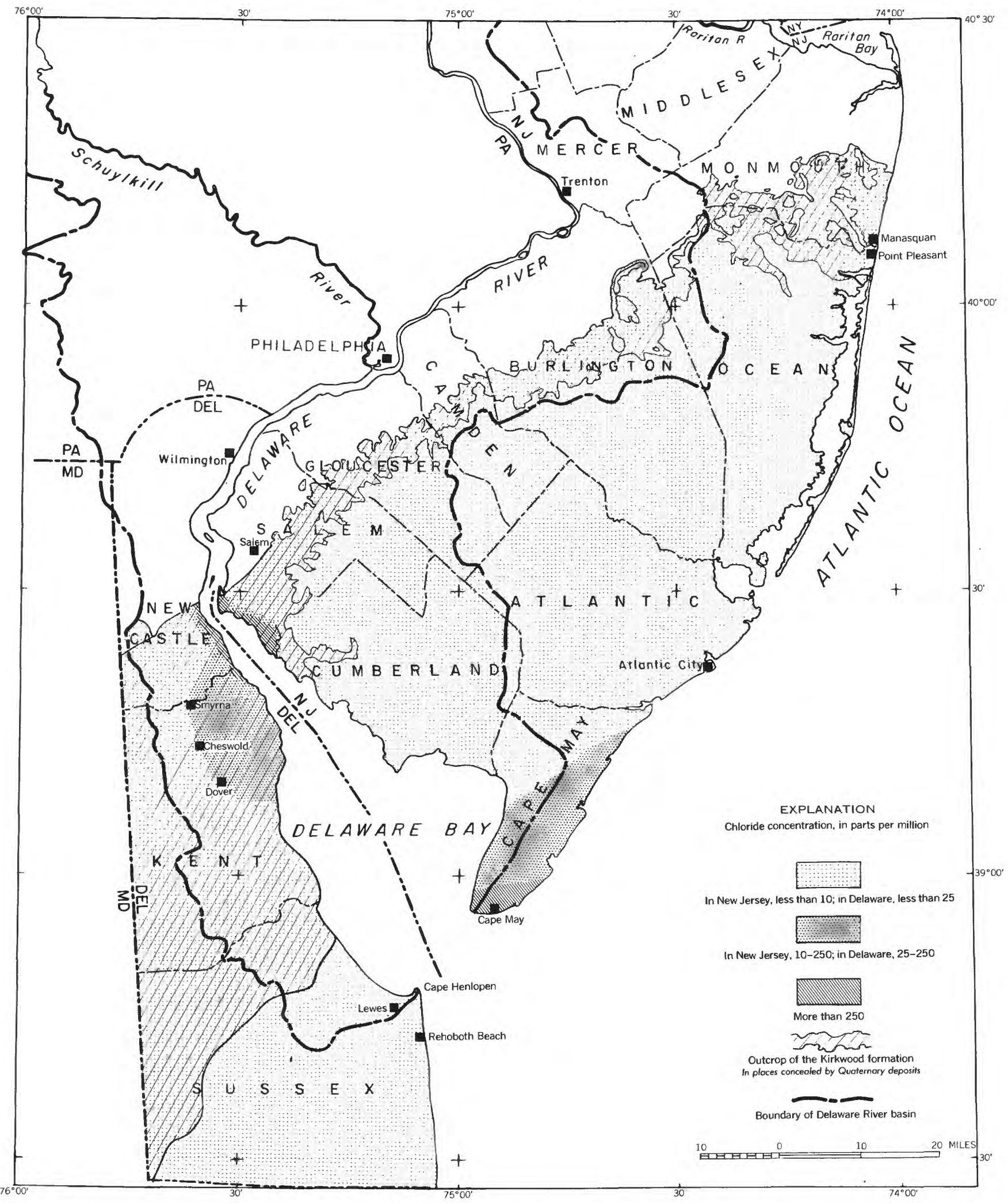

Figure 32.-Map showing chloride concentration of water in Kirkwood formation, 1957. 


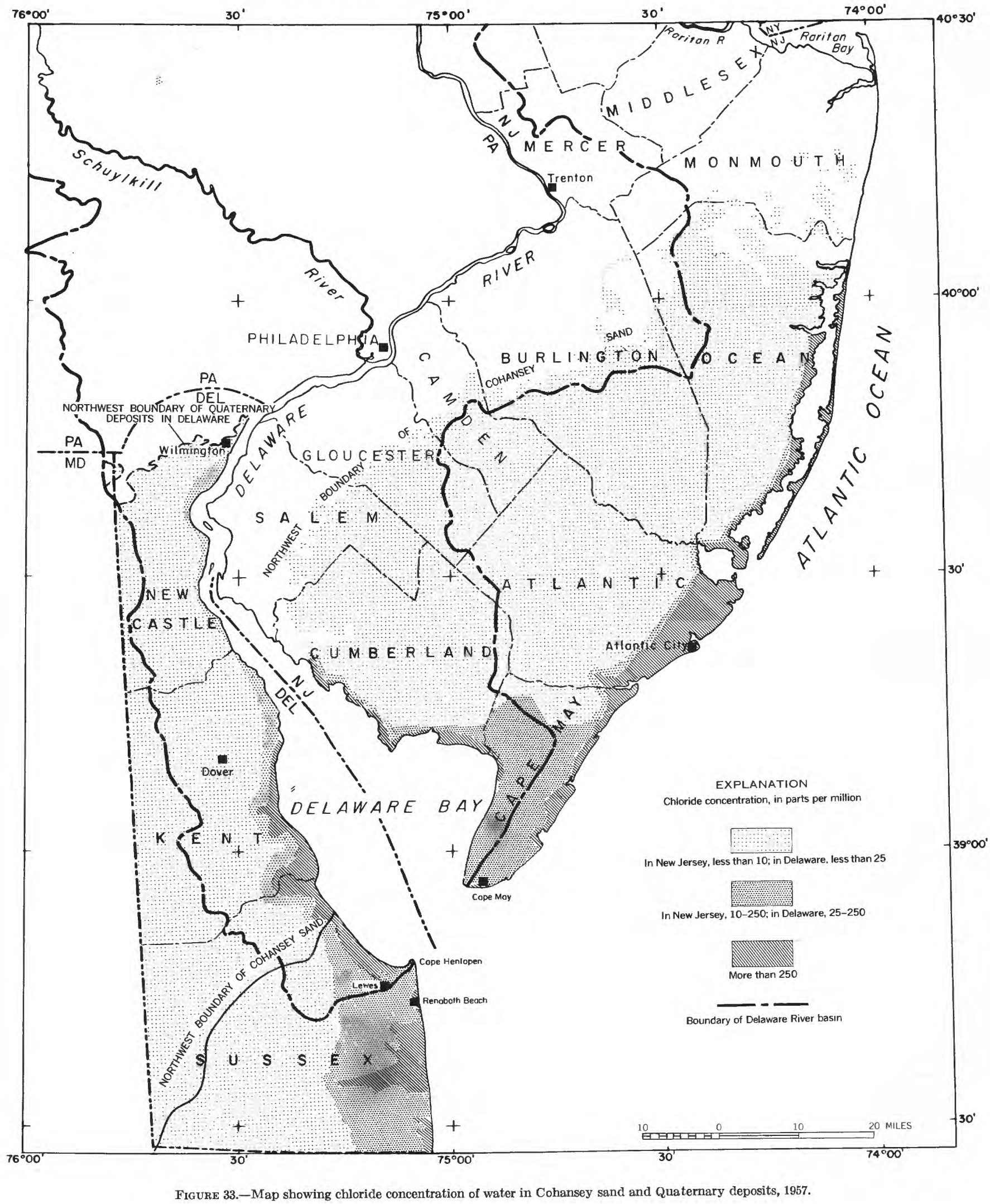


deepened and widened channel becomes an inland extension of the sea, or if pollutants are allowed to spoil the river water, the deepened channel would provide easy avenues of entrance to the aquifers, and the ground-water supplies would be endangered, if not ruined for most uses.

Much of the chloride in the strip on either side of the Delaware estuary, especially the reach upstream from the mouth of the Schuylkill River, is not derived from sea water but from industrial and municipal wastes. The shallow aquifer in South Philadelphia, especially in the vicinity of the U.S. Navy Yard and, reaching under the river, across to Camden, is rapidly becoming useless for most purposes except cooling.

How may the fresh-water supplies be best protected against damage or ruin by salt-water encroachment? The answer is not a simple one, because the problem itself is complex. First a better understanding of local conditions in all aquifers and related surfacewater bodies that have a bearing on the salt-water problem must be achieved. Comprehensive information is necessary for the whole Coastal Plain similar to, but even more detailed than that now available for the Atlantic City area. This information concerning the local geology and hydrology must include the depth, thickness, and effectiveness of aquifers and aquicludes; the hydraulic heads, and water-table or piezometric maps depicting these hydraulic heads; the variation of chloride in the aquifers, with isochlor maps constructed periodically, perhaps semiannually in some areas, and annually in others; other similar or related data, including changes of chloride content in, and of stage and flow of, surface-water bodies.

Given this essential background of permanent, chiefly geologic data and changing hydrologic and chemical quality data, local or State authorities would be in a position to enact and put into effect the required controls.

\section{SURFACE WATER-ITS VARIATIONS AND CHARACTER}

Surface water-water in streams, lakes, swamps, estuaries, and bays-is the source of about 95 percent of the water withdrawn for all uses in the Delaware River basin. Ground-water supplies may provide a larger part of the total in the future, but it is certain that surface water will always be the major source. Streamflow is the most important of these sources because the quality of the water in bays limits its use to certain industrial applications. The lakes and swamps are usually parts of stream systems and contribute to their storage capacity.

Streamflow is derived from the precipitation that falls within the basin boundaries. Unregulated streamflow is usually divided into two parts: (1) direct run- off-water that reaches stream channels quickly after a period of precipitation or snowmelt; and (2) base flow-water that reaches the channels much later either as ground-water discharge or as release from surface storage. Streamflow is one of the few parts of the hydrologic cycle for which direct measurements of the quantities involved can be made. It also is usually the part most susceptible to large-scale development and control.

The average annual precipitation on the Delaware River basin is about 44 inches, of which about 21 inches, or 4.7 trillion gallons, becomes streamflow.

The runoff varies markedly in both time and place. Average annual values range from about 14 inches in the southern part of the basin and adjacent parts of Delaware to about 42 inches in the Catskill Mountains. The variation in time is even greater, and the amount of variation differs in different parts of the basin. The following discussion and illustrations describe and summarize the streamflow and its variations. In most cases the data are for natural streamflow, but in several cases they are for regulated flows representing the status of stream development or use which existed for most of the period of record.

"Streamflow" is the actual flow in a natural stream course, and "runoff" is streamflow unaffected by artificial diversion, storage, or other works of man on the stream channel. Thus, for natural flow the terms, "discharge," "streamflow," and "runoff" are synonymous, but if the discharge for a particular period is affected by regulation, the term "runoff" should not be used. However, it is sometimes possible to compute runoff by adjusting streamflow figures for the effects of storage or diversion. Streamflow and runoff are often expressed in percent of mean (or as a ratio to the mean) to make the results from different streams more nearly equivalent regardless of size of drainage area or of variations in mean annual runoff.

In this report the term "runoff" is generally used for natural, or unregulated flow, especially when making comparisons with precipitation or water loss; the term "discharge" is used for the observed values of flow in a channel, especially when the magnitude of the flow at a point is considered.

A map of the Delaware River basin and New Jersey (pl. 10) shows the latest locations of the stations where surface-water records were obtained to September 30,1955 . Symbols indicate the sites where records of gage height and streamflow, chemical quality, suspended sediment, and water temperature were obtained. The numbers accompanying the symbols on the map are index numbers to aid in identifying and locating stations referred to in this report. The numbering follows the downstream order used since 1950 
by the Geological Survey (U.S. Geol. Survey, Annual reports on surface-water supply of the U.S.). Locations of many stations may have been changed at some time, but if the records are considered to be equivalent, the locations are shown by a single symbol.

Table 22 is a bar graph, showing the name, drainage area, and period of record for the locations shown on plate 10. Parts of names enclosed in parentheses indicate forms used in some earlier publications. Systematic collection of streamflow data in this area was begun about 1884, but it was not until about 1921 that a reasonably satisfactory network of stations was in operation. Collection of data on quality of water and sediment loads was practically negligible until about 1945 .

The drainage areas shown in table 22 are those for the locations on September 30,1955, or at the time of discontinuance. In other tables in this report the areas used are the ones for the sites used for most or all of the period involved. A few slight differences occur between the tables because of changes in locations of the gages.

Most of the data in table 22 were obtained from the index prepared by Knox (1956), but records for some periods not included in that index were computed later and are included in table 22.

\section{SUMMARY OF AVERAGE ANNUAL RUNOFF}

A summary of streamflow data for an area should be based on records that are comparable. Therefore, records of observed annual runoff that are affected by known diversions or changes in storage in large reservoirs were adjusted to indicate approximately the runoff that would have occurred under natural conditions. Evaporation and seepage losses from reservoirs are usually greater than natural water losses from the land areas; such increases are not included in the adjustments.

Because annual runoff may be below average for several consecutive years and above average for others, the averages computed for different periods are not comparable. For this report, the period 1921-50, which was used for computing average annual precipitation, was adopted as the standard for computing all values of average annual discharge and runoff when comparable values were needed. There is an offset of 3 months in the period used for runoff because precipitation data are based on calendar years and runoff data on water years, ending September 30 . This offset, however, is insignificant in a 30 -year period.

If annual runoff for the years in a short record for a given station is plotted against corresponding years in a 30-year record for a nearby station, a simple correlation is defined. Annual runoffs for other periods are then assumed to have the same relation to each other as in the correlation period. Double-mass analysis, a modification of this simple correlation technique, was used to adjust all means for periods less than 30 years to the mean for the standard period.

In making this adjustment, annual runoffs for groups of three long-term records were averaged and the 30year average for the group was computed. This procedure minimizes the effect of random occurrences of unusual runoff events which might affect the averages for individual stations. Seven such groups were selected. Cumulative annual runoff for the individual stations in the area represented by each group was then plotted against the cumulative annual runoff for the group. If correlation between the records is good, the resulting points define straight lines, and the slopes of these lines determine the relation between 30-year a verages for the individual stations and the group averages. Any change in the correlation during the period of record is indicated by a change in slope of the line. Such a change might be due to errors in streamflow records or to change in diversion of water from the area above the station but no corresponding adjustment in the published records. Therefore, the technique provides a check on consistency (not accuracy) of the records as well as a method of adjusting average annual runoff to the standard period.

Streamflow data for the Delaware River basin and New Jersey are summarized in table 23, which contains comparable values for the water years 1921-50. Values of average annual precipitation on the drainage areas (furnished by the U.S. Weather Bureau) and of the water loss, that is, the difference between precipitation and runoff, are also shown.

Plate 11 shows the principal streams of the area and the approximate average discharge. The area along the Delaware River below Trenton, N.J. (shaded on pl. 11), is a tidal reach and its discharge is computed by adding to the measured discharge at Trenton both the measured discharge of principal tributaries below Trenton and the estimated discharge from ungaged areas. The average discharge of the Delaware River at a point below Christina River, at Wilmington, Del., is about $17,000 \mathrm{cfs}$.

\section{AREAL VARIATIONS IN AVERAGE ANNUAL RUNOFF}

The areal variations in runoff, evident in table 23, are displayed to better advantage and in more detail in plate 12, a map showing lines of equal average annual runoff.

Although table 23 includes only stations that have at least 8 years of record within the standard period, the 30 -year average was computed for several additional stations having shorter records within the standard period by utilizing streamflow records for 1951-53 to help define their relations. Runoff from larger areas 


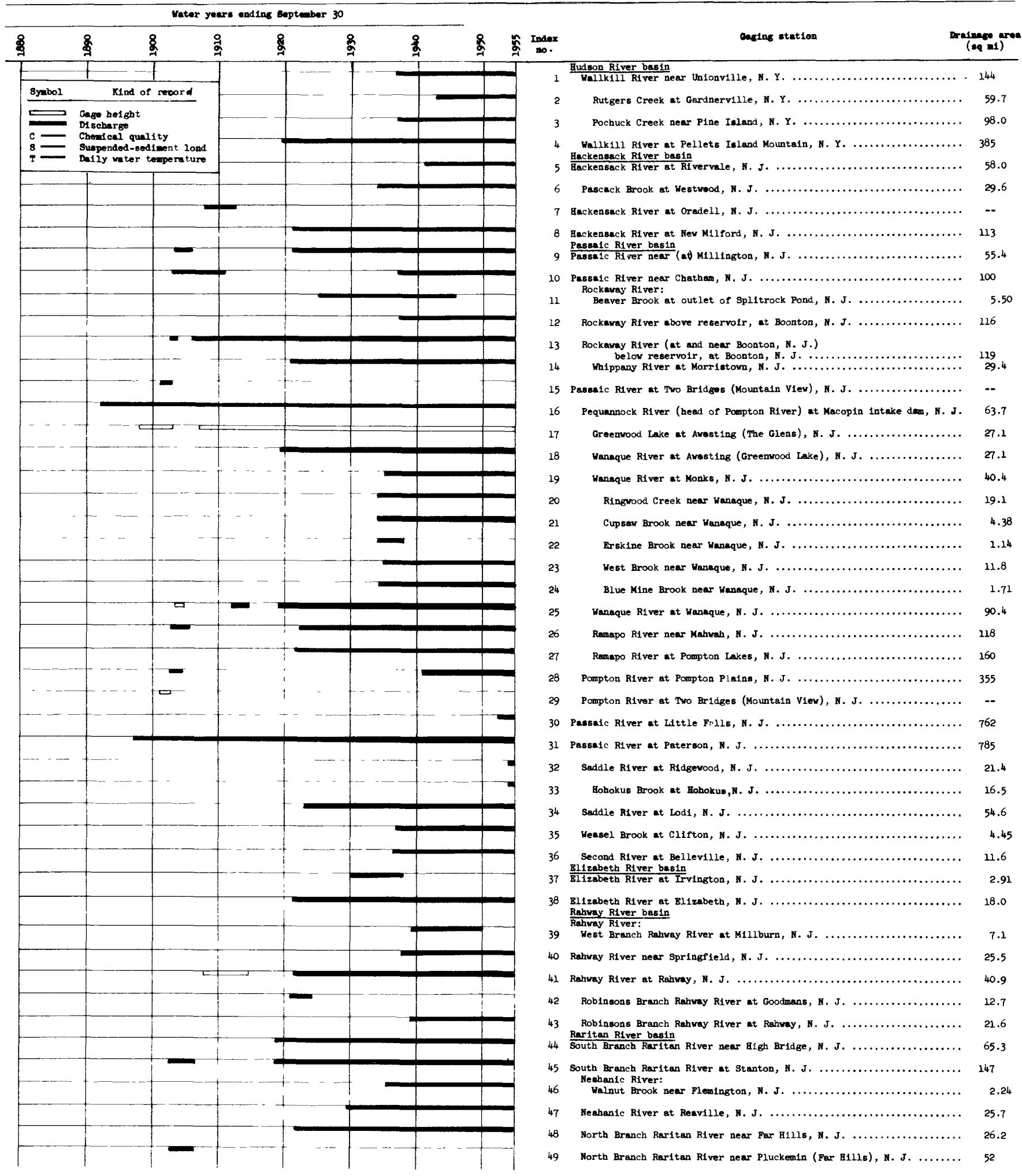

TABLE 22.-Bar graph showing periods of surface-water records to September 30, 1955. 


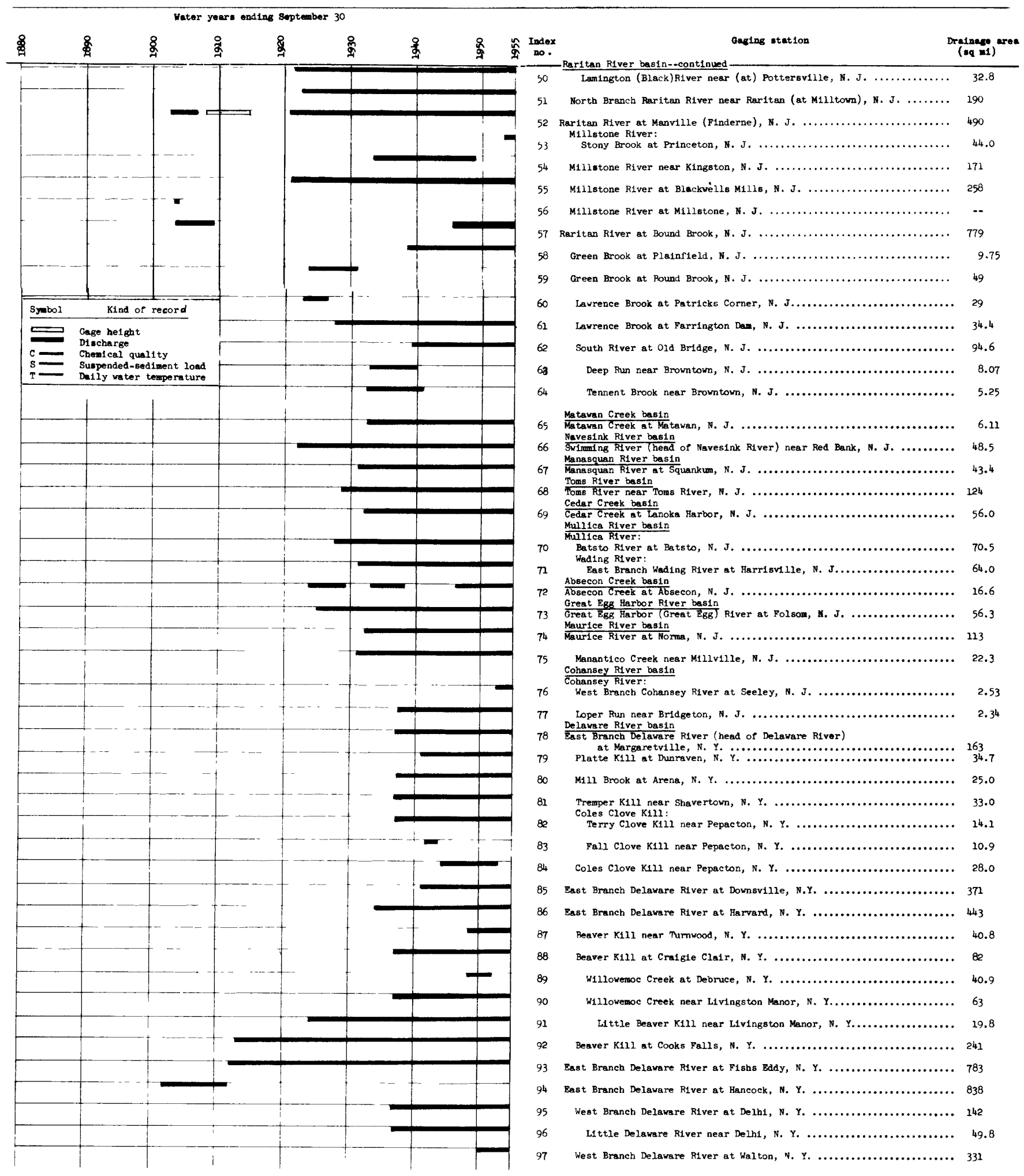

TABLE 22.-Bar graph showing periods of surface-water records to September 80,1955 - Continued 


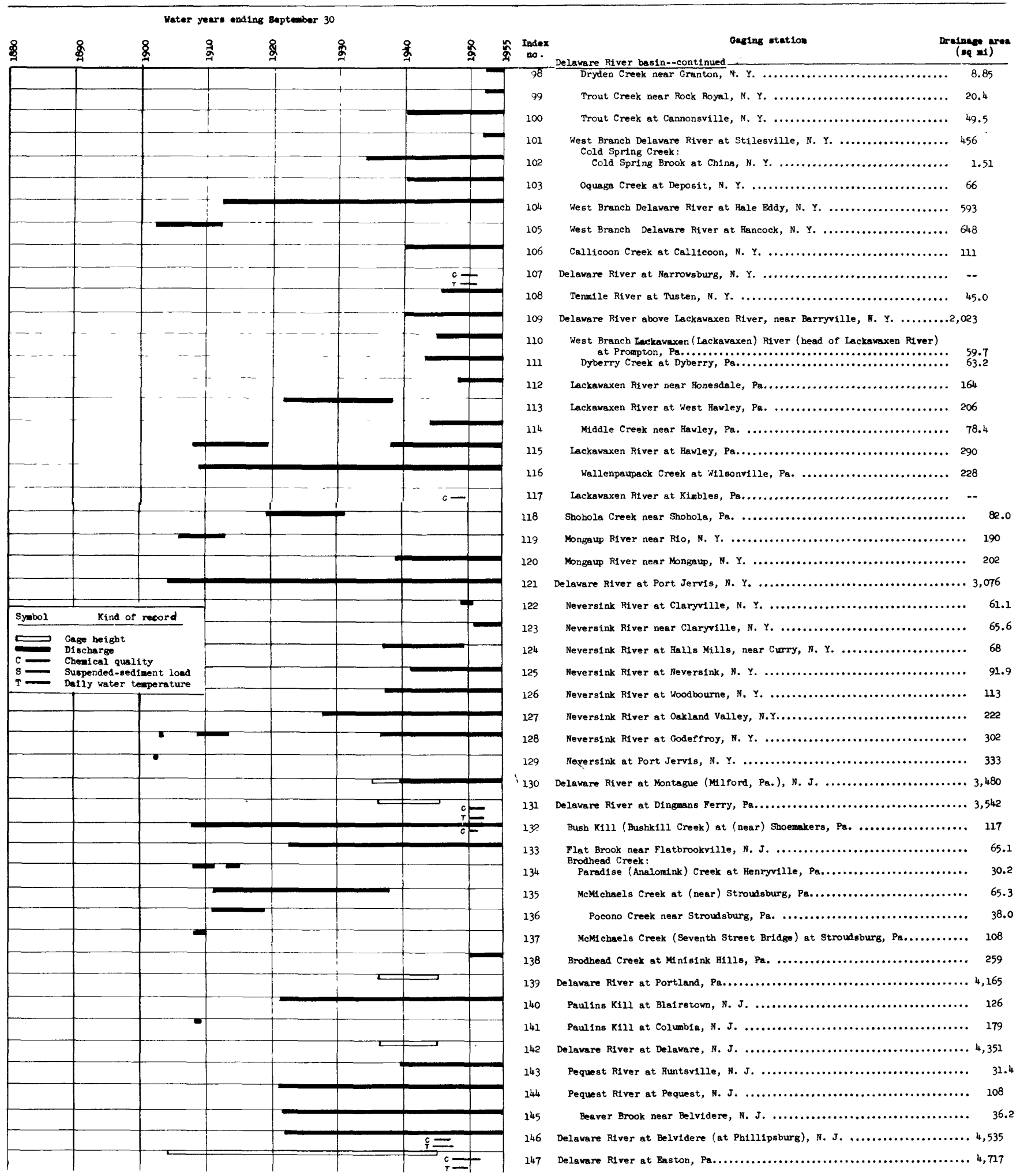

TABLE 22.-Bar graph showing periods of surface-water records to September 30, 1955-Continued 


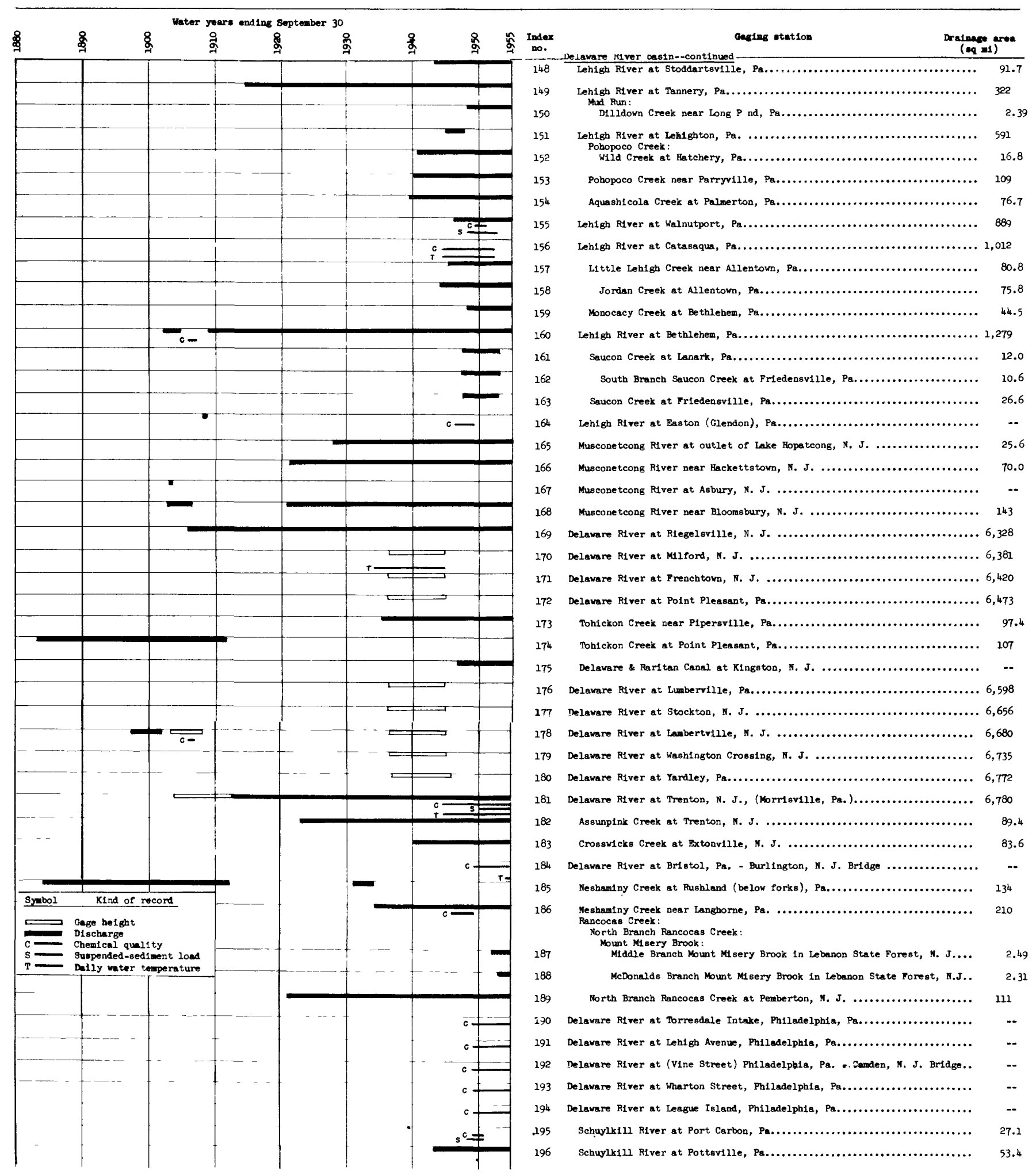

TABLE 22.-Bar gragh showing periods of surface-water records to September 30, 1955-Continued 


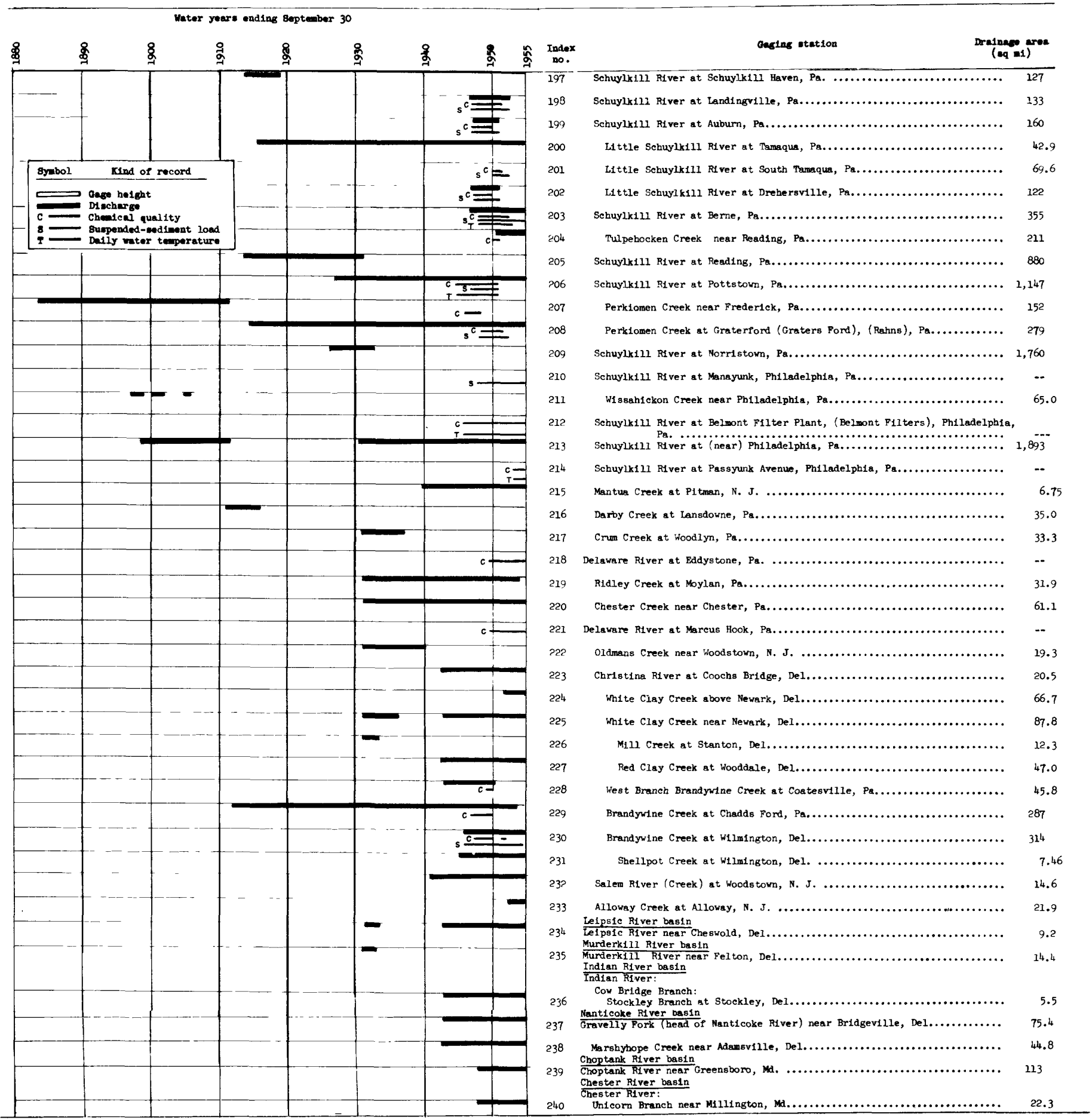

Note: - -Chemi ial quality records shown here consist of analyses of daily, monthly or occasional samples which include 6 or more individual months distributed throughout the year. All other rezords shown are for daily values. Breaks of less than one year are not shown.
Alditicnal data on mi=cellaneous discharge measurements, chemical analyses, water temperatures, zonductivity and pH are published in annual water-supply Adriticnal data on mi=cellaneous discharge measurements, chemical analyses, water temper
special reports of are avalable in district offices of the Geologial survey.

papers and special reports of are available in district offies of the Geologleal survey. minor changes will be maue ss a result of studjes yn progress for a compilation of records to September 30, 1950.

TABLE 22.-Bar graph showing periods of surface-water records to September 30, 1955-Continued 
TABLE 23.- Summary of average annual discharge, precipitation, and runoff for areas above selected gaging stations, 1921-50

[A verage annual precipitation from isohyetal map (pl. 3) for area above station; figures furnished by U.S. Weather Bureau. Discharge in million gallons per day equals 0.646317 times the discharge in cubic feet per second. Asterisk $\left({ }^{*}\right)$ indicates figure computed from records for less than 30 years and adjusted to standard period; dagger $(t)$ indicates figures adjusted for diversions]

\begin{tabular}{|c|c|c|c|c|c|c|c|}
\hline \multirow{2}{*}{$\begin{array}{c}\text { Index } \\
\text { No. } \\
\text { (pl. } \\
\text { 10) }\end{array}$} & \multirow{2}{*}{ Gaging station } & \multirow{2}{*}{$\begin{array}{c}\text { Drain- } \\
\text { age area } \\
\text { (sq mi) }\end{array}$} & \multicolumn{2}{|c|}{ Discharge } & \multirow{2}{*}{$\begin{array}{c}\text { Pre- } \\
\text { cipi- } \\
\text { tation } \\
\text { (in.) }\end{array}$} & \multirow{2}{*}{$\begin{array}{l}\text { Run- } \\
\text { off } \\
\text { (in.) }\end{array}$} & \multirow{2}{*}{$\begin{array}{l}\text { Dif- } \\
\text { fer- } \\
\text { ence } \\
\text { (in.) }\end{array}$} \\
\hline & & & (cfs) & (cfsm) & & & \\
\hline \multicolumn{8}{|c|}{ Hudson River basin } \\
\hline $\begin{array}{l}3 \\
4\end{array}$ & $\begin{array}{l}\text { Walkill River near Un- } \\
\text { ionville, N.Y } \\
\text { Pochuck Creek near } \\
\text { Pine Island, N.Y } \\
\text { Walkill River at Pellets } \\
\text { Island Mountain, N.Y. }\end{array}$ & $\begin{array}{l}144 \\
98.0 \\
385\end{array}$ & $\begin{array}{r}* 207 \\
* 148 \\
554\end{array}$ & $\begin{array}{r}* 1.44 \\
{ }^{*} 1.51 \\
1.44\end{array}$ & $\begin{array}{l}44.0 \\
43.3 \\
43.7\end{array}$ & $\begin{array}{r}{ }^{*} 19.6 \\
{ }^{*} 20.5 \\
19.6\end{array}$ & $\begin{array}{l}24.4 \\
22.8 \\
24.1\end{array}$ \\
\hline
\end{tabular}

Hackensack River basin

\begin{tabular}{|c|c|c|c|c|c|c|c|}
\hline 5 & $\begin{array}{c}\text { Hackensack River at } \\
\text { Rivervale, N.J......... }\end{array}$ & 58.0 & $* \nmid 91.6$ & $*+1.58$ & 43.6 & $* \nmid 21.5$ & 22.1 \\
\hline & Pascack Brook at West- & 29.6 & $* 485$ & $* 1.64$ & 439 & 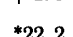 & 217 \\
\hline & $\begin{array}{c}\text { Hackensack River at } \\
\text { New Milford, N.J. }\end{array}$ & & & $* \dagger 1.61$ & 43. 7 & $* \nmid 21.8$ & 21.9 \\
\hline
\end{tabular}

Passaic River basin

\begin{tabular}{|c|c|c|c|c|c|c|c|}
\hline 9 & $\begin{array}{l}\text { Passaic River near Mill- } \\
\text { ington, N.J }\end{array}$ & 55.4 & ${ }^{*} 89.2$ & $* 1.61$ & 47.6 & *21. 8 & 25.8 \\
\hline 10 & Passaic River near Chat- & & & & & & \\
\hline 12 & Rockaway River above & 100 & *164 & ${ }^{* 1} 1.64$ & 47.9 & ${ }^{*} 22.2$ & 25.7 \\
\hline & reservoir at Boonton, & 116 & $*+215$ & ${ }^{*} \dagger 1.85$ & 48.1 & $*+25.1$ & 23.0 \\
\hline 14 & $\begin{array}{l}\text { Whippany River at } \\
\text { Morristown, N.J }\end{array}$ & 29.4 & ${ }^{*} 48.8$ & ${ }^{*} 1.66$ & 48. 0 & $* 22.5$ & 25.5 \\
\hline 18 & $\begin{array}{l}\text { Macopin intake dam, } \\
\text { N.J.- }\end{array}$ & 63.7 & $\dagger 121$ & $\dagger 1.90$ & 46.0 & $\dagger 25.8$ & 20.2 \\
\hline 19 & Awosting, N.J. & 27.1 & 49.3 & 1.82 & 44.4 & 24.7 & 19. 7 \\
\hline 20 & $\begin{array}{l}\text { Wanaque } \\
\text { Monks, N.J. River }\end{array}$ & 40.4 & $* 73.9$ & *1. 83 & 44.6 & ${ }^{*} 24.8$ & 19.8 \\
\hline & Wanaque, N.J. & 19.1 & $* 30.2$ & ${ }^{* 1 .} 58$ & 44.5 & $* 21.5$ & 23.0 \\
\hline 23 & $\begin{array}{l}\text { Wanaque, N.J....... } \\
\text { West Brook near Wa- }\end{array}$ & 4. 38 & $* 7.27$ & ${ }^{*} 1.66$ & 45.2 & $* 22.5$ & 22.7 \\
\hline 24 & $\begin{array}{l}\text { naque, N.J } \\
\text { Blue Mine Brook near }\end{array}$ & 11.8 & $* 21.6$ & $* 1.83$ & 45.9 & $* 24.9$ & 21.0 \\
\hline & Wanaque, N.J.-.. & 1.71 & *2.12 & $* 1.24$ & 46. 2 & ${ }^{*} 16.8$ & 29.4 \\
\hline & Wanaque, N.J. & 90.4 & $\dagger 160$ & $\dagger 1.77$ & 45.0 & $\nmid 24.0$ & 21.0 \\
\hline 2 & Ramapo River near & 118 & *206 & $* 1.75$ & 44.4 & ${ }^{*} 23.8$ & 20.6 \\
\hline 27 & $\begin{array}{l}\text { Ramapo River at Pomp- } \\
\text { ton Lakes, N.J }\end{array}$ & 160 & *285 & ${ }^{*} 1.78$ & 44.8 & ${ }^{*} 24.1$ & 20.7 \\
\hline 28 & $\begin{array}{l}\text { Pompton River at } \\
\text { Pompton Plains, N.J.-- } \\
\text { Passaic River at Pater- }\end{array}$ & 355 & $*+635$ & ${ }^{*}+1.79$ & 45.3 & $* \nmid 24.3$ & 21.0 \\
\hline 34 & $\begin{array}{l}\text { son, N.J } \\
\text { Saddle River at Lodi, }\end{array}$ & 785 & $\dagger 1,460$ & $\dagger 1.83$ & 46.6 & $\dagger 24.9$ & 21.7 \\
\hline 35 & Weasel Brook at Clifton, & & & 1.72 & 44.3 & *23. 4 & 20.9 \\
\hline 36 & River at Belle- & 4.45 & *4. 54 & ${ }^{* 1 .} 02$ & 48.0 & ${ }^{*} 13.8$ & 34.2 \\
\hline & ville, N.J._... & 11.6 & ${ }^{*} 17.5$ & ${ }^{* 1} 1.51$ & 47.9 & $* 20.5$ & 27.4 \\
\hline
\end{tabular}

Elizabeth River basin

\begin{tabular}{|c|c|c|c|c|c|c|c|}
\hline 37 & $\begin{array}{l}\text { Elizabeth River at Irv- } \\
\text { ington, N.J }\end{array}$ & 2.91 & $* 5,01$ & $* 172$ & 473 & * & 220 \\
\hline 38 & $\begin{array}{l}\text { Elizabeth River at Eliza- } \\
\text { beth, N.J. }\end{array}$ & 18.0 & $*+27.7$ & $*+1.54$ & 47.1 & $\begin{array}{r}20.4 \\
*+20.9\end{array}$ & 26.2 \\
\hline
\end{tabular}

Rahway River basin

\begin{tabular}{|c|c|c|c|c|c|c|c|}
\hline 39 & West Branch Rahway & \multirow{3}{*}{$\begin{array}{r}7.1 \\
25.5\end{array}$} & \multirow{3}{*}{$\begin{array}{r}{ }^{*} \dagger 11.9 \\
{ }^{*} \dagger 42.6\end{array}$} & \multirow{2}{*}{$*+1.68$} & \multirow{3}{*}{49.4} & \multirow[b]{2}{*}{$*+22.8$} & \multirow{4}{*}{$\begin{array}{l}26.6 \\
25.5 \\
25.6\end{array}$} \\
\hline 40 & River at Millburn, N.J. & & & & & & \\
\hline & Springfield, N.J & & & $*+1.67$ & & $*+22.6$ & \\
\hline 41 & $\begin{array}{l}\text { Rahway River at Rah- } \\
\text { way, N.J. }\end{array}$ & \multirow{2}{*}{40.9} & \multirow{2}{*}{${ }^{*}+65.4$} & \multirow{2}{*}{${ }^{*} \dagger 1.60$} & \multirow{2}{*}{47.3} & $*+217$ & \\
\hline 43 & Robinsons Branch Rah- & & & & & & \\
\hline & N.J. & 21.6 & $* \nmid 29.6$ & $*+1.37$ & 44. 0 & $*+18.6$ & 25.4 \\
\hline
\end{tabular}

TABLE 23.-Summary of average annual discharge, precipitation, and runoff for areas above selected gaging stations, 1921-50-Con.

\begin{tabular}{|c|c|c|c|c|c|c|c|}
\hline \multirow{2}{*}{$\begin{array}{c}\text { Index } \\
\text { No. } \\
\text { (pl. } \\
\text { 10) }\end{array}$} & \multirow{2}{*}{ Gaging station } & \multirow{2}{*}{$\begin{array}{l}\text { Drain- } \\
\text { age area } \\
\text { (sq mi) }\end{array}$} & \multicolumn{2}{|c|}{ Discharge } & \multirow{2}{*}{$\begin{array}{c}\text { Pre- } \\
\text { cipi- } \\
\text { tation } \\
\text { (in.) }\end{array}$} & \multirow{2}{*}{$\begin{array}{l}\text { Run- } \\
\text { off } \\
\text { (in.) }\end{array}$} & \multirow{2}{*}{$\begin{array}{l}\text { Dif- } \\
\text { fer- } \\
\text { ence } \\
\text { (in.) }\end{array}$} \\
\hline & & & (cfs) & (cfsm) & & & \\
\hline \multicolumn{8}{|c|}{ Raritan River basin } \\
\hline 44 & $\begin{array}{l}\text { South Branch Raritan } \\
\text { River near High } \\
\text { Bridge, N.J. }\end{array}$ & 65.3 & 114 & 1.75 & 47.5 & 23.7 & 23.8 \\
\hline 45 & $\begin{array}{l}\text { South Branch Raritan } \\
\text { River at Stanton, N.J.- }\end{array}$ & 147 & 237 & 1.61 & 46.1 & 21.8 & 24.3 \\
\hline 46 & $\begin{array}{l}\text { Walnut Brook near } \\
\text { Flemington, N.J. }\end{array}$ & 2.24 & $* 3.02$ & ${ }^{*} 1.35$ & 44.3 & *18. 3 & 26.0 \\
\hline 47 & $\begin{array}{l}\text { Neshanic River at Rea- } \\
\text { ville, N.J }\end{array}$ & 25.7 & $* 34.2$ & *1. 33 & 44.3 & *18. 0 & 26.3 \\
\hline 48 & $\begin{array}{l}\text { North Branch Raritan } \\
\text { River near Far Hills, } \\
\text { N.J. }\end{array}$ & 26.2 & $* 46.4$ & *1. 77 & 48.4 & $* 24.0$ & 24.4 \\
\hline 50 & $\begin{array}{l}\text { Lamington River near } \\
\text { Pottersville, N.J. }\end{array}$ & 32.8 & $* 54.4$ & $* 1.66$ & 48.7 & $* 22.5$ & 26.2 \\
\hline 51 & $\begin{array}{l}\text { North Branch Raritan } \\
\text { River near Raritan, } \\
\text { N.J. }\end{array}$ & 190 & *287 & *1. 51 & 47.0 & *20.5 & 26.5 \\
\hline 52 & $\begin{array}{l}\text { Raritan River at Man- } \\
\text { ville, N.J }\end{array}$ & 490 & $* 745$ & *1. 52 & 46.0 & $* 20.7$ & 25.3 \\
\hline 54 & $\begin{array}{l}\text { Millstone River near } \\
\text { Kingston, N.J. }\end{array}$ & 171 & *233 & ${ }^{*} 1.36$ & 43. 7 & *18. 5 & 25.2 \\
\hline 55 & $\begin{array}{l}\text { Milist on e River at } \\
\text { Blackwells Mills, N.J.- }\end{array}$ & 258 & *366 & $* 1.42$ & 43. 7 & *19. 3 & 24.4 \\
\hline 58 & $\begin{array}{l}\text { Green Brook at Plain- } \\
\text { field, N.J. }\end{array}$ & 9.75 & $* \dagger 13.9$ & $*+1.43$ & 47.0 & ${ }^{*}+19.4$ & 27.6 \\
\hline 59 & $\begin{array}{l}\text { Green Brook at Bound } \\
\text { Brook, N.J. }\end{array}$ & 49 & $* 69_{a} 1$ & $* 1.41$ & 44.8 & *19.2 & 25.6 \\
\hline 61 & $\begin{array}{l}\text { Lawrence Brook at Far- } \\
\text { rington Dam, N.J }\end{array}$ & 34.4 & *38. 5 & *1. 12 & 43.7 & $* 15.2$ & 28.5 \\
\hline 62 & $\begin{array}{l}\text { South River at old } \\
\text { Bridge, N.J. }\end{array}$ & 94.6 & ${ }^{*} \dagger 165$ & $*+1.74$ & 45.8 & $* \nmid 23.6$ & 22.2 \\
\hline 63 & $\begin{array}{l}\text { Deep Run near Brown- } \\
\text { town, N.J. }\end{array}$ & 8.07 & ${ }^{*} 12.7$ & $* 1.57$ & 44.5 & *21. 3 & 23.2 \\
\hline 64 & $\begin{array}{l}\text { Tennent Brook near } \\
\text { Browntown, N.J }\end{array}$ & 5.25 & $* 4.20$ & $* .80$ & 44.5 & $* 10.8$ & 33.7 \\
\hline
\end{tabular}

Matawan Creek basin

\begin{tabular}{r|r|r|r|r|r|r|r}
\hline 65 & $\begin{array}{c}\text { Matawan Creek at Mat- } \\
\text { awan, N.J............ }\end{array}$ & 6.11 & $* 9.84$ & $* 1.61$ & 44.5 & $* 21.8$ & 22.7 \\
\hline
\end{tabular}

Navesink River basin

\begin{tabular}{l|l|l|l|l|l|l|l}
\hline 66 & $\begin{array}{c}\text { Swimming } \\
\text { Red Bank, N.J._..... }\end{array}$ & 48.5 & $* 75.2$ & $* 1.55$ & 45.1 & $* 21.0$ & 24.1 \\
\hline
\end{tabular}

Manasquan River basin

\begin{tabular}{r|c|c|c|c|c|c|c}
\hline 67 & $\begin{array}{c}\text { Manasquan } \\
\text { Squankum, N.J._.... }\end{array}$ & 43.4 & $* 70.7$ & $* 1.63$ & 45.7 & $*_{22.1}$ & 23.6 \\
\hline 68 & Toms River basin \\
\hline 68 & $\begin{array}{c}\text { Toms River near Toms } \\
\text { River, N.J........ }\end{array}$ & 124 & $* 200$ & $* 1.61$ & 45.9 & $* 21.9$ & 24.0 \\
\hline
\end{tabular}

Cedar Creek basin

\begin{tabular}{|c|c|c|c|c|c|c|c|}
\hline 69 & $\begin{array}{l}\text { Cedar Creek at Lanoka } \\
\text { Harbor, N.J }\end{array}$ & 56.0 & ${ }^{*} 102$ & ${ }^{*} 1.82$ & 47.0 & *24. 7 & 22.3 \\
\hline
\end{tabular}

Mullica River basin

\begin{tabular}{|c|c|c|c|c|c|c|c|}
\hline 70 & Batsto River at Batsto, & 70.5 & *123 & $* 1.75$ & 46.2 & ${ }^{*} 23.8$ & 22.4 \\
\hline 71 & $\begin{array}{l}\text { East Branch Wading } \\
\text { River at Harrisville, } \\
\text { N.J. }\end{array}$ & 64.0 & *83. 2 & *1. 30 & 44.0 & $* 17.6$ & 26.4 \\
\hline
\end{tabular}

Absecon Creek basin

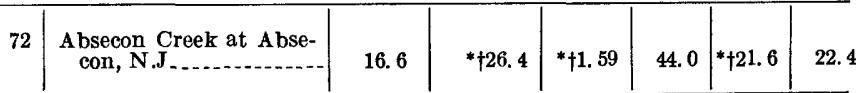


TABLE 23.- Summary of average annual discharge, precipitation, and runoff for areas above selected gaging stations, 1921-50-Con.

\begin{tabular}{c|c|c|c|c|c|c|c}
\hline $\begin{array}{c}\text { Index } \\
\text { No. } \\
\text { (pl. } \\
10)\end{array}$ & Gaging station & $\begin{array}{c}\text { Drain- } \\
\text { age area } \\
\text { (sq mi) }\end{array}$ & \multicolumn{2}{|c|}{ Discharge } & $\begin{array}{c}\text { Pre- } \\
\text { cipi- }\end{array}$ & $\begin{array}{c}\text { Run- } \\
\text { off } \\
\text { (in.) }\end{array}$ & $\begin{array}{c}\text { Dif- } \\
\text { fer- } \\
\text { ence } \\
\text { (in.) }\end{array}$ \\
\hline
\end{tabular}

Great Egg Harbor River basin

\begin{tabular}{|c|c|c|c|c|c|c|c|}
\hline 73 & $\begin{array}{l}\text { Great Fgg Harbor River } \\
\text { at Folsom, N.J. }\end{array}$ & 56.3 & ${ }^{*} 81.6$ & ${ }^{*} 1.45$ & 46.1 & *19. 7 & \\
\hline \multicolumn{8}{|c|}{ Maurice River basin } \\
\hline 74 & Maurice River at Norma, & \multirow{2}{*}{$\begin{array}{l}113 \\
22.3\end{array}$} & \multirow{2}{*}{$\begin{array}{l}{ }^{*} 159 \\
* 35.9\end{array}$} & \multirow{2}{*}{$\begin{array}{l}* 1.41 \\
* 1.61\end{array}$} & \multirow[b]{2}{*}{$\begin{array}{l}45.5 \\
45.5\end{array}$} & \multirow{2}{*}{$\begin{array}{l}{ }^{*} 19.2 \\
* 21.8\end{array}$} & \\
\hline 75 & $\begin{array}{l}\text { Manantico Creek near } \\
\text { Millville, N.J. }\end{array}$ & & & & & & \\
\hline
\end{tabular}

Cohansey River basin

\begin{tabular}{|c|c|c|c|c|c|c|c|}
\hline 77 & $\begin{array}{l}\text { Loper Run near Bridge- } \\
\text { ton, N.J. }\end{array}$ & 2.34 & $* 1.15$ & *. 49 & 44.0 & $* 6.6$ & 37.4 \\
\hline \multicolumn{8}{|c|}{ Delaware River basin } \\
\hline 78 & $\begin{array}{l}\text { East Branch Delaware } \\
\text { River at Margaret- }\end{array}$ & 163 & *302 & \multirow{2}{*}{$* 1.85$} & \multirow{2}{*}{44.0} & \multirow{2}{*}{${ }^{*} 25.1$} & \multirow{2}{*}{18.9} \\
\hline 79 & $\begin{array}{l}\text { Platte Kill at Dunraven, } \\
\text { N.Y }\end{array}$ & 100 & .002 & & & & \\
\hline 80 & Mili Brook at Arena, & 25.0 & ${ }^{*} 63.2$ & ${ }^{*} 1.82$ & 43.0 & ${ }^{* 24.7}$ & 18.3 \\
\hline 81 & Tremper Kill near Shav- & 25.0 & 50.8 & ${ }^{*} 2.27$ & 48.8 & ${ }^{*} 30.8$ & 18.0 \\
\hline 82 & Terry Clove Kill near & 33.0 & 62.0 & ${ }^{*} 1.88$ & 43.7 & ${ }^{*} 25.5$ & 18.2 \\
\hline 85 & $\begin{array}{l}\text { East Branch Delaware } \\
\text { River at Downsville, }\end{array}$ & 14.1 & ${ }^{2} 26.5$ & ${ }^{*} 1.88$ & 44.0 & ${ }^{*} 25.5$ & 18.5 \\
\hline 86 & $\begin{array}{l}\text { N.Y } \\
\text { East Branch Delaware }\end{array}$ & 373 & ${ }^{*} 712$ & $* 1.91$ & 44.5 & ${ }^{*} 25.9$ & 18.6 \\
\hline 88 & $\begin{array}{l}\text { River at Harvard, N. Y- } \\
\text { Beaver Kill at Craigie }\end{array}$ & 443 & $* 855$ & $* 1.93$ & 44.7 & ${ }^{*} 26.2$ & 18.5 \\
\hline 90 & $\begin{array}{l}\text { Clair, N.Y } \\
\text { willowemoc Creek near }\end{array}$ & 82 & ${ }^{* 203}$ & $* 2.48$ & 51.8 & *33. 7 & 18.1 \\
\hline & $\begin{array}{l}\text { Livingst } \\
\text { N.Y..... }\end{array}$ & 63 & ${ }^{* 152}$ & ${ }^{* 2.42}$ & 52.0 & *32. 9 & 19.1 \\
\hline 91 & $\begin{array}{l}\text { Little Beaver Kill near } \\
\text { Livingston Manor, } \\
\text { N.Y. }\end{array}$ & 19.8 & ${ }^{*} 45.3$ & $* 2.29$ & 49.3 & $* 31.1$ & 18.2 \\
\hline 92 & $\begin{array}{l}\text { Beaver Kill at Cooks } \\
\text { Falls, N.Y }\end{array}$ & 241 & 560 & 2.32 & 50.1 & 31.6 & 18.5 \\
\hline 93 & $\begin{array}{l}\text { East Branch Delaware } \\
\text { River at Fishs Eddy, }\end{array}$ & & & & 00.1 & 01.0 & \\
\hline 95 & West Branch Delaware & 783 & 1,650 & 2. 11 & 46.6 & 28.6 & 18.0 \\
\hline 96 & $\begin{array}{l}\text { River at Delli, N.Y... } \\
\text { Little Delaware River }\end{array}$ & 142 & ${ }^{*} 237$ & ${ }^{* 1.67}$ & 41.5 & ${ }^{*} 22.7$ & 18.8 \\
\hline & $\begin{array}{c}\text { Little } \\
\text { near Delhi, N.Y }\end{array}$ & 49.8 & $*_{90.1}$ & $*^{* 1.8}$ & 42.7 & ${ }^{* 24.6}$ & 18.1 \\
\hline 100 & Trout Creek at Cannons- & 49.5 & $* 90$ & $*^{*} 183$ & 434 & $* 048$ & 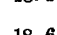 \\
\hline 102 & Cold 'spring Brook at & 49.0 & 30.0 & 1.85 & 40.4 & "24.8 & 18.6 \\
\hline 103 & $\begin{array}{l}\text { China, N.Y } \\
\text { Oquaga Creek at De- }\end{array}$ & 1.51 & ${ }^{* 2.72}$ & ${ }^{*} 1.80$ & 44.0 & ${ }^{*} 24.4$ & 19.6 \\
\hline 104 & $\begin{array}{l}\text { posit, N.Y } \\
\text { West Branch Delaware }\end{array}$ & 66 & ${ }^{*} 117$ & ${ }^{* 1.78}$ & 43.0 & ${ }^{*} 24.2$ & 18.8 \\
\hline & River at Hale Eddy, & 593 & 1000 & 178 & 48 & & \\
\hline 106 & Callicoon Creek at Cal- & & & 1.10 & 42.0 & 24.2 & 18.4 \\
\hline 109 & re River above & 111 & ${ }^{*} 185$ & ${ }^{* 1.67}$ & 42.8 & ${ }^{*} 22.6$ & 20.2 \\
\hline & $\begin{array}{l}\text { Lackawaxen River, } \\
\text { near Barryville, N.Y. }\end{array}$ & 2,023 & $* 3,880$ & ${ }^{*} 1.92$ & 44.4 & $*_{26.1}$ & 18.3 \\
\hline 113 & Lackawaxen River at & & & & & & \\
\hline 115 & $\begin{array}{l}\text { West Hawley, Pa-- } \\
\text { Lackawaxpn River at }\end{array}$ & 206 & *344 & ${ }^{*} 1.67$ & 43.4 & ${ }^{*} 22.6$ & 20.8 \\
\hline 116 & $\begin{array}{l}\text { Hawley, Pa } \\
\text { Wallenpaupack Creekat }\end{array}$ & 290 & ${ }^{*} 487$ & $* 1.68$ & 43.2 & ${ }^{* 22.8}$ & 20.4 \\
\hline 120 & $\begin{array}{l}\text { Wilsonville, } \mathrm{Pa}- \\
\text { Monoaun Bier }\end{array}$ & 228 & 338 & 1.48 & 42.4 & 20.5 & 21.9 \\
\hline & $\begin{array}{l}\text { Mongaup River near } \\
\text { Mongaup, N.Y. }\end{array}$ & 202 & *341 & $* 1.69$ & 42.7 & $* 23.0$ & 19.7 \\
\hline 121 & Delaware River at Port & 076 & 5.580 & 181 & 438 & 940 & \\
\hline 124 & Neversink $R$ & & 0,280 & & 40.0 & 24.0 & 19.2 \\
\hline 125 & $\begin{array}{l}\text { Mil } \\
\text { Never }\end{array}$ & 68 & ${ }^{*} 195$ & ${ }^{* 2.87}$ & 56.4 & *38. 9 & 17. \\
\hline 126 & ersin & 92.5 & ${ }^{*} 248$ & $* 2.70$ & 54.6 & *36. 6 & $18 .($ \\
\hline & Woodbourne, N.Y. & 113 & ${ }^{*} 284$ & $*_{2.51}$ & 52.5 & $* 34.1$ & 18.4 \\
\hline 127 & Neversink River at Oak- & 222 & $*_{4477}$ & $* 2.15$ & 48.1 & $*^{*} 29,2$ & 180 \\
\hline 128 & Neversink River at Go- & & Trt & & & & 10.0 \\
\hline 130 & $\begin{array}{l}\text { deltroy, N.Y } \\
\text { Delaware River at Mon- }\end{array}$ & 302 & ${ }^{* 607}$ & 2.01 & 47.1 & ${ }^{2} 27.3$ & 19.8 \\
\hline 132 & $\begin{array}{l}\text { tague, N.J } \\
\text { Bush Kill at Shoemak- }\end{array}$ & 3,480 & ${ }^{*} 6,580$ & ${ }^{*} 1.89$ & 44.4 & ${ }^{* 25.6}$ & 18.8 \\
\hline & ers, $\mathrm{Pa}$ & 117 & & 1.97 & 46.2 & 26.7 & 19.5 \\
\hline
\end{tabular}

TABLE 23.- Summary of average annual discharge, precipitation, and runoff for areas above selected gaging stations, 1921-50-Con.

\begin{tabular}{c|c|c|c|c|c|c}
\hline $\begin{array}{c}\text { Index } \\
\text { No.. } \\
\text { (pl. } \\
\text { 10) }\end{array}$ & Gaging station & $\begin{array}{c}\text { Drain- } \\
\text { age area } \\
\text { (sq mi) }\end{array}$ & Discharge & $\begin{array}{c}\text { Pre- } \\
\text { cipi- } \\
\text { tation } \\
\text { (in.) }\end{array}$ & $\begin{array}{c}\text { Run- } \\
\text { off } \\
\text { (in.) }\end{array}$ & $\begin{array}{c}\text { Dif- } \\
\text { fir- } \\
\text { ence } \\
\text { (in.) }\end{array}$ \\
\hline
\end{tabular}

Delaware River basin-Continued

\begin{tabular}{l|l}
\hline 133 & \\
135 & \\
140 & \\
14 & \\
14 &
\end{tabular}

149 Lehigh River at Tan-
nery, Pa
wild Creek at Hatchery,

Piver at Bel-

153 Pohopoco Creek near

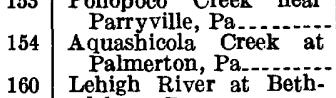

165 lehem, Pa Musconetcong River at

$165 \begin{gathered}\text { Musconetcong River at } \\ \text { outlet of Lake Hopat- } \\ \text { cong, N.J } \\ \text { Musconetcong River } \\ \text { near Hackettstown. }\end{gathered}$ near Hackettstown,

168 Musconetcong River

169 near Bloomsbury, N.J -

173 Tohickon Creek near

181 Delaware River at Tren-

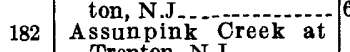

183 Trenton, N.J.-.

186 Extonville, N.J

189 North Brane, Pa

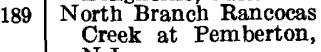

200 Nittle Schuylkill River

205 Schuylkill River at

206 Reading, Pa

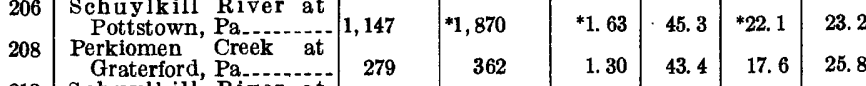

\begin{tabular}{|l|l|l|r|r|r|r}
213 & Schuylkill River at & & & & & \\
\end{tabular}

\begin{tabular}{ll|l|l|l|l|l}
215 & Philadelphia, Pa. & & \\
Mantua Creek at Pit- & 1,893 & $* 2,860$ & $* 1.51$ & 44.4 & $* 20.5$ & 23.9
\end{tabular}

\begin{tabular}{c|c|c|c|c|c|c}
219 & man, N.J & $* 11.2$ & $* 1.66$ & 45.0 & $* 22.5$ & 22.5
\end{tabular}

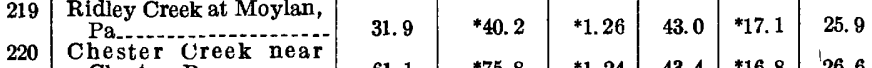

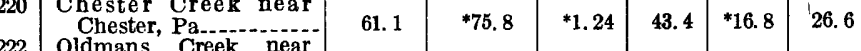

\begin{tabular}{|l|c|c|c|c|c|c|}
\hline Woodstown, N.J.-...- & 19.3 & $* 25.9$ & $* 1.34$ & 44.5 & $* 17.4$ & 27.1
\end{tabular}

\begin{tabular}{l|l|l|l|l|r|r|r}
229 & $\begin{array}{c}\text { Brandywine Creek at } \\
\text { Chadds Ford, Pa }\end{array}$ & 287 & 370 & 1.29 & 44.1 & 17.5 & 26.6
\end{tabular}

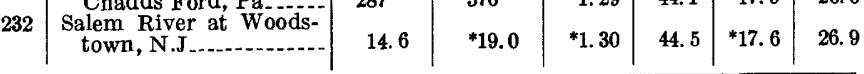

\begin{tabular}{|c|c|c|c|c|c|c|c|}
\hline \multicolumn{8}{|c|}{ Leipsic River basin } \\
\hline 234 & $\begin{array}{l}\text { Leipsic River near Ches- } \\
\text { wold, Del_. }\end{array}$ & 9.2 & *9. 94 & ${ }^{*} 1.08$ & 42.4 & ${ }^{*} 14.7$ & 27.7 \\
\hline
\end{tabular}

between gaging stations was computed by subtraction. These values were not included in table 23 because they are much less reliable than those shown, but they were used to help define the lines of equal runoff shown on the map (pl. 12). Lines of equal runoff were drawn on the basis of the observed and computed values and the shape of the isohyetal lines (pl. 3). Adjustments were then made where necessary to bring the maps of pre- 
cipitation, runoff, and water loss (pl. 4) into closer agreement. The areal variations in runoff are generally similar to those of precipitation; departures from this pattern are due chiefly to local influences.

Runoff represents the total outflow from the basin apart from discharge by evapotranspiration and underground outflow. Ground-water divides sometimes differ appreciably from surface divides (fig. 10) and considerable quantities of ground water sometimes leave the basin by subsurface routes bypassing the surface channel. These effects are greatest in small, headwater areas and in the Coastal Plain where channels are cut in deep, permeable deposits.

In humid regions, small areas near topographic divides usually produce only overland flow, or direct runoff, following storms. A little farther from the divides intermittent streams receive ground-water discharge part of the time, and still farther downstream the streams become perennial. This oversimplification of the relation between surface and ground water helps explain why annual runoff from areas of a few square miles cannot be estimated from runoff maps, such as plate 12 , or from streamflow records obtained at sites having drainage areas of many square miles.

In the Appalachian Highlands the map (pl. 12) should enable the reader to make reasonable estimates of runoff to be expected from areas of about 10 square miles or larger. For the Coastal Plain it provides a basis for rough approximations of runoff from areas of about 20 square miles or larger. It is likely that on the Coastal Plain appreciable flows bypass most of the gaging stations as ground-water discharge.

Loper Run near Bridgeton, N.J. (pl. 10, No. 77), is an outstanding example of a topographic situation favoring bypass of the gage by ground water. The gage is just above a low dam at the edge of a rather abrupt land-surface scarp. Water seeps out of the pool created by the dam to a swampy area in a valley about 30 feet lower than the gage. The measured runoff is only about one-third of that for other nearby areas.

Large withdrawals of ground water within an area may cause the measured streamflow to be less than it would be under natural conditions. An outstanding example is furnished by the record for Tennent Brook near Browntown, N.J. (pl. 10, No. 64) which indicates a runoff of about half that for adjacent areas.

The average runoff during the growing season, which is usually the season of lowest runoff and greatest demand, is shown as a percentage of the average annual runoff in plate 12 . The 5-month period, May to September, was selected to represent the growing season so that effects of runoff from the winter's accumulation of snow would be minimized.

\section{VARIABILITY OF DISCHARGE AND RUNOFF} ANNUAL RUNOFF

The nature of the variation of annual runoff from year to year is indicated by the hydrographs in figure 34 , which shows annual runoff and 5-year moving averages for three of the longest continuous records in the area. From these graphs and the corresponding precipitation graphs in figure 7 , it may be concluded that the standard period used in this report, 1921-50, is a fairly representative one although somewhat more extreme values, both high and low, can be expected as. the period of record becomes longer.

In the discussion of precipitation it was indicated that the distribution of recorded annual precipitation in this region is not the same as the normal distribution of events controlled by chance alone. However, the distribution of annual values approximates the normal, and the standard deviation and coefficient of variation could be used as measures of the variability. A similar study of annual runoff in this region was made. Figure 35 shows the actual and corresponding normal distributions for the three long-term records. The agreement is not as good as it was in the case of the 130-year precipitation record. This divergence is to be expected because of the smaller number of annual values, but may be partly due to other causes such as greater skew of the actual distribution for a very large number of years. It is concluded, as in the case of precipitation data, that the standard deviation and coefficient of variation do not apply strictly to annual runoff data but are useful measures of their variability. ${ }^{5}$

Coefficients of variation were computed for the 30-year standard period, 1921-50, for 18 gaging stations and for a 29-year period, 1922-50, for 7 additional stations. Coefficients for these two periods are considered essentially equivalent and the values are indicated in table 24 . The average of these 25 coefficients is 24.1 and the range is from 20.5 to 30.8 . Coefficients for 12 stations with slightly shorter records were computed but were not shown in the table because they are not strictly comparable. Their average is 24.8 and the range is from 22.5 to 27.5 , well within the range of those shown.

Coefficients of variation for the three long-term records used in the previous discussion also are shown in table 24. They show no marked difference from the coefficients for the standard period. The average coefficient of variation for runoff is considerably greater than that for precipitation. Furthermore, the difference probably would be even greater if the coefficients of variation were for the precipitation on areas com-

5 These measures are not applicable to daily discharge values unless the logarithms of the discharge are used. The distribution of the logarithms of daily discharge, not of the discharge itself, is approximately normal. 
DELAWARE RIVER AT PORT JERVIS, N.Y. 49- year average $(1905-53) 24.7$ inches 30 -year average $(1921-50) 24.6$ inches

PASSAIC RIVER AT PATERSON, N.J. 55 -year average $(1899-1953) 25.8$ inches 30 -year average $(1921-50) 24.9$ inches

BRANDYWINE CREEK AT CHADDS FORD,

EXAMPLE : ANNUAL RUNOFF FOR 1928 WAS 39.50 INCHES (POINT A)

5 - YEAR MOVING AVERAGE FOR 1928 IS 28.0 INCHES, THE AVERAGE FOR THE FIVE YEARS 1924-28 (POINT B)

42 -year average $(1912-53) 18.3$ inches 30 -year average $(1921-50) 17.5$ inches

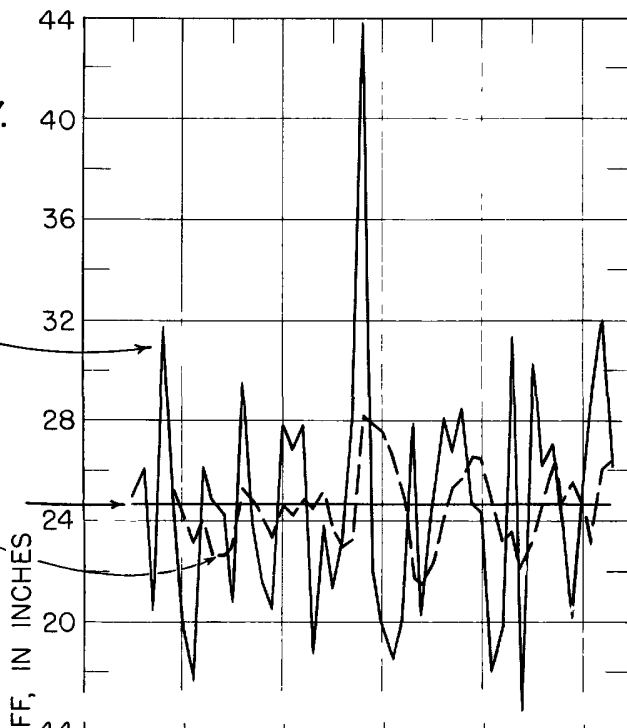

峁

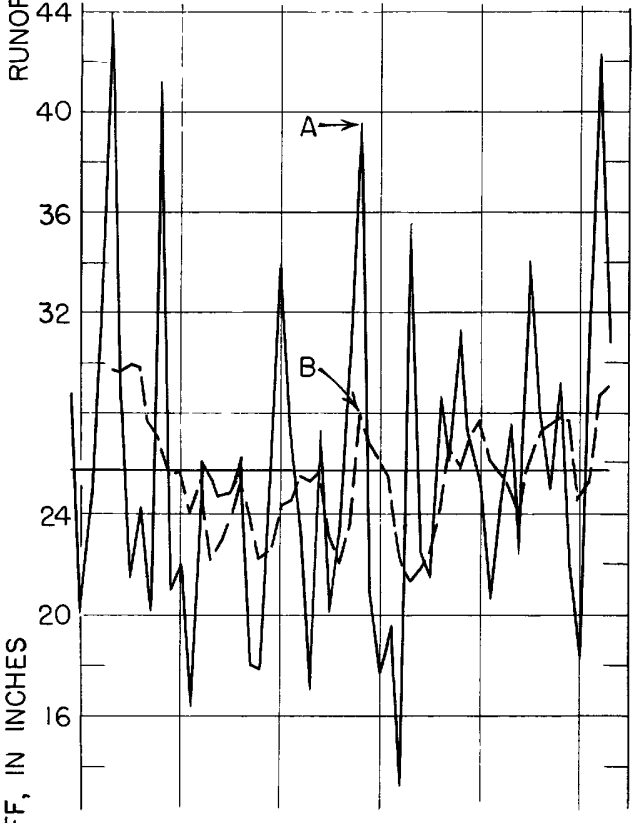

능

PA.
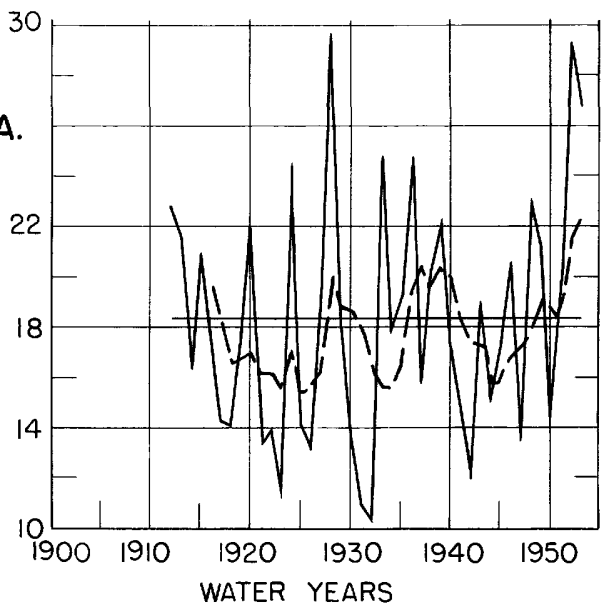

Figure 34.-Annual runoff and 5-year moving average for three gaging stations. 

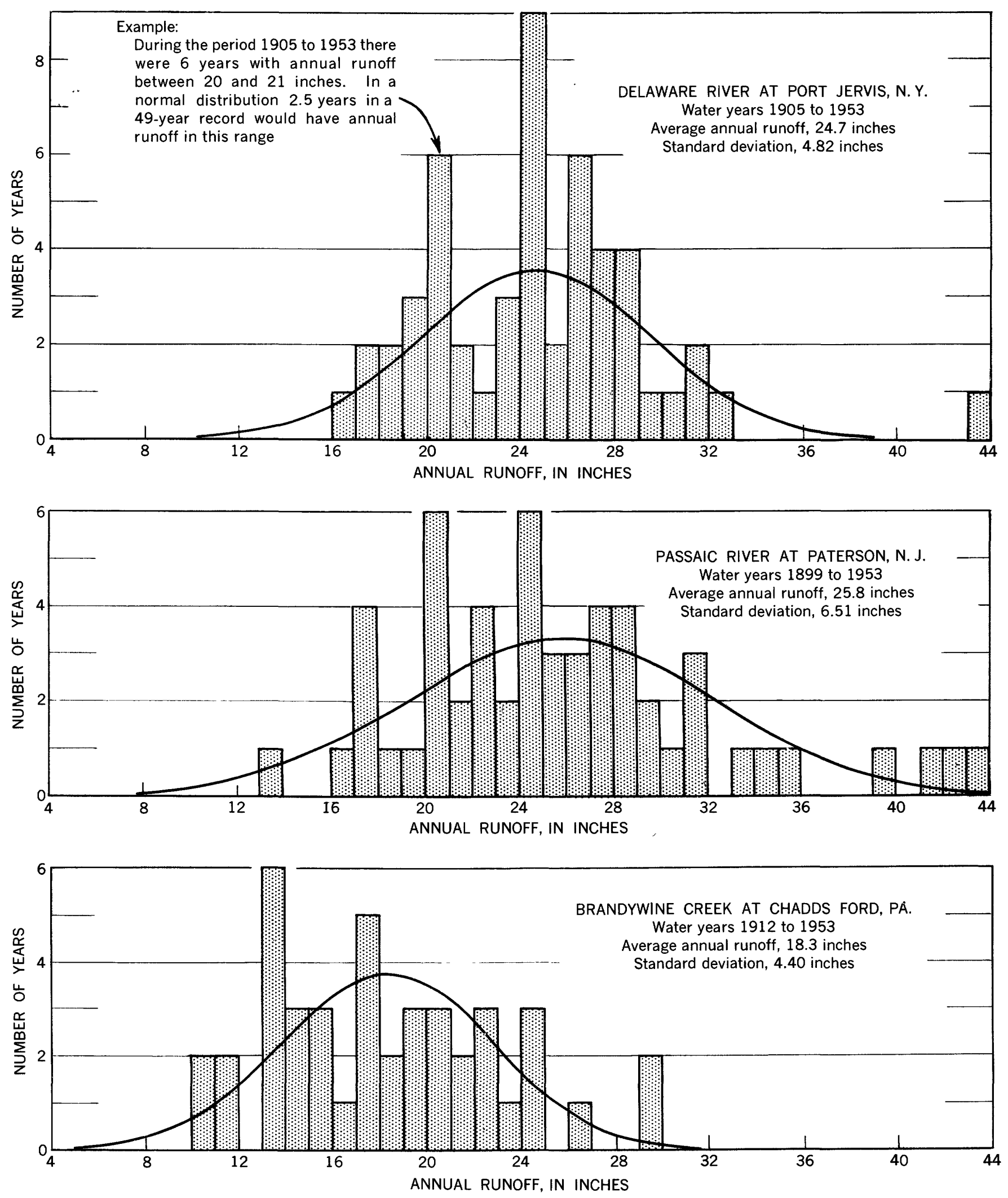

Figure 35.-Actual and normal distribution of annual runoff. 
parable in size to the areas above gaging stations instead of at a point. Any areal pattern of differences in the coefficient is obscured by random differences resulting from the short periods of record. A value near the mean should be useful in determining longperiod distribution of annual runoff, and a value near the upper limit should provide an estimate of maximum variation to be expected in shorter periods.

TABLE 24.-Coefficients of variation of annual runoff for selected gaging stations

\begin{tabular}{|c|c|c|c|}
\hline Gaging station (pl. 10) & Years & $\begin{array}{l}\text { Standard } \\
\text { deviation } \\
\text { (inches) }\end{array}$ & $\begin{array}{c}\text { Coefficient } \\
\text { of } \\
\text { variation }\end{array}$ \\
\hline 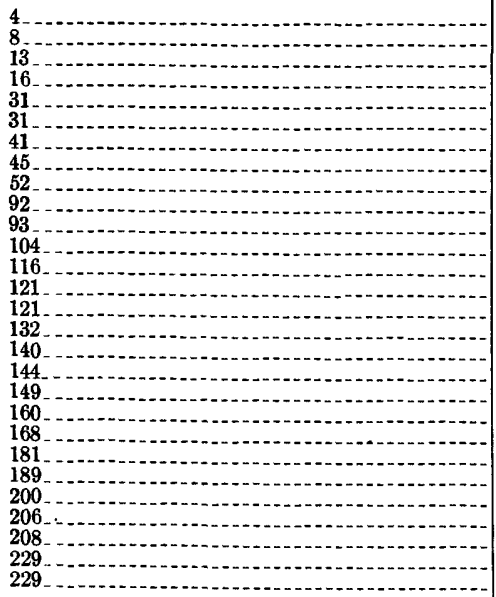 & $\begin{array}{l}30 \\
29 \\
30 \\
30 \\
30 \\
55 \\
29 \\
30 \\
29 \\
30 \\
30 \\
30 \\
30 \\
30 \\
49 \\
30 \\
29 \\
29 \\
30 \\
30 \\
29 \\
30 \\
29 \\
30 \\
30 \\
30 \\
30 \\
42\end{array}$ & $\begin{array}{l}5.22 \\
5.51 \\
5.79 \\
6.28 \\
5.66 \\
6.51 \\
4.52 \\
5.20 \\
5.40 \\
6.64 \\
5.98 \\
4.95 \\
5.37 \\
5.24 \\
6.82 \\
5.60 \\
5.23 \\
5.62 \\
5.55 \\
4.5 \\
4.33 \\
4.84 \\
5.38 \\
5.43 \\
6.44 \\
4.40\end{array}$ & $\begin{array}{l}26.6 \\
25.5 \\
23.6 \\
24.3 \\
22.7 \\
25.3 \\
20.9 \\
23.8 \\
26.2 \\
21.0 \\
20.9 \\
20.5 \\
26.2 \\
21.3 \\
19.5 \\
24.2 \\
27.9 \\
28.1 \\
20.5 \\
22.6 \\
21.3 \\
21.5 \\
22.8 \\
27.6 \\
24.3 \\
30.8 \\
27.0 \\
24.1\end{array}$ \\
\hline
\end{tabular}

MONTHLY RUNOFF

Major fluctuations in streamflow may occur in rather short periods of time, often measurable in minutes. Discharges for time units as short as 1 hour are used for some purposes, but the usual units are the day and month. The study of variation in time is consequently extended to these shorter units.

Mean and extreme values of runoff for each month at six selected gaging stations are compared graphically in figure 36 . In the comparison, the monthly values are shown in percent of mean annual runoff in order to reduce the effects of areal variations.

A definite seasonal pattern is indicated by the contrast between the graphs of mean monthly runoff and those of mean monthly precipitation (fig. 9), the latter indicate rather even distribution. Such a pattern would be expected as a consequence of the seasonal variations in evapotranspiration. Much of the summer and fall precipitation replenishes soil moisture used by vegetation and is not available for runoff. Data from East Branch Delaware River at Fishs Eddy, N.Y., (station 93) and Lehigh River at Tannery, Pa., (station 149) reflect drainage of mountainous country where effects of ground-water storage on streamflow are relatively small and temporary storage of winter pre- cipitation in snow is an important factor. The high runoff in the spring months is a result of this storage and later release. Ramapo River above the station near Mahwah, N.J., (station 26) drains a rather typical Piedmont and upland area where the runoff characteristics are similar to the preceding, but the effects of storage in snow are less pronounced. Delaware River at Trenton, N.J., (station 181) integrates characteristics for a large area most of which is similar to that drained by the previously mentioned three stations. The storage capacity of lakes and the system of stream channels is an important stabilizing factor here. Great Egg Harbor River above the station at Folsom, N.J., (station 73) is a typical stream of the Coastal Plain where snow storage is rarely a factor for more than a few days, but storage capacity of swamps and aquifers is very large. The equalizing effect of this storage on both the means and the extremes is readily apparent. Brandywine Creek above the station at Chadds Ford, Pa., (station 229) drains a Piedmont Upland area in which the ground-water contribution to streamflow is less than that in the Coastal Plain but much larger than that in most Piedmont and mountain areas. Snow storage has little or no effect on the monthly values.

Coefficients of variation of monthly runoff provide an interesting comparison of the variability with the annual runoff even though, statistically, its use may be incorrect. The distribution of monthly runoff departs from the normal much more than the distribution of annual runoff; consequently, it is unlikely that 68 percent of the values of monthly runoff will fall within the range represented by the mean \pm 1 standard deviation.

Coefficients of variation of monthly runoff for 1921-50 were computed for the runoff at three gaging stations and are here compared with the coefficients for annual runoff.

\begin{tabular}{|c|c|c|c|}
\hline \multirow{2}{*}{$\begin{array}{c}\text { Index } \\
\text { No. } \\
\text { (pl. 10) }\end{array}$} & \multirow{2}{*}{ Gaging station } & \multicolumn{2}{|c|}{$\begin{array}{l}\text { Coefficient of } \\
\text { variation }\end{array}$} \\
\hline & & Monthly & Annual \\
\hline $\begin{array}{r}73 \\
93 \\
208\end{array}$ & $\begin{array}{l}\text { Great Egg Harbor River at Folsom, N.J } \\
\text { East Branch Delaware River at Fishs Eddy, N.Y.- } \\
\text { Perkiomen Creek at Graterford, Pa... }\end{array}$ & $\begin{array}{l}45.3 \\
83.6 \\
88.7\end{array}$ & $\begin{array}{l}24.2 \\
20.9 \\
30.8\end{array}$ \\
\hline
\end{tabular}

The variability of monthly runoff is about two to four times as great as that of annual runoff. The lower monthly coefficient for Great Egg Harbor River is due to the very large aquifer storage of this part of the Coastal Plain. Although this storage causes a marked reduction in the monthly coefficient, it has little, if any, effect on the annual coefficient. 

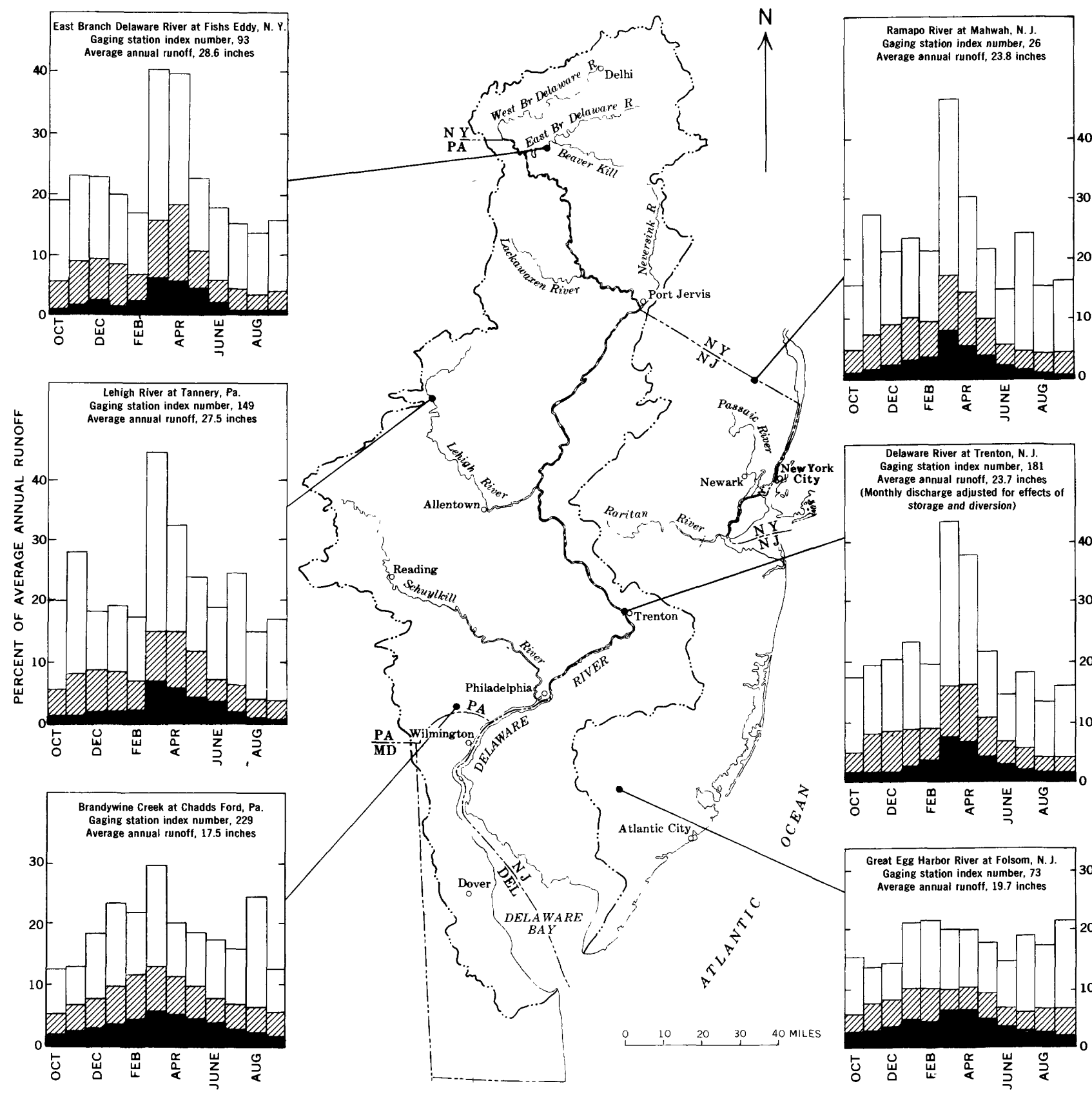


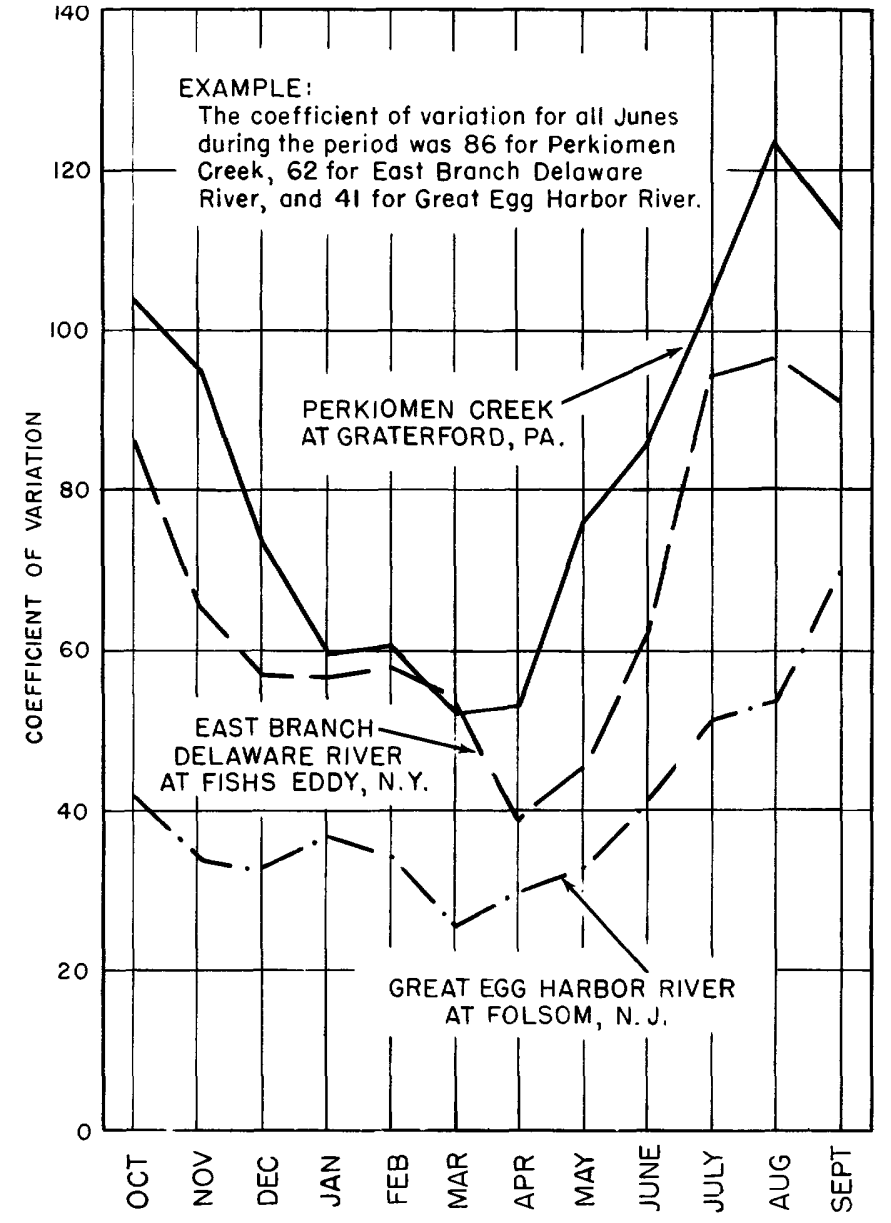

FIGURE 37.-Seasonal changes in the coefficient of variation of monthly runoff, 1921-50.

Because seasonal influences cause marked changes in runoff, it is enlightening to study the coefficients of variation for the same three stations computed for calendar months. Coefficients for all Octobers during the standard period, 1921-50, all Novembers, and so forth, were computed and are plotted in figure 37 . This graph shows the marked seasonal variation in the coefficient which is lowest in winter and spring and highest in summer and fall. The relative variability of some months is even greater than that of all months taken together. For example, the coefficient for all months at Graterford is 88.7 , but the coefficient for all Augusts is 123. This difference is due partly to the low value of mean runoff for August. The coefficient of 123 also indicates that the monthly runoff distribution is greatly skewed and that the coefficient of variation is not valid in the usual sense.

\section{DAILY DISCHARGE}

The comparison of monthly and annual coefficients of variation, shows that variations in streamflow for short periods are much greater than those for longer periods. The variability of daily flow is even greater and is usually shown by a flow-duration curve. This curve shows, for any given period, the percentage of the total number of days (percent of time) when the daily discharge equaled or exceeded any specific value. The steepness of the curve is an indication of the flashiness of the stream or variability of the daily discharge.

The flow duration for drainage areas of the sizes normally gaged are sometimes affected by chance occurrence of floods or droughts that are not representative of the region and period. For example, an extreme flood that normally might occur only once in a hundred years could be included in the record for one small area with no similar flood included in the record for adjacent areas. This would cause an appreciable difference in the flow duration of streams that might otherwise be the same. If the runoff experiences at one or more comparable gaging stations can be combined with those at the station in question, it is possible to define a regionalized flow duration curve which is a more reliable basis for estimating future flow duration. Such a regionalizing process, based on correlation of gaging station records and transposition of data for one area to other comparable areas, has been developed and used to make a regional analysis of flow duration characteristics of streams in the Delaware River basin.

Flow duration curves are affected by wet and dry periods; consequently curves for different areas should be based on the same period if comparisons are to be meaningful. However, for periods of 30 years or more, differences due to climatic fluctuations are usually slight. The longest practicable period (the 40 years 1914-53) was used in this analysis and all regionalized data are based on, or adjusted to, this period. Thus, the shape of the curves represents the flow-duration characteristics for the period 1914-53. The ordinates of some of the curves, however, are percentages of the average annual discharge for the previously adopted standard 30-year period (1921-50). The ordinates could be the percentage of average for any period without destroying the validity of the curve or altering any of the relationships. The 30 -year average is most convenient for use here because of its use elsewhere in this report.

Regionalized flow duration curves for three streams in the Delaware River basin are shown in figure 38. Pèrkiomen Creek drains a moderately hilly area with relatively small aquifer storage; Maurice River is a typical Coastal Plain stream where storage in swamps and aquifers is a dominant factor, and Neversink River drains a mountainous area which is glaciated and has storage characteristics between the other two. The curves reflect these differences. For example, the 
flow available 99.9 percent of the time is more than 20 percent of the average annual flow for Maurice River but less than 3 percent of the average annual flow for Perkiomen Creek. High discharges are affected in the opposite way by the natural storage capacity of the basins-Maurice River reaches less than 350 percent of average annual flow at 0.5 percent of the time, but flow of Perkiomen Creek reaches nearly 1,500 percent of average annual flow at 0.5 percent of the time.

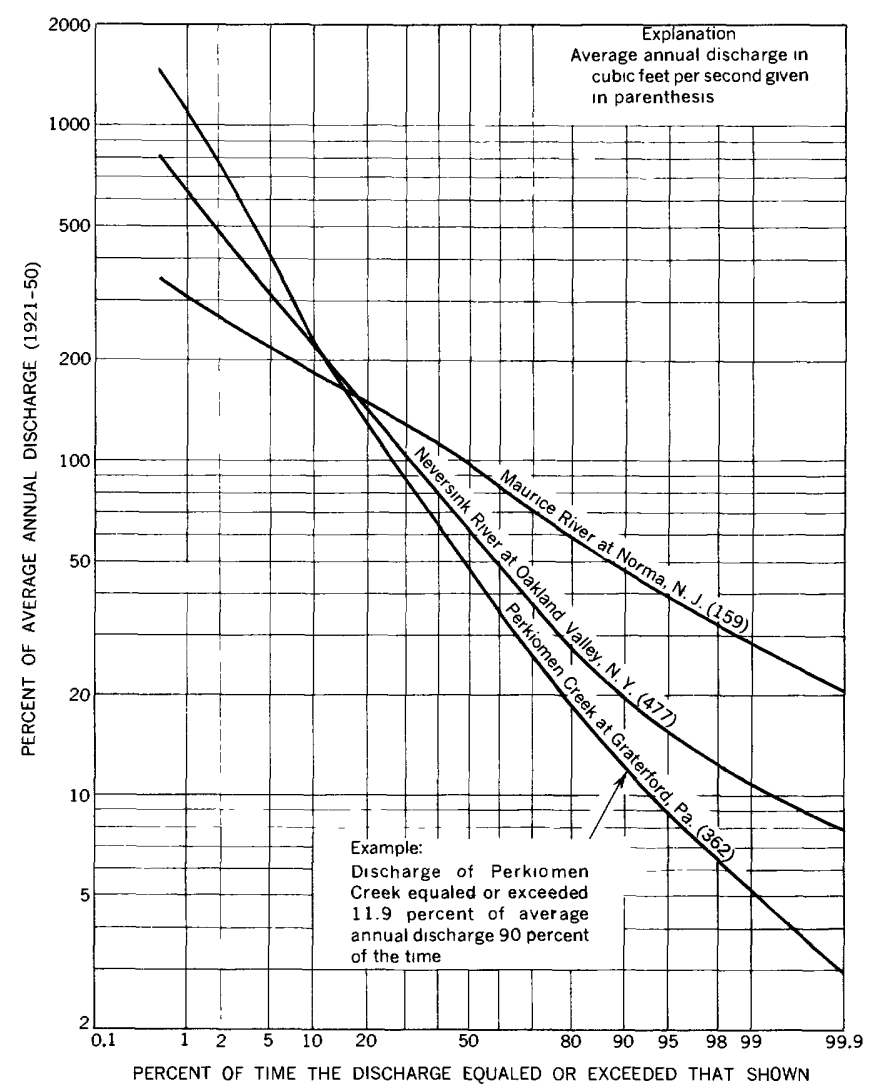

Figure 38,-Regionalized daily-flow duration curves for three gaging stations, 1914-53.

Studies of the regionalized daily flow-duration curves for 15 areas that were not appreciably affected by regulation are summarized in table 25. Enough values are given to define curves such as those illustrated in figure 38 ; graph paper with a probability scale for abscissa and logarithmic scale for ordinate is best for this purpose.

Results of the same study for eight areas that were affected by regulation are summarized in table 26 . At two of these gaging stations, Wallenpaupack Creek at Wilsonville, Pa., and Delaware River at Port Jervis, N.Y., sufficient data were available to define flowduration curves for natural conditions that existed before the start of regulation, as well as those for regulated conditions. These results, showing the effects of

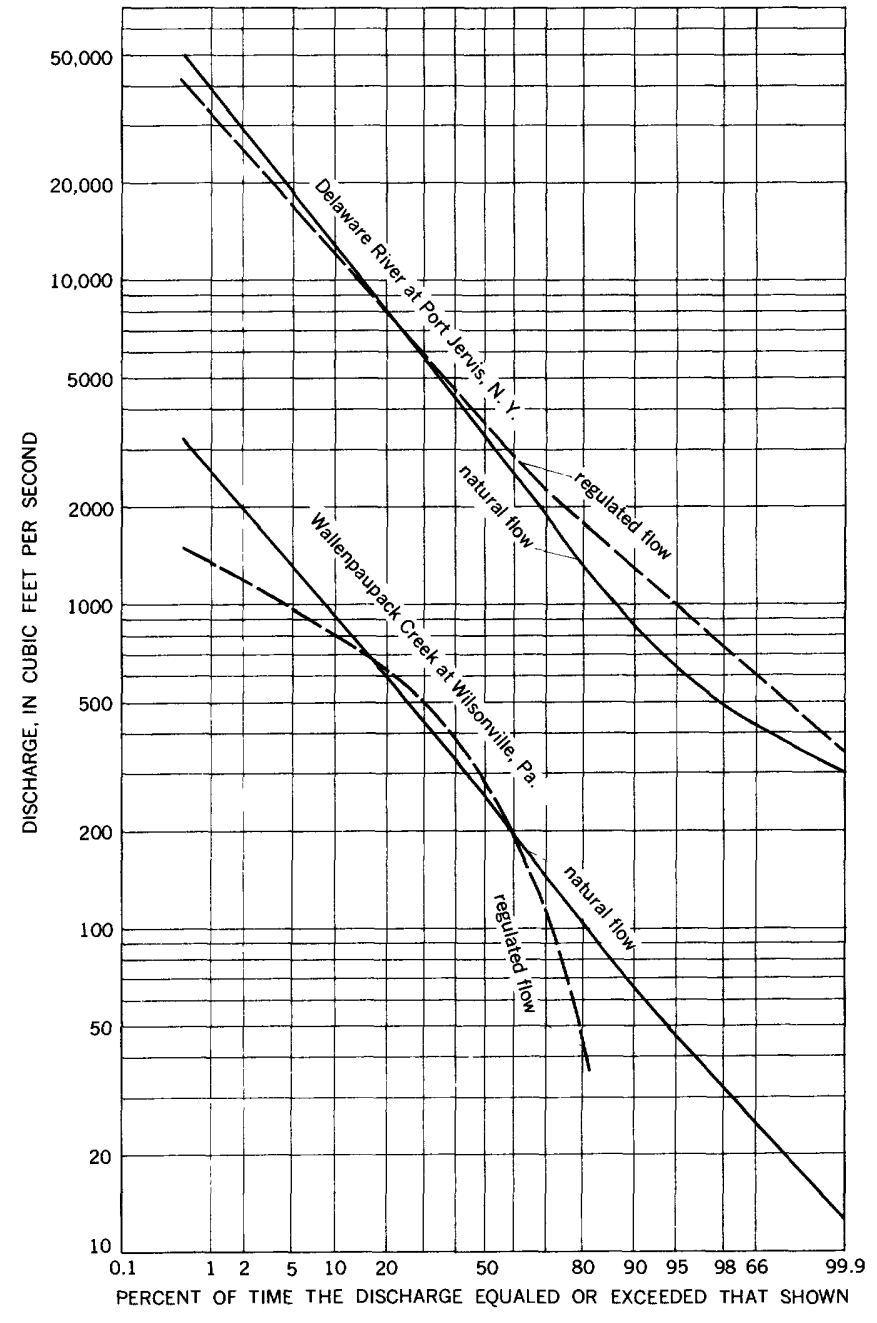

FIGURE 39.-Effect of regulation on the duration of daily flow at two gaging stations.

regulation on the duration characteristics, are illustrated in figure 39.

The station on Wallenpaupack Creek measures the outflow from Lake Wallenpaupack just below a large hydroelectric power plant. Storage of flood flows in the lake usually causes large reductions in the high flow, and operation of the power plant usually reduces flow to zero when the plant is shut down, which is about 10 percent of the time.

Regulation of the Delaware River at Port Jervis, N.Y., is by Lake Wallenpaupack and also by a series of reservoirs and a power plant on Mongaup River. The drainage area controlled by the reservoirs is only about 14 percent of the total drainage area above Port Jervis, and the gaging station is many miles downstream from the power plants. The fluctuations caused by the plants diminish as the distance from the plants increases, and the low flows from the plants do not reach Port Jervis simultaneously. The net result of regulation has been an increase in low flows and a small reduction 
in high flows. Surface storage, in general, reduces the high flows downstream from the reservoirs, but its effect on low flows depends on the magnitude and timing of releases and also on the distance from the reservoirs.

The effect of diversions between gaging stations largely for municipal water supplies, is shown by flowduration curves in figure 40 for Schuylkill River at Pottstown and at Philadelphia, $\mathrm{Pa}$. The diversion has slight effect at the high flows. If there were no diversions, the Philadelphia curve would be expected to lie above and approximately parallel to the Pottstown curve instead of crossing it at the $750 \mathrm{cfs}, 75$ percent duration point.

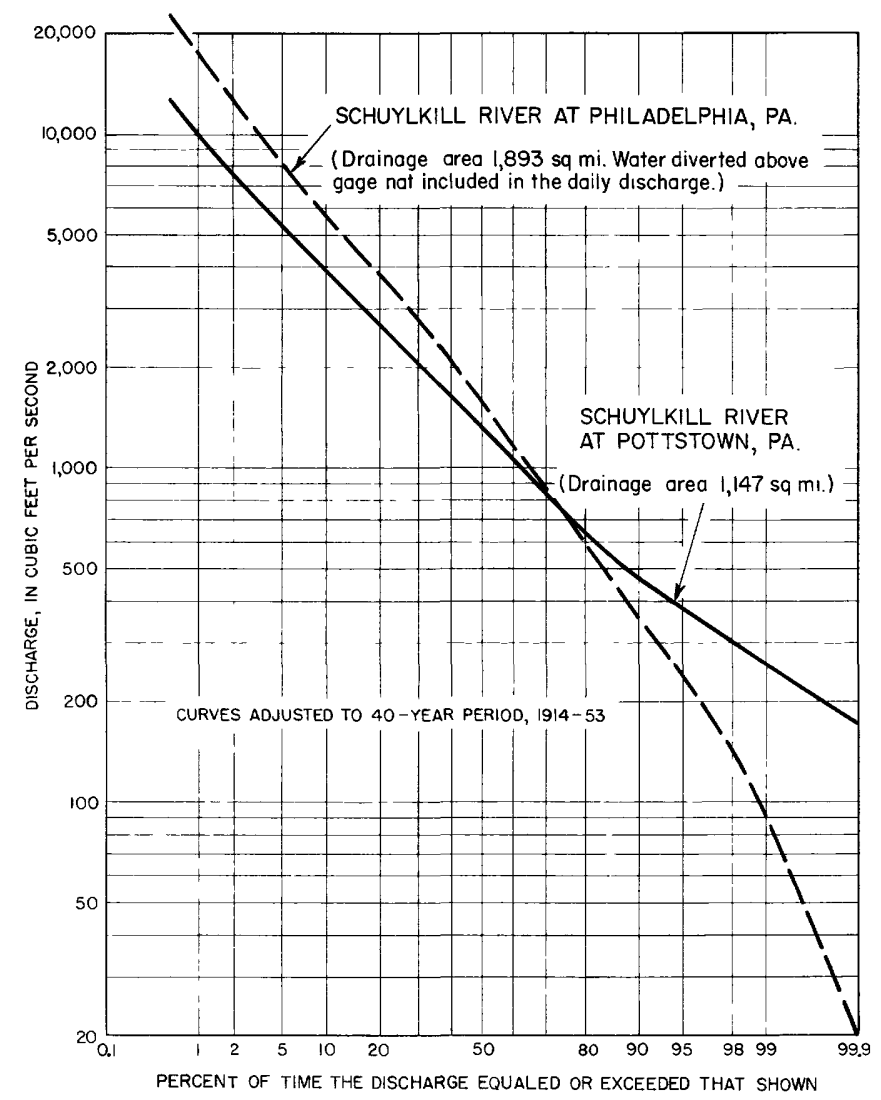

Figure 40.-Effect of diversion on the duration of daily flow of Schuylkill River.

Table 27 presents a summary of flow-duration characteristics for seven additional areas that were not included in the regional analysis. These data were adjusted, where necessary, to the standard 30-year period (1921-50) instead of the 40-year period used in tables 25 and 26. Consequently the two sets of data are not strictly comparable; however, comparison of flow-duration curves for several areas for both periods indicates that the differences are small and the results are close enough for general comparisons. Because the greatest differences occur near the extremes (especially the low end), these have not been carried as far in table 27.

It was not possible to compute daily flow-duration data for all the stations for which such data might be desired because of the time and labor required. ${ }^{6}$ To extend the duration analysis to the flow at an additional group of stations, flow-duration curves based on monthly mean discharge were prepared for 15 gaging stations and compared with those for daily flows. A sample is shown in figure 41 for East Branch Delaware River at Fishs Eddy, N.Y.

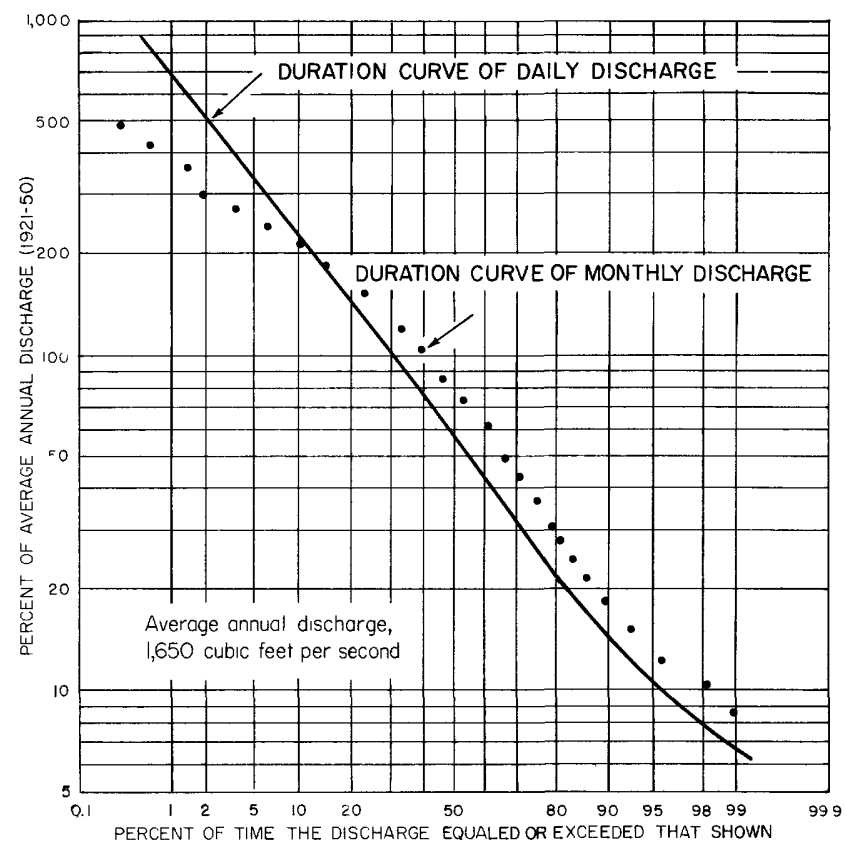

FIGURE 41.-Comparison of duration curves of daily and monthly flow of East Branch Delaware River at Fishs Eddy, N.Y., 1921-50.

There is no simple relation between the two types of flow-duration curves, and the relation varies from area to area. Certain points on duration curves are of more than usual interest. Among these are such points as the discharge available 10 percent of the time $\left(Q_{10}\right)$, the median discharge $\left(Q_{50}\right)$, and the discharge available 90 percent of the time $\left(Q_{90}\right)$. The ratios of these discharges to the mean annual flow $\left(Q_{m}\right)$ are often used for comparison with other streams. Of these, $Q_{90}$ is probably used most frequently by watersupply hydrologists and it is a useful indicator of the

${ }^{6}$ Flow data for 23 of the stations used in the regional analysis were processed on the electronic computer of the Geological Survey. Data for the remainder were not ready for such processing, which requires recording of the data on punched tape. Future studies of this type will be greatly facilitated by use of electronic computers. 
low-flow characteristics of a stream. For example, Tohickon Creek at Pipersville, Pa., one of the flashiest streams in the area, has a $Q_{9 n}$ that is only 2.99 percent of the mean annual, but Maurice River at Norma, N.J., which is influenced by large natural storage capacity, has a $Q_{90}$ that is 46.1 percent of the mean (table 25)!

Values of this ratio, $Q_{90} / Q_{m}$, taken from the daily curves were plotted against corresponding values from the monthly curves for the 15 stations. The results, shown in figure 42 , indicate very good correlation between these values; and the straight line defined by these points may be used to convert $Q_{90} / Q_{m}$ obtained from a monthly curve to the corresponding value that would be obtained from a daily curve. This conversion diagram is assumed to be applicable for the Delaware River basin and adjacent areas; however, it should be checked by comparison with values of the ratio from daily and monthly curves for representative stations in the region before it is used for any other region. Table 28 summarizes the monthly duration data for 12 gaging stations, for which no daily-duration data are available, and presents estimates of the daily $Q_{90} / Q_{m}$

Correlations involving $Q_{50}$ and $Q_{10}$ were much less satisfactory than that of $Q_{90}$ and are not considered usable.

In an area that is relatively uniform in hydrologic characteristics, the flow at several gaging stations may have duration characteristics which are either identical or very similar. In such an area the curves derived for the flow at the gaging stations provide a basis for estimating the flow duration of similar ungaged areas. Extreme caution must be used in making such estimates because even small adjacent areas often have markedly different flow-duration characteristics. A safer method of estimating the low-flow part of the curve is based on occasional measurements of base flow as described in a later section.

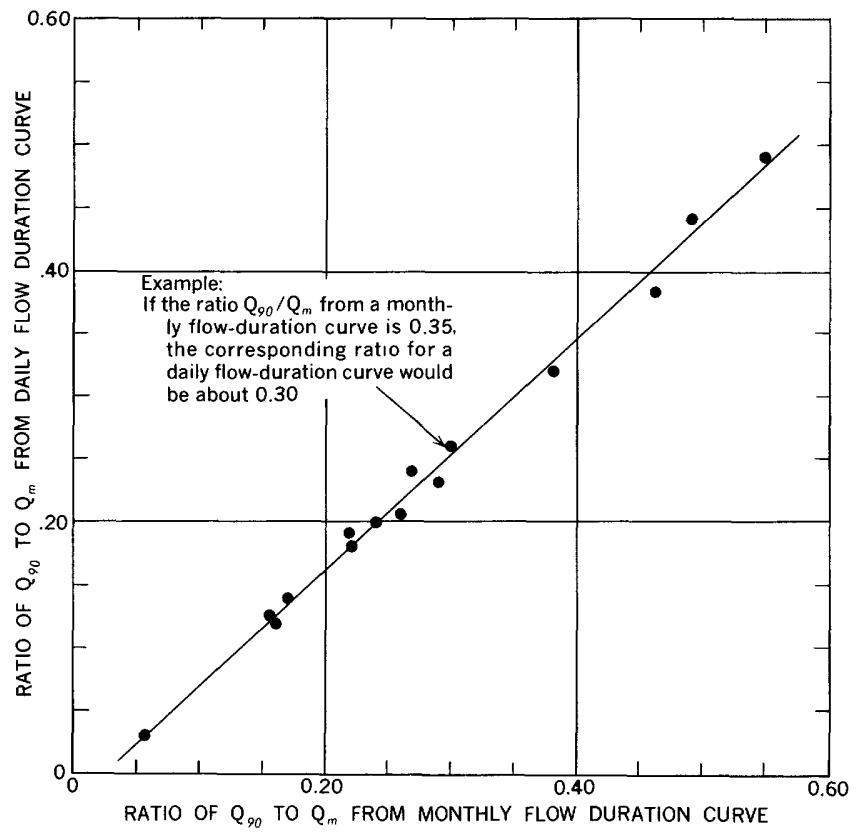

FiguRE 42.- Relation curve for obtaining 90-percent daily-flow duration from 90-percent monthly-flow duration.

TABLE 25.-Regionalized duration of daily flow at selected gaging stations on unregulated streams, 1914-53

[Duration data in this table based on records for less than 40 years and adjusted to the period 1914-53]

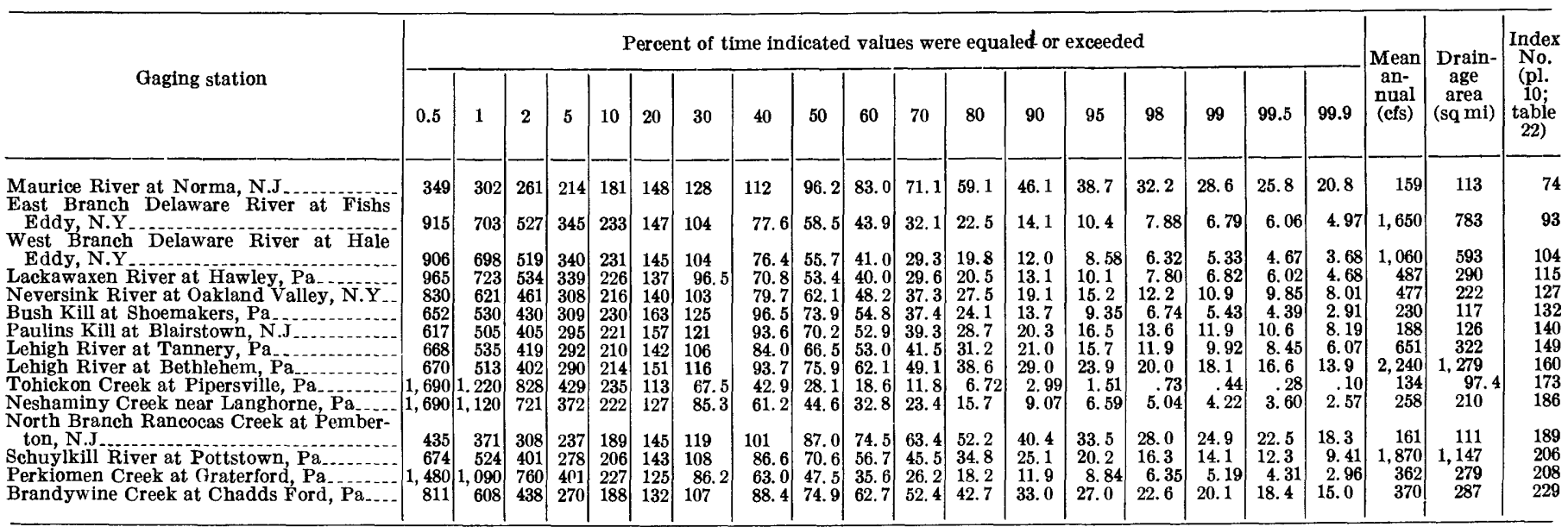


TABLE 26.-Regionalized duration of daily flow, in cubic feet per second, at selected gaging stations on regulated streams, $1914-53$ [Duration data are based on pattern of regulation existing during correlation period indicated. Any change in pattern of regulation would cause change in duration data. Regulated daily flows apply only at gaging station. Data for natural flow at two stations are included to show effects of regulation]

\begin{tabular}{|c|c|c|c|c|c|c|c|c|c|c|c|c|c|c|c|c|c|c|c|c|c|c|}
\hline \multirow{2}{*}{ Gaging station } & \multicolumn{18}{|c|}{ Percent of time indicated values were equaled or exceeded } & \multirow{2}{*}{$\begin{array}{l}\text { Corre- } \\
\text { lation } \\
\text { period }\end{array}$} & \multirow{2}{*}{$\mid \begin{array}{c}\text { Mean } \\
\text { an- } \\
\text { nual } \\
\text { (cfs) }\end{array}$} & \multirow{2}{*}{$\begin{array}{c}\text { Drain- } \\
\text { age } \\
\text { area } \\
\text { (sq } \mathrm{mi})\end{array}$} & \multirow{2}{*}{$\begin{array}{c}\text { Index } \\
\text { No. } \\
\text { (pl. } \\
10 ; \\
\text { table } \\
22 \text { ) }\end{array}$} \\
\hline & 0.5 & 1 & 2 & 5 & 10 & 20 & 30 & 40 & 50 & 60 & 70 & 80 & 90 & 95 & 98 & 99 & 99.5 & 99.9 & & & & \\
\hline $\begin{array}{l}\text { Wallenpaupack Creek at Wilson- } \\
\text { ville, } \mathrm{Pa} \text { : }\end{array}$ & & & & & & & & & & & & & & & & & & & & & & \\
\hline $\begin{array}{l}\text { Regulated } \\
\text { Natural }\end{array}$ & $\begin{array}{l}444 \\
973\end{array}$ & $\begin{array}{l}393 \\
757\end{array}$ & $\begin{array}{l}349 \\
583\end{array}$ & $\begin{array}{l}284 \\
391\end{array}$ & $\begin{array}{l}238 \\
272\end{array}$ & $\begin{array}{l}186 \\
178\end{array}$ & $\begin{array}{l}147 \\
129\end{array}$ & $\begin{array}{c}113 \\
99.1\end{array}$ & $\begin{array}{l}85.2 \\
75.7\end{array}$ & $\begin{array}{l}58.6 \\
58.6\end{array}$ & $\begin{array}{l}34.0 \\
44.1\end{array}$ & $\begin{array}{l}14.7 \\
31.4\end{array}$ & $\begin{array}{c}0 \\
20.0\end{array}$ & $\stackrel{0}{14.0}$ & $\begin{array}{l}0 \\
9.67\end{array}$ & $\begin{array}{l}0 \\
7.54\end{array}$ & $\begin{array}{l}0 \\
5.98\end{array}$ & $\begin{array}{l}\mathbf{0} \\
3.79\end{array}$ & $\left|\begin{array}{|c}1927-53 \\
1910-25\end{array}\right|$ & $\begin{array}{l}338 \\
338\end{array}$ & $\begin{array}{l}228 \\
228\end{array}$ & $\begin{array}{l}116 \\
116\end{array}$ \\
\hline $\begin{array}{l}\text { Mongaup River at Mongaup, } \\
\text { N.Y }\end{array}$ & 416 & 346 & 290 & 223 & 184 & 144 & 120 & 103 & 88.0 & 73.3 & 58.1 & 41.6 & 24.3 & 15.3 & 9.06 & 7.07 & 5.95 & 4.34 & $1940-53$ & 341 & 202 & 120 \\
\hline $\begin{array}{l}\text { Delaware River at Port Jervis, } \\
\text { N.Y.: } \\
\text { Regulated } \\
\text { Natural }\end{array}$ & $\begin{array}{l}724 \\
900\end{array}$ & $\begin{array}{l}573 \\
695\end{array}$ & $\begin{array}{l}446 \\
520\end{array}$ & $\begin{array}{l}305 \\
337\end{array}$ & $\begin{array}{l}217 \\
229\end{array}$ & $\begin{array}{l}144 \\
144\end{array}$ & $\begin{array}{l}108 \\
104\end{array}$ & $\begin{array}{r}83.3 \\
77.4\end{array}$ & $\begin{array}{l}65.9 \\
59.5\end{array}$ & $\begin{array}{l}52.0 \\
45.5\end{array}$ & $\begin{array}{l}40.9 \\
34.2\end{array}$ & $\begin{array}{l}31.4 \\
24.6\end{array}$ & $\begin{array}{r}22.4 \\
15.4\end{array}$ & $\begin{array}{l}17.3 \\
11.3\end{array}$ & $\begin{array}{c}12.9 \\
8.69\end{array}$ & $\begin{array}{c}10.7 \\
7.62\end{array}$ & $\begin{array}{l}8.91 \\
6.81\end{array}$ & $\begin{array}{l}6.18 \\
5.36\end{array}$ & $1931-52$ & $\begin{array}{l}5,580 \\
5,580\end{array}$ & $\begin{array}{l}3,076 \\
3,076\end{array}$ & $\begin{array}{l}121 \\
121\end{array}$ \\
\hline $\begin{array}{l}\text { McMichaels Creek at Strouds- } \\
\text { burg, Pa. } \\
\text { Musconetcong River near }\end{array}$ & 722 & 568 & 439 & 297 & 210 & 140 & 104 & 79. 7 & 62.6 & 49.4 & 39.2 & 30.5 & 22.6 & 18.5 & 15.2 & 13.3 & 12.0 & 9. 51 & $1912-38$ & 123 & 64.4 & 135 \\
\hline $\begin{array}{l}\text { Bloomsbury, N.J } \\
\text { Delaware River at Trenton, } \mathbf{N}^{-} \mathbf{J}_{-}^{-}\end{array}$ & $\begin{array}{l}430 \\
591\end{array}$ & $\begin{array}{l}372 \\
489\end{array}$ & $\begin{array}{l}313 \\
402\end{array}$ & $\begin{array}{l}247 \\
296\end{array}$ & $\begin{array}{l}198 \\
220\end{array}$ & $\begin{array}{l}151 \\
151\end{array}$ & $\begin{array}{l}122 \\
113\end{array}$ & $\begin{array}{c}101 \\
89.8\end{array}$ & $\begin{array}{l}84.0 \\
72.0\end{array}$ & $\begin{array}{l}69.8 \\
57.6\end{array}$ & $\begin{array}{l}56.9 \\
45.5\end{array}$ & $\begin{array}{l}46.2 \\
35.1\end{array}$ & \begin{tabular}{|l|}
37.3 \\
25.7
\end{tabular} & $\begin{array}{l}32.4 \\
20.7\end{array}$ & $\begin{array}{l}28.4 \\
16.9\end{array}$ & $\begin{array}{l}26.3 \\
15.2\end{array}$ & $\begin{array}{l}24.4 \\
13.8\end{array}$ & $\begin{array}{l}21.0 \\
11.3\end{array}$ & $\left|\begin{array}{l}1922-53 \\
1931-52\end{array}\right|$ & $\begin{array}{r}225 \\
11,810\end{array}$ & $\begin{array}{r}143 \\
6,780\end{array}$ & $\begin{array}{l}168 \\
181\end{array}$ \\
\hline Assunpink Creek at Trenton, & 750 & 597 & 459 & 312 & 222 & 147 & 110 & 85.3 & 67.4 & 54.1 & 42.7 & 32.8 & 22.7 & 16.8 & 11.8 & 8.97 & 7.07 & 4. 31 & $1924-53$ & 116 & 89.4 & 182 \\
\hline $\begin{array}{l}\text { Schuylkill River at Philadelphia, } \\
\mathrm{Pa}\end{array}$ & 797 & 608 & 448 & 281 & 195 & 130 & 97.2 & 73.1 & 54.2 & 40.9 & 30.1 & 20.9 & 12.6 & 8.32 & 5.17 & 3.18 & 1.95 & .70 & $1932-53$ & 2,860 & 1,893 & 213 \\
\hline
\end{tabular}

TABLE 27.-Duration of daily flow at selected gaging stations, 1921-50

[Data in this table computed from individual station records, adjusted to standard period, but not regionalized]

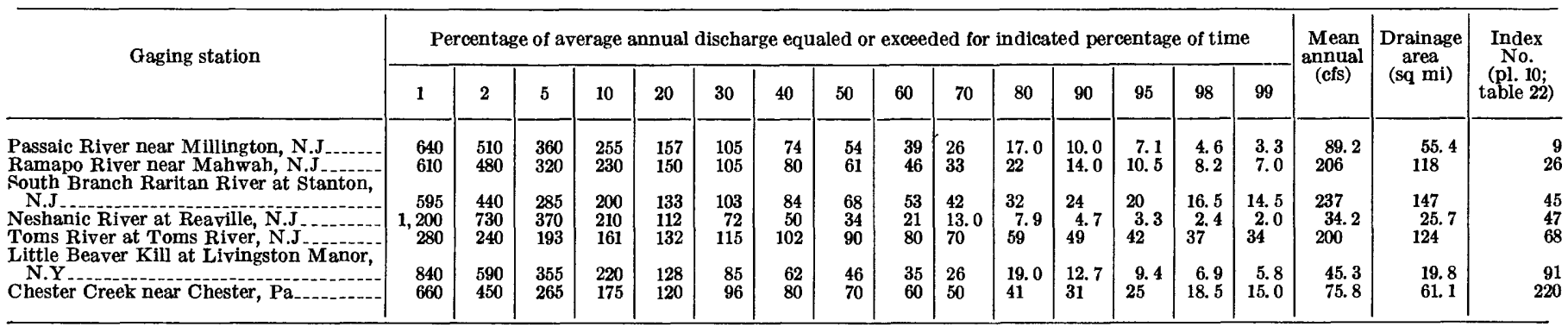

TABLE 28.-Duration of monthly flow and equivalent 90-percent duration of daily flow at selected gaging stations, 1921-50






\section{FLOODS AND FLOOD-FREQUENCY ANALYSIS}

The study of variations in streamflow leads to a study of the extremes which, for many purposes, are the most important parts of the record. The flowduration analysis provides useful data on the general variability of flow but does not indicate the magnitude and frequency of flood peaks or the length and frequency of droughts. Additional analyses have been made to provide this information.

\section{CAUSES AND OCCURRENCE OF FLOODS}

In August 1955 a summer drought came to an abrupt end when Hurricane Connie drenched large parts of the Delaware River basin and adjoining areas with very heavy rainfall. Some minor flooding resulted from this storm, but the dry soils and depleted surface storage absorbed most of the rainfall. Hurricane Connie would have been quickly forgotten if a second tropical storm, Hurricane Diane, had not followed within 5 days and again drenched much of the same area. When Diane reached the area the soils were still nearly saturated and the streams and lakes were already swollen. Although precipitation in the second storm was only slightly more than that in the first one, the resulting floods were the greatest known in many parts of the region not only in volume and stage of flow but in loss of life and property damage.

Such catastrophic events help create a public awareness of the need for stream development and control. However, flood damages are caused by many smaller floods, as well as by the outstanding ones.

Maximum floods on small streams usually result from rains of high intensity over relatively small areas during short periods of time. Those on larger streams of the region usually result from general storms that cover large areas and last much longer. Many additional factors also affect the floods that may occur in a basin. Most important of these is the storage capacity of the soil, aquifers, ponds, lakes, and reservoirs. The floods of August 1955 are outstanding examples of the ability of this storage capacity to reduce floods, as in the first storm, and its inability to reduce them, as in the second storm, because the storage space was already nearly filled. These floods are not isolated examples. Great floods in many parts of the world have resulted when heavy precipitation fell on saturated or frozen soil at a time when ponds, lakes, and stream channels were already filled, or when precipitation on snow cover caused the snowmelt and the rainfall to run off simultaneously.

Ice jams sometimes produce damaging floods but not excessive streamflow. At least one major flood in the basin, that of March 1904, was the result of an ice jam.
Such floods usually are confined to a relatively small area near the jam.

The orientation of the Delaware River and its major tributaries is such that warm weather tends to cause ice cover to disintegrate in the lower reaches first; the danger of ice jams is thus minimized. Conditions leading to an ice-jam flood probably would be either a rapid rise in temperature over the whole basin when snow cover is present, or rainfall over the whole basin, with resulting high runoff, before thick ice in the lower reaches of the river had time to melt.

The orientation of the basin also tends to reduce another danger - that of major storms traveling downstream for long distances at about the same rate as the flood wave in the river. Because most storms in this region tend to travel from west to east across the basin, or diagonally across it to the northeast, the runoff from downstream areas generally has time to pass a given point on the river before runoff from upstream areas reaches the same point.

As a result of timing of separate storms, runoff from downstream parts of the basin can reach a given point on the river at the same time as a flood wave from upstream. This event most commonly occurs after summer thunderstorms and can occur in any basin, regardless of orientation.

The long narrow form of the Delaware River basin and some of its major tributaries also tends to decrease flood heights because runoff from various parts of a basin reaches the lower end at different times if the precipitation occurs at about the same time over most of the basin.

Different types of flood information are required for proper solution of problems involving floods. A spillway of a large dam must be designed to pass the maximum flood without endangering the structure. The storage capacity of a flood-control reservoir might, for economic reasons, be based on the volume of water in much smaller flood. Many small structures, such as bridges and culverts, are designed on the basis of floods that on the average can be expected to recur at a certain frequency, such as once in 10 years or once in 50 years.

Hydrologic information needed for many purposes is provided by a flood-frequency analysis. Regionalizing techniques are applicable to flood-frequency data and are now used in most flood-frequency analyses.

The volume of water discharged during a flood cannot be determined from the frequency analysis of peak discharges but can be computed from daily discharge records of the flood in question or can be estimated from records of a similar flood on the same or a similar stream. 
REGIONAL FLOOD-FREQUENCY ANALYSIS

By Richard H. Tice

An analysis of streamflow records in the Delaware River basin was made to provide a means for determining the magnitude and frequency of floods on any stream within the basin draining an area of 10 square miles or more. All records of five or more years from streams not affected by excessive regulation were used; 86 records, ranging in length from 5 to 59 years, met the criteria and some historical information was available.

Records of peak discharge may be analyzed as an annual-flood series or as a partial-duration series. There is an important distinction in meaning between recurrence intervals determined by the two methods. In the annual-flood series the recurrence interval is the average interval in which a flood equal to or greater than a given magnitude will occur as the maximum annual flood. In the partial-duration series the recurrence interval is the average interval between floods of a given magnitude regardless of their relation to the year or any period of time. For floods having recurrence intervals of 10 years or more, the two methods give almost identical results. The following tabulation compares the recurrence intervals of floods of the same size computed by the two methods:

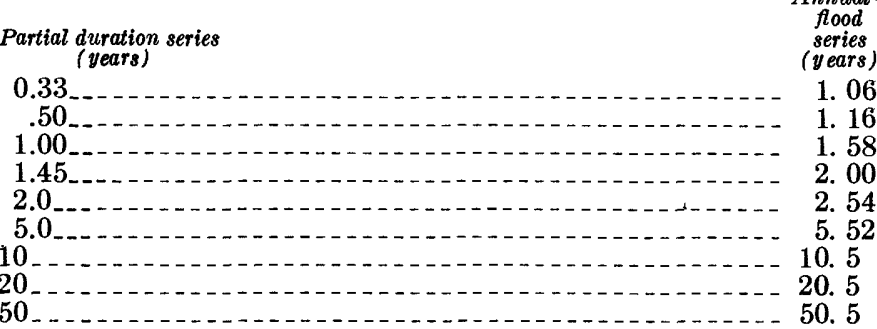

Because of its relative simplicity, the annual-flood series has been used in this study. Results may be converted to the partial-duration series by means of the above tabulation.

The results of the analysis are represented in two sets of curves. One set (fig. 43) consists of frequency curves that relate peak discharge, expressed as a ratio

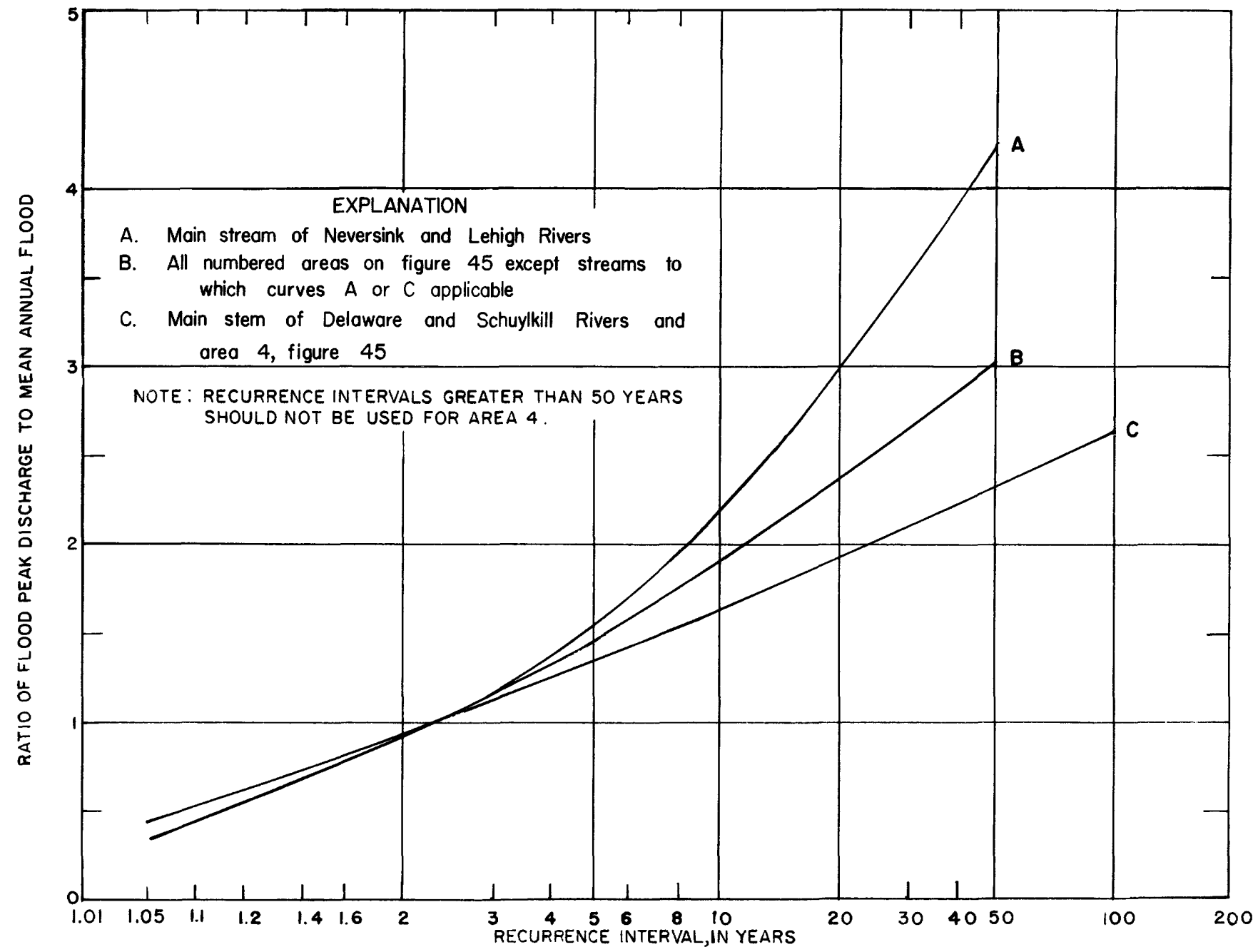

Figure 43.-Composite flood-frequency curves for Delaware River basin and southern New Jersey. 
to the mean annual flood, to recurrence interval; each curve is a composite of several curves for individual gaging stations. The second set of curves (fig. 44) relates mean annual flood to size of drainage area; and a map of the basin (fig. 45) shows areas for which each curve is applicable. By means of these sets of curves, a flood-frequency curve can be obtained for any stream in the basin or in southern New Jersey with a drainage area of 10 or more square miles, as explained in the following discussion.

Hydrologists have used many different methods to study flood frequencies and no single method is generally accepted by all. Significant features of the standard method used by the Geological Survey are:

1. It analyzes momentary peak discharges; only the maximum for each water year (October 1 to September 30) is used.

2. Recurrence intervals are computed by the formula $T=(n+1) / m$, in which $T$ is the recurrence interval in years, $n$ is number of years of record, and $m$ is the order number of each flood, the greatest being numbered 1 .

3. Curves are fitted graphically.

4. The mean annual flood is defined as the flood having a recurrence interval of 2.33 years.

The term "recurrence interval" means the average interval of time in which a flood of given magnitude may be equaled or exceeded. Thus, a 20-year flood is one that may be equaled or exceeded on the average once in 20 years, or, to state it another way, it is one

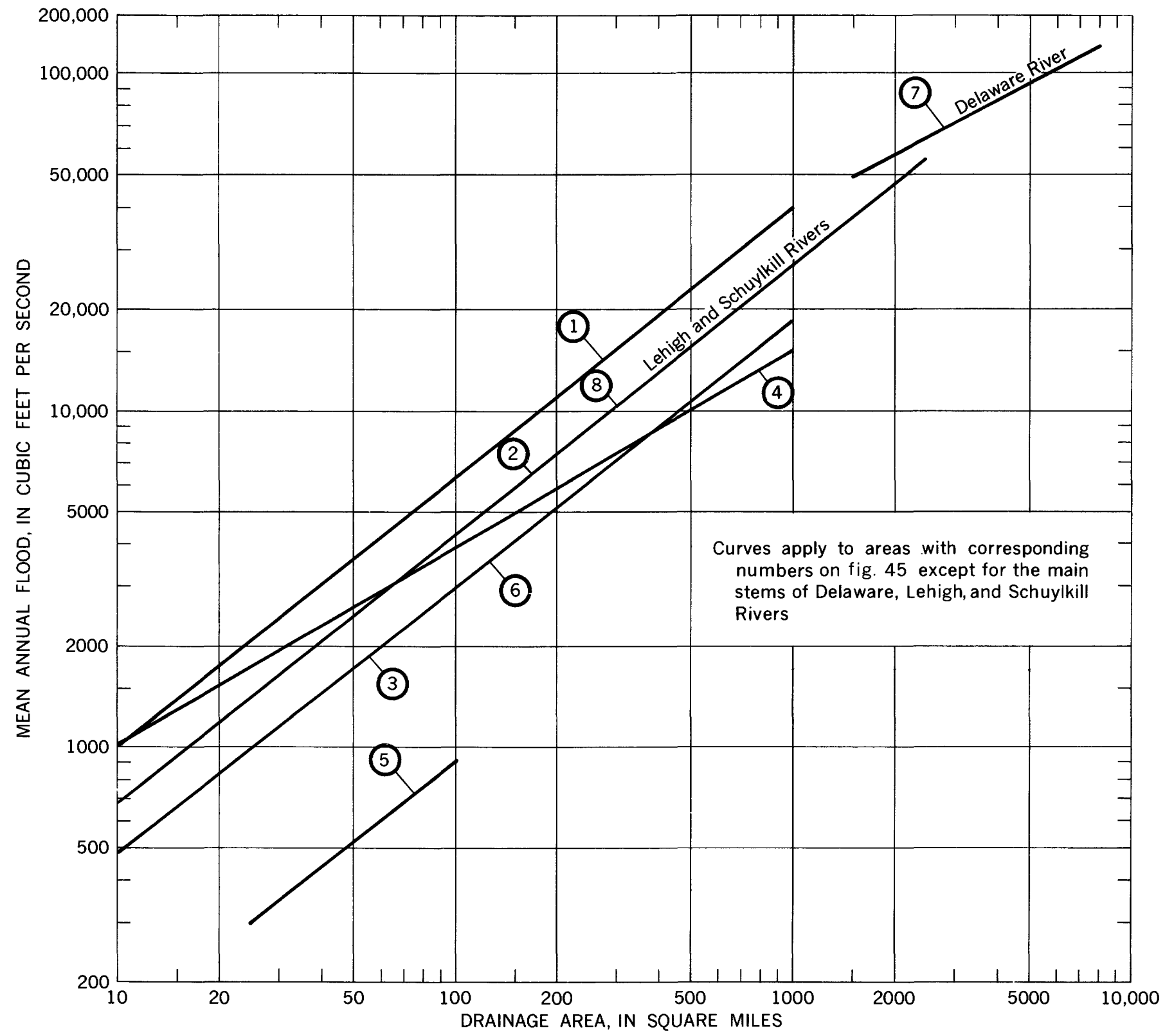

FigUre 44.-Relation of mean annual flood to drainage area in Delaware River basin and southern New Jersey. 


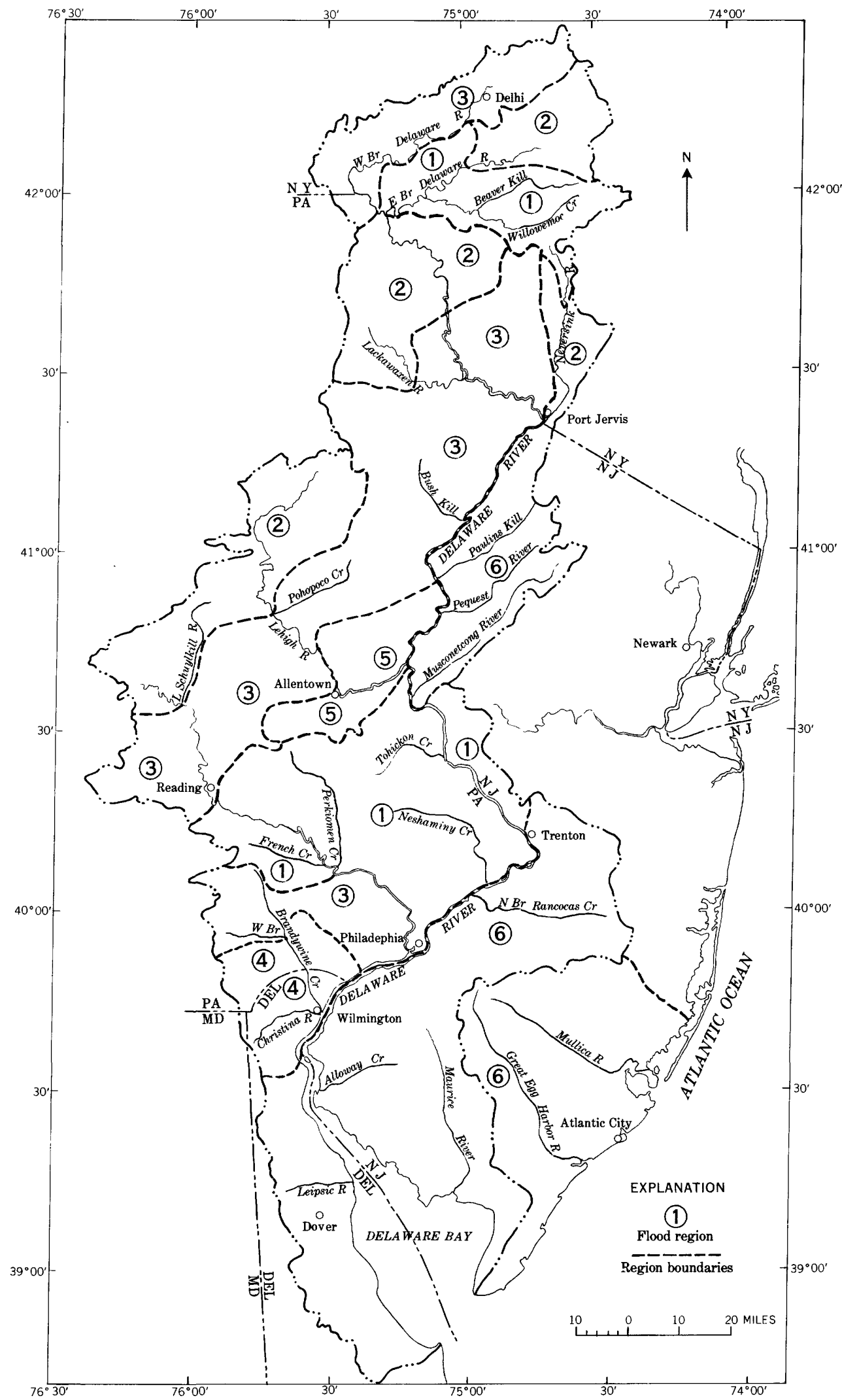

FIGURE 45.-Map of Delaware River basin and New Jersey showing flood regions used in regional flood-frequency analysis. 
having a 5 percent chance of occurring in any given year.

The frequency relations determined from individual gaging-station records are subject to considerable variation from the true long-term relation. When a number of records are combined, the dependability of the frequency graphs is greatly improved. This study combines those stations whose basins have been shown by tests to be similar in flood-producing characteristics. Because of the random nature of the occurrence of large floods and the possibility of changes in flood events due to changing land use and to large-scale weather fluctuations, flood-frequency graphs for different periods of time may be different. In this study the period used was 1913-55. For stations on the Delaware and Schuylkill Rivers, historical data extending back to 1692 were utilized along with the records for the period 1913-55.

\section{FLOOD-FREQUENCY RELATIONSHIPS}

The analysis indicated that the flood-frequency relations for this region can be defined by three curves, designated $A, B$, and $C$, in figure 43 . Curve $A$ is applicable only to the main stems of the Neversink and Lehigh Rivers; curve $B$ applies to all streams in the basin, plus the area in southern New Jersey immediately south of the basin, except those streams for which curve $A$ or $C$ applies; and curve $C$ applies to area 4 (fig. 45) and to the main stems of the Schuylkill and Delaware Rivers. The southern part of Delaware was not included in the analysis because of lack of data. These curves show the flood peak discharge as a ratio to the mean annual flood. The magnitude of the mean annual flood must be known before these curves can be applied.

\section{MEAN ANNUAL FLOOD}

The mean annual flood is influenced by a number of factors including: (1) the size of the drainage basin, (2) the shape of the basin, (3) basin alinement with the prevailing direction of storm travel, (4) land and stream slopes, (5) elevation, (6) geologic and soil characteristics of the basin, (7) flood-water storage in stream channels, swamps, and lakes, (8) type of vegetation and land use, and (9) several other minor factors. Of these nine factors, the size of the drainage area is dominant in influencing the mean annual flood.

The relation of mean annual flood to drainage area varies considerably within the area; however, the relation for any stream with drainage area larger than 10 square miles, except in most of Delaware, can be defined by one of the six curves in figure 44. Each curve is for an area of similar flood-producing characteristics and has been assigned a number to identify it; curve 3 (6) has two numbers, as explained in the following paragraph. The areas whose flood-producing characteristics are defined by these curves are shown and identified in figure 45. No area is shown for curve 7 as this curve is for the Delaware River which drains parts of several areas and integrates their characteristics. Similarly, no area is shown for Lehigh and Schuylkill Rivers but curve 2 is applicable.

Curve 6, which is identical with curve 3, applies to areas in New Jersey, except for a small part between the Musconetcong River and Assunpink Creek which is in area 1. Streams in area 6 are affected by considerable storage in lakes and swamps. The storage factor was so important that a separate flood-reduction factor, presented in figure 46 , must be used with streams in this area.

In other parts of the basin the effect of storage was combined with other factors and is reflected in the curves of figure 44 . Only in New Jersey was a separate flood-reduction factor found necessary.

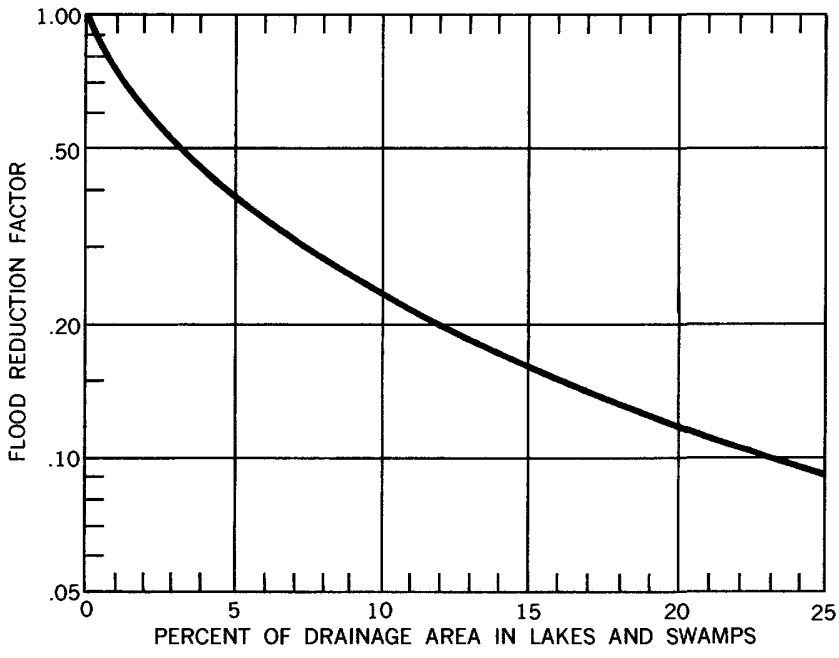

FIGURE 46.-Flood-reduction factor for streams in area 6, figure 45 .

\section{CONSTRDCTION OF A FREQDENCY CURVE}

A flood-frequency curve for any stream draining more than 10 square miles in the areas designated on figure 45 may be constructed by the following procedure:

1. Determine the drainage area in square miles. If in area 6 , determine also the percentage of the total area that is covered by lakes and swamps.

2. Locate the stream on figure 45 to find the area number.

3. Determine the mean annual flood, in cubic feet per second, from curve for that area on figure 44 . If the stream is in area 6, multiply by a flood-reduction factor obtained from figure 46. For Delaware River, use curve 7 and for Lehigh and Schuylkill Rivers, use curve 2 . 
4. Determine from the proper curve on figure 43 the ratio of flood peak discharge to mean annual flood for several recurrence intervals.

5. Multiply the mean annual flood discharge from step 3 by ratios obtained in step 4 to obtain flood-peak discharges corresponding to several recurrence intervals.

6. Plot the data from step 5 and draw the frequency curve.

\section{HISTORICAL FLOODS}

On the basis of peak discharge, the flood of August 1955 is the greatest known since colonial times (flood of February 1692) on the Delaware River from the mouth of Lackawaxen River to Trenton. The flood of October 1903 is the second greatest.

Systematic collection of records of river stage and discharge for the Delaware River was begun in 1897 at Lambertville, N.J. At that time the flood of January 1841 was considered the highest since the Revolutionary War. However, at Lambertville the flood of 1903 exceeded the flood of 1841 by 3.6 feet, and the flood of 1955 exceeded the flood of 1903 by 3.3 feet.

The flood of February 1692 may have been as great as, or greater than, the flood of 1955 . In a letter by Phineas Pemberton on February 27, 1692 (Watson, 1850 , p. 364), the flood of 1692 is described as having risen 12 feet above the usual high-water mark at the Delaware Falls (Trenton) and the water as reaching the upper stories of houses built on the lowlands.

The term "usual high-water mark" is somewhat vague. One measure of the level of the usual highwater mark would be the flood level reached or exceeded about once a year. At Trenton, a flood with a gage height of 10 feet is now experienced on an average of once a year. This 10 feet plus the 12 foot rise gives a stage of 22 feet for the 1692 flood. Twenty-two feet is higher than the floods of 1903 and 1955 but is about equal to an ice-jam flood in March 1904. Smith (1765, p. 208) gives data to check roughly a 22 -foot stage for the flood of 1692 . The settlers had built on the lowlands and had lived there for 16 years although the Indians had told them their buildings were liable to be damaged by freshets. A stage of about 22 feet would be required for a flood to reach the upper floors of 2-story buildings that had not been flooded in the previous 16 years. The records collected on the Delaware River for the past 60 years show that at Trenton a stage of 14 feet or greater can be expected on an average of once in 16 years, although a maximum stage of only 13 feet was experienced in one 16-year period (1916-32).

On the Lehigh River at Bethlehem, the highest floods in descending order of magnitude since 1786 occurred May 1942, August 1955, February 1902, and June 1862.

On the Schuylkill River at Reading, the greatest floods in order of size since 1757 occurred in September 1850, October 1869, February 1902, and May 1942.

The largest flood recorded at any of the gaging stations in the Delaware River basin in relation to the mean annual flood, occurred September 1, 1940, in southern New Jersey. The peak discharge of Mantua Creek at Pitman, N.J., was 38 times as great as the mean annual flood and more than 12 times as great as the 50-year flood, as determined by studies for this report. The recurrence interval of this flood cannot even be surmised from the data available.

Elevations in feet above mean sea level of major floods along the Delaware River follow.

\begin{tabular}{|c|c|c|c|c|c|}
\hline $\begin{array}{l}\text { Miles } \\
\text { from } \\
\text { Trenton } \\
\text { gage }\end{array}$ & Location & $\begin{array}{c}\text { Janu- } \\
\text { ary } \\
1841\end{array}$ & $\begin{array}{c}\text { Octo- } \\
\text { ber } \\
1903\end{array}$ & $\underset{1936}{\text { March }}$ & $\begin{array}{c}\text { August } \\
1955\end{array}$ \\
\hline-34.0 & Philadelphia, Pa.-Race Street.. & & 7.5 & & 8 \\
\hline & Burlington, N.J.-Water Works & & 9.7 & & \\
\hline-15.0 & Bristol, Pa.-Mill Street & & 10.1 & & $\ddot{9}$. \\
\hline-11.9 & Florence, N.J. $\rightarrow$ Municipal Building.- & & 13.6 & & 13.3 \\
\hline-6.2 & $\begin{array}{l}\text { Bordentown, N.J.-Mouth, Cross- } \\
\text { wicks Cr }\end{array}$ & & 17.5 & & \\
\hline-1.0 & Trenton, N.J.-Freeway bridge & & & & 22.6 \\
\hline 0 & Trenton, N.J.-U.S.G.S. gage & & 28.5 & 24.4 & 28. 6 \\
\hline $\begin{array}{l}3.5 \\
7.4\end{array}$ & $\begin{array}{l}\text { Yardley, Pa.-Highway bridge } \\
\text { Washington Crossing, N.J.-High- }\end{array}$ & & & 35.8 & \\
\hline & way bridge & & & 47.4 & 53.9 \\
\hline 14.3 & Lambertville, N.J.-Highway bridge-. & 66.5 & 70.1 & 67.1 & 73.4 \\
\hline & $\begin{array}{l}\text { Stockton, N.J.-Highwa } \\
\text { Frenchtown, N.J.-Higl }\end{array}$ & & $\begin{array}{r}81.7 \\
124.2\end{array}$ & 79.7 & $\begin{array}{r}84.5 \\
127.7\end{array}$ \\
\hline & Milford, N.J.-Highway bridge & 132.5 & 135.6 & 133.0 & 140.1 \\
\hline & Riegelsvile, N.J.-U.S.G.S. gage & & 161. 0 & 157.6 & 164.0 \\
\hline 48.6 & Phillipssburg, N.J.-C.R.R. of N.J & 187.1 & 191.2 & & 198.8 \\
\hline & Easton, Pa.-U.S.W.B. gage & --- & 193. 5 & 188.1 & 198. \\
\hline & Belvidere, N.J.-U.S.G.S. gage... & & & $251 . \overline{5}$ & \\
\hline & Portland, $\mathrm{Pa}$ - - Highway bridge.... & & 296.1 & & 298.9 \\
\hline 103.1 & Dingmans Ferry, $\quad \mathrm{Pa} .-\mathrm{H}$ ighway & & & & \\
\hline 111.8 & N.J.二U.S.G.S. gage & & & $\begin{array}{l}379.6 \\
400.1\end{array}$ & $\begin{array}{l}383.4 \\
405.1\end{array}$ \\
\hline 120. 0 & Port Jervis, N.Y.-U.S.G.S. gage. & & 438.6 & 432.9 & 439.3 \\
\hline & Barryville, N.Y.-U.S.G.S. gage.. & & & & 626.6 \\
\hline
\end{tabular}

RARE FLOODS

The frequencies in the preceding analysis have been indicated (fig. 43) only to the 50-year recurrence interval for most streams and the 100-year recurrence interval for main stems of the Delaware and Schuylkill Rivers. These curves are based on the plotting of a large number of points and are drawn through the range in which they are adequately defined. They are not dependent on any assumption that a specific natural law governs the distribution of flood peaks.

A basic problem in flood-frequency studies may be illustrated as follows: Suppose that a gaging-station record of only 10 years' length contains the record of a great flood that is much larger than any other recorded. It is known that this flood is the largest in 10 years; its recurrence interval ordinarily would be computed as once in 11 years. However, from information in this 10-year record alone it cannot be determined that this flood was not the greatest in 100 years or even 1,000 years. In other words, the proper plotting position for this flood on a frequency graph generally cannot be determined. Many attempts to solve this problem have been make, but many assumptions are 
involved and no general agreement among hydrologists has been attained. Recurrence intervals much longer than the period of record, derived partly from historical data, should be used only by those familiar with the methods employed in computing them and the limitations of such estimates.

The frequency of most floods with recurrence intervals greater than 50 to 100 years is less important than that of the flood cited above, and design of hydraulic structures becomes dependent on maximum known, maximum possible, or "project" 7 floods, with adequate safety factors applied as nacessary. The precipitation in the storms of August 1955 approached or equaled in places the maximum amounts of rainfall that were at that time considered probable in this area. It is now considered probable that even greater amounts of precipitation and also a closer spacing of the storms may occur. In such an event, the result would be higher floods than those of August 1955.

In addition to data on flood-peak discharge and frequency, the designers in this field employ such techniques as: (1) analysis of storm rainfall; (2) transposition of maximum known storms to positions which would cause the greatest flood at the point in question; (3) construction of synthetic hydrographs; and (4) flood routing. All these techniques are beyond the scope of this study.

SOME ASPECTS OF FLOOD DAMAGE AND FLOOD CONTROL

Prior to the floods of 1955 , flood damage was not considered by many hydrologists to be a major problem in the Delaware River basin. Now the flood problem is recognized as being of considerable magnitude even though it is much less severe in the Delaware River basin than in many other parts of the country.

The relative freedom from flood damage in the basin is due chiefly to the climate, shape of the basin, and topography. Torrential rains are less frequent in this region than in many other places even though the climate is quite humid. Perhaps the single most important factor, a topographic one, is the absence of extensive, highly developed flood plains in the basin. The largest metropolitan and industrial areas are along tidal parts of the streams where excessive flood waters can be accommodated without reaching damaging heights.

Flood damage is chiefly a result of man's occupancy of flood plains or parts of natural drainage channels that are inundated only during floods. In some places the occupants knowingly take a calculated risk; in

\footnotetext{
7 Economic considerations dictate that dams cannot be built to hold back the maximum fioods that eventually may come, therefore dams of smaller, economically feasible size are built. Such dams will contain all but the rarest large floods. A "project" fiood is a fiond of a size that a given project is designed to bandle.
}

others they are ignorant of the risk involved. The devastating effects of floods extend far beyond the actual property damage or loss of life-lines of communication and transportation may be disrupted, disease of epidemic proportions may result, and the economy of large areas may be seriously affected. Thus, increasing human occupancy of the basin has brought about an extremely complicated situation in relation to floods, flood-control works, and flood damages.

Flood-control works sometimes encourage further construction and additional occupancy in formerly flooded lands and may result in even higher damages from succeeding floods. Flood zoning, which would restrict vulnerable areas to certain specified uses, is being actively investigated in some places and may provide a workable solution to many of the problems involved. In the Delaware River basin the problems concern an interstate river and for proper solution will require interstate control.

Some degree of flood control may be accomplished by temporary storage of water during periods of high runoff or by confining floods to a channel by means of levees or other channel improvements. If levees are sufficiently high, they afford protection to the area behind them. However, levees by themselves, without channel improvement, will increase the stage in the river by reducing the channel area. It is possible for these changes to affect adversely other reaches of the river both upstream and downstream.

The temporary storage of flood water, augmenting the natural storage in the basin, may be accomplished by use of large, mainstream reservoirs or small, headwater reservoirs and ponds. To be effective in reducing flood peaks the storage must be available at the critical time. For example, the critical time in 1955 was at the onset of Hurricane Diane.

Soil-conservation measures and cropping practices that increase the capacity of the soil to absorb moisture reduce small flood peaks considerably and reduce most medium flood peaks measurably. These conservation practices have little or no effect in reducing the floods that occur after the soils have been saturated. Thus, most of the water from precipitation of Hurricane Diane ran off quickly, with devastating results, because nearly all storage space was occupied by precipitation from Hurricane Connie.

The effect of any type of storage is greatest immediately downstream from the storage site and decreases as the distance between storage site and the point in question increases. Ponds and small headwater reservoirs act much like soils in reducing small floods, but they have little or no appreciable effect on floods 
occurring after several days of heavy rain or snowmelt. The large reservoirs reduce flood peaks as long as operations are scheduled to keep the required storage capacity available when needed. This task is not always easy or possible to accomplish, especially on an interstate stream where there is no unity of control. Improvements in quantitative weather forecasting procedures should help materially in the future.

Flood-control reservoirs are sometimes designed with fixed open outlets so that stored water drains out at predetermined rates within a period of a few days after a flood. This plan removes the human element from operation of the reservoir and works satisfactorily for the area immediately downstream, provided a major storm does not occur before the reservoir has drained. If many such reservoirs are built in a river basin, the effects at downstream points are complicated by differences in the travel time required for outflow from the reservoirs to reach the designated point. For example, small uncontrolled reservoirs on tributaries to the lower reaches of a stream, such as the Schuylkill River, would discharge water at higher rates than the natural flow of the tributaries for a few days after the storm. This water might reach the Schuylkill River simultaneously with a flood crest originating farther upstream, and the effect would be to increase, rather than decrease, the resulting crest stage of the flood at the designated downstream point.

Similar problems arise in operation of controlled outlets. Maximum protection for an area a short distance below a reservoir is provided by emptying the reservoir as rapidly as possible without creating excessive stages in this reach of the stream, but such action may aggravate flood conditions at some other point farther downstream.

The preceding discussion emphasizes the fact that flood control is very complicated, that each flood hazard requires individual analysis, and that all floodcontrol elements in a basin need to be integrated for best results. In general, it can be stated that large reservoirs a short distance upstream from vulnerable urban centers, in combination with adequate levees or channel improvements in some cases, provide maximum protection for these areas. Damage from frequent flooding of valuable agricultural lands in headwater areas may be minimized by use of small reservoirs together with proper elements of land and forest management.

\section{DROUGHTS AND LOW-FLOW FREQUENCY ANALYSES}

Low flows in streams are affected by many factors in addition to the lack of rain during drought periods. The most important of these are: (1) the amount of water in storage as ground water, soil moisture, and surface water; (2) rates of evapotranspiration; and (3) rates of withdrawal for use. Commonly, demand for water is greatest at the time of lowest natural supply.

The low flows are critical for many design purposes because they determine the maximum supply available without artificial storage and the amount of such storage required to maintain specified minimum flows. In addition to data on the minimum rate of flow, information is needed on the lengths of the low-flow periods and their frequency of occurrence. This information is provided by low-flow frequency analyses.

In low-flow studies it is advantageous to use a climatic year that ends March 31 instead of the usual water year, which ends September 30 . The latter date is convenient for many hydrologic studies because it is a time when total storage in most river basins is near a minimum. Because it is also a time when low flows are likely to occur, it is not satisfactory for low-flow studies. By using a year beginning in April the entire low-flow season is contained within one climatic year. This year is conveniently designated by the calendar year in which most of the period occurs. For example, the year April 1952 to March 1953 is designated as climatic year 1952; it includes the low flows of the summer and fall of 1952.

\section{LOW-FLOW FREQUENCY}

By C. H. HaRdison and R. O. R. Martin

Low-flow frequency analysis of a streamflow record is based on the annual minimum flows for periods of various lengths. For example, the minimum 7-day flow for each climatic year of record, when computed and arranged in order of magnitude, can be related to average recurrence intervals on a frequency graph. The recurrence interval is computed as the number of years of record plus one divided by the order number. Similar plots can be' made for other length periods. In this report, periods of $7,30,60,120,183,274$, and 365 consecutive days were used. The resulting graphs of minimum discharge plotted against recurrence interval usually can be improved by further analysis.

The low-flow frequency data for the Delaware River basin have been analyzed on a regional basis to remove the effect of chance variations in weather in different areas. Annual low-flow data from a longterm (1913-52) gaging station were correlated with similar data from two other long-term stations so that effects of permanent differences in stream regimen could be removed and the data for all three stations made suitable for group analysis. This technique is equivalent to basing the frequency data on a somewhat longer period than the actual periods of record. Although the regional analysis used in this report is based on a 40-year period (April 1913 to March 1953), results 
are believed to be reliable for recurrence intervals of as much as 50 years.

Low-flow frequency data for short-term records were brought into the regional analysis by correlation with long-term records. Some short-term records were correlated with one or more of the long-term records used in the regional analysis, with medium-length records that were in turn correlated with regionalized long-term records. All low-flow frequency data in this report have been adjusted to the period 1913-52, although for many stations only minimum 7-day and minimum 30-day data were so analyzed.

The example of a family of low-flow frequency curves in Figure 47 shows low-flow frequency data for periods of $7,15,30,60120,183,274$, and 365 consecutive days. The 7-day discharge at the 2-year recurrence interval is the median of the annual minimum 7-day flows, that is, half of the years may be expected to have lower 7-day flows. Inasmuch as the discharge at the 20-year recurrence interval is the annual minimum 7 -day flow to be reached once in 20 years on the average, about 5 percent of the years may be expected to have lower 7-day flows. Similarly, about 98 percent of the years may be expected to have minimum 7-day flows less than that indicated at the 1.02-year recurrence interval. The graph paper used in figure 47 is a U.S. Geological Survey form with logarithmic ordinate and an extreme-value-type scale for abscissa. This combination of scales causes the curves to approach straight lines. If other scales are used, the shapes of the curves will be altered.

Curves similar to those in figure 47 were developed for the records for 18 gaging stations listed in table 30 and were used also as a basis for other data presented in this report. ${ }^{8}$

For a few streams, station records of low-flow frequencies are presented (table 29) for both regulated and natural flows. These records show the effects of the particular pattern of regulation that was in effect during the correlation period. Regulation beginning after the correlation periods used here, or any change in the pattern of regulation, may cause changes of

8 These curves are based on unpublished data of the U.S. Geological Survey.

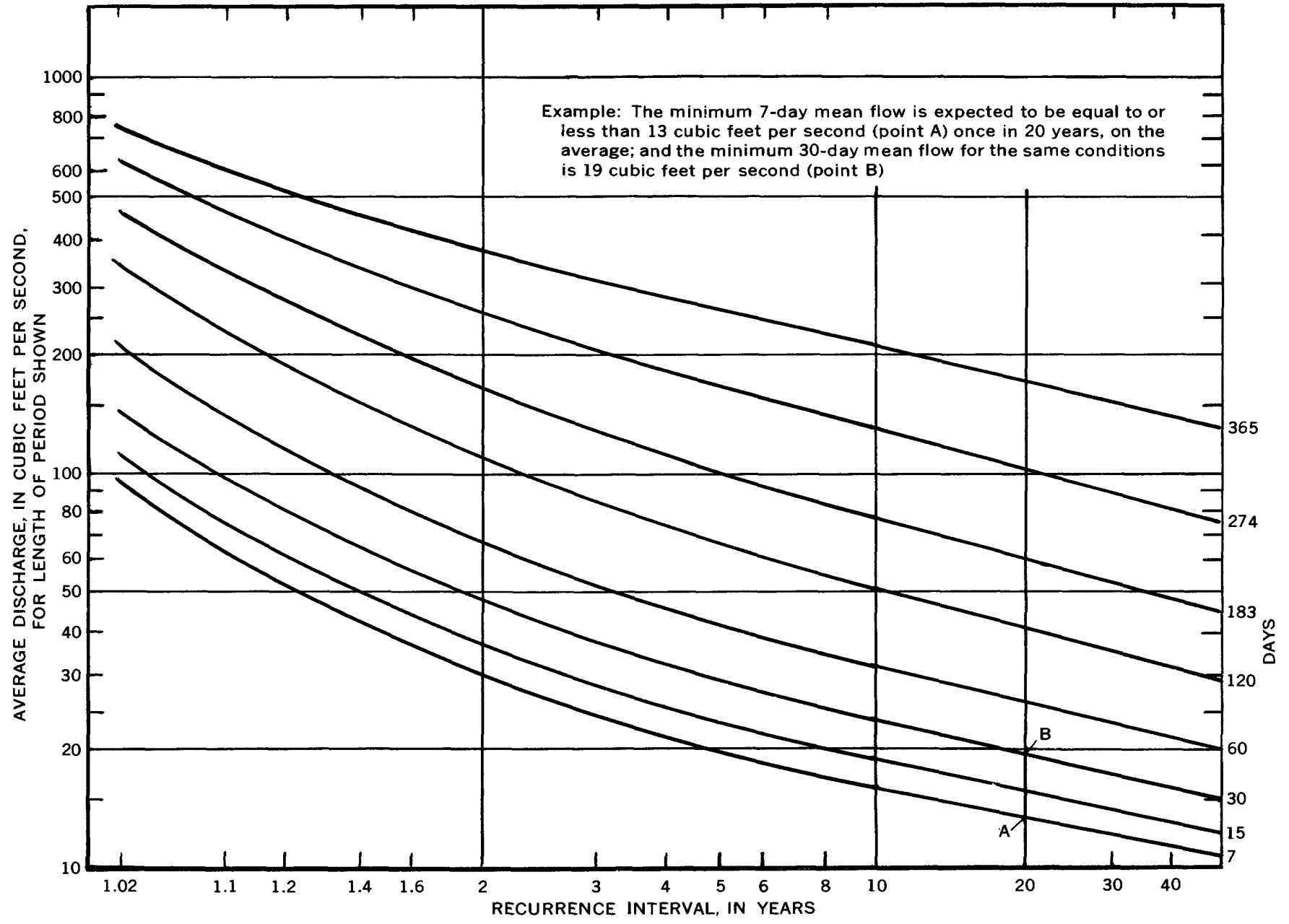

Figdre 47,-Regionalized low-flow frequency curves for Perkiomen Creek at Graterford, Pa., 1913-52. 
varying magnitude in the discharge-frequency relations. For example, the data for Neversink River at Neversink, N.Y., are based on the correlation period 1942-52. The river has been regulated by the reservoir since 1953, therefore the data for the station at

TABLE 29.-Minimum 7-day and 30-day discharges that recur at 2-year and 20-year intervals, 1913-52

\begin{tabular}{|c|c|c|c|c|c|c|}
\hline In- & \multirow{2}{*}{ Gaging station } & \multirow{2}{*}{$\begin{array}{l}\text { Corre- } \\
\text { lation } \\
\text { period }\end{array}$} & \multirow{2}{*}{$\begin{array}{l}\text { Drain- } \\
\text { age area } \\
\text { (sq mi) }\end{array}$} & \multirow{2}{*}{$\begin{array}{c}\text { Period } \\
\text { (days) }\end{array}$} & \multicolumn{2}{|c|}{ Discharge (cfs) } \\
\hline $\begin{array}{l}\text { No. } \\
\text { (pl. }\end{array}$ & & & & & $\begin{array}{c}2 \text {-yr } \\
\text { interval }\end{array}$ & $\begin{array}{c}20 \text {-yr } \\
\text { interval }\end{array}$ \\
\hline 70 & $\begin{array}{l}\text { Batsto River at Batsto, } \\
\text { N.J }\end{array}$ & $1928-52$ & 70.5 & 7 & 55.2 & 43.7 \\
\hline 71 & $\begin{array}{l}\text { East Branch Wading } \\
\text { River at Harrisville, }\end{array}$ & & & 30 & & \\
\hline 73 & N.J & $1931-52$ & 64.0 & $\begin{array}{r}7 \\
30\end{array}$ & $\begin{array}{l}31.0 \\
39.0\end{array}$ & $\begin{array}{l}22.5 \\
27.5\end{array}$ \\
\hline 10 & at Folsom, N.J. & $1926-52$ & 56.3 & $\begin{array}{r}7 \\
30\end{array}$ & $\begin{array}{l}31.7 \\
37.2\end{array}$ & $\begin{array}{l}23.0 \\
26.2\end{array}$ \\
\hline 74 & $\begin{array}{l}\text { Maurice River at Norma, } \\
\text { N.J }\end{array}$ & $1932-52$ & 113 & $\begin{array}{r}7 \\
30\end{array}$ & $\begin{array}{l}62.2 \\
70.8\end{array}$ & $\begin{array}{l}41.2 \\
46.2\end{array}$ \\
\hline 75 & $\begin{array}{l}\text { Manantico } \\
\text { Millville, N.J.......... }\end{array}$ & $1932-52$ & 22.3 & $\begin{array}{r}7 \\
30\end{array}$ & $\begin{array}{l}13.2 \\
17.7\end{array}$ & $\begin{array}{l}6.36 \\
12.0\end{array}$ \\
\hline 78 & $\begin{array}{l}\text { East Branch Delaware } \\
\text { River at Margaret- } \\
\text { ville, N.Y }\end{array}$ & $1937-54$ & 163 & $\begin{array}{r}7 \\
30\end{array}$ & $\begin{array}{l}23.0 \\
34.2\end{array}$ & $\begin{array}{l}10.6 \\
15.3\end{array}$ \\
\hline 79 & $\begin{array}{l}\text { Platte Kill at Dunraven, } \\
\text { N.Y }\end{array}$ & $1942-54$ & 34.7 & $\begin{array}{r}7 \\
30\end{array}$ & $\begin{array}{l}3.89 \\
5.94\end{array}$ & $\begin{array}{l}1.42 \\
2.43\end{array}$ \\
\hline 80 & Mill Brook at Arena, & $1937-54$ & 25.0 & $\begin{array}{r}7 \\
30\end{array}$ & $\begin{array}{l}4.60 \\
6.35\end{array}$ & $\begin{array}{l}1.83 \\
3.23\end{array}$ \\
\hline 81 & $\begin{array}{l}\text { Tremper Kill near Shav- } \\
\text { erton, N.Y..... }\end{array}$ & $1937-54$ & 33.0 & $\begin{array}{r}7 \\
30\end{array}$ & $\begin{array}{l}3.95 \\
5.62\end{array}$ & 2.15 \\
\hline 82 & $\begin{array}{l}\text { Terry Clove Kill near } \\
\text { Pepacton, N.Y........ }\end{array}$ & $1937-54$ & 14.1 & $\begin{array}{r}7 \\
30\end{array}$ & $\begin{array}{l}1.16 \\
1.88\end{array}$ & $\begin{array}{l}.446 \\
.680\end{array}$ \\
\hline 83 & $\begin{array}{l}\text { Fall Clove Kill near } \\
\text { Pepacton, N.Y....... }\end{array}$ & 1942 & 10.9 & $\begin{array}{r}7 \\
30\end{array}$ & $\begin{array}{r}.96 \\
1.32\end{array}$ & $\begin{array}{l}.50 \\
.68\end{array}$ \\
\hline 84 & $\begin{array}{l}\text { Coles Clove Kill near } \\
\text { Pepacton, N.Y. }\end{array}$ & $1945-52$ & 28.0 & $\begin{array}{r}7 \\
30\end{array}$ & $\begin{array}{l}2.16 \\
3.35\end{array}$ & $\begin{array}{r}.94 \\
1.36\end{array}$ \\
\hline 85 & $\begin{array}{l}\text { East Branch Delaware } \\
\text { River at Downsville, } \\
\text { N.Y. }\end{array}$ & $1941-53$ & 373 & 30 & $\begin{array}{l}53.3 \\
76.5\end{array}$ & $\begin{array}{l}26.3 \\
36.0\end{array}$ \\
\hline 86 & $\begin{array}{l}\text { East Branch Delaware } \\
\text { River at Harvard, N.Y. }\end{array}$ & $1935-54$ & 443 & $\begin{array}{r}7 \\
30\end{array}$ & $\begin{array}{l}68.1 \\
97.0\end{array}$ & $\begin{array}{l}33.9 \\
46.3\end{array}$ \\
\hline 87 & $\begin{array}{l}\text { Beaver Kill near Turn- } \\
\text { wood, N.Y }\end{array}$ & $1949-54$ & 40.8 & $\begin{array}{r}7 \\
30\end{array}$ & $\begin{array}{l}12.9 \\
18.0\end{array}$ & $\begin{array}{l}6.60 \\
9.07\end{array}$ \\
\hline 88 & $\begin{array}{l}\text { Beaver Kill at Craigie } \\
\text { Clair, N.Y... }\end{array}$ & $1937-54$ & 82 & 30 & $\begin{array}{l}21.2 \\
29.5\end{array}$ & $\begin{array}{l}10.8 \\
14.8\end{array}$ \\
\hline 89 & $\begin{array}{l}\text { Willowemoc Creek at } \\
\text { Debruce, N.Y. }\end{array}$ & 1949-51 & 40.9 & $\begin{array}{r}7 \\
30\end{array}$ & $\begin{array}{l}12.1 \\
16.0\end{array}$ & $\begin{array}{l}6.94 \\
8.97\end{array}$ \\
\hline 90 & $\begin{array}{l}\text { Willowemoc Creek near } \\
\text { Livingston Manor, } \\
\text { N.Y. }\end{array}$ & $1938-54$ & 63 & $\begin{array}{r}7 \\
30\end{array}$ & $\begin{array}{l}19.2 \\
25.1\end{array}$ & $\begin{array}{l}11.1 \\
14.4\end{array}$ \\
\hline 91 & $\begin{array}{l}\text { Little Beaver Kill near } \\
\text { Livingston Manor, } \\
\text { N.Y.. }\end{array}$ & $1924-52$ & 19.8 & $\begin{array}{r}7 \\
30\end{array}$ & $\begin{array}{l}3.62 \\
5.76\end{array}$ & $\begin{array}{l}\text { 1. } 46 \\
2.38\end{array}$ \\
\hline 92 & $\begin{array}{l}\text { Beaver Kill at Cooks } \\
\text { Falls, N.Y... }\end{array}$ & 1913-52 & 241 & $\begin{array}{r}7 \\
30\end{array}$ & $\begin{array}{l}62.5 \\
87.0\end{array}$ & $\begin{array}{l}32.0 \\
43.9\end{array}$ \\
\hline 93 & $\begin{array}{l}\text { East Branch Delaware } \\
\text { River at Fishs Eddy, } \\
\text { N.Y. }\end{array}$ & $1913-52$ & 783 & $\begin{array}{r}7 \\
30\end{array}$ & $\begin{array}{l}150 \\
207\end{array}$ & $\begin{array}{l}80.0 \\
106\end{array}$ \\
\hline 95 & $\begin{array}{l}\text { West Branch Delaware } \\
\text { River at Delhi, N.Y... }\end{array}$ & $1937-54$ & 142 & $\begin{array}{r}7 \\
30\end{array}$ & $\begin{array}{l}16.8 \\
24.5\end{array}$ & $\begin{array}{l}8.10 \\
11.2\end{array}$ \\
\hline 96 & $\begin{array}{l}\text { Little Delaware River } \\
\text { near Delhi, N.Y }\end{array}$ & $1938-54$ & 49.8 & $\begin{array}{r}7 \\
30\end{array}$ & $\begin{array}{l}\text { 5. } 71 \\
7.93\end{array}$ & $\begin{array}{l}2.56 \\
3.30\end{array}$ \\
\hline 100 & $\begin{array}{l}\text { Trout Creek at Cannons- } \\
\text { ville, N.Y............ }\end{array}$ & $1941-54$ & 49.5 & $\begin{array}{r}7 \\
30\end{array}$ & $\begin{array}{l}6.58 \\
8.90\end{array}$ & $\begin{array}{l}3.07 \\
3.90\end{array}$ \\
\hline 102 & $\begin{array}{l}\text { Cold Spring Brook at } \\
\text { China, N.Y............ }\end{array}$ & $1935-54$ & 1.51 & $\begin{array}{r}7 \\
30\end{array}$ & $\begin{array}{l}.044 \\
.080\end{array}$ & $\begin{array}{l}.019 \\
.032\end{array}$ \\
\hline 103 & $\begin{array}{l}\text { Oquaga Creek at De- } \\
\text { posit, N. Y... }\end{array}$ & $1941-54$ & 66 & ${ }_{30}^{7}$ & $\begin{array}{l}4.75 \\
7.42\end{array}$ & $\begin{array}{l}1.54 \\
2.20\end{array}$ \\
\hline
\end{tabular}

TABLE 29.-Minimum 7-day and 30-day discharges that recur at 2-year and 20-year intervals, 1913-52-Continued

\begin{tabular}{|c|c|c|c|c|c|c|}
\hline In- & \multirow[b]{2}{*}{ Gaging station } & \multirow{2}{*}{$\begin{array}{l}\text { Corre- } \\
\text { lation } \\
\text { period }\end{array}$} & \multirow{2}{*}{$\begin{array}{c}\text { Drain- } \\
\text { age area } \\
\text { (sq mi) }\end{array}$} & \multirow{2}{*}{$\begin{array}{c}\text { Period } \\
\text { (days) }\end{array}$} & \multicolumn{2}{|c|}{ Discharge (cfs) } \\
\hline $\begin{array}{l}\text { No. } \\
\text { (pl: } \\
\text { 10) }\end{array}$ & & & & & $\begin{array}{l}2-y r \\
\text { interval }\end{array}$ & $\begin{array}{l}\underset{20-y r}{\text { interval }} \\
\text { inter }\end{array}$ \\
\hline 104 & $\begin{array}{l}\text { West Branch Delaware } \\
\text { River at Hale Eddy, }\end{array}$ & & & & & \\
\hline 106 & Callicoon Creek at Calli- & $1913-52$ & 595 & 30 & 111 & 49.2 \\
\hline & coon, N.Y & $1941-54$ & 111 & $\begin{array}{r}7 \\
30\end{array}$ & $\begin{array}{l}14.8 \\
21.0\end{array}$ & $\begin{array}{l}7.55 \\
10.2\end{array}$ \\
\hline 108 & $\begin{array}{l}\text { Tenmile River at Tus- } \\
\text { ten, N.Y............ }\end{array}$ & $1946-54$ & 45.0 & $\begin{array}{r}7 \\
30\end{array}$ & $\begin{array}{l}4.22 \\
5.78\end{array}$ & $\begin{array}{l}2.42 \\
3.24\end{array}$ \\
\hline 110 & $\begin{array}{c}\text { West Branch Lacka- } \\
\text { waxen River at Promp- } \\
\text { ton, Pa- }\end{array}$ & $1945-55$ & 59.7 & $\begin{array}{r}7 \\
30\end{array}$ & $\begin{array}{l}12.0 \\
15.6\end{array}$ & $\begin{array}{l}7.42 \\
9.58\end{array}$ \\
\hline 111 & $\begin{array}{l}\text { Dyberry Creek at Dy- } \\
\text { berry, } \mathrm{Pa}^{-}\end{array}$ & $1944-55$ & 63.2 & $\begin{array}{r}7 \\
30\end{array}$ & $\begin{array}{r}7.20 \\
10.5\end{array}$ & $\begin{array}{l}3.70 \\
5.25\end{array}$ \\
\hline 112 & $\begin{array}{l}\text { Lackawaxen River near } \\
\text { Honesdale, Pa............ }\end{array}$ & $1949-55$ & 164 & $\begin{array}{r}7 \\
30\end{array}$ & $\begin{array}{l}30.0 \\
39.1\end{array}$ & $\begin{array}{l}18.6 \\
24.0\end{array}$ \\
\hline 114 & $\begin{array}{l}\text { Middle Creek near Haw- } \\
\text { ley, } \mathrm{Pa} \text { - }\end{array}$ & $1945-52$ & 78.4 & $\begin{array}{r}7 \\
30\end{array}$ & $\begin{array}{r}7.40 \\
10.8\end{array}$ & $\begin{array}{l}3.80 \\
5.40\end{array}$ \\
\hline 115 & $\begin{array}{l}\text { Lackawaxen River at } \\
\text { Hawley, } \mathrm{Pa} \text {. }\end{array}$ & $1913-52$ & 290 & $\begin{array}{r}7 \\
30\end{array}$ & $\begin{array}{l}43.5 \\
59.5\end{array}$ & $\begin{array}{l}25.0 \\
33.4\end{array}$ \\
\hline 116 & $\begin{array}{l}\text { Wallenpaupack Creek at } \\
\text { Wilsonville, Pa.1 }\end{array}$ & $1927-52$ & 228 & $\begin{array}{r}7 \\
30\end{array}$ & 111.8 & $\begin{array}{l}20 \\
20\end{array}$ \\
\hline 118 & $\begin{array}{l}\text { (natural flow) } \\
\text { Shohola Creek near Sho- }\end{array}$ & $1910-24$ & & $\begin{array}{r}7 \\
30\end{array}$ & $\begin{array}{l}47.4 \\
60.0\end{array}$ & $\begin{array}{l}26.8 \\
32.9\end{array}$ \\
\hline & hola, $\mathrm{Pa}$ & $1919-27$ & 82.0 & $\begin{array}{r}7 \\
30\end{array}$ & $\begin{array}{l}4.87 \\
8.60\end{array}$ & $\begin{array}{l}1.78 \\
3.01\end{array}$ \\
\hline 119 & $\begin{array}{l}\text { Mongaup River near Rio, } \\
\text { N.Y. }\end{array}$ & 1909-11 & 190 & $\begin{array}{r}7 \\
30\end{array}$ & $\begin{array}{l}61.0 \\
73.3\end{array}$ & $\begin{array}{l}44.0 \\
52.1\end{array}$ \\
\hline 120 & $\begin{array}{l}\text { Mongaup } \\
\text { Mongaup, River }{ }^{3} \text { near }\end{array}$ & $1940-52$ & 202 & $\begin{array}{r}7 \\
30\end{array}$ & $\begin{array}{l}105 \\
138\end{array}$ & $\begin{array}{l}43.7 \\
62.0\end{array}$ \\
\hline $20 \pi$ & Jervis, N.X.3............. & $1931-52$ & 3,076 & $\begin{array}{r}7 \\
30\end{array}$ & $\begin{array}{r}973 \\
1,210\end{array}$ & $\begin{array}{l}540 \\
692\end{array}$ \\
\hline & (natural flow) & $1914-25$ & 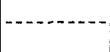 & $\begin{array}{r}7 \\
30\end{array}$ & $\begin{array}{l}551 \\
767\end{array}$ & $\begin{array}{l}298 \\
400\end{array}$ \\
\hline 124 & $\begin{array}{l}\text { Neversink River at Halls } \\
\text { Mills, N.Y. }\end{array}$ & $1938-48$ & 68 & $\begin{array}{r}7 \\
30\end{array}$ & $\begin{array}{l}28.6 \\
40.5\end{array}$ & $\begin{array}{l}15.9 \\
21.6\end{array}$ \\
\hline 125 & $\begin{array}{l}\text { Neversink River at Nev- } \\
\text { ersink, N.Y. }\end{array}$ & 1942-52 & 91.9 & $\begin{array}{r}7 \\
30\end{array}$ & $\begin{array}{l}35.3 \\
47.0\end{array}$ & $\begin{array}{l}20.3 \\
25.3\end{array}$ \\
\hline 127 & $\begin{array}{l}\text { Neversink River at Oak- } \\
\text { land, Valley, N.Y..... }\end{array}$ & $1929-52$ & 222 & $\begin{array}{r}7 \\
30\end{array}$ & $\begin{array}{l}66.0 \\
85.0\end{array}$ & $\begin{array}{l}40.0 \\
48.5\end{array}$ \\
\hline 132 & $\begin{array}{l}\text { Bush Kill at Shoemakers, } \\
\text { Pa_......... }\end{array}$ & 1913-52 & 117 & $\begin{array}{r}7 \\
30\end{array}$ & $\begin{array}{l}20.7 \\
28.5\end{array}$ & $\begin{array}{l}7.2 \\
9.8\end{array}$ \\
\hline 133 & $\begin{array}{l}\text { Flat Brook near Flat- } \\
\text { brookville, N.J. }\end{array}$ & $1924-52$ & 65.1 & $\begin{array}{r}7 \\
30\end{array}$ & $\begin{array}{l}15.3 \\
18.3\end{array}$ & $\begin{array}{r}8.5 \\
10.0\end{array}$ \\
\hline 134 & $\begin{array}{l}\text { Paradise Creek at Henry- } \\
\text { ville, Pa........... }\end{array}$ & $\begin{array}{l}\text { 1909-11, } \\
1913-14\end{array}$ & 30.2 & $\begin{array}{r}7 \\
30\end{array}$ & $\begin{array}{l}25.6 \\
27.5\end{array}$ & $\begin{array}{l}9.0 \\
9.6\end{array}$ \\
\hline 135 & $\begin{array}{l}\text { McMichaels Creek near } \\
\text { Stroudsburg, Pa.......- }\end{array}$ & $1912-38$ & 65.3 & $\begin{array}{r}7 \\
30\end{array}$ & 22.2 & 13. \\
\hline 136 & $\begin{array}{l}\text { Pocono Creek near } \\
\text { Stroudsburg, } \mathrm{Pa}\end{array}$ & 1911-19 & 38.0 & $\begin{array}{r}7 \\
30\end{array}$ & $\begin{array}{l}18.5 \\
25.5\end{array}$ & $\begin{array}{l}6.4 \\
8.8\end{array}$ \\
\hline 138 & $\begin{array}{l}\text { Brodhead Creek at Mini- } \\
\text { sink Hills, Pa... }\end{array}$ & $1951-55$ & 259 & $\begin{array}{r}7 \\
30\end{array}$ & $\begin{array}{l}94.0 \\
113\end{array}$ & $\begin{array}{l}51.1 \\
61.1\end{array}$ \\
\hline 140 & $\begin{array}{l}\text { Paulins Kill at Blairs- } \\
\text { town, N:J..... }\end{array}$ & $1922-52$ & 126 & $\begin{array}{r}7 \\
30\end{array}$ & $\begin{array}{l}29.8 \\
36.0\end{array}$ & $\begin{array}{l}16.4 \\
19.8\end{array}$ \\
\hline 143 & $\begin{array}{l}\text { Pequest River at Hunts- } \\
\text { ville, N.J. }\end{array}$ & $1940-52$ & 31.4 & $\begin{array}{r}7 \\
30\end{array}$ & $\begin{array}{l}5.00 \\
6.52\end{array}$ & $\begin{array}{l}2.00 \\
2.58\end{array}$ \\
\hline 144 & $\begin{array}{l}\text { Pequest River at Pequest, } \\
\text { N.J. }\end{array}$ & $1922-52$ & 108 & $\begin{array}{r}7 \\
30\end{array}$ & $\begin{array}{l}33.4 \\
40.0\end{array}$ & $\begin{array}{l}18.2 \\
21.5\end{array}$ \\
\hline 145 & $\begin{array}{l}\text { Beaver Brook near Belvi- } \\
\text { dere, N.J. }\end{array}$ & $1923-52$ & 36.2 & $\begin{array}{r}7 \\
30\end{array}$ & $\begin{array}{l}5.10 \\
7.30\end{array}$ & $\begin{array}{l}1.45 \\
2.04\end{array}$ \\
\hline 148 & $\begin{array}{l}\text { Lehigh River at Stod- } \\
\text { dartsville, Pa. }\end{array}$ & $1944-55$ & 91.7 & ${ }_{30}^{7}$ & $\begin{array}{l}27.0 \\
35.0\end{array}$ & $\begin{array}{l}11.3 \\
14.8\end{array}$ \\
\hline 149 & $\begin{array}{l}\text { Lehigh River at Tannery, } \\
\text { Pa }\end{array}$ & $1915-52$ & 322 & $\begin{array}{r}7 \\
30\end{array}$ & $\begin{array}{l}111 \\
141\end{array}$ & $\begin{array}{l}49.2 \\
64.0\end{array}$ \\
\hline 150 & $\begin{array}{c}\text { Dilldown Creek near } \\
\text { Long Pond, Pa........ }\end{array}$ & $1949-55$ & 2.39 & $\begin{array}{r}7 \\
30\end{array}$ & $\begin{array}{l}.818 \\
1.10\end{array}$ & $\begin{array}{l}.364 \\
.492\end{array}$ \\
\hline
\end{tabular}


TABLE 29.-Minimum 7-day and 30-day discharges that recur at 2-year and 20-year intervals, 1919-52-Continued

\begin{tabular}{|c|c|c|c|c|c|c|}
\hline \multirow{2}{*}{$\begin{array}{l}\text { In- } \\
\text { dex } \\
\text { No. } \\
\text { (pl. } \\
\text { 10) }\end{array}$} & \multirow{2}{*}{ Gaging station } & \multirow{2}{*}{$\begin{array}{l}\text { Corre- } \\
\text { lation } \\
\text { period }\end{array}$} & \multirow{2}{*}{$\begin{array}{l}\text { Drain- } \\
\text { age area } \\
\text { (sq } \mathrm{mi} \text { ) }\end{array}$} & \multirow{2}{*}{$\begin{array}{l}\text { Period } \\
\text { (days) }\end{array}$} & \multicolumn{2}{|c|}{ Discharge (cfs) } \\
\hline & & & & & $\underset{\text { interval }}{2-\mathrm{yr}}$ & $\begin{array}{l}\text { 20-yx } \\
\text { interval }\end{array}$ \\
\hline 152 & $\begin{array}{l}\text { Wild Creek at Hatchery, } \\
\text { Pa }\end{array}$ & $1941-52$ & 16.8 & $\begin{array}{r}7 \\
30\end{array}$ & 8. 62 & $\begin{array}{l}4.18 \\
5.28\end{array}$ \\
\hline 153 & 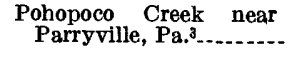 & $1945-55$ & 109 & $\begin{array}{r}7 \\
30\end{array}$ & $\begin{array}{l}37.2 \\
50.0\end{array}$ & $\begin{array}{l}16.7 \\
22.5\end{array}$ \\
\hline & (natural flow) ......... & $1945-55$ & ....... & 7 & 46.8 & 21.4 \\
\hline 154 & $\begin{array}{l}\text { Aquashicola Creek at } \\
\text { Palmerton, } \mathrm{Pa} \text { a....- }\end{array}$ & $1940-52$ & 76.7 & $\begin{array}{r}7 \\
30\end{array}$ & $\begin{array}{l}32.2 \\
41.3\end{array}$ & $\begin{array}{l}16.2 \\
20.9\end{array}$ \\
\hline 155 & $\begin{array}{l}\text { Lehigh River at Walnut- } \\
\text { port, } \mathrm{Pa}\end{array}$ & $1947-55$ & 889 & 30 & 302 & ${ }_{181}^{134}$ \\
\hline 157 & $\begin{array}{l}\text { Little Lehigh Creek near } \\
\text { Allentown, Pa }\end{array}$ & $1946-55$ & 80.8 & $\begin{array}{r}7 \\
30\end{array}$ & $\begin{array}{l}45.0 \\
59.5\end{array}$ & $\begin{array}{l}19.6 \\
25.2\end{array}$ \\
\hline 158 & $\begin{array}{l}\text { Jordan Creek at Allen- } \\
\text { town, } \mathrm{Pa}\end{array}$ & $1944-55$ & 75.8 & $\begin{array}{r}7 \\
30\end{array}$ & $\begin{array}{l}7.76 \\
15.0\end{array}$ & $\begin{array}{l}2.66 \\
3.86\end{array}$ \\
\hline 159 & $\begin{array}{l}\text { Monocacy Creek at Beth- } \\
\text { lehem, Pa }\end{array}$ & $1949-55$ & 44.5 & $30^{7}$ & $\begin{array}{l}25.3 \\
34.0\end{array}$ & $\begin{array}{l}11.3 \\
15.2\end{array}$ \\
\hline 160 & $\begin{array}{l}\text { Lehigh River at Bethle- } \\
\text { hem, Pa- }\end{array}$ & $1913-52$ & 1,279 & $\begin{array}{r}7 \\
30\end{array}$ & $\begin{array}{l}515 \\
615\end{array}$ & $\begin{array}{l}330 \\
378\end{array}$ \\
\hline 161 & Saucon Creek at Lanark, & $1948-52$ & 12.0 & 30 & $\begin{array}{l}2.43 \\
3.28\end{array}$ & $\begin{array}{l}1.41 \\
1.80\end{array}$ \\
\hline 162 & $\begin{array}{l}\text { South Branch Saucon } \\
\text { Creek at Friedensville, } \\
\text { Pa }\end{array}$ & $1948-52$ & 10.6 & 30 & $\begin{array}{l}3.90 \\
4.91\end{array}$ & $\begin{array}{l}2.54 \\
3.09\end{array}$ \\
\hline 166 & $\begin{array}{l}\text { Musconetcong River near } \\
\text { Hackettstown, N.J } J^{3} \ldots-\ldots\end{array}$ & $1922-52$ & 70.0 & 30 & $\begin{array}{l}23.2 \\
31.8\end{array}$ & $\begin{array}{l}13.0 \\
17.7\end{array}$ \\
\hline 168 & $\begin{array}{l}\text { Musconetcong River near } \\
\text { Bloomsbury, N.J. }\end{array}$ & $1922-52$ & 143 & $\begin{array}{r}7 \\
30\end{array}$ & $\begin{array}{l}70.0 \\
79.9\end{array}$ & $\begin{array}{l}47.8 \\
54.0\end{array}$ \\
\hline 169 & $\begin{array}{c}\text { Delaware River at } \\
\text { Riegelsville, N.J.3 }\end{array}$ & 1931-52 & 6,328 & $\begin{array}{r}7 \\
30\end{array}$ & $\begin{array}{l}2,390 \\
2,910\end{array}$ & $\begin{array}{l}1,410 \\
1,760\end{array}$ \\
\hline & (natural flow) & $1914-25$ & & $\begin{array}{r}7 \\
30\end{array}$ & $\begin{array}{l}1,640 \\
2,070\end{array}$ & $\begin{array}{l}1,060 \\
1,300\end{array}$ \\
\hline 173 & $\begin{array}{l}\text { Tohickon Creek near } \\
\text { Pipersville, Pa }\end{array}$ & $1936-52$ & 97.4 & 37 & 2.42 & .82 \\
\hline 181 & $\begin{array}{l}\text { Delaware River at Tren- } \\
\text { ton, N.J. }\end{array}$ & $1931-52$ & $6,78 \dot{0}$ & $\begin{array}{r}7 \\
30\end{array}$ & $\begin{array}{l}2,320 \\
2,910\end{array}$ & $\begin{array}{l}1.00 \\
1,400 \\
1,710\end{array}$ \\
\hline 182 & $\begin{array}{l}\text { Assunpink Creek at Tren- } \\
\text { ton, N.J... }\end{array}$ & $1924-52$ & 89.4 & 30 & $\mid \begin{array}{r}19.0 \\
26.0\end{array}$ & $\begin{array}{l}10.8 \\
14.0\end{array}$ \\
\hline 183 & $\begin{array}{l}\text { Crosswicks Creek at Ex- } \\
\text { tonville, N.J. }\end{array}$ & $1940-50$ & 83.6 & $\begin{array}{r}7 \\
30\end{array}$ & $\begin{array}{l}34.2 \\
44.0\end{array}$ & $\begin{array}{l}21.2 \\
26.2\end{array}$ \\
\hline 186 & $\begin{array}{l}\text { Neshaminy Creek near } \\
\text { Langhorne, } \mathrm{Pa} . \ldots\end{array}$ & $1935-52$ & 210 & $\begin{array}{r}7 \\
30\end{array}$ & $\begin{array}{l}17.5 \\
26.0\end{array}$ & $\begin{array}{l}7.72 \\
11.3\end{array}$ \\
\hline 189 & $\begin{array}{l}\text { North Branch Rancocas } \\
\text { Creek at Pemberton, N.J. } \\
\text { Schurlkill River at Potts- }\end{array}$ & $1922-52$ & 111 & 30 & $\begin{array}{l}51.0 \\
64.0\end{array}$ & $\begin{array}{l}32.9 \\
40.0\end{array}$ \\
\hline 200 & $\begin{array}{l}\text { Schuylle, Pa River at Potts- } \\
\text { Little Schuylkill River at }\end{array}$ & $1944-55$ & 53.4 & 30 & $\begin{array}{l}26.0 \\
32.8\end{array}$ & $\begin{array}{l}14.2 \\
17.6\end{array}$ \\
\hline 204 & $\begin{array}{l}\text { Tamaqua, } \mathrm{Pa}{ }^{3} \ldots . . . . \\
\text { Tulpehocken Creek near }\end{array}$ & 1941-52 & 42.9 & $\begin{array}{r}7 \\
30\end{array}$ & $\begin{array}{l}8.95 \\
13.8\end{array}$ & $\begin{array}{l}2.42 \\
3.74\end{array}$ \\
\hline 206 & Schuylkill River at Potts- & $1951-55$ & 211 & $\begin{array}{r}7 \\
30\end{array}$ & $\begin{aligned} 94.1 \\
109\end{aligned}$ & $\begin{array}{l}49.9 \\
55.8\end{array}$ \\
\hline 208 & Perkiomen Creek at $\mathrm{Gra}$ & $1936-52$ & 1,147 & $\begin{array}{r}7 \\
30\end{array}$ & $\begin{array}{l}401 \\
478\end{array}$ & $\begin{array}{l}230 \\
260\end{array}$ \\
\hline 200 & terford, $\mathbf{P a}$ & 1913-52 & 279 & 30 & $\begin{array}{l}30.7 \\
47.2\end{array}$ & $\begin{array}{l}13.1 \\
19.0\end{array}$ \\
\hline 213 & $\begin{array}{l}\text { Schuylkill River at Phil- } \\
\text { adelphia, } \text { Pa }^{3}\end{array}$ & 1932-52 & 1,893 & $\begin{array}{r}7 \\
30\end{array}$ & $\begin{array}{l}309 \\
443\end{array}$ & $\begin{array}{l}57.2 \\
88.2\end{array}$ \\
\hline 215 & $\begin{array}{c}\text { Mantua } \text { man, N.J.ek at Pit- } \\
\text { - }\end{array}$ & $1940-52$ & 6.75 & $\begin{array}{r}7 \\
30\end{array}$ & $\begin{array}{l}6.78 \\
7.79\end{array}$ & $\begin{array}{l}5.18 \\
5.75\end{array}$ \\
\hline 217 & Crum Creek at Woodlyn, & $1931-36$ & 33.3 & $\begin{array}{r}7 \\
30\end{array}$ & $\begin{array}{l}2.29 \\
5.41\end{array}$ & $\begin{array}{r}.90 \\
1.82\end{array}$ \\
\hline 219 & $\begin{array}{l}\text { Ridley Creek at Moylan, } \\
\text { Pa. }\end{array}$ & $1932-52$ & 31.9 & $\begin{array}{r}7 \\
30\end{array}$ & $\begin{aligned} 9.88 \\
14.8\end{aligned}$ & $\begin{array}{l}3.93 \\
6.18\end{array}$ \\
\hline 220 & $\begin{array}{l}\text { Chester Creek near Ches- } \\
\text { ter, } \mathrm{Pa}\end{array}$ & $1931-52$ & 61.1 & $\begin{array}{r}7 \\
30\end{array}$ & $\begin{array}{l}20.6 \\
24.4\end{array}$ & $\begin{array}{l}10.1 \\
11.4\end{array}$ \\
\hline
\end{tabular}

See footnotes at end of table.
TABLE 29.-Minimum 7-day and 30-day discharges that recur at 2-year and 20-year intervals, 1913-52-Continued

\begin{tabular}{|c|c|c|c|c|c|c|}
\hline \multirow{2}{*}{$\begin{array}{l}\text { In- } \\
\text { dex } \\
\text { No. } \\
\text { (pl. } \\
10)\end{array}$} & \multirow{2}{*}{ Gaging station } & \multirow{2}{*}{$\begin{array}{l}\text { Corre- } \\
\text { lation } \\
\text { period }\end{array}$} & \multirow{2}{*}{$\begin{array}{l}\text { Drain- } \\
\text { age area } \\
\text { (sq mi) }\end{array}$} & \multirow{2}{*}{$\begin{array}{l}\text { Period } \\
\text { (days) }\end{array}$} & \multicolumn{2}{|c|}{ Discharge (cfs) } \\
\hline & & & & & $\begin{array}{c}2-\mathrm{yr} \\
\text { interval }\end{array}$ & $\begin{array}{c}20-\mathrm{yr} \\
\text { interval }\end{array}$ \\
\hline 222 & $\begin{array}{l}\text { Oldmans } \\
\text { Woodstown, N.J }\end{array}$ & $1932-39$ & 19.3 & $\begin{array}{r}7 \\
30\end{array}$ & $\begin{array}{l}7.82 \\
9.92\end{array}$ & $\begin{array}{l}5.20 \\
6.46\end{array}$ \\
\hline 223 & $\begin{array}{c}\text { Christina } \\
\text { Coochs Briver }\end{array}$ & 1943-54 & 20.5 & $\begin{array}{r}7 \\
30\end{array}$ & $\begin{array}{l}4.68 \\
5.80\end{array}$ & $\begin{array}{l}1.91 \\
2.25\end{array}$ \\
\hline 224 & $\begin{array}{l}\text { White Clay Creek above } \\
\text { Newark, Del. }\end{array}$ & $1952-54$ & 66.7 & $\begin{array}{r}7 \\
30\end{array}$ & $\begin{array}{l}26.3 \\
30.6\end{array}$ & $\begin{array}{l}13.9 \\
15.5\end{array}$ \\
\hline 225 & $\begin{array}{l}\text { White Clay Creek near } \\
\text { Newark, Del. }\end{array}$ & $1943-54$ & 87.8 & $\begin{array}{r}7 \\
30\end{array}$ & $\begin{array}{l}34.8 \\
40.4\end{array}$ & $\begin{array}{l}18.4 \\
20.6\end{array}$ \\
\hline 226 & Mill Creek at Stanton, & $1931-33$ & 12.3 & $\begin{array}{r}7 \\
30\end{array}$ & $\begin{array}{l}2.52 \\
3.90\end{array}$ & $\begin{array}{l}1.32 \\
2.00\end{array}$ \\
\hline 227 & $\begin{array}{l}\text { Red Clay Creek at Wood- } \\
\text { dale, Del. }\end{array}$ & 1943-54 & 47.0 & $\begin{array}{r}7 \\
30\end{array}$ & $\begin{array}{l}18.4 \\
22.3\end{array}$ & $\begin{array}{l}11.2 \\
13.6\end{array}$ \\
\hline 229 & $\begin{array}{l}\text { Brandywine Creek at } \\
\text { Chadds Ford, Pa. }\end{array}$ & $1913-52$ & 287 & $\begin{array}{r}7 \\
30\end{array}$ & $\begin{array}{l}115 \\
134\end{array}$ & $\begin{array}{l}60.5 \\
67.9\end{array}$ \\
\hline 231 & $\begin{array}{c}\text { Shellpot Creek at Wil- } \\
\text { mington, Del. }\end{array}$ & $1946-54$ & 7.46 & $\begin{array}{r}7 \\
30\end{array}$ & $\begin{array}{l}.648 \\
.828\end{array}$ & .228 \\
\hline 232 & $\begin{array}{l}\text { Salem River at Woods- } \\
\text { town, N.J. }\end{array}$ & $1942-52$ & 14.6 & $\begin{array}{r}7 \\
30\end{array}$ & $\begin{array}{l}3.05 \\
5.40\end{array}$ & $\begin{array}{l}1.48 \\
2.54\end{array}$ \\
\hline 234 & $\begin{array}{l}\text { Leipsic River near Ches- } \\
\text { wold, Del. }\end{array}$ & $1943-54$ & 9.2 & $\begin{array}{r}7 \\
30\end{array}$ & $\begin{array}{l}3.48 \\
4.00\end{array}$ & $\begin{array}{l}2.16 \\
2.48\end{array}$ \\
\hline 235 & $\begin{array}{c}\text { Murderkfll River near } \\
\text { Felton, Del }\end{array}$ & 1932-33 & 14.4 & $\begin{array}{r}7 \\
30\end{array}$ & $\begin{array}{l}2.77 \\
3.34\end{array}$ & $\begin{array}{l}1.55 \\
1.81\end{array}$ \\
\hline
\end{tabular}

1 Regulated: results based on observed data without correlation.

2 Discharge zero at recurrence interval of less than 20 years.

${ }^{3}$ Regulated: results based on pattern of reglation during correlation period.

4 Seven-day flows below $40 \mathrm{cfs}$ affected by regulation.

Neversink and for other stations below the reservoir are not applicable to periods after 1953.

When low-flow parameters such as the minimum 7-day flow at the 2-year recurrence interval are used in areal hydrologic studies, the discharge for unregulated streams is usually converted to cubic feet per second per square mile, or to million gallons per day per square mile. When the effect of regulation is very great, conversion to discharge per square mile results in a misleading figure and should be avoided.

When expressed in million gallons per day per square mile, the median of the annual minimum 7-day flows shown in table 29 is 0.016 for Tohickon Creek near Pipersville, $\mathrm{Pa}$. (a very flashy stream in a region of relatively impermeable rocks and thin soils), and 0.506 for Batsto River at Batsto, N.J. (a stream draining deep permeable sediments and swamps). Thus, at the 2-year recurrence interval, Batsto River yields more than 30 times as much water per square mile as Tohickon Creek. At the 20-year recurrence interval this ratio increases to more than 70 .

\section{STORAGE REQUIRED TO MAINTAIN FLOWS}

Although low-flow frequency data presented in the previous section are sufficient for planning waterresources developments that use the natural flow of a stream, additional analyses must be made when the 
natural minimum flows are insufficient and storage reservoirs must be provided. Even when 50-year records are available, it is impossible to predict the worst possible condition that may occur; at some time in the future there may be a worse drought than has been experienced in the past. Furthermore, it is seldom economically feasible to provide sufficient storage for a rare condition that may recur at an average interval of several hundred years. Consequently the analysis of low-flows has been extended to determine the effect of different amounts of storage on the minimum flows.

In this analysis, "storage" refers only to water made available for release or withdrawal from reservoirs during periods when the natural flow is less than the specified flow. Results are based on the low-flow frequency curves discussed in the previous section and illustrated in figure 47. Minimum-flow data for a given recurrence interval is converted into volume of flow and used to plot a frequency-mass curve from which allowable drafts for various amounts of storage are computed. The resulting curves for Perkiomen Creek at Graterford, $\mathrm{Pa}$., are presented in figure 48 as an example, and similar data for 17 other stations are summarized in table 30 . The zero line in figure 48 represents the natural minimum 7-day flow and would be the same as the minimum 7-day line of figure 47 if the same units of discharge had been used.

The natural minimum daily flow, which would be somewhat lower than the minimum 7-day flow, has not

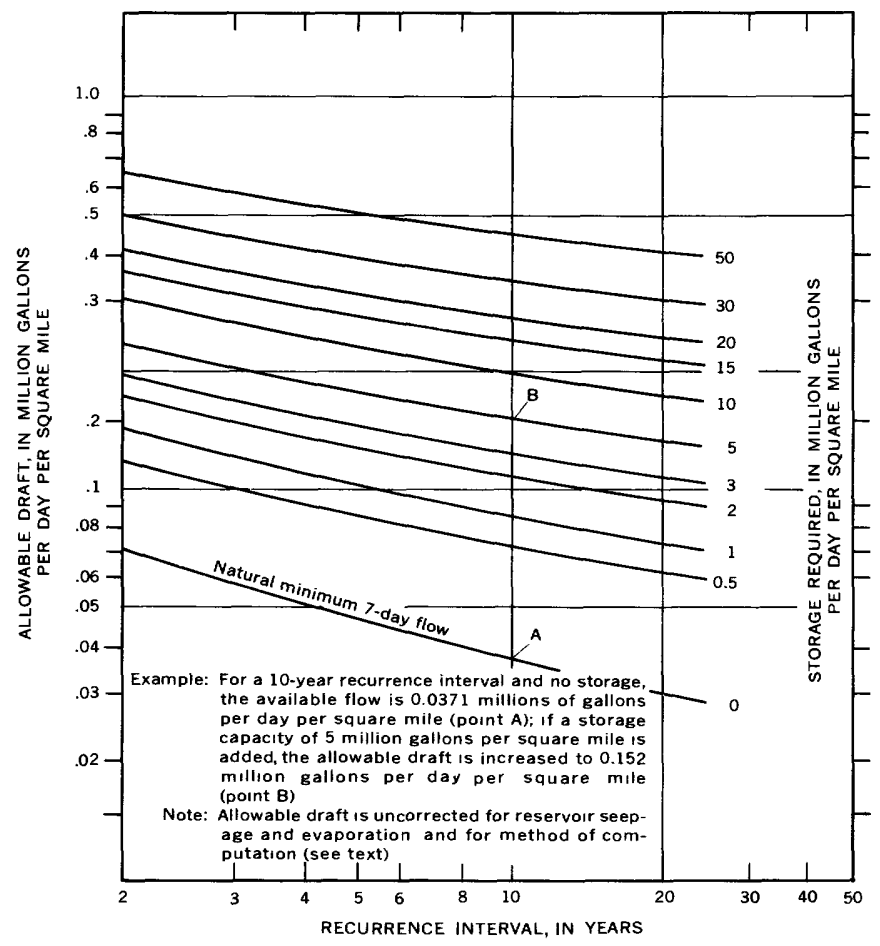

Figure 48.-Effect of storage on minimum 7-day flow of Perkiomen Creek at Graterford, Pa., 1913-52. been shown on these illustrations because in many instances the minimum daily flow is probably affected by an unknown amount of daily regulation by mills and power plants. Each line above the zero line represents a different amount of storage and indicates the effect of that amount of storage on the allowable draft. Similar diagrams for other stations can be obtained by plotting the data in table 30 on logarithmic extremevalue paper.

The frequency-mass curve method just described is a reliable short-cut method which gives allowable drafts that are about 10 percent greater than those obtained by the more detailed method based on a mass curve for each year of record. The data in table 30 and figure 48 are uncorrected for this difference. For comparisons of streams this is not important, but if the data are to be used in design an approximate allowance for this difference can be made by decreasing the allowable draft by 10 percent. The percentage to use varies with the extent of storage development and depends in part on the flow characteristics of a stream. Further investigation of this difference may indicate the nature and extent of its variation and provide a basis for more accurate adjustment.

In the computation of allowable draft, no allowance was made for evaporation and seepage losses from the reservoirs that would be built. Such losses are an individual problem for each reservoir site; the seepage loss depends largely on subsurface conditions, and the evaporation loss depends on the surface area of the reservoir and evaporation rates. Evaporation losses from water surfaces are usually higher than from land areas, and the difference between these is the net vapor loss resulting from construction of a reservoir. Annual values of evaporation and water loss in plate 4 and figure 11 will indicate whether detailed studies of vapor loss need to be made.

A graphic comparison of the effects of storage on low flows at 17 gaging stations is provided in figure 49 . Each line on this chart represents one gaging station (identified by number listed on pl. 10) and relates storage required to allowable draft for a 10-year recurrence interval. Similar charts could be plotted for any other recurrence interval. The positions of the lines on the chart represent yield characteristics, and the slopes represent the degree of improvement with storage, that is, the flashiness of the stream. Increasing storage on Tohickon Creek (station 173) from $1 \mathrm{mg}$ per sq mi to $5 \mathrm{mg}$ per sq mi increases the allowable draft from 0.0348 to $0.0878 \mathrm{mgd}$ per sq $\mathrm{mi}$, an increase of $0.053 \mathrm{mgd}$ per sq $\mathrm{mi}$, or 150 percent. A simliar increase in storage on Maurice River (station 74) increases the allowable draft by $0.079 \mathrm{mgd}$ per sq $\mathrm{mi}$, but only 24 percent. The relative increase on the 


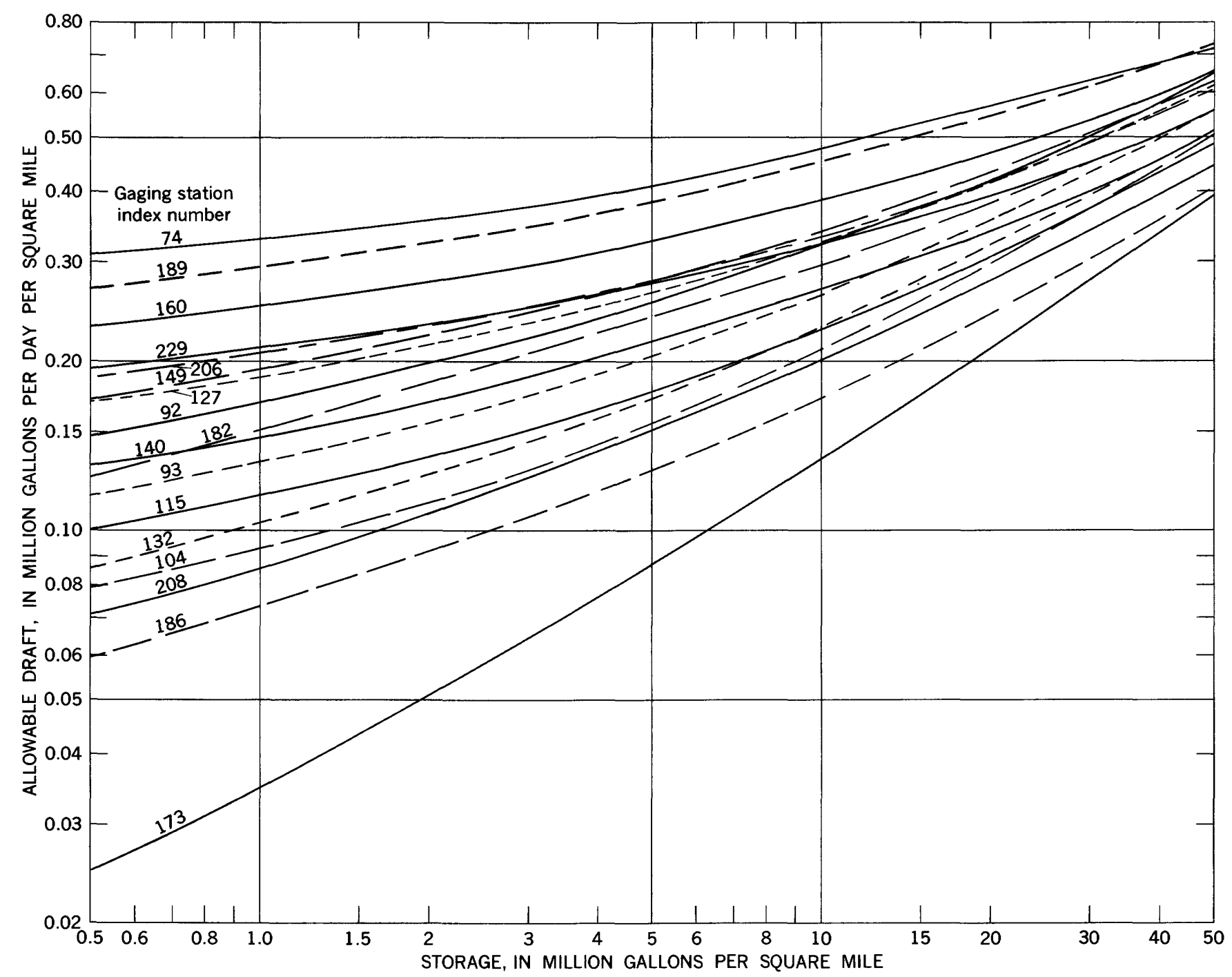

Figure 49.-Comparison of the effects of storage on minimum 7-day flows at selected gaging stations.

flashy stream is many times that on the stream with large natural storage although the absolute increase is smaller.

The amount by which storage of $0.5 \mathrm{mg}$ per sq $\mathrm{mi}$ would increase the flow available naturally at a 10-year recurrence interval, which is not shown in figure 49 , can be determined from table 30 . For example, the flow at station 173 would be increased from 0.00697 to $0.0250 \mathrm{mgd}$ per sq $\mathrm{mi}$, an increase of 350 percent; that at station 74 would be increased from 0.263 to $0.311 \mathrm{mgd}$ per sq mi, an increase of only 18 percent.

One of the 18 gaging stations included in table 30 (McMichaels Creek at Stroudsburg, Pa., No. 135) was omitted from this chart because its graph would have interfered excessively with other lines. Its graph is almost identical to that for Schyulkill River at Pottstown, Pa. (station 206).

\section{BASE FLOW OF STREAMS}

Base flow is derived from natural storage, both surface and subsurface. The flow at a particular time depends on: (1) difference in head between surface-water bodies and the water table in aquifers that are bydraulically connected to the surface-water bodies; (2) the drainage characteristics of the aquifers and surfacewater bodies; and (3) the discharge from natural storage by other means, such as evapotranspiration and withdrawal from wells. Maximum rates of base flow occur after long periods of wet weather or melting snow. During such periods streamflow consists of both direct runoff and base flow, and the latter then may be a relatively small part of the total. Base flow is most important during periods of fair weather when no additions to storage are being made and streamflow consists entirely of base flow. 
TABLE 30.-Minimum 7-day flows that could be maintained for selected recurrence intervals with indicated amounts of storage, 1913-52

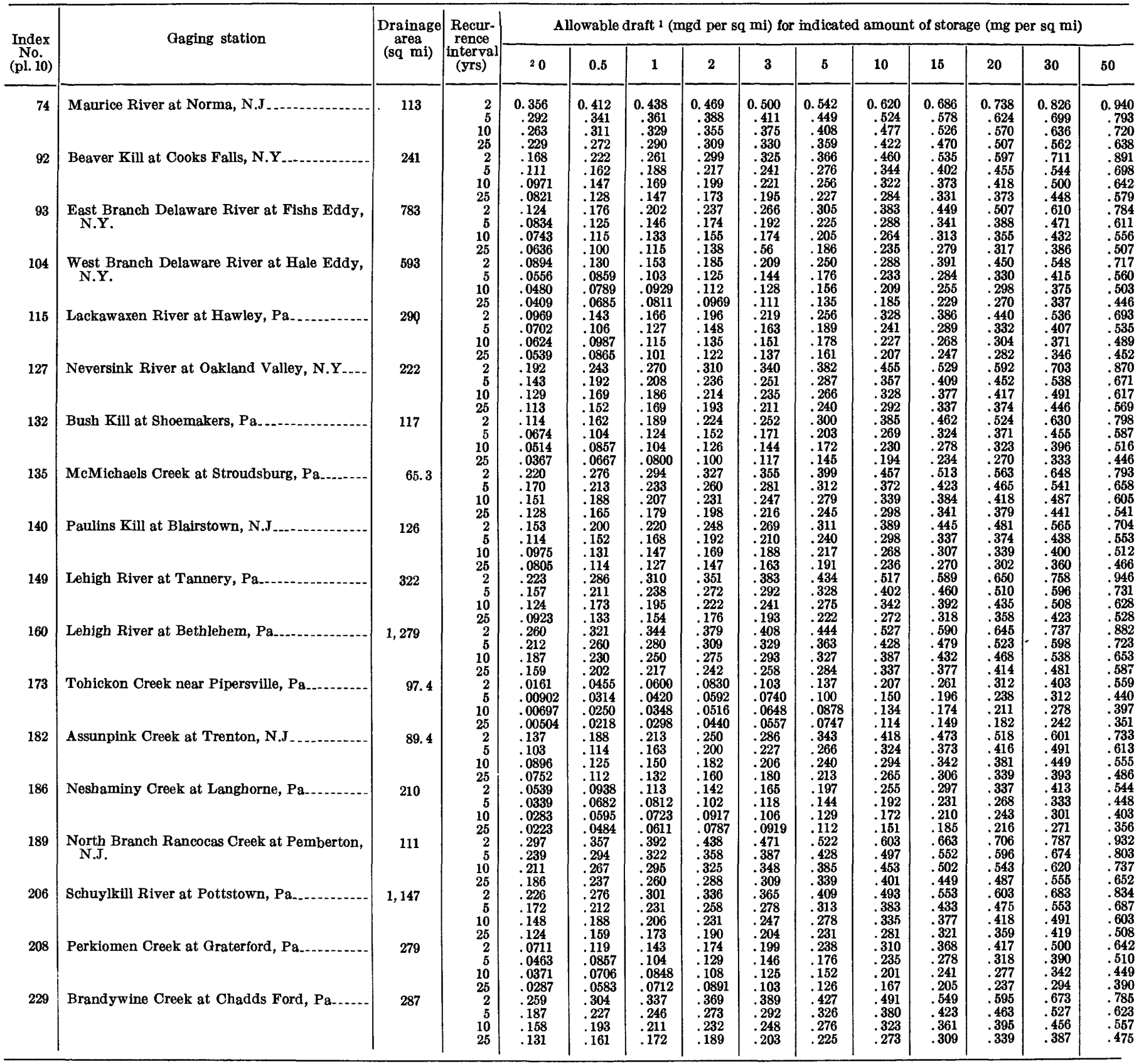

1 Allowable draft is uncorrected for reservoir seepage and evaporation

Figures in this column are annual minimum 7-day flows; minimum daily and minimum instantaneous flows are usually less.

Base flow tends to decrease in a systematic manner as the water in storage is depleted during these periods. The rate of recession at a particular rate of flow depends on the three items listed in the preceding paragraph. Streams draining areas where large storage capacities exist in lakes and swamps or in permeable rocks (either consolidated or unconsolidated) have large and wellsustained base flows, whereas streams in areas where storage capacities are small have small base flows that recede rapidly.

\section{BASE-FLOW RECESSION CURVES}

Graphs showing the recession of base flow with time (recession curves) can be developed for most gaging stations by combining and averaging from records of daily flow many short segments of the recession.

Not all these segments fit an average flow-recession curve because some of the factors that affect base flow may differ appreciably at a particular rate of flow. For example, when surface- or ground-water bodies in one part of a drainage basin receive disproportionate amounts of recharge, the water or piezometric surfaces 
may be at elevations that are abnormal in relation to those in the remainder of the basin. The effects of these variations are usually minor.

More important differences commonly are caused by seasonal changes in the rate of evapotranspiration from ground water. In some basins these changes apparently have a negligible effect on streamflow for recession follows the same general pattern in all seasons. In other basins flow recession is much more rapid during the growing season than during the winter when evapotranspiration is negligible.

Comparable recession' data can be developed from different periods of record. Although recharge to storage is greater and more frequent during a period of wet years than during a period of dry years, each recharge causes the next recession to start at a higher point on the same curve; however, such recurring recharge does not affect the shape of the curve.

To make flow-recession data comparable, a method is needed to relate recession curves to each other. For example, the initial points of all curves might be any of the following: (1) the mean annual discharges for a base period; (2) the median annual discharges; or (3) a constant value of runoff per square mile. The slope of the curve at a point corresponding to a low-flow parameter, such as the discharge equaled or exceeded 90 percent of the time, might be the most significant value in some applications.

In this study, flow-recession curves were developed for 47 gaging stations in and near the Delaware River basin; mean annual discharge for 1921-50 was used as the initial point. The means were used because they were readily available and are higher than medians or other parameters that are likely to be used in studies involving recession data. Data developed on the basis of the mean can be used in any study involving parameters smaller than the mean.

Both winter and summer curves were defined for several stations; for many stations the winter recession cannot be defined adequately because of the effects of high flow, delayed runoff, recharge from melting snow, and subfreezing temperatures. Winter and summer curves for a typical small stream in the Catskill Mountains, Little Beaver Kill at Livingston Manor, N.Y., are shown in the left part of figure 50.

A summary of the summer recession data is given in table 31 . Some of the means shown in table 31 are estimates which are omitted from table 23 because they are not considered reliable enough to be included in that summary.

\section{RUNOFF FROM NATURAL STORAGE}

The volume of runoff from natural storage can be computed from the base-flow recession curves. The

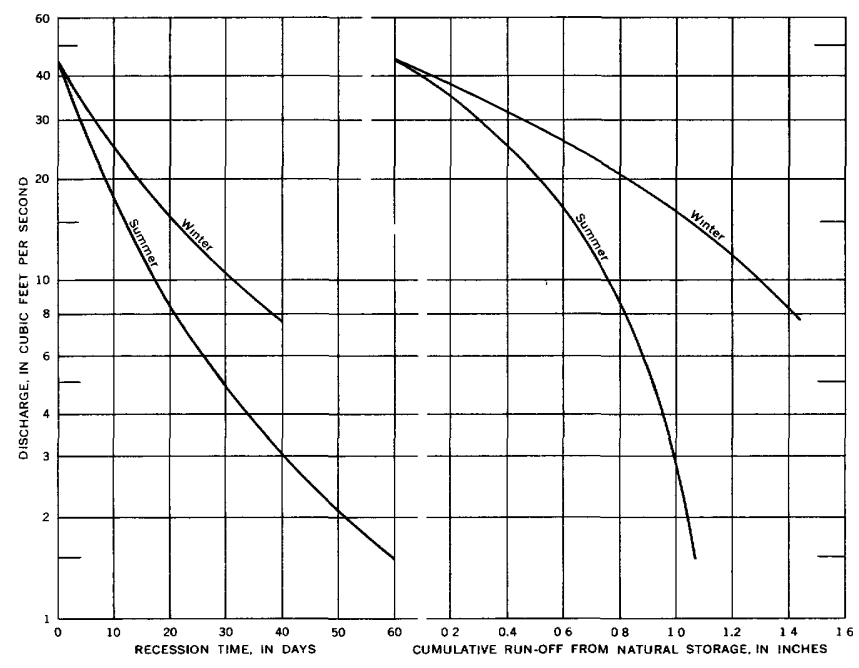

Figure 50.-Summer and winter curves of base-flow recession and runoff from natural storage for Little Beaver Kill at Livingston Manor, N.Y.

average discharge for each increment of time multiplied by the number of days in the increment equals the volume of water. The volume can be expressed in inches of runoff, or other convenient unit, and the volumes for the increments accumulated to obtain the total runoff from the initial time to any selected time of discharge.

An example of curves of cumulative runoff from natural storage, derived from the corresponding recession curves, is shown in the right side of figure 50 . Table 31 summarizes the storage data for summer conditions at the 47 stations studied.

\section{USES OF BASE-FLOW DATA}

Base-flow recession curves provide information for forecasting low flows several days or weeks in advance during rainless periods. A recession curve for Delaware River at Montague, N.J., is used in the Delaware River Master's office to help determine the amount of release from reservoirs in New York required to maintain specified flows in the lower reaches of the river. Recession curves for other streams could be used to forecast available water supply when conditions are expected to become critical. For example, using the summer curve shown in figure 50 and assuming that the daily discharge at a specified time is $4.9 \mathrm{cfs}$, one could calculate that the daily discharge 10 days later would be about $3.0 \mathrm{cfs}$-provided that precipitation during the period is not sufficient to cause either direct runoff or ground-water recharge. Summer curves are the most useful for this application because most water shortages occur in summer and fall.

Separation of direct runoff from base flow can be accomplished with the aid of recession curves. This separation provides useful information regarding the magnitude of the ground-water contribution to stream- 
TABLE 31.-Summer base-flow recession and natural storage characteristics for selected gaging stations

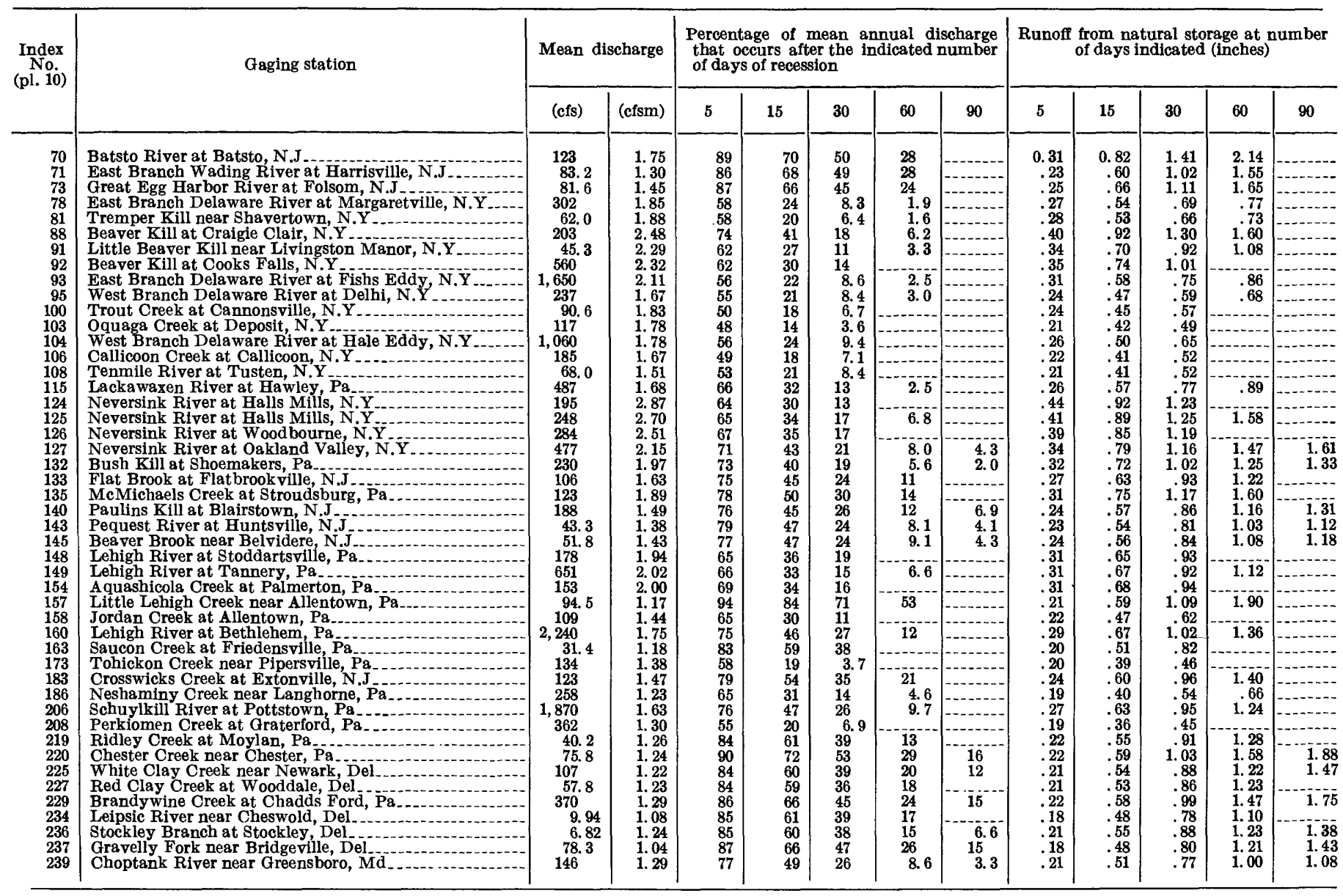

flow and is a necessary step in preparation of unit hydrographs for studies of floods and other hydrologic phenomena. As a part of the present study the total base flow at two gaging stations was determined for a 5 -year period (1928-32) that included both wet and dry years. On Perkiomen Creek at Graterford, Pa., a relatively flashy stream in the Triassic Lowland section of the Piedmont province, about 42 percent of the total runoff was base flow. On Brandywine Creek at Chadds Ford, Pa., a stream in the Piedmont Upland with wellsustained fair-weather flow, about 67 percent of the total was base flow.

Recession and storage data may be sources for derivation of useful parameters for comparing low-flow characteristics of streams. Such comparisons are important not only in water-supply studies, but also in investigations of the effects of various factors, such as vegetative cover, methods of cultivation or land use, topography, precipitation characteristics, and the geologic environment. Duration characteristics and low-flow frequencies are satisfactory for many purposes, but most of these parameters are affected to varying extents by direct runoff. The rare extremes of low flow may be independent of direct runoff but may be excessively affected by purely local channel characteristics or by unusual weather phenomena. The shapes of recession (and storage) curves are independent of precipitation characteristics and winter curves for the northern part of the Nation are practically free of the effects of evapotranspiration from ground water. Research will be required to determine which parameters are best suited to some purposes.

Examination of the duration data, the low-flow frequencies, or the recession and storage data presented in this report shows very clearly that the geologic environment is the dominant factor affecting variations in streamflow characteristics. The geologic environment includes such items as topography and soil types but not land-management practices. Landmanagement conservation practices may cause very desirable improvements in stream regimen if for example, the base flow is increased. Such effects, however, are completely overshadowed by those of the geologic environment in an area as large and diverse as the Delaware River basin. 
An outstanding example of the effects of geologic characteristics on stream regimen is provided by streamflow records for two adjacent drainage areas of similar size in the Great Valley near Allentown, Pa. Little Lehigh Creek (station 157) drains an area of 80.8 square miles, about 60 percent of which is underlain by permeable carbonate rocks. Jordan Creek (station 158) drains 75.8 square miles of predominantly shale and slate terrane having considerably greater relief than Little Lehigh Creek basin. The base-flow recession curves and cumulative runoff from natural storage for these two stations are shown in figure 51. Little or no seasonal change in the recession characteristics of Little Lehigh Creek is apparent, but distinct curves for summer and winter are defined for Jordan Creek. The winter curve is shown in figure 51 so that most of the difference indicated may be attributed to the geologic environments. Differences of this magnitude, or even greater, are common in such different regions as the Catskill Mountains and the Coastal Plain but are rather uncommon for areas adjacent to them.

The average annual discharge as well as the base flow is affected by the environment. Both basins receive the same average annual precipitation (43 inches), but Jordan Creek has an average discharge of 1.44 cfsm (cubic feet per square mile) and Little Lehigh has an average of only $1.17 \mathrm{cfsm}$. Part of the difference may be due to underground outflow in the carbonate rocks of Little Lehigh Creek basin, and part to greater evapotranspiration there. In spite of this difference in average discharge, after 30 days of winter recession, the discharge per square mile for Little Lehigh Creek is more than 2.2 times as great as that of Jordan Creek (0.83 cfs and $0.37 \mathrm{cfs}$, respectively).

Drastic changes in stream regimen result from removal of large quantities of ground water from a basin without return of at least a major portion to the basin's aquifers or streams. Tennent Brook near Browntown, N.J., is an outstanding example of this condition. Pumping from the aquifers in the basin without return of water to the same basin has reduced the total runoff to about half that from adjacent basins and reduced the dry-weather flow to zero (table 23). Similar situations may arise in much larger areas as large-scale ground-water development proceeds.

\section{RUNOFF FROM SMALL DRAINAGE AREAS}

About 70 percent of the total perennial stream length in the northeastern United States consists of streams having drainage areas of less than 8 square miles. The importance of runoff from these small areas is easily overlooked because any single project involving such an area is insignificant in comparison with larger projects. It is estimated that 50 percent of the total expenditures for highway bridges and culverts is for crossings of streams having drainage areas of less than 10 square miles. Large numbers of small water supplies depend on runoff from such areas, and design of storm drainage systems has been almost entirely empirical because of lack of information on runoff rates. Evaluation of the effects of land-management practices depend largely on runoff data from affected areas.
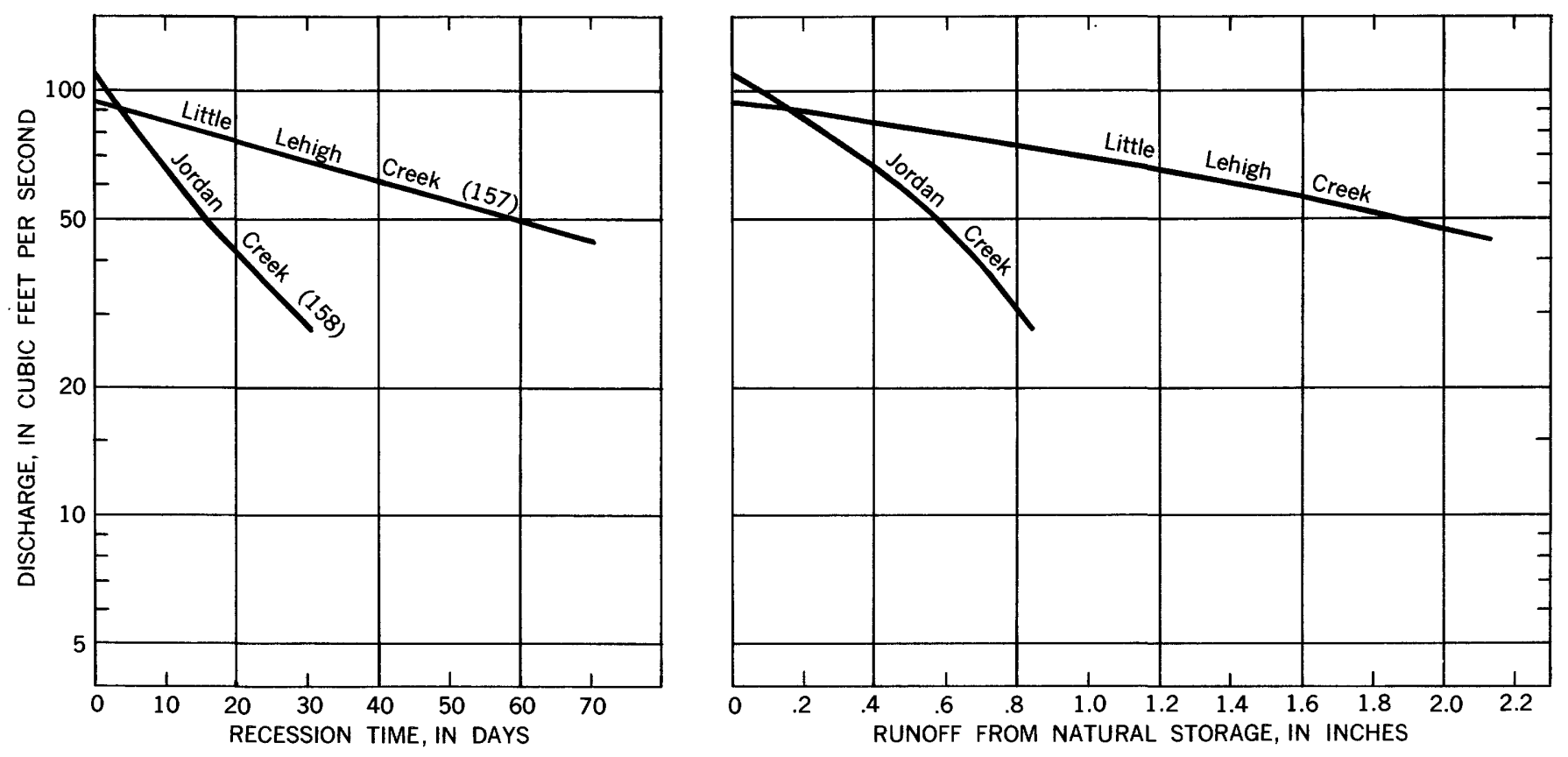

FIGURE 51.-Comparison of base-fiow recession and natural-storage characteristics for two adjacent streams in different geologic environments. 
The Federal-State stream-gaging network quite naturally developed first on the larger streams. As time progressed smaller streams have been included in the network as needs became apparent and funds became available. Of the 240 stations listed on the bar graph (pl. 23), about 18 percent have drainage areas of less than 25 square miles, but only about 9 percent have areas of less than 10 square miles.

The paucity of hydrologic information on these small areas is the single greatest deficiency in streamflow data. Data obtained for one small area can seldom be used for other small areas unless they are very close together and very similar in all the critical characteristics.

The number of these small basins in the region is so large that it is not practical to attain even 10 percent coverage with long-term gaging stations. However, information from long-term records may be supplemented by information from short-term and partialrecord stations.

Seven years of record is usually enough to establish a relation between the short record on one area and a long one on a similar, nearby area. The long-term average runoff and duration characteristics for the shortterm station can be estimated from this relation and the long-term record.

Interest in runoff from small areas centers mainly in peak flows and low flows; consequently for many of these areas partial records may be sufficient. A parital record is obtained by the systematic collection of information on peak flows; daily discharge for periods of low flows; or discharge measurements made during periods of base flow. To obtain the most information from the data available, flood-peak data should be incorporated in a regional flood-frequency analysis, and low-flow data should be correlated with long-term records. For example, from the correlation of lowflow data it is possible to obtain the low end of the duration curve and low-flow frequency curves.

Programs based on these methods are progressing rapidly in some parts of the nation. Miscellaneous measurements of low flow have been obtained in the Delaware River basin for many years but coordinated programs of the type described above have either just recently been started or are now only in formative stages.

\section{QUALITY OF SURFACE WATER}

CHEMICAL QUALITY

In assessing a potential water supply, the quality of the water available may be as important, or even more important, than the quantity-a river full of salt water is of no use for a city's municipal supply. The quality determines the usefulness of the water for particular purposes. For example, water used for cooling need not be of high quality, though preferably it should be neither excessively corrosive nor encrusting; but water used in some of the food industries must satisfy specifications more exacting than those for drinking water. Water used in making high-grade paper must be soft, low in iron and manganese content, and low in suspended matter. Hard water is not suitable for laundering, tanning, textile bleaching, or soap manufacture; water high in iron content causes stains on fixtures and laundry. Water of poor quálity sometïmes may be treated to improve its quality, but always at an increase in cost. For example, hard water may be softened to make it suitable for laundering.

This report will not be concerned with sanitary quality of water, which lies in the field of public health agencies, although such measures of quality as bacterial content are of interest to those who wish to use the water for drinking or food processing. Quality will be discussed here in terms of the concentrations of dissolved materials or with respect to hardness, acidity, temperature, color, turbidity, and concentration of suspended sediment.

As rainwater runs over or percolates through the ground to the streams, it dissolves mineral matter. The character and concentration of the dissolved solids depend upon: (1) the kind of rock or soil with which the water comes in contact; (2) the water and rock temperatures; and (3) the length of time the water remains in contact with the solid material. Dissolved solids in surface water may also arise from industrial or municipal wastes, or contamination of fresh water by sea water. Evaporation of water increases the concentration of the dissolved solids but does not change their composition, unless evaporation is so extreme as to cause loss of gaseous constituents or precipitation of some of the dissolved material.

\section{DISSOLVED SOLIDS AND ELECTRICAL CONDUCTIVITY}

The concentration of dissolved solids is determined by weighing the residue after evaporation of the water. This residue is chiefly dissolved mineral matter, but it may also contain bound water and some organic matter. Pure water is a poor conductor of electricity but dissolved minerals increase its electrical conductivity roughly in proportion to their concentrations. Thus electrical conductivity, which is expressed quantitatively as specific conductance in micromhos per centimeter at $25^{\circ} \mathrm{C}$, is a measure of the concentration of dissolved solids. Because the determination of the concentration of dissolved solids by evaporation requires larger samples, takes more time, and is more expensive than the measurement of specific conductance, the dissolved-solids concentration is sometimes estimated 
from the specific conductance where a suitable empirical relation has been determined. Several such relations are given in table 32 .

These relations were used in this report to estimate the daily concentrations of dissolved solids from which, for example, the duration curves (fig. 56) were constructed or from which the loads of dissolved solids in table 33 were calculated.

TABLE 32.-Equations for the estimation of the dissolved-solids concentration from the measured specific conductance

$[S=$ dissolved-solids concentration, in parts per million. $K=$ specific conductance,

\begin{tabular}{|c|c|c|}
\hline $\begin{array}{c}\text { Index } \\
\text { No. } \\
\text { (pl. 10) }\end{array}$ & Gaging station & Equation \\
\hline $\begin{array}{l}147 \\
156 \\
181 \\
203 \\
206 \\
212\end{array}$ & $\begin{array}{l}\text { Delaware River at Easton, Pa } \\
\text { Lehigh River at Catasauqua, Pa. (Morrisville, Pa) } \\
\text { Delaware River at Trenton, N.J. (Mat } \\
\text { Schuylkill River at Berne, Pa.... } \\
\text { Schuylkill River at Pottstown, Pa. } \\
\text { Schuylkill River at Belmont Filters, Philadelphia, Pa. }\end{array}$ & $\begin{array}{l}S=0.518 K+12.0 \\
S=0.625 K+2.5 \\
S=0.574 K+5.4 \\
S=0.820 K-51 \\
S=0.678 K+0 \\
S=0.644 K+1\end{array}$ \\
\hline
\end{tabular}

CONCENTRATION OF DISSOLVED SOLIDS AND STREAMFLOW

The concentration of dissolved solids in stream water varies with the streamflow. When discharge increases, concentration of dissolved solids is likely to decrease; during a time when the discharge is low, the concentration of dissolved solids is likely to increase. Figure 52 shows this probability to be true for the Delaware River at Easton, Pa., and for the Schuylkill River at Berne, $\mathrm{Pa}$. The Delaware River flows through a mountainous, glaciated area that has many lakes and ponds. Upstream from Delaware Water Gap it traverses shale, sandstone, and glacial drift, and from the Delaware Water Gap to Easton, shale and limestone. The Schuylkill River above Berne drains a mountainous region containing anthracite coal. Its drainage area is but one-thirteenth that of the Delaware River above Easton and its rate of fall per mile is somewhat greater. The water of the upper Schuylkill River is acid, owing to coal-mine drainage, and has a much higher concentration of dissolved solids than the water of the Delaware River. Figure 52 indicates that doubling the daily discharge at Berne results in a 20-25 percent reduction in the concentration of dissolved solids, but that a similar change in discharge at Easton has only half this effect.

It is evident from the scatter of the points plotted in figure 52 that there is no precise relationship between streamflow and concentration of dissolved solids, only that the concentration is greater at lower flows. At low discharge a greater proportion of the streamflow consists of the more highly mineralized ground water or mine drainage; at higher flows the more dilute direct runoff forms a greater proportion of the total streamflow. The composition of the ground water varies in different parts of the basin, and so does the composition of direct runoff. A specified discharge will not always consist of the same proportions of water from each of the sub-basins and so does not always have the same concentration of dissolved solids. This variation explains, in part, the scatter of plotted points in figure 52. Actually, the scatter of daily conductances is probably greater than shown, because the points plotted were selected to represent what were believed to be periods of nearly constant conductance.

\section{RANGE OF DISSOLVED-SOLIDS CONCENTRATTON AND HARDNESS}

The quality of stream water varies from stream to stream, from location to location on the same stream, and from time to time at any specified location. More than an occasional analysis is required to indicate the quality of water of a stream, or of any given place on the stream. Water samples were taken daily at the six locations listed in table 32 . Water temperature and specific conductance were determined for each sample. These daily samples were composited usually in groups of 10 to give 3 composite samples for each month. The composite samples were then analyzed in some detail. The analyses at these stations cover periods from 4 to years, between October 1944 and September 1956. The dissolved-solids concentrations at these six locations are compared in figure 53. The range of dissolved-solids concentration for the central four-fifths of the daily samples is shown by the length and position of the vertical bar, the median concentration by the position of the short horizontal bar. Ten percent of the concentrations exceed and 10 percent are less than the concentrations indicated by the vertical bar.

Hardness as $\mathrm{CaCO}$ in parts per million is similarly plotted in the lower part of figure 53. Hard water requires more soap to produce lather and, among other things, forms scale in boilers. Hardness is caused by the presence of calcium, magnesium, aluminum, iron, manganese, or acid. The water of the Schuylkill River at Berne is hard, and for most uses requires softening. It also has the highest concentration of dissolved solids. The Schuylkill River rises in the anthracite coal-mining region of Pennsylvania. Coal is associated with iron sulfide, which is exposed when the coal is mined. Water, saturated with air, converts the iron sulfide to iron sulfate and sulfuric acid. This acid water dissolves the rock material more readily than would neutral or slightly alkaline water. The acidity also contributes to the hardness. As the water moves downstream, it is neutralized and diluted with water of lower mineral content, at Pottstown and Philadelphia the Schuylkill River water is still hard, but is less so than at Berme and has a lower dissolved-solids concentration. In contrast, the water of the Delaware River at Easton is 

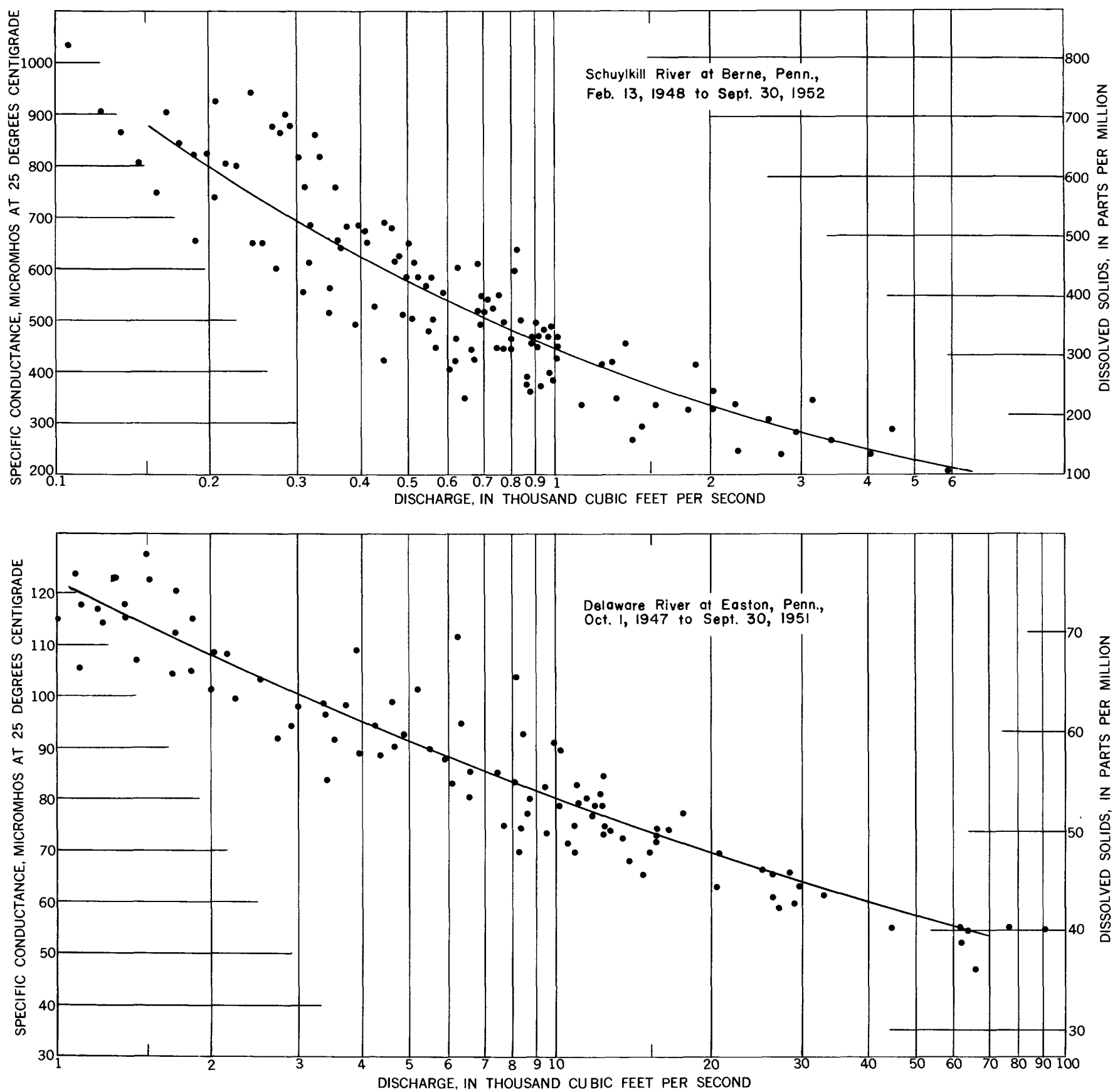

FIGURE 52.--Variation of conductance and concentration of dissolved solids with discharge at two stations.

soft and is low in dissolved solids. The waters of the Lehigh River at Catasauqua and of the Delaware River at Trenton are somewhat higher in dissolved solids and are harder than the water of the Delaware River at Easton, although each of these three waters are either soft or only moderately hard.

\section{QUANTITIES OF DISSOLVED MATERIALS (LOADS)}

Streamflow, even sparkling clear water, may carry many tons of dissolved material in a comperatively short time. The load, in tons per month, may be calculated from the concentration of dissolved solids and the daily stream discharge. The monthly loads for eight parts of the basin, and the loads for the 1948, 1949, 1950 , and 1951 water years are given in table 33 . Some of these regions overlap; for example, the load of the Delaware River at Trenton includes the dissolved material in the water of the Lehigh River at Catasauqua and of the Delaware River at Easton; the load of the Schuylkill River at Philadelphia is the sum of the loads calculated for the three segments of the Schuylkill River drainage basin. The total of the measured loads 


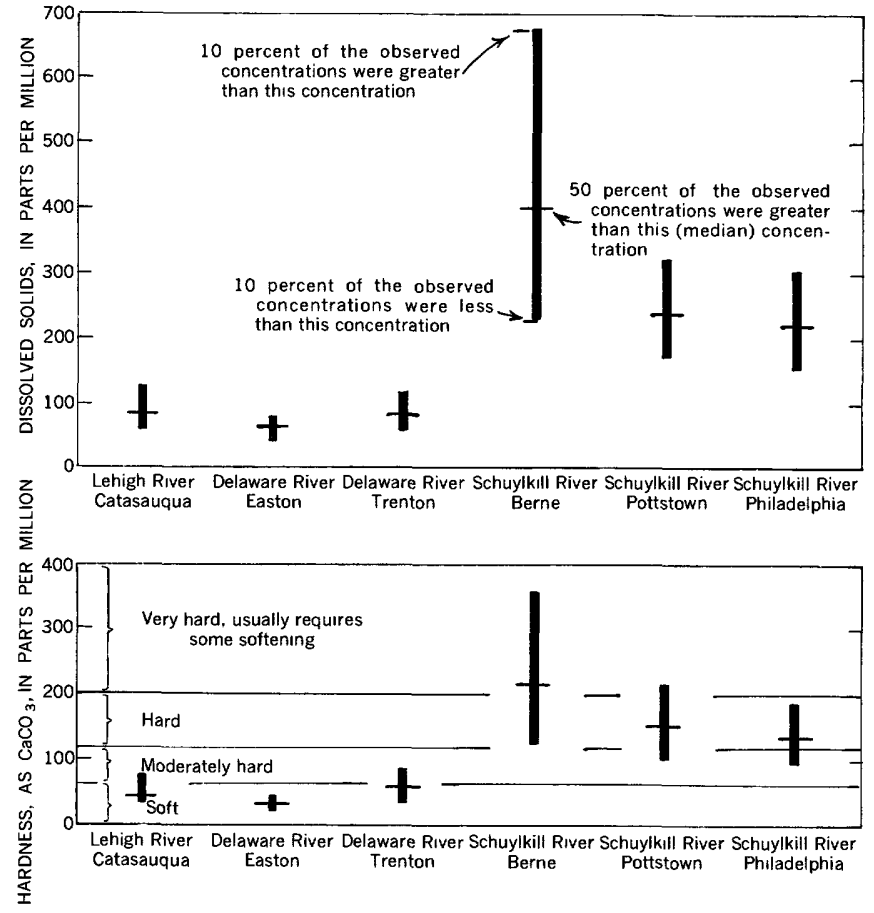

FIGURE 53.-Usual range of dissolved-solids concentration and hardness at six stations.

of the Delaware River at Trenton and the Schuylkill River at Philadelphia represents but 68 percent of the total drainage area of the Delaware River and Bay.

These 4 years of record are typical with respect to quantity of runoff, and represent a moderate range in runoff. At Trenton the monthly runoff ranged from 23 to 288 percent of the 30 -year average and the annual runoff ranged from 93 to 125 percent. The loads of dissolved solids in the 1951 water year were roughly one-third larger than the smallest annual load in these 4 years, no doubt because of the greater annual runoff in 1951. Schuylkill River at Philadelphia drains only 28 percent as much area as the Delaware River at Trenton and has an average annual discharge of 24 percent as much; nevertheless, the annual load of dissolved solids carried by the Schuylkill River is 60 percent as great as that carried by the Delaware River.

The monthly loads of dissolved solids are plotted in figure 54. In general the smaller loads are carried in August, September, and October, the larger loads in January, February, March, and April. Two-thirds of the annual load of dissolved material is carried by the streams in the 6 months from December to May because of the greater total discharge in those months and in spite of the lower concentration.

The preceding data are summarized in table 34 which shows the average annual load of dissolved solids carried by streams and the load in tons per square mile of drainage area for the eight areas listed in table 33 . The
TABLE 33.-Monthly and annual loads of dissolved solids for selected drainage areas

[Data in thousand tons]

\begin{tabular}{|c|c|c|c|c|c|c|c|c|}
\hline Date & 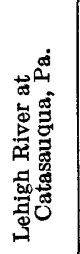 & 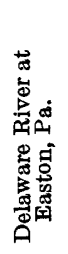 & 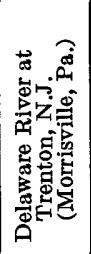 & 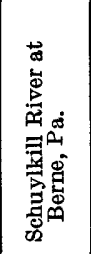 & 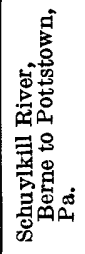 & 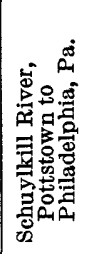 & 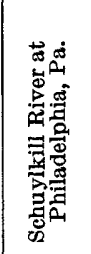 & 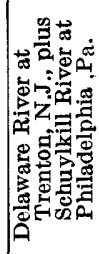 \\
\hline $\begin{array}{l}1947 \\
\text { Oct_- }\end{array}$ & 6.7 & 10.7 & 31.5 & & & & & \\
\hline $\begin{array}{l}\text { Nov... } \\
\text { Dec-... }\end{array}$ & $\begin{array}{r}14.5 \\
8.9\end{array}$ & $\begin{array}{l}41.3 \\
25.5\end{array}$ & $\begin{array}{l}85.8 \\
54.5\end{array}$ & $\cdots$ & 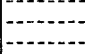 & $\begin{array}{r}12.4 \\
6.8\end{array}$ & $\begin{array}{l}53.5 \\
28.5\end{array}$ & $\begin{array}{r}139.3 \\
83.0\end{array}$ \\
\hline 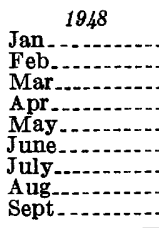 & $\begin{array}{r}6.8 \\
11.7 \\
19.0 \\
18.8 \\
19.2 \\
10.7 \\
9.1 \\
10.8 \\
7.0\end{array}$ & $\begin{array}{r}19.3 \\
32.2 \\
98.8 \\
69.5 \\
57.6 \\
35.7 \\
23.5 \\
15.9 \\
9.8\end{array}$ & $\begin{array}{r}47.5 \\
70.0 \\
152.9 \\
124.5 \\
120.6 \\
81.6 \\
55.0 \\
49.0 \\
32.5\end{array}$ & $\begin{array}{r}22.7 \\
25.4 \\
29.0 \\
16.1 \\
12.6 \\
12.0 \\
8.6\end{array}$ & $\begin{array}{r}23.3 \\
23.2 \\
26.8 \\
18.3 \\
10.2 \\
15.5 \\
9.3\end{array}$ & $\begin{array}{r}10.3 \\
16.6 \\
17.5 \\
14.2 \\
23.8 \\
11.8 \\
7.0 \\
7.5 \\
4.1\end{array}$ & $\begin{array}{l}32.0 \\
48.7 \\
63.5 \\
62.8 \\
79.6 \\
46.2 \\
29.8 \\
35.0 \\
22.0\end{array}$ & $\begin{array}{r}79.5 \\
118.7 \\
216.4 \\
187.3 \\
200.2 \\
127.8 \\
84.8 \\
84.0 \\
54.5\end{array}$ \\
\hline $\begin{array}{c}\text { Total, wa- } \\
\text { ter year } \\
1948\end{array}$ & 143.2 & 439.8 & 905.4 & 1240 & $\begin{array}{ll}1 & 1 \\
145\end{array}$ & $\begin{array}{ll}1 & 137\end{array}$ & 1522.2 & $11,427.6$ \\
\hline $\begin{array}{l}1948 \\
\text { Oct_- } \\
\text { Nov }\end{array}$ & $\begin{array}{l}6.4 \\
9.3\end{array}$ & $\begin{array}{r}9.8 \\
19.6\end{array}$ & $\begin{array}{l}31.7 \\
46.6\end{array}$ & $\begin{array}{r}8.1 \\
14.6\end{array}$ & $\begin{array}{r}8.5 \\
12.9\end{array}$ & $\begin{array}{l}4.1 \\
5.1\end{array}$ & $\begin{array}{l}20.7 \\
32.6\end{array}$ & $\begin{array}{r}52.4 \\
79.2\end{array}$ \\
\hline 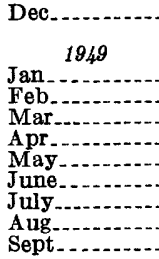 & $\begin{array}{r}24.9 \\
14.0 \\
11.2 \\
14.1 \\
12.7 \\
6.4 \\
7.0 \\
6.3 \\
5.9\end{array}$ & $\begin{array}{r}84.5 \\
49.3 \\
39.1 \\
41.5 \\
45.8 \\
17.4 \\
11.9 \\
8.4 \\
7.9\end{array}$ & $\begin{array}{l}159.5 \\
107.6 \\
86.2 \\
85.4 \\
84.1 \\
38.9 \\
34.9 \\
27.0 \\
27.0\end{array}$ & $\begin{array}{l}28.8 \\
18.4 \\
14.2 \\
16.5 \\
15.9 \\
10.0 \\
9.2 \\
8.1 \\
9.3\end{array}$ & $\begin{array}{r}31.5 \\
21.5 \\
14.8 \\
18.3 \\
12.9 \\
7.5 \\
8.8 \\
4.0 \\
3.5\end{array}$ & $\begin{array}{r}26.4 \\
22.5 \\
14.6 \\
13.5 \\
8.4 \\
3.3 \\
7.0 \\
4.6 \\
3.8\end{array}$ & $\begin{array}{l}86.7 \\
62.4 \\
43.6 \\
48.3 \\
37.2 \\
20.8 \\
25.0 \\
16.7 \\
16.6\end{array}$ & $\begin{array}{r}246.2 \\
170.0 \\
129.8 \\
133.7 \\
121.3 \\
59.7 \\
59.9 \\
43.7 \\
43.6\end{array}$ \\
\hline $\begin{array}{c}\text { Total, wa- } \\
\text { ter year } \\
1949\end{array}$ & 134.8 & 374.3 & 809.2 & 183.1 & 149.6 & 142.2 & 474.9 & $1,284.1$ \\
\hline $\begin{array}{l}1949 \\
\text { Oct_- } \\
\text { Nov-_.-. } \\
\text { Dec.-.... }\end{array}$ & $\begin{array}{l}5.1 \\
5.4 \\
9.5\end{array}$ & $\begin{array}{r}8.8 \\
15.1 \\
34.0\end{array}$ & $\begin{array}{l}25.7 \\
32.3 \\
58.7\end{array}$ & $\begin{array}{r}9.0 \\
9.8 \\
15.3\end{array}$ & $\begin{array}{l}3.6 \\
3.7 \\
8.5\end{array}$ & $\begin{array}{r}3.9 \\
3.0 \\
11.4\end{array}$ & $\begin{array}{l}16.5 \\
16.5 \\
35.2\end{array}$ & $\begin{array}{l}42.2 \\
48.8 \\
93.9\end{array}$ \\
\hline 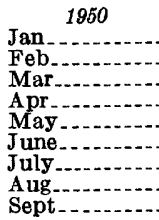 & $\begin{array}{r}11.5 \\
11.9 \\
18.0 \\
11.7 \\
11.9 \\
9.2 \\
8.5 \\
5.8 \\
6.1\end{array}$ & $\begin{array}{l}41.7 \\
35.1 \\
68.1 \\
69.5 \\
43.1 \\
37.7 \\
26.2 \\
17.6 \\
15.5\end{array}$ & $\begin{array}{r}67.2 \\
73.7 \\
113.2 \\
97.4 \\
75.7 \\
66.7 \\
53.4 \\
37.3 \\
35.9\end{array}$ & $\begin{array}{l}18.3 \\
20.0 \\
23.6 \\
23.4 \\
18.1 \\
17.3 \\
21.3 \\
11.9 \\
10.2\end{array}$ & $\begin{array}{r}10.8 \\
21.6 \\
19.4 \\
11.9 \\
14.9 \\
11.9 \\
7.9 \\
4.8 \\
8.3\end{array}$ & $\begin{array}{r}6.7 \\
21.1 \\
23.6 \\
8.0 \\
11.4 \\
6.2 \\
4.4 \\
9.0 \\
5.7\end{array}$ & $\begin{array}{l}35.8 \\
62.7 \\
66.6 \\
43.3 \\
44.4 \\
35.4 \\
33.6 \\
25.7 \\
24.2\end{array}$ & $\begin{array}{r}103.0 \\
136.4 \\
179.8 \\
140.7 \\
120.1 \\
102.1 \\
87.0 \\
63.0 \\
60.1\end{array}$ \\
\hline $\begin{array}{c}\text { Total, wa- } \\
\text { ter year } \\
1950\end{array}$ & 115.6 & 412.4 & 737.2 & 198.2 & 127.3 & 114.4 & 439.9 & $1,177.1$ \\
\hline 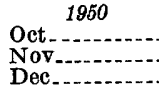 & $\begin{array}{r}6.1 \\
19.4 \\
25.6\end{array}$ & $\begin{array}{l}10.5 \\
40.6 \\
69.0\end{array}$ & $\begin{array}{r}29.1 \\
82.8 \\
127.4\end{array}$ & $\begin{array}{l}10.6 \\
26.4 \\
51.3\end{array}$ & $\begin{array}{r}7.1 \\
21.9 \\
23.6\end{array}$ & $\begin{array}{r}4.7 \\
25.2 \\
13.8\end{array}$ & $\begin{array}{l}22.4 \\
73.5 \\
88.7\end{array}$ & $\begin{array}{r}51.5 \\
156.3 \\
216.1\end{array}$ \\
\hline 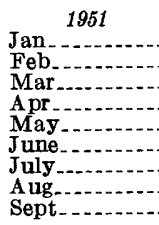 & $\begin{array}{r}17.5 \\
20.2 \\
17.1 \\
17.4 \\
10.1 \\
8.5 \\
13.4 \\
11.1 \\
6.6\end{array}$ & $\begin{array}{l}57.0 \\
67.4 \\
71.7 \\
81.8 \\
27.7 \\
23.8 \\
25.8 \\
24.3 \\
14.9\end{array}$ & $\begin{array}{r}98.8 \\
128.9 \\
118.6 \\
129.4 \\
59.5 \\
55.1 \\
63.5 \\
59.1 \\
37.2\end{array}$ & $\begin{array}{l}27.2 \\
34.5 \\
30.4 \\
27.1 \\
17.5 \\
11.2 \\
18.3 \\
19.6 \\
13.8\end{array}$ & $\begin{array}{r}15.3 \\
24.1 \\
18.6 \\
17.3 \\
8.0 \\
8.5 \\
9.2 \\
3.9 \\
6.6\end{array}$ & $\begin{array}{r}21.3 \\
21.7 \\
16.8 \\
15.7 \\
7.6 \\
8.0 \\
6.0 \\
5.6 \\
2.1\end{array}$ & $\begin{array}{l}63.8 \\
80.3 \\
65.8 \\
60.1 \\
33.1 \\
31.7 \\
33.5 \\
29.1 \\
22.5\end{array}$ & $\begin{array}{l}162.6 \\
200.2 \\
184.4 \\
189.5 \\
92.6 \\
86.8 \\
97.0 \\
88.2 \\
59.7\end{array}$ \\
\hline $\begin{array}{c}\text { Total, wa- } \\
\text { ter year } \\
1951\end{array}$ & 173.0 & 514.5 & 989.4 & 291.9 & 164.1 & 148.5 & 604.5 & $1,593.9$ \\
\hline
\end{tabular}

1 Loads for periods of no record estimated.

totals in tables 33 and 34 are given exactly for the benefit of those making detailed computations, but they are accurate to no more than three significant figures. 


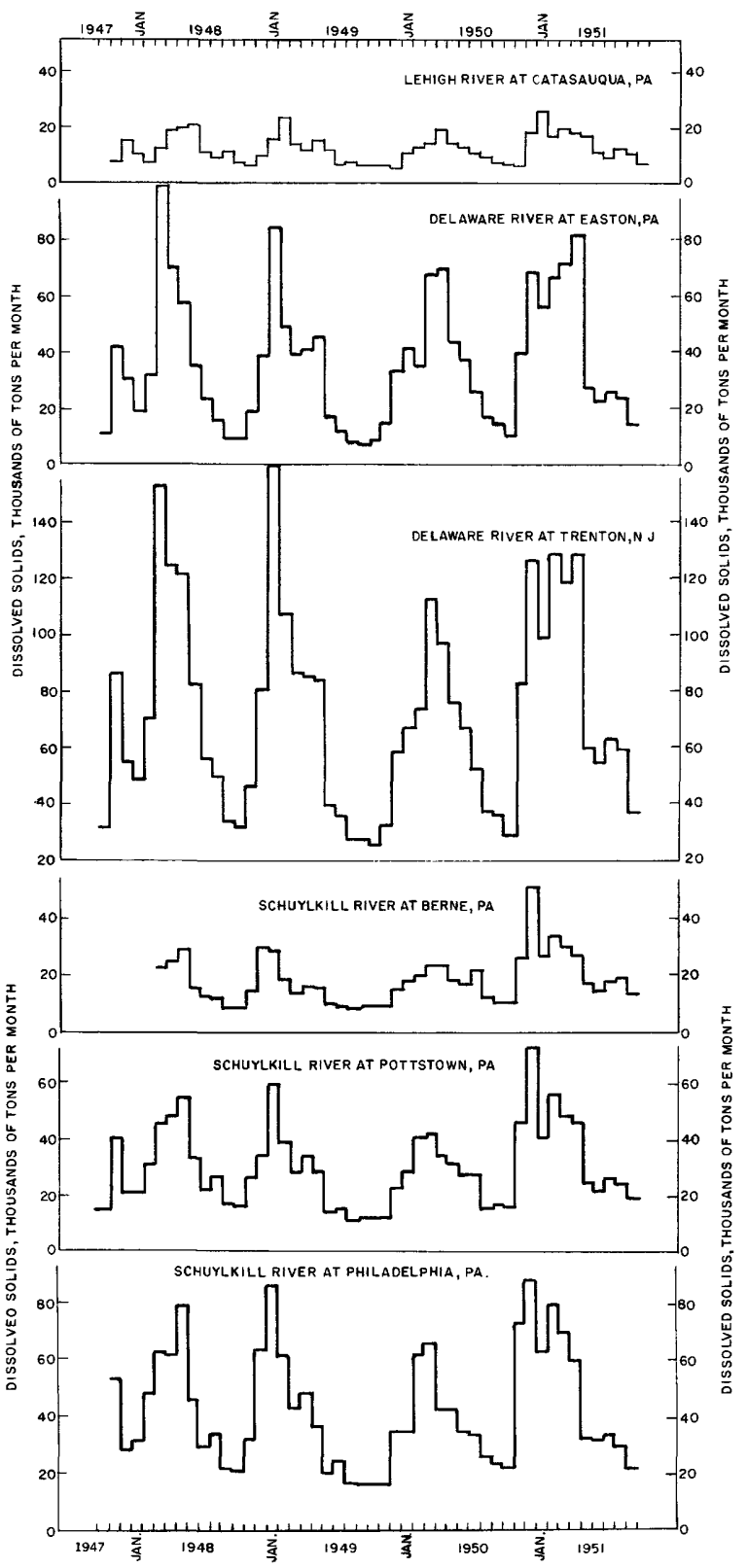

FIGURE 54.-Monthly loads of dissolved solids at selected stations.

From the area above the gaging stations on the Delaware River at Trenton, N.J., and the Schuylkill River at Philadelphia, $\mathrm{Pa}$., which comprises 68 percent of the total Delaware River basin, there is dissolved an average of nearly 1.4 million tons per year. Nearly two-thirds of this is carried by the Delaware River, the remainder by the Schuylkill River. In this part of the basin an average of 158 tons of minerals is dissolved annually for each square mile.

Data graphed in figure 54 may also be expressed thus: The dissolved solids load for 68 percent of the basin is 1.4 million tons. If this percentage of yield holds for the entire basin, the annual load is about 2 million tons. The load carried by the rivers, if transported by train, would require 1667 trains of 60 freight cars each, or one train every 5 hours and 12 minutes throughout the year.

In the Delaware River above Easton the concentrations of dissolved solids are low and the quantity dissolved per square mile is less than 60 percent of the average for the basin. The load per square mile is greater in the Lehigh River basin and in the Delaware River basin between Easton and Trenton. The greatest load per square mile, four times the average, is in the headwaters of the Schuylkill River. Here, in 20 percent of the Schuylkill River basin, originates almost half of the total load of dissolved solids for the Schuylkill River.

TABLE 34.-Average annual loads of dissolved solids carried by streams from specified areas

[Accurate to no more than three significant figures]

\begin{tabular}{|c|c|c|c|c|}
\hline \multirow[b]{2}{*}{ Location } & \multirow{2}{*}{$\begin{array}{c}\text { Drainage } \\
\text { area } \\
\text { (sq mi) }\end{array}$} & \multirow{2}{*}{$\begin{array}{l}\text { 4-year total, } \\
\text { Oct. 1947- } \\
\text { Sept. 1951 } \\
\text { (tons) }\end{array}$} & \multicolumn{2}{|c|}{ A verage annual load } \\
\hline & & & Tons & $\begin{array}{l}\text { Tons per } \\
\text { sq mi }\end{array}$ \\
\hline 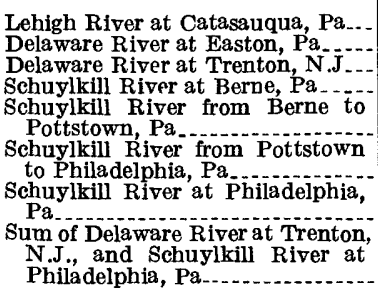 & $\begin{array}{l}1,012 \\
4,717 \\
6,780 \\
355\end{array}$ & $\begin{array}{r}566,600 \\
1,741,000 \\
3,441,200 \\
1913,000 \\
1586,000 \\
2542,200 \\
22,041,500\end{array}$ & $\begin{array}{l}141,600 \\
435,200 \\
826,300 \\
228,000 \\
146,000 \\
135,600 \\
510,400\end{array}$ & $\begin{array}{r}140 \\
9 \\
127 \\
64\end{array}$ \\
\hline
\end{tabular}

1 Load estimated for 5 months.

2 Load estimated for 1 month.

The relation of monthly load of dissolved solids to monthly streamflow for Delaware River at Trenton, N.J., is shown in figure 55 .

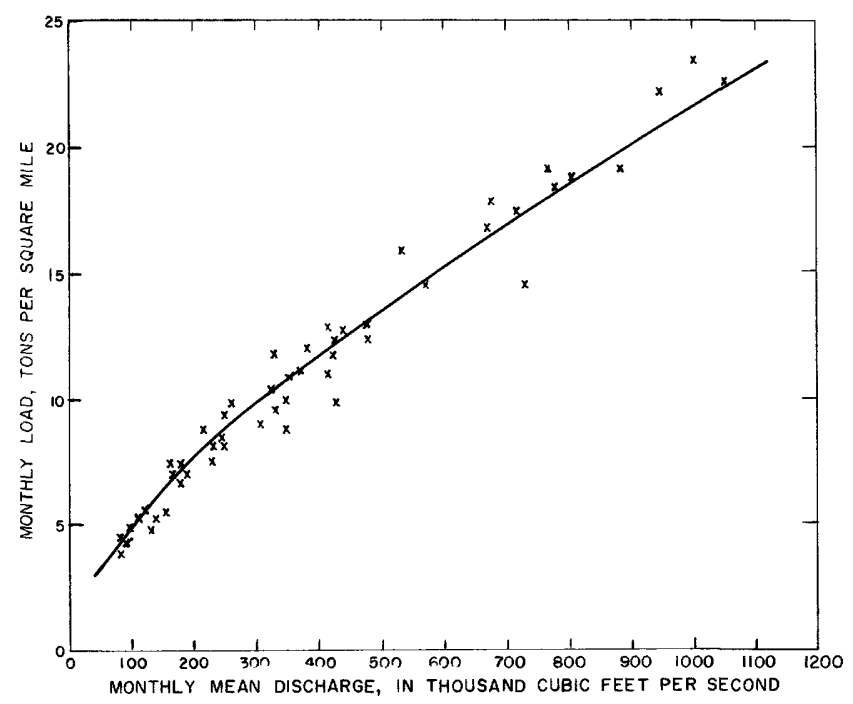

Figure 55.-Variation of dissolved-solids load with discharge, Delaware River at Trenton, N.J., 1949-51. 
DAILY VARIATIONS IN CONCENTRATIONS OF DISSOLVED SOIIDS

The daily variation in concentration of dissolved solids in the water at a particular location may be more fully presented by a duration curve. Such a curve shows the percent of time for which specified concentrations are equaled or exceeded. Duration
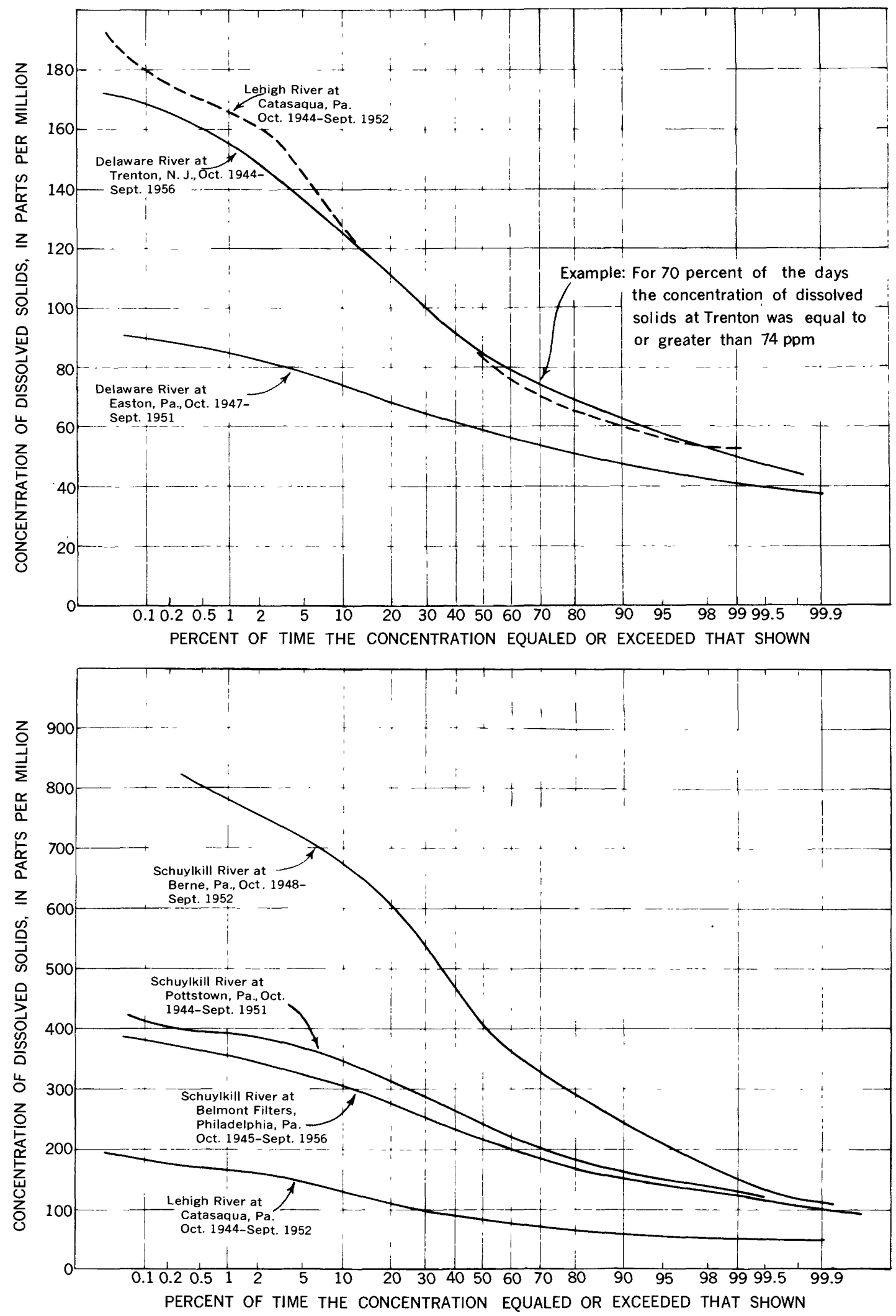

FigURE 56.-Duration curves of concentration of dissolved solids at selected locations. 
curves for the Lehigh River at Catasauqua and the Delaware River at Easton and Trenton are shown on figure 56. The corresponding curves on a different scale are shown for the Schuylkill River at Berne, Pottstown, and Philadelphia. The duration curve for the Lehigh River at Catasauqua also is plotted at this scale for comparison. The greater the variation in the concentration, the steeper is the slope of the duration curve. The concentration of dissolved solids obviously varied more widely in the Schuylkill River at Berne than at any of the other five locations, probably because of a steady inflow of acid mine drainage diluted by varying quantities of overland drainage from precipitation. The water of the Delaware River at Easton shows the least variation in concentration of dissolved solids, as well as the least concentration.

These duration curves are an interpretation of a short record of the past. They tell us, for example, that the dissolved-solids concentration of Schuylkill River water equaled or exceeded 300 ppm 76 percent of the time at Berne (1948-52 water years), 26 percent of the time at Pottstown (1945-51 water years), and 11 percent of the time at Philadelphia (1946-56 water years). One cannot say with certainty that these same statements can be made for any other years. The duration curves can be used to make reasonable estimates of conditions in the future, provided the controlling conditions are the same as those in the years in which the records were obtained. Excessively dry or wet years, or radical changes in land use or industrial development might, however, change the position or shape of the duration curve. Even for the years plotted there is variation from year to year.

The extent of this variation is shown on figure 57 for the Schuylkill River at Berne and for the Delaware River at Trenton. Here are plotted duration curves of specific conductance (which is proportional to dissolved-solids concentration). Duration curves for each of the 4 years at Berne and each of the 12 years at Trenton lie within the shaded areas. At Berne the average difference between the curve for any 1 year

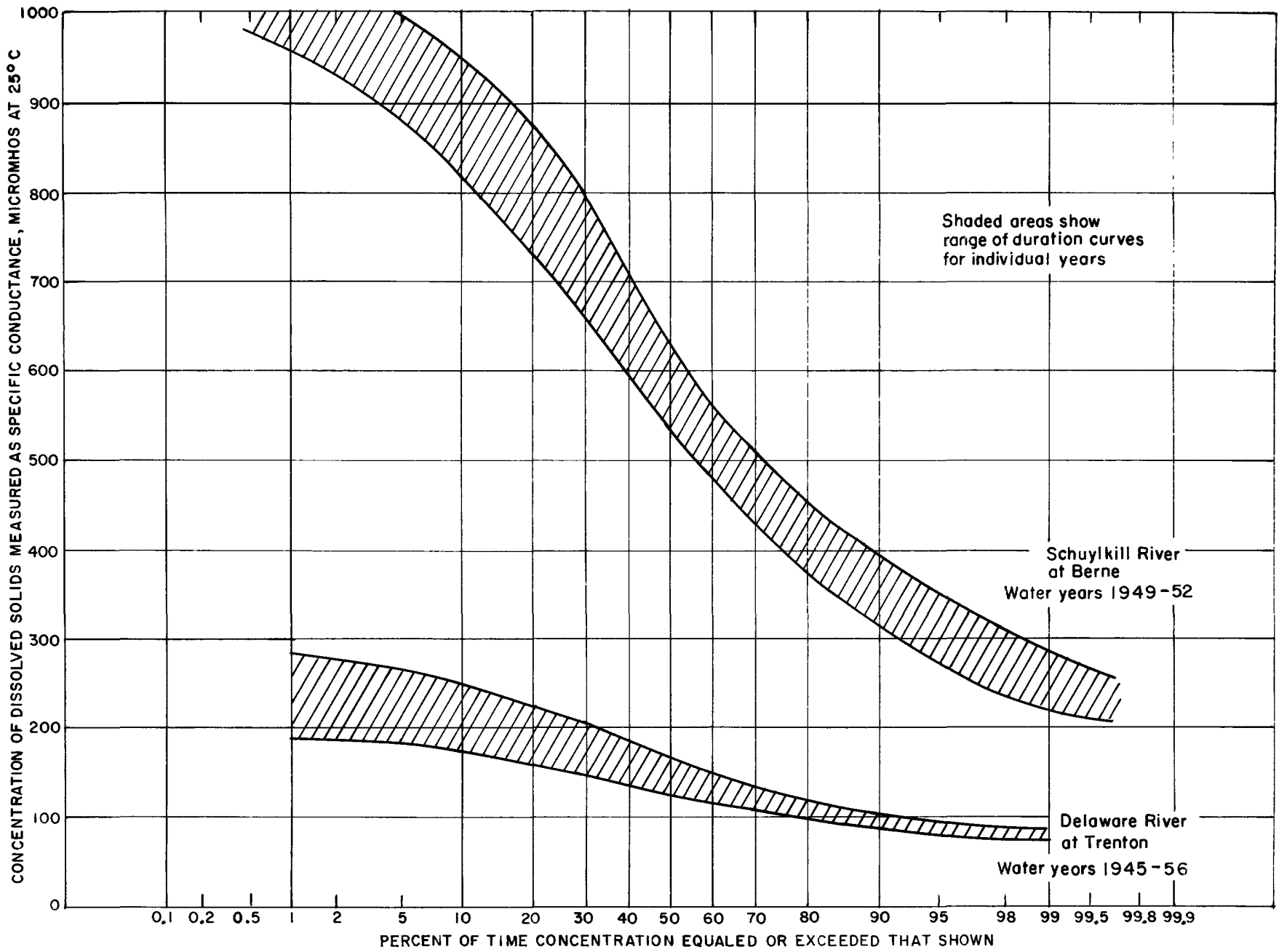

FIGURE 57.-Range in position of duration curves of dissolved-solids concentration for two stations. 
and the mean curve is about 5 percent of the conductance; at Trenton it is about 15 percent.

\section{SEASONAL VARIATION IN CONCENTRATION OF DISSOLVED SOLIDS}

Seasonal changes occur in the concentration of dissolved solids because of seasonal influences on the distribution of precipitation and runoff. Water that soaks deeply into the ground remains in contact with the soil or rock for days or months and during this time dissolves more mineral matter than overland flow that runs off quickly. Much of the water that enters the soil percolates to the water table and eventually is discharged into the streams. In the late summer, especially in a dry season, streams are fed largely by ground water, and at such a time the concentration of dissolved solids is highest. The water of spring freshets usually has a low concentration of dissolved solids because much of the runoff is snowmelt that has not penetrated the ground. Frozen or saturated soils sometimes decrease the opportunity for infiltration and cause a relatively large direct runoff in winter. Consequently, in the Delaware River basin above Philadelphia, the stream water has a dissolved-solids concentration generally above average in the late summer and early fall (July to October) and lower than average in the winter and early spring (December to May).

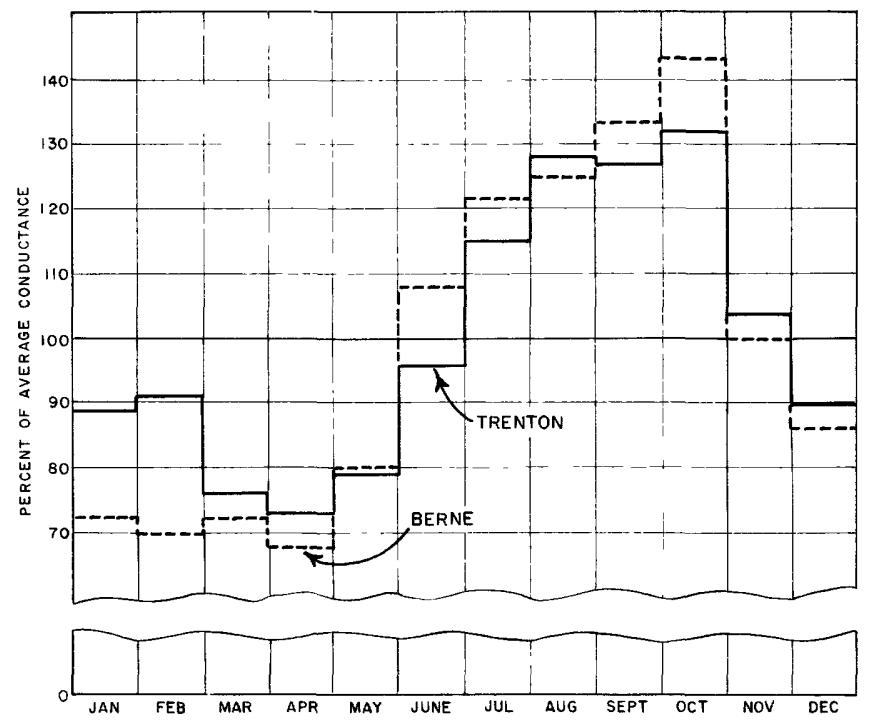

Figure 58.-A verage monthly conductance, Delaware River at Trenton, N.J. (October 1944 to September 1956), and Schuylkill River at Berne, Pa. (March 1948 to September 1952).

Low river-water hardness in winter and high riverwater hardness in summer is shown clearly on figure 58 by the specific conductance of the Delaware River at Trenton and the Schuylkill River at Berne. At Trenton, in March and April, the water has only 75 percent of its average conductance. The conductance then rises until, in August, September, and October, it is greater than 125 percent of the average. Seasonal change in hardness is also characteristic of the seasonal change in conductance of the water of the Delaware River at Easton, the Lehigh River at Catasauqua, and the Schuylkill River at Pottstown and Philadelphia. The Schuylkill River at Berne, however, varies in a slightly different manner (as shown by the dashed line in figure 58). At Berne the specific conductance is approximately 70 percent of the average in January to April and then in October increases to a maximum of greater than 140 percent of the average. The variation in conductance (and dissolved-solids concentration) is somewhat greater at Berne than at the other five locations, as has already been shown in figure 56 .

For each of these six locations the monthly variation in dissolved-solids concentration is shown in figure 59. Note that in this plate a more compressed scale has been used for the three Schuylkill River stations (right side of illustration) than for the Lehigh and Delaware River stations.

\section{COMPOSITION OF DISSOLVED SOLIDS}

In additon to the concentration of dissolved solids, the composition of the dissolved material is important. The concentration of dissolved solids in water of the Delaware River at Trenton is nearly 50 percent greater than at Easton, but the dissolved solids have substantially the same typical composition-28 percent calcium, 15 percent magnesium, 7 percent sodium plus potassium, 26 percent bicarbonate, 17 percent sulfate, and 7 percent chloride plus nitrate-when calculated as equivalents. The dissolved solids in the Lehigh River water are similar in composition except that, owing to mine drainage entering the Lehigh River by way of some of its tributaries, there is more sulfate and less bicarbonate. Some of the tributaries are acid from mine drainage, although the Lehigh River at Catasauqua is not. These facts are shown graphically in figure 60 in which the chemical compositon of the water at the six locations listed in table 32 is given by bar charts. The relative hardness and mineral content of the typical water at these six locations are also shown.

The water of the Schuylkill River is more mineralized and harder than the water of the Lehigh River or of the nontidal part of the Delaware River. The water at Berne is a calcium and magnesium sulfate water and is acid owing to mine drainage. Typically its dissolved solids have the composition: 20 percent calcium, 20 percent magnesum, 5 percent sodum and potassium, 5 percent hydrogen ion (acid), 49 percent sulfate, and 1 percent chloride plus nitrate, expressed as equivalents. 

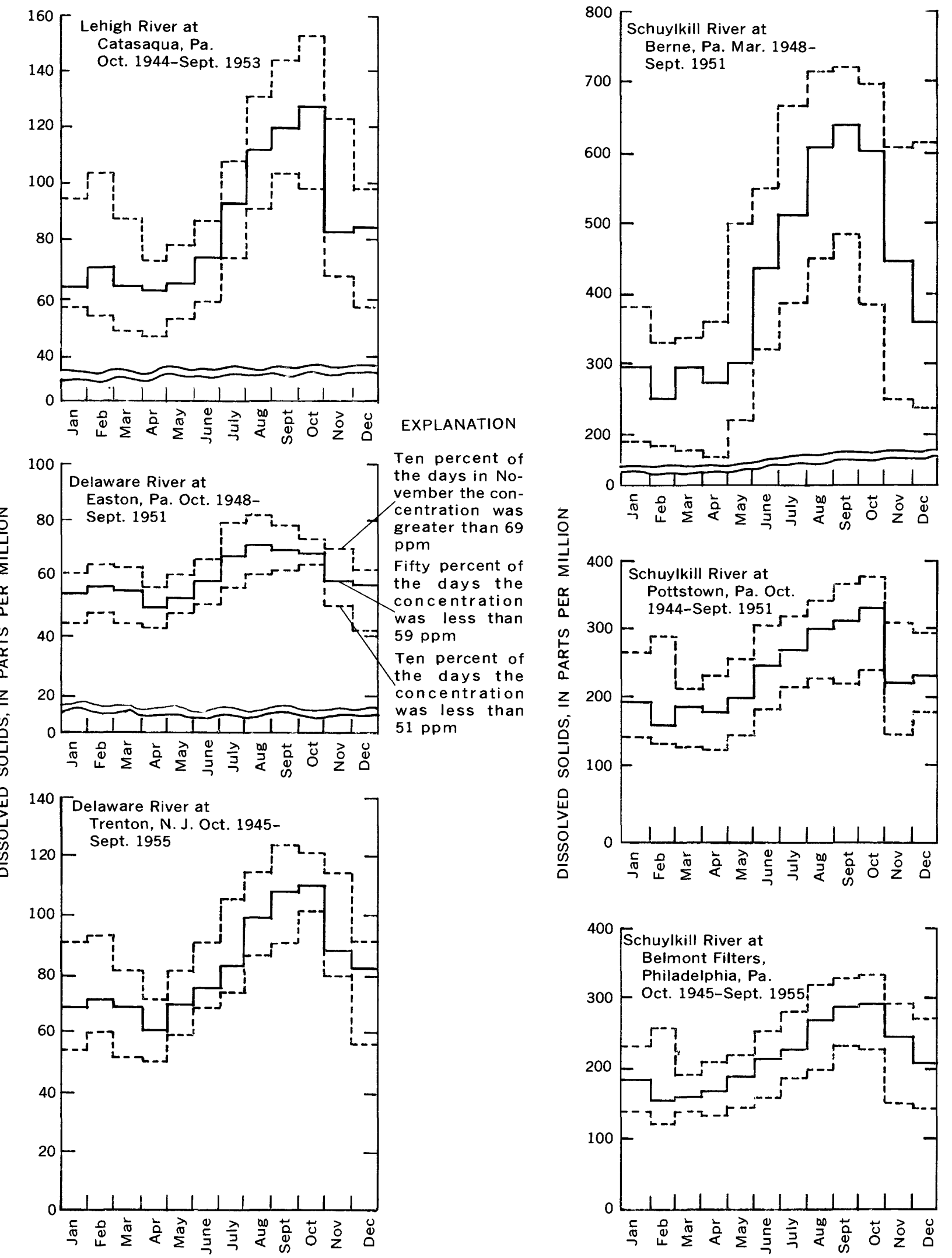

Figure 59.-Seasonal variations in concentration of dissolved solids at six stations. 


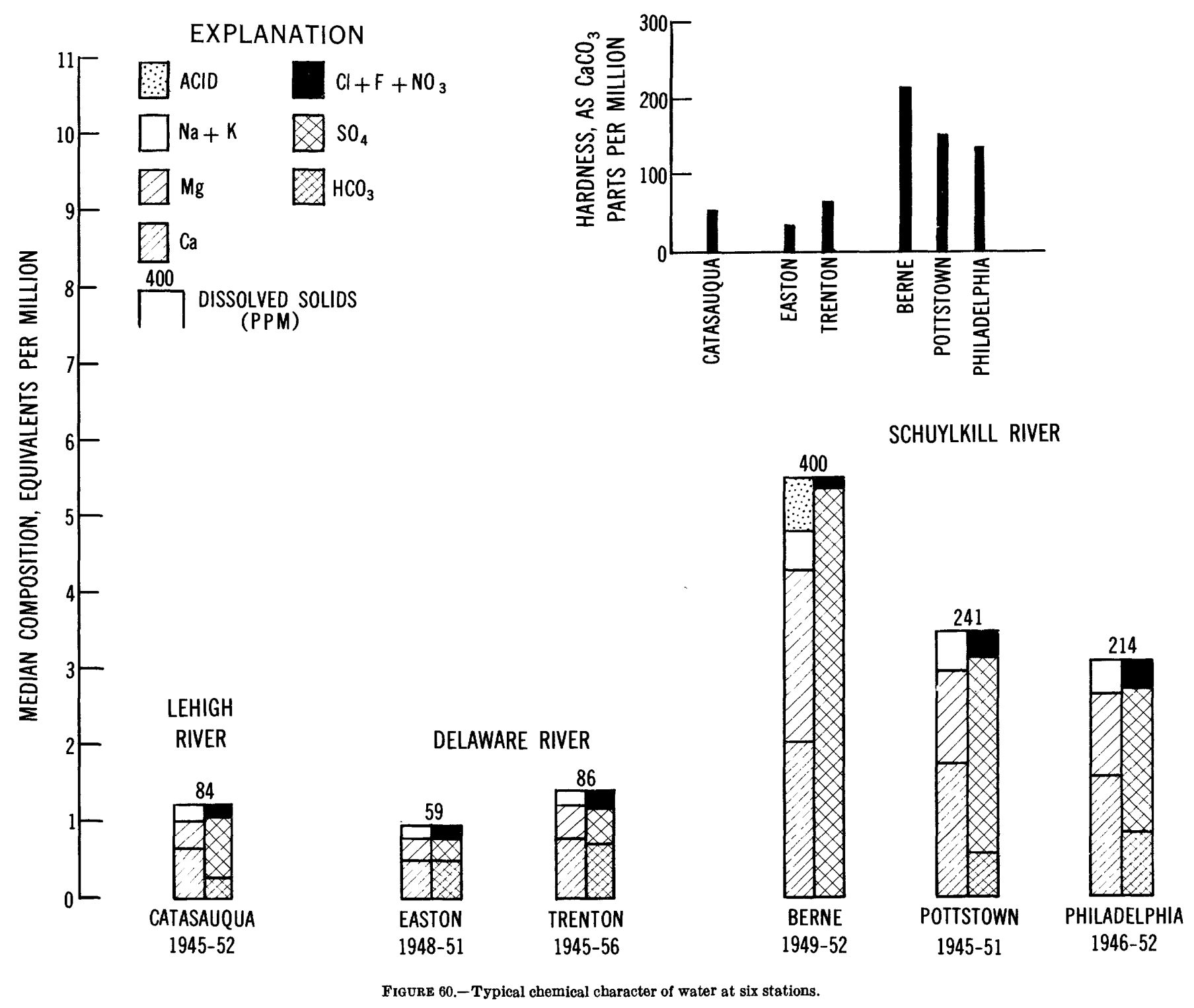

The dissolved minerals are therefore chiefly calcium and magnesium sulfates plus sulfuric acid. As the Schuylkill River flows downstream it mixes with Maiden Creek, Tulpehocken Creek, and other tributaries which flow through limestone regions in the Great Valley (pl. 1). These tributaries are alkaline, and neutralize the acid water of the Schuylkill River. Consequently at Pottstown the water is no longer acid, contains bicarbonate as well as sulfate, and has a lower concentration of dissolved solids than it had in the headwaters above Berne. At Pottstown and Philadelphia the dissolved solids usually are composed of 26 percent calcium, 17 percent magnesium, and 7 percent sodium plus potassium, on an equivalent basis. The percentages of bicarbonate and of chloride plus nitrate increase. The increase of the latter may be due to pollution in the more populated and industrialized downstream reaches of the stream, as well as to tributary or ground-water inflow.

The cumulative concentrations of the mineral constituents of the Schuylkill River water are shown on figure 61. The river water decreases in mineral content more sharply between Berne and Pottstown than between Pottstown and Philadelphia. This sharp change in mineralization means that the inflow above Berne is more mineralized than that downstream. A given volume of water dissolves more minerals from a given area in that part of the basin above Berne than in the part below. It is particularly evident that sulfate is added principally above Berne. Bicarbonate, which was absent at Berne, is added in increasing quantities downstream. 


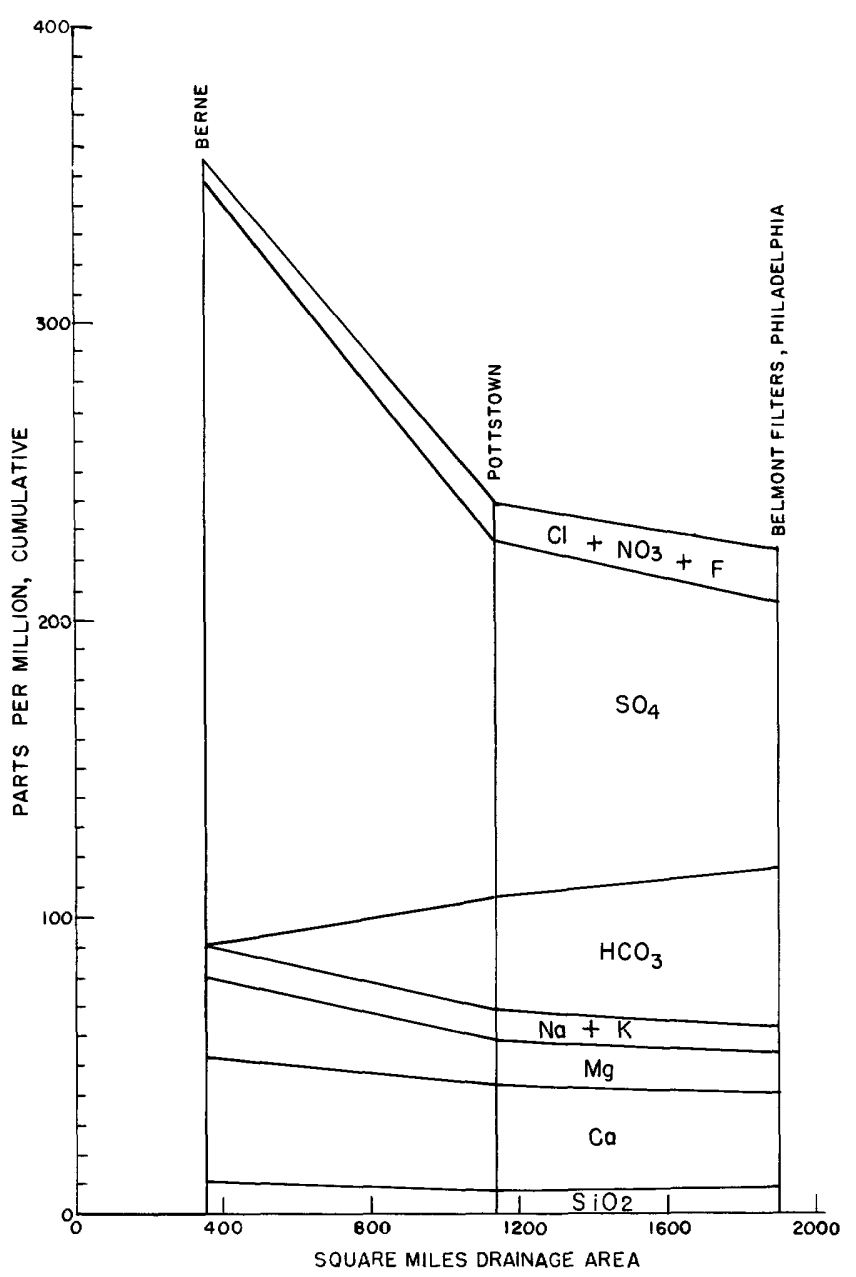

Figure 61.-Cumulative quantities of chemical constituents in Schuylkill River water.

It has been shown that the concentration of dissolved solids generally varies with the discharge, and it might be expected that the composition of the dissolved solids also would depend upon the discharge; that it does not for most of the six selected stations is shown by figure 62 . In this plot the percentage composition of the dissolved solids is shown for typical high and low flows at each of the six stations. In the Lehigh River at Catasauqua the composition is virtually uninfluenced by discharge. In the Delaware River at Easton and at Trenton the only effect of discharge is an increase in the bicarbonate-sulfate ratio at low flows. In the Schuylkill River at Berne the proportion of the dissolved minerals is almost the same at high or low flows, except for an increase in acidity at low flows. In the downstream parts of the Schuylkill River, change in flow rate has no significant effect on the composition of the dissolved minerals.

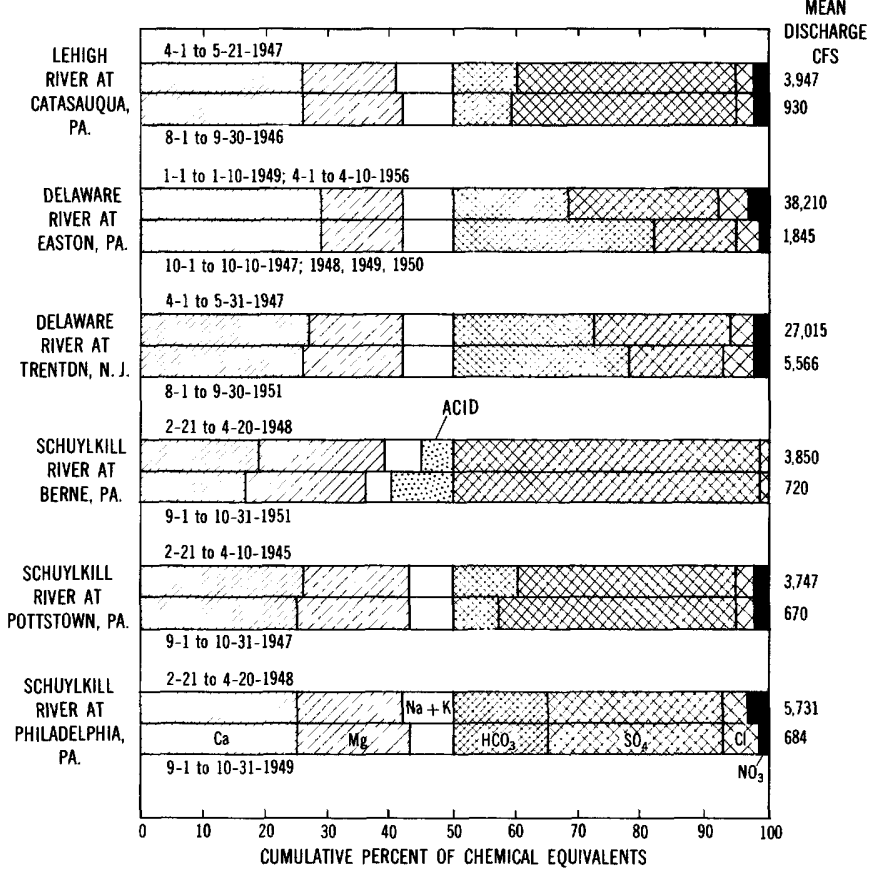

Figure 62.-Comparison of composition of dissolved solids for selected periods of high and low flow at six stations.

DAILY VARIATION IN CHEMTCAL QDALITY

The time during which certain critical concentrations are exceeded is also of considerable interest. Figure 56 provides this information for dissolved solids. From these plots, for example, one can determine that in the Lehigh River water at Catasauqua, Pa., the dissolved-solids concentration equaled or exceeded 127 ppm in 10 percent of the days, $104 \mathrm{ppm}$ in 25 percent, $84 \mathrm{ppm}$ in 50 percent, $70 \mathrm{ppm}$ in 75 percent, and 60 ppm in 90 percent. This information is also given in table 35 , as is the equivalent information for specific conductance, hardness, and the concentrations of a number of chemical constituents.

As an example of the usefulness of these data, the U.S. Public Health Service standards require that the sulfate concentration of drinking water should not exceed $250 \mathrm{ppm}$, except where a better supply is not available (U.S. Public Health Service, 1946). It is apparent that surface water at the six stations considered in table 35 would all contain less than $250 \mathrm{ppm}$ of sulfate almost all the time, except for the Schuylkill River at Berne, in which the sulfate concentration would exceed the recommended limit somewhat more than 50 percent of the time.

Table 35 was compiled by first plotting the conductance values of daily samples and drawing duration curves for conductance at each station, similar to the duration curves for dissolved solids in figure 56 . Next, for each station, the relation of conductance to the 
concentrations of each constituent was established for the concentration range exhibited by the samples at that location. From the specific conductance duration curve the values of conductance that were exceeded in $10,25,50,75$, and 90 percent of the days were determined and listed. Finally, for each value of conductance in the table, corresponding concentrations were also tabulated. The resulting table 35 then gives the conductances or concentrations that were equaled or exceeded in the percent of days shown, for the period of record. Insofar as conditions such as precipitation, runoff, temperature, land use, and pollution remain the same as for the period of record, such a table probably is a satisfactory basis for estimating the percentage of time during which the given concentrations may be expected in the future.

The usefulness of the data may be illustrated by several examples. Water containing sulfate may be corrosive to concrete. There is some difference of opinion as to the threshold value at which corrosion becomes significant, but if it is assumed to be $360 \mathrm{ppm}$ of sulfate, the Schuylkill River waters at Berne will be corrosive to concrete 25 percent of the time; water at the other five stations listed in table 35, however, would not corrode concrete. For the refining of sugar the recommended limiting concentrations of calcium and magnesium have been given as 20 and $10 \mathrm{ppm}$, respectively (California Water Pollution Control Board, 1952, p. 199, 206).

Based on these criteria alone, the water of the Schuylkill River is satisfactory for sugar refining less than 10 percent of the time; the Delaware River at Trenton is satisfactory more than 75 percent of the time; and the Delaware River at Easton and the Lehigh River at Catasauqua is satisfactory at least 90 percent of the time. Such information should be useful in selecting industrial sites and in estimating the cost of treating water to assure that it will meet specifications.

CHEMICAL QUALITY OF WATER IN THE DELA WARE ESTOARY

The quality of the water above tidewater in the Delaware River at Trenton, N.J., was described in a previous section. The water at Trenton contains less than $126 \mathrm{ppm}$ of dissolved solids and less than $8 \mathrm{ppm}$ of chloride 90 percent of the time. The ocean water contains about $35,000 \mathrm{ppm}$ of dissolved solids which includes about $19,000 \mathrm{ppm}$ of chloride.

In the Delaware estuary between Trenton and the Capes, sea water mixes with fresh water; most of the mixing occurs between Philadelphia and Liston Point. The extent of encroachment of sea water is indicated by the concentration of dissolved solids and by the proportions of the various minerals in the dissolved solids. For example, sea water generally con-
TABLE 35.-Specific electric conductance (microhomos at $25^{\circ} C^{\prime}$ ) and concentration (parts per million) which were equaled or exceeded in percent of days shown

\begin{tabular}{|c|c|c|c|c|c|}
\hline & \multicolumn{5}{|c|}{ Percent of days } \\
\hline & 10 & 25 & 50 & 75 & 90 \\
\hline \multicolumn{6}{|l|}{$\begin{array}{l}\text { Lehigh River at Catasauqua, Pa., } \\
\text { 1945-52: }\end{array}$} \\
\hline $\begin{array}{l}\text { Specific conductance } \\
\text { Calcium }\end{array}$ & \multirow{7}{*}{$\begin{array}{c}200 \\
19 \\
6.6 \\
7.4 \\
22 \\
60 \\
4.0 \\
127 \\
74\end{array}$} & \multirow{7}{*}{$\begin{array}{c}162 \\
15 \\
54 \\
5.9 \\
17 \\
48 \\
3.3 \\
104 \\
60\end{array}$} & \multirow{7}{*}{$\begin{array}{c}130 \\
12 \\
4.3 \\
4.7 \\
13 \\
38 \\
2.7 \\
84 \\
47\end{array}$} & \multirow{7}{*}{$\begin{array}{c}107 \\
9.8 \\
3.6 \\
3.8 \\
9 \\
32 \\
2.3 \\
70 \\
39\end{array}$} & \multirow{7}{*}{$\begin{array}{c}92 \\
8.3 \\
3.0 \\
3.2 \\
7 \\
27 \\
2.1 \\
60 \\
33\end{array}$} \\
\hline $\begin{array}{l}\text { Calcium }(\mathrm{Ca}) \\
\text { Magnesium }(\mathrm{Mg})\end{array}$ & & & & & \\
\hline & & & & & \\
\hline $\begin{array}{l}\text { Bica } \\
\text { Sulf: }\end{array}$ & & & & & \\
\hline Chloride (CI). & & & & & \\
\hline & & & & & \\
\hline Delaw & & & & & \\
\hline Sp & \multirow{8}{*}{$\begin{array}{c}118 \\
13 \\
3.7 \\
3.9 \\
43 \\
16 \\
3.4 \\
73 \\
48 \\
4\end{array}$} & \multirow{8}{*}{$\begin{array}{c}105 \\
12 \\
3.3 \\
3.5 \\
36 \\
15 \\
3.0 \\
66 \\
42\end{array}$} & \multirow{7}{*}{$\begin{array}{c}91 \\
10 \\
2.8 \\
3.0 \\
29 \\
14 \\
2.5 \\
59 \\
36\end{array}$} & \multirow{7}{*}{$\begin{array}{c}78 \\
8.7 \\
2.4 \\
2.6 \\
23 \\
13 \\
2.1 \\
52 \\
30\end{array}$} & \multirow{8}{*}{$\begin{array}{c}70 \\
7.7 \\
2.1 \\
2.3 \\
19 \\
12 \\
1.9 \\
48 \\
26\end{array}$} \\
\hline $\begin{array}{ll}\mathrm{Ca} \\
\mathrm{M}\end{array}$ & & & & & \\
\hline Sod & & & & & \\
\hline & & & & & \\
\hline & & & & & \\
\hline & & & & & \\
\hline $\mathrm{O}_{3}$ & & & & & \\
\hline Delaware Rive & & & & & \\
\hline Spe & \multirow{7}{*}{$\begin{array}{c}210 \\
22 \\
7.5 \\
7.3 \\
62 \\
32 \\
8.2 \\
126 \\
86\end{array}$} & \multirow{7}{*}{$\begin{array}{c}176 \\
18 \\
6.1 \\
61 \\
51 \\
28 \\
6.6 \\
106 \\
71\end{array}$} & \multirow{7}{*}{$\begin{array}{c}140 \\
15 \\
4.9 \\
4.9 \\
39 \\
23 \\
4.9 \\
86 \\
56\end{array}$} & \multirow{7}{*}{$\begin{array}{c}116 \\
12 \\
3.9 \\
4.0 \\
31 \\
20 \\
3.8 \\
72 \\
46\end{array}$} & \multirow{7}{*}{$\begin{array}{c}100 \\
11 \\
3.3 \\
3.5 \\
26 \\
18 \\
3.0 \\
63 \\
39\end{array}$} \\
\hline & & & & & \\
\hline $\mathrm{um}(\mathrm{Na}+\mathrm{K})$ & & & & & \\
\hline & & & & & \\
\hline & & & & & \\
\hline & & & & & \\
\hline & & & & & \\
\hline Schuyl & & \multirow{3}{*}{$\begin{array}{r}765 \\
60 \\
37 \\
16\end{array}$} & \multirow{2}{*}{$\begin{array}{r}553 \\
42 \\
26 \\
12\end{array}$} & \multirow{3}{*}{$\begin{array}{c}440 \\
32 \\
19 \\
9.1\end{array}$} & \\
\hline (n) & \multirow{2}{*}{$\begin{array}{r}872 \\
69 \\
42 \\
19\end{array}$} & & & & $\begin{array}{c}15 \\
7 .\end{array}$ \\
\hline & & & & & \\
\hline & 432 & & 257 & & \\
\hline & 6.5 & 5.8 & 4.1 & 3.8 & $238^{3}$ \\
\hline ........... & $\begin{array}{l}674 \\
360\end{array}$ & $\begin{array}{l}536 \\
310\end{array}$ & ${ }_{215}^{400}$ & $\begin{array}{l}304 \\
165\end{array}$ & $\begin{array}{l}236 \\
128\end{array}$ \\
\hline Pottstown, Pa., & & & & & \\
\hline & 510 & 446 & 356 & 292 & 246 \\
\hline & 52 & 45 & 36 & 29 & \\
\hline & 22 & 19 & 15 & 12 & 10 \\
\hline$a+K) \ldots$ & 16 & 13 & 10 & 8.0 & \\
\hline -..-.- & ${ }_{180}^{53}$ & $\begin{array}{r}47 \\
156\end{array}$ & 38 & $\begin{array}{l}32 \\
95\end{array}$ & 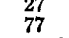 \\
\hline & 13 & ${ }_{11}^{156}$ & 8 & $\begin{aligned} 90 \\
6.2\end{aligned}$ & \\
\hline & 345 & 302 & 241 & 197 & 166 \\
\hline & 220 & 191 & 151 & 122 & 102 \\
\hline Imont Filters, & & & & & \\
\hline & & & & & \\
\hline & 45 & 39 & 32 & 26 & \\
\hline & & & & & \\
\hline & & & & 7.7 & $\begin{array}{r}6 \\
38 \\
\end{array}$ \\
\hline (1) & $\begin{array}{r}75 \\
130\end{array}$ & $\begin{array}{r}65 \\
112\end{array}$ & $\begin{array}{l}53 \\
89\end{array}$ & 43 & $\begin{array}{l}50 \\
62\end{array}-12$ \\
\hline & 17 & & & 7.7 & \\
\hline 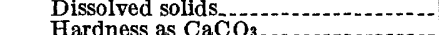 & $\begin{array}{l}304 \\
190\end{array}$ & ${ }_{166}^{266}$ & ${ }_{134}^{214}$ & 174 & ${ }_{96}^{152}$ \\
\hline & & & & & \\
\hline
\end{tabular}

tains three times as much magnesium as calcium, whereas fresh water commonly contains only half as much magnesium as calcium. The encroachment of sea water into the Delaware estuary is shown clearly in figure 63 , both by the concentration and composition of dissolved solids. Sea water evidently encroached farther upriver in October 1955 than in June and July 1956.

The extent of sea-water encroachment into the estuary depends upon a number of factors, among which are: (1) fresh-water discharge, (2) sea level, (3) tides, (4) winds, and (5) depth, shape, roughness, and configuration of the river channel. In view of all these items operating to control salinity and the time usually 

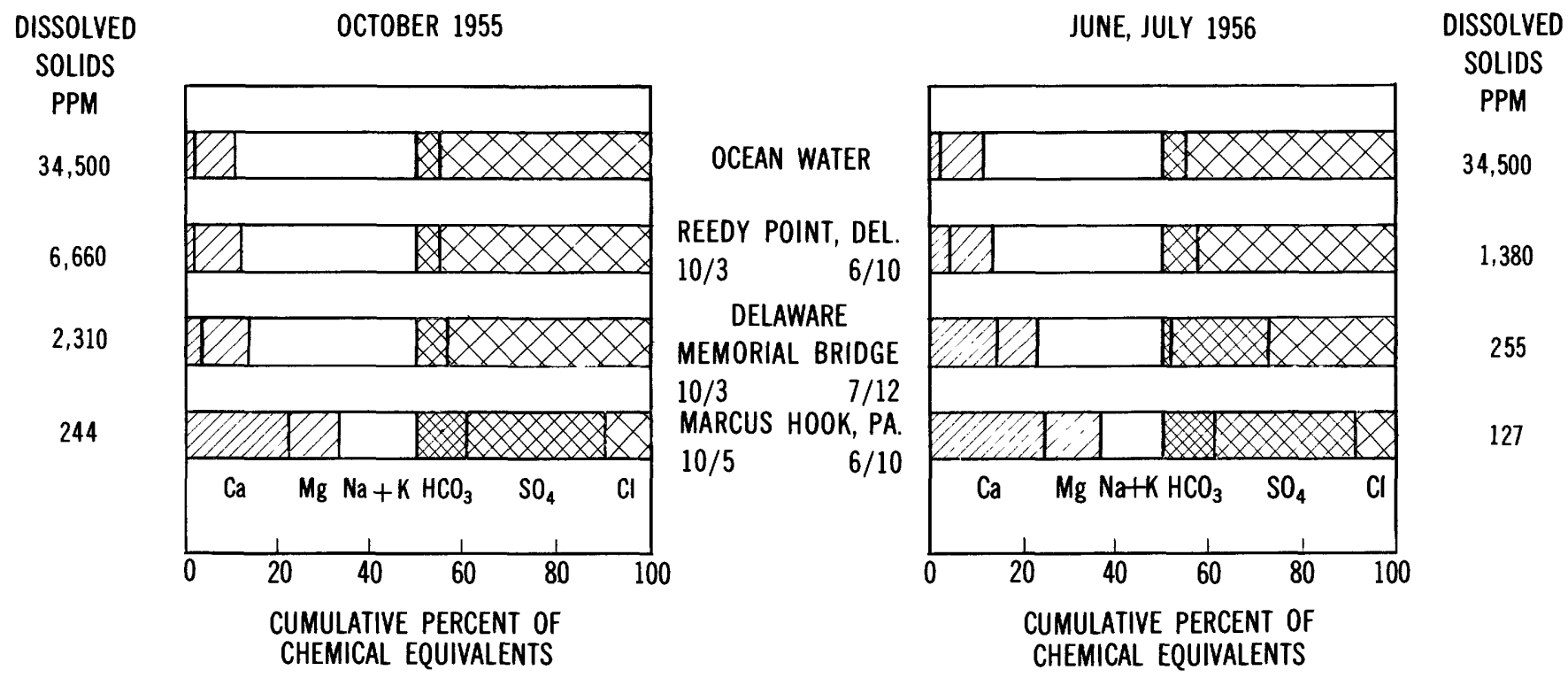

Figure 63.-Composition of dissolved solids in the ocean and in Delaware estuary.

required to reach equilibrium, the salinity rarely reaches a steady state. Instead, the interface or zone between fresh and salt water is usually moving up or down river in response to the character of the last or dominating influence. Movement of the salt front caused by a change in any of these factors may continue for some days, and several factors may change at the same or nearly the same time. Therefore, establishment of a definite quantitative relation between any of these controlling elements to the position of the salt front is difficult.

Salinity in the Delaware estuary and the factors influencing salinity are discussed in a number of publications of which the following have been selected for reference: Cohen (1957); U.S. Corps of Engineers (1952); U.S. Corps of Engineers (1956); Durfor and Keighton (1954); Keighton (1954); Ketchum (1952, 1953); Mason and Pietsch (1940): Parker (1955); Pennsylvania Department of Health (1935); Pritchard (1954); and Terenzio (1953).

\section{SALINITY VARIATION IN THE RIVER CROSS SECTION}

If there were no fresh-water discharge into the estuary, the sea water, seeking its own level, would occupy the river channel to the head of the estuary at Trenton, N.J. However, fresh water does discharge into the estuary and, being less dense than sea water, tends to override it. In many estuaries the salt water forms a distinct layer on the bottom under the fresh water above (Parker, 1955). The fresh-water flow erodes the salt-water surface, and the encroaching salt water assumes a wedge shape with the thin edge upstream; concomitantly, the fresh water above the wedge becomes somewhat saline from admixture with the eroded salt water (Parker and others, 1955, p. 618-711).

In the Delaware estuary the mixing processes are so efficient that a definite salt-water wedge is uncommon. Although frequently there is no significant difference in salinity between samples from the surface and bottom of the estuary, the majority of samples from near the bottom do have a higher salinity than those from near the surface. In an occasional sample the water at the bottom is as much as 50 percent more saline than the water at the surface, but typically the concentration difference between the surface and the bottom is only $5-10$ percent.

Although differences in concentration of salinity between the water in the right side, center, and left side of the river are observed, these differences are in general small and variable with respect to time and place. When and where these differences do occur, they are probably related to tributary discharge, water from fresh-water marshes, or discharge of industrial wastes.

\section{SALINITY AND FRESH-WATER DISCHARGE}

Large fresh-water flows in the estuary flush saline water seaward; conversely, low rates of iresh-water flow allow the sea water to encroach farther inland. For example, during July 1955, when the fresh-water discharge was one-fourth to one-sixth the mean annual discharge, the salinity at Chester increased throughout the month, owing to the encroachment of salt water (fig. 64). On August 10 the fresh-water discharge increased to more than double the mean annual discharge and saline water retreated seaward as shown by the marked decrease in chloride concentration. 


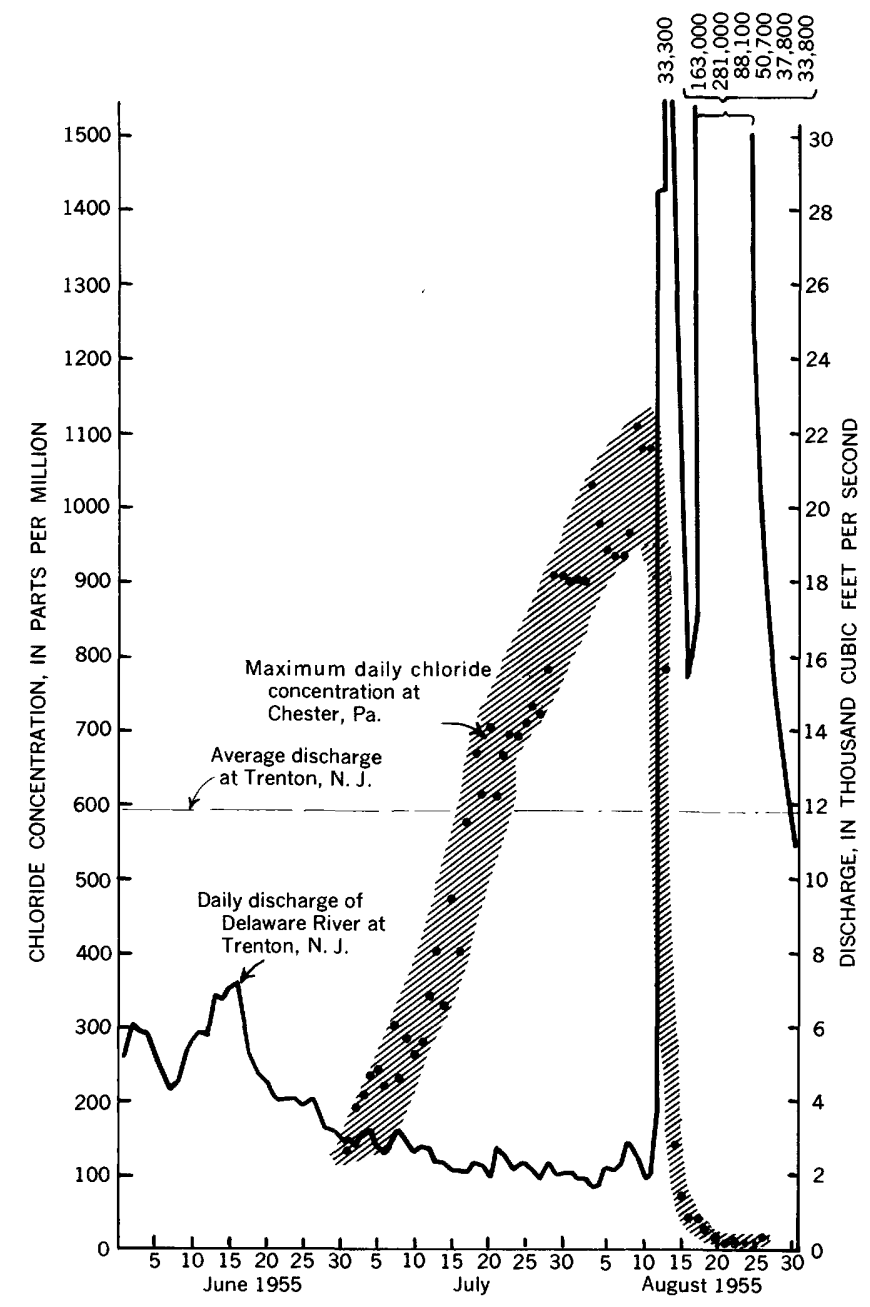

FIGURE 64.-Effect on maximum daily chloride concentration in Delaware River at Chester, Pa., of a period of low flow and a large increase in flow.

The effect on the salinity of an increased or decreased fresh-water flow depends largely upon the duration of the flow in question. The flushing time may be defined as the ratio of the daily inflow to the total volume of water in that part of the river. Thus, at the mean annual flow (11,810 cfs at Trenton, N.J.), the flushing time for the Delaware estuary from Trenton to Marcus Hook is 12-13 days; to Reedy Point about 23 days; and to the Capes more than 90 days. A river flow of double the mean annual flow (as often occurs in the spring) may be expected to reduce the salinity at Marcus Hook for 1 week and at Reedy Point for nearly 2 weeks. Low flows, such as occur in the later summer or fall, may permit the salinity of the river to increase for several months. After a change in rate of flow the salinity comes to a steady state near Philadelphia sooner than it does downstream. Furthermore, at times of high river flows the salinity changes are at first most evident upstream, but ultimately greatest downstream; when the flow is substantially reduced, the salinity increases first downstream but, after a steady state is reached, the percentage increase is greater upstream (fig. 65).

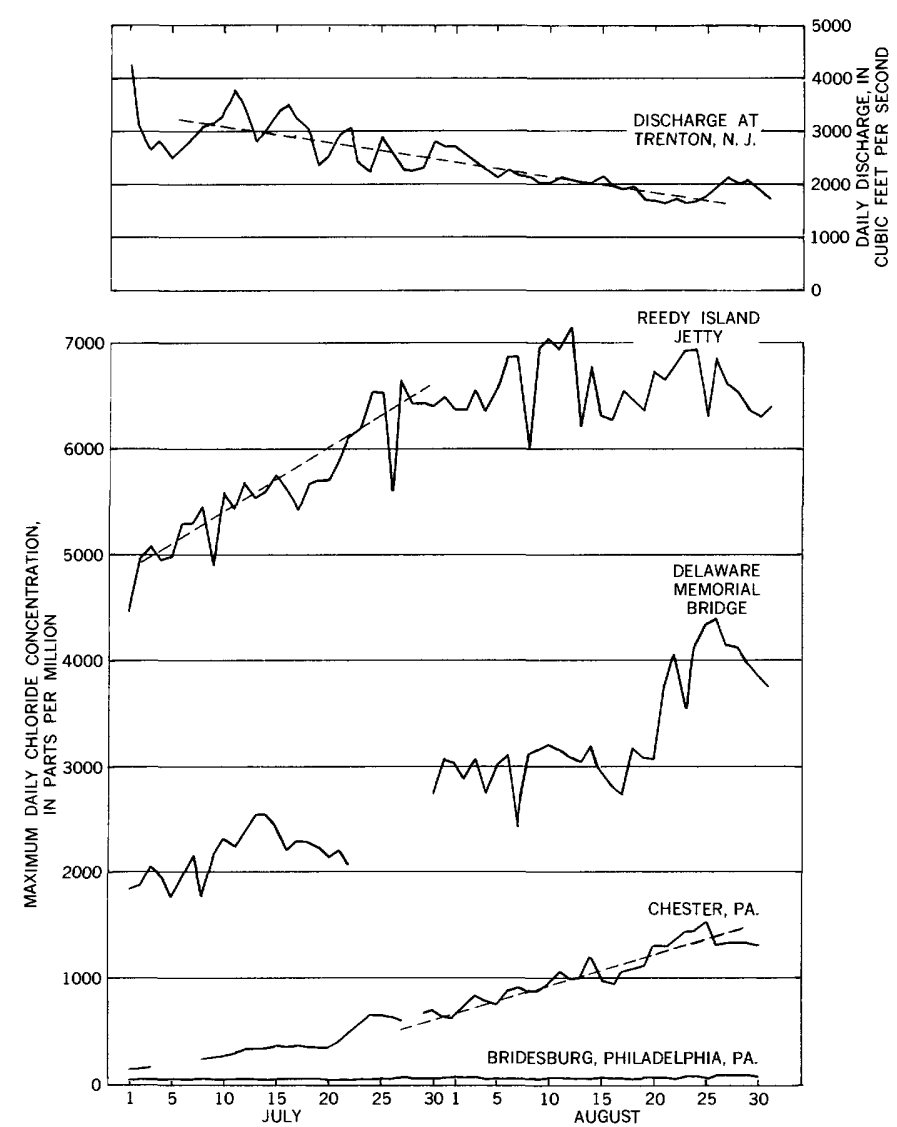

FIGURE 65.-Fresh-water discharge and salinity in Delaware River, July and A ugust 1957.

During July and August, 1957, the fresh-water discharge at Trenton, N.J., decreased from more than $3,000 \mathrm{cfs}$ to less than 2,000 cfs. During July the chloride concentration at Reedy Island Jetty increased from about $5,000 \mathrm{ppm}$ to $6,500 \mathrm{ppm}$ near the end of the month. Farther upriver at Chester, $\mathrm{Pa}$., the increase in chloride concentration was moderate in early July, but at an accelerated rate in late July and in August. In October and early November 1957 the discharge was low but increasing (fig. 66). During this period the chloride concentrations at Delaware Memorial Bridge and Chester decreased slightly. On November 16, 1957, the discharge increased to $6,000 \mathrm{cfs}$-more than double the discharge of the previous day. This discharge caused a decrease in chloride concentration which was greater, percentagewise, at Chester, Pa., than at Delaware Memorial Bridge and Reedy Island Jetty.

The flushing action of a large fresh-water discharge is also illustrated in table 36 . High streamflow accompanying the hurricane of August 12-13, 1955, 


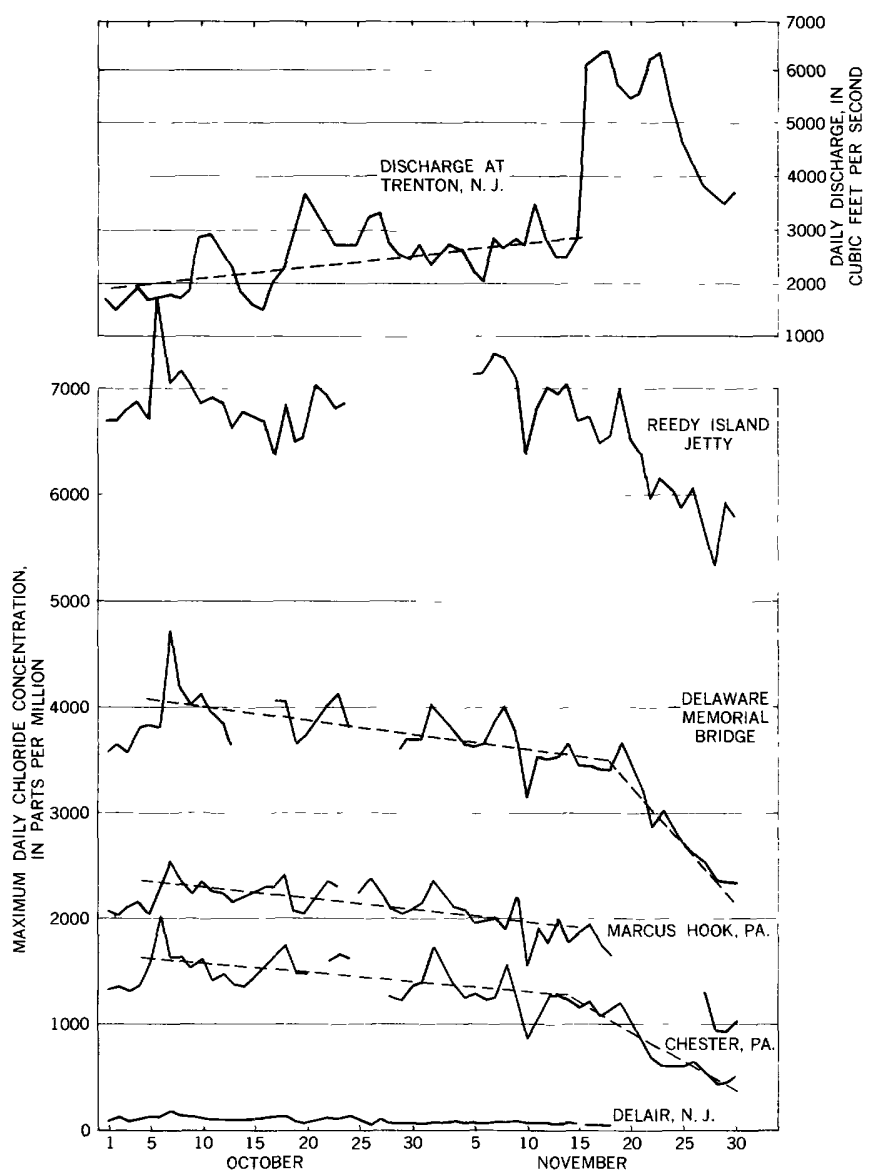

FiguRE 66.-Fresh-water discharge and salinity in Delaware River, October and November 1957 .

flushed the saline water seaward in the entire estuary, but the flushing action was more marked at Chester and Marcus Hook than upstream or downstream.

TABLE 36.-Effect of high streamflow on salinity in Delaware [Chloride concentrations, in parts per million, at high-water slack]

\begin{tabular}{|c|c|c|c|c|c|}
\hline Date & $\begin{array}{l}\text { Phila- } \\
\text { delphia }\end{array}$ & Chester & $\underset{\text { Mook }}{\text { Marcus }}$ & $\begin{array}{l}\text { Delaware Memo- } \\
\text { rial Bridge }\end{array}$ & Reedy Point \\
\hline Aug. 2.- & 75 & 900 & 1,200 & 2,650 (top) & 5,000 (top) \\
\hline Aug. 15. & 17 & 70 & 80 & $\begin{array}{l}3,100 \text { (bottom) } \\
460 \text { (top) }\end{array}$ & $\begin{array}{l}5, \text { bou (bottom) } \\
2,350 \text { (top) }\end{array}$ \\
\hline Aug. 30 & 6 & & 10 & & $\begin{array}{l}3,400 \text { (bottom) } \\
1,500 \text { (top) } \\
2,750 \text { (bottom) }\end{array}$ \\
\hline
\end{tabular}

SEASONAL VARIATION IN SALINITY

The monthly variation of fresh-water discharge in the Delaware River at Trenton, N.J., is indicated in figure 67. The highest flows usually occur in March and April and the lowest flows in August and September. In late summer there is less direct runoff to dilute the ground-water discharge (which has a relatively high concentration of dissolved solids) and the wastes that are discharged into the river; also, because of lower flows at this time, sea water encroaches farther upstream. The degree of salinity of the estuary therefore, usually correlates with the discharge of the river-greatest in August and September and least in March and April.

The release of water from upstream reservoirs to augment low flows may be expected to retard the summer encroachment of saline water to the extent that the daily flows increase from the releases.
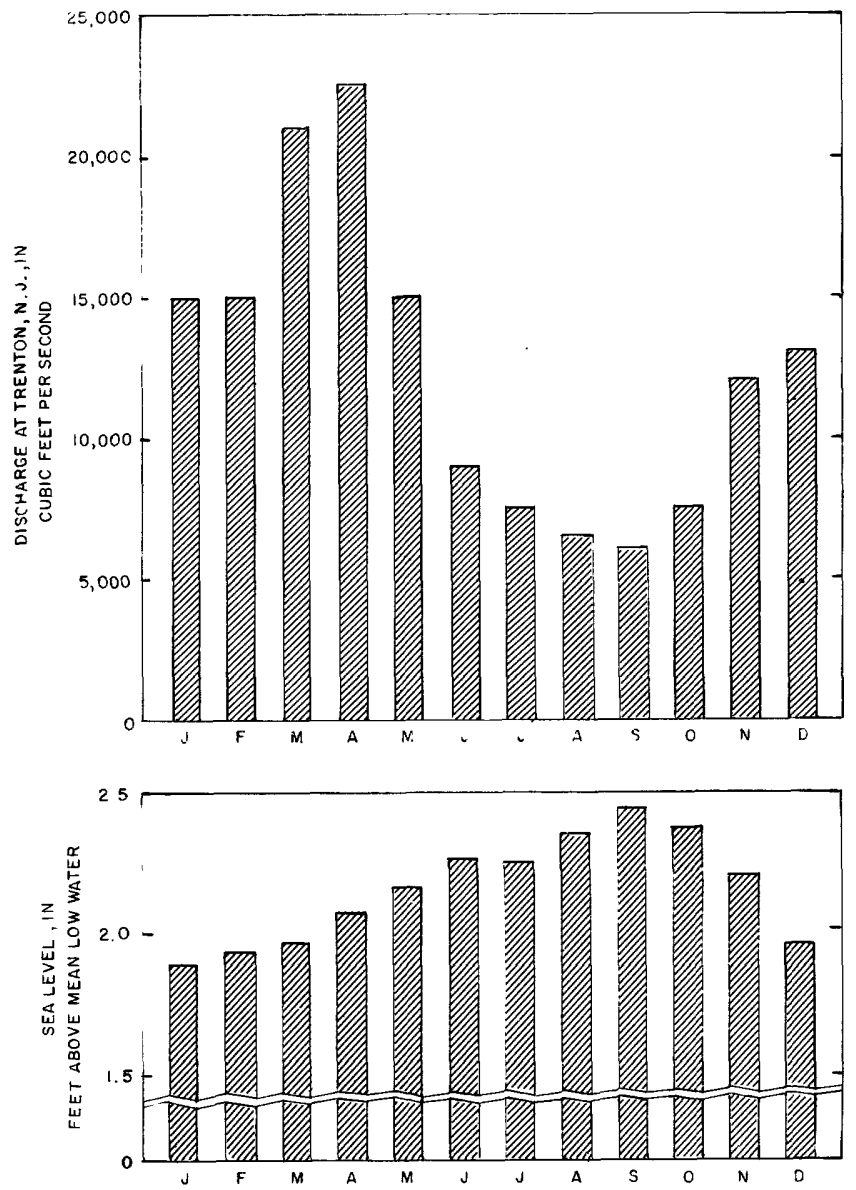

FrguRE 67.-Average monthly discharge of Delaware River at Trenton, N.J., and average monthly sea level at Atlantic City, N.J., 1923-65.

SALINITY AND SEA LEVEL

The salinity of the estuary is also influenced by variations in sea level. Water tends to seek its hydrostatic level; when sea level rises, the level of salt water in the estuary rises also and salt water forces its way further upstream along the gently sloping stream bed.

A slow worldwide rise in sea level may be taking place (Parker, 1955, p. 622). In this region, sea level has risen more than 6 inches since 1930, and, if this rate continues, sea level here will rise two feet in 100 years. Already Chester, Pa., has felt the effect of this 
TABLE 37.-Range in concentrations, (in parts per million) of mineral constituents in water of Delaware estuary

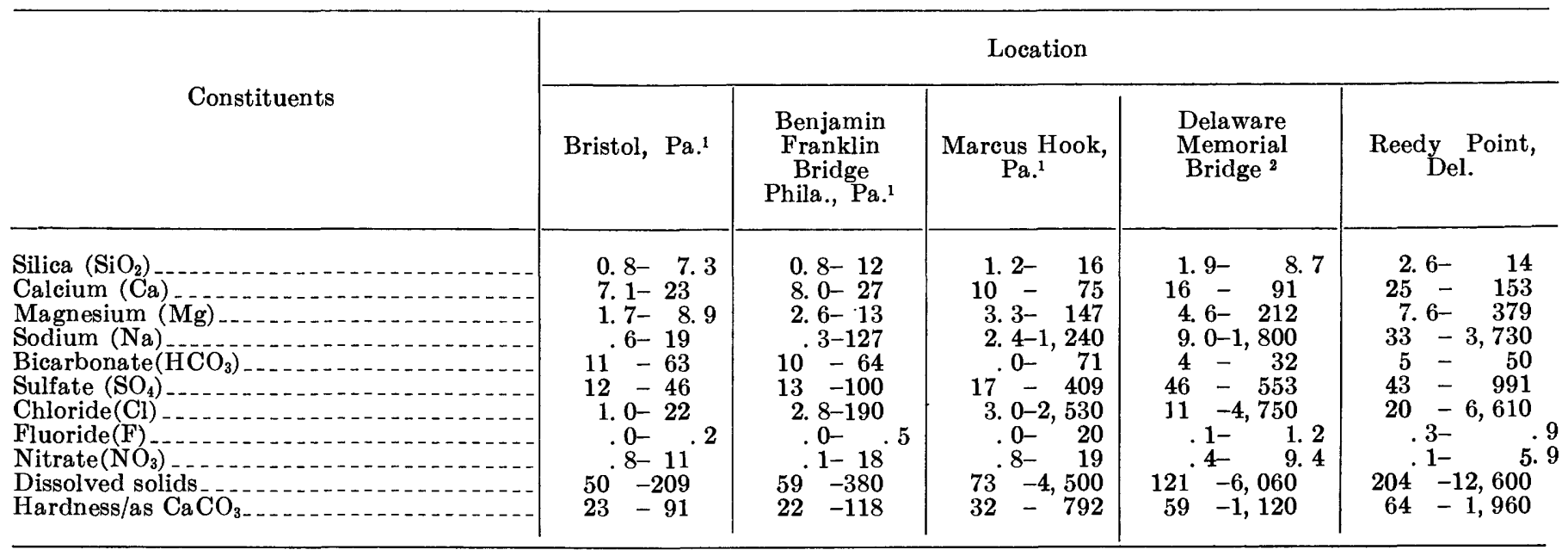

1 Based on once-a-month sampling, August 1949 to December 1957.

2 Based on 27 samples, July 1955 to May 1958.

3 Based on 35 samples, July 1955 to December 1957.

6-inch rise, for estuary water at Chester, usable for municipal supply until recently, is now too salty. If the rise continues, unabated, the salt front will advance farther and farther upstream and will eventually destroy more fresh-water supplies in the estuary and adjacent aquifers.

Sea level in this region also rises and falls in an annual cycle, as shown in figure 67 for Atlantic City, N.J. It is lowest in January and highest in September, the difference being about 0.5 foot. High sea level and low fresh-water discharge both favor sea-water encroachment, which consequently is often at maximum in September. The relatively high fresh-water discharge and low sea level during the first 3 or 4 months of the year cause the waters of the estuary to be freshest at that time. This seasonal fluctuation of sea level is more spectacular than the slow worldwide rise mentioned above but it is not nearly so harmful. The seasonal fluctuation is like a minor wave that accompanies a major flood wave and merely "goes along for the ride."

\section{RANGE IN CONCENTRATION OF CHEMICAL CONSTITUENTS}

As the fresh-water discharge changes from the high flows of winter and spring to the lower flows of summer and fall, and as other factors contribute to change in the salinity of the water, the general chemical quality of the water also changes. The extent of these variations is shown in table 37, in which the maximum and minimum concentrations of various constituents are summarized for five locations on the estuary.

The effects of discharge and sea level on salinity are shown by the following data compiled by Cohen $(1957$, p. 47$)$ in which specific conductance is used as a measure of salinity. All values shown are monthly averages.

\begin{tabular}{|c|c|c|c|}
\hline Month & $\begin{array}{c}\text { Fresh-water } \\
\text { discharge at } \\
\text { Trenton, } \\
\text { N.J. (efs) }\end{array}$ & $\begin{array}{l}\text { Sea level at } \\
\text { Atlantic } \\
\text { City, N.J., } \\
\text { (ft above } \\
\text { mean low } \\
\text { water) }\end{array}$ & $\begin{array}{l}\text { Specific } \\
\text { conductance } \\
\text { at Reeddy } \\
\text { Point, Del., } \\
\text { (micromhos } \\
\text { at } 25^{\circ} \mathrm{C} \text { ) }\end{array}$ \\
\hline October 1955 & $\begin{array}{l}28,700 \\
21,600\end{array}$ & $\begin{array}{r}2.73 \\
2.38\end{array}$ & $\begin{array}{l}5,910 \\
2,800\end{array}$ \\
\hline April 1956_. & $\begin{array}{l}31,000 \\
18,300\end{array}$ & $\begin{array}{l}2,00 \\
2.38 \\
2.06\end{array}$ & \\
\hline
\end{tabular}

'Even though discharges in October and April were nearly the same, the salinity was much greater in October because of the higher sea level (by $0.35 \mathrm{ft}$ ). With sea level identical in November and April, the salinity was greater in November because of the lower fresh-water discharge. The flow in November was slightly larger than in May, but the salinity was greater because of the higher sea level (by 0.32 foot). In spite of the still greater fresh-water discharge in October, the salinity was high because the sea level was high. ,

\section{SALINITY AND THE TIDES}

Sea level rises and falls twice daily in the Delaware estuary and produces two high tides and two low tides in each lunar day of 24 hours and 50 minutes. On the flood tides, salt water moves upstream; on the ebb tides it is flushed seaward. In the lower part of the Delaware estuary the concentration of dissolved solids varies during the day. The concentration is at its greatest just after high tide, when the water has stopped flowing upstream and is about to flow downstream. (high-water slack), and is at its lowest just after low tide when the current is about to change its direction 
from downstream to upstream. Figure 68 shows the tidal change in water-surface elevation and the concurrent change in salinity at Reedy Island Jetty in a 32-hour period.

Two high tides and three low tides are shown. Slack water, or time of no current, on this day at Reedy Island Jetty occurred about 3 hours after high tide and 3 hours after low tide. The changes shown in specific conductance by the lower curve are based on sampling each half hour. The maximums and minimums of specific conductance occur later than the maximums and minimums of the water surface and are probably at the times of actual slack water.

The influence of the tidal cycle on salinity changes can best be understood by considering the way in which the tides move salt water upstream. Fresh water flows downstream to the ocean, and salt water moves upstream against the fresh-water flow. The resulting gradation in chloride concentration ranges from a median of $5 \mathrm{ppm}$ at Trenton, above tidewater, to $19,000 \mathrm{ppm}$ in the undiluted ocean water at the Capes. Consider the estuary to be divided into longitudinal segments where the tide is high enough to reverse the flow. Each segment holds more water at high tide than at low tide. As the tide rises, the volume represented by the difference between low and high tide is filled by saltier water from the next downstream segment; the salinity increases at that location and reaches a maximum when the upstream tidal flow ceases at the slack following high water. As the tide ebbs, the water in the segment flows downstream and is replaced by fresher water from upstream. In this manner the river reaches its minimum salinity when the water ceases its downstream flow at low-water slack.

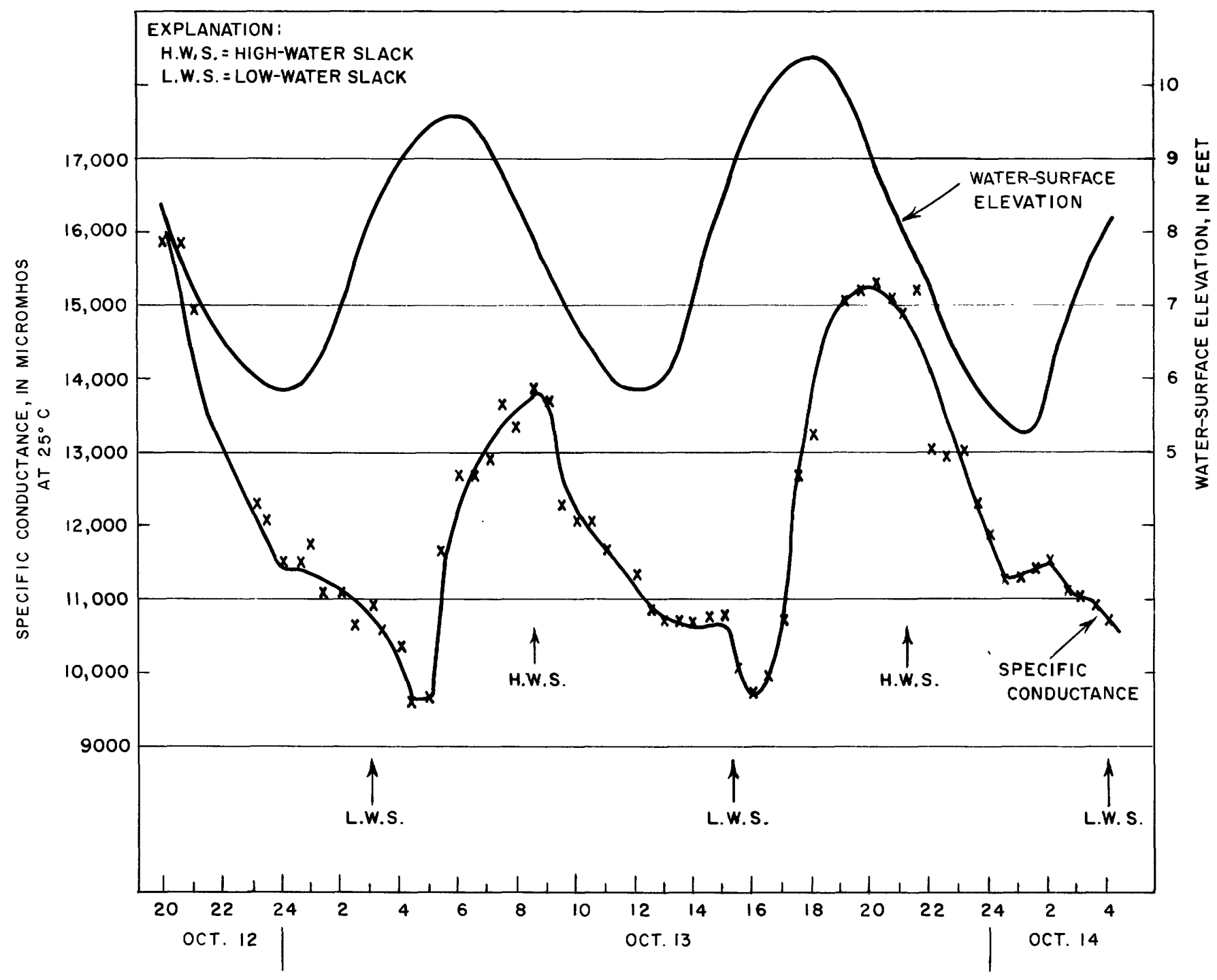

FIGURE 68.-Effect of tides on specific conductance at Reedy Island Jetty, October 1956. 
When the tidal range (the difference between the heights of high water and low water) is large, then the intertidal volume is a larger proportion of the total high-tide volume of the segment and the range of salinity is greatest.

In figure 68 , for example, the range of the morning tide was 3.8 feet and the maximum specific conductance 13,800 micromhos; the range of the afternoon tide was 4.6 feet and the maximum specific conductance 15,200 micromhos. The effect of the tidal range is further illustrated by the following examples for the Delaware River at Chester, Pa. (Keighton, 1954, p. 20).

Effect of tidal range on chloride concentration, Chester, Pa., 1949

\begin{tabular}{|c|c|c|c|}
\hline \multirow{2}{*}{ Date } & \multirow{2}{*}{$\begin{array}{l}\text { Range of } \\
\text { tide (ft) }\end{array}$} & \multicolumn{2}{|c|}{ Chloride (ppm) } \\
\hline & & Maximum & Average \\
\hline Aug. 6-7 & 6.6 & 358 & 142 \\
\hline Sept. 2-3.. & $\begin{array}{l}5.3 \\
5.7\end{array}$ & $\begin{array}{l}191 \\
817\end{array}$ & $\begin{array}{l}143 \\
434\end{array}$ \\
\hline Oct. 15 & $\begin{array}{l}4.7 \\
5.0\end{array}$ & $\begin{array}{r}555 \\
1,060\end{array}$ & $\begin{array}{l}430 \\
646\end{array}$ \\
\hline & 3.8 & 805 & 643 \\
\hline
\end{tabular}

In each of the three examples, the average chloride concentration is about the same for the two daily tides, but the maximum chloride concentration is greater following the tidal cycle with the greater range of tidal elevations. Although the daily variations in concentration are controlled by the tidal cycle, the average daily concentration is controlled by the average sea level and fresh-water discharge.

\section{SALINITY AND THE WINDS}

Strong winds, such as those that accompany a hurricane, may temporarily raise the level of water in the estuary, especially in its lower reaches. Hurricane winds in the northern hemisphere rotate counterclockwise around the eye of the hurricane, as shown in figure 69. As a hurricane moves northward along the Atlantic Coast, the wind direction along the coast changes. For example, long before the hurricane reaches the latitude of Delaware Bay (Delaware Bay in position $\mathrm{A}$ ), the onshore winds create high tides at the mouth of the bay. As the hurricane moves on northward, perhaps crossing the coast north of Delaware Bay (Delaware Bay in position B), offshore winds may then cause very low tides. If the hurricane path is inland, to the west of Delaware Bay (Delaware Bay in position $\mathrm{C}$ ), the hurricane winds have less effect on sea level.

In addition to the effect of onshore winds raising sea level and offshore winds lowering sea level, strong winds may also drive water into or out of the bay. For example, as the eye of the hurricane (fig. 69) moves

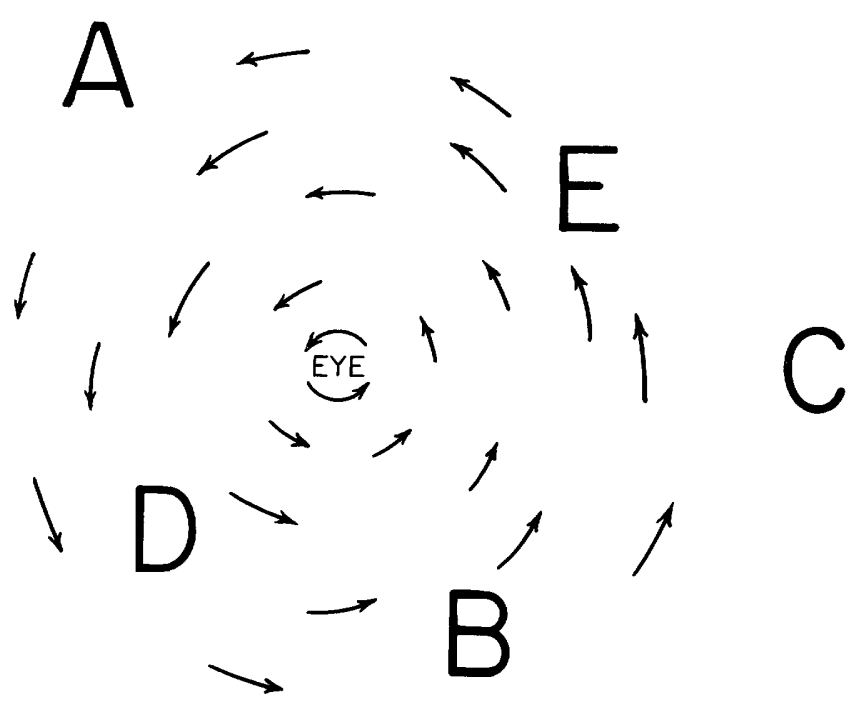

Figure 69.-Hurricane winds relative to position of entrance of Delaware Bay.

northward well to the east of the bay, the winds at the mouth of the bay change from northeast to north and northwest (position D); this change drives water out of the bay and tends to lower the water level. A hurricane on an inland path as it approaches the latitude of Delaware Bay (position E) would bring winds from the southeast that would drive water into the bay, and raise the water level. The effect of these and other factors on salinity in the Delaware estuary is shown by the following examples:

1. Hurricane Hazel, in October 1954, followed a path to the west of Delaware Bay. From October 14 to 15 , mean sea level at Atlantic City, N.J., not far from the mouth of the bay, increased by 1 foot. Winds from the south and southeast apparently drove water into the bay, for the mean river level at Philadelphia rose 2 feet. At Chester, Pa., the maximum daily chloride concentration increased from $1,030 \mathrm{ppm}$ on October 14 to $2,120 \mathrm{ppm}$ on October 15. Two days later, when the winds had subsided, both sea level and river level returned to normal and the chloride concentration at Chester decreased to $1,110 \mathrm{ppm}$, close to what it had been on October 14.

2. Hurricane Edna, in September of the same year, passed to the east of Delaware Bay. The east wind on September 10 raised mean sea level at Atlantic City 0.6 foot and raised the mean river level at Philadelphia 0.7 foot above the levels on the preceding day. On September 11, mean sea level increased another 0.4 foot, but the winds, by then from the northeast, apparently drove water out of the bay for the mean river level dropped 0.4 foot. At Chester the daily maximum 
chloride concentration rose from $1,050 \mathrm{ppm}$ on the 9 th to 1,300 and $1,340 \mathrm{ppm}$ on the 10 th and 11 th. On the 12th, after the hurricane had passed by, the chloride concentration fell to $1,100 \mathrm{ppm}$ and on the 13 th to $990 \mathrm{ppm}$.

3. Hurricanes are frequently accompanied by heavy rainfall in the Delaware River basin. The resulting fresh-water discharge, if large, may flush the saline water seaward. Hurricane Connie, in August 1955, like Hazel of the previous year, passed to the west of Delaware Bay. Winds at the mouth of the bay on August 12 and 13 were from the southeast. Mean sea level at Atlantic City rose 0.6 foot from August 11 to August 12, and an additional 0.6 foot on the 13th. The mean river level at Philadelphia rose also. However, heavy rain fell on the Delaware River basin on August 12 and 13, the discharge at Trenton increased from 2,120 cfs on August 11 to $3,840 \mathrm{cfs}$ on August 12 and 28,500 cfs on August 13. During August 11-15 the maximum daily chloride concentrations at Chester were $1,080,955,680,140$, and $70 \mathrm{ppm}$, respectively. Thus, in spite of the rise in sea level, the high streamflow resulting from the rain flushed the saline water seaward and decreased the salinity in the entire estuary (table 36).

\section{POLLUTION AND CHEMICAL QUALITY OF WATER}

The concentration and nature of the dissolved solids in the water of the Delaware estuary may also be affected by municipal and industrial wastes. For example, it is estimated that municipal sewage contributes less than $10 \mathrm{ppm}$ to the chloride concentration of the Delaware River at Marcus Hook when the river flow is approximately equal to the mean annual flow, and perhaps as much as $50 \mathrm{ppm}$ when the flow is onesixth as great, as it may be in August, "September, or October. Various wastes will also add dissolved minerals to the river water to an extent determined by their concentration and the quantity of the waste.

The quantities of wastes now being discharged are unlikely to make substantial or significant changes in the concentrations of dissolved mineral solids, except near the point of their introduction. At times, however, concentration changes may be significant although not substantial. For example, according to the newspapers of April 9, 1952, 5,350 pounds of acetone cyanhydrin, a poisonous chemical, was accidentally discharged to the river at Bristol on the preceding evening. If as estimated, the release required an hour, about 1 billion gallons of water flowed past the point of discharge and was available to dilute the poison. A concentration of $0.6 \mathrm{ppm}$ would result, which, although not large, is significant because of the poisonous nature of the compound.

There is always the possibility that accidental discharge of wastes will impair the chemical quality of the river water. In the event just cited the contaminated river water was unsafe for public supply. Industrial plants were closed to conserve the water already in the city reservoirs. Tidal action and streamflow eventually diluted the poisonous chemical, it was slowly decomposed by hydrolysis, and public water supplies were heavily chlorinated to oxidize the remaining traces. A parallel problem might arise from pollution by radioactive wastes, but if that happens chemical destruction of the impurity might be more difficult.

D. W. Pritchard (1954) has studied pollution in the Delaware River model at the Waterways Experiment Station of the Corps of Engineers at Vicksburg, Miss. In the model, pollution appears to move downstream more slowly than the net downstream movement of water. Owing to tidal action, the pollutant spreads longitudinally (along the channel axis) as it moves. At lower discharge rates, pollution travels more slowly downstream and spreads less in a longitudinal direction. Isolated and somewhat concentrated segments of the pollutant become trapped in shore indentures or behind structures' and feed out into the main stream. This temporary entrapment contributes to the longitudinal spreading of the pollution.

Although municipal and industrial wastes affect the mineral content of the river water, the organic material that these wastes contribute to the river is frequently of greater concern. Unlike most mineral substances, organic pollutants are often removed by natural purification processes through the agency of dissolved oxygen and bacteria.

Since August 1949 the city of Philadelphia, in cooperation with the U.S. Geological Survey, has made monthly determinations of dissolved oxygen (D.O.) and biochemical oxygen demand (B.O.D.) of the Delaware River water between Bristol and Marcus Hook, Pa. The dissolved oxygen is a measure of the oxygen available for destroying organic pollutants; the biochemical oxygen demand is a measure of the oxygen required to destroy the organic pollutants in the presence of bacteria.

In August, September, and October, the river water is relatively warm and dissolves less oxygen than when cold. Moreover, the biochemical processes proceed faster in warm water and demand oxygen at a greater rate. During these months the low flow of the river and the high temperature of the water result in less oxygen to consume the organic pollutants. Consequently, this season of the year is critical with respect to organic pollution in the river. 
In the table below information is given for samples from eight stations between Torresdale (Philadelphia) and Marcus Hook, Pa., as follows: (1) the percent of saturation with oxygen; (2) the percent of the samples that were less than 50 percent saturated; and (3) the river flow. In those years in which the average monthly river flow in August, September, and October was low, there were more samples with a low concentration of dissolved oxygen, and the average dissolved oxygen, expressed as percent of saturation, was low.

\begin{tabular}{|c|c|c|c|c|}
\hline \multirow[b]{2}{*}{ Year } & \multirow{2}{*}{$\begin{array}{c}\text { Average } \\
\text { dissolved } \\
\text { oxygen } \\
\text { percent of } \\
\text { saturation }\end{array}$} & \multirow{2}{*}{$\begin{array}{c}\text { Percent of } \\
\text { samples less } \\
\text { than } 50 \\
\text { percent } \\
\text { saturated }\end{array}$} & \multicolumn{2}{|c|}{ A verage river flow } \\
\hline & & & $\underset{\text { (mgd) }}{\text { Annual }}$ & $\begin{array}{l}\text { August to } \\
\text { October } \\
\text { (mgd) }\end{array}$ \\
\hline 1950 & $\begin{array}{l}45.9 \\
51.4 \\
55.2 \\
43.5 \\
48.3 \\
54.4 \\
52.0 \\
40.1\end{array}$ & $\begin{array}{l}48.6 \\
51.7 \\
34.3 \\
56.8 \\
47.8 \\
42.7 \\
45.3 \\
64.9\end{array}$ & $\begin{array}{r}8,659 \\
9,818 \\
13,470 \\
8,418 \\
5,984 \\
8,805 \\
7,997 \\
5,616\end{array}$ & $\begin{array}{r}2,403 \\
3,455 \\
4,306 \\
1,620 \\
1,672 \\
14,310 \\
3,270 \\
1,435\end{array}$ \\
\hline
\end{tabular}

PHYSICAL QUALITY

TEMPERATURE AND ITS VARIATION

Temperature readings of the river water were taken daily at several locations, usually between $7: 30$ and 9:30 a.m., and are summarized in table 38. For the 9 years of record of the Delaware River water at Trenton, the median temperature was $57^{\circ} \mathrm{F}, 10$ percent of the readings exceeded $76^{\circ} \mathrm{F}$, and 10 percent were lower than $38^{\circ} \mathrm{F}$. As compared with the Delaware at Trenton, the water of the Lehigh River at Catasauqua averaged about $4^{\circ} \mathrm{F}$ colder, that of the Schuylkill River at Pottstown was about $1^{\circ} \mathrm{F}$ colder, and that of the Schuylkill River at Philadelphia averaged about $1^{\circ} \mathrm{F}$ warmer-additionally it showed a greater temperaturefluctuation range.

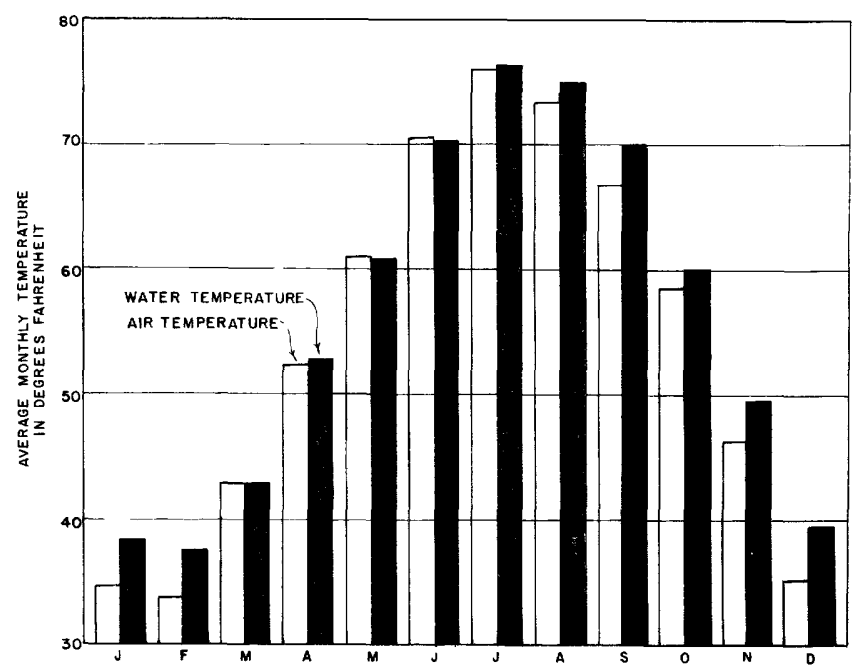

FiguRE 70.-Monthly variation in Delaware River water temperature and air temperature at Trenton, N.J., 1944-52.
The monthly variations in temperature are summarized for the Schuylkill River at Philadelphia in table 39 and for the Delaware River at Trenton in figure 70. The temperature of most surface waters of the basin is highest in July and August. The water temperature drops $2^{\circ}-6^{\circ} \mathrm{F}$ in September, then roughly $10^{\circ} \mathrm{F}$ a month until it becomes coldest in December, January, and February. It usually rises $4^{\circ}-12^{\circ} \mathrm{F}$ each month until July. The water temperature increases in the spring and decreases in the autumn at about the same rate as the air temperature. The mean monthly water temperature is nearly the same as the mean monthly air temperature from March through June, but $2^{\circ}-6^{\circ} \mathrm{F}$ warmer than the air temperature from July to February, for the water holds its heat longer than does the air. Because the lowest water temperature is limited by the freezing point and the air may cool below $32^{\circ} \mathrm{F}$, the temperature difference is greatest in December, January, and February.

An examination of the maximum and minimum temperatures each day for the Delaware River water at Trenton, N.J., shows that although the water temperature may vary as much as $12^{\circ} \mathrm{F}$ in a single day, the daily fluctuation is usually only $2^{\circ}-3^{\circ} \mathrm{F}$ from November to May, and rises to an average daily range of $8^{\circ} \mathrm{F}$ in July and August.

For the Delaware River from Trenton to Eddystone there is no evident temperature difference between the

TABLE 38.-Temperatures $\left({ }^{\circ} F\right)$ which were equaled or exceeded in percent of days shown

\begin{tabular}{|c|c|c|c|c|c|}
\hline \multirow[t]{2}{*}{ Station } & \multicolumn{5}{|c|}{$\begin{array}{l}\text { Temperatures }\left({ }^{\circ} \mathrm{F}\right) \text { equaled or } \\
\text { exceeded for indicated percent } \\
\text { of days }\end{array}$} \\
\hline & 10 & 25 & 50 & 75 & 90 \\
\hline $\begin{array}{l}\text { Lehigh River at Catasauqua, Pa., } 1945-52 \\
\text { Delaware River at Trenton, N.J., } 1945-56 \text {, exclud- }\end{array}$ & 73 & 66 & 52 & 39 & 34 \\
\hline $\begin{array}{l}\text { ing 1954-55 } \\
\text { Schuylkill River at Pottstown, Pa., 1945-50- } \\
\text { Schuylkill River at Philadelphia, Pa., 1946-52 }\end{array}$ & $\begin{array}{l}76 \\
76 \\
79\end{array}$ & $\begin{array}{l}71 \\
69 \\
73\end{array}$ & $\begin{array}{l}57 \\
56 \\
58\end{array}$ & $\begin{array}{l}42 \\
42 \\
42\end{array}$ & $\begin{array}{l}38 \\
36 \\
37\end{array}$ \\
\hline
\end{tabular}

TABLE 39.-Temperatures $\left({ }^{\circ} \mathrm{F}\right)$ which were equaled or exceeded in percent of days shown, by months, for Schuylkill River at Philadelphia, Pa., 1946-52

\begin{tabular}{|c|c|c|c|c|c|}
\hline \multirow[t]{2}{*}{ Month } & \multicolumn{5}{|c|}{$\begin{array}{l}\text { Temperatures }\left({ }^{\circ} \mathrm{F}\right) \text { equaled or } \\
\text { exceeded for indicated percent } \\
\text { of days }\end{array}$} \\
\hline & 10 & 25 & 50 & 75 & 90 \\
\hline $\begin{array}{l}\text { January } \\
\text { February } \\
\text { March } \\
\text { April } \\
\text { May } \\
\text { June } \\
\text { July } \\
\text { August } \\
\text { September } \\
\text { Ootober- } \\
\text { November- } \\
\text { December }\end{array}$ & $\begin{array}{l}42 \\
43 \\
50 \\
60 \\
69 \\
81 \\
83 \\
84 \\
78 \\
68 \\
61 \\
46\end{array}$ & $\begin{array}{l}40 \\
40 \\
47 \\
56 \\
66 \\
76 \\
82 \\
83 \\
76 \\
66 \\
56 \\
42\end{array}$ & $\begin{array}{l}38 \\
38 \\
43 \\
54 \\
63 \\
72 \\
80 \\
80 \\
74 \\
63 \\
52 \\
40\end{array}$ & $\begin{array}{l}35 \\
35 \\
40 \\
52 \\
59 \\
69 \\
77 \\
78 \\
71 \\
59 \\
47 \\
37\end{array}$ & $\begin{array}{l}34 \\
34 \\
38 \\
49 \\
57 \\
65 \\
75 \\
77 \\
68 \\
55 \\
44 \\
35\end{array}$ \\
\hline
\end{tabular}


right and left sides of the river. At Marcus Hook an apparent difference of about $1^{\circ} \mathrm{F}$ between the water on the Pennsylvania side and that on the New Jersey side may be a result of dissipation of heat to the water by industries in the Chester-Marcus Hook region. In this reach of the river there is more industrial development on the Pennsylvania side than on the New Jersey side.

\section{FLUVIAL SEDIMENT \\ SUSPENDED SEDIMENT}

James K. Culbertson (written communication, June 1957), and John W. Wark (written communication, July 1959), both of the U.S. Geological Survey, summarized the sedimentation data available for the Delaware River basin; much of the following section is based on information supplied by them.

All natural streams transport suspended sediment; the quantity, size and physical and chemical nature of the particles vary from time to time and place to place. Most of the sediment originates as the result of erosion but some comes from the activities of man in industry, mining, and agriculture. The quantity and nature of natural sediments are influenced by topography, precipitation, temperature, geology, soil conditions, and vegetative cover. Sediment is most effectively transported in narrow, steep channels in which running water flows turbulently. Where the flow is retarded or less turbulent, or the water temperature higher, the sediment has an opportunity to settle to the bottom. Reservoirs provide favorable conditions for sedimentation and may in time lose part or all of their storage capacity to settled solids; canals, navigation channels, and harbors may lose part or all of their effective depth and require dredging for maintenance of capacity.

In the construction of large reservoirs, provision is usually made for sediment storage in the reservoir below the outlets. In time these spaces fill with sediment, but the deposits of sediment are not confined to the lowest parts of the reservoir. The coarsest and heaviest materials settle out at the head of the reservoir, where the velocity of the stream first slackens, and some of the finer materials settle in the dead-storage space at the bottom of the reservoir. Consequently, the sediment occupies part of the original live-storage space as well as space reserved for sediment. Dredging of sediments from reservoirs has seldom been economically feasible, but in the future as reservoir sites become occupied and it is no longer possible to abandon silted up sites and move to new ones, this situation will likely change.

Suspended solids are often removed from streams by settling or desilting basins constructed for the purpose, such as those in the upper Schuylkill River, which remove culm and silt. Settling basins are also used for the clarification of domestic and industrial water supplies and sewage. For a number of reasons, it is important to know the sediment regimen of the stream: (1) to plan the location and design of reservoirs, (2) to determine the nature of treatment to make the water suitable for domestic or industrial use, (3) to aid in planning and operation of waterways and harbors, (4) to help evaluate effects of natural and cultural environments on rates of erosion; and (5) to aid in planning for the control of erosion.

The sediment concentration in streams of the Delaware River basin is less than that in many streams elsewhere in the United States. For example, during the water years 1950-57 the suspended-sediment concentration of the Delaware River at Trenton, N.J., was equal to or less than $5 \mathrm{ppm} 30$ percent of the time and equal to or less than $25 \mathrm{ppm} 81$ percent of the time. Nevertheless, large quantities of sediment are transported because of the high runoff in the basin.

The combined average annual suspended-sediment load during the water years 1954-57 for Delaware River at Trenton, N.J., Schuylkill River at Manayunk, Philadelphia, Pa., and Brandywine Creek at Wilmington, Del., was approximately 1.4 million tons, or 158 tons per square mile. If the same load per square mile applies to the remainder of the basin, a total of approximately 2 million tons of sediment left the basin annually. The annual load at Trenton ranged from 59 tons per square mile in 1957 to 342 tons per square mile in 1955 . The high load in 1955 was the result of heavy rains and floods accompanying Hurricane Diane in August.

The daily loads at this station have ranged from less than half a ton per day to 1 million tons per day (August 20, 1955). During the 2-day period, August 19-20, 1955 the Delaware River carried about 1.8 million tons of sediment, or approximately 22 percent of the total load for the 8-year period, 1950-57. The daily load at Trenton exceeded 180 tons 50 percent of the time and 900 tons only 5 percent of the time. Very large proportions of the total erosion and resulting sediment load are produced by a few intense storms, and a high 
annual sediment load may occur in a year of low runoff. Nevertheless, there is a general tendency for annual sediment load to increase with annual runoff.
In the following table 40 the annual sediment loads at six stations are shown; the annual runoff at one station is included for comparison.

TABLE 40.-Annual sediment load at six selected stations and annual runoff at one station for comparison

\begin{tabular}{|c|c|c|c|c|c|c|c|c|c|c|c|}
\hline \multirow{2}{*}{$\begin{array}{l}\text { Index } \\
\text { No. } \\
\text { (pl. 10) }\end{array}$} & \multirow{2}{*}{ Station } & \multicolumn{10}{|c|}{ Water year } \\
\hline & & 1948 & 1949 & 1950 & 1951 & 1952 & 1953 & 1954 & 1955 & 1956 & 1957 \\
\hline 155 & Lehigh River at Walnutport, $\mathrm{Pa}_{-}$ & & 249 & & 576 & 292 & & & & & \\
\hline $\begin{array}{l}181 \\
203\end{array}$ & $\begin{array}{l}\text { Delaware River at Trenton, N.J } \\
\text { Sehuylkill River at Berne. }\end{array}$ & 3220 & 1150 & 64.4 & $\begin{array}{l}217 \\
211\end{array}$ & $\begin{array}{l}261 \\
268\end{array}$ & 163 & $\begin{array}{l}63.5 \\
46.4\end{array}$ & $\begin{array}{l}342 \\
228\end{array}$ & $\begin{aligned} 113 \\
46.1\end{aligned}$ & $\begin{array}{l}59 \\
63.7\end{array}$ \\
\hline 208 & Perkiomen Creek at Graterford, $\mathbf{P a}$ & & 1,150 & 147 & 211 & 283 & & & & & \\
\hline \multicolumn{12}{|c|}{ Annual runoff, in inches } \\
\hline 206 & Schuylkill River at Pottstown, $\mathbf{P a}_{\ldots}$ & 24.63 & 21.10 & 19.24 & 27.95 & 43.32 & 31.84 & 16.51 & 18.83 & 22.61 & 19.71 \\
\hline
\end{tabular}

For the water years, 1950-51, the yield for the Schuylkill River at Manayunk, Philadelphia, Pa., was more than five times as great as the yield for the Delaware River at Trenton. This difference reflects chiefly the influence of the extensive mining operations in the upper Schuylkill River basin. After 1951 the sediment yields at Manayunk and at Berne decreased sharply as compared to that of the Delaware River at Trenton. This decrease is a result of the construction and operation of several desilting basins as a part of the Schuylkill River Restoration project, the prohibition of discharge of coal wastes to the stream, and the removal of culm and silt by dredging. The high sediment yields of 1955 are associated with the floods in the late summer of that year.

Part of the decrease in load for the Lehigh River for 1952, a year of high runoff, probably resulted from decreased mining in the region, as well as from the control of discharge of sediment to the river.

Working with data for the Brandywine Creek at Wilmington, Del., Guy (1957) found, after adjustment for rainfall intensity and season, a lower sediment yield for the period 1952 to 1955 than for the period 1947 to 1951. In 1952, the Soil Conservation Service, in cooperation with the Brandywine Valley Association, made recommendations for controlling erosion and alleviating floods in Brandywine Creek basin. Apparently the decrease in sediment yield is related to the improvement of land use and the consequent reduction in erosion.

Records of suspended-sediment concentrations in parts per million and loads of suspended sediment in tons per day for streams in the Delaware River basin are given in U.S. Geological Survey Water-Supply Papers 1132, 1162, 1186, 1197, 1250, and 1290 for the water years 1943 through 1953. Records are available for most of these years for Schuylkill River at Berne,
Pa., Schuylkill River at Manayunk (Philadelphia), Pa., Lehigb River at Walnutport, Pa., Delaware River at Trenton, N.J., and Brandywine Creek at Wilmington, Del. Samples were taken intermittently or daily for shorter periods at a number of other localities. ${ }^{9}$

\section{TRANSPORT OF STREAMBED MATERIAL}

The detrital materials washed from steep slopes by heavy rains and eroded from the beds and banks of streams in flood include not only the finer clay and silt, but also sand, gravel, cobbles, and boulders. Only the finer materials are transported by the streams as suspended sediment. The coarser materials that are transported move as bed load in the stream by rolling, sliding, or skipping.

The movement of detritus too heavy to be carried in suspension is especially evident after floods. Such evidence is provided by: (1) migration of gravel bars, (2) scour of channels in old bars, and (3) deposition of detritals from distant sources. Few satisfactory estimates of the magnitude of bed load have been made, but judgment of experienced observers indicates that the bed load would probably account for about 10 percent of the total load in the Delaware River basin.

\section{USE OF WATER}

\section{WITHDRAWAL OF WATER IN THE DELAWARE RIVER BASIN}

By John C. Kammerer

The people of the Delaware River basin withdraw from its surface- and ground-water resources approximately 6.1 bgd excluding use for generating hydroelectric power. About 95 percent of this amount is taken from streams, lakes, and reservoirs, and the

${ }^{\ominus}$ Sediment data are on file at the U.S. Geological Survey's Sedimentation Laboratory, Harrisburg, Pa. 
remainder comes from wells and springs. All but 1 or 2 percent of the water withdrawn in the basin is used for municipal and industrial purposes (fig. 71).

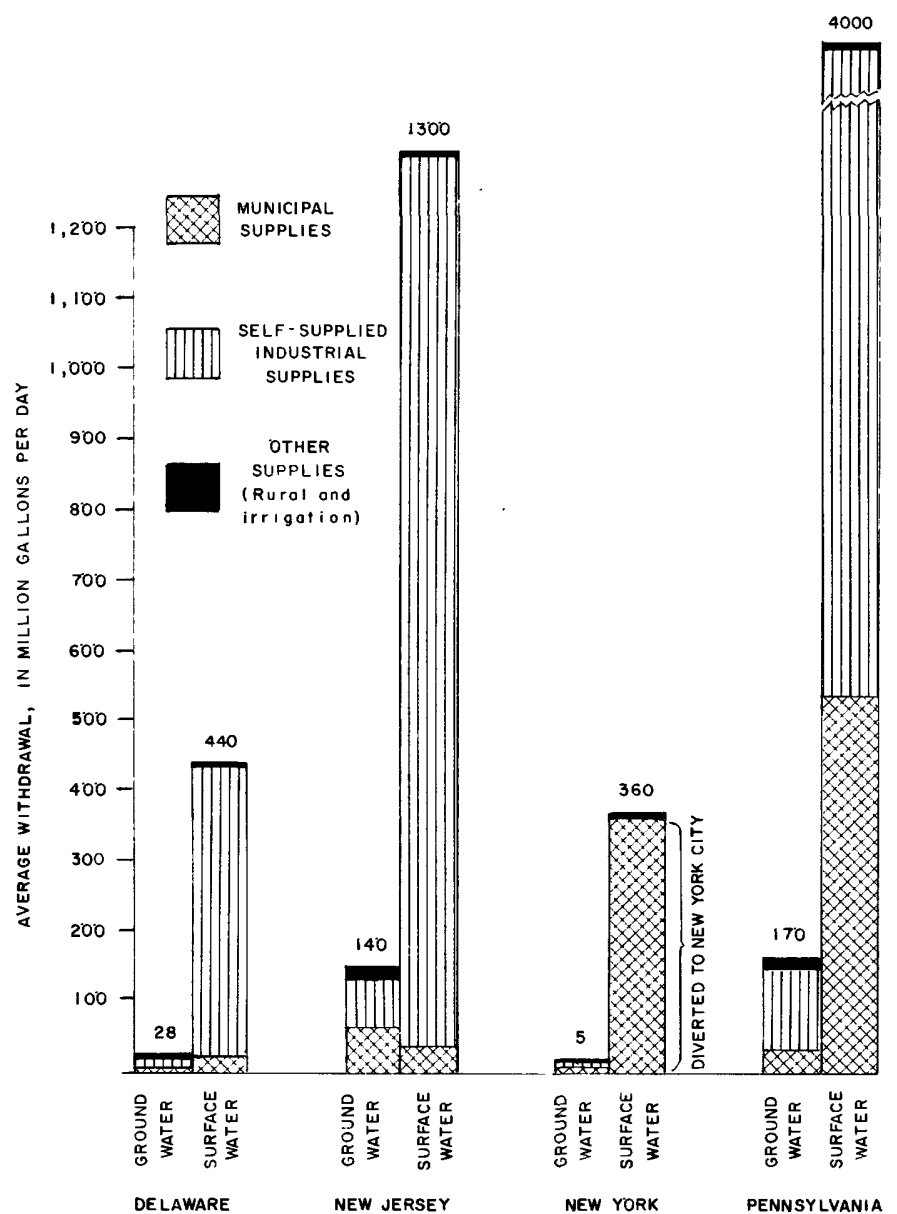

FIGURE 71.-Withdrawal of water in Delaware River basin by type of source and type of supply

An additional amount, averaging $1.6 \mathrm{bgd}$ in 1955 , is used for the generation of hydroelectric power. The use of water for this purpose does not alter either the quantity or quality of the water.

Most of the water used in the basin is fresh, and can be used for drinking or most other purposes after a minimum amount of treatment. After the water has been used, it is usually discharged into the nearest stream and is therefore available for reuse by other municipalities and industries downstream. The only large withdrawals of saline or brackish water in the basin are from the Delaware estuary below Philadelphia. Almost all this water is returned to the river after use. Therefore, many of the data on withdrawals cited in this section include a significant but undetermined amount of reuse of the same water.

The region of greatest water withdrawal in the basin coincides with the most heavily populated region and is centered at Philadelphia. The 11 counties bordering or near the estuary between Trenton, N.J., and Wilmington, Del., account for about 70 percent of the water withdrawn from the basin but have an area of only 30 percent of the total. Large amounts of water are also withdrawn along the Lehigh and Schuylkill Rivers.

The amount of water used in the basin (not including water for hydroelectric plants) is between 1,000 and 1,100 gpcd, based on an average withdrawal of $6.1 \mathrm{bgd}$ and an estimated population of between 5.7 and 6 million. This per capita use is a little higher than the average for the 31 Eastern States, but it is only about one third as much as the per capita withdrawal in the 17 Western States. The greater part of the per capita use of about 1,000 gpd in the Delaware River basin is withdrawn by large water-using industries. The per capita use of municipal supplies is between 60 and 220 gpd in the larger communities of the basin, and all but $50-60 \mathrm{gpd}$ of this amount is delivered to commerce and industry by these municipal water systems.

The large water-using industries are steam-electric power and manufacturing industries, such as steel, petroleum, and chemicals. About 87 percent of the water used in the basin is self-supplied by industry. Of this industrial withdrawal which amounts to about $5.3 \mathrm{bgd}$, approximately $5.1 \mathrm{bgd}$ is from streams and $180 \mathrm{mgd}$ from wells. All but 5-10 percent of this water is returned to the basin after use.

The major diversions from the basin are for the public supply of New York City and for municipal and industrial supplies in or near Middlesex County, N.J. In 1955, 350 mgd was diverted from the upper Delaware River basin to the lower Hudson River basin for the use of New York City, and about $38 \mathrm{mgd}$ was diverted from the basin in Mercer County, N.J., through the Delaware and Raritan Canal. Since 1951, the Chester Municipal Authority has been diverting water from the Susquehanna River basin (Octoraro Creek) into the Delaware River basin for the municipal supply of Chester. This addition to the water supply averaged about $13 \mathrm{mgd}$ in 1955 .

A large amount of water-use information on the Delaware River basin has been collected by various organizations and agencies during the past 10 years. Much of this information, including a classification of type of source and type of supply, was summarized by Kammerer (1957); his report was based in large part on information and estimates prepared by field offices of the Geological Survey. During 1957 and 1958, as contributions to the Corps of Engineers' survey of the water resources of the Delaware River basin, the Public Health Service compiled additional data on municipal and industrial use of water, and the Soil 
Conservation Service gathered information on water for irrigation and other rural use. As a result of exchange of water-use information among these agencies and the Geological Survey, a revised table of wateruse data for 1955 (table 41) has been prepared. Addi- tional data on withdrawals of ground water in the Coastal Plain parts of the Delaware River basin were collected by Geological Survey personnel making ground-water investigations in those States. These data are summarized in figure 72 and table 42.

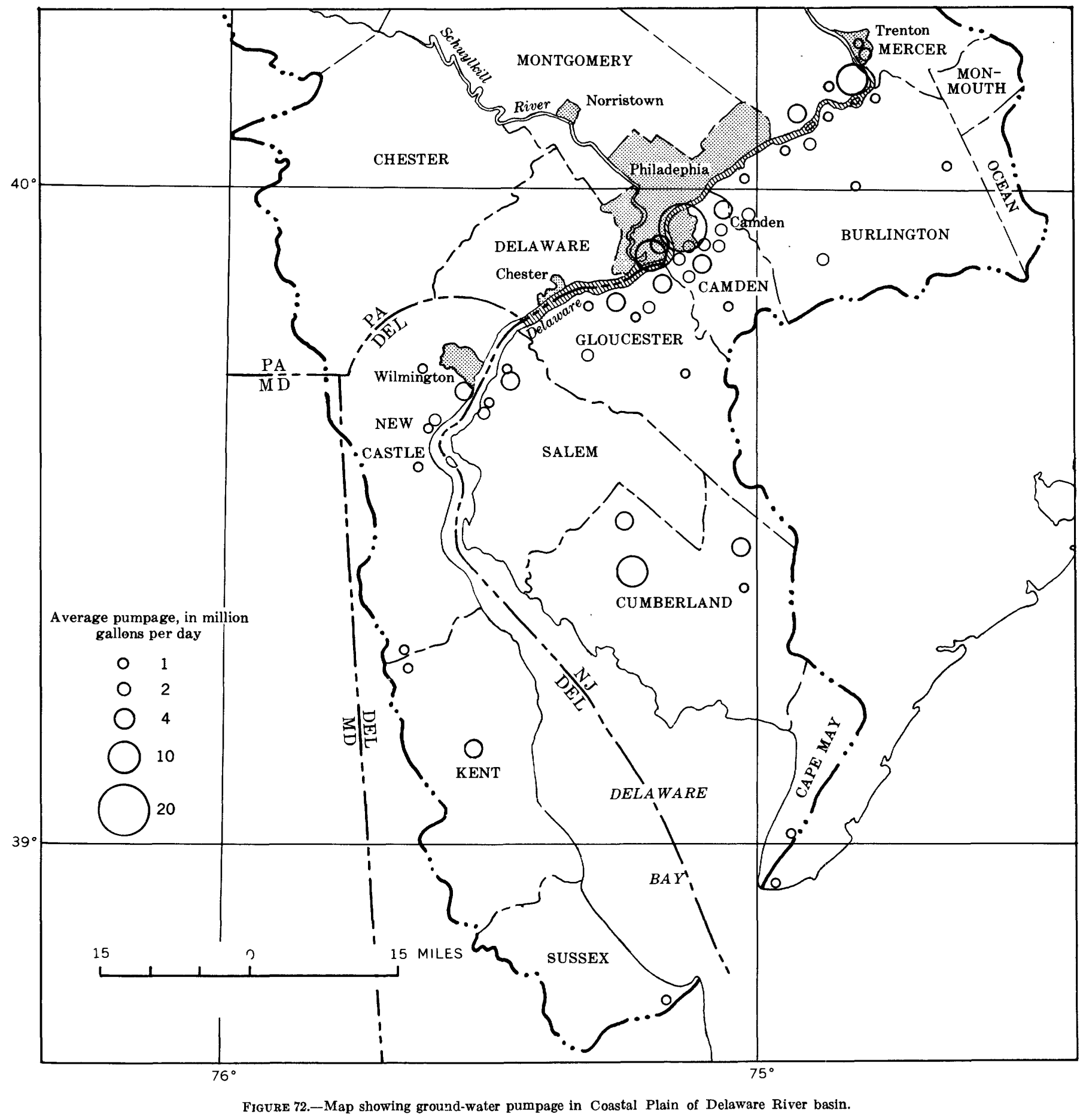


TABLE 41.-Withdrawal of water in Delaware River basin by State parts of basin, 1955

[Source of data: Modified from Kammerer (1957, p. 9). Most revisions based on preliminary data for 1955 obtained in water-use studies made by U.S. Public Service (irrigation supplies). All data rounded to two significant figures]

\begin{tabular}{|c|c|c|c|}
\hline Type of supply & $\begin{array}{c}\text { Ground } \\
\text { water } \\
(\mathrm{mgd})\end{array}$ & $\begin{array}{c}\text { Surface } \\
\text { water } \\
\text { (mgd) }\end{array}$ & $\begin{array}{l}\text { Total } \\
\text { (mgd) }\end{array}$ \\
\hline \multicolumn{4}{|l|}{ Delaware } \\
\hline $\begin{array}{l}\text { Municipal } \\
\text { Self-supplied industrial } \\
\text { Irrigation } \\
\text { Rural (excludes irrigation) }\end{array}$ & $\begin{array}{r}10 \\
14 \\
1 \\
3\end{array}$ & $\begin{array}{r}27 \\
410 \\
0 \\
1\end{array}$ & $\begin{array}{r}37 \\
430 \\
1 \\
4\end{array}$ \\
\hline Total & 28 & 440 & 470 \\
\hline \multicolumn{4}{|l|}{ New Jersey } \\
\hline $\begin{array}{l}\text { Municipal } \\
\text { Self-supplied industrial } \\
\text { Irrigation } \\
\text { Rural (excludes irrigation) }\end{array}$ & $\begin{array}{r}64 \\
61 \\
5 \\
10\end{array}$ & $\begin{array}{r}138 \\
1,300 \\
5 \\
1\end{array}$ & $\begin{array}{r}100 \\
1,400 \\
10 \\
11\end{array}$ \\
\hline Total & 140 & 1,300 & 1,500 \\
\hline
\end{tabular}

New York

\begin{tabular}{|c|c|c|c|}
\hline $\begin{array}{l}\text { Municipal. } \\
\text { Self-supplied industrial. } \\
\text { Irrigation } \\
\text { Rural (excludes irrigation) }\end{array}$ & $\begin{array}{l}3 \\
0 \\
0 \\
\mathbf{2}\end{array}$ & $\begin{array}{l}27 \\
1 \\
0 \\
1\end{array}$ & $\begin{array}{r}10 \\
1 \\
0 \\
3\end{array}$ \\
\hline Total. & 5 & 9 & 14 \\
\hline
\end{tabular}

Pennsylvania

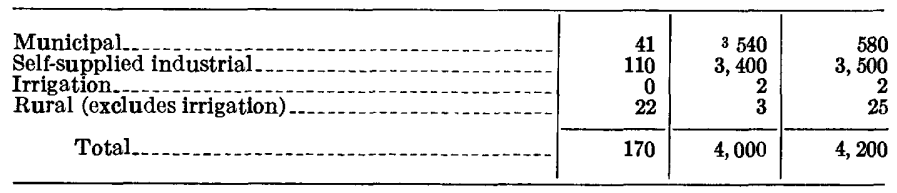

Totals of type of supplies

\begin{tabular}{|c|c|c|c|}
\hline $\begin{array}{l}\text { Municipal } \\
\text { Self-supplied industrial } \\
\text { Irrigation } \\
\text { Rural (excludes irrigation) }\end{array}$ & $\begin{array}{r}120 \\
180 \\
6 \\
37\end{array}$ & $\begin{array}{r}610 \\
5,100 \\
7 \\
6\end{array}$ & $\begin{array}{r}730 \\
5,300 \\
13 \\
43\end{array}$ \\
\hline Total (excludes hydroelectric power) & 340 & 5,800 & 6,100 \\
\hline Hydroelectric power... & $\mathbf{0}$ & 1,600 & 1,600 \\
\hline
\end{tabular}

1 Excluding diversion from the basin through the Delaware and Raritan Canal for use by municipalities and industries outside the basin, a diversion that totals $38 \mathrm{mgd}$.

2 Excluding $350 \mathrm{mgd}$ diverted from Delaware River basin to Hudson River basin for part of the municipal water supply of New York City.

${ }^{3}$ Including diversions from Octoraro Creek in Susquehanna River basin, $13 \mathrm{mgd}$ for municipal supply of Chester, Pa. (Chester Municipal Authority), and $20 \mathrm{mgd}$ for Philadelphia Municipal supply.

TERMINOLOGY, UNITS, AND SOURCES OF INFORMATION

The data in table 41 and in most of the text, are for 1955. Other years, mainly 1954, are identified in the heading of each of the other tables. All data are average for the year indicated, unless otherwise described. The principal sources of information used in preparation of this section are listed below.
Principal references on water-use statistics, 1949-57, by type of supply and State

Municipal and industrial:

Basinwide:

Not subdivided: MacKichan, 1955 data (1957).

Subdivided by State: Kammerer, 1955 data (1957).

Subdivided by county: Barksdale and others, 1954 data on ground water (1958) ; Barksdale and Graham, 1951-52 data on ground water (1952).

Delaware:

Not subdivided: MacKichan, 1955 data $^{2}$ (1957)

Subdivided by county or city: Delaware Water Resources Study Committee, 1954 data (1955); Marine and Rasmussen, 1953-54 data, mainly on ground water (1955).

Northern part: Rasmussen and others, 1955 data (1957).

New Jersey:

Not subdivided: MacKichan, 1955 data $^{2}$ (1957).

Subdivided by county or city: Tippetts and others, 1954-55 data (1955).

Lower basin part: Friel, 1952 data (1954).

New York:

Not subdivided: MacKichan, 1955 data $^{2}$ (1957).

Pennsylvania:

Not subdivided: MacKichan, 1955 data $^{2}$ (1957).

Subdivided by county: Mangan and Graham, 1951 data (1953).

Lower basin part: Interstate Commission on the Delaware River Basin, 1954 data (1955).

Municipal supplies only:

Basinwide:

Subdivided by city: U.S Public Health Service, 1956 data (1957), and similar reports for preceding years; Picton, 1953 data (1954); Malcolm Pirnie Engineers and others, 1948-49 data (1950).

New York:

Subdivided by city: New York State Department of Health, 1954 data- (1954).

Delaware, New Jersey, New York, Pennsylvania:

Not subdivided: U.S. Federal Power Commission, 1954 data on fuel-electric power (1957); U.S. Bureau of the Census, 1954 data on manufacturing industries (1957a); and 1954 data on mineral industries (1957b).

Pennsylvania:

Part of lower basin: Pennsylvania Water Resources Committee, 1952 data (1953).

1 Information on irrigation and rural supplies is also given in cited publications by Barksdale and Graham (1952); Barksdale and others (1958); Kammerer (1957); MacKichan (1951); Marine and Rasmussen (1955); and Rasmussen, Groot, and others (1957).

2 Data for 1950, by each State as a whole, are given in MacKichan (1951).

The classification of types of supplies is:

1. Municipal. Publicly or privately owned water system established mainly to serve a city, town, or residential development, but also usually supplying some of the water required by local commerce and industry. 
2. Self-supplied industrial. Water system established by an industry for its own use (water withdrawn by hydroelectric power plants not included in this study).

3. Irrigation: Water supplied to crops by a system of sprinklers or ditches.

4. Rural: Water for rural home, farm (other than for irrigation), lawn-watering and stock-watering purposes, and not obtained from a municipal system.

The words "withdrawal," "intake," and "use" (when not otherwise identified) refer to water taken from its source by pumping or diversion for one of the types of supplies described above. Most of the water is returned to the same or a different source of water soon after use, and this return water is identified by the words "discharge" or "discharged" in tables 44 and 45.

Consumptive use is the quantity of water prevented from returning to a water source by evaporation, by transpiration from vegetation, or by incorporation into food products, industrial products or solidified wastes. However, in any evaluation of the water resources of a particular basin, diversion of water from that basin is equivalent to consumptive use because none of the water is returned to the basin. Discharge of used water to the ocean or bay may also be considered as equivalent to consumptive use because such water is no longer usable for most purposes. Water discharged to brackish water, as in the Delaware estuary between Philadelphia, Pa., and Wilmington, Del., is unusable for many purposes but still usable for others, hence that part that is equivalent to consumptive use is indefinite.
The statistics in most of the tables in this section have been rounded to two or three significant figures. Use of water for hydroelectric power is omitted from this section except in table 41.

\section{SOURCES OF WATER}

By far the largest withdrawals of water in the basin are from streams; in fact, more than two-thirds of the water withdrawn in 1955 was from the Delaware, Schuylkill, and Lehigh Rivers, exclusive of all other tributaries. Inasmuch as most of the water withdrawn was soon returned to these same rivers, there was a large amount of water reused as it flowed downstream. The largest present use of Delaware River water is from the estuary between Trenton and Wilmington, of Schuylkill River water from Reading south to the mouth of the river, and of Lehigh River water in the AllentownBethlehem-Easton region.

More ground water is withdrawn from the unconsolidated deposits of the Coastal Plain than from the consolidated rocks of the Appalachian Highlands, and the wells of largest yield tap the sand and gravel of the Coastal Plain.

At present the largest ground-water withdrawals in the Coastal Plain in the Delaware River basin are in Camden, Cumberland, Burlington, and Gloucester Counties, N.J., New Castle County, Del., and Bucks and Philadelphia Counties, $\mathrm{Pa}$. The geologic formations from which most of this water is pumped are the Magothy and Raritan formations (nonmarine sediments of Cretaceous age), the Quaternary deposits, and the Cohansey sand (table 42).

TABLE 42.-Withdrawal of ground water in Coastal Plain of Delaware River basin, by geologic source and type of supply for each county, 1956-57

[From W. C. Rasmussen, written communications, 1958. All data rounded to two significant figures in million gallons per day]

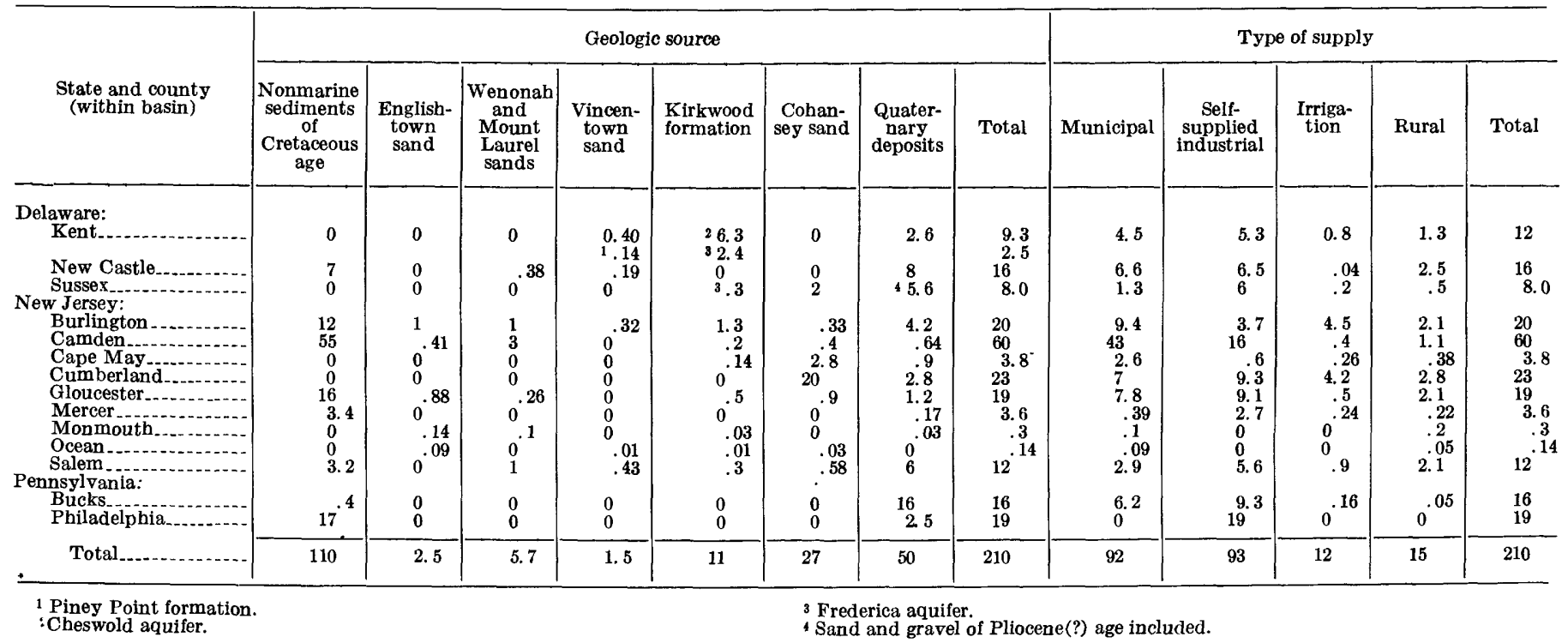


TABLE 43.- Source and type of withdrawal by large municipal water systems serving areas within Delaware River basin, 1955 [U.S. Public Health Service (1956) and other sources]

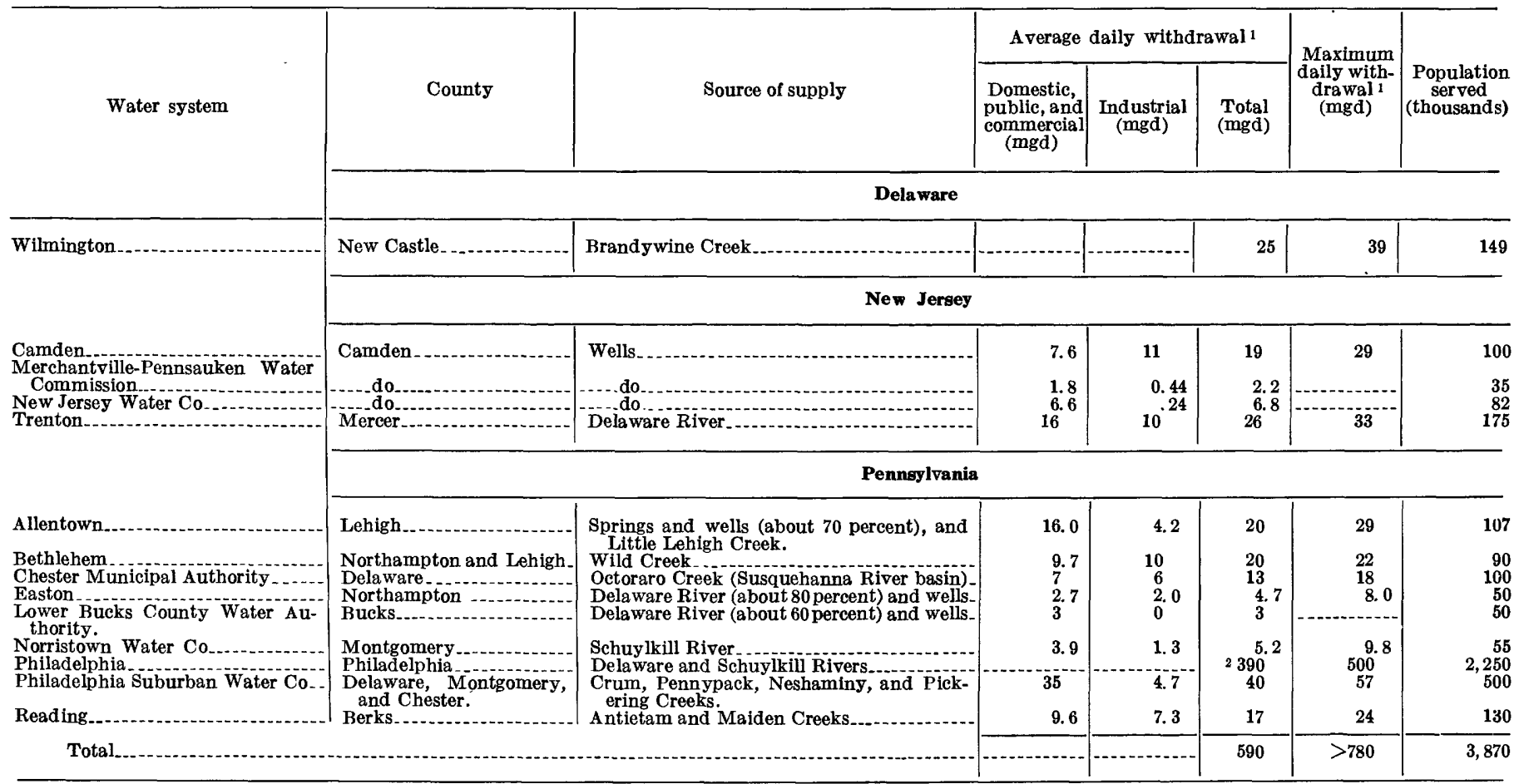

1 Data rounded to 2 significant figures.

2370 mgd treated.

TYPES OF SUPPLIES

MUNICIPAL SUPPLIES

The withdrawal of water in 1955 for municipal supplies averaged $730 \mathrm{mgd}$, including $13 \mathrm{mgd}$ transported into the basin from Octoraro Creek (Susquehanna River basin) for Chester, Pa., and excluding $350 \mathrm{mgd}$ diverted from the basin for New York City and $38 \mathrm{mgd}$ diverted through the Delaware and Raritan Canal to New Jersey cities and industries. Of more than 200 municipal systems in the basin, the 14 largest ones used 590 of the $730 \mathrm{mgd}$ withdrawn, and served 3.9 million people and a part of the local commerce and industry at a per capita rate of about $150 \mathrm{gpd}$ (table 43). Probably about one-third of this amount was for residential use. The Philadelphia municipal water system is by far the largest municipal water system within the basin in terms of population served and water delivered to home, commerce, and industry. Trends in daily, monthly, and annual water use by the Philadelphia system are given in table 44.

\section{INDUSTRIAL SUPPLIES}

Industry is the big water user in the Delaware River basin and in the entire service area, it mainly draws water from its own private systems, but also uses much of the water distributed by municipal systems. Inasmuch as the streams are the largest readily available water sources in the basin, the principal concentrations

\begin{tabular}{|c|c|c|c|c|c|c|}
\hline \multirow{2}{*}{ Year } & \multirow{2}{*}{$\begin{array}{l}\text { Population } \\
\text { (millions) }\end{array}$} & \multicolumn{4}{|c|}{ Daily use of treated water (mgd) } & \multirow{2}{*}{$\begin{array}{l}\text { A verage } \\
\text { daily use } \\
\text { of raw wa } \\
\text { ter (mgd) }\end{array}$} \\
\hline & & A verage & Maximum & January & July & \\
\hline 1946. & & 335 & & & & 362 \\
\hline & & $\begin{array}{l}353 \\
358\end{array}$ & . & $\begin{array}{l}343 \\
354\end{array}$ & $\begin{array}{l}364 \\
382\end{array}$ & \\
\hline $\begin{array}{l}1948 . \\
1949 .\end{array}$ & $\ldots$ & $\begin{array}{l}358 \\
351\end{array}$ & (n) & $\begin{array}{l}354 \\
323\end{array}-x-10$ & 387 & - \\
\hline $\begin{array}{l}1950- \\
1950-\end{array}$ & 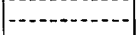 & 341 & 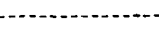 & 328 & 358 & . \\
\hline & n & $\begin{array}{l}348 \\
355\end{array}-120$ & (n) & $\begin{array}{l}334 \\
347\end{array}-10$ & $\begin{array}{l}365 \\
396\end{array}$ & $\cdots$ \\
\hline & & 370 & & 34 & 415 & -1 \\
\hline & 2.15 & $\begin{array}{l}368 \\
370\end{array}$ & $483(\mathrm{Ju}-2-190$ & 360 & 410 & 388 \\
\hline & $\begin{array}{l}2.16 \\
2.17\end{array}$ & $\begin{array}{l}370 \\
352\end{array}-10$ & 423 (Aug. 1 & $\begin{array}{l}360 \\
361\end{array}$ & 420 & 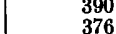 \\
\hline & 2.18 & 352 & 456 (June 18) & 346 & 394 & \\
\hline
\end{tabular}

of large water-using industries are along the main rivers, in and near the larger cities. Northampton and Carbon Counties, Pa., are the northern limits of most of the industrial as well as municipal use of water; Salem County, N.J., and New Castle, Del., are the southern limits, except for some small ground-water supplies.

The major use of water by industry is for cooling, including air conditioning; a small proportion of the water is used for processing, boiler feed, sanitation, and drinking. The largest water users are fuel-electric power plants. In 1954, 15 of these plants withdrew nearly 2.9 bgd in the basin, almost all from privately 
owned water systems on the Delaware, Schuylkill, and Lehigh Rivers. The withdrawal, more than 99 percent for cooling of condensers, was at a rate between 40 and 135 gallons per kwhr (kilowatthour), and practically all the water was returned to the rivers after use (table 45).
The other largest water-using industries in the basin are steel, petroleum, chemicals, and paper. Statistics on industrial water use by purpose, source, or site are given in table 46. More than 95 percent of the water used by all manufacturing establishments is withdrawn by only 3 percent of these establishments.

TABLE 45.-Withdrawal, discharge, and evaporation of water by steam-electric generating plants, Delaware River basin, by counties, 1954 [Source of data: U.S. Federal Power Commission (1957) and original data on which that report was based. $L=$ less than 0.05]

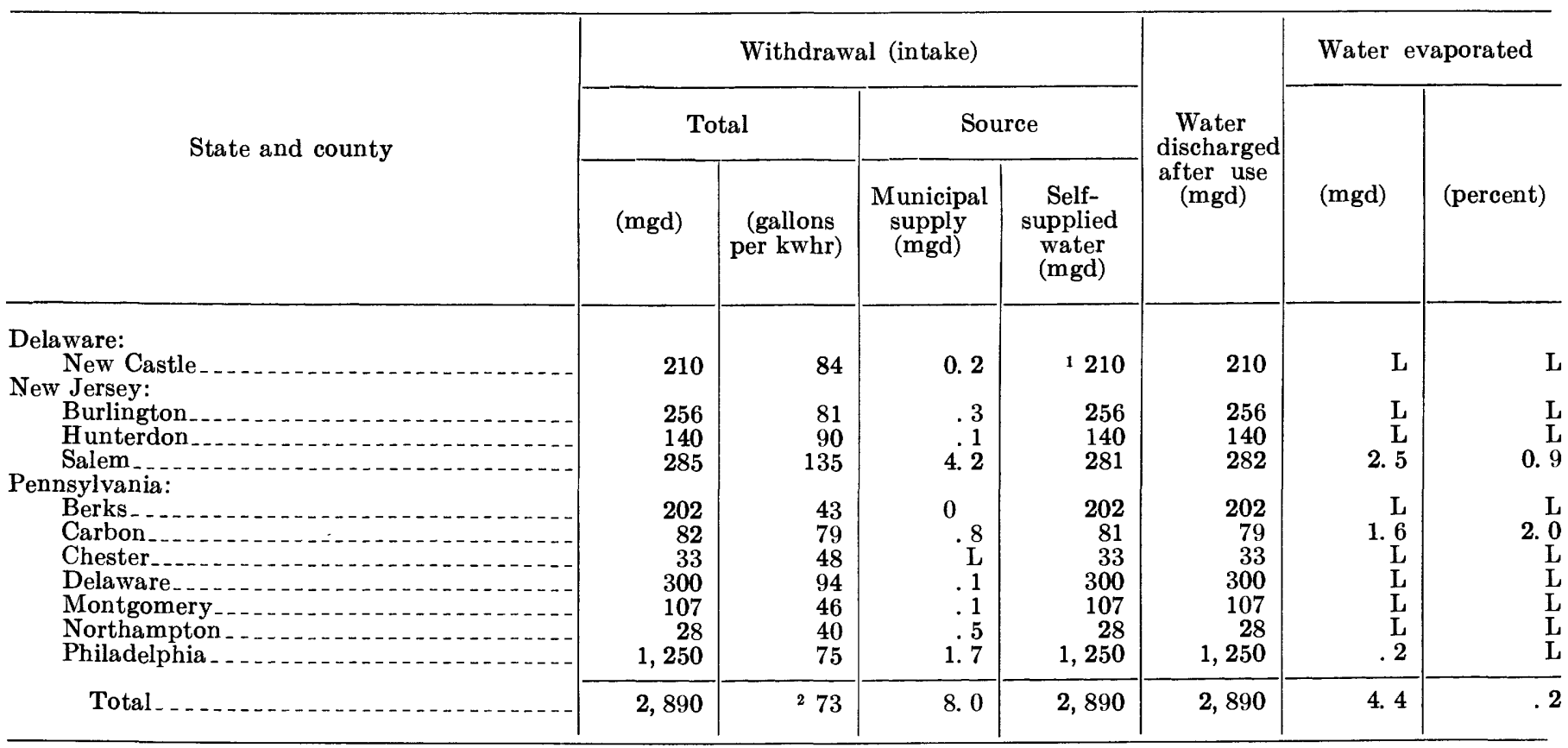

1 Saline water (dissolved-solids concentration more than $1,000 \mathrm{ppm}$ )

2 Average.

TABLE 46.-Withdrawal, discharge, and recirculation of water by manufacturing industries in Delaware River basin, by selected counties, 1954

[Source of data: U.S. Bureau of the Census (1957a, p. 209-42, 209-43). Data represent manufacturing establishments where average w ater withdrawal (intake) during 1954 was $0.055 \mathrm{mgd}$ ( 20 million gallons per year) or more; withdrawal is from municipal and self-supplied sources combined]

\begin{tabular}{|c|c|c|c|c|c|c|c|c|c|c|c|}
\hline \multirow{3}{*}{ State and county } & \multirow{3}{*}{$\begin{array}{c}\text { Number } \\
\text { of } \\
\text { establish- } \\
\text { ments }\end{array}$} & \multicolumn{5}{|c|}{ Withdrawal source } & \multicolumn{2}{|c|}{ Purpose } & \multirow{3}{*}{$\begin{array}{l}\text { A verage } \\
\text { discharge } \\
\text { of water } \\
\text { after use } \\
\text { (mgd) }\end{array}$} & \multirow{3}{*}{$\begin{array}{l}\text { Water con- } \\
\text { sumed in } \\
\text { process or } \\
\text { by evapo- } \\
\text { ration } \\
\text { (percent) }\end{array}$} & \multirow{3}{*}{$\begin{array}{l}\text { Water con- } \\
\text { served by } \\
\text { reuse or } \\
\text { recircula- } \\
\text { tion }^{3} \text { (mgd) }\end{array}$} \\
\hline & & \multirow{2}{*}{$\underset{\text { supply }}{\text { Municipal }}$} & \multicolumn{3}{|c|}{ Self-supplied } & \multirow{2}{*}{$\underset{(\mathrm{mgd})}{\text { Total }}{ }^{2}$} & \multirow{2}{*}{$\begin{array}{l}\text { Process } \\
\text { (mgd) }\end{array}$} & \multirow{2}{*}{$\begin{array}{l}\text { Cooling } \\
\text { and air } \\
\text { condi- } \\
\text { tioning } \\
\text { (mgd) }\end{array}$} & & & \\
\hline & & & $\begin{array}{l}\text { Ground } \\
\text { water } \\
\text { (mgd) }\end{array}$ & $\begin{array}{l}\text { Surface } \\
\text { water } \\
\text { (mgd) }\end{array}$ & $\begin{array}{l}\text { Saline } \\
\text { water } 1 \\
\text { (mgd) }\end{array}$ & & & & & & \\
\hline $\begin{array}{l}\text { Delaware: } \\
\text { New Castle... } \\
\text { Sussex }\end{array}$ & & & 0 & 19 \\
\hline $\begin{array}{l}\text { New Jersey: } \\
\text { Camden }\end{array}$ & & & & 30 & & 81 & & 00 & & & \\
\hline Gamden & $\begin{array}{r}32 \\
7\end{array}$ & 14 & 11 & $\begin{array}{l}36 \\
14\end{array}$ & 8.2 & $\begin{array}{l}69 \\
41\end{array}$ & $\stackrel{19}{2,7}$ & $\begin{array}{l}19 \\
5,5\end{array}$ & $\begin{array}{l}63 \\
38\end{array}$ & 9 & $\begin{array}{r}8 \\
90\end{array}$ \\
\hline $\begin{array}{l}\text { Salem } \\
\text { Pennsvlynig. }\end{array}$ & 8 & & 2.7 & 8.2 & 74 & 85 & 5.5 & $77^{\circ}$ & 85 & 0 & 3 \\
\hline $\begin{array}{r}\text { Pennsylvania: } \\
\text { Bucks..... }\end{array}$ & & & 8.2 & 208 & & 219 & & 203 & 216 & 1 & 52 \\
\hline Chester................... & 13 & 2.7 & 2.7 & 60 & & 66 & 8.2 & $\begin{array}{r}200 \\
49\end{array}$ & 63 & 5 & 47 \\
\hline Delaware & 34 & 8.2 & & 318 & 2.7 & 328 & 16 & 164 & 315 & 4 & $\begin{array}{r}249 \\
38\end{array}$ \\
\hline $\begin{array}{l}\text { Montgomery } \\
\text { Northampton }\end{array}$ & $\begin{array}{l}37 \\
30\end{array}$ & $\begin{array}{l}8.2 \\
8.2\end{array}$ & 8.2 & $\begin{array}{r}69 \\
211\end{array}$ & - & 225 & $\begin{array}{l}16 \\
11\end{array}$ & $\begin{array}{r}05 \\
164\end{array}$ & 211 & $\stackrel{4}{6}$ & $\begin{array}{l}38 \\
74\end{array}$ \\
\hline Philadelphia & 131 & 52 & 11 & 192 & 19 & 274 & 36 & 186 & 266 & 4 & 461 \\
\hline Total & 360 & 135 & 60 & 1,190 & 134 & 1,520 & 169 & 1,000 & 1,470 & ${ }^{4} 3$ & 1,040 \\
\hline Total for Delaware and IIudson region ${ }^{5}$ & 1,286 & 362 & 211 & 1,590 & 830 & 2,990 & 507 & 1,970 & 2,820 & ${ }^{4} 6$ & 2,580 \\
\hline
\end{tabular}

1 Dissolved-solids concentration more than 1,000 ppm

Total includes water for boiler feed, sanitary service, and other purposes.

3 A mount of additional water which would have been required had there been no reuse or recirculation of water.

5 Census area, roughly consisting of the Delaware and Hudson River basins plus the area between the two. 


\section{IRRIGATION AND RURAL SUPPLIES}

The withdrawal of water for irrigation in 1955 averaged $13 \mathrm{mgd}$, and for rural uses other than irrigation averaged an additional $43 \mathrm{mgd}$ (table 41 ). The wells and other sources of water used for one or both these purposes are scattered throughout the basin, as contrasted with the areal concentration of water use by city and industry. Because the need for water for these purposes is so widespread and the quantity required at any given place is usually fairly small, a large part of the irrigation and rural supplies come from wells and springs.

Rural withdrawals of water (except for irrigation) are mainly for domestic purposes, stock watering, and lawn watering. The amount used is about the same from year to year, except in extremely dry or wet years, and much of the water is returned to the ground or stream after use.

The use of water for irrigation is generally small in this region, but it is significant for three reasons: (1) The actual rate of use during a growing season of 3 months would be $52 \mathrm{mgd}$ instead of a 12-month average of $13 \mathrm{mgd}$; (2) a large part, perhaps $90-95$ percent, is consumptively used, and is therefore not available for reuse; and (3) the irrigation season is also the season of minimum streamflow and maximum water use for other purposes, and the different users may be competing for the same supply.

Within recent years, there has been an increasing use of water for irrigation in the Eastern States, especially by portable sprinkler systems. The U.S. Bureau of the Census (1956a, p. 282-283; 1956b, p. 60) reported 32,500 acres under irrigation in 1954 in Burlington, Camden, Cumberland, Gloucester, and Salem Counties, N.J., and 4,300 acres in Kent and New Castle Counties, Del. These acreages represented increases of 110 percent and 1,000 percent, respectively, of acreages irrigated in these two areas in 1949.

CONSUMPTIVE USE, REUSE, AND AVERAGE USE

Generally, consumptively used water is lost to further use for water supply because it has either returned to the atmosphere or has become part of a product or solidified waste. As described in preceding parts of this section, less than 10 percent of municipal and industrial supplies are consumptively used (tables 45 and 46), whereas from 90 to 95 percent of the water used for irrigation in this region may be consumed by evaporation and transpiration.

The consumptive use of water in the Delaware River basin in 1955 may be estimated if it is assumed that:
(1) 5 percent of the water withdrawn for municipal and rural use was consumptively used, (2) 3 percent of water withdrawn for industry was so consumed, and (3) 90 percent of that for irrigation was consumed. Water-use figures given in table 41 indicate that consumptive use was:

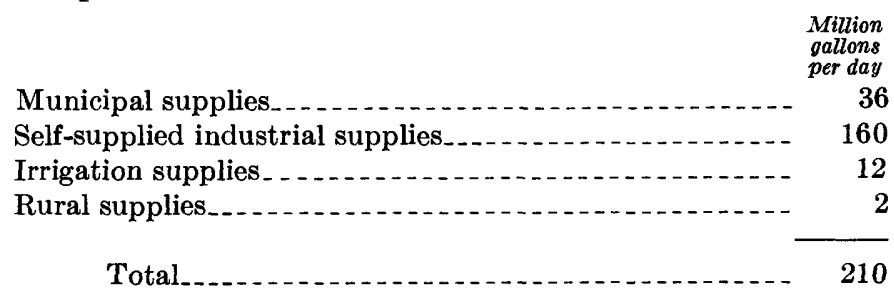

But, in addition to these in-basin consumptive uses, $350 \mathrm{mgd}$ was diverted to New York City and $38 \mathrm{mgd}$ was diverted to use in New Jersey via the Delaware and Raritan Canal. Although this total of $388 \mathrm{mgd}$ (rounded to $390 \mathrm{mgd}$ ) is not necessarily consumptively used at its final places of use, as far as the Delaware basin is concerned the use is consumptive - the water is never again available for reuse in the Delaware basin.

Thus the total consumptive use of Delaware River basin water, in 1955 , was $600 \mathrm{mgd}(210+390)$.

Downstream municipalities and industries reuse a substantial (but unknown) amount of the same water previously used and returned to the stream by upstream municipalities or industries. Even within a single industrial plant water may be used over and over again. Table 46 (last column) shows that if this type of reuse had not occurred, an additional $1.04 \mathrm{bgd}$ would have been required in 1954 by manufacturing industries in 11 counties in the basin.

Most data in this section are expressed as average use for the year. Summer withdrawals are at a considerably higher rate than the annual average because of less efficient cooling with higher temperature water and also because of higher rates of water use for air conditioning, lawn watering, and irrigation. Water use from a municipal system on a maximum-use day may be as much as three times the use on an average day, and the maximum hourly use rate may be as much as 10 times the average daily rate (Henderson, 1956, p. 363 ; Finch, 1956; and Hatcher, 1956).

If it is assumed that a maximum-day consumptive use of 200 percent of the 1955 average daily rate of consumptive use for municipal, rural, and irrigation supplies, and 110 percent for industrial supplies, then the maximum-day consumptive use and average outof-basin diversions, which are equivalent to consumptive use, can be computed as: 


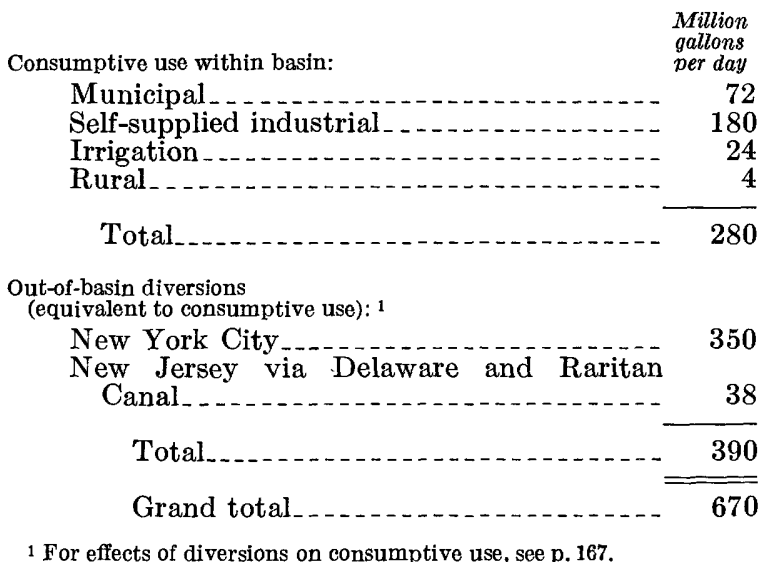

By comparing this total with the information on average daily consumptive use given on page 167 , we see that maximum-day consumptive use $(670 \mathrm{mgd})$ is only 11.6 percent larger than average-day consumptive use. This small percentage increase is, of course, because the out-of-basin diversions constitute such a large part of total consumptive use of the basin's waters.

\section{TRENDS IN USE}

Few data on water use in the Delaware River basin prior to 1945 are available, except for municipal supplies. Table 47 shows that during the past 60 years the withdrawal by nine of the largest supply systems has more than doubled. The population of cities served by eight of these supplies was $1,335,000$ in 1890 and $1,675,000$ in 1900 . If we take the average of these totals, 1.5 million, as the population served in 1895 by a total of $257 \mathrm{mgd}$ (table 47 ), the rate is about 170 gpcd, compared with a rate of 150 gpcd for 14 systems in 1955 (table 43). The comparison of these rates may be affected by some, or all, of the following factors: (1) Some of the urban population in 1895 was

TABLE 47.-Withdrawals, in million gallons per day, by nine large municipal water systems for selected years, 1895-1955

\begin{tabular}{|c|c|c|c|c|c|c|c|c|}
\hline State and city & 18951 & $1920^{2}$ & $1930^{3}$ & 1940 & $1945^{4}$ & 1950 & $1953^{5}$ & $1955^{6}$ \\
\hline $\begin{array}{l}\text { Delaware: } \\
\text { Wilmington }\end{array}$ & 5.8 & 15 & 14 & $-\ldots$ & 14 & & 20 & 25 \\
\hline $\begin{array}{l}\text { New Jersey: } \\
\text { Camden }\end{array}$ & 12 & 14 & 19 & ${ }^{7} 17$ & ${ }^{7} 23$ & 722 & 20 & 22 \\
\hline $\begin{array}{l}\text { Trenton } \\
\text { Pennsylvania: }\end{array}$ & 5.5 & 818 & 18 & 818 & 822 & 25 & 26 & 26 \\
\hline Allentown & 4. 0 & 12 & & -...- & 16 & -...-. & 18 & 20 \\
\hline Bethlehem & .8 & & & -...... & 7.2 & & 19 & 20 \\
\hline Chester & 2.8 & 7.5 & 6.7 & $\ldots$ & 11 & & 13 & 13 \\
\hline $\begin{array}{l}\text { Philadelphia } \\
\text { Philadelphia Suburban }\end{array}$ & & 310 & 340 & $\cdots-\cdots$ & 336 & ${ }^{9} 341$ & 370 & 10370 \\
\hline Water Company.... & & & 21 & & 22 & 1132 & 39 & 1243 \\
\hline Reading & 6.5 & & 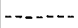 & -..... & 17 & $\ldots+\ldots$ & 17 & 17 \\
\hline
\end{tabular}

1 Baker (1897).

2 American City (1920-21).

Pristate District (1932).

4 U.S. Federal Security Agency (1945)

${ }_{6}^{5}$ Picton (1954)

6 U.S. Public Health Service (1956).

7 Records of Camden Water Department

$\theta$ Records of Trenton Water Department.

10390 raw.

11 390 raw.

12 American Water Works Association (1957). not served by municipal systems; (2) waste of water was probably considerably greater prior to extensive use of metering; (3) modern household appliances cause an increase in domestic use; (4) many industrial plants that formerly used municipal supplies now have their own supplies, which greatly reduce the gallons per capita per day charged against municipal supplies.

An example of the effect of unforeseen events upon water use is the decreased use resulting from water shortage and the resulting water-conservation campaign which occurred in New York City in 1949 and 1950. Average consumption reached a high of 1,203 mgd in 1949, dropped to $982 \mathrm{mgd}$ in 1950 and still averaged no higher than $1,155 \mathrm{mgd}$ in $1955,4 \frac{1}{2}$ years after water-use restrictions had been removed (New York City Board of Water Supply, 1956, p. 27; New York City Engineering Panel on Water-Supply, 1951, p. 20).

Trends indicated by existing records of water use are of limited value for forecasting water requirements, especially for long periods. Water requirements are dependent not only on population and industry, but also on changes in living standards, costs of water, changes in industrial processes, and the use of conservation practices, including the reuse of water.

\section{RELATION OF QUAJTTY OF WATER TO USE REQUIRE- MENTS \\ MUNICIPAL SUPPLIES}

The quality of water for municipal use is often evaluated in terms of the U.S. Public Health Service Drinking Water Standards (U.S. Public Health Service, 1946), which apply to drinking water and water-supply systems used by interstate carriers. In these standards the chemical characteristics are considered in two classes. For the first group the concentrations must not exceed the limits specified:

$\begin{gathered}\text { Parts per } \\ \text { million }\end{gathered}$
Lead
Arsenicic
Selenium
Hexavalent chromium

For the second group, certain limits of concentration are recommended, though are not mandatory:

\begin{tabular}{|c|c|}
\hline & $\begin{array}{l}\text { Parts per } \\
\text { million }\end{array}$ \\
\hline Copper & 3. 0 \\
\hline Iron and manganese together & .3 \\
\hline Magnesium & 125 \\
\hline Zinc & 15 \\
\hline Chloride. & 250 \\
\hline Sulfate. & 250 \\
\hline Phenolic compounds, as phenol & .001 \\
\hline Total solids, desirable & 500 \\
\hline Total solids, permitted (if better water & \\
\hline
\end{tabular}


Almost all surface water receives some treatment before it is used as a public supply. Most of it is filtered to remove sediment and disinfected by chlorination. If necessary, the $\mathrm{pH}$ is adjusted by adding lime or soda to prevent corrosion of valves and conduits. Tastes and odors are removed by chlorination, by addition of activated carbon, chlorine dioxide, or ozone, or by aeration.

Hardness of water is principally due to calcium and magnesium and is calculated in terms of $\mathrm{CaCO}_{3}$. Water having a hardness of less than $60 \mathrm{ppm}$ as $\mathrm{CaCO}_{3}$ is classified as soft; from 61 to $120 \mathrm{ppm}$, moderately hard; and from 121 to $200 \mathrm{ppm}$, hard. Water having a hardness of more than $200 \mathrm{ppm}$ is rated as very hard and requires sof tening to be suitable for most purposes. Hard water requires an excessive quantity of soap to form a lather and deposits scale in vessels in which the water is boiled. Water that is too soft, however, may corrode the distribution mains, especially if the $\mathrm{pH}$ is low.

Most surface waters have small concentrations of iron and manganese, but ground water, or surface waters containing mine drainage or industrial wastes, may have relatively high concentrations of dissolved iron. Iron and manganese cause stains on procelain fixtures and on laundry. Fluoride is added to many municipal water supplies for the purpose of reducing the incidence of tooth decay in the permanent teeth of children who drink the water (Dean, 1936, p. 1269-1272).

\section{INDUSTRIAL SUPPLIES}

Each industry has its own requirements for water quality; even within a given industry, quality requirements may vary widely with variations in the process, the product desired, and the water available. In a single plant several distribution systems may have water of different quality for processing, for drinking, for cooling, for boiler feed, and for firefighting and flushing. A part of the water supply may be ground water and a part surface water, or all the water may be supplied from a single source, but may undergo different kinds of treatment, each appropriate to the special use of the water. The kind of treatment may be as simple as neutralization, filtration, settling, or aeration, or it may involve softening, distillation, or demineralization by means of ion exchange.

As an example of the kinds of water-quality specifications in industrial use and of their variability, limiting concentrations for steam boiler feed waters are given in table 48. Note that high-pressure steam boilers require water of much better quality than do lowpressure boilers.

Boiler water meeting these specifications will have little tendency to cause corrosion, embrittlement, scale
TABLE 48.-Suggested water-quality tolerance for boiler-feed water [Moore (1940); Lohr and Love (1954, p. 41)]

\begin{tabular}{|c|c|c|c|c|}
\hline & \multicolumn{4}{|c|}{$\begin{array}{l}\text { Allowable limits (ppm) for indicated pressure } \\
\text { (lb per sq in) }\end{array}$} \\
\hline & 150 & $150-250$ & $250-400$ & $>400$ \\
\hline 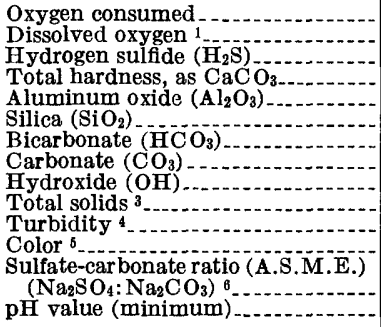 & $\begin{array}{r}15 \\
1.4 \\
25 \\
80 \\
5 \\
40 \\
50 \\
200 \\
50 \\
3,000-500 \\
20 \\
80 \\
1: 1 \\
8.0\end{array}$ & $\begin{array}{c}10 \\
23 \\
40 \\
.14 \\
20 \\
30 \\
100 \\
40 \\
2,500-500 \\
10 \\
40 \\
\\
2: 1 \\
8.4\end{array}$ & $\begin{array}{r}0^{4} \cdot 0 \\
10 \\
.05 \\
5 \\
40 \\
30 \\
1,500-100 \\
5 \\
5 \\
3: 1 \\
9.0\end{array}$ & $\begin{array}{l}3 \\
0^{3} \\
2 \\
1 \\
0 \\
20 \\
15 \\
50 \\
1 \\
2 \\
3: 1 \\
9.6\end{array}$ \\
\hline
\end{tabular}

1 Limits applicable only to feed water entering boiler, not to original water supply. 2 Except when odor in live steam would be objectionable.

3 Depends on design of boiler.

3 Depends on design of boiler.
${ }_{5}^{4}$ Parts per million of $\mathrm{SiO}_{2}$ (Rain water and Thatcher, 1960, p. 289).

6 American Society of Mechanical Engineers Standards.

formation, or foaming. Corrosion is partly due to acid or dissolved gases; embrittlement is associated with high concentrations of sodium carbonate or bicarbonate. Scale consists chiefly of calcium carbonate or calcium sulfate, and silica, substances that are deposited when their concentration becomes high owing to evaporation of the water. Foaming is caused by too high a concentration of sodium compounds or of finely divided suspended solids.

If the natural water does not meet specifications, it may be treated. Such treatment, depending upon requirements, may include filtering, softening, or adding chemicals to the boiler water to prevent scale from adhering to the boiler tubes. Sludge is removed from the boiler by blowdown and replacement with fresh water.

The quality requirements for water for many industrial and other uses have been described by California Water Pollution Control Board $(1952 ; 1954)$. Methods of treatment of public water supplies for industrial use and the characteristics of the raw and the treated water are discussed by Lohr and Love (1954). The treatment of water for industrial and other uses is also discussed by W. H. and L. D. Betz (1953) and by Nordell (1951).

\section{AGRICULTURAL SUPPDAS}

In addition to the traditional farm uses of water such as stock watering, increasing quantities of water are being used in the Delaware River region for irrigation. Evapotranspiration discharges water vapor, but no salts, to the atmosphere. Consequently, salinity of water in the root zone increases unless rainfall or irrigation is sufficient to leach out the excess salt. The amount of irrigation water required for leaching depends upon the salt tolerance of the crops and the 
amount of rainfall. Asparagus and sugar beets, for example, can tolerate a higher salinity than apples, beans, or strawberries.

When the proportion of sodium in water becomes too high, the sodium may undergo ion exchange with the soil. This deflocculates the soil and reduces its permeability to air and water, and thus retards or stunts plant growth. Irrigation water should contain sufficient calcium and magnesium, in relation to sodium, to replace some of the exchangeable sodium in the soil. In addition, calcium and magnesium are essential plant foods. Too high a concentration of bicarbonate impairs the quality of water for irrigation, for as evaporation takes place, precipitation of calcium and magnesium carbonates may occur; this precipitation increases the ratio of sodium to calcium and magnesium in the water.

Irrigation waters are classified for quality on the basis of: (1) total concentration of dissolved solids, (2) sodium adsorption ratio (SAR), and (3) residual sodium carbonate. These terms and the quality classifications based on them are discussed by Wilcox (1955), and by the U.S. Salinity Laboratory Staff, (1954). Such classifications of irrigation waters are of more significance in drylands regions than in the relatively humid Delaware River basin, where the root zone is leached by rainfall several times each year and where consequently the chemical quality requirements for irrigation water are less stringent.

Special problems are presented by irrigation waters containing industrial wastes, which may contain boron, metal ions, or other substances toxic to plants. Acid waters may corrode metal pipes of sprinkler systems and introduce toxic metals into the water. Saline irrigation waters may cause leaf burn. The tolerance limits for some such substances cannot be stated simply. For example, traces of boron (perhaps 0.1 ppm) are necessary for good plant growth, but concentrations of $0.5 \mathrm{ppm}$ are injurious to many plants. Other plants, however, tolerate as much as $2 \mathrm{ppm}$. Similarly, traces of copper or molybdenum appear to be essential for plant growth, but larger concentrations are toxic.

For stock-watering supplies, the chemical-quality requirements are roughly the same as those for drinking water for human beings. However, livestock and poultry generally can adapt themselves to higher salinity tolerances and to higher tolerance limits for some toxic materials than can humans.

The first effects of low-quality water on farm animals, such as cattle and chickens, are impaired lactation and reproduction; this results in lower production of milk and eggs. Nitrate, fluoride, selenium, and molybdenum are toxic to animals. Blue-green algae appear to produce poisons acting on the liver, the nervous system, and the skin; cattle, sheep, horses, and poultry have been fatally stricken as a result of drinking water with high concentration of blue-green algae (California Water Pollution Control Board, 1952, p. 170-171).

An exhaustive compendium of data on the limiting or threshold concentration of potentially polluting substances, together with their likely sources and bibliographical reference numbers, is given by the California Water Pollution Control Board (1954).

\section{USE OF WATER FROM THE DELAWARE ESTUARY}

The largest use of surface water in the industrial area from Trenton, N.J. to New Castle, Del., is for cooling. Slight increases in salinity are of little consequence for this use. Brackish water corrodes some metals, but corrosion may be avoided with properly designed equipment. Highly saline water cannot be used for drinking; it foams in boilers, corrodes pipes, valves, and machinery, consumes soap, and is undesirable in such industries as textiles, paper, and sugar refining. The deterioration of quality of Delaware River water caused the city of Chester, Pa., in 1951 to abandon its Delaware River source and to develop a new water supply from Octoraro Creek in the Susquehanna River basin.

In some places along the river, ground water is obtained from aquifers that are connected hydraulically with the river. Where heavy ground-water pumping occurs close enough to the river, river water may flow into the aquifer. As a result of groundwater studies of sand and gravel aquifers between Trenton and Philadelphia, Leggette and Brashears (1954) concluded that "the Delaware River is the source of from 50 to more than 80 percent of the withdrawal at existing well fields." A similar situation may exist along other parts of the river and estuary.

At present the ground water, at least in the aquifers above Philadelphia, is generally more mineralized than the river water, and in such places the infiltration of river water lowers the mineral content of the pumped well water. If, however, the salinity of the river water should increase and become higher than that of adjacent ground water, the water withdrawn from the wells would be more highly mineralized.

\section{DEVELOPMENT OF THE WATER RESOURCES OF THE DELAWARE RIVER BASIN}

In the preceding sections, the water supply and its variations, water use, and some of the water problems of the basin were examined. Reference was also made to several methods of developing and protecting water supplies and to the hydrologic effects of such developments. 
The following discussion summarizes the principal methods of developing and protecting water supplies of the basin and presents comparisons of 1955 demands and estimated future demands with available, or potentially available, supply.

This discussion relates primarily to hydrologic aspects of development and is not intended as a recommendation for or against any particular project or plan. In addition to hydrologic studies, investigations for any large-scale development must include economic, engineering, legal, political, health, recreational, and esthetic aspects, most of which are beyond the scope of this report.

\section{INCREASING AND PROTECTING THE WATER CROP}

The harvestable water crop, as discussed on page 2433 , can be increased principally by use of surface and subsurface storage. Surface water and ground water are not separate resources but merely different phases of the same resource. When selecting a source of supply the choice between surface water and ground water depends mainly on the following factors: (1) relative availability of water and suitable storage space, (2) costs of development and maintenance, and (3) water-quality requirements, both physical and chemical.

In future large-scale water-supply developments surface reservoirs will be most important in the Appalachian Highlands, because in that part of the basin surface-storage sites are abundant and ground-water storage capacity is small. The opposite situation exists in the Coastal Plain; ground-water storage will be most important there.

\section{SURFACE RESERVOIRS}

The role of surface storage in increasing the water crop is discussed on page 31. Flood-control storage and amounts of storage required to maintain specified flows are discussed on page 133-134.

Many sites suitable for surface reservoirs are desirable sites for urbanization and industrialization, highways, railroads, and airports. Such activity may precede the need for storage so that the storage can be increased only at great expense or at less satisfactory sites. If any site is essential to a long-range plan of water development, acquisition of the site, or of development rights, before the site is used for other purposes could save much trouble and expense.

Construction and operation of reservoirs on stream channels often have many effects unrelated to the primary purpose of development. For example, development of hydroelectric power commonly causes rapid fluctuations in streamflow that may be detrimental to fish and wildlife and to water users for several miles downstream from the plant. On the other hand, the storage capacity of such reservoirs may help to reduce damaging flood peaks. Construction of a water-supply reservoir might help to create recreational opportunities, but the existence of a dam in a stream may interfere with the migration of certain species of fish unless fish ladders are installed.

Formerly reservoirs were usually built for a single purpose and with little regard for other uses. In recent years, however, coordinated development of river basins is becoming a more common practice. Such development may include storage for several purposes, such as flood control, power development, irrigation, municipal or industrial water supply, and augmentation of low flows. Most of these purposes are conflicting, at least to some extent. For example, flood-control reservoirs should be kept as nearly empty as possible so that space will be available when needed to store flood waters, but reservoirs for water-supply or hydroelectric power should be kept as full as possible to provide water when natural flow is insufficient to meet demands.

Storage for conflicting uses has sometimes been provided in a single reservoir, particularly in the arid Western United States where runoff volumes are small relative to available storage space. For example, Lake Mead, on the Colorado River in Arizona and Nevada, has a capacity sufficient to store nearly twice the mean annual runoff from its drainage area. Consequently it was possible to combine storage space for water supply, power production, and flood control in a single reservoir.

Such a combination in a single reservoir would be much more difficult in the Delaware River basin. However, combination of conservation storage and flood storage may be practical at some of the large reservoir sites and some other uses have less divergent requirements that can be met readily by a single reservoir. For example, Pepacton and Neversink Reservoirs, in the upper part of the basin, store water primarily for diversion to New York City and secondarily to augment low flows in the Delaware River, in accordance with the U.S. Supreme Court decree that authorizes the diversion. These uses are compatible, because water may be stored during periods of high runoff for release or diversion principally during periods of low runoff. Conflict over allocation of the stored water may occur during extended periods of low runoff.

Optimum development of water resources requires integrated planning and operation of surface storage facilities to best serve the many interests involved.

The combined storage capacity of the 10 major reservoirs existing or under construction (1959) in the Delaware River basin is about $1,410,000$ acre-feet, a small part of the potential surface-storage capacity; the drainage area above these reservoirs is 1,840 square 
miles, or about 15 percent of the total area. Numerous smaller reservoirs exist but their total capacity is small.

Of this total capacity, 874,000 acre-feet is in the New York City system of reservoirs for water supply and low-flow augmentation, 289,000 acre-feet is in hydroelectric power systems, 204,000 acre-feet is in floodcontrol reservoirs, and 44,500 acre-feet is in municipal water-supply reservoirs for cities within the basin.

The operation of the New York City system under the Supreme Court decree controlling that operation is important in the development of the water resources of the basin. The subject is discussed in the section entitled "River Master of the Delaware River."

GROUND-WATER DEVELOPMENT AND MANAGEMENT DESIGN, DEVELOPMENT, AND OPERATION OF WELLS AND WELL FIELDS

In recent years, great progress has been made in the scientific spacing, design, construction, development, and maintenance of wells. The design and operation of wells or of well fields, to recover the maximum yield of ground water, is usually the responsibility of specialists outside the Geological Survey. It is appropriate here only to sketch examples of recent progress in the techniques of ground-water development.

The application of principles of ground-water hydraulics is of particular importance in determining the proper spacing of wells, not only to minimize interference among pumped wells, but to obtain the maximum sustained yield from an area. The application of hydraulic theory to well spacing involves the determination of the aquifer characteristics such as the coefficients of transmissibility and storage, the geometry of the aquifer, and the relations of the aquifer to other aquifers and to aquicludes.

In the past the location and spacing of water wells usually have been dictated by convenience or by limitations of property ownership, rather than by hydrologic factors. However, when ground-water supplies in an area become more intensively developed, the hydrologic factors that determine proper well spacing need to be considered. A useful parallel may be found in the petroleum industry where the "unit operation" of many large oil fields, which requires rational spacing of wells, has been practiced for more than 20 years. Unit operation results in a higher oil recovery at lower cost than could have been achieved by haphazard development.

Data are generally insufficient in the Delaware River basin to permit applying hydraulic theory to the problem of well spacing over large areas, but there is opportunity for steady improvement in the design of individual well fields in localities where the required data are available or can be obtained.

Many improvements have been made recently in the design and construction of individual wells, and these improvements contribute to the more efficient recovery of ground-water supplies. Determination of the best well sites has been aided greatly by the increased use of test drilling, by geophysical prospecting, and by careful analysis of existing subsurface data. The application of modern sampling techniques and the use of electrical and radioactivity logs will give assurance that productive zones are located accurately, and further, that the physical and water-bearing" properties "or aquifers are best determined.

Many types of well casings and screens, each suited to a particular need, are now available. From analysis of cores or drill cuttings and examination of electrical or radioactivity logs, the best screen slot sizes can be selected, and the screens can be set accurately opposite the producing zones.

Other notable improvements in the design and construction of wells include: (1) the refining of methods of mechanical underreaming and gravel packing by which the effective radius of a well and hence its yield may be increased to the proper size, (2) the availability of greatly improved pumps, and (3) the use of horizontal collector-type wells in areas where induced recharge may be utilized.

Advances also are being made continually in welldevelopment methods. Well development consists of those processes that are used, after a well is constructed, to: (1) increase the yield, (2) prolong the productive life of the well, and (3) improve the quality of the water (particularly the physical quality by reducing or eliminating the sediment). Development of some wells may take several times as long as the time required to drill, case, and screen the well.

The development process increases the permeability of the aquifer adjacent to the well. Natural development commonly occurs as a well is pumped, provided that the correct screen slot size was chosen. In this process a certain proportion of the smaller particles in the aquifer pass through the screen into the well and are pumped to waste. This process gradually produces an envelope of material surrounding the well that is coarser than that in the surrounding aquifer.

Physical processes of development include surging, overpumping, backwashing, bailing, the use of dry ice (frozen carbon dioxide), and, in consolidated rocks, pressure fracturing and the use of explosives. All these processes are designed to achieve the same effect as that previously described.

Chemical processes often are as effective as, or even more effective than, the physical processes of development. The chemical processes include the use of acid (particularly useful in limy sands like those in the Vincentown sand) and polyphosphate detergents. 
Proper maintenance of wells is fully as important in the efficient use of ground-water supplies as proper design, construction, and development of wells. Maintenance consists partly of a repetition or continuation of the processes of development and partly of the repair or replacement of screens and casing, and pump motors, turbines, or shafts. Maintenance problems are important, because they determine, in part, the extent to which drillers and water users will attempt development of an aquifer. Superior maintenance methods should extend greatly the usability of wells and aquifers.

\section{AUGMENTATION OF GROUND-WATER SUPPLIES}

Ground-water supplies are augmented when man's activities increase recharge to aquifers. This increase may be brought about in two ways: (1) by induced recharge, in which recharge from streams and other surface-water bodies or from precipitation is increased from the natural amount simply by lowering the water table or piezometric surface or (2) by artificial recharge, in which manmade facilities are used to add water to the aquifers. Artificial recharge includes infiltration of irrigation water withdrawn from streams, which in the Delaware River basin will probably always be relatively small.

In a sense, both these methods are forms of artificial recharge. The amount of recharge usually is less subject to direct control in use of the first method than in the second. Neither method permits an increase in the water crop of an area unless: (1) underground inflow is induced from adjacent areas (the gross supply in those areas is correspondingly reduced, however), (2) the water used for artificial recharge is imported by conduit from outside the area; or (3) the induced or artificial recharge otherwise would have been lost as evapotranspiration or as unused flood flow.

\section{INDUCED RECHARGE}

Induced recharge is the water that seeps into aquifers from streams, lakes, or swamps when the cone of depression around a pumping well or a well field intersects a body of surface water. Induced recharge also may be considered to include infiltration of precipitation in excess of the natural amount when such recharge results from an artificially lowered water table. The latter type of induced recharge generally is difficult to evaluate and is not discussed herein.

Induced recharge often is begun accidently in the early stages of well development in an area. As knowledge of hydrologic conditions accumulates, it is possible to plan ground-water development either to induce or to prevent recharge from a stream-a method of water conservation and aquifer management.
Where drawdown from a pumped well reverses the gradient between stream and well, gradients much steeper than exist in nature may become established, and under these circumstances much larger quantities of water will move from stream to aquifer than previously moved from aquifer to stream.

Where an aquifer is in direct contact with a body of surface water, such as a stream, the rate of induced recharge is directly proportional to the transmissibility of the aquifer and to the hydraulic gradient established in it by pumping. The recharge rate will be much less if a layer of clay or silt partially seals the aquifer from the stream, or if the area of contact between stream and aquifer is small. As an example, Barksdale and others (1958, p. 92-105) cite the Delaware estuary between Trenton, N.J., and Wilmington, Del., which lies along the intake areas of aquifers in the Raritan formation. Where a large area of an aquifer in the Raritan formation is exposed directly to river water, induced recharge is limited only by the capacity of the aquifer to transmit water from the channel under the prevailing hydraulic gradient, not by the infiltration capacity of the aquifer. In contrast, where the channel bottom is covered with clay, the induced recharge is negligible, even though the transmissibility of the underlying aquifer is high. This relation exists because a layer of clay one foot thick may create as much head loss as 10,000 feet of aquifer material at any given rate of flow.

The desirability of inducing recharge depends on the quality of the waters involved as well as the quantity of the available supply. In most parts of the basin above Chester, $\mathrm{Pa}$., the stream waters are as good as, or better than, the native ground waters; hence induced recharge is desirable insofar as water quality is a consideration. However, induced recharge from the Delaware estuary below Chester, under present conditions, would generally be undesirable because of the probability of contaminating large parts of the aquifers with water of poor quality.

There is substantial evidence that induced recharge from the Delaware River is already occurring in the Philadelphia-Camden area. An aquifer test on the Morro Phillips tract in Camden indicated that after 2 years of operation a new well near the river would be delivering about 90 percent river water (Barksdale and others, 1958, p. 106).

The intimate relationship of water in the Delaware estuary to water in the adjacent aquifers dictates that great care must be taken either in the future development of these aquifers, or in planning for the dredging and deepening the river, or of channels connecting thereto. 
ARTIFICIAL RECHARGE

Artificial recharge has been practiced successfully in many areas where water is scarce and the cost is justified, especially in parts of the arid West. Barksdale and DeBuchananne (1946) have described the artificial recharge of productive aquifers in New Jersey, outside the Delaware River basin. It may be many years before artificial-recharge practices are widely needed or adopted, but there are places in the basin where deep cones of depression in the piezometric surfaces warrant early consideration of recharge by artificial means. Among such places are the heavily developed parts of the Magothy and Raritan formations in the Philadelphia-Camden area, and, in Delaware, the Patuxent formation in the Delaware City area, the Cheswold aquifer in the Dover area, and the Frederica aquifer in the Milford area.

Successful artificial recharge requires a dependable source of water and a means of putting the water into the aquifer or aquifers at a sufficient rate and at a low cost. The methods of recharge include the use of input wells, spreading basins, infiltration canals, or sprinkling systems. Selection of any particular recharge method depends on local geology and economics. These methods are described briefly in the following paragraphs.

The use of input wells, usually to restore cooling water to an aquifer, is the most common method of artificial recharge in the East. On Long Island, N.Y., input wells are required for each air-conditioning well supplying more than $100,000 \mathrm{gpd}$. The water circulates from a supply well to a recharge well through an airtight cooling system and is returned to the ground unaltered except for a slight rise in temperature.

Input wells generally must be supplied with nonturbid and chemically stable water to prevent plugging of the surrounding aquifer. This and many related problems of recharging aquifers through input wells are now undergoing research in several places, notably in Arkansas, Texas, and California, by the U.S. Geological Survey and other agencies.

One of the cheapest and most practical means of achieving artificial recharge is to build check dams on streams where they cross the intake areas of aquifers. Such dams would retard runoff to allow seepage to take place, increase the hydraulic gradient in the aquifers, and induce more water to move downdip beneath the confining beds. Artificial recharge can be accomplished also by constructing spreading basins--shallow ponds, or pits-that receive excess runoff during storms. The stored water seeps into the underlying aquifer for later withdrawal. The bottoms of such recharge structures must be maintained in a permeable condition, and either a steep hydraulic gradient or a zone of aeration must be maintained between the water in the spreading basin and the water in the aquifer.

For more than 50 years Runyon pond at the Perth Amboy Water Works, N.J., about 26 miles northeast of the Delaware River basin, has been used effectively as a spreading basin to recharge the Old Bridge sand member of the Raritan formation at a rate of $0.6 \mathrm{mgd}$ per acre (Barksdale and DeBuchananne, 1946, p. 727); such recharge basins are currently being used successfully on Long Island to receive the drainage from storm-water conduits.

Infiltration canals built on permeable substrata offer a means of inducing water that otherwise would have gone to waste as flood runoff to seep into, and be stored in, aquifers for later use. Such canals cost no more to construct than other canals or ditches of similar size, but, because they tend to silt up, they cost more to maintain.

For several years, on farms at Seabrook, N.J., recharge has been accomplished by sprinkling. The water applied is waste water from a vegetable-processing plant. Barksdale and Remson (1956, p. 522) observe:

* * * at Seabrook, N.J., where recharge water is applied by sprinkling, no soil management has been necessary. The organic matter in the water is removed by biochemical action in the soil. The accelerated soil-forming processes and plant growth that accompany the irrigation seem to maintain and may even increase the infiltration capacity of the forest floor. Some parts of the Seabrook waste-water spreading area have received 4,000 inches of water during the last 4 years and have suffered no apparent diminution of infiltration capacity. Gradual changes in soil structure over a longer period may produce adverse effects, but present indications suggest improvement rather than deterioration of the infiltration capacity.

Such high infiltration rates are possible only when a zone of aeration exists between the soil and the water table. If the capacity of the shallow aquifer or aquifers is insufficient to transmit the applied water from the area, the zone of aeration eventually disappears owing to the rise in water table; waterlogging then results, and infiltration is reduced or eliminated. Sizable adjoining areas also may become waterlogged, if the local topography and water-table gradients are suitable.

Careful study of possible sites for artificial recharge is required to insure that the hydrologic conditions are favorable and that adverse effects from the recharge operation will not occur.

\section{CONSERVATION MEASURES}

Methods of conserving water receive little attention until water costs become high and competition for supplies becomes serious. Some conservation measures may increase the harvestable water crop; some may reduce the demand for water, an effect which is 
practically equivalent to increasing the water crop; still others may affect only individual users.

\section{REUSE AND RECYCLING OF INDUSTRIAL WATER}

Reuse of water in the Delaware River basin is important, as it is in any highly developed basin. Most water used in upstream areas for industrial and municipal purposes returns, with altered quality, to the streams and aquifers where natural processes tend to purify it. Farther down the basin this same water is reused by other consumers, and the process may be repeated many times. Eventually the water is discharged to salty or brackish water in or near the ocean, where it is no longer suitable for most uses; however, it still is usable for such purposes as cooling in industrial and power plants provided these plants are equipped with noncorrosive pipes and fixtures. Frequently trouble arises when the wastes discharged exceed the purification capacities of the streams and aquifers. Continuation of the cycle of reuse is dependent either on pollution control by treating used water before it is discharged or on removal of polluting wastes from the water supply before reuse.

In this region, large quantities of water that could be reused are discharged to salty or brackish water. On Long Island about half the total quantity of water pumped is so discharged. New York City imports much of its water from headwater areas in the Catskill Mountains region and directly discharges effluents to salt-water bays and estuaries. Such water has not served other up basin municipalities or industriesin this sense it is single-use water. Effluents from the Philadelphia-Wilmington area enter the Delaware River in a reach where salinity becomes appreciable, especially in low-flow periods, and the water is fit only for purposes such as flushing and cooling.

Temperature of the available supply is important in cooling. Surface-water supplies in this region usually range from about $32^{\circ}$ to $90^{\circ} \mathrm{F}$ and most cooling systems in the area are designed for this range. Use of cooling towers and ponds, or design of systems for higher temperatures, permit recycling of the same water. Ground-water supplies have a much smaller temperature, range, commonly no more than $1^{\circ}-2^{\circ}$; the average temperature is ordinarily equal to, or only a little greater than, the average annual air temperature for the locality. Owing to their lower temperatures in summer, ground-water supplies usually can be recycled more times than surface-water supplies.

Recycling of water for some other uses is also possible. In some cases treatment may be required after each cycle.

The following data from Hudson and Abu-Lughod (1956, p. 16) indicate the potential magnitude of reduction in water requirements for some industries by use of conservation methods. Conventional steam power plants require 40-135 gallons of water per kwhr (p. 164). With maximum conservation this quantity can be reduced to only 1-2 gallons per kwhr. Conventional steel plants require $30,000-60,000$ gallons of water per ton of steel; the Fontana plant, in watershort California, requires about 1,400 gallons per ton. Most petroleum refineries require 18-34 gallons of water per gallon of crude oil, but some refineries have reduced their requirements to about 1-2 gallons of water per gallon of crude oil.

Wholesale reductions of this magnitude are not to be expected in a short time. However, as competition for water supplies and costs of development increase, greater use of recycling will inevitably result.

The cooling process usually consumes only a fraction of the water withdrawn. Recycling tends to increase that fraction but reduces the total withdrawal; in some plants only enough water is withdrawn to make up the the losses from evaporation. Recycling does not increase the water crop, but the reduction in the withdrawal requirement of a plant makes it possible for that plant to operate in a location where the supply is limited.

USE OF LOW-QUALITY WATER WHERE HIGH QUAIITY IS NO'T REQUIRED

Large supplies of water that are not suitable for domestic use are available and suitable for some industrial uses. Many industries located on estuaries or bays use brackish water for cooling, which is an important item in the total water requirements for this area.

Treated sewage effluent is a source of supply for some uses where brackish water is not satisfactory. For example, the Sparrows Point plant of Bethlehem Steel Company in Baltimore, Md., purchases about $70 \mathrm{mgd}$ of treated sewage effluent, and it is planned to increase this to more than $140 \mathrm{mgd}$, the entire output of Baltimore's treatment plant. Estimated cost in 1946 was 1.73 cents per 1,000 gallons (Powell and Knoedler, 1956 , p. 73,76$)$.

\section{ELIMINATION OF WASTEFUL PRACTICES}

Where water supplies of good quality are, or have been, abundant, many cities provide water without metering. The individual customer then has little concern for leaks resulting from faulty plumbing, or for excessive use of water for irrigation of lawns and gardens, car washing, and other uses; consequently much water is wasted. Metering and increasing costs of water provide an incentive for reducing such waste.

In water mains, particularly old ones, large leaks often occur which not only cause considerable damage to streets and foundations, but also waste water. Smaller leaks may remain undetected for long periods of time. An adequate system for detecting and repairing leaks could save considerable quantities of water and prevent costly damage. 
Water of good quality used for airrconditioning or other cooling processes, which alter only the temperature of the water, is often discharged to polluted or brackish streams or bays where it is no longer usable for purposes requiring water of high quality. Under favorable conditions such water can be used to replenish a ground-water supply that is overdrawn.

In many parts of the country, flowing wells have been allowed to flow uncontrolled for years or until the water in the aquifer was so depleted that the wells ceased to flow. This depletion indicates the indifference to waste which is common in all parts of the country-even in the arid and semi-arid regions.

Wasteful practices sometimes cause increase devapotranspiration losses and therefore decrease the water crop.

\section{EVAPORATION SUPPRESSANTS}

Evaporation losses from open-water bodies can be reduced by the application of certain materials that form a film over the water surface. Some such materials such as oil, are unusable because of objectionable properties. However, the waxy substances, hexadecanol and octodecanol, and several chemically related materials, are colorless, odorless, tasteless, and nontoxic; moreover, oxygen and carbon dioxide seem to pass readily through the film formed by these substances (U.S. Bureau Reclamation, 1957). Tests made at Kids Lake near Oklahoma City, Okla., indicated that hexadecanol film did not have any serious effects on the fauna in the lake and that the content of dissolved oxygen was not greatly reduced, even near the water surface (Harbeck, 1958b, p. 12-13).

Experiments to date have indicated different amounts of reduction in evaporation from ponds and lakes by use of a hexadecanol film. Roberts (1957, p. 741) stated that evaporation during the summer may be reduced by as much as one-third; Harbeck (1958a, p. 7) found an 18 percent reduction in evaporation from a pond in Texas. Research scientists in this field think that eventually savings of about 20 percent can be obtained during the months of May to September under normal conditions for water surfaces of limited extent. Methods of applying, detecting, and maintaining the film have not been perfected. Research by the Geological Survey, the U.S. Bureau of Reclamation, and others is being directed to finding a solution of these problems as well as to determining the amount of reduction in evaporation to be expected.

To cite an example of what is hoped might be accomplished by use of evaporation suppressants: Suppose that the average annual evaporation at a particular site is 33 inches and that 70 percent, or 23 inches, occurs during the months of May to September; also suppose that the reduction of evaporation by application of a film is 20 percent. Under these conditions a saving of 4.6 inches would result from use of the chemical film during the 5 -month period. This is about 1.25 million gallons per acre of water exposed.

Reductions of this magnitude are not expected to be a very large factor in the overall development of the water resources in the Delaware River basin because open-water bodies cover such a small proportion of the total area. However, the savings could be a matter of great importance to individuals, water companies, industrial plants, or municipalities depending upon ponds or lakes with inadequate supplies in storage at the beginning of the summer season. For example, Wanaque Reservoir, one of the principal reservoirs for municipal water supply in northeastern New Jersey, went dry during the drought of 1957 . If the average watersurface area for the period May to September was 800 acres and if use of a film reduced evaporation 20 percent, a saving of about 1 billion gallons would have resulted.

\section{IAND-DSE PRACTICES}

Land-use practices that increase infiltration capacity, and thereby decrease direct runoff, may increase ground-water recharge and base flow of streams. This would increase the harvestable water crop. But when soil-moisture deficits occur, as they do in all parts of the Delaware River basin, particularly in the southern part, some of the increase in water absorbed by the soil is used to restore the moisture deficit, resulting in a decrease of the harvestable water crop. Measures which are usually considered conservation practices do conserve scil and moisture for growing crops, but may either increase or decrease the water crop. Effects of land-use practices upon infiltration rates are discussed on pages 33, 173.

The magnitude of the change in the harvestable water crop resulting from soil conservation practices in this region is unknown but probably is quite small. This is not to say that soil conservation practices are of little value or that they seriously deplete the water crop; rather, the limits within which man can affect the water crop are very small compared to the effects resulting from geologic controls. Soil- and moisture-conservation practices, in a year of marginally deficient rainfall, may be the salvation of farmers whose crops are benefited, and doubtless the runoff will be reduced by holding precipitation longer in the area where it falls ("holding the raindrop in place"). Soil moisture thus may be built up and held longer than it would be held without such conservation practices; increased evapotranspiration will result. However, the benefits of these practices far outweigh any reduction that may result in the harvestable water crop. 
PHREATOPHYTES AND SWAMPLAND

Phreatophytes (Greek: "well-plants") are plants that obtain their water supply directly from the water table. Included, in this region, are such plants as goldenrod, pickleweed, reeds, giant reedgrass and willow. This list is representative but by no means exhaustive. (Robinson, 1958, p. 76-77).

The problem of reclaiming water used by so-called nonbeneficial types of phreatophytes has received little attention in this region, because water generally is plentiful, and the phreatophytes have not become nuisances. Though phreatophytes are not a problem, substantial areas of waterlogged land, particularly in the Coastal Plain, are likely to be drained as changing conditions make land reclamation more attractive financially and as increasing demand for water encourages large-scale development of ground-water supplies. Such a combination of land reclamation and ground-water development might appreciably decrease the natural evapotranspiration loss and increase the water crop of the affected areas. One particularly large area (about 2,000 square miles) which may eventually be affected by such changes is the Pine Barrens (pl. 1).

\section{PROTECTION OF WATER QUAJTTY}

An abundant water supply is of little value unless its quality is suitable for the uses intended. Treatment or purification of some low-quality supplies is possible but expensive, and practical limits on the quantities of impurities in a given supply must not be exceeded if that supply is to be considered part of the water crop.

\section{POLLUTION CONTROL}

Suitable treatment of wastes before discharge becomes increasingly important as the volume of wastes increases. Failure to provide for such treatment may cause large reductions in the usable, and especially the potable, water supply.

The cleaning up of the Schuylkill River in Pennsylvania is an outstanding example of what can be done to restore a polluted stream after it has become unfit for most uses. This program, begun in 1947 and completed in 1951, involved control measures to prevent discharge of wastes (principally coal washings and culm) to the river, channel rectification, construction of sediment-retention pools, and dredging of the sediment from the pools (Pitkin, 1956, p. 88-104).

Restoration of an aquifer that has become polluted is extremely difficult, and in some cases almost impossible. In South Philadelphia, for example, industrial wastes of many kinds have so polluted the aquifers that it is doubtful if the pollution can ever be reduced to the point where the aquifers will produce potable water. When the source of pollution is eliminated from aquifers that are not so badly used, natural processes gradually restore the utility of the aquifers.

\section{SEDIMENT CONTROL}

Sediment in streams is a troublesome pollutant; it decreases the storage capacity of reservoirs, and it creates a hazard to navigation in harbors and shipping lanes. Reduction of sediment movement increases the usability of the water supply, conserves storage space, and is a boon to shipping. Control methods include: (1) land-use practices that minimize erosion, (2) construction of dams and pools for sediment retention, and (3) removal of sediment deposits from pools, stream channels, and harbors.

The Schuylkill restoration project in Pennsylvania, cited as an example of pollution control, is also an outstanding example of sediment control in the stream channels. Brandywine Creek valley is an outstanding example of the control of sediment before it reaches the streams. The soil-conservation practices used in this valley have caused a significant reduction in the sediment load of Brandywine Creek (Guy, 1957, p. 2).

Cultivated land, even with the best of conservation practices, yields more sediment than grassland or forested areas in places where the climate, topography, and soils are similar (Colman, 1953, p. 213). Increased use of soil-conservation methods in the future may be expected to cause a reduction in sediment yield in the area, though any increase in the amount of cultivated land would tend to increase the sediment yield. The future sediment yields, relative to present yields, are unknown, but the sediment problems of the area will always be of considerable significance.

\section{SAIT-WATER ENCROACHMENT CONTROLS}

The problem of salt-water encroachment is discussed to some extent on p. 10, 95, 98-103 and 150-157. Present methods of control consist of: (1) augmenting low flows in the Delaware River by releases from Pepacton and Neversink Reservoirs in New York, (2) the abandonment of pumping from the parts of aquifers that have been invaded by salt water, and (3) limitation of pumping rates in aquifers subject to encroachment.

Additional surface-storage capacity above Trenton, N.J., may increase low flows and thus aid in reducing encroachment in the Delaware estuary. A great disadvantage of flushing salt water out with increased fresh-water flows is that the fresh water required eventually may be greater than that needed for all other nonwithdrawal purposes. The fresh water so used and discharged to the ocean may be too high a price to pay for control of salt-water encroachment, especially when and if demands for water become nearly equal to the supply that can be provided by 
reasonable development. Furthermore, if mean sea level continues to rise, increasingly larger minimum flows will be required from year to year to control encroachment.

A possible alternative to control by low-flow augmentation is the construction of a low dam, or saltwater barrier, in the lower estuary. Such dams have been proposed at various times for tidal reaches of some streams, including the Hudson River near New York, N.Y., and the Sacramento River near Suisun Bay, Calif. Notable success was achieved in the Miami, Fla., area with the placement and operation of such barriers in the Miami River and in numerous drainage canals ending in salt water (Parker and others, 1955, p. 587-591). Other existing barriers in the United States that are working satisfactorily are in the Charles River at Boston, Mass., and the Santa Ynez River, Calif.

A proposal has been made for a dam in the Delaware estuary at a point below Wilmington, Del., and is the subject of a preliminary investigation by the U.S. Corps of Engineers to determine feasibility. The effects of such a structure would be far-reaching and complex. A fresh-water lake in this locality would be an extremely valuable asset because a large part of the water withdrawn for use within the Delaware River basin is withdrawn from the reach that the lake would occupy; however, comprehensive measures might be required to protect the quality of the water, and the dam and lake might interfere with various aspects of defense, shipping, and industry in the area. One of the most importan $t$ considerations may be the increase in minimum flow required for control of encroachment if sea level continues to rise.

Aside from reduction of pumping, artificial recharge using surplus streamflow is the most promising method for control of salt-water encroachment in aquifers of the Delaware River region. Most other methods are far too expensive for use except where potential demands for water exceed available supplies.

The use of outpost wells to detect the encroaching of undesirable water is a recommended procedure. Three such wells have been put into service by the Corps of Engineers along the Chesapeake and Delaware Canal (Rasmussen, Groot, and Beamer, 1958). The intake areas of the Magothy and Raritan formations are crossed by the canal just west of the boundary of the Delaware River basin. Two wells are finished in the Raritan formation and one in the Magothy formation for periodic sampling and measurement of water level. No contamination was recorded during almost 2 years of measurement prior to preparation of this report (1958).

Control of salt-water encroachment in the Delaware estuary is of particular importance to both groundwater and surface-water supplies. Where the quality of the water in the estuary is poor, induced recharge caused by heavy pumping of ground water results in the contamination and possibly the eventual ruination of the aquifers that are hydraulically connected with the channel.

\section{INCREASING THE TOTAL FRESH-WATER SUPPLY}

The advance of science and technology has been so rapid in recent years that new hope sometimes arises that man can alter the natural occurrences of the hydrologic cycle to increase the gross water supply or even bypass the natural cycle and produce fresh water directly from the sea.

\section{WEATHER MODIFICATION}

Recently improved techniques of artificially inducing precipitation have fostered a considerable amount of optimism, especially among the general public, that precipitation can be substantially increased in watershort areas.

The President's Advisory Committee on Weather Control, in its final report of December 31, 1957, concluded:

1. The statistical procedures employed indicated that the seeding of winter-type storm clouds in mountainous areas in western United States produced an average increase in precipitation of 10 to 15 percent from seeded storms with heavy odds that this increase was not the result of natural variations in the amount of rainfall.

2. In nonmountainous areas, the same statistical procedures did not detect any increase in precipitation that could be attributed to cloud seeding. This does not mean that effects may not have been produced. The greater variability of rainfall patterns in nonmountainous areas made the techniques less sensitive for picking up small changes which might have occurred there than when applied to the mountainous regions.

Although early efforts to induce precipitation by cloud seeding have produced some encouraging results, the reliability and full potentialities of this procedure must await an improved understanding of cloud physics and more experimentation in cloud-seeding techniques. Whether or not additional rain can be produced in appreciable quantities is only part of the problem. If additional rain can be produced, the cost must be considered. But the cost cannot be estimated until more is known of the actual effects of cloud seeding. An unusually high cost would be justified if rain could be produced where needed when water supplies are critically low, but clouds suitable for seeding are rare during such periods. Some people believe that when rain is artificially induced in one area, some nearby area may be deprived of precipitation that might otherwise have occurred. Such considerations and the 
possibility of damaging effects of induced precipitation may present difficult legal problems.

If the seeding of clouds does prove to be an effective method of increasing precipitation, the method is likely to be most applicable to the Western States where the depth of snow pack in the high mountains can be increased to provide additional water supply for the valleys in the summer months (Schaefer, 1956, p. 615).

\section{SALINE-WATER CONVERSION}

Methods of obtaining fresh water from saline sources have been available for a long time, but the costs are so high that converted sea water has been used only for small, special, and emergency supplies. Recent scientific and technological advances affecting this problem are of two general types: the first relating to new or improved conversion processes, and the second relating to energy production. Much current research is directed toward both of these problems.

The most promising methods for conversion include: (1) various modifications of the distillation process, (2) freezing, and (3) electric membrane methods (electrodialysis). Costs of conversion by the last method decrease with decreasing mineral concentration of the water, consequently the method is becoming economically feasible in arid regions and may become feasible in humid regions for conversion of some brackish-water supplies such as those in the Delaware estuary below Philadelphia, $\mathrm{Pa}$. On the other hand, minimum foreseeable costs of converted sea water (based on present energy costs) are far greater than costs of fresh water obtainable from reasonable development of streams and aquifers in the Delaware River basin region (Ellis, 1954, p. 206).

All conversion processes require large amounts of energy, and the energy cost is one of the controlling factors in the attempt to develop such processes. Many new advances in energy production have been made, but a method of generating power at a cost much below costs of power produced by conventional methods is not yet in sight. If future advances do produce cheap power, the potentialities of salt-water conversion will increase accordingly.

Ocean-water conversion will be necessary in the Delaware River region only in the rather distant future. However, the conversion of tidal streams and other brackish supplies may be necessary, especially in the lower estuary region, in a relatively short time. The existence of the major metropolitan areas close to such large supplies makes their utilization doubly attractive, and such utilization would help to relieve the competition for supplies from the upstream reaches of the rivers in the region.

\section{INTERBASIN DIVERSIONS}

Diversion of water, both out of and into the Delaware River basin, is important in the development of the region's water resources. Diversion out of the basin decreases the total water supply in the basin by the amount diverted but does not necessarily decrease the usable supply. For example, water diverted to New York City is excess streamflow that is captured during periods of high runoff. The diversion does not deplete low flows; instead, the low flows are increased by release of some of the stored water. The decrease in total supply could be harmful to lower basin users only if they needed a large proportion of the total supply for consumptive use.

Diversions to northeastern New Jersey through the Delaware and Raritan Canal and possibly by other means probably will increase considerably, because much of the available supply in that area is already developed. Diversion through the Delaware and Raritan Canal is made with no compensating release to the river.

These diversions are the principal ones affecting the basin and are discussed in a following section, "River Master of the Delaware River."

Diversion into the basin from the Susquehanna River basin to meet the needs of the Chester, $\mathrm{Pa}$., area probably will increase considerably, unless the quality of water in the Delaware River at Chester improves enough to justify use of that source again. The lower part of the Susquehanna River basin is also a potentia] source for additional water for other municipalities along the lower Delaware estuary, if needs there exceed supplies that can be obtained locally.

The upper part of the Susquehanna River basin was considered many years ago as a source for diversion to New York City but was rejected because of its remoteness. When Cannonsville Reservoir, on West Branch Delaware River, is completed and connected to the rest of the city's Delaware system, the Susquehanna River will be only about 12 miles beyond the limits of that system. Thus, the Susquehanna might eventually become a feasible source of additional supply, to supplement either the diversions to New York City or the releases to the Delaware River.

Although all of New Jersey east of the basin is included in what has been called the water-service area of the Delaware River, most of southeastern New Jersey is not dependent on the Delaware River basin. Local ground-water sources are more than adequate to meet foreseeable needs in parts of this area and may become important sources for diversion of water to the Camden, N.J., area in the basin and to coastal resort areas, such as Atlantic City, N.J. 
The Pine Barrens (pl. 1) cover an area of about 2,000 square miles in the Coastal Plain of southern New Jersey. Within this area water demand is small, and is likely to remain small in relation to the potential supply unless irrigation greatly expands. The large natural storage capacity of the area, both underground and in swamps, causes relatively even distribution of runoff in time. Furthermore, additional storage capacity may be used by pumping from aquifers in the Cohansey sand and Quaternary deposits.

If one-fourth of the average annual water yield ${ }^{10}$ from the Pine Barrens could be recovered feasibly by withdrawals from aquifers and streams, such withdrawals would amount to $500 \mathrm{mgd}$ or more. If a large proportion of the water is withdrawn from aquifers, the total might be somewhat larger than one-fourth the water yield because some of the ground water puinped otherwise might have been lost by evapotranspiration. During the period of development when the water table was being permanently lowered, some of the water pumped would be derived from permanent depletion of ground-water storage. Although yields of as much as $500 \mathrm{mgd}$ from the Pine Barrens may occur only in the distant future, this source obviously is one of major importance.

\section{COMPARISON OF AVAILABLE SUPPLY AND DEMAND}

The total use of water commonly has been compared with available supply. Such comparisons, however, are misleading because total use may be several times greater than the available supply when the same water is used over again and again, as is done in the Delaware River basin with all water except that diverted to New Jersey and to New York City.

A significant and useful comparison is that of the maximum daily rate of consumptive use to the low flows of streams. Maximum use tends to occur at, or about, the same time as the minimum streamflow, and minimum streamflow approximates the limit of consumptive use. (As defined on page 103, "streamflow" is the actual flow in a natural stream course and includes any water released from storage to augment water supplies.)

In making such a comparison, diversions to other basins are included in the consumptive use if they deplete low flows (as the diversion in the Delaware and Raritan Canal), but are excluded if they do not deplete low flows (as the diversion to New York City).

In 1955 the maximum daily rate of consumptive use within the basin was about $280 \mathrm{mgd}$ and the diversion from low flows to eastern New Jersey was $38 \mathrm{mgd}$. Thus the total of consumptive use was about $320 \mathrm{mgd}$.

\footnotetext{
${ }^{10}$ Water yield (runoff plus underground outflow) is used here because underground outflow in parts of this area amounts to 2 inches or more.
}

From table 29 the minimum 7-day flow that can be expected once in 20 years, on the average, was selected as the basis of determining the magnitude of the water supply with no further utilization of storage. The table applies to conditions that existed prior to 1953. At Trenton, N.J., where the drainage area of the Delaware River is a little more than half the area of the entire basin, this minimum is $1,400 \mathrm{cfs}$, or 905 mgd. By adding similar flows for remaining areas that are gaged and estimating runoff from ungaged areas, an estimate of about $1.7 \mathrm{bgd}$ is obtained for the minimum 7-day discharge from the basin. This is more than five times the maximum rate of consumptive use in 1955.

The preceding comparison indicates that the quantity of water available was ample to satisfy consumptiveuse requirements, but it does not make allowance for water needed for dilution of wastes and other nonwithdrawal uses, particularly for salt-water control if it is to be accomplished by flushing the estuary with fresh water.

If Picton's forecast of future water demand (Picton, 1956, p. 4) is correct and can be applied to this region, the $280 \mathrm{mgd}$ of consumptive use within the basin will be increased by 76 percent to about $490 \mathrm{mgd}$ by 1975 . The Supreme Court's amended decree of June 7, 1954, authorizes a maximum daily diversion to eastern New Jersey of $120 \mathrm{mgd}$ without compensating release to the river from storage. Thus the maximum daily rate of consumptive use (not including the out-of-basin diversions to New York City) may reach $610 \mathrm{mgd}$, an increase of about $290 \mathrm{mgd}$ over the 1955 volume.

Storage must be used to meet the requirement of the increase in consumptive use and to maintain flows sufficient to protect the water quality in streams and estuaries. The amount of storage required to maintain specified flows, or allowable draft rates, is shown in table 30 for selected gaging stations. If storage capacity equivalent to $50 \mathrm{mgsm}$ (million gallons per sq $\mathrm{mi})$ of drainage area were made available ${ }^{11}$ above each of the following listed stations, the approximate increase in allowable draft rate would be as shown:

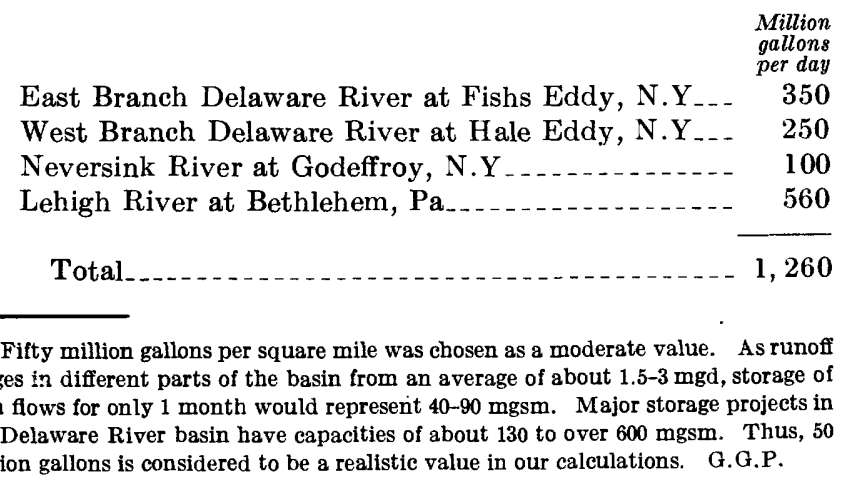
the Delaware River basin have capacities of about 130 to over $600 \mathrm{mgsm}$. Thus,
G.G.P. 
These increases in storage are less than the capacity provided by dams in existence, under construction, or proposed for conservation storage and represent only a few of many possible developments for increasing water supplies. Thus, moderate development of surface storage would provide abundant water to meet much larger demands than those predicted for 1975 $(610 \mathrm{mgd})$ and also to augment low flows.

The use of ground-water storage will add to the available supply in the Appalachian Highlands and probably will be the principal means of increasing available supply in the Coastal Plain.

Serious local problems frequently develop within a large area, such as the Delaware River basin, even though the large area has an abundant water supply. The metropolitan areas along the Fall Line in the basin and east of it have the greatest need because of the concentration of demand and the pollution of streams and aquifers in the vicinity. Most of the problems of these areas can be solved by provision of storage on the principal streams, development of nearby aquifers, and control of both pollution and salt-water encroachment.

One of the most severe problems is in the Wilmington, Del., area where water of the estuary is brackish. Ninety percent of the drainage area of Brandywine Creek, Wilmington's principal source of fresh water, is in Pennsylvania, and interstate competition for the available supply may arise. Conversion of brackish water at a cost competitive with natural supplies would be of particular importance to this area. If demands exceed the supply available from local streams and aquifers, additional natural supplies might be obtained from the Susquehanna River basin, the Delaware River above the upper limit of brackish water or aquifers in the central part of Delaware. Competition for supplies and costs of development are particularly important in the utilization of any of these sources. If the proposed salt-water barrier in the Delaware estuary proves to be feasible and is constructed, it would provide an abundant supply of fresh water for this area.

In southern New Jersey, use of water in coastal resort areas and for irrigation in the interior may be expected to increase greatly. Local supplies are adequate to meet any foreseeable need, except that water from the interior may have to be diverted to the coastal area to prevent or limit salt-water encroachment. Increasing needs in the Camden area may be met by development of storage in the Delaware River basin, by additional development of local aquifers, or by water from the Pine Barrens in south central New Jersey.

Irrigation requirements in the Coastal Plain can generally be met by local ground-water withdrawals. One-fourth of the average annual water yield amounts to about 5-6 inches, and much larger withdrawals could be made when needed during unusually dry seasons because of the large ground-water storage capacity. Because irrigation of the entire Coastal Plain is unlikely, withdrawals in irrigated areas can be at higher rates than those assumed for the entire Coastal Plain.

In the Appalachian Highlands, most demands for large supplies will be met by development of storage on streams, although locally many smaller demands may be met by ground-water sources, particularly in limestone 'valleys and permeable glacial deposits. Increases in water use throughout the area are to be expected, but the water requirements will probably never approach those of the area along the Fall Line, and most of the water crop from the upper part of the basin will be available to serve the metropolitan areas.

\section{RIVER MASTER OF THE DELAWARE RIVER}

By Robert E. Fish

Delaware, New Jersey, New York, and Pennsylvania have large and varied interests in the Delaware River. Any major water-utilization project in upstream areas affects to some degree the interests of downstream States.

Efforts to effect an interstate compact concerning waters of the Delaware River were unsuccessful. Litigation resulted in the decree of the U.S. Supreme Court in 1931 and the amended decree of 1954 (see p. 186-188). In entering the amended decree of 1954, the Court retained jurisdiction of the suit and designated as River Master the Chief Hydraulic Engineer of the U.S. Geological Survey, or such other engineer of the U.S. Geological Survey as shall at any time be designated by the Chief Hydraulic Engineer. The amended decree provides that diversions and releases of water be made under the supervision and direction of the River Master.

\section{HISTORICAL BACKGROUND OF THE DELAWARE} RIVER CASE

During the quest for water for New York City, water supplies of high quality that could be obtained by gravity were sought. As its water requirements increased, additional supplies were sought farther upland. Construction of the Croton water system was completed about 1911, the Catskill system in 1927. When development was considered of additional sources for the time when the 1927 systems would become insufficient, the Delaware River basin was believed to offer the best source, and plans were made for a Delaw are system. Original plans provided for diversion of $100 \mathrm{mgd}$ from Rondout Creek, a tributary of the Hudson River, 440 mgd from Neversink and East Branch Delaware Rivers, 
and $160 \mathrm{mgd}$ from other streams in the Delaware River basin.

The proposed diversion of waters of the Delaware River was a matter of interest and concern to all States of the basin. In an effort to resolve this problem, the States of New York, New Jersey, and Pennsylvania entered into negotiations for the equitable apportionment of waters of the Delaware River. In 1925 and 1927, representatives of the three States agreed upon compacts which, in each case, were ratified by the legislature of New York only. Following those unsuccessful attempts to negotiate compacts, New York City proceeded with plans to construct reservoirs and aqueducts of the proposed Delaware system, and to divert such waters to its urban use. In May 1929, New Jersey filed in the U.S. Supreme Court its original bill of complaint seeking to enjoin the city from diverting water from the Delaware River basin. Later, Pennsylvania became a party to the suit by intervention.

Following 2 years of litigation the Supreme Court ordered the entry of a decree (May 25, 1931) which, among other things, permitted the State of New York and the city of New York to divert water from the Delaware River or its tributaries. The diversion was limited to the equivalent of $440 \mathrm{mgd}$. The decree also required construction of a plant for the treatment of sewage and industrial waste at Port Jervis, N.Y., and compensatory releases from the impounding reservoirs under certain conditions of as much as $305.5 \mathrm{cfs}$ to the Delaware River. The decree further provided that any of the parties might apply for further action, and the Supreme Court retained jurisdiction of the suit. Diversion did not begin until January 1, 1953.

New York City water consumption increased to unprecedented rates in the years 1944-48, attaining an average rate in 1948 of more than $1.2 \mathrm{bgd}$. In four of those years the consumption exceeded the dependable yield of all the city's sources, but the needed water was supplied by heavy precipitation and an emergency connection to Rondout Creek. Evidence was at hand that within the next 20 years the city would need more water than could be supplied by the addition to its watersupply system of reservoirs on Rondout Creek and Neversink and East Branch Delaware Rivers. To cope with the anticipated water shortage, the New York City Board of Water Supply in January 1948 began investigation of possible additional sources of supply. As a result of the investigation, development of West Branch Delaware River and construction of an impounding reservoir near Cannonsville, N.Y., were recommended.

Concurrent with anticipation of needs in New York City, it became apparent in the downstream States that areas of the lower Delaware River basin and of northeastern New Jersey would need additional water supplies within a few years. Consequently, another attempt was made by the States to solve the interstate water problem by a compact. The Interstate Commission on the Delaware River Basin, a joint advisory board known as INCODEL, was established to formulate and recommend integrated programs for the development of the water resources of the basin.

The compact recommended in 1950 by INCODEL was adopted, with some reservations, by Delaware, New Jersey, and New York; Pennsylvania, however, rejected it.

With the new compact thus stalled, New York City instituted a proceeding for modification of the 1931 decree on April 1, 1952. The Supreme Court ordered that the petition by New York City for modification of the 1931 decree, a memorandum of the State of New York, and answers to the petition by the State of New Jersey and the Commonwealth of Pennsylvania be referred to Kurt F. Pantzer, of Indianapolis, Ind., as a Special Master, for consideration of the issues and report to the Court. After the formal hearings began, the State of Delaware was permitted to intervene. As a result of the proceedings, the Court entered its amended decree of June 7, 1954.

The Act of the New Jersey legislature referred to in paragraph $\mathrm{V}$ of the Court decree gave authority to the Commonwealth of Pennsylvania to construct a storage dam across the Delaware River at or near Wallpack Bend.

Two significant modifications of the 1931 decree found in the amended decree concerned diversions and release requirements at New York City reservoirs. New York City was permitted to increase diversions from the equivalent of $440 \mathrm{mgd}$ to the equivalent of $490 \mathrm{mgd}$ upon completion and placing in operation of Neversink and East Branch (Pepacton) Reservoirs. The amended decree further allowed diversions of the equivalent of $800 \mathrm{mgd}$ upon the completion of Cannonsville Reservoir. The modification concerning releases was embodied in what was called the Montague Formula, which at times would require compensating releases from the reservoirs significantly larger than the releases required by the 1931 decree. The amended decree specified that the diversions and releases by the city would be made under the supervision and direction of the River Master.

It should be noted that construction of Neversink and Pepacton Reservoirs and diversion tunnels was nearing completion at the time the Court entered the amended decree. The diversion and the release works had been designed and built to comply with provisions of the 1931 decree. 
The plans for Cannonsville Reservoir and diversion tunnel were completed and construction was begun after the entry of the amended decree. As specified in the decree, the release works of Cannonsville Reservoir are to be of such capacity as will provide a minimum aggregate release capacity from all the city's reservoirs in the Delaware River basin of not less than $1,600 \mathrm{cfs}$ under conditions of maximum depletion. Completion of the Cannonsville project is expected about 1963 .

\section{RIVER MASTER}

By letter dated July 14, 1954, the Director of the Geological Survey notified the Governors of Delaware, New Jersey, New York, and Pennsylvania and the Mayor of New York City that Carl G. Paulsen, Chief Hydraulic Engineer of the Geological Survey, had been designated River Master to administer the provisions of the Supreme Court decree. He also invited them to designate representatives to meet with the River Master as an advisory committee in the organization of the Delaware River work.

The decree states that diversions and releases of water shall be made under the supervision and direction of the River Master. Conservation of the waters of the basin and studies of needs and developments are also among the duties of the River Master.

In the first few months after the entry of the decree, representatives of the River Master studied the problems involved and proposed a plan of operation. Transit times of flows between various gaging stations were determined from streamflow records, and operating procedures were initiated on the basis of these and other hydrologic relationships. Adjustments to results of those studies were made later, on the basis of actual operations.

The River Master established an office in Milford, $\mathrm{Pa}$., for administration and performance of his duties and responsibilities. The River Master's office currently maintains the daily records of discharge at key gaging stations, amounts of water estimated to be released and actually released through the hydroelectric plants on Wallenpaupack Creek in Pennsylvania and on Mongaup River in New York, and estimated flow from the uncontrolled area of the Delaware River above the gaging station at Montague, N.J. An up-to-the-minute water budget based on these records is used to determine the amount of release from the New York City reservoirs that is designed to maintain the flow at Montague as specified in the decree. The water diverted from the basin by New York City and by New Jersey is also continuously recorded.

The River Master Advisory Committee continues to function for the purpose of reviewing with the River
Master operating plans and procedures for the Delaware River under the terms of the decree.

Operations under the Montague Formula.-Releases of water to be made during the early months of River Master operation, until Pepacton Reservoir was completed and placed in operation, were prescribed in the decree. The decree specified under this phase of the Montague Formula (par. III-B-1(a)) that releases be made by New York City from Neversink Reservoir for flow deficiencies in the Delaware River at Montague or at Trenton, N.J. This phase was effective June 7, 1954 to September 1, 1955.

The second, or current, phase of operation under the Montague Formula began September 1, 1955, upon the placing in operation of Pepacton Reservoir following completion of Neversink Reservoir January 1, 1954. Under this phase the decree specifies (par. III-B-1(b)) that amounts of water be released by the city from one or more of its reservoirs designed to maintain a minimum basic rate of flow at Montague of $1,525 \mathrm{cfs}$. The decree also specifies (par. III-B-1(c)(d)) that an excess quantity of water be released beginning June 15 each year and continuing not later than the following March 15.

A third phase of operation will be introduced when the Cannonsville project is completed and its reservoir first filled to 50 billion gallons above the lowest outlet. Beginning on that date the prescribed minimum basic rate of flow at Montague shall be $1,750 \mathrm{cfs}$. An excess quantity of water would also be released as under the second phase.

Analysis of flow, Delaware River at Montague, N.J.The discharge of the Delaware River at Montague, N.J., includes the following components: (1) natural flow from 2,587 sq mi of drainage area; (2) water discharged by two hydroelectric plants on Wallenpaupack Creek and Mongaup River (Rio Reservoir); and (3) water released from Pepacton and Neversink Reservoirs to supplement low flows.

For flows of 1,500 to $2,200 \mathrm{cfs}$ at Montague, the times of transit of water from the various sources to Montague are approximately: 8 hours from Rio Reservoir; 16 hours from Wallenpaupack Reservoir; 33 hours from Neversink Reservoir; 60 hours from Pepacton Reservoir. Because Pepacton Reservoir is the major source of release water from New York City's reservoirs, the required release must be designed 60 hours ahead of need at Montague. The natural flow at Montague, therefore, must be estimated 3 days in advance, the power load at Wallenpaupack plant 2 days in advance, and the power load at Rio plant 3 days in advance.

Water is released from the two powerplants principally for the production of power to help meet peak demands. The combined daily release from these 
plants at times amounts to as much as $2,800 \mathrm{cfs}$ and at other times the release is zero. The preparation of estimates of peak power requirements involves many factors and unpredictable variations may arise during the 3-day forecast period. Estimates of powerplant operation are made available to the River Master's office by the power companies.

Natural flow from the uncontrolled area above Montague is estimated from daily reports of key gaging stations which indicate the runoff from about half of the 2,587 square miles. However, because this flow is estimated for Montague 3 days in advance, an increment of flow to be expected from forecasted precipitation is added, adjusted for soil-moisture conditions and season of the year. This weather adjustment to the natural flow recession is estimated from forecasts for 3 days obtained from the U.S. Weather Bureau.

The decree directs that the upstream reservoir releases be designed to maintain a minimum specified rate of flow at Montague. Involved is the transportation of reservoir water down a hundred miles of river channel to meet an estimated need determined 3 days in advance. When this water arrives at Montague along with uncontrolled flow and powerplant water, the total quantity should be equal to the specified rate.

\section{RECORDS FOR 1956-57}

The River Master makes reports at least annually to the Supreme Court concerning administration of provisions of the decree. The annual report also includes records of the reservoirs, Delaware River at Montague, Delaware and Raritan Canal, and salinity in the lower river. The report year is from December 1 to November 30.

The following discussion of records was prepared for the two report years $1956-57$ because they were the first complete years of River Master operation during the present phase.

Diversions by New York City.-Water is diverted from Pepacton and Neversink Reservoirs in the Delaware River basin to Rondout Reservoir in the Hudson River basin. From Rondout Reservoir, water is conveyed through the Delaware Aqueduct to New York City.

During the period Dec. 1, 1955, to Nov. 30, 1957, the maximum prescribed diversion rate of the equivalent of $490 \mathrm{mgd}$ to New York City was not exceeded at any time. The city diverted about 143 billion gallons in 1956 and about 145 billion gallons in $1957 . .^{12}$

Delaware River at Montague, N.J.-The flow of the upper Delaware River, including Neversink River, is measured at the gaging station, Delaware River at

\footnotetext{
12 Records of diversions from Pepacton and Neversink Reservoirs furnished by the Board of Water Supply, New York City.
}

Montague, N.J. The average annual flow of the river at this station for the standard period $1921-50$ is $6,580 \mathrm{cfs}$. Compared to this, the mean discharge for the 1956 report year $(6,143 \mathrm{cfs} \text {, adjusted })^{13}$ was lower than average, and that for $1957(4,392 \mathrm{cfs} \text {, adjusted })^{13}$ was unusually low.

The effects of operation of the New York City reservoirs on flow of the Delaware River at Montague, N.J., are shown in figure 73 , where the monthly flow as observed and as adjusted for change in reservoir contents, diversions, and releases at Pepacton and Neversink Reservoirs are compared.

The effect of the reservoirs upon the flow at Montague is illustrated also in the daily flow-duration curves in figure 74. One curve depicts the duration of daily flows under actual river conditions during the 2-year period; the other indicates the estimated daily flows at Montague, had the two reservoirs not been constructed. The difference in position of the two curves shows the net effect of storage, diversion, and release at the reservoirs upon the flow at Montague. The difference between the upper parts of the two curves is largely the effect of storing water during high flows. The spread in the lower parts of the curves is largely the result of releasing water during low flows. The effects of diversions are not readily apparent because the diversions were a small part of the total during periods of high runoff and their effects were obscured by the releases during periods of low runoff.

Usable capacities of Pepacton and Neversink Reservoirs are 140,190 million gallons and 34,491 million gallons, respectively, above minimum levels for normal operation. Storage in the reservoirs varied markedly during the period December 1, 1955, to November 30, 1957 , as shown by monthly contents in figure 75 . Net storage depletion during the period was 134 billion gallons. ${ }^{14}$ Also shown by months in the plate are releases to Delaware River and diversions to New York City via Rondout Reservoir. In addition to the releases, spillway flows totalled 34 billion gallons during April, May, and June 1956.

During this 2-year period the prescribed minimum basic rate of flow in the Delaware River at Montague, was $1,525 \mathrm{cfs}$. In addition to the prescribed basic rate, the decree provides for an excess release rate of $515 \mathrm{cfs}$ or a total design rate of $2,040 \mathrm{cfs}$ during the period June 15, 1956 to March 14, 1957. During the period June 15 to November 30,1957 , the excess release rate was $500 \mathrm{cfs}$, or a total design rate of $2,025 \mathrm{cfs}$.

The first directed release from Pepacton and Neversink Reservoirs for the 1956 low-flow period was made

\footnotetext{
${ }^{13}$ Adjusted for diversion and change in contents of Pepacton and Neversink Reservoirs.

14 Records of contents in Pepacton and Neversink Reservoirs furnished by the Board
} of Water Supply, New York City. 


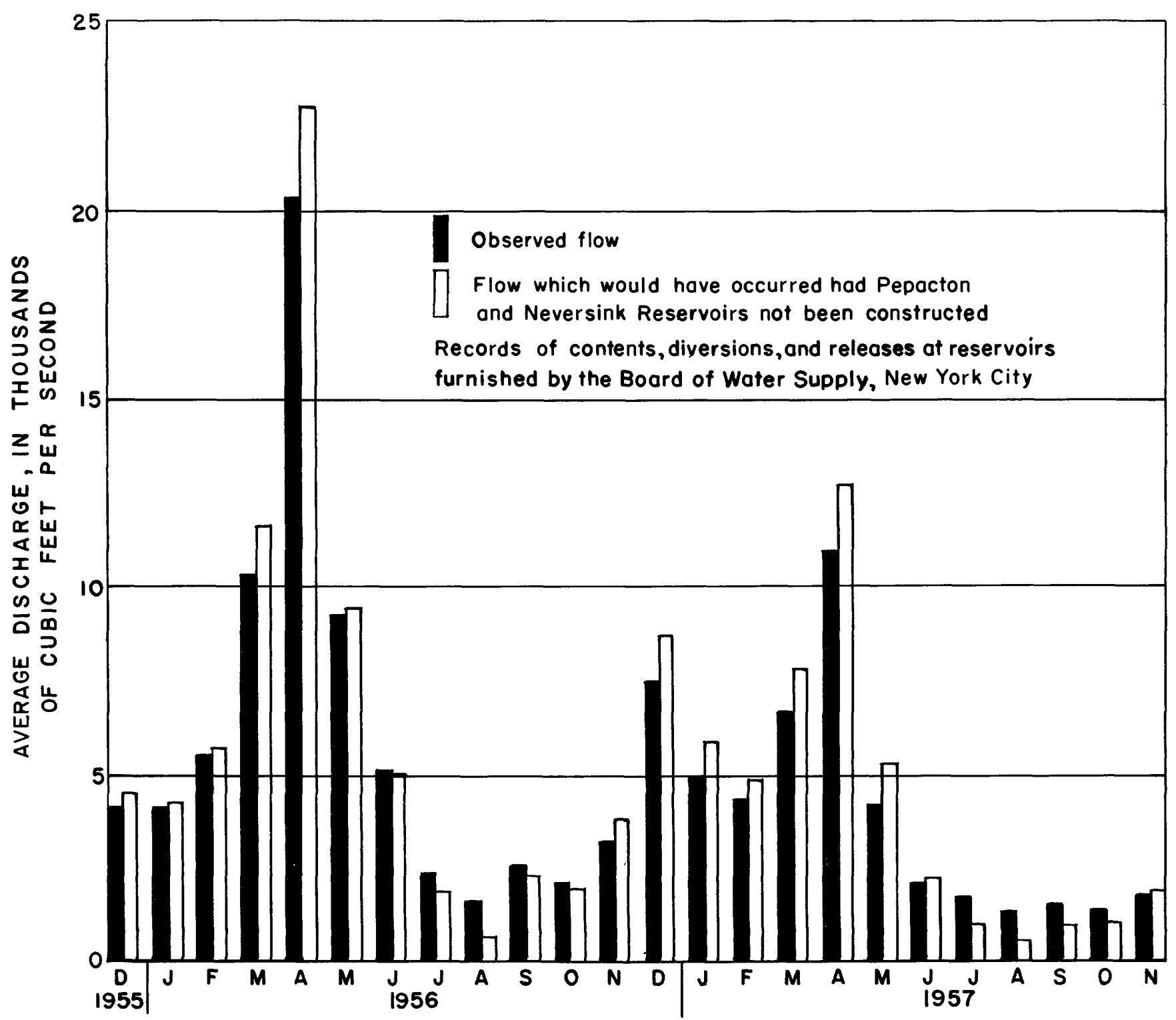

Frgure 73.-Effect of regulation on monthly flow of Delaware River at Montague, N.J., December 1955 to November 1957.

June 17 , and releases were continued almost uninterruptedly until mid-November. At times, principally in August and early September, the releases needed to maintain the design rate of flow at Montague exceeded the capacity of the release works. The directed releases in the 1956 report year totalled 65 billion gallons. ${ }^{15}$

For the 1957 low-flow period, releases from the reservoirs were required during the period June 6 to
November 30, except for a few days. The required releases to maintain the design rate at Montague exceeded the capacity of the release gates on many days of this period. The directed releases in 1957 totalled 68.6 billion gallons. ${ }^{15}$

15 Records of releases from Pepacton and Neversink Reservoirs furnished by the Board of Water Supply, New York City. 


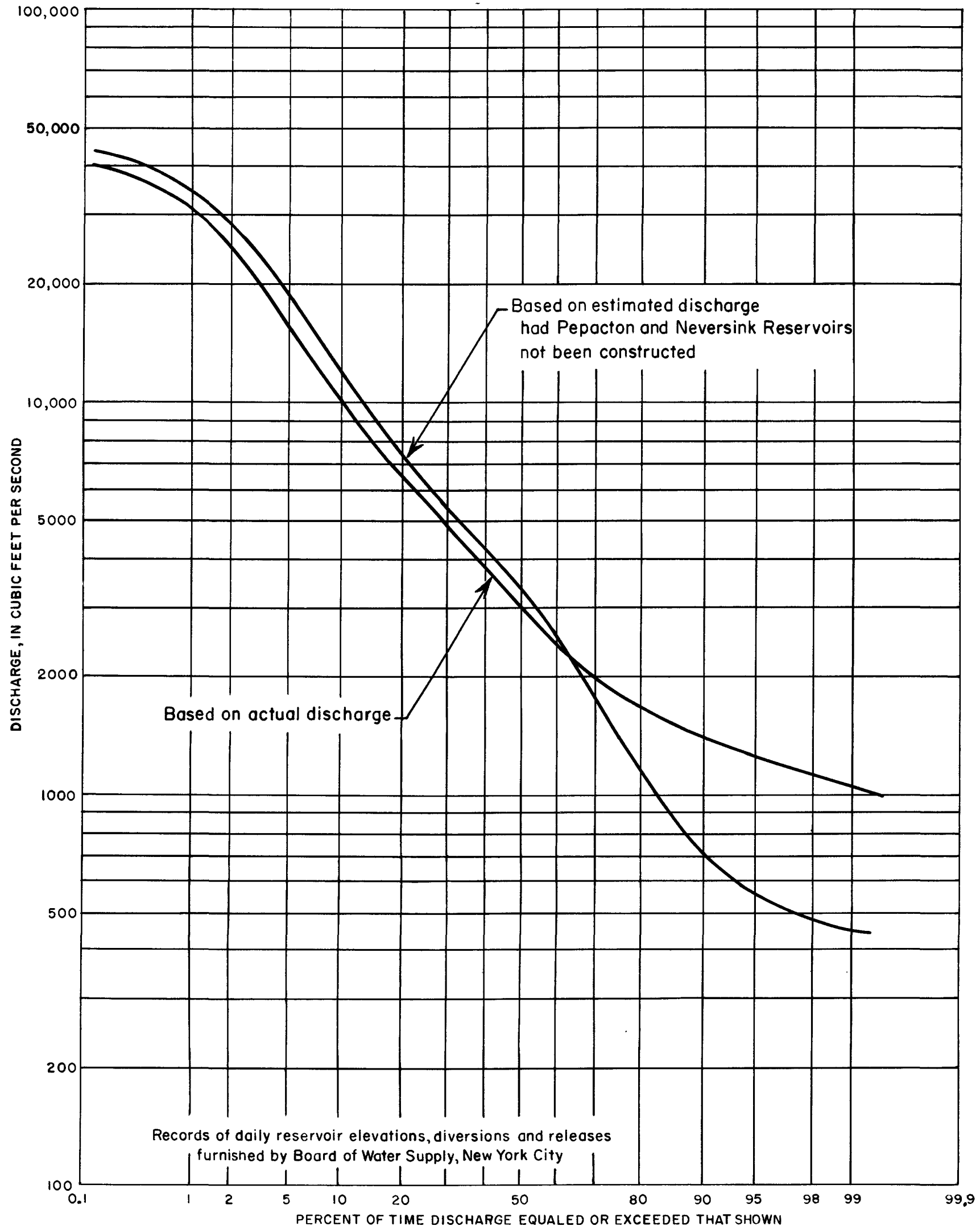

Figure 74.-Effect of regulation on daily-flow duration of Delaware River at Montague, N.J., December 1955 to November 1957. 


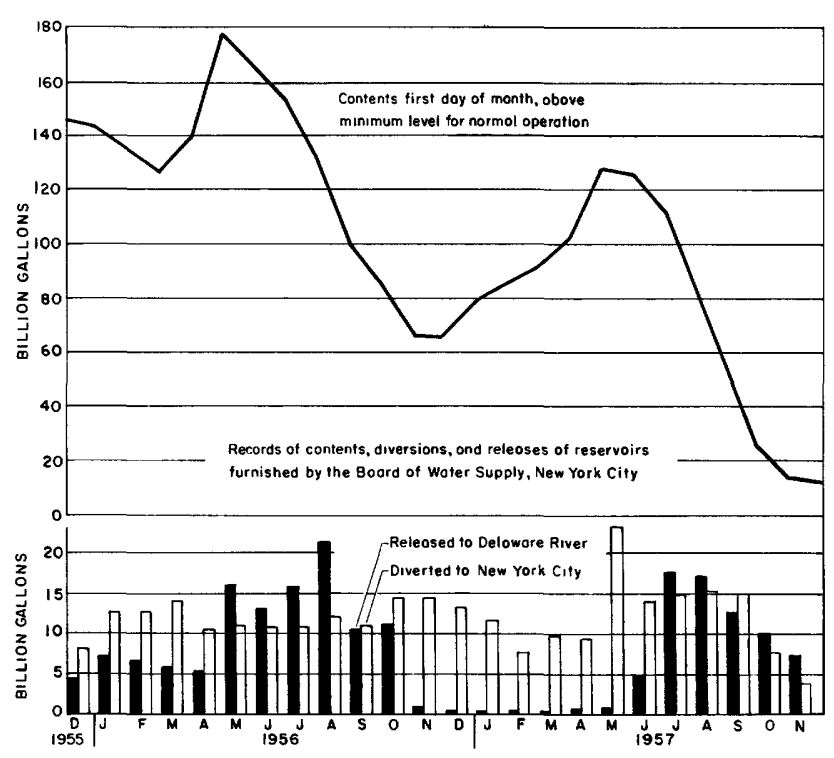

Frgure 75.-Contents, releases, and diversions at Pepecton and Neversink Reservoirs, December 1955 to November 1957.

Diversions by the State of New Jersey.-During the 2-year period ended November 30, 1957, water was also diverted from the Delaware River through the Delaware and Raritan Canal. This canal begins at Raven Rock, N.J., about 21 miles upstream from Trenton; it passes through Trenton and terminates at the Raritan River in New Brunswick. The part from Raven Rock to Trenton was formerly the feeder canal for the abandoned barge canal constructed 1830-34. Discharge records are collected at the gage of the U.S. Geological Survey at Kingston, N.J. According to the decree, the State of New Jersey may divert water for use outside the Delaware River basin not more than $100 \mathrm{mgd}$ $(155 \mathrm{cfs})$ as a monthly average, with the diversion on any day not to exceed $120 \mathrm{mgd}(186 \mathrm{cfs})$. The average diversion rates during 1956 and 1957 were 44.3 and 60.5 mgd, respectively, and the decree limitation was not exceeded at any time.

Salinity investigations in Delaware estuary.-Upstream reservoirs and other upstream river developments affect the salinity and movement of the salt front in the Delaware estuary. As the effects may be either beneficial or deleterious to downstream interests, especially in the upper part of the estuary, the direction and magnitude of any change that may occur becomes a matter of concern to all interests involved, therefore to the River Master. The annual reports of the River Master contain data showing the extent of the saline-water invasion in the Delaware estuary during the low-flow season. The occurrence of salt water, and the salt-water encroachment problems in the Delaware River basin, are discussed elsewhere in this report.
DECREE OF U.S. SUPREME COURT

The decree of the U.S. Supreme Court in the case "New Jersey $v$. New York et al, Delaware River" is given below:

The Court, having considered the amended petition of the City of New York, joined by the State of New York, to which is appended the consent of the State of New Jersey, the answer filed by the State of New Jersey seeking affirmative relief and the answers filed by the Commonwealth of Pennsylvania and the State of Delaware, the evidence and exhibits adduced by the parties, and the report of Kurt F. Pantzer, Esquire, Special Master, and being fully advised in the premises, now enters the following order:

I. REPORT OF SPECIAL MASTER APPROVED. The "Report of the Special Master Recommending Amended Decree", filed May 27, 1954, is in all respects approved and confirmed.

II. 1931 DECREE SUPERSEDED. The decree of this Court entered May 25, 1931 (283 U.S. 805) is modified and amended as hereinafter provided and, upon the entry of this amended decree, the provisions of the decree of May 25, 1931, shall be of no further force and effect.

III. DIVERSIONS BY THE CITY OF NEW YORK ENJOINED EXCEPT AS HEREIN AUTHORIZED. The State and City of New York are enjoined from diverting water from the Delaware River or its tributaries except to the extent herein authorized and upon the terms and conditions herein provided.

A. AUTHORIZED DIVERSIONS.

1. 440 M.G.D. The City of New York may divert from the Delaware River watershed to its water supply system the equivalent of $\mathbf{4 4 0}$ million gallons daily (m.g.d.) until the City completes and places in operation its reservoir presently under construction on the East Branch of the Delaware River.

2. 490 M.G.D. After the completion and commencement of operation of the East Branch reservoir, the City may divert the equivalent of $490 \mathrm{~m}$.g.d. until the completion of its proposed dam and reservoir at Cannonsville on the West Branch of the Delaware River, provided, however, that in the event of an abnormal or unforeseeable interruption of its facilities, the City may divert in excess of the equivalent of $490 \mathrm{~m}$.g.d. to meet its emergency requirements, but in no event shall such diversion impair the obligation of the City to make the releases hereinafter specified.

3. 800 M.G.D. After the completion of the Cannonsville reservoir, the City may divert the equivalent of 800 m.g.d.

4. Computation of Diversion. At no time during any twelvemonth period, commencing June 1 , shall the aggregate total quantity diverted, divided by the number of days elapsed since the preceding May 31, exceed the applicable permitted rate of diversion.

B. CONDITIONS AND OBLIGATIONS IMPOSED IN CONNECTION WITH DIVERSIONS AND RELEASES BY CITY. The diversions and releases by the City of New York from the Delaware River shall be made under the supervision and direction of the River Master, hereinafter appointed, and shall be subject to the following conditions and obligations:

1. Compensating Releases-The Montague Formula. The City shall release water from its reservoirs as follows:

(a) Until the East Branch reservoir is completed and placed in operation, on the day following each day in which the average flow in the Delaware River falls short of 0.50 cubic foot per second per square mile (c.s.m.), either at Montague, New Jersey (below the mouth of the Neversink River), or at Trenton, New Jersey 
(0.50 c.s.m. being equivalent to a flow of 1740 cubic feet per second (c.f.s.) at Montague and 3400 c.f.s. at Trenton), the City shall release water from the Neversink reservoir at an average of 0.66 c.s.m. or 61.38 c.f.s.

(b) Upon the completion and placing in operation of the Neversink and East Branch reservoirs, the City shall release water from one or more of its storage reservoirs in the upper Delaware watershed. Such releases shall be in quantities dedesigned to maintain a minimum basic rate of flow at the gaging station of the United States Geological Survey (U.S.G.S.) at Montague of 1525 c.f.s. (985.6 m.g.d.) until the Cannonsville project is completed and its reservoir first filled to the extent that 50 billion gallons above the lowest outlet are available for diversion and release, and of 1750 c.f.s. (1131.1 m.g.d.) thereafter. Compliance by the City with directions of the River Master with respect to such releases shall be considered full compliance with the requirements of this subsection (b).

(c) At the commencement of the calendar year following the completion and placing in operation of the Neversink and East Branch reservoirs and of each calendar year thereafter, the City of New York shall estimate and report to the River Master the anticipated consumption of water during such year to be provided for by the City from all its sources of supply. The City shall as hereinafter provided, release in the aggregate from all its storage reservoirs in the upper Delaware watershed, in addition to the quantity of water required to be released for the purpose of maintaining the then applicable minimum basic rate of flow as hereinabove provided, a quantity of water equal to 83 percent of the amount by which the estimated consumption during such year is less than the City's estimate of the continuous safe yield during such year of all its sources obtainable without pumping. In any such year the City's estimate of anticipated consumption shall not exceed by more than $71 / 4$ billion gallons the actual consumption in any previous calendar year; and its safe yield in any such year, obtainable without pumping, shall be estimated at not less than 1355 m.g.d. after the Neversink and East Branch reservoirs are put into operation; and at not less than 1665 m.g.d. after the Cannonsville reservoir is put into operation. If, at any time after the completion of the Cannonsville reservoir and prior to the year 1993, the continuous net safe yield for water supply of all of the City's sources of water supply, obtainable without pumping, is increased by the development of additional sources, such greater safe yield shall be used in determining the excess releases.

(d) The City of New York shall release the excess quantity provided for in subsection (c) at rates designed to release the entire quantity in 120 days. Commencing with the fifteenth day of June each year, the excess releases shall continue for as long a period, but not later than the following March 15, as such additional quantity will permit. Such period is hereinafter referred to as the "seasonal period". The excess quantity required to be released in any seasonal period shall in no event exceed 70 billion gallons. In releasing the excess quantity specified for any seasonal period, the City shall not be required to maintain a flow at Montague greater than the applicable minimum basic rate plus the excess quantity divided by 120 days, or in any event greater than 2650 c.f.s., nor to release at rates exceeding the capacity of its release works. The City shall in each seasonal period continue its excess releases until March 15 or until the aggregate quantity of the flow at Montague in excess of the basic rate or in excess of such higher rates as are not the result of the City's prior releases, is equal to the total -specified excess quantity.

(e) The terms and conditions provided in subsections (b), (c), and (d) hereof shall continue to be applicable in all respects in the event that the U.S.G.S. gaging station at Montague shall be relocated at a point below the confluence of the Neversink River with the Delaware River.

2. Minimum Capacity of Release Works at Reservoirs of City. In constructing the Cannonsville reservoir, the City shall install release works of such capacity as will provide a minimum aggregate release capacity from all its reservoirs in the Delaware River watershed of not less than 1600 c.f.s. under conditions of maximum reservoir depletion.

3. Releases to be Continued in Spite of Interference. In the event that any works hereafter constructed by public or private interests in the watershed of the Delaware River outside of the State of New York shall prevent the proper operation of the U.S.G.S. gaging station at Montague or interfere with the effective operation of the above release requirements by diverting water past the station or by intercepting the natural flow and storing it in reservoirs with an aggregate storage capacity in excess of 25 billion gallons, the City of New York shall continue to make the releases above specified which would be required in the absence of such interference, and appropriate gaging stations shall be established for that purpose.

4. Inspection Permitted. The States of New Jersey and Delaware and the Commonwealth of Pennsylvania, through accredited representatives, and the River Master, shall at all reasonable times have the right to inspect the dams, reservoirs and other works constructed by the City of New York, to inspect the diversion areas and the inflow, outflow and diverted flow of such areas, to inspect the meters and other apparatus installed by the City of New York and to inspect all records pertaining to inflow, outflow and diverted flow.

IV. TREATMENT OF PORT JERVIS SEWAGE. The effluent from the sewage treatment plant at the City of Port Jervis, New York, shall be treated so as to effect a reduction of 85 percent in the organic impurities and shall be treated with a chemical germicide, or otherwise, so that the B. coli originally present in the sewage shall be reduced by 90 percent. Untreated industrial waste from plants in the City of Port Jervis shall not be allowed to enter the Delaware and Neversink Rivers. The treatment of such industrial wastes shall be such as to render the effluent practically free from suspended matter and nonputrescent. The treatment of both sewage and industrial waste shall be maintained so long as any diversion is made from the Delaware River or its tributaries.

V. DIVERSIONS BY NEW JERSEY AUTHORIZED UNDER SPECIFIC DEFINITIONS.

A. Authorized Diversions. The State of New Jersey may divert outside the Delaware River watershed, from the Delaware River or its tributaries in New Jersey, without compensating releases, the equivalent of 100 m.g.d., if the State shall not, prior to July 1, 1955, repeal Chapter 443 of the New Jersey Laws of 1953, and if, when the Commonwealth of Pennsylvania accepts the conditions as specified in Section 19 of that Chapter, the State of New Jersey shall join with the Commonweal th of Pennsylvania in requesting the consent of Congress to the agreement embodied in Chapter 443 of the New Jersey Laws of 1953 and an Act of the Commonwealth of Pennsylvania accepting the conditions of such New Jersey Act.

B. Conditions and Obligations Imposed in Connection with Diversions by New Jersey. The diversions by New Jersey from the Delaware River shall be made under the supervision of the River Master and shall be subject to the following conditions and obligations:

1. Until the State of New Jersey builds and utilizes one or more reservoirs to store waters of the Delaware River or its 
tributaries for the purpose of diverting the same to another watershed, the State may divert not to exceed 100 m.g.d. as a monthly average, with the diversion on any day not to exceed 120 million gallons.

2. If and when the State of New Jersey has built and is utilizing one or more reservoirs to store waters of the Delaware River or its tributaries for the purpose of diversion to another watershed, it may withdraw water from the Delaware River or its tributaries into such impounding reservoirs without limitation except during the months of July, August, September and October of any year, when not more than 100 m.g.d. as a monthly average and not more than $\mathbf{1 2 0}$ million gallons in any day shall be withdrawn.

3. Regardless of whether the State of New Jersey builds and utilizes storage reservoirs for diversion, its total diversion for use outside of the Delaware River watershed without compensating releases shall not exceed an average of 100 m.g.d. during any calendar year.

VI. EXISTING USES NOT AFFECTED BY AMENDED DECREE. The parties to this proceeding shall have the right to continue all existing uses of the waters of the Delaware River and its tributaries, not involving a diversion outside the Delaware River watershed, in the manner and at the locations presently exercised by municipalities or other governmental agencies, industries or persons in the Delaware River watershed in the States of New York, New Jersey and Delaware and the Commonwealth of Pennsylvania.

VII. RIVER MASTER.

A. Designation. Subject to the concurrence of the Director of the U.S. Geological Survey, the Chief Hydraulic Engineer of the U.S. Geological Survey, or such other engineer of the U.S. Geological Survey as shall at any time be designated by the Chief Hydraulic Engineer, is hereby designated as River Master.

B. Duties. The River Master shall either in person or through his assistants possess, exercise and perform the following duties and functions:

1. General Duties.

(a) Administer the provisions of this decree relating to yields, diversions and releases so as to have the provisions of this decree carried out with the greatest possible accuracy;

(b) Conserve the waters in the river, its tributaries and in any reservoirs maintained in the Delaware River watershed by the City of New York or any which may hereafter be developed by any of the other parties hereto;

(c) Compile and correlate all available data on the water needs of the parties hereto;

(d) Check and correlate the pertinent streamflow gagings on the Delaware River and its tributaries;

(e) Observe, record and study the effect of developments on the Delaware River and its tributaries upon water supply and other necessary, proper and desirable uses; and

(f) Make periodic reports to this Court, not less frequently than annually, and send copies thereof to the Governors of Delaware, New Jersey, New York and Pennsylvania, and to the Mayor of the City of New York.

2. Specific Duties with Respect to the Montague Release Formula. In connection with the releases of water which the City of New York is required to make under Par. III-B-1(b) of this decree, the River Master, in cooperation with the City of New York, shall, by appropriate observation and estimates, perform the following duties:

(a) Determine the average times of transit of the flow between the release works of the several reservoirs of the City and Montague and between the release works of other storage reservoirs in the watershed and Montague; (b) Make a daily computation of what the average flow observed on the previous day at Montague would have been, except for that portion previously contributed by releases of the City or as affected by the contributing or withholding of water at other storage reservoirs, for the purpose of computing the volume of water that would have had to be released in order to have maintained precisely the basic rate on that day;

(c) Take account of all changes that can be anticipated in the flow from that portion of the watershed above Montague not under the City's control and allow for the same by making an appropriate adjustment in the computed volume of the daily release; and

(d) Af ter taking into consideration (a), (b) and (c), direct the making of adjusted daily releases designed to maintain the flow at Montague at the applicable minimum basic rate.

C. Distribution of Costs. The compensation of, and the costs and expenses incurred by, the River Master shall be borne equally by the State of Delaware, State of New Jersey, Commonwealth of Pennsylvania, and the City of New York.

D. Replacement. In the event that for any reason the Chief Hydraulic Engineer of the U.S.G.S. or the designee cannot act as River Master, this Court will, on motion of any party, appoint a River Master and fix his compensation.

VIII. NO PRIOR APPROPRIATION NOR APPORTIONMEN'T. No diversion herein allowed shall constitute a prior appropriation of the waters of the Delaware River or confer any superiority of right upon any party hereto in respect of the use of those waters. Nothing contained in this decree shall be deemed to constitute an apportionment of the waters of the Delaware River among the parties hereto.

IX. DECREE WITHOUT PREJUDICE TO THE UNITED STATES. This decree is without prejudice to the United States. It is subject to the paramount authority of Congress in respect to commerce on navigable waters of the United States; and it is subject to the powers of the Secretary of the Army and Chief of Engineers of the United States Army in respect to commerce on navigable waters of the United States.

X. RETENTION OF JURISDICTION; NO ESTOPPEL. Any of the parties hereto, complainant, defendants or intervenors, may apply at the foot of this decree for other or further action or relief, and this Court retains jurisdiction of the suit for the purpose of any order or direction or modification of this decree, or any supplemental decree that it may deem at any time to be proper in relation to the subject matter in controversy. The fact that a party to this cause has not filed exceptions to the report of the Special Masier or to the provisions of this decree shall not estop such party at any time in the future from applying for a modification of the provisions of this decree, notwithstanding any action takem by any party under the terms of this decree.

XI. COSTS OF THIS PROCEEDING. The costs of this proceeding shall be paid by the parties in the following proportions: State of New Jersey, 262/3 percent, City or New York, $26^{2 / 3}$ percent, State of New York, 10 percent, Commonwealth of Pennsylvania, 26\% percent, and State of Delaware, 10 percent.

\section{SELECTED BIBLIOGRAPHY}

American City Publ. Co., 1920, Water-supply statistics of metered cities: The American City, v. 23, no. 12, p. 613-620. 1921, Water-supply statistics of metered cities. The American City, v. 24, no. 1, p. 41-49. 
American Water Works Association, 1948, A survey of operating data for water works in 1945: Am. Water Works Assoc. Jour., v. 40, no. 2, p. 167-260.

1957, A survey of operating data for water works in 1955: Am. Water Works Assoc. Jour., v. 49, no. 5, p. 555-596.

Baker, M. W., ed., 1897, The manual of American water works, 4th issue: New York, Engineering News Publishing Co., $611 \mathrm{p}$.

Barghoorn, E. S., 1953, Recent changes in sea level along the New England coast; new archeological evidence: Science, v. 117 , no. 3048 , p. $597-598$.

Barksdale, H. C., 1945, Ground-water problems in New Jersey: Am. Water Works Assoc. Jour., v. 37, no. 6, p. 563-568.

Barksdale, H. C., and DeBuchananne, G. D., 1946, Artificial recharge of productive ground-water aquifers in New Jersey: Econ. Geol., v. 41, no. 7, p. 726-737.

Barksdale, H. C., and Graham, J. B., 1952, Progress of the investigation of the ground-water resources of the lower Delaware River basin: Interstate Comm. Delaware River Basin Proc., Sept. 29-30, 19 p, Philadelphia.

Barksdale, H. C., Greenman, D. W., Lang, S. M., Hilton, G. S., and Outlaw, D. E., 1958, Ground-water resources in the Tri-State region adjacent to the lower Delaware River: New Jersey Dept. Conserv. Econ. Devel. Spec. Rept. 13, $190 \mathrm{p}$.

Barksdale, H. C., Johnson, M. E., Baker, R. C., Schaefer, E. J., and DeBuchananne, G. D., 1943, The ground-water supplies of Middlesex County, New Jersey: New Jersey Water Policy Comm. Spec. Rept. 8, 160 p.

Barksdale, H. C., and Remson, Irwin, 1956, The effect of landmanagement practices on ground water: Internat. Assoc. Hydrology Pub. 37, Assemblée générale de Rome, v. 2, 520-525 p.

Barksdale, H. C., Sundstrom, R. W., and Brunstein, M. S., 1936, Supplementary report on the ground-water supplies of the Atlantic City region: New Jersey Water Policy Comm. Spec. Rept. 6, 139 p.

Bascom, Florence, Clark, W. B., Darton, N. H., Kümmel, H. B., Salisbury, R. D., Miller, B. L., and Knapp, G. N., 1909, Description of the Philadelphia district [Pennsylvania-New Jersey-Delaware]: U.S. Geol. Survey Geol. Atlas, Folio 162.

Bascom, Florence, Darton, N. H., Kümmel, H. B., Clark, W. B., Miller, B. L., and Salisbury, R. D., 1909, Description of the Trenton quadrangle [New Jersey-Pennsylvania]: U.S. Geol. Survey Geol. Atlas, Folio 167.

Bascom, Florence, and Miller, B. L., 1920, Description of the Elkton-Wilmington quadrangles [Maryland-Delaware-New Jersey-Pennsylvania]: U.S. Geol. Survey Geol. Atlas, Folio 211.

Bascom, Florence, and Stose, G. W., 1932, Description of the Coatesville-West Chester quadrangles [Pennsylvania]: U.S. Geol. Survey Geol. Atlas, Folio 223.

- 1938, Geology and mineral resources of the Honeybrook and Phoenixville quadrangles [Pennsylvania]: U.S. Geol. Survey Bull. 891, 145 p.

Bayley, W. S., Salisbury, R. D., and Kümmel, H. B., 1914, Description of the Raritan quadrangle [New Jersey]: U.S. Geol. Survey Geol. Atlas, Folio 191.

Behre, C. H., Jr., 1933, Slate in Pennsylvania: Pennsylvania Geol. Survey Bull. M 16, 4th Ser.

Betz, W. H., and L. D., 1950, Betz handbook of industrial water conditioning: 3rd ed., Philadelphia, W. H. and L. D. Betz, $197 \mathrm{p}$.

Blair, T. A., 1942, Climatology: New York, Prentice-Hall, 235 p.
Brown, Harrison, 1957, The age of the solar system: Sci. Am., v. 196 , no. 4 , p. $80-94$.

California Water Pollution Control Board, 1952, Water quality criteria: Pub. 3, 512 p.

- 1954, Water quality criteria: Pub. 3, addendum 1, $164 \mathrm{p}$

Chadwick, G. H., 1932, Catskill, Chemung, Portage: Eastern States Oil and Gas Weekly, v. 1, no. 17, p. 7.

Chubb, R. S., and Merkel, P. P., 1946, Effect of acid wastes on natural purification of the Schuylkill River: Sewage Works Jour., v. 18, no. 4, p. 692-694, Washington, D.C.

Clarke, F. W., 1924, The data of geochemistry: 5th ed., U.S. Geol. Survey Bull. 770, 841 p.

Cohen, Bernard, 1957, Salinity of the Delaware estuary: U.S. Geol. Survey open-file report, $86 \mathrm{p}$.

Colman, E. A., 1953, Vegetation and watershed management: New York, Ronald Press, $412 \mathrm{p}$.

Darton, N. H., Bayley, W. S., Salisbury, R. D., and Kümmel, H. B., 1908, Description of the Passaic quadrangle [New Jersey-New York]: U.S. Geol. Survey Geol. Atlas, Folio 157.

Dean, H. T., 1936, Chronic endemic dental fluorosis: Am. Med. Assoc. Jour., v. 107, p. 1269-1272.

Delaware Water Resources Study Committee, 1955, Water in Delaware: $69 \mathrm{p}$.

Durfor, C. N., and Keighton, W. B., 1954, Chemical characteristics of Delaware River water, Trenton, N.J., to Marcus Hook, Pa.: U.S. Geol. Survey Water-Supply Paper 1262, $173 \mathrm{p}$.

Ellis, C. B., 1954, Fresh water from the ocean: New York, Ronald Press, 217 p.

Ewing, Maurice, Woollard, G. P., and Vine, A. C., 1939, Barnegat Bay, N.J., pt. 3 of Geophysical investigations in the emerged and submerged Atlantic Coastal Plain: Geol. Soc. Am. Bull v. 50, p. 257-296.

- 1940, Cape May, N.J., pt. 4 of Geophysical investigations in the emerged and submerged Atlantic Coastal Plain: Geol. Soc. Am. Bull., v. 51, p. 1821-40.

Fenneman, N. M., 1938, Physiography of eastern United States: New York, McGraw-Hill Book Co., 691 p.

Finch, L. S., 1956, The lawn-sprinkling load, Indianapolis, Ind.: Am. Water Works Assoc. Jour., v. 48, no. 4, p. 364-373.

Flint, R. F., 1957, Glacial and Pleistocene geology: New York, John Wiley and Sons, $509 \mathrm{p}$.

Fluhr, T. W., 1953, Geology of New York City's water-supply system: Municip. Eng. Jour., v. 39, p. 125-245.

Friel, F. S., 1954, Water-supply problems: Am. Soc. Civil Eng. Proc., v. 80, sep. 555, 7 p. (Nov.).

Gill, H. E., 1959, Geology and ground-water resources of the Cape May peninsula, lower Cape May County, N.J.: New Jersey Dept. Conserv. Econ. Devel., New Jersey Water Resources Circ. no. 1, 19 p. 12 figs.

Grabau, A. W., 1906, Geology and paleontology of Schoharie Valley: New York State Mus. Bull. 92, 385 p.

Graham, J. B., 1950, Ground-water problems in the Philadelphia area: Econ. Geol., v. 45, no. 3, p. 210-221.

Gray, Carlyle, and others, 1960, Geologic map of Pennsylvania: Pennsylvania Geol. Survey, 4th ser.

Greenman, D. W., 1955, Ground-water resources of Bucks County, Pa.: Pennsylvania Geol. Survey Bull. W 11, 4th ser., $66 \mathrm{p}$.

Groot, J. J., Organist, D. M., and Richards, H. G., 1954, Marine Upper Cretaceous formations of the Chesapeake and Delaware Canal: Delaware Geol. Survey Bull. 3, 64 p.

Guy, H. P., 1957, The trend of suspended-sediment discharge of the Brandywine Creek at Wilmington, Del., 1947-55: U.S. Geol. Survey open-file report. 
Hague, J. M., Baưm, J. L., Herrman, L. A., and Pickering, R. J., 1956, Geology and structure of the Franklin-Sterling area, N.J.: Geol. Soc. America, v. 67, p. 435-474.

Hall, G. M., 1934, Ground water in southeastern Pennsylvania: Pennsylvania Geol. Survey Bull. W 2, 4th ser., 255 p.

Harbeck, G. E., Jr., 1958, Can evaporation losses be reduced?: Am. Soc. Civil Eng. Proc. (Irrigation and Drainage Div. Jour.) v. 84, no. IR 1, Jan., p. 1-7.

- 1959, Evaporation suppression in laboratory and field: Iowa Inst. Hydraulic Research Proc., 7th Hydraulic Conf., Bull. 39, Iowa City, June, p. 43-51.

Hatcher, 'M. P., 1956, The lawn-sprinkling load, Kansas City, Mo.: Am. Water Works Assoc. Jour., v. 48, no. 4, p. 373-376.

Hazen, Allen, 1892, A new color standard for natural waters: Am. Chem. Soc. Jour., v. 12, p. 427-428.

Hely, A. G., Nordenson, T. J., and others, 1960, Precipitation, water loss, and runoff in Delaware River basin and New Jersey: U.S. Geol. Survey Hydrologic Atlas HA 11.

Henderson, A. D., 1956, The lawn-sprinkling load, Long Island, N.Y., and Levittown, Pa.: Am. Water Works Assoc. Jour., v. 48 , no. 4 , p. $361-364$.

Herpers, Henry, and Barksdale, H. C., 1951, Preliminary report on the geology and ground-water supply of the Newark, N.J., area: New Jersey Dept. Conserv. Econ. Devel., Div. Water Policy and Supply Spec. Rept. 10, 52 p.

Holman, W. W., McCormack, R. K., Minard, J. P., and Jumikis, A. R., 1957, Practical applications of engineering soil maps: New Jersey Eng. Soil Survey Rept. 22, Rutgers Univ. Eng. Research Bull. 36, 114 p.. New Brunswick.

Hotz, P. E., 1953, Magnetite deposits of the Sterling Lake, N.Y.Ringwood, N J, area: U.S. Geol. Survey Bull. 982-F, p. 153-244.

Howell, B. F., Roberts, Henry, and Willard, Bradford, 1950, Subdivision and dating of the Cambrian of eastern Pennsylvania: Geol. Soc. America Bull., v. 61, p. 1335-1368.

Hoyt, J. C., 1936, Droughts of 1930-35: U.S. Geol. Survey Water-Supply Paper 680, 106 p.

Hudson, H. E., and Abu-Lughod, Janet, 1956, Water requirements, in Graham, J. B., and Burrill, M. F., eds., Water for industry: Am. Assoc. Advance. Sci. Pub. 45, 131 p.

Interstate Commission on the Delaware River Basin, 1955, Inventory and appraisal of the water-supply facilities in southeastern Pennsylvania: Philadelphia, 115 p.

Johnson, Douglas, Bascom, Florence, and Sharp, Henry, 1933, Geomorphology of the central Appalachians: 16th Internat. Geol. Congr. Guidebook 7, p. 242.

Johnson, M. E., and MeLaughlin, D. B., 1957, Triassic formations in the Delaware valley: Geol. Soc. America Guidebook, Atlantic City meeting, p. 31-68.

Kammerer, J. C., 1957, Records available to September 30, 1956 on use of water in the Delaware Basin Project area: U.S. Geol. Survey open-file report, $33 \mathbf{p}$.

Keighton, W. B., 1954, The investigation of chemical quality of water in tidal rivers: U.S. Geol. Survey open.file report, $54 \mathrm{p}$.

Ketchum, B. H., 1952, The distribution of salinity in the estuary of the Delaware River: Woods Hole Oceanographic Inst., Woods Hole, Mass. [Prepared for Board of Water Supply, City of New York].

1953, Supplementary report on the distribution of salinity in the estuary of the Delaware River: Woods Hole Oceanographic Inst., Woods Hole, Mass. [Prepared for Board of Water Supply, City of New York].
Knopf, E. B., and Jonas, A. I., 1929, Geology of the crystalline rocks of Baltimore County: Maryland Geol. Survey, p. 97-199.

Knox, C. E , 1956, Index of surface-water records to September 30, 1955: Geol. Survey Circ. 381, 30 p.

Kohler, M. A., 1954, Lake and pan evaporation, in Water-loss investigations: Lake Hefner studies, technical report: U.S. Geol. Survey Prof. Paper 269, p. 127-148.

Kümmel, H. B., 1897, Annual report of State Geologist for 1896: New Jersey Geol. Survey, p. 25-88.

Leggette, R. M. and Brashears, M. L., 1954, Ground-water recharge from river infiltration along the Delaware River, pt. B of Report on the effect of ship channel enlargement above Philadelphia: prepared for the Committee for Study of the Delaware River, pt. VI.

Lewis, J. V., and Kümmel, H. B., 1910-12, revised by Kümmel, 1931, and Johnson, M. E., 1950, Geologic map of New Jersey: New Jersey Dept. Conserv. Econ. Devel. Atlas, sheet 40.

Lewis, J. V., and Kümmel, H. B., 1915, The geology of New Jersey: New Jersey Geol. Survey Bull. 14, p. 56.

Lohman, S. W., 1937, Ground water in northeastern Pennsylvania: Pennsylvania Geol. Survey Bull. W 4, 4th ser., $300 \mathrm{p}$.

Lohr, E. W., and Love, S. K., 1954, The industrial utility of public water supplies in the United States, 1952: U.S. Geol. Survey Water-Supply Papers 1299 Part 1 and 1300, Part 2, 639 p. and 462 p.

MacClintock, Paul, and Richards, H. G., 1936, Correlation of late Pleistocene marine and glacial deposits of New Jersey and New York: Geol. Soc. America Bull., v. 47, p. 289-338.

MacKichan, K. A., 1951, Estimated use of water in the United States, 1950: U.S. Geol. Survey Circ. 115, 13 p. -1957, Estimated use of water in the United States, 1955: U.S. Geol. Survey Circ. 398, 18 p.

Malcolm Pirnie Engineers and Albright and Friel, Inc., Consulting Engineers, 1950, Report on the utilization of the waters of the Delaware River basin: Interstate Comm. Delaware River Basin, Philadelphia, 154 p.

Mangan, J. W., and Graham, J. B., 1953, The use of water in Pennsylvania, 1951: U.S. Geol. Survey Circ. 257, 11 p.

Marine, I. W., and Rasmussen, W. C., 1955, Preliminary report on the geology and ground-water resources of Delaware: Delaware Geol. Survey Bull. 4, 335 p.

Marmer, H. A., 1949, Sea-level changes along the coast of the United States in recent years: Am. Geophys. Union Trans., v. 30, p. 201-204.

Mason, W. D., and Pietsch, W. H., 1940, Salinity movement and its causes in the Delaware River estuary: Am. Geophys. Union Trans., pt. 2, p. 457-463.

Meinzer, O. E., and Stearns, N. D., 1929, A study of ground water in the Pomperaug basin, Connecticut: U.S. Geol. Survey Water-Supply Paper 597, 146 p.

Merrill, F. J. H., Darton, N. H., Hollick, Arthur, Salisbury, R. D., Dodge, R. E., Willis, Bailey, and Pressey, H. A., 1902, Description of the New York City district [New York-New Jersey]: U.S. Geol. Survey Geol. Atlas, Folio 83.

Miller, B. L., 1906, Description of the Dover quadrangle [Delaware-Maryland-New Jersey]: U.S. Geol. Survey Geol. Atlas, Folio 137.

Miller, B. L., Fraser, D. M., Miller, R. L., and others, 1941, Lehigh County, Pa., geology and geography: Pennsylvania Geol. Survey Bull. C 39, 4th ser., 492 p. 
Miller, B. L., Willard, Bradford, Fraser, D. M., and others, 1939, Northampton County, Pa., geology and geography: Pennsylvania Geol. Survey Bull. C 48, 4th ser., 495 p.

Moore, E. E., 1940, Progress report of the committee on quality tolerances of water for industrial uses: New England Water Works Assoc. Jour., v. 54, p. 263.

New York City Board of Water Supply, 1956, Fifteenth annual report, 1955: $108 \mathrm{p}$.

New York City Engineering Panel on Water Supply, 1951 Future water sources of the City of New York: $81 \mathrm{p}$.

New York State Department of Health, 1954, Public water supply data for New York State: Bull. 19, $44 \mathrm{p}$.

Nordell, Eskel, 1961, Water treatment for industrial and other uses, 2nd ed.: New York, Reinhold Publishing Corp., 598 p.

Parker, Garald G., 1955, The encroachment of salt water into fresh, in Water, the Yearbook of Agriculture: U.S. Dept. Agriculture, p. 615-635, 723.

Parker, Garald G., Ferguson, G. E., Love, S. K., and others, 1955, Water resources of southeastern Florida: U.S. Geol. Survey Water-Supply Paper 1255, 965 p.

Penck, W., [translated by Czech and Boswell] 1953, Morphological analysis of landforms: London, MacMillan and Co., $429 \mathrm{p}$.

Pennsylvania Department of Health, 1935, Final report to the Sanitary Water Board by the Bureau of Engineering on the salinity survey of the Delaware River: $75 \mathrm{p}$.

Pennsylvania Water Resources Committee, 1953, Delaware River basin report: Pennsylvania Water Resources Comm. Engineer's Study Comm., Philadelphia, 56 p.

Philadelphia Inquirer, 1957, Fairmount Park springs contaminated and unsafe: Oct. 10.

Picton, W. L., 1954, Community water supplies, inventory and adequacy: U.S. Business and Defense Services Adm., Business Inf. Service Bull. (June), 20 p.

- 1956, Summary of information on water use in the United States, 1900-75: U.S. Business and Defense Services Adm., Business Inf. Service Bull. 136 (Jan.) 6 p.

Pitkin, F. A., 1956, Correction of a fluviatile delinquent, the Schuylkill River, in Graham, J. B., and Burrill, M. F., eds., Water for Industry: Am. Assoc. Advance. Sci. Pub. 45, $131 \mathrm{p}$.

Postel, A. W., and Jaffee, H. W., 1957, Lead-alpha age determinations of zircon from the Swarthmore granodiorite and associated rocks: Pennsylvania Acad. Sci. Proc., v. 31, p. 120-123.

Powell, S. T., and Knoedler, E. L., 1956, Water supply and waste disposal, in Graham, J. B., and Burrill, M. F., eds., Water for industry: Am. Assoc. Advance Sci. Pub. 45, $131 \mathrm{p}$.

Pritchard, D. W., 1954, A study of flushing in the Delaware Model: Johns Hopkins Univ., Chesapeake Bay Inst. Tech. Rept. 7.

Rainwater, F. H., and Thatcher, L. L., 1960, Methods for collection and analysis of water samples: U.S. Geol. Survey Water-Supply Paper 1454, p. 289.

Raisz, Erwin, 1939, Map of the landforms of the United States, prepared to accompany Atwood's Physiographic Provinces of North America: Harvard Univ., Cambridge, Mass.

Rankama, Kalervo, and Sahama, Th. G., 1950, Geochemistry: Chicago, The Univ. of Chicago Press, $912 \mathrm{p}$.

Rasmussen, W. C., 1953, Periglacial frost-thaw basins in New Jersey-a discussion: Jour. Geol., v. 61, p. 473-474.

-1955, Magnitude of the ground waters of Delaware: Maryland-Delaware Water and Sewage Assoc. Proc. 28th Ann. Conf., p, 53-66.
Rasmussen, W. C., and Andreasen, G. E., 1959, Hydrologic budget of the Beaverdam Creek basin, Maryland: U.S. Geol. Survey Water-Supply Paper 1472, $106 \mathrm{p}$.

Rasmussen, W. C., Groot, J. J., and Beamer, N. H., 1958, Wells for the observation of chloride and water levels in aquifers that cross the Chesapeake and Delaware Canal: Delaware Geol. Survey Rept. 3, 22 p.

Rasmussen, W. C., Groot, J. J., and Depman, A. J., 1958, High-capacity test well developed at the Air Force Base, Dover, Del.: Delaware Geol. Survey Rept. inv. 2, 36 p.

Rasmussen, W. C., Groot, J. J., Martin, R. O. R., McCarren, E. F., Behn, V. C., and others, 1957, Water resources of northern Delaware: Delaware Geol. Survey Bull. 6, 23 p.

Rasmussen, W. C., Slaughter, T. H., Hulme, A. E., and Murphy, J. J., 1957, The water resources of Caroline, Dorchester, and Talbot Counties [Maryland]: Maryland Dept. Geol., Mines, and Water Resources Bull. 18, pl. 2.

Regional Planning Federation of the Philadelphia Tri-State District, 1932, Regional plan of the Philadelphia tri-State district: $589 \mathrm{p}$.

Richards, H. G., 1956, Geology of the Delaware valley: Pennsylvania Mineralog. Soc., Philadelphia, 106 p:

Rima, D. R., 1955, Ground-water resources of the Lansdale area, Pa.: Pennsylvania Geol. Survey Prog. Rept. 146, 24 p.

Roberts, W. J., 1957, Evaporation suppression from water surfaces: Am. Geophys. Union Trans., v. 38, no. 5, p. 740-744.

Robinson, T. W., 1958, Phreatophytes: U.S. Geol. Survey Water-Supply Paper 1423, 84 p.

Rogers, F. C., Lueder, D. R., and Obear, G. H., 1951, Passaic County: New Jersey Eng. Soil Survey Rept. 22, Rutgers Univ. Eng. Research Bull. 36, 114 p., New Brunswick.

Ruxton, B. P., and Berry, Leonard, 1957, Weathering of granite and associated erosional features in Hong Kong: Geol. Soc. America Bull., v. 68, p. 1263-1292.

Schaefer, V. J., 1956, Artificially induced precipitation and its potentialities, in W. L. Thomas, Jr., ed., Man's role in changing the face of the earth: Chicago Univ. Press, p. 607-608.

Sims, P. K., 1958, Geology and magnetite deposits of Dover district, Morris County, N.J.: U.S. Geol. Survey Prof. Paper 287, $162 \mathrm{p}$.

Smith, B. L., 1957, Summary of the Precambrian geology of the Jersey Highlands: Geol. Soc. America Guidebook, Atlantic City mtg., p. 71-76.

Smith, Samuel, 1765, History of the Colony of Nova Cesaria or New Jersey to the year 1721: Burlington, James Parker, $573 \mathrm{p}$.

Spencer, A. C., Kümmel, H. B., Wolff, J. E., Salisbury, R. D., and Palache, Charles, 1908: Description of the Franklin Furnace quadrangle [New Jersey]: U.S. Geol. Survey Geol. Atlas, Folio 161.

Swartz, C. K., and Swartz, F. M., 1931, Early Silurian formations of southeastern Pennsylvania: Geol. Soc. America Bull. v. 42, p. 621-662.

- 1941, Early Devonian and Late Silurian formations in southeastern Pennsylvania: Geol. Soc. America Bull., v. 52, p. 1129-1191.

Terenzio, V. G., 1953, Report of studies related to salinty behavior in the Delaware estuary: New York City Board of Water Supply: 
Thompson, D. G., 1928, Ground-water supplies of the Atlantic City region: New Jersey Dept. Conserv. Devel. Bull. 30, $138 \mathrm{p}$.

1930, Ground-water supplies in the vicinity of Asbury Park, N.J.: New Jersey Dept. Conserv. Devel. Bull. 35, 50 p.

Thornthwaite, C. W., 1948, An approach toward a rational classification of climate: Geogr. Rev., v. 38, p. 55-94.

- 1951, Agricultural climatology at Seabrook Farms: Weatherwise, v. 4, no. 2, Philadelphia.

Tilton, G. R., Wetherill, G.'W., Davis, G. L., and Hopson, C. A., 1958, Ages of minerals from the Baltimore gneiss near Baltimore, Md.: Geol. Soc. America Bull., v. 69, p. 14691474.

Tippetts-Abbett-McCarthy-Stratton (T-A-M-S), 1955, Survey of New Jersey water resources development: New Jersey Legislative Comm. Water Supply, 130 p.

U.S. Bureau of the Census, 1955, Water use in manufacturing: 1953 Ann. Survey Manufactures, ser. MAS 53-3, 9 p.

1956a, Counties and State economic areas, Middle Atlantic States: 1954 Census of Agriculture, v. 1, pt. 2, $618 \mathrm{p}$.

1956b, Counties and State economic areas, Delaware and Maryland: 1954 Census of Agriculture, v. 1. pt. 14, 276 p.

1957a, Industrial water use in Summary statistics: 1954 Census of Manufactures, v. 1, p. 209-1-209-52.

1957b, Energy, water, and selected supplies: 1954 Census of Mineral Industries, $19 \mathrm{p}$.

U.S. Bureau of Reclamation, 1957, Report of committee on water-quality studies with hexadecanol, Kids Lake, Oklahoma City, Okla.: Report of Comm. Collaborators, Commissioner's Office, Denver, $18 \mathrm{p}$.

U.S. Federal Power Commission, 1957, Water requirements of utility steam electric generating plants, 1954: $3 \mathrm{p}$.

I†.S. Geological Survey, 1952, Index of water-resources records in the Delaware River basin to September 30, 1951: U.S. Geol. Survey Circ. 190, 19 p.

U.S. Geological Survey, 1944-1952, Annual reports on the quality of surface waters of the United States, Delaware River basin: U.S. Geol. Surv. Water Supply Papers 1022 p. 13-15, 1030 p. 15-33, 1050 p. 14-36, 1102 p. 22-43, 1132 p. $22-95,1162$ p. $21-96,1186$ p. $22-94,1197$ p. $21-97,1250$ p. $24-79,1290$, p. $42-81$.

[.S. Geologica] Survey, 1960, Compilation of surface waters of the United States through September, 1950: U.S. Geol. Survey Water-Supply Paper 1302, p. 231-352.
U.S. Public Health Service, 1946, Drinking water standards: Public Health repts., v. 61, No. 11 (reprint 2697); Am. Water Works Assoc. Jour., v. 38, p. 361.

- 1955, Inventory of municipal water facilities for larger communities, 1954 revised.

1957. Municipal water facilities for communities of 25,000 population and over, continental United States and territorial possessions, as of December 31, 1956: $163 \mathrm{p}$.

U.S. Salinity Laboratory Staff, Richards, L. A., ed., 1954, Diagnosis and improvement of saline and alkali soils: U.S. Dept. Agriculture Handb. 60, 160 p.

Upson, J. E., 1949, Late Pleistocene and Recent changes of sea level along the coast of Santa Barbara County, Calif.: Am. Jour. Sci., v. 247, p. 94-115.

Ward, R. F., 1956, The geology of the Wissahickon formation in Delaware: U.S. Geol. Survey open-file report, $59 \mathrm{p}$.

Waterways Experiment Station, 1952, Effects of proposed channel enlargement between Philadelphia and Trenton in: Delaware River Model Study Report 3, U.S. Corps of Engineers, Waterways Experiment Station Tech. Memo. 2-337, Vicksburg, Miss., 14 p.

1956, Hydraulic and salinity verification in: Delaware River Model Study Report 1, U.S. Corps of Engineers, Waterways Experiment Station Tech. Memo. 2-337, Vicksburg, Miss., 25 p.

Watson, E. H., 1957, Crystalline rocks of the Philadelphia area: Geol. Soc. America Guidebook, Atlantic City meeting, p. $153-180$.

Watson, J. F., 1850, Annals of Philadelphia and Pennsylvania in the olden time, vol 2: Philadelphia, J. F. Watson.

Weller, S., 1900: New Jersey Geol. Survey Ann. Rept. 1899, p. $1-46$.

Wherry, E. T., 1909, The early Paleozoic at the Lehigh Valley district, Pennsylvania: Science, new series, v. 30, p. 416

White, I. C., 1881, The geology of Susquehanna County and Wayne County: 2nd Pennsylvania Geol. Survey Rept. $\mathrm{G}_{5}$ p. 68,115 .

Wilcox, L. V., 1955, Classification and use of irrigation waters: U.S. Dept. Agriculture Circ. 969, 19 p.

Willard, Bradford, 1935, Hamilton Group along the Allegheny Front, Pa.: Geol. Soc. America Bull., v. 46, no. 8, p. $1276-1290$.

- 1936, in Chadwick, G. H., History and value of the name "Catskill" in geology: New York State Mus. Bull. 307, p. 74.

Willard, Bradford, Swartz, F. M., and Cleaves, A. B., 1939, The Devonian of Pennsylvania: Pennsylvania Geol. Survey, Bull. G19, 4th ser., 481 p. 
.

.

. 


\section{INDEX}

[Italic page numbers indicate major references]

\begin{abstract}
$\begin{array}{ccr}\text { A } & \text { Page } \\ & 110\end{array}$ Abstract

Acetone cyanhydrin....................... 157

Acid mine water............... 10, $56,37,81,140,145,146$

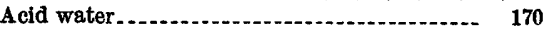

Acknowledgments..............

Aerobic bacteria.......... 35

Agricultural areas............ 6

Agricultural water supplies_................... 169

Agricultural wastes..................... $\$ 5,63,159$

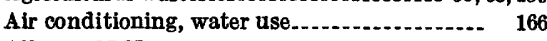

Albany, N.Y.................................... 16

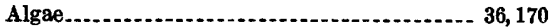

Allegheny formation. 81

Allentown, $\mathrm{Pa} . . . . . . . . . . . . . . . ~ 7,19,22,87,88,138,164$

Allowable draft............. 133, 180

Alluvium....................... 65
\end{abstract}

Anaerobic decomposition ...................... 38

Analysis of flow, Delaware River at Montague,

N.J.............................. 183

Ancora, N.J. ....................... 62

Anthracite and quality of water........... 140

Antietam quartzite

Appalachian Highlands _. _ 5, 22, 70, 83, 88, 93, 171, 181

ground water in . . .

runoff from............................. 112

water budget.

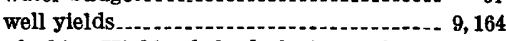

Appalachian Highlands hydrologic province.. $\quad 41$

Appalachian Plateaus physiographic prov-

ince.................. 41, 70, 71

Aqueducts...................................... 12

Aquicludes, defined..... 39

head losses through...................... 173

movement of water through............. 48

permeability of ............................. 49,60

Aquifer development and management _. $92,172,173$

Aquifer recharge................ 69, 70, 92, 170, 173

Aquifer restoration . . ........................ 177

Aquifer-stream relationships............. 138, 170, 173

A quifer tests . . ................... 49, 52, 60, 62, 86, 173

Aquifers, consolidated rocks as............. 71 contaminated by river water............. 170 crystalline rocks....................... functions............................. 38, 42, 71, 72 major group in Coastal Plain............. 48 physical characteristics............... 39 pollution of......................... $10,52,54,170$ salt water flushed from................... 42 types.

Aquifers and aquicludes above the Merchantville and Woodbury clays........- 54

Argillite . . . . . .

Arid regions. .................................. 12, 171

Arkansas........................................... 174

Arkose.................... 83, 84

Arsenic, allowable in drinking water.......... 168

Artesian aquifers...................... $\$ 8,48,62,69,90$

Artesian wells .............................. 82, 86

Artificial discharge from aquifers.............. 68

Artiflcial recharge............. 34, 70, 83, 173, 174, 178

Asbury Park, N.J., salt-water encroachment__ $\quad 99$

Assunpink Creek, N.J........................ 126

Atlantic City, N.J................. 42

$54,56,58,60,62,69,99,153,157,179$

Atlantic County, N.J....................... 60,63

Atlantic Plain hydrologic province.
Page

Augmentation of ground-water supplies _ _ 34, 91, 17 s Augmentation of low flows.........., 171, 177, 179, 180 A vailable water supply versus demand....... 180

Baltimore, Md B

Barksdale, H. C., and Remson, Irwin, quoted.................... 33, 174

Basalt and diabase of Triassic age

Base flow, streams.......... 66, 67, 74, 78, 103, 134, 136

Base-flow data, uses........................... $\quad 196$

Base-flow recession curves...................... $\quad 195$

Base runoft.

Basher Kill, N.Y

Basin-rim sand.

Beach and dune sands

Beacon Hill Gravel

Beaverdam Creek, Md..... 66, 70

Becraft limestone............................ 77

Bed load of streams. . . .

Bedrock surface beneath Coastal Plain....... 5, 53

Bergen County, N.J...................... 87

Berne, Pa. ....................... 37, 140, 146, 160

Bethlehem, Pa......... 8, 22, 127, 164

Bethlehem Steel Co........................ 175

Bibliography ................................. 189

Biochemical oxygen demand ............... 35, 157

Bloomsburg red beds............................ 80

Blue Mountain

Blue Mountain ridge................ 77

Boiler-feed water.................................. 169

Boron in irrigation water.

Bossardsville limestone........................ $\quad 77$

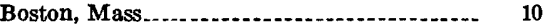

Brackish-water use...................... 160, 170, 181

Bradley Beach, N.J.

Brandywine Creek. ......... 115, 137, 159, 160, 177, 181

Brandywine Valley Association . . ............ 160

Bridgeton, N.J.

Bridgeton formation................... 62, 64, 65, 88

Bristol, Pa......... 157

Brookhaven, Long Island, N.Y.

Browntown, N.J.

Brunswick formation ........................ 83, 86, 93

Bryn Mawr Gravel .............................. 63

Bucks County, $\mathrm{Pa}$. . . .

Burlington County, N.J............ 63, 68, 164, 167

Byram granite gneiss...

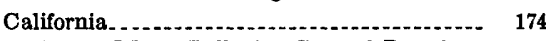

California Water Pollution Control Board.- 150, 169

Cambrian rocks. .............................. 77,79

Camden, N.J......... 6, 49, 52, 103, 173, 174, 179, 181 Camden County, N.J. .................. 58, 164, 167 Canals or drainage facilities, effects........... 98

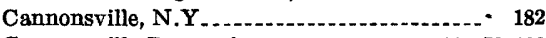
Cannonsville Reservoir $\ldots . . . \ldots \ldots . . . . . . .11,179,183$ Cape Henlopen, Del......................... 42, 99

Cape May, N.J . Cape May County, N.J._........ 60, 62, 63, 65, 99 Cape May formation................ 62, 64, 65, 66, 88

Capes, The

Carbon County, $\mathbf{P a}$.

Carbonate rocks

hydrology of...

Carbonation, deffned
Catasauqua, Pa. ............... 141, 145, 146, 149, 158 Cation exchange...

Catskill formation ............. 80, 81, 82, 93

Catskill Mountains.................. 6,11, 103, 175 precipitation . ............... 15 base-flow recession curves................. 136, 138 water losses.............................. 22 Catskill section, Appalachian Plateaus province.

Catskill water system, New York City....... 181 Cedar Creek basin........................ 110 Chadd's Ford, Pa........................ 115, 137

Charles River, Boston, Mass................. 178

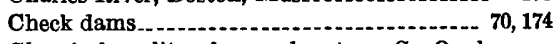

Chemical quality of ground water. See Quality of ground water.

Chesapeake and Delaware Canal......... 56, 95, 178 Chester, Pa_......... 151, 152, 153, 156, 157, 173, 179 water supply .......... 11, 12,154, 161, 163, 165, 170 Chester County, Pa.......................... 95

Chester Municipal Authority............... 161, 163 Chester Valley . . ........ 70,73

Cheswold, Del

Cheswold aquifer....................... 62, 164, 174

Chickies quartzite............................. 73, 76

Chloride, Kirkwood formation............ 99 allowable in drinking water............... 168 Christina River, Del. . . Chromium, allowable in drinking water.....- 168

Clastic rocks. . ........................... 40, 72, 79 Clay, head-losses through Climate of the area............................ 6 Climatic year, defined........................ 129

Clinton formation.

Cloud seoding .

Coal-mining region................... 6

Coastal Plain ......... $62,64,66,67,68,69,88,138,171,180,181$ bedrock surface beneath............... 5 chemical character of ground water....... ground-water outflow .................. 22, 67, 112 potential ground-water supply ............ 67 ground-water withdrawals............... 164 recoverable ground water................. 67 runoff from water stored........ 5,62 Cockeysville marble.................... 73, 76, 77,79 Coefficient of permeability ......... 39, 49,62, 63, 75, 84 Coefficient of storage.............. 39, 49, 62, 63, 75, 78 Coefficient of transmissibility ......... $39,62,63,75,81$ Coefficient of variation. . . ................. 16, 18, 112 Coeymans limestone Cohansey River basin.......................... 111 Cohansey sand..... 47, 48, 60, 62, 68, 93, 98, 99, 164, 180 Colorado River (Ariz. and Nev.) .............- 171 Condensers, use of water for cooling.......... 166 Conductance................................... 146

Conductivity, electrical.................... 199

Conestoga limestone.......................... 79

Conglomerate and sandstone aquifers......... $\quad 80$

Connate water................................. 95

Connecticut.................. 91

Conochocheague limestone . . . . .

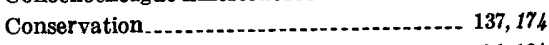

Consolidated rocks. . ........................... 71, 164

Consumptive use of water........... 12, 164, 167, 180 maximum-use day - 
Page

Contamination of water-

Continental Shelf

Conversion of brackish water............... 179, 181

Conversion of sea water........................ 179

Cooling systems................. 139, 165, 170, 174, 175 Copper, allowable in drinking water Copper in irr igation water .................... 170

Corrosion of pipes.

Cretaceous period........................... 42

Croton water system $\ldots . . \ldots \ldots \ldots \ldots \ldots \ldots \ldots \ldots$

Crystalline rocks. .................. 40,72,75

Culbertson, James K.................... 159

Culm

Cumberland County, N.J._.......... 60,63, 164, 167

Cyanide in streamflow

D

Dams for induced recharge _.................. 174

Data, deficiencies................................ 19

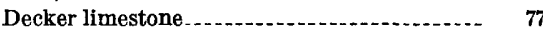

Deflocculation of soils. ................... 170

Delaware $\ldots . .52,54,56,60,62$, $64,65,66,69,95,99,163,174,181,182$

aquifer tests........................... 49,52 lower, middle, and upper aquifers........ 49

Delaware and Raritan Canal ....... 11, 161, 163, 165, $179,180,184,187$

Delaware Aqueduct......................... 184

Delaware Bay ............................ 68, 99, 151

climate................................... 6

depth to bedrock below $\ldots$

formation of........................... 41

hurricane winds.......................... 156

salinity................................... 6

water losses............................. 22

Delaware City, Del....................... 99, 174

Delaware County, N.Y.................. 88

Delaware County, $\mathrm{Pa}_{2} \ldots \ldots \ldots \ldots$

Delaware estuary ........... 41, 67, 68, 95, 150, 151, 157,

$161,164,173,177,178,180,187$

flushing time.......................... 152 tides

Delaware Memorial Bridge ................... 152

Delaware River -............. 80, 84, 85, 99, 104, 126, $127,146,152,157,159,164,170,173,177$ augmentation of low flows...... 171, 177, 179, 180 contamination of ................. 52,60

effect of reservoir regulation............... 184 gaging stations:

at Chester, $\mathrm{Pa}$

at Easton, $\mathrm{Pa}$

at Montague, N.J............... 136, 183, 184

at Port Jervis, N.Y

at Trenton, N.J.

$146,149,158,159,160,180$

at Wilmington, Del_.............. 104 geologic reasons for present course.......... $\quad 42$

lower course................................. 6 navigation regulation of flows......................... 1184

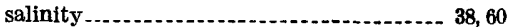
salt from sewage ....................... 36 tides

Delaware River basin........... 65, 67, 111, 161, 163 consumptive water use $\ldots . . . . . . . . .167$ dissolved solids load....................... 143 general description

isohyets.

年- 15

precipitation................................ 103

stream flow

stratigraphic section........................ 44

total surface storage capacity.............. 171

water budget_........................... 14, 66,67

water diverted from and into...............

water losses........................... $\quad 22$

Delaware River case, historical background ... 181

Delaware River Master..................... 136, 183

Delaware River Master Advisory Committee_ 183

Delaware River.model, Corps of Engineers... 157
Page

Delaware River region, water problems..... 4, 8, 181 Delaware River water-service area Delaware River water system for New York$$
\text { City }
$$

181

Delaware State water laws.................... 12

Delaware Water Gap...................... 71, 80, 140

Delhi, N.Y

Deposits of Pleistocene age, unclassified...... 64

Desilting basins.............................. 37, 159

Developing and protecting water supplies.... 171

Devonian rocks............................... $\quad 77$

Diabase, water quality in ................... 76

Dilution of wastes. ......................... 31,180

Dip of formations in the Coastal Plain....... 42

Direct runoff .............. 31, 103, 136

Discharge, defined . . ....................... 103 variability of daily _................... 11 \% ground water

Dissolved carbon dioxide ..................... 35

Dissolved oxygen ......................... 34, 37, 157

Dissolved solids, average for basin ............. 143 composition . 146 effect on electrical conductivity _._._._._. 199 Schuylkill River...................... 37

Dissolved solids as load of streams ............. 141

Dissolved-solids concentrations, dally variations. .

effect of stream flow

144
140

range 140

seasonal variation $\ldots$

Diversions of water, effects on streamfiow .... 119 equivalent to consumptive use _. . . . . . . 12, 164 inter basin . . ..................... 6, 11, 12, $14,161,163,167,171,179,182,184,187$

Double-mass analyses. .................. 16, 109 Dover, Del ............................. 7, 99, 174 Dover Air Force Base, Del...

Drainage inducing salt-water encroachment _. $\quad 65$ Drainage from mines. See Acid mine water.

Dredging............................... 38, 99, 159, 173 Drinking water standards .................. 149, 168 Droughts ...................... 6, 19, 69, 84, 129 Duration curves........................... 144, 145 Dust bowl of the Great Plains...... $\quad 19$

\section{E}

East Branch Delaware River... 115, 119, 180, 181, 182 Easton, $\mathrm{Pa} \ldots \ldots .140,143,145,146,164$ Economic factors, water crop ................ 32 Eddystone, $\mathrm{Pa}$. ...................... 158 “800-foot" sand, Atlantic City, N.J _....... 62,69, 99 Electrical conductivity of water.............. 139 Elizabeth River basin ................... 110 Englishtown sand.................. 42, 54, 55, 58, 68 Environment of the Delaware River Basin ... \& Erosion ....................... 37, 41, 70, 74, 159, 177 of coal-mine wastes............... 10

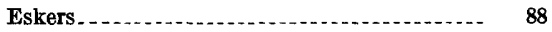

Esopus shale ....................... 77, 81 Evaporation, Blue Mountain . computation ....................... 13 from free water surfaces . ....... $22,23,24,104,133$ from industrial uses . . . . . . . . . . . . . . . . . $\quad 166$ from land surfaces .......................... 133 Kittatinny Mountain .................. 23 See also Evapotranspiration.

Evaporation suppressants.

Evapotranspiration ......... 7, 9, 14, 21, 22, 39, 48, $65,66,70,115,137,164,167,169,177$

Everglades, Fla ......................... 66

\section{F}

Fairmount Park, Philadelphia, pollution of springs ......................... 76

Fall Line............................ $6,41,42,70,181$ Farm ponds. Faults, ground water in . ............. 82

Feldspars, hydrolosis of......................

Fish and wildlife . . . ...................... 31, 171
Page

115,119

Five-year moving average .................... 113

Flood control.............................. 128

Flood-control reservoirs . . . . . . . . . . . . . . . 129

Flood-control storage

Flood damage ............................... 128

Flood-frequency analysis ....... $122,123,124,126,127$

Flood-frequency curves, construction $\quad 126$

Flood-frequency relationships............... 126

Flood hazards....................... 11, 12

Flood heights, Delaware River................ 127

Flood plains city zoning -................................. 128

Flood, 20-year-............-............-... 124

Floods, August, 1955................. 8, 15, 127, 128 causes and occurrence....................- 122 Feb., 1692 Feb., 1902_.............................. 127

general_..................................... 128 historical_............................... 127 hydrometeorology

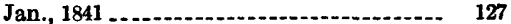
June, 1862 ............................. 127 Mar., 1904 ............................... 21, 127

May, 1942 mean annual versus size of drainage basin.. 124

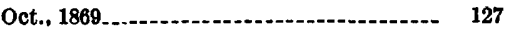
1903 . “project”-................................ 128 rare .................................... 127

recurrence interval...................... 123, 124

Sept., $1850 \ldots$ 1940

Florida...............

7119,120

Flow-duration curves

Flow-frequency curves_...................... 129, 130

Fluoride_................................ $52,168,169,170$

Flushing time, Delaware estuary ............... 152

Flushing the Delaware estuary.............. 177, 180

Fluvial sediment in surface waters............. $\quad 159$

Foaming of boiler water..................... 169

Folsom, N.J.

Fractures in clastic rocks................ 80, 81, 84, 86

Fractures in crystalline rocks.................. 74,77

Franklin limestone......................... 73, 76

Frederica aquifer........................... 62, 164, 174

Frequency curves........................... 126

Frequency-mass curves........................... 133

Fresh water beyond shoreline............... 60, 69, 99

Fresh water from the sea....................... 178

Fresh-water-salt-water interface_.......... 68, 99, 151

Funnel effect, defined.

G

General features, Appalachian Highlands..... Coastal Plain

Delaware River Basin

Geologic cross sections, major streams, Delaware River basin.

Geologic effects on streamflow

Geology, Beacon Hill Gravel

Cape May formation

Cohansey sand.

Englishtown sand..

Hornerstown marl

Kirkwood formation

Manasquan marl

Marshalltown formation

Merchantville clay.

Mount Laurel sand

Navesink marl.

nonmarine sediments of Cretaceous age.

Piney Point formation

Red Bank sand.

Shark River marl.

Talbot formation

Vincentown sand

Wenonah sand.

Woodbury clay

70
41
4
89
.137
63
65
62
54
58
62
60
54
52
56
56
49
60
58
60
65
58
56
54




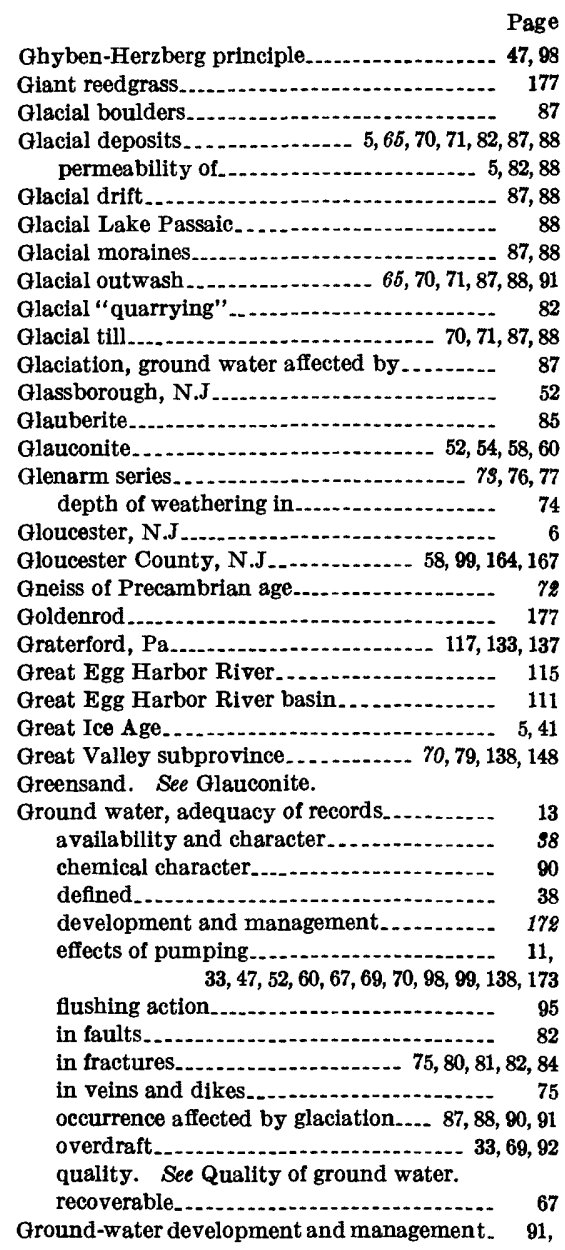

92, 17\%

Ground-water discharge.............. 66,90, 91, 112 Ground-water divide....................... 112 Ground-water flow bypassing gaging stations. 112 Ground-water hydrology, Delaware River basin Ground-water inflow and outflow Ground-water laws........................... 12 Ground-water movement, aquifers....... $\$ 8,53,69,85$

Coastal Plain aquifers Ground-water occurrences, Coastal Plain.- 42, 69, 99 Ground-water recharge......... 66, 67, 90, 91, 172, 173 Ground-water storage. aquifers in the Appalachian Highlands ... 74,91 Coastal Plain............................. 69 Ground-water supplies, augmentation ........ 179 Ground water-surface water relationships..... 138, 170,173 Ground-water temperatures................. 175 Ground-water waste............................ 176 Ground-water withdrawals_................... 168 Growing season................................. 112

H

Hackensack River basin.................. $\quad 110$ Hamilton group ............................. 82

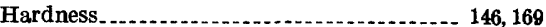
Hardness of surface water, range........... $\quad 140$ "Hard-rock" aquifers.......................... 40, 74 Hard rocks. See Crystalline rocks. Hardystone quartzite........................... 73 Harpers schist.................................. 73 Hawley, $\mathrm{Pa} \ldots \ldots \ldots \ldots$ Hexadecanol................................... 176 High-water mark, defined................... 127
Historical background of the Delaware River

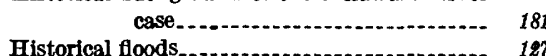

Hornerstown marl

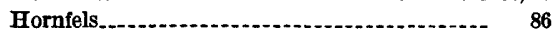

Hudson River. 74,178

Hudson River basin __ 4, 110, 161, 163

Hurricanes $\quad 6,15,20,122,152,156,159$

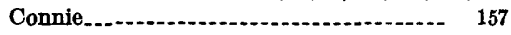
Connie and Diane.................. 15, 19, 21, 128

Edna - 156 Hazel ............................................. 156, 157

Hurricane winds, directions of............... 156

Hydroelectric power, effects on streamflow . . $\quad 171$

Hydrologic cycle . .......................... 19, 14

Hydrologic properties, carbonate rocks ....... $\quad 7 \gamma$ crystalline rocks.............................- $\quad \gamma_{4}$

Cohansey sand

Englishtown sand

Kirkwood formation.

Marshalitown form

Mount Laurel sand.

Navesink marl

Piney Point formation

Red Bank sand.

Shark River marl

Vincentown sand

Wenonah sand...

Hydrologic provinces, Delaware River basin

Hydrolysis, defined

Hydrometeorology of floods, Delaware River basin.

Hydroelectric plants .

Hydroelectric power........................... 32,160

\section{I}

Ice jams. 21,122

Igneous rocks 72

Illinoian glacial stage

Importance, Delaware River basin

Impurities from atmosphere

from rocks and soils

in rainwater

INCODEL

Increasing and protecting water crop.

Increasing total fresh-water supply........... 178

Induced precipitation....................... 178

Induced recharge............. $65,67,69,70,00,91,173$ Industrial use of ground water.... $63,70,139,165,175$ Industrial water requirements ............... 175

Industríal wastes... 10, 34, $\$ 5,99,103,157,159,169,170$ Industrial water supplies........ 161, 163, 164, 165, 175 Industry.

6,9

Infiltration canals. ..... 70, 174

Infiltration capacity of soil............... \$4, 174

Inflitration rates.................... 33, 173, 174, 176

Inflow to a hydrologic basin.................. 14

Input wells................ 70,174

Interbasin diversion. See Diversions of water.

Interbedded sandstone and shale aquifers....- 80

Intermittent streamflow........................ 112

Interstate Commission on the Delaware River Basin.

Introduction.

182

Ion exchange............................ 35, 95, 170

Iron in natural waters........................ 169 allowable in drinking water.............. 163

Iron sulfide and quality of water ............ 140

Irrigation..... $9,10,63,69,70,163,164,167,169,170,181$ water losses from......................... 9, 167 Irrigation water, classification............ 170 Isohyetal maps, use of ................ 14, 15 Isohyets..................... 111

Jacksonburg limestone 77,78 “Jerseyan" glacial stage . ................... 87 Jordan Creek, $\mathrm{Pa}$. .
$\mathbf{K}$

Page

Kame-terrace deposits................ 8, 88, 90

Kames . ..... 88

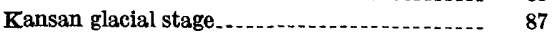

Kent County, Del . .

Kids Lake . . ........... 176

Kingston, N.J............... 187

Kirkwood formation . ....... 47, 54, 58, 60, 69, 93, 98, 99

Kittatinny Mountains, See Blue Mountain.

$\mathbf{I}$

Lackawaxen River . . . .

Lake Hefner, Okla.......................... 23

Lake Mead, Nev.-Ariz _................... 171

Lake Wallenpaupack, $\mathbf{P a} \ldots$

Land-use practices............ 33, 137, 160, 173, 176, 177

Lansdale, $\mathbf{P a} \ldots \ldots$

Lead, allowable in drinking water........... 168

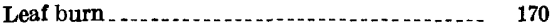

Leaks from water distribution systems . . . ... $\quad 175$

Leaky aquifers and aquicludes............... $\quad 68$

Iegal factors, water crop................... $\quad 32$

Lehigh County, $\mathbf{P a} \ldots \ldots$

Lehigh River............................... $8,71,115,126,127,141,145,146,149,158$, $160,161,164,180$.

Leipsic River basin . .

Levees. . . . . . . . . . . . .

Lewes, Del., salt-water encroachment. . . . . 66, 98, 99

Lewes-Rehoboth Canal, Del................. 98

Limestone aquifers, water losses from......... $\quad 22$

Linwood, N.J ..... 63

Liston Point, N.J.

Little Beaver Kill, N.Y

Little Lehigh Creek, $\mathrm{Pa}$

Livingston, N.Y............. 136

Loads . . . . . .

Lockatong formation................... 83, 85, 93

Long Branch, N.J........ 60

Long Island, N.Y .................... 12, 67, 174, 175

Long-term records of precipitation

Loper Run, N.J .

Losee diorite gneiss........................ 73

Louisvilte, $\mathrm{Ky}$

Low-flow frequency analyses.............. 129

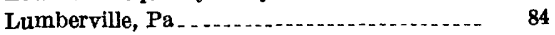

\section{M}

Madison, N.J _...

Magnesium, allowable in drinking water ..... 168

Magothy formation ............ 48, 52, 68, 164, 174, 178

Mahantango formation of Willard........ 80

Mahwah, N.J .............. 115

Maiden Creek, $\mathrm{Pa} \ldots \ldots$

Manasquan, N.J ................. 99

Manasquan marl................. 60

Manasquan River basin ................... 110

Manayunk, $\mathrm{Pa}$............................. 159

Manganese, allowable in drinking water...... 168

in natural waters. .................... 169

Manlius limestone

Mantua Creek, N.J . . . . . . . 127

Marcellus shale . . .

Marcus Hook, $\mathrm{Pa} \ldots \ldots \ldots \ldots \ldots \ldots \ldots$ 6, 152, 153, 157, 158

Marsh and swamp deposits . .............. 65

Marshalltown formation . .

Martinsburg shale_....................... 79,93

Matawan Creek basin..................... $\quad 110$

Mauch Chunk formation ................. 81

Maurice River, N.J . . . . . . . . . . . 117, 120, 133

Maurice River basin . ...................... 111

Maximum daily water use versus low flow of streams

Mean annual flood . ..................... 124,126

Mean annual flood versus size of drainage basin............................. 124

Merchantville Clay ........ 58,68

Metamorphic rocks $\ldots . . \ldots \ldots \ldots$

Miami, Fla................. 178

Miami River, Fla. .......... 178 
Page

Middlesex County, N.J . . . . . . . . . . . . . . . . . 49, 161 Middletown, N.Y.......................... 22

Milford, Del

Milford, Pa... . . .

Mine drainage . ...................... $\$ 6,169$

Mining of ground water. .................... 34,69

Mining effect on sediment load of streams . ... $\quad 160$

Molybdenum in irrigation water . . . . . . ...... 170

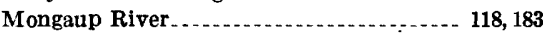

Monmouth County, N.J $\ldots \ldots \ldots$ 54, 58,60,63

Montague, N.J .................. 183, 184

Montague Formula .

Morristown, N.J

Morro Phillips tract aquifer test.............. 173

Mount Laurel sand . . . . . . . . . . . . . . . . . 54,56

Movement of ground water, Coastal Plain aquifers....................... 68

general . . . . . . . . . Mullica River basin . ... . . Multiple-purpose reservoirs Municipal wastes...................... $\$ 5,157,175$ Municipal water supplies: ....... $63,163,165,167,168$ Musconetcong River, N.J ................... 126

\section{N}

Natural flow pattern in aquifers, theoretical - $\quad 68$ Natural storage, runoff from.................. 136

Navesink marl . . ......................... . . 56, 58, 62 Navesink River basin . .......... 110 Navigation ........................ 31, 38, 177 Neversink Reservoir, N.Y ...... 171, 177, 182, 183, 184 Neversink River. . . . . . . . 92, 117, 126, 131, 180, 181, 182 Newark, N.J . . . . . . . . . . . . 95,99 Newark group.......... Newark, N.J., salt-water encroachment...... . 99 New Brunswick, N.J................ 187 New Castle County, Del................ 164, 165, 167 New England physiographic province...... 41,70 New England Upland subprovinces .......... 70,72 New Jersey _ . . . . . . . . . 12, $52,54,56,60,62,66,69$ $95,99,126,163,174,176,179,180,181,182$

aquifer tests . . . . . . . . . . . . . . . . . steamflow ................... 104

State water laws......................... 12

New Scotland limestone.................... 77

Newton, N.J .................. 19

New York City, N.Y _ 16, 163, 171, 178, 179, 180, 182

New York City Board of Water Supply ...... 182

New York City water supply............... 6 $11,19,161,165,168,172,175,181$

New York City water-supply tunnels . . ...... 82

New York metropolitan area

New York (State) ..................... 136, 163, 182

New York State water laws. . .............. 12

Nitrate contamination

Nitrate, effects on animals...................... $\quad 170$

Nonmarine sediments of Cretaceous age ..... 48 ,

$68,69,99$

$\begin{array}{ll}\text { Northampton County, } \mathrm{Pa}_{1} \ldots \ldots \ldots & 120\end{array}$

Northeasters . . . . . .

O

Occurrence of ground water, Appalachian Highlands....................... 71

general_... 38

Ocean County, N.J. . . . . $\ldots \ldots \ldots \ldots \ldots \ldots .54,58,63,68$

Ocean water, characteristics of. ....... 95,150

Octodecanol................................ $\quad 176$

Octoraro Creek .................. 12, 161, 163, 165, 170

Odessa, Del ................................. 99

Offishore sandbars............................. 42

Oklahoma City, Okla .......... 176

Old Bridge sand member.................... 174

“100-foot”' sand, Atlantic City, N.J........ 99

Onondaga limestone....................... 77,81

Orange County, N.Y., water losses........... 22

Ordovician rocks. .............. 77,79
Organic sediments............. Page

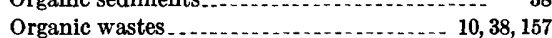
Oriskany sandstone . . . . . . . .

Outcrop belts in the Coastal Plain ............ 41

Outflow from a hydrologic basin ............. 14

Outpost wells, to detect contamination ....... 178

Overdraft of ground water................ 33, 70

Oxidation, defined............ 35

Oxidation of wastes......................... 38

Paleozoic rocks, water-bearing qualities.......

Palisades.......... 74

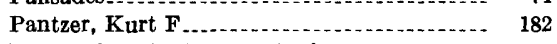

Passaic County, N.J., water losses............ 22

Passaic River

Passaic River basin ......................... 110

Patapsco formation........ 48

Patuxent formation................. 48, 174

Paulsen, Carl G.......................... 183

Pegmatite veins and ground water........ 74,75

Penns Grove, N.J., salt-water encroachment . - 99

Pennsylvania _............ 13, 49, 52, 78, 79, 163, 181, 182 aquifer tests.......................... 49,52

Pennsylvania Topographic and Geological Survey

Pennsylvania Water and Power Resources Board .

Pennsylvania well-drillers licensing

Pennsylvania State water laws

Pennsylvanian rocks.................... 79

Pensauken formation .................. 64,65, 88

Pepacton Reservoir, N.Y .... 33, 171, 177, 182, 183, 184

Pequest River basin, water losses.............. 22

Per captia use of water................... 161, 165, 168

Perkiomen Creek, $\mathrm{Pa} \ldots \ldots \ldots \ldots$ 117, 133, 137

Permeability, aquifers............. 39, 54, 60, 62, 84, 88 directional.

Perth Amboy, N.J . .

Perth Amboy, N J., salt-water encroachment $\quad 99$

Peters Creek schist.

Petroleum plant water requirement. .......... 175

$p$ H in drinking water............ 169

$p H$ of mine drainage........................ $\quad 37$

Phenols, allocable in drinking water........ 168

Philadelphia, Pa., climate................ 7,8,16

salt-water at............... 10,36,38, 95, 150, 152

Philadelphia County, $\mathrm{Pa} \ldots \ldots+\ldots$

Philadelphia metropolitan area, water use ..... 4, 165

Philadelphia metropolitan area and city .... 4, $6,52,119,140,145,146,156,157,159,161$, $170,173,174,175,179$

Philadelphia municipal supply $\ldots . . . . . \ldots . . .163,165$ Phreatophytes....... effect on water crop.....

Physical quality of surface waters. . . .......... 158

Pickering gneiss.

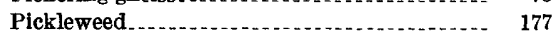

Pledmont Lowland......................... 70

Piedmont physiographic province ......... 41, 70

Piedmont Upland ...................... 70, 72, 137

Piezometric surface, defined. 39

Pine Barrens ........................ 6, 177, 180, 181

Piney Point formation...................... 60,164

Pipersville, $\mathbf{P a} \ldots \ldots \ldots \ldots$

Pitman, N.J.

Pleasantville, N.J.

Pleistocene epoch; continental glaciers........ 5

Pleistocene high-level seas...................... 95

Pleistocene Period............................ 5, 64

Pochuck gabbro gneiss...................... 73

Pocono formation. ........... 80, 82

Pocono Mountains _............... 6, 71

Point Pleasant, N.J........................... 99

Political factors, water crop.................... $\quad 32$

Pollution...................................... 148

Pollution Control Board, California........... 150
Page

Pollution, Delaware River estuary ........-..- $\quad 167$ in limestone aquifers. ................ 10, 93 South Philadelphia, Pa...............103, 177 springs......................... 76 streams and aquifers................. 10, 52, 76, 99 Pomperaug River basin, Connecticut......... 91

Ponds_...-............... 33, 128, 174

Population and per capita use of water....... 168

Population growth.......................... 8, 9, 168

Population of the region............. 6, 8

Population, urban versus rural............... $\quad 8,9$

Porosity, defined.................. $\quad 39$ clastic rocks. ............. 84 crystalline rocks........................... 74

Port Ewen limestone......... 77

Port Jervis, N.Y............................ 118, 182

Portage group................................. 80, 81

Potential evapotranspiration. ............... 7

Pottstown, Pa........................ 119, 140, 145, 146

Pottsville formation.

Poxono Island shale of White

Precambrian rocks, water-bearing qualities... $\quad 75$

Precipitation, Albany, N.Y.............. 16

average annual for Delaware River basin_ $\quad 103$

Baltimore, Md.......................... 16

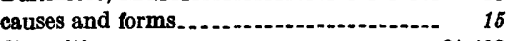

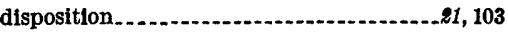

long-term records........................ 13,16,17

New York City, N.Y.................. 16

Philadelphla, Pa........................... 16

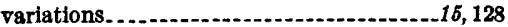

Precipitation and Gaussian curve............. 16

Preclpitation and hurricanes................. 157

President's Advisory Committee on Weather Control, quoted.................. 178

Process water use..................................... 166

"Project" floods.................. 127

Protection of water quality .................... $\quad \mathbf{1 7 7}$

Public water supplies, methods of treatment.. 168

Pumping of ground water, effects...........- 11, $33,47,48,52,60,65,67,69,70,86,88,99$, $170,173$.

Pumping tests....

Pyrite, polluting mine drainage................. 36

Q

Quality of grouud water, Appalachian crystaline rocks

Appalachian Highlands

Brunswick formation.

carbonate rocks....

Catskill formation

Coastal Plain.

Cohansey sand.

crystalline rocks...

Englishtown sand

Kirkwood formation

Lockatong formation

Marcellus shale...

Martinsburg shale.

Merchantville clay.

Mount Laurel sand

nonmarine sediments of Cretaceous age

Quaternary deposits.

unconsolidated glacial sediments..........- 90

Vincentown sand....................... 60, 93

Wenonah sand .......................... 56

Wissahickon formation. ................. 93

Woodbury clay $\quad 52$

Quality of surface water, daily variation..... $\quad 149$

Delaware estuary .................... 150,151

general . _ . . . . . . .

Quality of water, adequacy of data ......... 13

factors affecting .......... 9, \$4, 140

Quality of water resources, protection ......... 177

Quality of water standards, U.S. Public

Health service................... 149, 169

Quantity and distribution of the water crop.. $\quad$ s1 


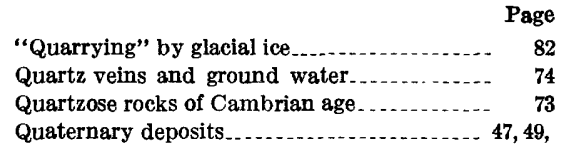
$52,60,62,63,64,66,68,98,99,164,180$

\section{$\mathbf{R}$}

Radioactive wastes...................... 157

Rahway River basin ........... 110

Ramapo River-... 115

Raritan Bay ......... 41,49,68

Raritan formation ...... 48, 49, 52, 68, 164, 173, 174, 178

Raritan River....................... 49, 68, 69, 187

Raritan River basin 4,110

Raven Rock, N.J ................... 187

Reading, Pa_............... 10, 37, 70, 127

Reading prong

Recent storage

Recession curves ........................... 136

Recharge and discharge, Appalachian High-

Coastal Plain 52,66

Recharge by sprinkling

Recirculation of industrial water...... 166

Reclaiming phreatophyte-wasted water...... 177

Recreational uses of water............. 9,31

Recurrence interval of fioods.......... 123, 124, 129

Red Bank sand..... 42, 56, 58

Reeds.............. 177

Reedy Island Jetty . . . . . . . . . . . . . . . . 152, 155

Reedy Point, Del . .......... 152

Regionalized fiood-frequency analyses. ....... 123

Regionalized fiow duration curves . . . ..... 117, 120

Rehoboth Beach, Del., salt-water encroachment...

Relation of quality of water to use requirements........ 168

Reservoir sites

Reservoirs...................... 10, 128, 129, 171, 184

sedimentation of ................... 10, 13, 33

evaporation losses ........................ 104, 133

seepage losses.................................... 104

multiple-purpose...................... 171

Residual saline water........................ 95

Residual sodium carbonate............... 170

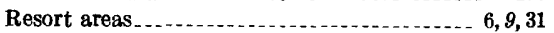

Reuse of water.............. 161, 164, 166, 167,175

Rio Grande, N.J . . . . . . .

Ridgewood, N.J. 87

Rio Reservoir .............. 183

Riparian rights, doctrine $\ldots \ldots \ldots$

River M aster of the Delaware River...... 181, 183

River Master's reports, 1956-57 .......... 184

Kocks of the Applachian Plateaus province... $\quad 81$

Rocks of the Triassic lowland............... 83

Rocks of the Valley and Ridge province..... $\quad 79$

Rondout Creek, N.Y...... 181, 182

Roundout limestone.......... $7 \gamma$

Roxbury, N.Y

Runoff, areal variations in average annual.... 104 defined -... 103 general _......................... 14, $25,103,112$ small drainage areas...................... 188 summary of average annual............. 103,104 variabllity of annual.............. 118 variability of monthly....................... 115 Runoff from natural storage................. 186

Runyon pond, N.J.......................... 174 Rural water supplies.................. 163, 164, 167

$\mathbf{S}$

Sacramento River, Calif. Salem, N.J.178 Salem County, N.J................ 54, 58, 99, 165, 167 Saline water conversion. Saline water, sources. Saline-water conversion. Saline-water use.

161,166

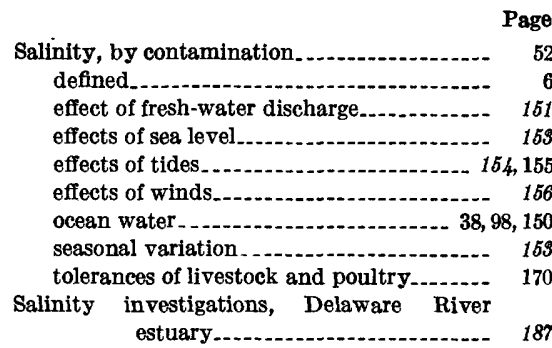

Salinity variations, Delaware River estuary -- $\quad 6$, $38,151,152$

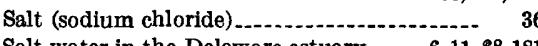

Salt water in the Delaware estuary..... $6,11,38,181$ Salt-water barrier . . . .................... 31, 178, 181 Salt-water conversion.................. 179 Salt-water encroachment ....... 10,11, 31, 42, 52, 53,54, $60,62,63,65,69,95,98,99,149,180,181$

Salt-water encroachment controls............. $\quad 177$ Salt water-fresh water interface.......... 68, 99, 151 Salt tolerance of crops......... 169,170 Sand, porosity of...

Santa Ynez River, Calif.

Sandstone.

Saugus, Mass. .

Sayreville, N.J., salt-water encroachment...-- 99 Schuykill County, $\mathrm{Pa}$....................... 80, 81

Schuylkill River....... 6, 10, 37, 103, 119, 126, 127,129, gaging stations: $140,143,146,148,150,159,161,164,177$ at Berne, $\mathrm{Pa}$. . . ......... 140,145,146, 148, 160 at Manayunk, $\mathrm{Pa}$ at Philadelphia, $\mathrm{Pa}$..... 146, 148, 158, 159, 160 at Pottstown, Pa.............. 146, 148, 158 Schuylkill River Restoration project....... 160,177 Scranton, $\mathrm{Pa}$ Seabrook, N.J._... 19 Sea level fiuctuations. Sea level, rising ...................... 11, 41, 98, 153, 178 Sea water, characteristics of.............. 95,150 Sediment control. Sediment, effect on organisms. Sediment in reservoirs . . . ............... 37, 38, 159 Sediment in streams..................... $87,159,177$ Sediment-retention pools...................... 177 Sedimentation......................... 10,37, 38, 159. 177 Seepage from streams into aquifers...-.-.-. 66 Selenium, allowable in drinking water......... 168

effects on animals. Self-supplied industrial water.........- 163, 167, 168 Septic tanks, hydrologic effects of............ 11 Serpentine, quality of water in Setters formation.................. 73, 77 Settling basins. . . . Settling ponds Sewage. See Municipal wastes.

Sewage effluent as water supply $\ldots . . . \ldots \ldots \ldots \ldots \quad 175$ Sewers, hydrologic effects of................ 11 pollution from

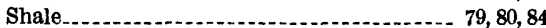

Shale aquifers. . ....... 81 Shark River marl Shawangunk conglomerate . . . . Shawangunk Mountains. See Blue Mountain.

Shiloh marl member

Silurian rocks. ................................. 77,79

Ship channels and salt-water encroachment... $\quad 99$

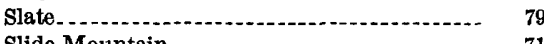

Slide Mountain

Smyrna, Del. ....................................... 99

Sodium adsorption ratio (SAR)

“Soft-rock" aquifers........................... 40

Soil Soil conservation. ................. 128, 160, 176, 177 Soil management.............................. 174, 177 Soil moisture deficit. ...................... 176 Soil moisture........................... 128, 129, 176

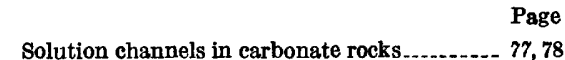

Source of ground water

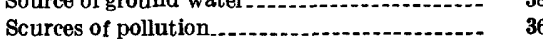

Sources of water supplies. . ..........-.-.-..... 164

South Amboy, N.J., salt-water encroachment. 99

South Philadelphia, polluted aquifers

South River.................................. 69

Southern New York section, Appalachian Plateaus province. Sparrows Point Steel Mill, Baltimore, Md _- 175 Specific capacity (of wells) .............. 49, 75, 81, 85 Specific conductance, defined .............. 139

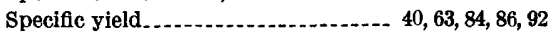
Spreading basins. ..................... 70, 174 Sprinkler irrigation

Suisun Bay, Calif.

Standard deviation

Standards, agricultural water supplies........ 169

industrial water supplies................... $\quad 169$

municipal water supplies................... 168

Statistical analyses, general discussion......... 16

Steam-electric generating plants, water use ... 166

Steam power plants, water required...-_-_... $\quad 175$

Steel-plant water requirements.

Stock-watering supplies........................ 170

Stock ton formation

Storage developments in future............- 171

Storage fluctuations and aquifer recharge, Coastal Plain -....... 69

Storage effects on streamflow... 115, 126, 128, 133, 134

Storage fluctuations in aquifers. ............. 39

Storage of water in aquifers..................... 38, 91

Storage reduction in reservoirs............... 177

Storage required to maintain flows........... 182, 180

Storm-drainage systems, hydrologic effects of. 11

Stratified glacial deposits.................. 88, 89, 90

Stratigraphic column, Delaware River basin..

Streambed materials, transport............. 160

Streamfiow, defined.

dissolved solids load

effect on concentration of dissolved solids. 140

length and adequacy of records.

peak-discharge analyses, by annual flood series.

by partial-duration series.

Streamflow affected by geology ................. 137

Streamflow affected by lake and swamp

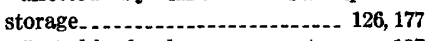

Streamfiow affected by land management.... 137

Streamflow and concentration of dissolved solids.

Streamflow of Coastal Plain and Piedmont contrasted

Streamflow records, where inapplicable....... 112

Steamflow-records analyses................. 123, 126

Steams, pollution of

self-purification of

Stroudsburg, $\mathrm{Pa}$

Structure and topography

Sulfate, allowable in drinking water........... 168

Sulfate ion, from mine wastes................ 36

Sulfuric acid, from mine wastes................ 36

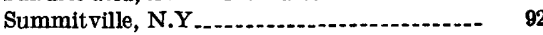

Supply and demand of water............. 180

Surface storage................................ $\$ 2,171$

Surface water

Surface waters, quality. See Quality of surface waters.

Surface-water temperatures................... 175

Suspended sediment in surface waters... 10, 159, 160

Susquehanna River basin..................... 4, $6,11,12,161,163,165,170,179,181$

Sussex County, Del........................ 22, 60, 69

Sussex County, N.J., water losses............. 22

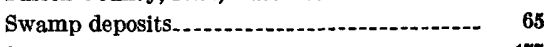

Swamps....................

$\mathbf{T}$

Talbot formation............ 64,65 


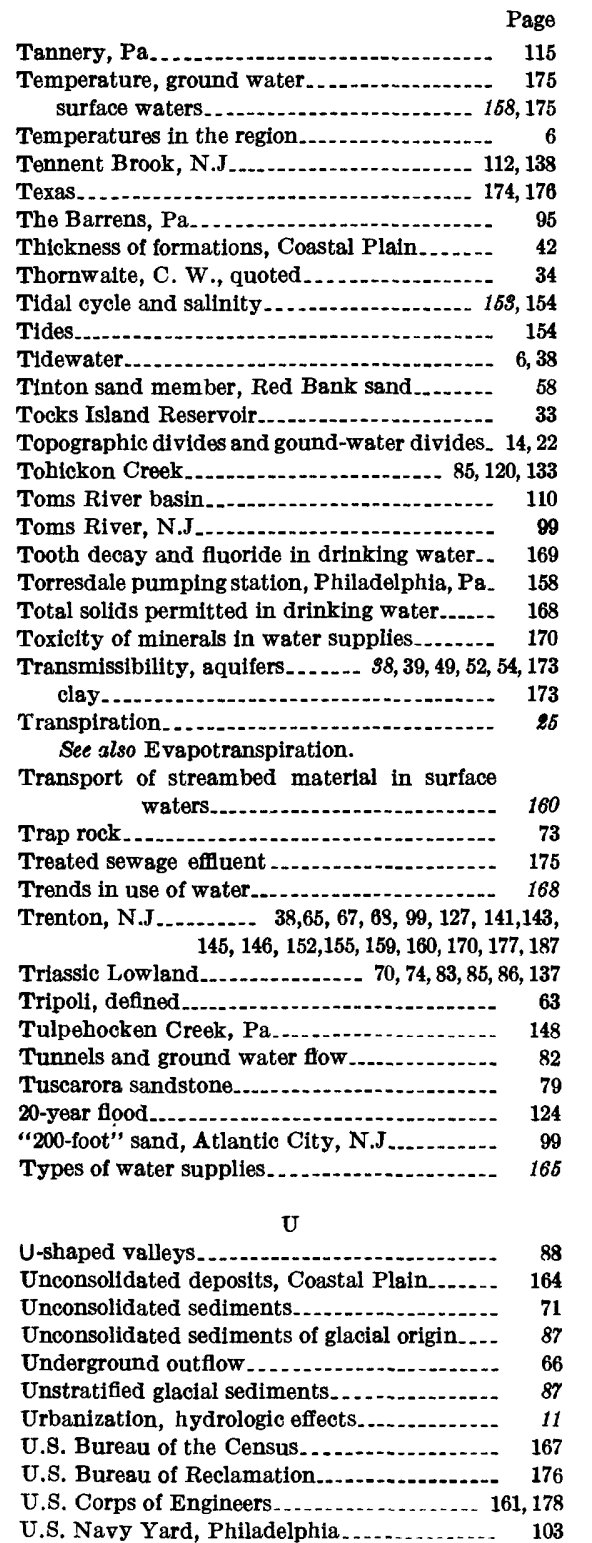
U.S. Public Health Service water standards. 149, 168 U.S. Salinity Laboratory ....................... 170 U.S. Soil Conservation Service........... 161

U.S. Supreme Court $11,12,180$ U.S. Supreme Court decree......... 171, 180, 181,187

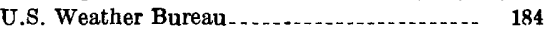

Use of water, average Delaware River estuary . ................. $\quad 170$ general.............. 160

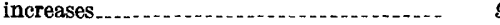
per capita..................................... 10 Use of ground-water storage, Coastal Plain . . $\quad 69$ Use of low-quality water..................... 175

\section{V}

Valley and Ridge physiographic province..... 41 $70,79,80,8$ Variations in precipitations................. 15,19 Vincentown sand.................... $42,58,93,172$

\section{W}

Walnutport, $\mathrm{Pa}$

Wallenpaupack Creek, $\mathrm{Pa}$................... 118, 183

Wallpack Bend of Delaware River......... 182

Wanaque Reservoir, N.J .................... 176

Wark, John W

Waste disposal, hydrologic effects of ......... 11

Wastes, agricultural ................... $\$ 5,159$ industrial _...... 10, $85,99,103,157,159,170$ municipal ................ $35,157,175$ Watchung Mountains.-.................. 74 Water budgets. ................... 13, 14, 25, 66, 78, 91 Water costs ................................... 12, 179 Water crop.............. 25, 174, 176 Water-crop quality, factors affecting -......... $\quad 34$ Water demand, future requirements.......... 180 Water development, economic and legal aspects. .

Water development and management

Water law, summary by states 12

Waterlogging .............. 174, 177

Water loss, defined

evapotranspiration . ..................... 9,22

Water problems, Delaware River region .... 4, 8, 181

Water resources in the modern community...

Water resources of the Delaware River basin (development) . .

Water rights . Water supplies, agricultural and rural ...... 167, 169 general .................................. 19 industrial .................. 161, 164, 165, 169, 175 municipal . . . . natural variations.
Water table, defined

water-table fluctuations................ 88, 89,92 water use .......................... 160,180

water-use statistics, misleading

10

principal references.

wster use, trends. .

Water year versus calendar year.

Wayne County, $\mathbf{P a}$

Weather and climate, effect on water crop.... 31

Weather modification to increase water supplies

Weathered zone, permeability effects on fracture permeability .................

Weathering, carbonate rocks ................. clastic rocks

crystalline rocks.

Well development...

Well log, near Willowemoc, Sullivan County, N.Y.

Well location and spacing.

Well maintenance

Well yields.

9

$49,58,60,62,63,65,75,78,79,80,81$, $82,84,85,86,87,88,90,164$.

data adequacy

Wells and well flelds, design, development, and operation. ......................

Wells, dug -....-

Wells flowing to waste......................... 176

Wells, "unit operation method".............. 172

Wenonah sand............................... 54,56

West Branch Delaware River. . . . ........ 180, 182

Wicomico formation......................... 64

Willows.

Wills Creek shale

Wilmington, Del.... 11, 99, 104, 159, 161, 175, 178, 181

Wilmington, Del., water supply............ 181

Wilsonville, $\mathrm{Pa}$

Wisconsin glacial stage . . . . . . . . . . . $41,65,71,87$

Wissahickon formation .................. 73, 75, 77,93

Withdrawal of water, Coastal Plain........... 164

Delaware River basin . . ................ 160, 167

Woodbury clay ...................

Woodstown, N.J

Z

Zinc, allowable in drinking water............ $\quad 168$ Zone of aeration. ......... 174 Zones of weathering, in hard rocks............ $\quad 74$ in carbonate rocks ....................... 77,78

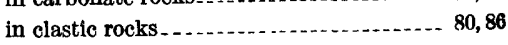

